


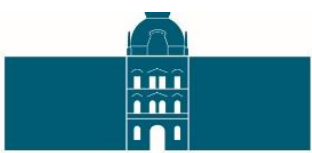

University of Maribor Press 

Naslov: Zdravstveno strukovno staleško pravo

Title: Health Professional Law

Autori: red. prof. dr. sc. Jozo Čizmić (Sveučilište u Splitu, Pravni fakultet), Miran Cvitković, dr. med. (Hrvatska lječnička komora), mr. sc. Ante Klarić (Hrvatska lječnička komora).

Strokovna recenzija: red. prof. dr. sc. Anita Kurtović Mišić (Sveučilište u Splitu, Pravni fakultet), red. prof. dr. sc. Hrvoje Kačer (Sveučilište u Splitu, Pravni fakultet), red. prof. dr. sc. Davor Vagić (Sveučilište u Splitu, Stomatološki fakultet), red. prof. dr. sc. Sven Seiwert (Sveučilište u Zagrebu, Medicinski fakultet), doc. dr. sc. Dinka Šago (Sveučilište u Splitu, Pravni fakultet), izv. prof. dr. sc. Petar Bačić (Sveučilište u Splitu, Pravni fakultet), izv. prof. dr. sc. Boštjan Brezovnik (Sveučilište u Mariboru, Pravni fakultet).

Jezikovna recenzija: prim. dr. Ante Zvonimir Golem (Klinički bolnički centar Zagreb).

Tehnički urednik: Jan Perša (University of Maribor Press).

Izrada prve stranice: Jan Perša (University of Maribor Press).

Grafički prilozi: Autori.

\section{Izdavanje:}

Sveučilište u Splitu, Pravni fakultet

Domovinskog rata 8, 21000 Split, Hrvatska

tel. +38521393500, faks +38521393597

http://www.pravst.unist.hr/, dekanat@ pravst.hr

Sveučilište u Mariboru

Slomškov trg 15, 2000 Maribor, Slovenija

tel. +3862 2504200 , faks +38622523245

http://www.pf.um.si, info.pf@um.si

Hrvatska liječnička komora

Ulica Grge Tuškana 37, 10000 Zagreb, Hrvatska

tel. +38514500 830, faks +38514655465

https://www.hlk.hr, hlk@hlk.hr

\section{Izdavač / Založnik:}

Univerzitetna založba Univerze v Mariboru

University of Maribor Press

Slomškov trg 15, 2000 Maribor, Slovenija

tel. +386225042 42, faks +38622523245

http://press.um.si, zalozba@um.si 


\section{Izdanje: Prvo izdanje \\ Vrsta publikacije: E-knjiga \\ Dostupno u: http://press.um.si/index.php/ump/catalog/book/293}

Ishod: Maribor, listopad 2017

\section{(C) University of Maribor Press}

All rights reserved. No part of this book may be reprinted or reproduced or utilized in any form or by any electronic, mechanical, or other means, now known or hereafter invented, including photocopying and recording, or in any information storage or retrieval system, without permission in writing from the publisher.

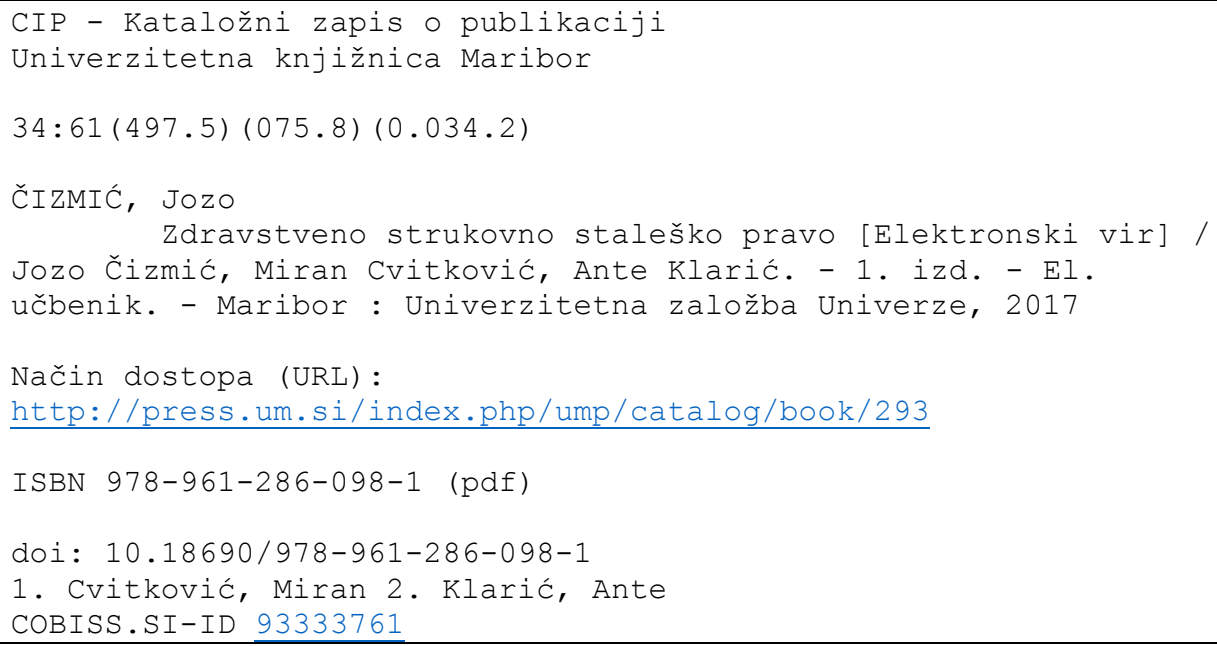

ISBN: 978-961-286-098-1 (PDF)

978-961-286-099-8 (tiskano izdanje)

DOI: https://doi.org/10.18690/978-961-286-098-1

Cijena: Besplatna kopija

Odgovorna osoba izdavača: red. prof. dr. sc. Igor Tičar, rektor Sveučilišta u Mariboru. 



\title{
Zdravstveno strukovno staleško pravo
}

\author{
Jozo ČIZMIĆ, MiRAn CVITKOVIĆ \& ANTE KlaRić
}

Rezime Knjiga je po svojoj namjeni udžbenik za studente poslijediplomskog specijalističkog studija „Medicinsko pravo“ " na Pravnom fakultetu Sveučilišta u Splitu.

U knjizi se, nakon objašnjavanja pojmova „medicinsko pravo“ i „,zdravstveno strukovno staleško pravo“, prikazuje pravno uređenje statusa i poslova radnika zdravstvene struke (obrazovanje, pripravnički staž i stručni ispit, trajno stručno usavršavanje, uvjeti i odobrenje za samostalni rad - licencija, liječnička iskaznica, specijalizacija u grani zdravstvene djelatnosti i specijalistički ispit, priznavanje inozemnih stručnih kvalifikacija, stalni sudski vještak zdravstvene struke), objašnjavaju se prava, obveze i odgovornosti zdravstvenih radnika (međusobni odnosi zdravstvenih radnika, pravila struke - deontologija, medicinska etika, priziv savjesti, rješavanje sporova (arbitraža), nadzor, liječnička tajna, medicinska dokumentacija), te posebno osiguranje od odgovornosti zdravstvenih radnika.

U drugom dijelu knjige prikazuju se razni oblici staleškog udruživanja radnika zdravstvene struke, kako obveznog udruživanja u strukovne komore (s naglaskom na javne ovlasti), tako i dobrovoljnog udruživanja u strukovne udruge i sindikalne organizacije zdravstvenih radnika.

Ključne riječi: • medicinsko pravo zdravstvene struke $\bullet$ komore• staleško pravo $\bullet$ zdravstvo $\bullet$ zdravstvene udruge $\bullet$

ADRESE AUTORA: prof. dr. sc. Jozo Čizmić, redoviti profesor u trajnom zvanju, Sveučilište u Splitu, Pravni fakultet, Domovinskog rata 8, 21000 Split, Hrvatska, e-mail: pbacic@ pravst.hr. Miran Cvitković, dr. med., voditelj Ureda za medicinsko pravo, Hrvatska liječnička komora, Ured za medicinsko pravo, Ulica Grge Tuškana 37, $10 \quad 000$ Zagreb, Hrvatska, e-mail: miran.cvitkovic@hlk.hr. mr. sc. Ante Klarić, voditelj Službe stručno-medicinskih, pravnih i međunarodnih poslova, Hrvatska liječnička komora, Služba stručno-medicinskih, pravnih i međunarodnih poslova, Ulica Grge Tuškana 37, 10000 Zagreb, Hrvatska, e-mail: ante.klaric@hlk.hr. 


\title{
Health Professional Law
}

\author{
Jozo ČIzMiĆ, MiRAn CVITKOVIĆ \& ANTE KLARIĆ
}

\begin{abstract}
This book is, by its purpose, a tutorial for postgraduate specialist medical studies at the Faculty of Law of the University of Split. In it's content, following the explanation of the terms "medical law" and "health care professional law", the book presents the legal regulation of the status of health professionals (education, internships and professional exams, permanent professional training, conditions and approval for self - health professionals, healthcare professionals, professional medical certificates, specialization in the field of healthcare and specialist examination, recognition of foreign professional qualifications, permanent expert witness in health care). Also the book authors elaborate the rights, obligations and responsibilities of healthcare workers, dispute settlement (arbitration), supervision, medical secret, medical documentation), and in particular health insurance responsibility.
\end{abstract}

In the second part of the book various forms of professional association of health professionals are presented, both compulsory association in professional chambers (with emphasis on public powers), and voluntary association in professional associations and trade union organizations of health workers.

Keywords: - medical law - healthcare professionals • chambers • Professional Law $\bullet$ health care $\bullet$ health associations $\bullet$

CORRESPONDENCE AdDRESS: Jozo Čizmić, Ph.D., Full Professor, University of Split, Faculty of Law, Domovinskog rata 8, 21000 Split, Croatia, e-mail: pbacic@pravst.hr. Miran Cvitković, dr. med., Head of the Medical Law Office, Croatian Medical Chamber, Medical Law Office, Ulica Grge Tuškana 37, 10000 Zagreb, Croatia, e-mail: miran.cvitkovic@ @lk.hr. Ante Klarić, M.S., Head of the Department of Professional, Medical, Legal and International Affairs, Croatian Medical Chamber, Professional, Medical, Legal and International Affairs Department, Ulica Grge Tuškana 37, 10000 Zagreb, Croatia, e-mail: ante.klaric@hlk.hr. 


\section{Predgovor}

\section{JOZO ČIZMIĆ, MiRAN CVITKOVIĆ \& ANTE KLARIĆ}

Knjiga koja je pred nama po svojemu je karakteru i namjeni (sveučilišni) udžbenik, obzirom kako je, između ostalog, osnovna nastavna literatura za predmet „Zdravstveno strukovno staleško pravo“, na Poslijediplomskom specijalističkom studiju „Medicinsko pravo, " Pravnoga fakulteta Sveučilišta u Splitu. Udžbenik je po svom sadržaju, opsegu i razradi pojedinih instituta prilagođen tomu biti nastavni materijal za praćenje nastave i pripremanje ispita. Udžbenik je i pomoćna literatura pri izradi seminarskih i završnih radova $\mathrm{i}$ to ne samo na navedenom studiju, već i na drugim studijskim programima na kojima se izvodi predmet „Zdravstveno/Medicinsko pravo“, na bilo kojoj razini sa istim ili sličnim sadržajem i opsegom programa predmeta.

Autori su nastojali prikazati i pojasniti najznačajnija pitanja i problematiku zdravstvenih struka (obrazovanje, pripravnički staž i stručni ispit, trajno stručno usavršavanje, uvjeti i odobrenje za samostalni rad, specijalizacije u granama zdravstvene djelatnosti sa specijalističkim ispitima, poslovi zdravstvenih radnika, etička i deontološka načela, odgovornost zdravstvenih radnika i osiguranje od odgovornosti i druga značajna pitanja), ali isto tako i ukazati na značaj, nužnost i korist od udruživanja radnika zdravstvenih struka u (zdravstvene) staleške asocijacije (komore, udruge, organizacije, sindikate, društva).

Želja autora je da udžbenik bude koristan i širemu krugu čitatelja, odnosno svima onima koji na bilo koji način dolaze u dodir s problematikom koja se obrađuje u ovom udžbeniku.

Posebno zahvaljujemo uvaženim recenzentima, nakladniku, uredniku, lektoru i svima onima koji su nesebično pomogli pri izradi i objavljivanju ovog djela. Budući kako će autori težiti doradi postojećega teksta, bit ćemo zahvalni svima koji nam svojim prijedlozima, primjedbama i kritikama pomognu u tome da izložena materija u mogućem novom izdanju bude bolje razrađena. 


\section{Sadržaj}

I/ UVOD 1

1/ Medicinsko pravo- pojam, izvori i načela 3

1.1. Pojam 3

1.2 Medicinsko pravo, medicinska etika i (integrativna) bioetika - odnos 3

1.3 Predmet proučavanja medicinskog prava $\quad \mathbf{5}$

1.4 Pravni izvori medicinskog prava 5

1.5 Načela medicinskog prava $\quad \mathbf{1 1}$

2/ Pojam strukovnog staleškog prava $\quad 19$

3/ Zdravlje, zdravstvena djelatnost i zdravstvena zaštita 25

3.1 "Zdravlje" 25

3.2 Zdravstvena zaštita $\quad \mathbf{2 6}$

$\begin{array}{ll}3.3 \text { Zdravstvena djelatnost } & \mathbf{2 7}\end{array}$

II/ RADNICI ZDRAVSTVENE STRUKE 31

1/ Pojam 33

1.1 Zdravstveni radnici $\quad 33$

1.2 Zdravstveni suradnici $\quad \mathbf{3 4}$

2/ Obrazovanje $\quad 37$

3/ Pripravnički staž i stručni ispit 39

4/ Trajno stručno usavršavanje $\quad 43$

4.1 Značaj i dužnost stalnog stručnog usavršavanja $\quad \mathbf{4 3}$

4.2 Postupak trajnog stručnog usavršavanja $\quad \mathbf{4 5}$

4.3 Trajno stručno usavršavanje na području medicinskog prava $\quad \mathbf{4 9}$

5/ Uvjeti i odobrenje za samostalni rad - licencija 55

6/ Članska iskaznica $\quad 65$

7/ Specijalizacija u grani zdravstvene djelatnosti i specijalistički ispit $\quad 67$

$\begin{array}{ll}7.1 \text { Ovlaštenici i svrha specijalističkog usavršavanja } & \mathbf{6 7}\end{array}$

7.2 Specijalisti

7.3 Odgovornost za rad specijalizanata $\quad \mathbf{7 1}$

$\begin{array}{ll}7.4 \text { Primarijus } & \mathbf{7 7}\end{array}$

8/ Priznavanje inozemnih stručnih kvalifikacija $\quad 83$

8.1 Pojam i postupak priznavanja inozemnih stručnih kvalifikacija $\quad \mathbf{8 3}$

8.2 Priznavanje inozemnih stručnih kvalifikacija stečenih u državama EU $\quad \mathbf{8 4}$

8.3 Izdavanje potvrda o osposobljenosti za obavljanje profesije $\quad \mathbf{8 5}$

$\begin{array}{ll}\text { 9/ Stalni sudski vještak zdravstvene struke } & 87\end{array}$

$\begin{array}{ll}9.1 \text { O pojmu vještačenja i vještaka - Vještačenje } & \mathbf{8 7}\end{array}$

9.2 Uvjeti za obavljanje poslova stalnog sudskog vještaka $\mathbf{8 9}$

9.3 Određivanje vještaka $\quad 93$

9.4 Obavljanje vještačenja - fizičke i pravne osobe $\quad 94$

9.5 Dužnost vještačenja $\quad 96$

9.6 Izuzeće vještaka $\quad 96$

9.7 Pozivanje vještaka $\quad 98$ 
9.8 Nalog vještaku i identifikacija vještaka $\quad 98$

9.9 Rukovođenje vještačenjem $\quad \mathbf{9 8}$

9.10 Izlaganje nalaza i mišljenja vještaka $\quad \mathbf{1 0 0}$

9.11 Proturječnosti i nedostaci u nalazu i mišljenju $\quad \mathbf{1 0 6}$

$\begin{array}{ll}9.12 \text { Žalba protiv rješenja o određivanju vještaka } & \mathbf{1 0 7}\end{array}$

$\begin{array}{ll}9.13 \text { Kažnjavanje vještaka } & \mathbf{1 0 8}\end{array}$

9.14 Naknada i nagrada za vještačenje $\quad \mathbf{1 0 9}$

9.15 Umjesto zaključka $\quad 111$

III/ PRAVA, OBVEZE I ODGOVORNOSTI RADNIKA U 123

OBAVLJANJU DJELATNOSTI

1/ Poslovi zdravstvenih radnika i način obavljanja $\quad \mathbf{1 2 5}$

$\begin{array}{ll}1.1 \text { Pravno uređenje } & \mathbf{1 2 5}\end{array}$

1.2 Utvrđivanje potrebe za dežurstvom i pripravnošću $\quad \mathbf{1 2 7}$

$\begin{array}{ll}\text { 1.2.1 Dežurstvo } & \mathbf{1 2 7}\end{array}$

$\begin{array}{ll}\text { 1.2.2 Pripravnost } & \mathbf{1 2 8}\end{array}$

1.2.3 Rad po pozivu $\quad \mathbf{1 2 9}$

1.2.4 Dodatni rad $\quad \mathbf{1 3 0}$

2/ Međusobni odnosi zdravstvenih radnika 133

2.1 Dužnost međusobne suradnje $\quad 133$

2.2 Pružanje stručnih savjeta $\quad \mathbf{1 3 4}$

2.3 Stručna kritika $\quad \mathbf{1 3 4}$

2.4 Obveza prijavljivanja nestručnog i pogrešnog vođenja bolesnika $\mathbf{1 3 5}$

2.5 Neovlašteno pridobivanje pacijenata $\quad \mathbf{1 3 5}$

2.6 Upućivanje pacijenta drugom liječniku $\quad \mathbf{1 3 5}$

2.7 Poštivanje učitelja $\quad \mathbf{1 3 6}$

3/ Pravila struke - deontologija 139

3.1 Deontologija 139

3.2 Pravila struke $\quad 139$

3.3 Autonomija u obavljanju profesije $\quad 140$

4/ Medicinska etika $\quad 143$

4.1 Pojam, načela i pravni izvori $\quad \mathbf{1 4 3}$

4.2 Medicinska etika, bioetika, integrativna bioetika i odnos prema $\mathbf{1 4 8}$ medicinskom pravu

4.2.1 Bioetika $\quad \mathbf{1 4 8}$

4.2.2 Integrativna bioetika $\quad \mathbf{1 4 8}$

4.2.3 Odnos medicinskog prava i (medicinske, integrativne, bio) etike $\mathbf{1 5 0}$

5/ Priziv savjesti $\quad \mathbf{1 5 5}$

5.1 Uvod - pojam i sadržaj ,priziva savjesti““ $\quad \mathbf{1 5 5}$

$\begin{array}{ll}5.2 \text { Povijesni razvitak instituta ,priziva savjesti“ } & \mathbf{1 5 7}\end{array}$

5.3 Područja primjene instituta ,priziva savjesti““

$\begin{array}{ll}5.4, \text { „Priziv savjesti“ u medicini } & \mathbf{1 6 1}\end{array}$

5.5 Pravo na priziv savjesti u reproduktivnoj medicini $\quad \mathbf{1 6 7}$

5.6 Zaključak $\quad 172$

6/ Odgovornost zdravstvenih radnika i osiguranje od odgovornosti 185

6.1 Liječnička pogreška i građanska odgovornost $\quad \mathbf{1 8 5}$

$\begin{array}{ll}6.2 \text { Komplikacija } & 191\end{array}$ 
6.3 Defanzivna medicina

6.4 Uzroci nastanka liječničkih pogrešaka

6.5 Vrste građanske odgovornosti zdravstvenih radnika

6.6 Osiguranje od odgovornosti

6.7 Kaznena odgovornost

6.8 Disciplinska (stegovna) odgovornost

6.9 Prekršajna odgovornost

6.10 Odgovornost za rad u timu

6.11 Zaključak

7/ Rješavanje sporova (arbitraža)

7.1 Pojam i cilj arbitražnog rješavanja sporova $\quad \mathbf{2 5 3}$

7.2 Arbitražno rješavanje sporova u zdravstvu $\quad \mathbf{2 5 5}$

8/ Nadzor

8.1 Unutarnji nadzor $\quad \mathbf{2 6 1}$

8.2 Stručni nadzor komore $\quad \mathbf{2 6 2}$

8.3 Zdravstveno-inspekcijski nadzor $\quad \mathbf{2 6 2}$

9/ Liječnička tajna $\quad 265$

9.1 Ustavni okvir $\quad \mathbf{2 6 5}$

9.2 Zakon o tajnosti podataka $\quad \mathbf{2 6 6}$

9.3 Pojam i vrste tajni - Tajnom $\quad \mathbf{2 6 7}$

9.4 Profesionalna tajna $\quad \mathbf{2 6 9}$

9.5 Sadržaj liječničke tajne $\quad \mathbf{2 7 3}$

9.6 Uzroci i načini povrede liječničke tajne $\quad \mathbf{2 7 4}$

9.7 Neovlašteno odavanje liječničke tajne $\quad \mathbf{2 7 5}$

9.8 Ovlašteno odavanje liječničke tajne $\quad \mathbf{2 7 8}$

9.9 Umjesto zaključka - odnos liječnika i pacijenta - pravo na povjerljivost $\mathbf{2 8 4}$ (privatnost)

10/ Medicinska dokumentacija $\quad 299$

10.1 Uvod $\quad \mathbf{2 9 9}$

$\begin{array}{ll}10.2 \text { Svrha i cilj medicinske dokumentacije } & \mathbf{3 0 0}\end{array}$

10.3 Sadržaj i vrste medicinske dokumentacije $\quad 300$

10.4 Dužnost vođenja medicinske dokumentacije $\quad 304$

10.5 Uredno vođenje medicinske dokumentacije $\quad 305$

10.6 Pravo pacijenta na uvid u svoju medicinsku dokumentaciju $\mathbf{3 1 2}$

10.7 Podzakonski propisi $\quad \mathbf{3 1 5}$

10.8 Umjesto zaključka - odgovornost za vođenje medicinske $\quad \mathbf{3 2 2}$ dokumentacije

IV/ KOMORE U ZDRAVSTVU 331

1/ Pojam, povijesni razvitak i svrha osnivanja zdravstvenih komora $\quad 333$

1.1 Uvodne napomene o komorama u zdravstvu $\quad 333$

1.2 Povijesni razvitak komorskog sustava u zdravstvu $\mathbf{3 3 3}$

1.3 Svrha osnivanja zdravstvenih komora $\quad \mathbf{3 3 5}$

2/ Članstvo u komori 339

3/ Nadležnost i zadaci komora $\quad 341$

4/ Pravni izvori 343

5/ Javne ovlasti komora $\quad 345$ 
\begin{tabular}{l|l} 
iv & $\begin{array}{l}\text { ZDRAVSTVENO STRUKOVNO STALEŠKO PRAVO } \\
\text { Sadržaj }\end{array}$
\end{tabular}

6/ Komora kao jamac zaštite prava pacijenata 351

7/ Komora u novim izazovima $\quad 355$

V/ UDRUGE ZDRAVSTVENIH RADNIKA 359

1/ Svrha i načini udruživanja zdravstvenih radnika $\quad 361$

2/ O pojedinim udrugama zdravstvenih radnika 362

$\begin{array}{ll}\text { POPIS KRATICA } & 371\end{array}$

$\begin{array}{lr}\text { LITERATURA } & \mathbf{3 7 7}\end{array}$ 
ZDRAVSTVENO STRUKOVNO STALEŠKO PRAVO

J. Čizmić, M. Cvitković \& A. Klarić 



\section{1/ Medicinsko pravo- pojam, izvori i načela}

\subsection{Pojam}

Medicinsko pravo je grana prava koja se odnosi na medicinsku djelatnost. ${ }^{1} \mathrm{U}$ zadnjih nekoliko desetljeća medicinsko pravo postoji i afirmiralo se kao zasebna disciplina pravne znanosti i kao zasebna grana prava. ${ }^{2}$ Medicinsko pravo čini skup pravnih pravila kojima se uređuje medicinska djelatnost, utvrđuje status osoba koje tu djelatnost obavljaju, kao i njihov odnos s korisnicima njihovih usluga, ${ }^{3}$ odnosno kojima se uređuje zaštita prava čovjeka na zdravlje, zdravstvenu zaštitu i zdravstveno osiguranje, odgovornost i prava zdravstvenih radnika i zdravstvenih organizacija te organizacija zdravstva kao javne djelatnosti od posebnoga društvenog interesa. ${ }^{4}$ Medicinsko pravo obuhvaća sve pravne aspekte zdravstvenih djelatnosti, sve subjekte, odnose i postupke za koje pravo vezuje određene pravne učinke, odnosno prava i/ili obveze. ${ }^{5} \mathrm{Na}$ ovom području pravo i medicina se susreću i teže zajedničkom cilju - očuvanju čovjekovih najvrjednijih dobara: života, tijela, zdravlja i ljudskog dostojanstva, kao iznimno značajnog segmenta zaštite ljudskih prava. ${ }^{6}$

Živimo u vremenu u kojemu je uobičajeno i nužno u znanstvenom i praktičnom pristupu bilo kojem problemu prilaziti multidisciplinarno. U tom smislu postoji niz područja u kojima se medicinska i pravna znanost i praksa, a i druge poput etike, isprepliću i nužno koegzistiraju. Pri tome nije od presudnog značaja je li u konkretnom slučaju veći udio medicine ili prava, odnosno etike. Svjedoci smo postojanja niza problema na koje samo medicinska i samo pravna struka ne mogu za širu javnost dati brz i eksplicitan odgovor. Štoviše, na brojna pitanja ne mogu argumentirano odgovoriti niti zajedničkim pristupom bez pomoći (integrativne) bioetike. Naveli bismo, primjerice, neka područja kojima se može i mora pristupiti s medicinskog, pravnog i etičkog aspekta: eutanazija, patentiranje gena, kloniranje, uporaba matičnih stanica, odbijanje pojedinih zdravstvenih usluga iz vjerskih razloga, biološki testament, nesavjesno liječenje, samovoljno liječenje, nepružanje liječničke pomoći, patentiranje gena, fertilizacija in vitro i genetske intervencije; dužnost liječnika da obznani vlastitu stručnu pogrešku, ispitivanje lijekova na ljudima, biomedicinska istraživanja, priziv savjesti i dr. ${ }^{7}$

Upravo zbog toga držimo zanimljivim i korisnim ukazati na neke posebnosti tih znanstvenih područja i njihovog međuodnosa.

\subsection{Medicinsko pravo, medicinska etika i (integrativna) bioetika - odnos}

Svrha i cilj medicinskog prava jest upravo rješavanje brojnih, složenih i multidisciplinarnih problema i odnosa u na području zdravstva od strane stručnjaka koji istovremeno posjeduju znanja i vještine iz dvaju različitih znanstvenih područja i struka - prava i medicine, a pri tome nije od presudnog značaja koja znanja i vještine posjeduju u većoj mjeri. 
Medicinsko pravo u užem (funkcionalnom) smislu obuhvaća pravna pravila koja uređuju odnose u obavljanju zdravstvene/medicinske zaštite. ${ }^{8}$ Gledano u širem smislu, medicinsko pravo obuhvaća i druge propise kojima se ne uređuju izravno odnosi u obavljanju zdravstvene djelatnosti, ali su u svezi s njima, kao što su, primjerice, propisi o prometu i izdavanju lijekova, osiguranju od odgovornosti, medicinskim proizvodima, ${ }^{9}$ organizacije zdravstvenog sustava (statusno i organizacijsko medicinsko pravo) i sl. Medicinsko pravo u širem smislu obuhvaća, dakle, i pravne norme koje se tiču lijekova, medicinskih sredstava, prikupljanja i transfuzije krvi i sl. ${ }^{10}$

U pravnoj teoriji i judikaturi u zadnje vrijeme pojavljuje se i naziv «zdravstveno pravo» ili «pravo zdravlja» (Health Law), koji je prema mišljenju nekih autora sadržajno širi od pojma «medicinsko pravo», jer obuhvaća sve propise vezane uz zdravstvo, odnosno zdravlje. ${ }^{11}$ Drže da je zdravstveno pravo ne samo širi pojam, nego i socijalno-zdravstveno područje aktivnosti različito od medicinskog prava. Termin i pojam zdravstva daleko je sveobuhvatniji od onoga što se shvaća pod medicinom, te sadrži u sebi naglaske na društvenim i pravnim konotacijama i ingridijentima, jer se radi o važnoj socijalnoj djelatnosti, dok medicina ima svoje biološke, somatske, organske, morfološke komponente i elemente. ${ }^{12}$ Smatraju, usto, da je pojam „medicinsko pravo“ uži od pojma „zdravstveno pravo“ jer medicinsko pravo, u načelu, uređuje odnos između liječnika i pacijenta kao pružatelja i korisnika zdravstvene zaštite, i tek posredno uključuje druge zdravstvene radnike u području svoje regulacije, pa može predstavljati samo jednu od grana zdravstvenog prava. ${ }^{13}$ Treba napomenuti da ima i suprotnih mišljenja. Tako Šeparović smatra da je pojam „medicinsko pravo“ obuhvatniji od pojma „zdravstveno pravo" jer pokriva cjelovito područje medicine kao djelatnosti, kao medicinskog (zdravstvenog) čina, kao struke i poziva, umijeća (art) i znanosti (scientia). ${ }^{14}$

Iako medicinsko pravna teorija daje različito sadržajno značenje pojmovima «medicinsko pravo» i «zdravstveno pravo», na način da jedni drže da je pojam «medicinsko pravo» sadržajno širi od pojma «zdravstveno pravo», dok drugi tvrde suprotno, držimo da su i pojam «medicinsko pravo» i pojam «zdravstveno pravo» postali svojevrsni terminus technicus za označavanje (sve brojnijih) pravnih (i etičkih) pravila koja uređuju kompleksne odnose u obavljanju zdravstvene/medicinske zaštite, kao i sve druge odnose i pojave koje su na bilo koji način u svezi s obavljanjem te djelatnosti. Držimo, također, da pri tome nije od primarnog i presudnog značenja koji je pojam sadržajno uži, a koji širi jer se, uostalom, oni vrlo često koriste i kao sinonimi.

Prilikom pojmovnog i sadržajnog objašnjenja „,medicinskog prava“ svakako treba ukazati i na njegov odnos prema sudskoj medicini. Pojmovi „sudska medicina“ i „,medicinsko pravo" nisu sinonimi. Sudska medicina (engl. Forensic Medicine, njem. Recht Medizin) je grana znanstvenog područja biomedicine i zdravstva, polja kliničkih i medicinskih znanosti koja se, najčešće za potrebe suda, bavi utvrđivanjem činjenica kao što su, primjerice, nastupanje smrti, ozljede i sl. ${ }^{15}$ Sudska medicina je medicinska disciplina koja povezuje dvije različite struke i znanosti - medicinu iz kruga bioloških znanosti i pravo kao predstavnika društvenih znanosti, a temeljni joj je zadatak pružanje pomoći pravnoj struci u slučajevima kad u pravnim postupcima treba riješiti različite medicinske probleme. ${ }^{16}$ Znanja iz sudske medicine služe uglavnom za razjašnjavanje pravnih problema iz domene zdravlja i bolesti, života i smrti ljudi. ${ }^{17}$ Možemo zaključiti da sudska 
medicina predstavlja, zapravo, pravo u medicini, a medicinsko pravo predstavlja medicinu u pravu. ${ }^{18}$ Sudska se medicina naziva i forenzičkom medicinom. Često se kao sinonim koristi i pojam «pravna medicina», koja u sebi uključuje i sudsku psihopatologiju i medicinsku kriminalistiku. ${ }^{19}$

\subsection{Predmet proučavanja medicinskog prava}

Područje medicinskog/zdravstvenog prava vrlo je opsežno s tendencijom širenja, jer zdravstvena djelatnost, kao predmet proučavanja medicinskog prava, svakim danom postaje sve razvijenija, a pitanja i problemi koji iz te djelatnosti proizlaze postaju sve brojniji. ${ }^{20}$ Što se predmeta medicinskog prava tiče, norme medicinskog prava u pravilu su vezane i odnose se na tri subjekta: čovjeka (bolesnika, pacijenta) i njegova temeljna prava (na zdravstvenu zaštitu, odnosno život, zdravlje i sigurnost); liječnika i druge zdravstvene radnike (a posebno na njihovu odgovornost); te bolnice i druge zdravstvene ustanove u kojima pacijenti ostvaruju svoje pravo na zdravstvenu zaštitu, kao i na zdravstveni sustav u cjelini i njegovo uređenje i djelotvorno funkcioniranje. ${ }^{21}$ Usto, zaseban predmet medicinskog prava je i zdravstveno osiguranje i s tim u svezi pravo čovjeka na zdravstvenu zaštitu, financiranje zdravstva. ${ }^{22} \mathrm{U}$ našem pravu predmet zdravstvenog prava proizlazi iz same definicije zdravstvene djelatnosti koja je dana $\mathrm{u}$ Zakonu o zdravstvenoj zaštiti («Narodne novine», broj 150/08, 71/10, 139/10, 22/11, 84/11, 154/11, 12/12, 35/12, 70/12, 144/12, 82/13, 159/13, 22/14 , 154/14, 70/16, dalje ZOZZ). Tako se propisuje da zdravstvena zaštita obuhvaća sustav društvenih, skupnih i individualnih mjera, usluga i aktivnosti za očuvanje i unaprjeđenje zdravlja, sprječavanje bolesti, rano otkrivanje bolesti, pravodobno liječenje te zdravstvenu njegu i rehabilitaciju (ZOZZ, čl. 2.), a zdravstvena djelatnost je djelatnost od interesa za Republiku Hrvatsku koja se obavlja kao javna služba i koju po stručno-medicinskoj doktrini i uz uporabu medicinske tehnologije obavljaju zdravstveni radnici pri pružanju zdravstvene zaštite, pod uvjetima i na način propisan ovim Zakonom (ZOZZ, čl. 23.).

\subsection{Pravni izvori medicinskog prava}

Medicinsko pravo je skup raznorodnih pravila, koja pripadaju različitim granama prava, a zajedničko im je da uređuju odnose u obavljanju zdravstvene djelatnosti. Izvori medicinskog prava brojni su s tendencijom da budu sve brojniji, a usto su i disperzirani. Izvore medicinskog prava mogli bismo svrstati u više skupina: propise koji izravno uređuju odnose koji nastaju u obavljanju zdravstvene djelatnosti, te propise iz drugih područja prava (primjerice, ustavnog, građanskog, građanskog procesnog, kaznenog, ${ }^{23}$ kaznenog procesnog, radnog i socijalnog, upravnog, obiteljskog, međunarodnog i sl.), koji dijelom (posredno) uređuju pojedina pitanja vezana za odnose u obavljanju zdravstvene djelatnosti. ${ }^{24}$

Ustav Republike Hrvatske («Narodne novine», pročišćeni tekst, 56/90, 135/97, 8/98, 113/00, 124/00, 28/01, 41/01, 55/01, 76/10, 85/10, 05/14), sadrži i neke odredbe kojima se na izravan ili neizravan način uređuju i odnosi na području medicinskog prava. Tako Ustav svakom jamči pravo na zdravstvenu zaštitu u skladu sa zakonom (Ustav, čl. 59.), te propisuje da svatko ima pravo na zdrav život. Usto, propisuje da je država dužna osigurati uvjete za zdrav okoliš, te da je svatko dužan, u sklopu svojih ovlasti i djelatnosti, 
posvećivati osobitu skrb zaštiti zdravlja ljudi (čl. 70.). Nadalje, propisuje da svako ljudsko biće ima pravo na život (Ustav, čl. 21.), te da nitko ne smije biti podvrgnut bilo kakvu obliku liječničkih pokusa bez svoje privole (Ustav, čl. 23.). Koliko značenje Ustav daje zaštiti zdravlja može se najbolje vidjeti iz odredaba čl. 16. i 51. Ustava prema kojima se sva druga ustavna prava i slobode mogu ograničiti, ako je to potrebno radi zaštite zdravlja. $^{25} \mathrm{~S}$ druge strane izostala je sustavna zaštita zdravstvenih radnika kao nositelja zdravstvene zaštite u obavljanju zdravstvene djelatnosti. Stoga je na potezu zakonodavac da ispravi i doradi postojeću pravnu regulativu u segmentu zaštite zdravstvenog radnika u obavljanju zdravstvene djelatnosti. ${ }^{26}$

Nadalje, pravne izvore medicinskog prava mogli bismo podijeliti i po drugim kriterijima: nacionalne i međunarodne; s obzirom na donositelja na one koje donose državni organi, razne ustanove i druge pravne osobe (tzv. autonomno pravo), komore i udruge zdravstvenih radnika (tzv. staleško pravo) i dr.

Zakoni predstavljaju temeljni izravni izvor medicinskog prava. Kao najznačajnije za područje medicinske djelatnosti izdvojili bismo: a/ Zakon o zdravstvenoj zaštiti ZOZZ, kojim se uređuju: načela, mjere, način provođenja te organizacija zdravstvene zaštite, nositelji društvene skrbi za zdravlje stanovništva, prava i obveze osoba u korištenju zdravstvene zaštite te sadržaj, način obavljanja i nadzor nad obavljanjem zdravstvene djelatnosti (ZOZZ, čl. 1. st. 1.); b/ Zakon o liječništvu („Narodne novine“, br. 121/03, 117/08, dalje - ZOL), kojim se uređuje pojam, ustrojstvo i uvjeti za obavljanje liječničkog zvanja te djelovanje liječnika kao temeljnog, samostalnog i odgovornog nositelja zdravstvene djelatnosti koja je od posebnog interesa za Republiku Hrvatsku i koja osigurava zdravstvenu zaštitu svakom pojedincu i cjelokupnom pučanstvu u Republici Hrvatskoj; c/ Zakon o sestrinstvu („Narodne novine“, br. 121/03, 117/08, 57/11, dalje - ZOS), kojim se uređuju sadržaj i način djelovanja, standard obrazovanja, uvjeti za obavljanje djelatnosti, dužnosti, kontrola kvalitete i stručni nadzor nad radom medicinskih sestara u Republici Hrvatskoj; d/ Zakon o primaljstvu („Narodne novine“, br. 120/08, 145/10, dalje - ZOP), kojim se uređuju sadržaj i način djelovanja, standard obrazovanja, uvjeti za obavljanje djelatnosti, dužnosti, kontrola kvalitete i stručni nadzor nad radom primalja u Republici Hrvatskoj; e/ Zakon o dentalnoj medicini („Narodne novine“", broj 121/03, 117/08, 120/09, dalje - ZODM), kojim se uređuju ustrojstvo te uvjeti za obavljanje stomatološke djelatnosti kao službe koja osigurava pružanje stomatološke pomoći osobama u ostvarivanju i zaštiti oralnog zdravlja; f/ Zakon o ljekarništvu („Narodne novine“, broj 121/03, 142/06, 35/08, 117/08, dalje - ZOLJK), kojim se uređuje način organiziranja i provođenja ljekarničke djelatnosti kao dijela zdravstvene djelatnosti od interesa za Republiku Hrvatsku koja se obavlja kao javna služba i koju obavljaju magistri farmacije pod uvjetima i na način propisan tim Zakonom; g/ Zakon o medicinsko-biokemijskoj djelatnosti („Narodne novine“", broj 121/03, 117/08, dalje - ZOMBD), kojim se uređuju načela, način organiziranja i provođenja medicinsko-biokemijske djelatnosti, kao dijela zdravstvene djelatnosti od interesa za Republiku Hrvatsku koja se obavlja kao javna služba i koju obavljaju magistar medicinske biokemije pod uvjetima i na način propisan tim Zakonom; h/ Zakonom o djelatnostima u zdravstvu (,Narodne novine“, broj 87/09, dalje - ZODUZ), kojim se uređuje sadržaj i način djelovanja, standard obrazovanja, uvjeti za obavljanje djelatnosti, dužnosti, kontrola kvalitete i stručni nadzor nad radom sanitarnih inženjera, radioloških 
tehnologa, radnih terapeuta i zdravstvenih radnika medicinsko-laboratorijske djelatnosti; i/ Zakon o obveznom zdravstvenom osiguranju («Narodne novine», broj 80/13, 137/13), kojim se uređuje: sustav obveznoga zdravstvenog osiguranja u Republici Hrvatskoj koje provodi Hrvatski zavod za obvezno zdravstveno osiguranje, opseg prava na zdravstvenu zaštitu i druga prava i obveze osoba osiguranih prema ovom zakonu, uvjeti i način njihova ostvarivanja i financiranja kao i prava i obveze nositelja obveznoga zdravstvenog osiguranja, uključujući i prava i obveze ugovornih subjekata nositelja provedbe zdravstvene zaštite (Zakon o obveznom zdravstvenom osiguranju, čl. 2.); j/ Zakon o zaštiti prava pacijenata («Narodne novine», broj 169/04., 37/08., dalje ZOZPP), kojim se određuju prava pacijenata prilikom korištenja zdravstvene zaštite te način zaštite i promicanja tih prava. Pacijentom u smislu ovoga Zakona smatra se svaka osoba, bolesna ili zdrava, koja zatraži ili kojoj se pruža određena mjera ili usluga u cilju očuvanja i unaprjeđenja zdravlja, sprječavanja bolesti, liječenja ili zdravstvene njege i rehabilitacije (ZOZPP, čl. 1.); k/ Zakon o fizioterapeutskoj djelatnosti (Narodne novine, broj 120/2008), kojim se uređuju sadržaj i način djelovanja, standard obrazovanja, uvjeti za obavljanje djelatnosti, dužnosti, kontrola kvalitete i stručni nadzor nada radom fizioterapeuta u Republici Hrvatskoj. Odredbe ovoga Zakona koje se odnose na fizioterapeute na odgovarajući način se primjenjuju i na fizioterapeutske tehničare, masere-kupeljare koji sudjeluju u procesu fizioterapeutske skrbi pacijenta, uzimajući u obzir njihov djelokrug rada. ${ }^{27}$

Pored zakona, izravni izvor medicinskog prava su i vrlo brojni (provedbeni) podzakonski propisi, koje ponajviše donose Ministarstvo zdravstva i Hrvatski zavod za zdravstveno osiguranje. Podzakonskim se propisima obično razrađuju pitanja koja su samo općenito, načelno regulirana zakonom.

Samo dio pravnih pravila nalazi se u pravnim propisima kojima se izravno i jedino uređuje medicinska djelatnost $\mathrm{i}$ status njezinih radnika, dok je drugi dio pravila medicinskog prava raspoređen, odnosno nalazi se u brojnim drugim zakonskim i podzakonskim tekstovima koji pripadaju različitim područjima prava, a jednim dijelom uređuju i područje medicinskog prava. ${ }^{28}$ Tako Ustav Republike Hrvatske («Narodne novine», broj 41/01 - pročišćeni tekst, 55/01., 76/10, 85/10, 05/14), sadrži i neke odredbe kojima se na izravan ili neizravan način uređuju i odnosi na području medicinskog prava. Ustav svakom jamči pravo na zdravstvenu zaštitu u skladu sa zakonom (Ustav, čl. 58.), te propisuje da svatko ima pravo na zdrav život. Usto, propisuje da je država dužna osigurati uvjete za zdrav okoliš, te da je svatko dužan, u sklopu svojih ovlasti i djelatnosti, posvećivati osobitu skrb zaštiti zdravlja ljudi (čl. 69.). Nadalje, propisuje da svako ljudsko biće ima pravo na život (Ustav, čl. 21.), te da nitko ne smije biti podvrgnut bilo kakvu obliku liječničkih pokusa bez svoje privole (Ustav, čl. 23.). Koliko značenje Ustav daje zaštiti zdravlja može se najbolje vidjeti iz odredaba čl. 16. i 50. Ustava prema kojima se sva druga ustavna prava i slobode mogu ograničiti, ako je to potrebno radi zaštite zdravlja. ${ }^{29}$ Kao neizravne izvore medicinskog prava spomenuli bismo i sljedeće zakone: Zakon o obveznim odnosima («Narodne novine», broj 35/05., 41/08, 125/11, 78/15); Kazneni zakon («Narodne novine», broj 125/11, 144/12, 56/15, 61/15); Zakon o zaštiti tajnosti podataka („Narodne novine“, broj 108/96.); Zakon o tajnosti podataka („Narodne novine“", broj 79/07, 86/12.); Zakon o zaštiti osobnih podataka ("Narodne novine”, br. 103/03, 118/06, 41/08, 130/11, 106/12); Zakon o pravu na pristup informacijama 
("Narodne novine", br. 25/13, 85/15); Zakon o kaznenom postupku, «Narodne novine», broj 152/08, 76/09, 80/11, 121/11, 91/12, 143/12, 56/13, 145/13, 152/14, 70/17); Zakon o parničnom postupku («Narodne novine», broj 53/91, 91/92, 58/93, 112/99, 88/01, 117/03, 88/05, 02/07, 84/08, 123/08, 57/11, 148/11, 25/13, 89/14.); Zakon o općem upravnom postupku («Narodne novine», br. 47/09.); Zakon o zaštiti od ionizirajućih zračenja («Narodne novine», broj 91/10.); Zakon o sanitarnoj inspekciji («Narodne novine», broj 113/08, 88/10.); Zakon o otrovima («Narodne novine», broj 27/99.); Zakon o obrtu («Narodne novine», broj 143/13.); Zakon o trgovačkim društvima («Narodne novine», broj 111/93, 34/99, 121/99, 52/00, 118/03, 107/07, 146/08, 137/09, 125/11, $152 / 11,111 / 12,68 / 13,110 / 15)$ i dr.

Značajni predmet zanimanja medicinskog prava predstavlja odnos između liječnika (zdravstvenog radnika) i pacijenata u pogledu pružanja medicinske usluge, a taj odnos nije samo pravni, nego je i etički. U njemu su moralni i pravni obziri pomiješani u znatno većoj mjeri nego što je to slučaj s ostalim pravnim odnosima među ljudima. Liječnik (zdravstveni radnik) je (pravno) dužan pridržavati se određenih načela medicinske etike. Moralne i pravne dužnosti liječnika toliko su se stopile da ih je u pojedinostima gotovo nemoguće razlučiti. ${ }^{30}$ Etička pravila i pravila struke nisu po svojoj prirodi pravna pravila. Međutim, odnos zdravstvenog radnika i pacijenta povodom pružanja medicinske usluge nije uređen jedino pravnim pravilima, već su i pravila medicinske etike i pravila medicinske struke veliki i iznimno značajan segment medicinskog prava kojim se uređuju obveze (njihov sadržaj i opseg) zdravstvenih radnika prilikom pružanja medicinskih usluga, do te mjere da ih je u našem pravu zakonodavac odredbom čl. 120. ZOZZ-a digao na razinu pravne norme, za čije se nepoštivanje odnosno kršenje vežu ne samo moralne, nego i stegovne (disciplinske), kaznenopravne i građanskopravne sankcije. ${ }^{31}$ Medicinska etika i pravo međusobno se nadopunjuju, pravilima medicinske etike sudovi priznaju i pravnu snagu jer nepostupanje zdravstvenih radnika po tim pravilima podliježe pravnoj sankciji, pa je neprijeporno da je medicinska etika izvor medicinskog prava. ${ }^{32}$

Pravila medicinske etike uobičajeno se kodificiraju u posebnim, nacionalnim i međunarodnim, etičkim odnosno deontološkim kodeksima. Kodeksima etike i deontologije u pravilu se utvrđuju načela i pravila ponašanja kojih su se dužni pridržavati zdravstveni radnici, članovi pojedinih komora, pri obavljanju svoje profesionalne djelatnosti, a radi očuvanja dostojanstva i ugleda profesije. Najstarija kodifikacija liječničke etike je Hipokratova zakletva. ${ }^{33}$ 


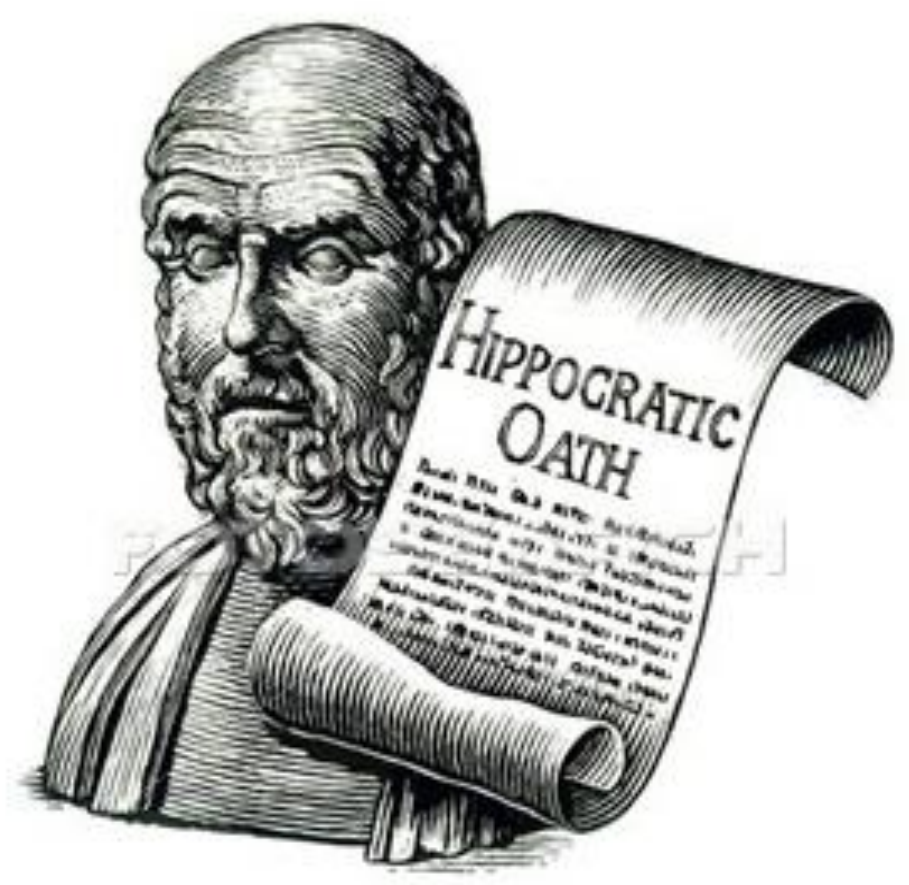

Slika 1: $\mathrm{FN}^{34}$

U Republici Hrvatskoj najznačajniji su Kodeks medicinske etike i deontologije («Narodne novine», broj 55/08,139/15.); Kodeks stomatološke etike i deontologije, od 7. lipnja 1996. godine; Kodeks ljekarničke etike i deontologije, od 18. travnja 1996. godine; Etički kodeks medicinskih sestara, od 22. prosinca 2005. godine; Kodeks etike i deontologije djelatnosti sanitarnih inženjera, zdravstvene radiološko-tehnološke djelatnosti, djelatnosti radne terapije i medicinsko laboratorijske djelatnosti, od 5.12.2012. godine; Kodeks etike i deontologije medicinskih biokemičara, od 8. svibnja 1996. godine; Etički kodeks primalja od 27. siječnja 2010 godine, Etički kodeks fizioterapeuta od 21. veljače 2011. godine . Što se međunarodnih kodeksa medicinske etike i deontologije tiče, spomenuli bismo Međunarodni kodeks medicinske etike, usvojen na 3. generalnoj skupštini Svjetskog medicinskog udruženja u Londonu, 1949. godine, te Načela etike za europske liječnike, Međunarodne konferencije predstavnika liječničkih komora i sličnih liječničkih organizacija iz zemalja članica Europske unije iz 1987. i 2001. godine.

Pravni izvor medicinskog prava kojeg nije donio zakonodavac predstavlja i tzv. autonomno pravo. Autonomni izvori prava su oni koje je donio (ili je barem sudjelovao u njihovom donošenju) subjekt na kojeg će se oni i primjenjivati. Kod tih su izvora adresant i adresat pravne norme iste (pravne) osobe. Autonomni su izvori oblik samoregulacije i samoobvezivanja, u granicama slobode koju im je dao zakonodavac. Oni imaju karakter prava jer su popraćeni državnom sankcijom, ali kroz te norme dolazi do 
izražaja volja i odluka subjekta na kojeg se primjenjuju. ${ }^{35} \mathrm{Na}$ području zdravstvene djelatnosti to bi najčešće bili statuti, pravilnici, poslovnici, kolektivni ugovori, rješenja i drugi opći akti zdravstvenih ustanova (bolnice, lječilišta, domovi zdravlja, zavodi, poliklinike i sl.) te trgovačkih društava za obavljanje zdravstvene djelatnosti. Značajan izvor medicinskog prava predstavlja i tzv. staleško pravo o kojemu će više riječi biti u nastavku rada.

Ubrzanim razvitkom medicinskog prava povećava se i broj njegovih pravnih izvora, i to ne samo na nacionalnoj razini, nego i na međunarodnoj razini. ${ }^{36}$ I međunarodne izvore medicinskog prava mogli bismo svrstati u one kojima se izravno uređuje područje medicinskog prava, te one iz drugih područja koji dijelom (posredno) uređuju pojedina pitanja iz područja medicinskog prava. ${ }^{37}$ Osim višestranih međunarodnih sporazuma, međunarodni izvor medicinskog prava mogu biti i bilateralni sporazumi. Tako su međunarodni bilateralni sporazumi izvor i hrvatskog medicinskog prava, kako oni koje je sklopila Republika Hrvatska, tako i oni koje je preuzela sukcesijom od bivše SFR Jugoslavije. ${ }^{38}$

Medicinska djelatnost podvrgnuta je i sudskoj kontroli s ciljem da se osigura i zajamči da će se zdravstveni radnici u obavljanju svoje profesije pridržavati važećih standarda svoje struke te da će postupati s dužnom pozornošću. Granice dužne pažnje i odgovornosti određuju sudovi u svojim odlukama, pa je neprijeporno da je sudska praksa od iznimnog značenja za medicinsko pravo, a posebno jer puno pitanja koja nastaju u odnosima između zdravstvenih radnika i pacijenata nisu precizno i jednoznačno ili nisu uopće uređena pisanim pravnim pravilima. ${ }^{39}$ Sudsku praksu sačinjava niz sudskih presuda kojima se pravna norma primjenjuje na isti način. Sudskom praksom kao izvorom prava naziva se donošenje više suglasnih presuda od strane istog suda o istom pravnom pitanju na temelju kojih se ustaljuje obvezujuća pravna norma. Sudska praksa nije izravan, nego neizravan izvor prava. Naime, rješavajući konkretan slučaj, sudac se ne može pozvati niti na koju svoju raniju presudu, niti pak na presudu višeg suda kao na neki propis. Ni pravna shvaćanja usvojena na sjednicama sudskih odjela ili na općim sjednicama Vrhovnog suda ne vezuju sudove odnosno odjele koji nisu sudjelovali u njihovu usvajanju. Sudska odluka nema u nas karakter presedana. Sudskoj praksi ne može se dati ono značenje koje ona ima u zemljama gdje postoji precedentno pravo. Odluke viših sudova formalno ne obvezuju niže sudove, ali stvarno je neizbježno da niži sudovi o njima vode račune iz različitih razloga (psihološki, odgovornost se prenosi na više sudove, čije se stajalište poštuje, i dr.). Odluka višeg suda djeluje na niži sud snagom svoje uvjerljivosti. Razumije se da sudac koji je uvjeren da je viši sud donio ispravnu presudu neće u konkretnom sličnom slučaju donositi drukčiju presudu, pa je utoliko i sudska praksa (engl.. cases, franc. jurisprudence, njem. Rechtssprechung) neizravan izvor prava. Čak i u uvjetima iscrpnog reguliranja pisanim pravilima, kreativnoj funkciji sudske prakse ostaje značajna uloga $u$ interpretaciji pravnih pravila. Naročito kad se radi o tekstovima koji zbog svoje nepotpunosti, nedorečenosti, praznina ili nedosljednog tretiranja određenih pitanja nužno iziskuju stvaralački doprinos onih koji ih primjenjuju. ${ }^{40}$ Unatoč činjenici što sudska praksa, prema izloženome, ne predstavlja općevažeći izvor prava, odluke sudova u konkretnim predmetima izvor su prava za subjekte na koje se njihova pravomoćnost odnosi. ${ }^{41}$ Sudska odluka djeluje kao izvor prava za same stranke za koje je u konkretnom slučaju donesena (res iudicata facit ius inter partes). ${ }^{42}$ Možemo zaključiti, iako sudska 
praksa nije de iure izvor prava, ona de facto može biti izvor prava. Osim što sudska praksa na području medicinskog prava ima iznimno značenje u popunjavanju pravnih praznina, ima i veliki utjecaj na prihvaćanje novih pravnih ideja i stajališta, kao i na zakonodavnu djelatnost (de lege ferenda), do te mjere da postoji mišljenje, i to ne samo u SAD-u nego i u zemljama Zapadne Europe, da je medicinsko pravo u velikoj mjeri djelo sudske prakse. Posebno se to odnosi na područje odgovornosti zdravstvenih radnika gdje su sudovi, tumačeći i prilagođavajući opća pravna pravila, tijekom vremena izgradili moderni sustav odgovornosti medicinskih radnika. ${ }^{43}$

Pravna znanost utječe na zakonodavca, na sudsku/arbitražnu praksu, na stvaranje i odgoj pravnika, ali i ostalih djelatnika. Metode provedbe toga utjecaja su neposredne (poznati pravnici i drugi znanstveni radnici sudjeluju u radu savjetodavnih tijela zakonodavca, sude kao članovi sudskih i arbitražnih vijeća, djeluju kao eksperti kada na zahtjev suda daju pravno ili drugo stručno mišljenje itd.), ili posredne (članci, studije, znanstvena djela, znanstvene kritike normativnih propisa, prijedlozi za dopune, izmjene ili donošenje novih propisa i sl.). Znanstvena djela u kojima se teorijski obrađuju pravni problemi imaju veliko značenje za razvitak pravne znanosti, izravno utječu na stručno i znanstveno uzdizanje pravničkog kadra, ali nemaju snagu izravnog pravnog izvora. Pravna znanost djeluje na sud samo snagom svoje uvjerljivosti, ali se sudac ne može u konkretnom slučaju pozvati na neko znanstveno djelo kao zakon. Iako pravna znanost uvelike utječe i na zakonodavca, ni zakonodavac se pri donošenju propisa ne poziva na stajalište doktrine, kao takve, ili istaknutih pravnika. Zato je pravna znanost danas samo neizravan izvor prava. ${ }^{44} \mathrm{~S}$ druge strane, znanstvena i stručna djela iz područja prava imaju znatan utjecaj na stvaranje primjenu i izmjene pravnih pravila. Pravna znanost komentira, sistematizira, obrađuje i analizira pojedina pitanja s gledišta postojećeg prava, de lege lata, i daje prijedloge i upućuje na rješenja koja bi zakonodavac i sudska praksa ubuduće trebali imati u vidu (de lege ferenda). Znanstvenici i stručnjaci za pitanja medicinskog prava trebali bi redovito sudjelovati u pripremnim radovima za izradu i donošenje novih propisa iz područja medicinskog prava. Usto, pozitivni pravni propisi iz područja medicinskog prava predmet su stalnog znanstvenog proučavanja i tumačenja, što pomaže utvrđivanju pravnog smisla tih propisa, a time i ispravnoj primjeni propisa u konkretnim slučajevima. Tako pravna znanost, iako nije izravni izvor prava, posredno ima veliki utjecaj na sudsku praksu i na zakonodavno reguliranje, pa joj se ne može osporiti zapaženu ulogu koju ima na razvitak medicinskog prava.

\subsection{Načela medicinskog prava}

Iz sadržajne strukture pojma medicinskog prava i temeljnih ciljeva zdravstvene politike nužno proizlaze i dvije vrste temeljnih načela medicinskog prava - načela pružanja zdravstvene zaštite i načela provođenja zdravstvene zaštite. ${ }^{45}$

U našem pravu načela pružanja zdravstvene zaštite sadržana su ponajprije u odredbama čl. 11.-15. Zakona o zdravstvenoj zaštiti. Zdravstvena zaštita stanovništva Republike Hrvatske provodi se na načelima sveobuhvatnosti, kontinuiranosti, dostupnosti i cjelovitog pristupa u primarnoj zdravstvenoj zaštiti, te specijaliziranog pristupa $\mathrm{u}$ specijalističko-konzilijarnoj i bolničkoj zdravstvenoj zaštiti (ZOZZ, čl. 10.). 
Načelo sveobuhvatnosti zdravstvene zaštite - Sveobuhvatnost zdravstvene zaštite uključuje cjelokupno stanovništvo Republike Hrvatske u provedbi odgovarajućih mjera zdravstvene zaštite u skladu sa zakonom (ZOZZ, čl. 11.), ali i sve osobe koje se zateknu ili nalaze na njezinu području. ${ }^{46}$ Ovim se načelom stvaraju ujedno i zakonske pretpostavke za realizaciju populacijske orijentacije nove zdravstvene politike koja teži očuvanju i unapređenju zdravlja, produljenju trajanja i poboljšanja kvalitete života populacije i pojedinaca. ${ }^{47}$ Načelo kontinuiranosti zdravstvene zaštite - Kontinuiranost zdravstvene zaštite postiže se ukupnom organizacijom zdravstvene djelatnosti, osobito na razini primarne zdravstvene djelatnosti koja pruža neprekidnu zdravstvenu zaštitu stanovništvu kroz sve životne dobi. U osiguranju kontinuiranog djelovanja, sustav zdravstvene djelatnosti u Republici Hrvatskoj mora biti međusobno funkcionalno povezan i usklađen (ZOZZ, čl. 12.).

Načelo dostupnosti zdravstvene zaštite - Dostupnost zdravstvene zaštite ostvaruje se takvim rasporedom zdravstvenih ustanova, trgovačkih društava koja obavljaju zdravstvenu djelatnost i zdravstvenih radnika na području Republike Hrvatske koji će omogućiti stanovništvu podjednake uvjete zdravstvene zaštite, naročito na primarnoj razini zdravstvene djelatnosti (ZOZZ, čl. 13.). Sustav treba biti dostupan svim građanima po načelu jednake dostupnosti, uvažavajući pravo na zdravlje i zdrav život kao temeljno ljudsko pravo. ${ }^{48}$

Načelo cjelovitog pristupa (u primarnoj) zdravstvenoj zaštiti - Načelo cjelovitog pristupa primarne zdravstvene zaštite osigurava se provođenjem objedinjenih mjera za unapređenjem zdravlja i prevencijom bolesti te liječenjem i rehabilitacijom (ZOZZ, čl. 14.). Zamišljeno je da osigura slobodan izbor doktora medicine i doktora stomatologije koji kod građana provodi mjere za unapređenje zdravlja i prevenciju bolesti te liječenje i rehabilitaciju do razine radne osposobljenosti. ${ }^{49}$

Načelo specijaliziranog pristupa u specijalističko-konzilijarnoj i bolničkoj zdravstvenoj zaštiti - Načelo specijaliziranog pristupa osigurava se organiziranjem i razvijanjem posebnih specijaliziranih kliničkih, javnozdravstvenih dostignuća i znanja te njihovom primjenom u praksi (ZOZZ, čl. 15.). Ovo načelo zapravo afirmira pružanje zdravstvenih usluga $\mathrm{u}$ skladu $\mathrm{s}$ razvitkom i dostignućima medicinske znanosti te materijalnim mogućnostima društva u cjelini. ${ }^{50} 51$

Treba napomenuti da se obveznim zdravstvenim osiguranjem jamče i osiguravaju pod jednakim uvjetima svim osiguranim osobama prava i obveze iz obveznog zdravstvenog osiguranja na načelima uzajamnosti i solidarnosti, a na način i pod uvjetima utvrđenim Zakonom o obveznom zdravstvenom osiguranju (vidi Zakon o obveznom zdravstvenom osiguranju, čl. 1. st. 2.). ${ }^{52}$ 


\section{Primjedbe}

${ }^{1}$ Vidi ŠEPAROVIĆ, Z., Granice rizika - Etičkopravni pristupi medicini, Zagreb, 1998., str. 3.

${ }^{2}$ Iako je medicinsko pravo relativno nova grana prava, elemente medicinskog prava možemo naći među najstarijim pravnim izvorima. U Hamurabijevu zakoniku (1729.-1686. prije Krista) nalaze se, primjerice, odredbe o profesionalnoj odgovornosti liječnika. Hipokrat (460.-377. prije Krista) je radio na etičkom i pravnom uređenju odgovornosti liječnika (Corpus hippocraticum), a treba spomenuti i Justinijanove zakone (Codex, Institutiones i Novellae) u kojima se, među ostalim, uređuje i profesionalna odgovornost liječnika, potreba ocjenjivanja težine tjelesnih povreda, uloga liječnika u vještačenju i sl. Tako i podrobnije o povijesnom razvitku medicinskog prava i sudske medicine kod ZEČEVIĆ, D. i dr., Sudska medicina i deontologija, Zagreb, 2004., str. 1.-5.; JOVANOVIĆ, LJ., Lekarska tajna - krivičnopravna razmatranja, Beograd, 1959., str. 5.-12.; JAHNKE, Leipziger Kommentar zum Strafgesetzbuch, 10. Auflage, 5. Band, Leipzig, 1988., par. 203.; Medicinska enciklopedija, knjiga 4., Zagreb, MCMLXIX, str. 294.

${ }^{3}$ Tako RADIŠIĆ, J., Medicinsko pravo, Beograd, 2004., str. 21.

${ }^{4}$ Usp. ŠEPAROVIĆ, Z., Granice rizika - Etičkopravni pristupi medicini, Zagreb, 1998., str. 5.

${ }^{5}$ Pravo i medicina imaju puno zajedničkih točaka, a u nekima se čak i preklapaju. Zajednički cilj i medicine i prava jest humanost, jer se staraju o životu i zdravlju ljudi, svatko na svoj način. RADIŠIĆ, J. (2004). Medicinsko pravo, Beograd: Fakultet za poslovno pravo: Nomos., str. 5. Snažan i ubrzani razvitak medicine i znanosti o životu otvaraju značajna pitanja koja traže i pravnu regulaciju. U pitanjima života i smrti, zdravlja i bolesti, prava pacijenata i dužnosti/odgovornosti liječnika, razumljivo je da se sve više javlja i potreba za uređivanjem tih složenih pitanja putem pravnih normi. ŠEPAROVIĆ, Z. (1998). Granice rizika - Etičkopravni pristupi medicini, 3. izmijenjeno i dopunjeno izdanje, Zagreb: Informator., str. 5. Medicina u svom ubrzanom razvitku ide, u pravilu, ispred prava, pa se nužno nameće potreba konstantnog pravnog uređenja brojnih pitanja iz područja medicine. Tako JELAČIĆ, O. (1977). O nastavi iz sudske medicine na pravnim fakultetima, Zbornik radova Pravnog fakulteta u Splitu, XIV, str. 236. Danas je uobičajeno da na području (bio)medicine pravna regulacija kasni za razvitkom društvenih odnosa što je ponajviše posljedica ekspanzije znanstveno-tehnoloških inovacija. Usp. VISKOVIĆ, N. (1995). Država $i$ pravo, Zagreb: Birotehnika., str. 219. Time nastaju i tzv. pravne praznine pa značajni i prijeporni biomedicinski odnosi nisu obuhvaćeni pravnim normama, nego su kontrolirani ponajviše normativnom sviješću općeg morala i znanstvene i medicinske deontologije. Kašnjenje pravne intervencije na području biomedicine ima značajne negativne učinke za društvo u cjelini. Tako i podrobnije o tome kod VISKOVIĆ, N. (1995). Bioetika i biomedicinsko pravo, Zbornik radova Pravnog fakulteta u Splitu, god. 32 (1-2), str. 78.-82. U cilju pravnog uređenja medicinske djelatnosti donose se novi propisi koje nameće medicinska praksa, brojna medicinska etička načela preuzimaju se i daje im se pravna snaga, pristupa se kodifikaciji prava pacijenata i sl.

6 Vidi MUJOVIĆ-ZORNIĆ, H., Pravo kao garant vršenja medicine, «Bilten Jugoslovenskog udruženja za medicinsko pravo», septembar/decembar 2001., str. 15.

${ }^{7}$ Više o tome kod ČIZMIĆ, J., Značaj medicinskog prava za uređenje odnosa u području zdravstva, rad u zborniku radova sa savjetovanja «Aktualna pravna problematika u zdravstvu», 1. kongres pravnika u zdravstvu, Topusko 9. i 10. listopada 2008., str. 13.-54

${ }^{8}$ Za tzv. medicinsko pravo u užem smislu ponekad se koristi i naziv „liječničko pravo“, jer se drži da su liječnici temeljni nositelji medicinske djelatnosti. Međutim, pretežito je mišljenje da taj naziv nije u potpunosti prikladan jer navodi na pomisao da se radi o grani prava koja se isključivo bavi statusom i radom liječnika, te tako skreće pozornost s činjenice da je cilj medicinskog prava zaštita pacijenata. Stoga se naziv medicinsko pravo drži prikladnijim jer, kao i nazivi drugih pravnih disciplina, ukazuje na djelatnost kojom se bavi, a ne na djelatnike koji tu djelatnost obavljaju. RADIŠIĆ, J., Medicinsko pravo, Beograd, 2004., str. 21.; vidi i KLARIĆ, P., Odštetno pravo, Zagreb, 2003., str. 378., bilješka 13. 
${ }^{9}$ Tako KLARIĆ, P., Odgovornost za štete u medicini, «Informator», br. 5016-5017. od 3. i 6. travnja 2002., male stranice, str. 3.

${ }^{10}$ Usp. DEUTSCH, E. - SPICKHOFF, A., Medizinrecht, Berlin, 2003., str. 3.

${ }^{11}$ Vidi LAUFS, A. - UHLENBRUCK, Handbuch des Arztrecht, Munchen, 2002., str. 4.; KLARIĆ, P., Odgovornost za štete u medicini, «Informator», br. 5016-5017. od 3. i 6. travnja 2002., male stranice, str. 3.

${ }^{12}$ Tako i podrobnije kod RADOVANČEVIĆ, LJ. - RUŠINOVIĆ SUNARA, Đ., Sadržaj i kontekst zdravstvenog prava i bioetike, referat na skupu Lošinjski dani bioetike, Mali Lošinj, Hrvatska, 13.15. lipnja 2005., str. 3.

${ }^{13}$ Usp. BABIĆ, T. - ROKSANDIĆ, S., Osnove zdravstvenog prava, Zagreb, 2006., str. 19.

${ }^{14}$ Tako ŠEPAROVIĆ, Z., Granice rizika - Etičkopravni pristupi medicini, Zagreb, 1998., str. 3.

15 Ibid., str. 3.

${ }^{16}$ Vidi ZEČEVIĆ, D. i dr., Sudska medicina i deontologija, Zagreb, 2004., str. 1.

17 Tako JELAČIĆ, O., Osnove sudske medicine za studente prava, Split, 1981., str.5.

${ }^{18}$ Usp. RADIŠIĆ, J., Medicinsko pravo, Beograd, 2004., str. 21.; RADIŠIĆ, J., Medicinsko pravo u svetu i kod nas, „Pravni informator“, 2002., br. 9. str. 1.

${ }^{19}$ Tako RAMLJAK, A. - VESEL, J., - Pravna medicina, Banja Luka, 1986., str. 17.-18. O pravnoj medicini vidi i kod MARIĆ, J. - LUKIĆ, M., Pravna medicina, Beograd, 1998.

${ }^{20}$ Tako BABIĆ, T. - ROKSANDIĆ, S., Osnove zdravstvenog prava, Zagreb, 2006., str. 20.

${ }^{21}$ Usp. ŠEPAROVIĆ, Z., Granice rizika - Etičkopravni pristupi medicini, Zagreb, 1998., str. 4.

${ }^{22}$ Ibid., str. 4.

${ }^{23} \mathrm{O}$ tzv. medicinskom kaznenom pravu podrobnije kod KOROŠEC, D., Medicinsko kazneno pravo, Ljubljana, 2004.

24 Šeparović navedene izravne izvore medicinskog prava naziva izvorima medicinskog prava u užem smislu, dok ostale pravne izvore medicinskog prava koji se odnose na «zdravstveni čin», naziva izvorima medicinskog prava u širem smislu. ŠEPAROVIĆ, Z., Granice rizika Etičkopravni pristupi medicini, Zagreb, 1998., str. 4.

${ }^{25}$ Tako KLARIĆ, P., Odštetno pravo, Zagreb, 2003., str. 379.

26 Vidi https://www.hlk.hr/hlk-o-novom-nasilju-nad-lijecnicima-trazimo-izmjene-kaznenogzakona.aspx

${ }^{27}$ Pored ovih temeljnih zakona, kao izravni izvor medicinskog prava mogli bi spomenuti i sljedeće zakone: Zakon o lijekovima («Narodne novine», broj 76/13, 90/14.), kojim se radi osiguranja djelotvornih, kvalitetnih i sigurnih lijekova kao proizvoda od posebnog značaja za zdravstvenu zaštitu ljudi utvrđuje postupak ispitivanja i stavljanja u promet, proizvodnja, označavanje, klasifikacija, promet, farmakovigilancija, oglašavanje i informiranje, nadzor nad lijekovima te provjera kakvoće lijekova (Zakon o lijekovima, čl. 1.); Zakon o medicinskim proizvodima („Narodne novine“, broj 76/13.), kojim se radi osiguranja kakvoće, sigurnosti i izvedbenih mogućnosti medicinskih proizvoda kao proizvoda od posebnog značenja za zdravstvenu zaštitu ljudi utvrđuju zahtjevi za medicinske proizvode, klinička ispitivanja medicinskih proizvoda, upis u očevidnik proizvođača medicinskih proizvoda, ocjenjivanje sukladnosti i oznaka »CE«, tijela za ocjenjivanje sukladnosti, upis u očevidnik, promet, oglašavanje, vigilancija i nadzor nad medicinskim proizvodima (Zakon o medicinskim proizvodima, čl. 1.); Zakon o zaštiti osoba s duševnim smetnjama («Narodne novine», broj 76/14.), kojim se propisuju temeljna načela, zaštita prava te uvjeti za primjenu mjera i postupanje prema osobama s duševnim smetnjama (Zakona o zaštiti osoba s duševnim smetnjama, čl. 1.); Zakon o zaštiti pučanstva od zaraznih bolesti («Narodne novine», broj 79/07, 113/08, 43/09 i 22/14 - RUSRH), kojim se utvrđuju zarazne bolesti čije je sprečavanje i suzbijanje od interesa za Republiku Hrvatsku, kao i mjere za zaštitu pučanstva od zaraznih bolesti (Zakona o zaštiti pučanstva od zaraznih bolesti, čl. 1.); Zakon o obveznom zdravstvenom osiguranju i zdravstvenoj zaštiti stranaca u Republici Hrvatskoj («Narodne novine», broj 80/13.), kojim se uređuje obvezno zdravstveno osiguranje i zdravstvena zaštita stranaca u Republici Hrvatskoj, opseg prava iz obveznog zdravstvenog osiguranja, prava i obveze nositelja obveznoga zdravstvenog osiguranja, opseg prava na zdravstvenu zaštitu te druga prava i obveze 
stranaca prema ovom Zakonu, uvjeti i način ostvarivanja i financiranja zdravstvene zaštite stranaca u Republici Hrvatskoj te prava i obveze provoditelja zdravstvene zaštite. (Zakon o obveznom zdravstvenom osiguranju i zdravstvenoj zaštiti stranaca u republici hrvatskoj, čl. 1.); Zakon o evidencijama u oblasti zdravstva («Narodne novine», broj 53/91.), koji je, u stvari, preuzeti zakon bivše SFR Jugoslavije; Zakon o presađivanju ljudskih organa u svrhu liječenja (prije: Zakon o uzimanju i presađivanju dijelova ljudskog tijela u svrhu liječenja) («Narodne novine», broj 144/12.), kojim se utvrđuju uvjeti za presađivanje ljudskih organa, te osiguranje kvalitete i sigurnosti ljudskih organa namijenjenih presađivanju u svrhu liječenja (Zakon o presađivanju ljudskih organa u svrhu liječenja, čl. 1.); Zakon o krvi i krvnim pripravcima («Narodne novine», broj 79/06., 124/11.), kojim se uređuje opskrba stanovništva Republike Hrvatske krvlju i krvnim pripravcima koja obuhvaća sustav društvenih, skupnih i individualnih mjera i aktivnosti na području planiranja, prikupljanja i testiranja krvi te proizvodnje, čuvanja i raspodjele krvnih pripravaka. Odredbe ovoga Zakona ne primjenjuju se na opskrbu lijekovima iz ljudske krvi ili ljudske plazme (Zakon o krvi i krvnim pripravcima, čl. 1.); Zakon o dobrovoljnom zdravstvenom osiguranju («Narodne novine», broj 85/06., 150/08, 71/10.), kojim se uređuju vrste, uvjeti i način provođenja dobrovoljnoga zdravstvenog osiguranja (Zakon o dobrovoljnom zdravstvenom osiguranju, čl. 1.); i dr.

${ }^{28}$ Usp. RADIŠIĆ, J., Medicinsko pravo u svetu i kod nas, „Pravni informator“, 2002., br. 9. str. 1. ${ }^{29}$ Tako KLARIĆ, P., Odštetno pravo, Zagreb, 2003., str. 379.

${ }^{30}$ Tako RADIŠIĆ, J., Medicinsko pravo u svetu i kod nas, „Pravni informator“, 2002., br. 9. str. 1. ${ }^{31}$ Usp. KLARIĆ, P., Odgovornost za štete u medicini, «Informator», br. 5016-5017. od 3. i 6. travnja 2002., male stranice, str. 3.

32 Vidi RADIŠIĆ, J., Medicinsko pravo, Beograd, 2004., str. 24.

${ }^{33}$ Hipokratova zakletva drevni je dokument i temelj je medicinske etike. Nastala je u V. stoljeću prije Krista. Hipokrat je postavio temelje moderne medicine, oslobađajući je od religije, nametanja kulta čovjeka i uvođenjem znanstvenog načela promatranja čovjeka i prirode. Hipokrat je u zakletvu unio temeljna deontološka načela koja su u to vrijeme važila u Grčkoj. Vidi NIKOLIĆ, S., Etika zdravstvenih radnika danas, «Timočki medicinski glasnik», vol. 28., 2003., broj 3-4, str. 87.-90. Polagali su je prilikom stupanja na dužnost svi liječnici koji su pripadali Hipokratovom društvu Asklepiada. Cjeloviti tekst Hipokratove zakletve objavljen je kod MILIČIĆ, V., Deontologija profesije liječnik, život čovjeka i integritet liječnika - ćudoredna raskrižja bioetike, Zagreb, 1996., Prilog B, str. XXIII. Zdravstveni djelatnici najčešće se susreću sa Ženevskom formulacijom Hipokratove zakletve, u kojoj su naglašene obveze koje, prema iskustvima iz prethodna dva svjetska rata, nisu poštivane. Usp. NIKOLIĆ, S., Etika zdravstvenih radnika danas, «Timočki medicinski glasnik», vol. 28., 2003., broj 3-4, str. 87.-90. Usvojena je u Ženevi, 1948. godine, dopunjena na 22. Skupštini Svjetskog liječničkog udruženja u Sydneyu 1968., i 35. skupštini u Veneciji, 1983. godine. Cjeloviti tekst objavljen je kod MILIČIĆ, V., Deontologija profesije liječnik, život čovjeka i integritet liječnika - ćudoredna raskrižja bioetike, Zagreb, 1996., Prilog B, str. XXIII.-XXIV. I Međunarodni kodeks liječničke etike nalaže : "Liječnik je dužan držati u tajnosti sve što zna o bolesniku, čak i nakon njegove smrti". Usvojen je u Londonu 1949. godine, te dopunjavan dva puta: na skupštini Svjetskog liječničkog udruženja u Sydneyu 1986., i Veneciji 1983. godine. Cjeloviti tekst objavljen je kod MILIČIĆ, V., Deontologija profesije liječnik, život čovjeka i integritet liječnika - ćudoredna raskrižja bioetike, Zagreb, 1996., Prilog B, str. XXIV.-XXV. Usp. DOURAKI, T., Ethical and Legal Dimensions of Medical Confidentiality in European Law of Human Rights, «Pravni život», god. LI, 2002., br. 9, str. 183.

$34 \quad$ Podatak na stranici: https://www.google.hr/search?q=hipokratova+zakletva+slika\&hl=bs\&tbm=isch\&imgil=rrjIyr5Xu dFg9M\%253A\%253BJOBeDoxDKK3fAM\%253Bhttp\%25253A\%25252F\%25252Fopusteno.rs\% 25252Fslike\%25252F2013\%25252F08\%25252Fsmesne-slike-19546\%25252Fsavremenahipokratova-

zakletva.html\&source=iu\&pf=m\&fir=rrjIyr5XudFg9M\%253A\%252CJOBeDoxDKK3fAM $\% 252$ C_\&usg=_rHN083wLa8igboTC4hgLWChP1 zg\%3D\&biw=1920\&bih=971\&ved=0ahUKEwivs 
9yJvsfVAhVEaRQKHUTUDFQQyjcIRQ\&ei=8ZmJWe_2BcTSUcSos6AF\#imgrc=9WeUil409N vKAM:

${ }^{35}$ Podrobnije kod BOŠKOVIĆ, Z., Pravni nadzor u području farmacije, JAHR, vol. 3, 2012., br. 6, str. 473.

36 Tako MEMETEAU, G., Droit medical, Paris, 1986., str. 19.

37 Tako se najvažnija pitanja i načela iz područja medicinske djelatnosti inkorporiraju i u konvencijama o ljudskim pravima kao što je, primjerice, Konvencija o zaštiti ljudskih prava $i$ temeljnih sloboda iz 1950. godine. Što se međunarodnih izvora medicinskog prava tiče, naveli bismo, primjerice, sljedeće: Konvencija Vijeća Europe o zaštiti ljudskih prava i dostojanstva ljudskog bića u pogledu primjene biologije $i$ medicine; Konvencija o ljudskim pravima $i$ biomedicini, koja je stupila na snagu 1. prosinca 1999.; Dodatni protokol uz Konvenciju o zaštiti ljudskih prava i dostojanstva ljudskog bića u pogledu primjene biologije i medicine o zabrani kloniranja ljudskih bića, koji je stupio na snagu 1. ožujka 2001.; Dodatni protokol uz Konvenciju o zaštiti ljudskih prava i dostojanstva ljudskog bića u pogledu primjene biologije i medicine u svezi presađivanja organa i tkiva ljudskog porijekla, sastavljen u Strasbourgu, 24. siječnja 2002. (vidi «Narodne novine - Međunarodni ugovori», broj 13/03.); Deklaracija Svjetske zdravstvene organizacije o promicanju prava pacijenata u Europi iz 1994. godine; Deklaracija ujedinjenih naroda o borbi protiv HIV/AIDS-a iz 2001. godine; Helsinška Deklaracija o etičkim načelima biomedicinskih istraživanja na ljudskim subjektima iz 2000. godine; Madridska deklaracija o etičkim standardima za psihijatrijsku djelatnost iz 1996.; Lisabonska deklaracija o pravima pacijenata iz 1981.; Deklaracija Svjetskog medicinskog udruženja o nezavisnosti i profesionalnoj slobodi liječnika iz 1986.; Deklaracija Svjetskog medicinskog udruženja o ljudskim pravima $i$ osobnoj slobodi medicinskih radnika iz 1985.; Deklaracija Svjetskog medicinskog udruženja o medicinskoj edukaciji iz 1987. i 1991.; Madridska deklaracija Svjetskog medicinskog udruženja o profesionalnoj autonomiji i samoregulaciji iz 1987.; Malteška deklaracija Svjetskog medicinskog udruženja o štrajku glađu iz 1991. i 1992. i dr. Treba napomenuti da međunarodni ugovori koji su sklopljeni i potvrđeni u skladu s Ustavom Republike Hrvatske i objavljeni, a koji su na snazi, čine dio unutarnjega pravnog poretka Republike Hrvatske, te su po pravnoj snazi iznad zakona. Njihove se odredbe mogu mijenjati ili ukidati samo uz uvjete i na način koji su u njima utvrđeni, ili suglasno općim pravilima međunarodnog prava (Ustav, čl. 141.).

${ }^{38}$ Spomenuli bismo, primjerice, Temeljni sporazum između Vlade Republike Hrvatske i Svjetske zdravstvene organizacije o uspostavi tehničko-savjetodavne suradnje («Narodne novine Međunarodni ugovori», broj 5/06.); Sporazum o suradnji u oblasti zdravstvene zaštite SFRJ i ČSSR («Službeni list - Međunarodni ugovori i drugi sporazumi», br. 6/64.) (sukcesija); i Konvenciju između Vlade FNRJ i Vlade NR Mađarske o sprječavanju i suzbijanju zaraznih bolesti («Službeni list - Međunarodni ugovori i drugi sporazumi», br. 9/58.) (sukcesija).

${ }^{39}$ Usp. RADIŠIĆ, J., Medicinsko pravo, Beograd, 2004., str. 25. U sudskoj praksi medicinskog prava formirani su sudski (pravni) standardi poput dužne pozornosti liječnika kao standarda profesionalnog ponašanja, liječničke greške, opća pravila o teretu dokazivanja pretrpjela su izmjene i sl.

${ }^{40}$ Vidi TRIVA, S. - BELAJEC, V. - DIKA, M., Građansko parnično procesno pravo, Zagreb, 1986., str. 37.

${ }^{41}$ Ibid., str. 37.

42 Tako VEDRIŠ, M. - KLARIĆ, P., Građansko pravo, Zagreb, 1998., str. 23.

${ }^{43}$ Usp. LAUFS, A. - UHLENBRUCK, W., Handbuch des Artzrechst, Munchen, 2002., str. 4.

44 Vidi VEDRIŠ, M. - KLARIĆ, P., o. c., str. 23.

45 Tako BABIĆ, T. - ROKSANDIĆ, S., Osnove zdravstvenog prava, Zagreb, 2006., str. 27. Što se načela provođenja zdravstvene djelatnosti tiče, Babić-Roksandić drže da su zajednička za sve zdravstvene struke jer naglašavaju specifičnosti zdravstvene djelatnosti u cjelini, te posebno navode sljedeća načela: 1/ Načelo o zdravstvenoj djelatnosti kao o djelatnosti od posebnog interesa za Republiku Hrvatsku; 2/ načelo cjeline ljudskog života; 3/ načelo humanosti zaštite prava pacijenata; 4/ načelo integriteta zdravstvenih radnika; 5/ načelo savjesnog obavljanja zdravstvene djelatnosti; 
6/ načelo adekvatne, kvalitetne i stručne zdravstvene usluge; 7/ načelo zakonitosti u obavljanju zdravstvene djelatnosti; te 8/ načelo čuvanja profesionalne tajne. BABIĆ, T. - ROKSANDIĆ, S., Osnove zdravstvenog prava, Zagreb, 2006., str. 31.-34. Šeparović navodi sljedeća načela medicinskog prava: 1/ Načelo jamstva prava čovjeka na primjerenu zdravstvenu zaštitu uz poštivanje dostojanstva pacijenta, njegove volje da slobodno izabere liječnika, slobodu odlučivanja s pravom samoodlučivanja, uz jednakost pred zakonom; 2/ načelo odgovornosti liječnika i drugih zdravstvenih djelatnika za primjeren zdravstveni postupak zaštite i liječenja; 3/ načelo o zdravstvenoj djelatnosti kao djelatnosti od interesa za RH; 4/ načelo o posebnoj brizi za ugrožene i posebno osjetljive skupine i pojedince (djeca, mlađež, trudnice, stari, žrtve rata i dr.); 5 / načelo o pravu na život u zdravu okolišu. ŠEPAROVIĆ, Z., Granice rizika - Etičkopravni pristupi medicini, Zagreb, 1998., str. 5.

${ }^{46}$ Vidi u tom smislu Zakon o zdravstvenoj zaštiti stranaca, „Narodne novine“, broj 114/97.

${ }^{47}$ Usp. JADRO, D. - HRABRIĆ, M. - KRAMARIĆ, D., Zakon o zdravstvenoj zaštiti, rad u knjizi Zbirka zdravstvenih zakona s obrazloženjem, Zagreb, 2003., str. 15.

${ }^{48}$ Ibid., str. 15.

49 Vidi BOŠKOVIĆ, Z., Sustav zdravstvene zaštite te prava i dužnosti građana u ostvarivanju zdravstvene zaštite, «Informator», broj 4838-4839., od 19. i 22. srpnja 2000. godine, str. 9.

${ }^{50}$ Ibid., str. 9.

${ }^{51}$ Tako i podrobnije o načelima kod BABIĆ, T. - ROKSANDIĆ, S., Osnove zdravstvenog prava, Zagreb, 2006., str. 27.-34. i ŠEPAROVIĆ, Z., Granice rizika - Etičkopravni pristupi medicini, Zagreb, 1998., str. 5.; KOROŠEC, D., Medicinsko kaznensko pravo, Ljubljana, 2004., str. 34.-38.; JADRO, D. - HRABRIĆ, M. - KRAMARIĆ, D., Zakon o zdravstvenoj zaštiti, rad u knjizi Zbirka zdravstvenih zakona s obrazloženjem, Zagreb, 2003., str. 14.-15.; BOŠKOVIĆ, Z., Sustav zdravstvene zaštite te prava i dužnosti građana u ostvarivanju zdravstvene zaštite, «Informator», broj 4838-4839. od 19. i 22. srpnja 2000. godine, str. 9.

$52 \mathrm{O}$ ovome više kod ČIZMIĆ, J., Medicinsko pravo - pojam izvori i značaj, Zbornik radova s međunarodnog simpozija "Medicinsko pravo u sustavu zdravstvene djelatnosti", Plitvice, 13. i 14. studenoga 2015., str. 1.-34. 
18 ZDRAVSTVENO STRUKOVNO STALEŠKO PRAVO 


\section{2/ Pojam strukovnog staleškog prava}

Struka je grana znanosti, npr. medicinska, tehnička, pravna, ekonomska itd. Struka znači i teorijsko i praktično znanje nekog područja. Pojam „struke“ nije identičan pojmu „stručne spreme“ odnosno akademskog nazivlja. Naime, akademski naziv (stručna sprema) je stupanj obrazovanja, a struka je područje u kojem je taj naziv stečen - pravo, ekonomija, građevinarstvo, arhitektura itd. ${ }^{1}$ Struka je izraz kojim se opisuje nečiji posao, poziv ili zanimanje za čije je obavljanje potrebna specifično stručno obrazovanje i osposobljavanje, čime ona dobiva svoj novi sadržaj kao profesija. Profesija je disciplinirana skupina pojedinaca koji se pridržavaju etičkih standarda i koji su prihvaćeni od strane javnosti kao posjednici posebnih znanja i vještina od priznatog obrazovnog tijela, a koja su proizašla iz istraživanja, obrazovanja i obuke na visokoj razini, i koji su spremni primijeniti svoja znanja i vještine u interesu drugih. U ovakvoj definiciji, naglašava se: a) postojanje i djelovanje po etičkim standardima, b) posjedovanje posebnih znanja i vještina, c) znanstveno utemeljenje, d) djelovanje u društvenu korist. ${ }^{2}$ Kao sinonimi koriste se riječi poziv ili zvanje. Zdravstvene struke zbog specifičnosti izobrazbe, uvjeta i načina obavljanja poslova, te utvrđenih standarda i normativa obavljanja djelatnosti, kao i načina organiziranja iste nazivaju se zdravstvene profesije. Zdravstvene profesije karakterizira da su načini obavljanja djelatnosti istih profesija propisani zakonskom normom. Postoje stroga zakonska pravila koja definiraju izobrazbu, stručno osposobljavanje i stručno usavršavanje, kao i samostalno obavljanje predmetnih profesija.

Sastavni dio medicinskog prava je i strukovno zdravstveno pravo. ${ }^{3}$ Strukovno medicinsko pravo tiče se u prvom redu zdravstvenih profesija, odnosno pripadnika tih profesija. Strukovno pravo predstavlja skup pravnih pravila kojima se definiraju i utvrđuju struke, tj. profesije u sustavu zdravstva, djelatnosti, uvjeti i načini obavljanja djelatnosti u zdravstvu, ovlaštenja, dužnosti i odgovornosti u obavljanju zdravstvenih djelatnosti, način organizacije $\mathrm{i}$ zaštita prava pripadnika struke, odnosno profesije u sustavu zdravstva, međusobni odnosi zdravstvenih radnika i dr. Predmet proučavanja strukovnog prava je, među ostalim, propisivanje standarda navedenih profesija, uvjeta pod kojim se obavljaju djelatnosti istih profesija, te kriterija kojima moraju udovoljavati pripadnici tih profesija.

Vlada Republike Hrvatske je na sjednici 29. svibnja 2013. godine, temeljem članka 72. stavka 1. Zakona o reguliranim profesijama i priznavanju inozemnih stručnih kvalifikacija ("Narodne novine", br. 124/09, 45/11, sada 82/15), donijela popis reguliranih profesija u Republici Hrvatskoj. U području zdravstva to su primjerice: doktor medicine, doktor dentalne medicine, ljekarnik, primalja, medicinska sestra/tehničar, medicinski biokemičar, fizioterapeut, sanitarni inženjer, prvostupnik medicinskolaboratorijske dijagnostike, prvostupnik radiološke tehnologije, prvostupnik radne terapije i dr. 
Uvod: Pojam strukovnog staleškog prava

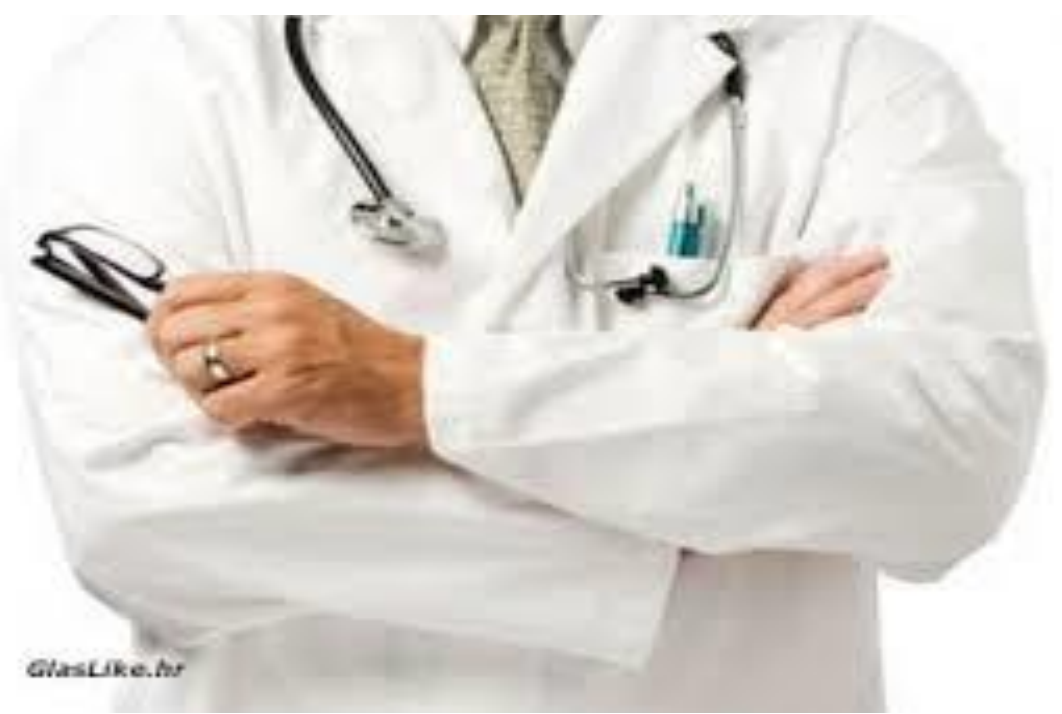

Slika 2: $\mathrm{FN}^{4}$

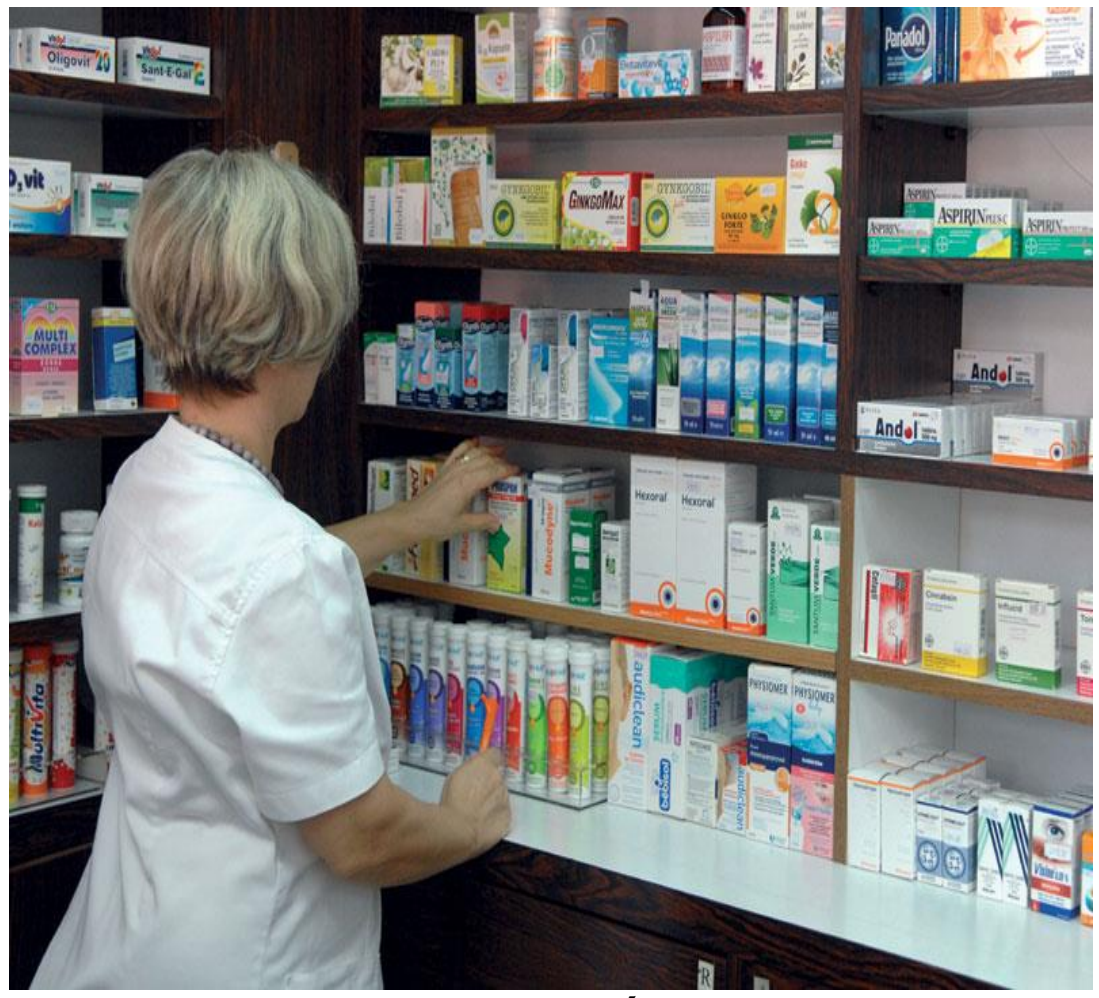

Slika 3: $\mathrm{FN}^{5}$ 


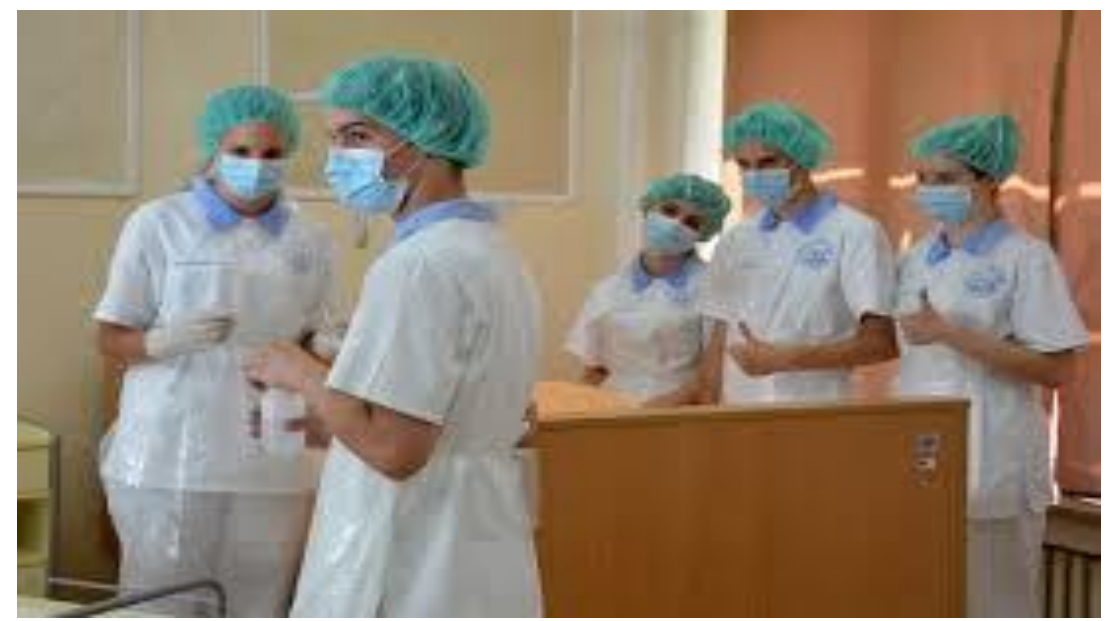

Slika 4: $\mathrm{FN}^{6}$

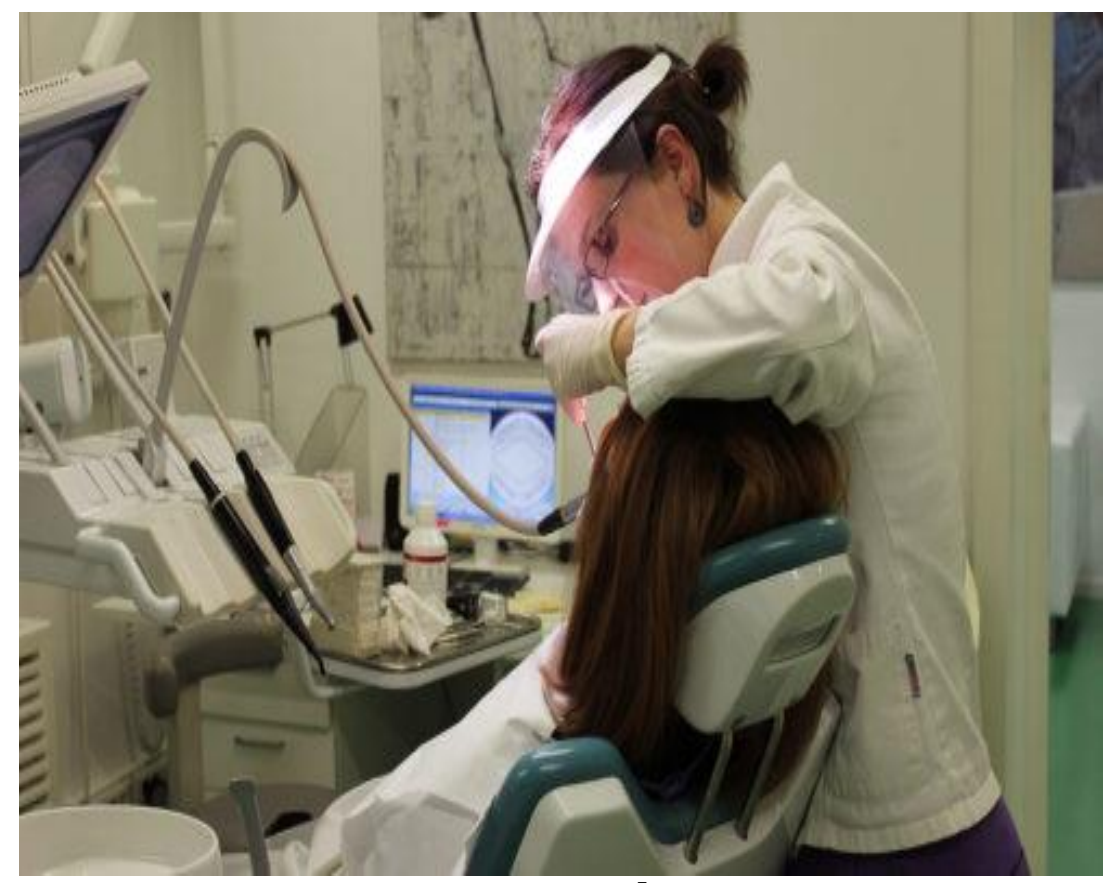

Slika 5: $\mathrm{FN}^{7}$

Pravni izvori strukovnog medicinskog prava jesu u prvom redu tzv. strukovni zakoni, kojima se jasno i nedvojbeno definiraju prije svega: zdravstvene djelatnosti; ovlaštenici obavljanja zdravstvenih djelatnosti - zdravstveni radnici; svi opći i posebni uvjeti kojima moraju udovoljiti zdravstveni radnici (obrazovanje, osposobljavanje i usavršavanje); prava i odgovornosti zdravstvenih radnika u samostalnom obavljanju djelatnosti; način 
organiziranja zdravstvenih radnika radi zaštite svojih interesa i interesa profesije u obavljanju navedenih djelatnosti i dr.

Povijesno gledano stalež je, u pravilu, društveni sloj koji se zasniva na ugledu i časti. Tragovi staleške podjele u suvremenom su se društvu održali u nekim oblicima profesionalnih ili znanstvenih ustanova (pa i komora zdravstvenih radnika u području zdravstva) ili strukovnih udruga koje primjenjuju zahtjevne kriterije primanja u članstvo (primjerice, Hrvatski liječnički zbor, Hrvatska udruga bolničkih liječnika i sl.). Stalež možemo definirati i kao skupinu ljudi koji imaju isto zvanje (primjerice, obrtnika, liječnika, odvjetnika). Osim propisa koje donosi država, izvor staleškog zdravstvenog prava su i propisi koje, uz eventualno odobrenje nadležnog organa (ministarstva), donose razne profesionalne udruge i organizacije zdravstvenih radnika (primjerice, liječnička, ljekarnička, stomatološka ili sestrinska komora, udruga inženjera medicinske radiologije i dr.), ${ }^{8}$ deklaracije međunarodnih strukovnih organizacija i sl., a kojima se uređuje ponašanje zdravstvenih radnika prilikom obavljanja svoje profesije, međusobni odnosi članova pojedine profesije/komore, odnos prema pacijentima, društvenoj zajednici, kao i druga prava i dužnosti. ${ }^{9}$ Staleško zdravstveno pravo rezultat je samostalnosti strukovnih organizacija unutar zdravstvenog sustava koje na temelju zakonskih ovlasti mogu donositi podzakonske opće akte kojima reguliraju temeljna pitanja iz područja njihove struke. ${ }^{10}$ Propisi staleškog prava ograničenog su dosega jer važe isključivo za članove komore/udruge određene zdravstvene profesije, a ne obvezuju pacijente i treće osobe, ali im ipak mogu jamčiti određena prava. ${ }^{11}$ Staleško pravo pojavljuje se najčešće u obliku statuta strukovnih komora, ${ }^{12}$ te pravila pojedine medicinske profesije, odnosno kodeksa etike i/ili deontologije pojedine zdravstvene profesije i struke.

\section{Primjedbe}

1 Tako Što se smatra radnim iskustvom u struci?, IUS-INFO, podatak na stranici: http://www.iusinfo.hr/DailyContent/Topical.aspx?id=21741.

${ }^{2}$ Usp. UHLIR, Ž., Promišljanje o dilemi - komora vs udruga vještaka, poglavlje magistarskog rada na Ekonomskom fakultetu u Zagrebu, 2011., podatak na stranici: http://www.sudskivjestaci.hr/fdsak3jnFsk1Kfa/inicijative/Promisljanje_o_dilemi-komora_vs_udruga_vjestaka.pdf.

${ }_{3}^{3}$ Vidi ČIZMIĆ, J., BABIĆ, T., ROKSANDIĆ VIDLIČKA, S, Liječničko pravo, Split, 2009., neobjavljeno, str. 29-30.

${ }^{4}$ Podatak na stranici:

https://www.google.hr/search?q=doktor+medicine+slika\&hl=bs\&tbm=isch\&tbo=u\&source=univ \&sa=X\&ved=0ahUKEwi2h4SJq8fVAhWIWRoKHXFuAMAQ7AkIRA\&biw=1920\&bih=971.

${ }^{5}$ Podatak na stranici:

https://www.google.hr/search?q=apotekar+slika\&hl=bs\&tbm=isch\&tbo=u\&source=univ\&sa=X\& ved=0ahUKEwi6jrv2q8fVAhXLXhoKHYafCwAQ7AkINg\&biw=1920\&bih=971\#imgdii=GDeT zglG9yt0lM:\&imgrc=z0nOQSHWMjsT5M:

${ }^{6}$ Podatak na stranici:

https://www.google.hr/search?q=medicinska+sestra+slika\&hl=bs\&tbm=isch\&tbs=rimg:CSx_1gQ samheLIjhXyUqdJ11PFkePA0VN9UgZRG0zWnCRrwCSFNM5LxIiwtAK4GBz9DvzBnTBnaS 38y8GRbj9AJsCDyoSCVfJSp0nXU8WEQiuvH2QCwM6KhIJR48DRU31SBkROQ5-

MYA8hAUqEglEbTNacJGvABHTzj0ohq4v8SoSCZIU0zkvEiLCEWMg1sm9c0XxKhIJ0ArgYH P0O_1MR_1_1oQevrALzAqEgkGdMGdpLfzLxGz6NsFs77xwioSCQZFuP0AmwIPEbAN61CH 
nO_1F\&tbo=u\&sa=X\&ved=0ahUKEwiko7T6rMfVAhVGrxoKHbDhDFEQ9C8IHA\&biw=1920 \&bih=971\&dpr=1.

${ }^{7}$ Podatak na stranici:

https://www.google.hr/search?q=dentist+slika\&hl=bs\&tbm=isch\&tbo=u\&source=univ\&sa=X\&v ed=0ahUKEwih1fnlrcfVAhXGmBoKHRomB18QsAQIZA\&biw=1920\&bih=971\#imgrc=m8wR5 -LjxKutYM:

${ }^{8}$ U Republici Hrvatskoj djeluju Hrvatska liječnička komora, Hrvatska stomatološka komora, Hrvatska ljekarnička komora, Hrvatska komora medicinskih sestara, Hrvatska komora medicinskih biokemičara, koje su strukovne organizacije zdravstvenih radnika sa statusom pravne osobe (arg. ZOZZ, čl. 189.). Ako posebnim zakonom nije drukčije određeno, zdravstveni radnici visoke stručne spreme i medicinske sestre koji obavljaju zdravstvenu djelatnost na području Republike Hrvatske, obvezno se učlanjuju u navedene komore (ZOZZ, čl. 190.).

${ }^{9}$ U tom smislu RADIŠIĆ, J., Medicinsko pravo, Beograd, 2004., str. 23.

${ }^{10}$ Vidi BABIĆ, T. - ROKSANDIĆ, S., Osnove zdravstvenog prava, Zagreb, 2006., str. 41.

11 Tako RADIŠIĆ, J., Medicinsko pravo, Beograd, 2004., str. 23.

12 Vidi Statut Hrvatske liječničke komore, («Narodne novine» br. 47/04.); Statut Hrvatske stomatološke komore («Narodne novine», broj 44/04., 69/06.); Statut Hrvatske ljekarničke komore, od 27. svibnja 2004. godine; Statut Hrvatske komore medicinskih sestara, od 1. listopada 2003. (izmjene 18. rujna 2005.); Statut Hrvatske komore medicinskih biokemičara, od 29. studenog 1994. godine, izmijenjen 23. siječnja 2004. godine. 


\section{3/ Zdravlje, zdravstvena djelatnost i zdravstvena zaštita}

\section{1 "Zdravlje"}

- je široki pojam kojeg je teško definirati i kojeg se može tumačiti na mnogo načina. U idealnom bi slučaju medicina trebala ići u smjeru postizanja simbioze objektivnog dobrog zdravstvenog stanja i subjektivnog doživljaja, tj. da su ljudi de facto zdravi i da se tako i osjećaju. Iskustvo nam je već pokazalo da se pojam zdravlja ne može shvaćati samo po definiciji Oxfordovoga rječnika - kao "stanje odsutnosti bolesti ili ozljede." Zdravlje je u većini slučajeva jedno individualno iskustvo vlastitog psihofizičkog stanja, te se često ne može testirati, dijagnosticirati, kalkulirati, izmjeriti ili izvagati. ${ }^{1}$ Čovjek se smatra zdravim samo onda ako je zdrav u sve tri dimenzije: psihološkoj, tjelesnoj i socijalnoj. ${ }^{2}$ U znakove zdravlja svakako upisujemo pozitivno raspoloženje, optimizam u suočavanju s problemima kao i toplina i zadovoljstvo u odnosu s drugim ljudima. Osjećaj sigurnosti, bezbrižnost u stanovanju, školovanju, radu kao i mogućnost uživanja u općim životnim dobrima znatno i nedvojbeno produljuju životni vijek. Zdrav okoliš, kvalitetno zadovoljena potreba za pitkom vodom, odgovarajuća prehrana, uvjeti stanovanja, upotreba sigurnih tehničkih pomagala osiguravaju zdravu okolinu tj. omogućavaju razvoj pojedinca i društva u cjelini. ${ }^{3}$

Postoji više aspekata zdravlja kao što su:

- Fizičko zdravlje - odražava mehaničko funkcioniranje tijela,

- Mentalno zdravlje - odražava sposobnost jasnog i koherentnog mišljenja,

- Emocionalno zdravlje - omogućava da se prepoznaju i adekvatno iskaže emocije (radost, ljutnja, uživanje), što podrazumijeva i adekvatno reagiranje na stres,

- Socijalno zdravlje - označava sposobnost uspostavljanja i održavanja socijalnih kontakata s ljudima,

- Zdravlje zajednice - kojim se ističe neraskidiva veza individualnog zdravlja i svega onoga što nas okružuje.

Faktori koji utječu na zdravlje su mnogobrojni i raznovrsni, a u osnovi se mogu podijeliti na: endogene (faktore nasljeđa) i egzogene (socio-ekonomski, sociokulturni, stil života, fizičko-biološka sredina). ${ }^{4}$

Zato i jest najbolja, poznata definicija Svjetske Zdravstvene Organizacije (SZO) koja je zdravlje definirala kao stanje potpunog fizičkog, psihičkog i socijalnog blagostanja, a ne samo odsustva bolesti i iznemoglosti. "Zdravlje nije puko nepostojanje bolesti, već stanje potpunog fizičkoga, mentalnoga, duhovnoga i socijalnoga blagostanja." (Deklaracija Svjetske zdravstvene organizacije, Alma Ata, 1974.).

Poznato je da zdravlje stanovništva predstavlja društveno bogatstvo i u pravnoekonomskom smislu. Brinući o zdravlju ljudi, medicina održava njihovu radnu sposobnost, pridonosi ekonomskom razvitku društva. Stoga se zdravlju svuda u svijetu 
posvećuje osobita pažnja, a državi i njezinim tijelima nije svejedno tko i kako tu djelatnost obavlja. ${ }^{5}$

Svake se godine 7. travnja obilježava Svjetski dan zdravlja, kad je na taj dan 1948. održana prva skupština Svjetske zdravstvene organizacije, a prvi predsjednik bio je dr. Andrija Stampar.

\section{Svjetska zdravstvena organizacija (WHO) - definicija zdravlja}

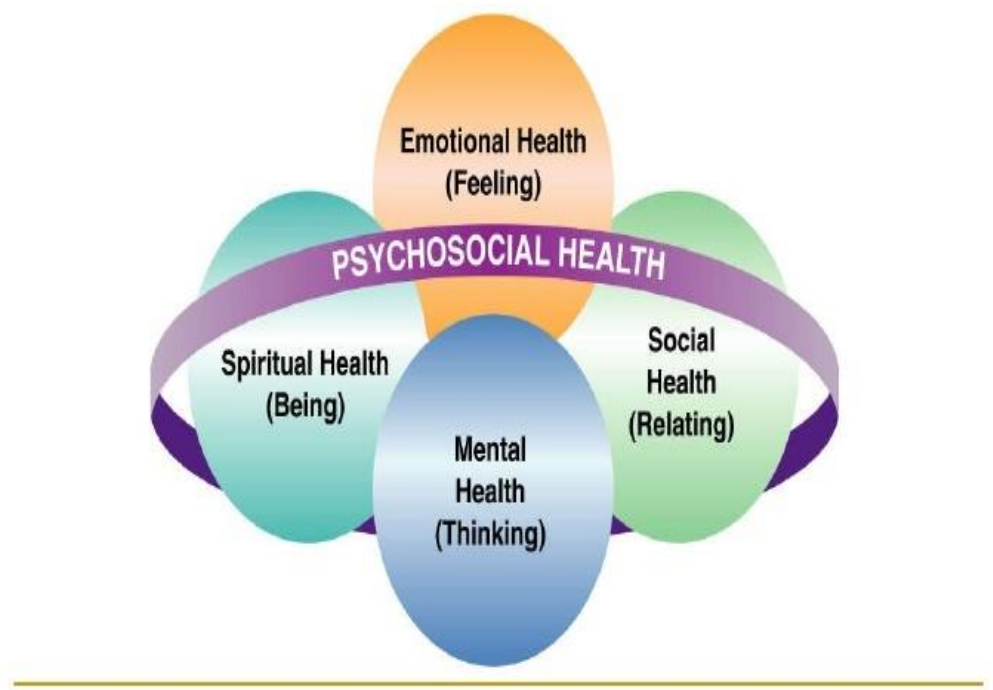

Slika 6: $\mathrm{FN}^{6}$

\subsection{Zdravstvena zaštita}

- u smislu Zakona o zdravstvenoj zaštiti obuhvaća sustav društvenih, skupnih i individualnih mjera, usluga i aktivnosti za očuvanje i unapređenje zdravlja, sprečavanje bolesti, rano otkrivanje bolesti, pravodobno liječenje te zdravstvenu njegu i rehabilitaciju (ZOZZ, čl. 2.). ${ }^{7}$ Svaka osoba ima pravo na zdravstvenu zaštitu i na mogućnost ostvarenja najviše moguće razine zdravlja, u skladu s odredbama ovoga Zakona i Zakona o obveznom zdravstvenom osiguranju. Svaka je osoba obvezna brinuti se o svome zdravlju. Nitko ne smije ugroziti zdravlje drugih. Svaka osoba je u hitnim slučajevima obvezna pružiti prvu pomoć ozlijeđenoj ili bolesnoj osobi i omogućiti joj pristup do hitne medicinske pomoći (ZOZZ, čl. 3.). 


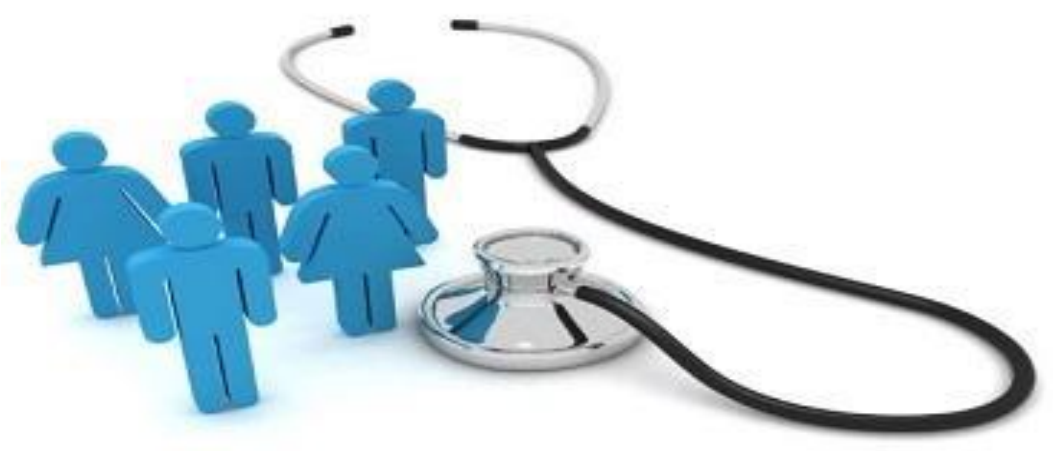

\section{Slika 7: $\mathrm{FN}^{8}$}

Pravo na zdravstvenu zaštitu je i ustavna kategorija. Ustav Republike Hrvatske svakom jamči pravo na zdravstvenu zaštitu u skladu sa zakonom (Ustav, čl. 59.). Od najstarijih vremena javna briga o zdravlju vezivala se uz zaštitu zajednice od različitih bolesti koje pogađaju njezine članove, a nakon Drugog svjetskog rata briga o zdravlju i zdravstvenim službama uvodi se u pravne akte te se osmišljavaju i nova prava. ${ }^{9}$ Primjerice, uvodi se "pravo na zdravlje" (kojega naš Ustav ne koristi), kao i "pravo na zdrav život”. Ustav tako propisuje da svatko ima pravo na zdrav život te da je svatko dužan, u sklopu svojih ovlasti i djelatnosti, osobitu skrb posvećivati zaštiti zdravlja (Ustav, čl. 70.).

Zdravstvena zaštita u Republici Hrvatskoj temelji se na načelima sveobuhvatnosti, kontinuiranosti, dostupnosti i cjelovitog i specijaliziranog pristupa svakom pojedinom primatelju zdravstvenih usluga, pacijentu, odnosno bolesniku. Zdravstvena zaštita ostvaruje se obavljanjem zdravstvene (ih) djelatnosti.

\subsection{Zdravstvena djelatnost}

- jedna je od najvažnijih ljudskih djelatnosti jer štiti i unaprjeđuje najveće ljudske (ali i društvene) vrijednosti - život i zdravlje (ZOZZ, čl. 25.).

Zdravstvena djelatnost jedna je od najstarijih čovjekovih djelatnosti. Ona je prvobitno podrazumijevala isključivo liječenje ili ublažavanje bolesti, tjelesnih oštećenja ili patnje (tzv. terapija). Otuda je i potekao izraz liječnik, koji označava osobu što tu djelatnost obavlja. Liječenje je i danas temeljni dio medicinske djelatnosti, ali se ona u njemu ne iscrpljuje nego obuhvaća i druge mjere. To su, ponajprije, sve one radnje i postupci kojima je cilj otkrivanje i prepoznavanje bolesti kod određenih ljudi (tzv. dijagnoza). Na dijagnozu se nadovezuje i prognoza, tj. predviđanje daljeg razvitka i krajnjeg ishoda bolesti. Osim toga, i zaštita ili sprječavanje od bolesti (tzv. prevencija) spada, također, u medicinsku djelatnost. Tako se smatra da suvremena medicina ima četiri zadatka: 1) liječenje i suzbijanje bolesti; 2) omogućavanje bolesnicima da se vrate u normalan život; 3) sprječavanje pojave bolesti; 4) poboljšanje zdravlja zdravih osoba. ${ }^{10}$ 
I ZOZZ određuje pojam zdravstvene djelatnosti na sličan način: Zdravstvena djelatnost je djelatnost od interesa za Republiku Hrvatsku koja se obavlja kao javna služba i koju po stručno-medicinskoj doktrini i uz uporabu medicinske tehnologije obavljaju zdravstveni radnici pri pružanju zdravstvene zaštite, pod uvjetima i na način propisan ZOZZ-om (ZOZZ, čl. 24. st. 1.). Iznimno, zdravstvenu djelatnost na području promicanja zdravlja, prevencije bolesti te zaštite mentalnoga zdravlja mogu obavljati i nezdravstveni radnici pod uvjetima i na način koji pravilnikom, uz prethodno pribavljeno mišljenje nadležnih komora, propisuje ministar (ZOZZ, čl. 24. st. 2.). Zdravstvena djelatnost je u funkciji ostvarivanja zdravstvene zaštite i ima status javne službe od posebnog interesa za Republiku Hrvatsku, koju po stručno-medicinskoj doktrini i uz uporabu medicinske tehnologije obavljaju zdravstveni radnici. ${ }^{11}$ Zdravstvena djelatnost razlikuje se od svake druge profesije po tome jer je usmjerena na tijelo i dušu čovjeka pa se, za razliku od drugih profesija, u zdravstvenoj djelatnosti štete nije uvijek moguće izbjeći pošto je to djelatnost koja je, već po samoj svojoj prirodi, skopčana s opasnostima koje se ne daju uvijek obuzdati. ${ }^{12}$

Osnovni postulat $\mathrm{u}$ obavljanju zdravstvene djelatnosti jest da ista mora biti organizirana tako da stanovništvu uvijek bude osigurana i dostupna hitna medicinska pomoć, uključujući i hitni medicinski prijevoz. Efikasno organiziranje obavljanja zdravstvene djelatnosti preduvjet je funkcioniranja zdravstvenog sustava svake pojedine države. ${ }^{13}$ ZoZZ određuje da se zdravstvena djelatnost u Republici Hrvatskoj obavlja se na primarnoj, sekundarnoj i tercijarnoj razini te na razini zdravstvenih zavoda (ZoZZ, čl. 25.)._Primarna zdravstvena zaštita je najčešći oblik kontakta stanovništva sa zdravstvenom službom. Ona objedinjuje djelatnost opće/obiteljske medicine, djelatnost za zdravstvenu zaštitu dojenčadi i male djece, stomatološku djelatnost i djelatnost hitne medicinske pomoći. U širem smislu primarnu zdravstvenu zaštitu pružaju i timovi za zdravstvenu zaštitu žena, patronažna djelatnost, ustanove za zdravstvenu njegu u kući te preventivna školska medicina i epidemiologija. Za razliku od primarne razine, zdravstvena djelatnost na sekundarnoj razini obuhvaća specijalističko-konzilijarnu i bolničku djelatnost te je usmjerena isključivo na dijagnostiku i liječenje. Liječnici specijalisti raznih specijalnosti samostalno obavljaju poslove više razine zdravstvene zaštite. Na zahtjev liječnika primarne zdravstvene zaštite, oni obavljaju tražene specijalističko-konzilijarne preglede. U praksi to izgleda na način da liječnik primarne zdravstvene zaštite nakon obrade upućuje bolesnika na specijalističko-konzilijarni pregled s uputnicom i naznakom koje konzilijarno mišljenje ili zahvat traži. Konzilijarni liječnik daje mišljenje i nalaz nakon provedenoga dijagnostičkog postupka, mišljenje o terapijskom ili rehabilitacijskom postupku te mišljenje o prognozi bolesti i stanju. Zdravstvena djelatnost na tercijarnoj razini obuhvaća najsloženije oblike zdravstvene zaštite iz specijalističko-konzilijarnih i bolničkih djelatnosti tijekom obrade i terapijskih zahvata, najčešće, bolesnika s teškim i rijetkim bolestima, koji tu mogućnost ne mogu ostvariti na primarnoj i sekundarnoj razini. Tercijarna zdravstvena zaštita pruža se u klinikama, kliničkim bolnicama i kliničkim bolničkim centrima te državnim zdravstvenim zavodima (za javno zdravstvo, za transfuzijsku medicinu, za zaštitu od zračenja, za toksikologiju, za medicinu rada itd.) Ujedno ova djelatnost obuhvaća znanstveno - istraživački rad i izvođenje nastave na fakultetima zdravstvenog usmjerenja (vidi ZoZZ, čl. 26.-33.). 


\section{Primjedbe}

${ }^{1}$ Što je zdravlje i kako biti zdrav?, http://savjetovaliste.tvz.hr/briga-o-zdravlju/sto-je-zdravlje-ikako-biti-zdrav/.

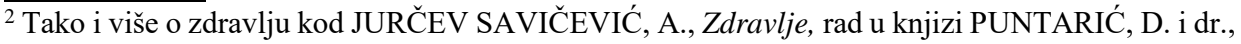
Javno zdravstvo", Medicinska naklada, Zagreb, 2015., str. 24.-26.

3 Što je zdravlje?, https://uppt.hr/savjeti-mainmenu-44/zdravlje-mainmenu-62/353-to-je-zdravlje.

4 Vidi Zdravlje $i$ faktori koji na njega utječu, podatak na web stranici http://www.izjzv.org.rs/app/soc.katedra/Zdravljeifakorikojinanjegauticu.pdf.

5 Tako BOŠKOVIĆ, Z., Profesionalno obrazovanje zdravstvenih djelatnika, „Informator“, broj 4987-4990. od 22.,26. i 29. prosinca. 2001. i 2.siječnja. 2002., str. 61.

${ }^{6}$ Podatak na stranici:

https://www.google.hr/search?q=zdravlje+slika\&hl=bs\&tbm=isch\&imgil=i0NRkjbEcPyd6M\%25 3A\%253BWEKTkBSgRKqa2M\%253Bhttp\%25253A\%25252F\%25252Fwannabemagazine.com $\% 25252$ Fsreca-izvor-

zdravlja\%25252F\&source=iu\&pf=m\&fir=i0NRkjbEcPyd6M\%253A\%252CWEKTkBSgRKqa2

$\mathrm{M} \% 252 \mathrm{C} \&$ \&usg= -

bD254k1Fd3ThLCpz4Ev5pw37IM\%3D\&biw=1920\&bih=971\&ved=0ahUKEwjy0tfUsMfVAhX LXBQKHQQcAigQyjcIQw\&ei=4IuJWfLiDMu5UYS4iMAC\#imgdii=JxHEMWFlsxcwUM:\&im grc=zZyE5vf NZWKEM:

${ }^{7}$ Više o tome Enciklopedijski članak: zdravstvena zaštita, on-line izdanje Hrvatske enciklopedije Leksikografskog zavoda Miroslav Krleža, http://www.enciklopedija.hr/natuknica.aspx?ID=67020.

${ }^{8}$ Fotografija na stranici:

https://www.google.hr/search?q=zdravstvena+za\%C5\%A1 tita\&tbm=isch\&imgil=owCa0kLQRZ Y 1M\%253A\%253Bm04EBm7B4kgSwM\%253Bhttps\%25253A\%25252F\%25252Fwww.zastita. eu\%25252Fstrucni-clanci\%25252Fzastita-na-radu\%25252Fzdravstvena-zastita-na-radu-

$112 \&$ source $=$ iu \&pf $=$ m\&fir $=$ owCa0kLQRZY_lM\%253A\%252Cm04EBm7B4kgSwM\%252C_\&u

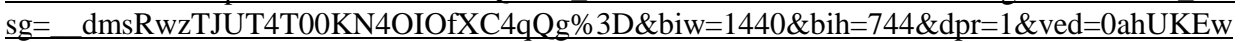
iZj9Harc_UAhUBXBoKHXQtCGIQyjcIWw\&ei=pp5KWdmkL4G4afTaoJAG\#imgrc=owCa0kL QRZY 1M:

${ }^{9}$ Vidi BAČIĆ, A., Leksikon Ustava Republike Hrvatske, Pravni fakultet Sveučilišta u Splitu, Split, 2000., str. 284.

${ }^{10}$ No, zdravstvena djelatnost obuhvaća i radnje zdravstvenih radnika kojima nije cilj nijedan od navedenih zadataka, koje se izvode na zdravim ljudima. Tu spadaju, primjerice: kozmetička ili estetska operacija, sterilizacija, vještačko oplođenje, prekid trudnoće bez medicinske indikacije, naučni medicinski ogledi na čovjeku. RADIŠIĆ, J., Medicinsko pravo, „Nomos“, beograd, 2004., str. 29.-30.

${ }^{11}$ Tako BOŠKOVIĆ, Z., Osnivanje $i$ organiziranje ljekarničke djelatnosti - pravni aspekti, „Hrvatska pravna revija“, godina IX., 2009., broj 7-8, str. 33.

${ }^{12}$ Usp. RADIŠIĆ, J., Medicinsko pravo, „Nomos“, beograd, 2004., str. 168.

13 Vidi BODNARUK, S. - ČIZMIĆ, J. - HRABAČ, B. - HUSEINAGIĆ, S., Komentari zdravstvenih zakona, knjiga 1., Privredna štampa, Sarajevo, 2011., str. 118. 
ZDRAVSTVENO STRUKOVNO STALEŠKO PRAVO

P. Bačić \& B. Brezovnik 



\section{1/ Pojam}

\subsection{Zdravstveni radnici}

Za obavljanje poslova u bilo kojoj djelatnosti nužni su odgovarajući kadrovi. Zdravstvena djelatnost pretpostavlja posebna medicinska znanja te je mogu obavljati samo osobe koje su za to stručno osposobljene i koje ispunjavaju zakonske uvjete. Razina stručne spreme, pripravnički staž, stručni ispit, stručno usavršavanje i druga pitanja koja se tiču zdravstvenih radnika i zdravstvenih suradnika uređena su odgovarajućim zakonskim propisima. ${ }^{1}$ Medicinski su kadrovi, bez obzira na tehničko-tehnološka dostignuća, uvijek glavni nositelji i predstavnici medicine svoga doba i ondje gdje tih kadrova nema dovoljno, nedostatna je i medicina. ${ }^{2}$ Ljudski resursi imaju centralnu ulogu u unapređenju sektora zdravstva i ključni su nosioci uspješne implementacije reforme zdravstvenih sistema. Postoje mnogi dokazi da broj, osposobljenost i kvaliteta zdravstvenih radnika, njihova regionalna distribucija koreliraju s pozitivnim ishodima preživljavanja djece i majki, kardiovaskularnih bolesti, s pokrivenošću imunizacijom, većim obuhvatom primarnom zdravstvenom zaštitom itd. ${ }^{3}$ Ipak, kadrovski potencijal ne može se danas gledati odvojeno od mogućnosti opreme jer su ta dva entiteta međusobno isprepletena i izuzetno su jako međusobno ovisna. Koliko je važna tehnološka opremljenost, toliko je važna i uloga samoga kliničara $u$ racionalnoj primjeni dostupne tehnologije. ${ }^{4}$ Profesionalna sloboda zdravstvenih radnika i autonomija njihove profesije potiču iz same prirode zdravstvene djelatnosti i povijesno su utemeljene kroz pravo koje se priznaje tom "cehu“ da posebnim pravilima, koje sami donose, uređuje postupanje svojih pripadnika. ${ }^{5}$ Glavna obveza zdravstvenog radnika je pružanje zdravstvene usluge, tj. poduzimanje svih zahvata i terapijskih mjera na ljudskom tijelu, da bi se bolest, patnje, ozljede ili duševne smetnje spriječile, prepoznale, izliječile ili ublažile. Terapija podrazumijeva izbor (konkretne) metode liječenja, a u praksi se naziva i liječenje u užem smislu. U načelu, zdravstveni radnik autonoman je u izboru metode liječenja, ali to uvijek mora biti u skladu sa stručno medicinskom doktrinom, prema pravilima zdravstvene struke i uz obvezno poštovanje moralnih i etičkih načela zdravstvene struke. Ako postoje različite metode liječenja, preporuča se ona općeprihvaćena, odnosno ona s kojom zdravstveni radnik ima najveće iskustvo. ${ }^{6}$

Pojam „zdravstveni radnik“ obuhvaća sve fizičke osobe koje se bave medicinskom djelatnošću kao svojim stalnim zanimanjem, tj. profesionalno. Da bi netko imao status zdravstvenog radnika, treba obavljati poslove zdravstvene djelatnosti. ${ }^{7}$ Zdravstvena djelatnost pretpostavlja posebna medicinska znanja. Mogu je obavljati samo osobe koje su za to stručno osposobljene i koje ispunjavaju zakonske uvjete. Prema odredbama ZOZZ-a, zdravstveni radnici su osobe koje imaju obrazovanje zdravstvenog usmjerenja i neposredno u vidu zanimanja pružaju zdravstvenu zaštitu stanovništvu, uz obvezno poštovanje moralnih $\mathrm{i}$ etičkih načela zdravstvene struke (ZOZZ, čl. 124.). ${ }^{8}$ Pojednostavljeno, zdravstveni radnik je osoba koja profesionalno obavlja neki dio zdravstvene djelatnosti. Zdravstveni radnici u Republici Hrvatskoj su liječnici odnosno doktori medicine, doktori stomatologije, diplomirani inženjeri medicinske biokemije, 
magistri farmacije, medicinske sestre, medicinski tehničari, fizioterapeuti i primalje, sanitarni inženjeri, radiološki tehnolozi, radni terapeuti, laboranti te druge osobe koje su to posebnim propisima određene. Sustav zdravstva prepoznao je jedanaest zdravstvenih profesija, svaka sa svojim zakonitostima i utvrđenjima, a sve s ciljem nesmetanog, sveobuhvatnog i trajnog ostvarivanja cilja pružanja zdravstvene zaštite i zaštite zdravlja svakog pojedinca. Kompleksnost poslova profesija kao i potreba realiziranja cilja osiguranja odgovarajuće zdravstvene zaštite svakom pojedincu, rezultirala je nužnošću da se zdravstvene djelatnosti provode i organiziraju u timskom radu zdravstvenih radnika. Svaka profesija nije dostatna sama za sebe, niti se samostalnim obavljanjem pojedine profesije mogu ostvariti zadani ciljevi pružanja zdravstvene zaštite, t $\mathrm{j}$. pružanja usluge i/ili pomoći svakom pojedinom pacijentu. ${ }^{9}$ Dakle, nositelji svake od nabrojenih profesija obavljaju dio zdravstvene djelatnosti i sve su one od javnog interesa za Republiku Hrvatsku sukladno posebnim zakonima koje ih određuju. $\mathrm{Na}$ prava i dužnosti zdravstvenih radnika te druga pitanja u vezi s obavljanjem djelatnosti zdravstvenih radnika koja nisu uređena ZOZZ-om primjenjuju se odredbe posebnih zakona o profesijama u zdravstvu (ZOZZ, čl. 128.).

Iako to u zakonu nije izrijekom propisano, držimo da status zdravstvenog radnika imaju i nastavnici i suradnici koji na fakultetima zdravstvene struke izvode nastavu iz tzv. kliničkih predmeta u nekoj zdravstvenoj ustanovi u skladu s propisima o visokom obrazovanju. Oni su u mogućnosti ili su dužni (zbog kumulativnog radnog odnosa i prirode djelatnosti kojom se bavi) pružati zdravstvene usluge u toj ustanovi, jer bilo bi neprimjereno da nastavnik ili suradnik na kliničkim predmetima nema kliničko iskustvo ili ne pruža zdravstvene usluge u (toj) zdravstvenoj ustanovi. ${ }^{10}$

\subsection{Zdravstveni suradnici}

Pojam „zdravstveni radnik“ ne ograničava se na jednu kategoriju ljudi kojima je zdravstvena djelatnost stalno zanimanje, on obuhvaća višeslojne kategorije. Takve djelatnosti u okviru svoje struke obavljaju i zdravstveni suradnici - nezdravstveni radnici koji nisu uvjetovani strogim pravilima obrazovanja, osposobljavanja i usavršavanja. Zdravstveni suradnici su osobe koje nisu završile obrazovanje zdravstvenog usmjerenja, a rade u zdravstvenim ustanovama i sudjeluju u dijelu zdravstvene zaštite (dijagnostički i terapijski postupci). Sadržaj i način stručnog usavršavanja zdravstvenih suradnika uz prethodno pribavljeno mišljenje nadležnih komora pravilnikom utvrđuje nadležni ministar (ZOZZ, čl. 129.). Time se ističe činjenica da oni imaju pomoćnu ulogu u procesu zaštite zdravlja građana. ${ }^{11}$ Dakle, u sustavu zdravstva osim navedenih zdravstvenih djelatnosti i zdravstvenih radnika koji su ovlašteni iste obavljati, postoje i djelatnosti koje se obavljaju kao pomoćne djelatnosti, odnosno suportirajuće djelatnosti s ciljem omogućavanja i osiguravanja obavljanja i provedbe zdravstvenih djelatnosti ili kao dio zdravstvenih djelatnosti. Drugim riječima, u medicinske zaposlenike ne spadaju svi koji se staraju o zaštiti zdravlja građana na bilo koji način, nego jedino oni koji tu zaštitu obavljaju medicinskim sredstvima i neposredno. Stoga državne institucije koje se bave organizacijom zdravstvene djelatnosti (primjerice, Ministarstvo zdravstva, Hrvatski zavod za zdravstveno osiguranje i dr.), ne spadaju u zdravstvene radnike. ${ }^{12}$ 


\section{Primjedbe}

${ }^{1}$ Tako TIMOTIĆ, B. - ANĐELSKI, H., Zdravstveno zakonodavstvo, Elita - Medica, Beograd, 2004., str. 91.

${ }^{2}$ Usp SREMAC, Đ. - ŽUŽA, B., Hrvatsko zdravstveno zakonodavstvo 1830.-1941., Školska Knjiga, Zagreb, 2002., str. 92.

${ }^{3}$ Vidi BODNARUK, S. - ČIZMIĆ, J. - HRABAČ, B. - HUSEINAGIĆ, S., Komentari

zdravstvenih zakona, knjiga 1., Privredna štampa, Sarajevo, 2011., str. 203.

${ }^{4}$ Profesionalna odgovornost prema postojećoj primjeni suvremene tehnologije nije u potpunosti definirana pravnom regulativom, već je u primjeni s obzirom na njenu dostupnost, odnosno stručnu preporuku pojedinih društava. Te preporuke najvećim dijelom nisu rezultat dobro isplaniranih potreba za unapređenjem tehnologije, pri čemu bi se trebale uzeti u obzir sve relevantne činjenice uključujući potrebe šire društvene zajednice, morbiditetnu strukturu pučanstva ili raspoloživost financijskih resursa u društvu. HALLER, H., Medicinski pogled na liječničku odgovornost, rad u zborniku „Građanskopravna odgovornost u medicini“, HAZU, Zagreb, 2008., str. 19.

${ }^{5}$ Tako MALETIĆ, D., Profesionalna sloboda lekara, „Pravni život“", 2011., broj 9, str. 485.

${ }^{6}$ Vidi MATIJEVIĆ, B., Osiguranje od profesionalne odgovornosti u djelatnosti zdravstva, „Hrvatska pravna revija“, 2008., broj 6, str. 45.

${ }^{7}$ Usp. URDAREVIĆ, B., Zdravstveni radnici kao pružaoci zdravstvenih usluga i stručna greška lekara, rad u Zborniku radova „Usluge i zaštita korisnika“, Kragujevac, 2016., str. 568.

${ }^{8}$ Zdravstveni radnik može uz odobrenje poslodavca za svoj račun sklopiti posao iz zdravstvene djelatnosti poslodavca, a odobrenje se daje na vrijeme od godinu dana. Uvjet za davanje odobrenja jest prethodno sklopljeni ugovor o međusobnim pravima i obvezama između poslodavca i zdravstvene ustanove, trgovačkog društva koje obavlja zdravstvenu djelatnost, odnosno privatnog zdravstvenog radnika kod kojeg će zdravstveni radnik za svoj račun obavljati poslove iz djelatnosti poslodavca (ZOZZ, čl. 125.).

${ }^{9}$ Vidi KLARIĆ, A., Medicinsko pravo - osnov definiranja komorskih prava, Zbornik radova s međunarodnog simpozija „Medicinsko pravo u sustavu zdravstvene djelatnosti“, Split, Sveučilište u Splitu - Pravni fakultet, 2015., str. 65-82.

${ }^{10}$ Više o tome kod URDAREVIĆ, B., Zdravstveni radnici kao pružaoci zdravstvenih usluga $i$ stručna greška lekara, rad u Zborniku radova „Usluge i zaštita korisnika“, Kragujevac, 2016., str. 568.

${ }^{11}$ Tako BOŠKOVIĆ, Z., Profesionalno obrazovanje zdravstvenih djelatnika, „Informator“, broj 4987-4990. od 22., 26. i 29. prosinca. 2001. i 2.siječnja. 2002., str. 62.

${ }^{12}$ Vidi RADIŠIĆ, J., Medicinsko pravo, „Nomos“, beograd, 2004., str. 31. 


\section{2/ Obrazovanje}

Zdravstveni radnici obrazuju se na medicinskom, stomatološkom ili farmaceutskobiokemijskom fakultetu, te drugom visokom učilištu zdravstvenog usmjerenja, kao i u srednjim školama zdravstvenog usmjerenja, odnosno učilištu ili u srednjim školama koje imaju odobrenje za provođenje obrazovnog programa zdravstvenog usmjerenja (ZOZZ, čl. 124.).

Zdravstveni radnik u Republici Hrvatskoj stječe svoje temeljno obrazovanje na više zdravstvenih učilišta koji se organiziraju u sklopu sveučilišta ili veleučilišta. $\mathrm{Na}$ medicinskim fakultetima u pravilu se školuju doktori medicine. Uvođenjem Bolonjskog načina obrazovanja te izmjenom kriterija edukacije u skladu s europskom pravnom stečevinom ostali zdravstveni radnici dobili su mogućnost aktivno sudjelovati u svoj daljnjoj visokoškolskoj edukaciji. Naime, standard temeljne edukacije zdravstvenih radnika (osim doktora medicine, doktora dentalne medicine, magistra farmacije, magistra biokemije) u okviru europskog pravnog prostora je postojanje i utvrđivanje najmanje VI. razine obrazovanja (razina prvostupnika, tzv. bacheleor). Europski gospodarski prostor napustio je srednjoškolsko obrazovanje kao temelj stjecanja osnovnih kompetencija za zdravstvene radnike. U Republici Hrvatskoj i nadalje egzistiraju srednje strukovne škole koje obrazuju pojedine zdravstvene radnike, te ih zdravstveni sustav još uvijek kao takve prepoznaje i vrednuje. Međutim tendencija usvajanja europskog kvalifikacijskoj okvira vezanog za školovanje zdravstvenih radnika nalaže aktivno usklađivanja usvojenih zajedničkih standarda, što bi u konačnici trebalo dovesti do toga da svi zdravstveni radnici koji obavljaju zdravstvenu djelatnost moraju zadovoljiti minimum obrazovnog standarda koji uključuje posjedovanje razine prvostupnika struke. Međutim kako je prethodno navedeno danas u Republici Hrvatskoj postoji srednjoškolsko obrazovanje za većinu zdravstvenih radnika koji kao takvi mogu ishoditi licenciju od nadležne Komore i samostalno obavljati djelatnost (zdravstveno laboratorijski tehničari, medicinske sestre, sanitarni tehničari).

Osim medicinskih fakulteta gdje se školuju u pravilu doktori medicine, ostali zdravstveni radnici svoje visokoškolske kompetencije stječu na zdravstvenim fakultetima i studijima u okviru stručnog i sveučilišnog studija ili na visokim zdravstvenim školama gdje stječu isključivo stručne kompetencije koje su većinom ograničene na stjecanje radnih stručnih kompetencija, dakle ne i temeljnih kompetencija koje omogućuju nastavak daljnjeg školovanja. Prednost tzv. sveučilišnih kompetencija sastoji se u mogućnostima daljine nadogradnje, edukacije koju zdravstveni radnici mogu temeljem zakona stjecati nakon završene prethodno navedene prvostupničke razine školovanje. Ovakvim sustavom školovanja praktički je omogućeno svim zdravstvenim radnicima stjecanje daljnje razine obrazovanja (tzv. stupnja magistra struke), što u konačnici utječe na cjelokupni zdravstveni sustav i na kvalitetu pružanja zdravstvene zaštite. Osima toga istima je omogućeno na takav način stjecanje i znanstvenih akademskih kompetencija, te napredovanje u znanstvenom smislu, kao i stjecanje različitih teorijskih specijalizacija, a primjer je i specijalistički poslijediplomski studij „Medicinsko pravo“ na Pravnom 
fakultetu Sveučilišta u Splitu kojeg mogu upisati svi polaznici zdravstvene struke sa završenom VII. razinom obrazovanja.

Standardi obrazovanja, kvalifikacija kojima će biti definirani svi segmenti obrazovanja zdravstvenih radnika je nužnost, te se u okviru provedbe istog mogu očekivati iznimni rezultati koji će dovesti do usklađivanja i utvrđivanja jasnih kriterija temeljnih edukacija kao i obrazovne stručne nadgradnje svih zdravstvenih radnika u Republici Hrvatskoj. Prema tome doktori medicine završavaju integrirani šestogodišnji studij medicine na Medicinskim fakultetima u Splitu, Osijeku, Rijeci i Zagrebu. Doktori dentalne medicine završavaju studije dentalne medicine također, u pravilu, u okviru sada integriranog studija na Stomatološkom fakultetu u Zagrebu, Medicinskom fakultetu u Splitu, Osijeku i Rijeci. Magistri farmacije završavaju svoje integrirane petogodišnje studije na Farmaceutsko biokemijskom fakultetu u Zagrebu i Medicinskom fakultetu u Splitu. Magistri medicinske biokemije završavaju svoje integrirane petogodišnje studije na Farmaceutsko biokemijskom fakultetu u Zagrebu. Fizioterapeuti završavaju svoje diplomske ili preddiplomske sveučilišne ili stručne studije u okviru više različitih Sveučilišta (Fakultet zdravstvenih studija u Rijeci, Medicinski fakultet u Osijeku, u okviru Sveučilišnog odjela zdravstvenih studija u Splitu ili Veleučilišta u Zagrebu). Medicinske sestre završavaju preddiplomske ili diplomske stručne ili sveučilišne studije u okviru brojnih fakulteta ili visokih učilišta u RH, od kojih se izdvaja Medicinski fakultet u Zagrebu, Zdravstveno veleučilište u Zagrebu, Katoličko Sveučilište u Zagrebu, Medicinski fakultet u Osijeku, Fakultet zdravstvenih studija u Rijeci, Sveučilišni odjel zdravstvenih studija u Splitu, Studij sestrinstva Sveučilišta u Dubrovniku, Studij sestrinstva Sveučilišta u Zadru, Studij sestrinstva Sveučilišta Sjever, u Novoj Gradiški, Puli, Vukovaru, Karlovcu, itd. Primalje stječu preddiplomsku visokoškolsku kvalifikaciju na studijima primaljstva na Sveučilišnom odjelu zdravstvenih studija u Splitu, Fakultetu zdravstvenih studija u Rijeci, Veleučilištu u Zagrebu. Radiološki tehnolozi stječu svoju preddiplomsku ili diplomsku visokoškolsku kvalifikaciju na Sveučilišnom odjelu zdravstvenih studija u Splitu, Fakultetu zdravstvenih studija u Rijeci, Veleučilištu u Zagrebu. Medicinski laboranti, pak, stječu svoju preddiplomsku ili diplomsku visokoškolsku kvalifikaciju na Sveučilišnom odjelu zdravstvenih studija u Splitu, Fakultetu zdravstvenih studija u Rijeci, Veleučilištu u Zagrebu, Medicinskom fakultetu u Osijeku. Sanitarni inženjeri stječu svoju visokoškolsku kvalifikaciju diplomsku ili preddiplomsku na Medicinskom fakultetu u Rijeci i Veleučilištu u Zagrebu. Radni terapeuti stječu svoju stručnu preddiplomsku kvalifikaciju na Zdravstvenom veleučilištu u Zagrebu.

Sustav obrazovanja zdravstvenih radnika uključuje sve načine stjecanja stručnih i sveučilišnih kvalifikacija na preddiplomskim ili diplomskom studijima u Republici Hrvatskoj. 


\section{3/ Pripravnički staž i stručni ispit}

Zdravstveni radnici imaju dužnost nakon svog temeljenog stručnog ili sveučilišnog preddiplomskog ili diplomskog školovanja, a radi pripreme za obavljanje zdravstvene djelatnosti i svog profesionalnog zanimanja, odraditi pripravnički staž i položiti stručni ispit.

Pripravnički staž je organizirani oblik stručnog osposobljavanja zdravstvenih radnika za samostalan rad koji se obavlja pod nadzorom. Zdravstveni suradnici obavljaju pripravnički staž i polažu stručni ispit suglasno propisima svoje struke. Zdravstveni radnici obvezni su nakon završenog obrazovanja obaviti pripravnički staž. Pripravnički staž je rad pod nadzorom kojim se zdravstveni radnik osposobljava za samostalan rad (ZOZZ, čl. 130.). Institut pripravničkog staža poznat je ili kao zaseban element godišnjeg stručnog usavršavanja ili kao integralni element inkorporiran u studijski program školovanja. Kao segment studijskog programa prepoznat je kod integriranih zdravstvenih studija, te je kao takav prisutan u većini europskih zdravstvenih sustava. Hrvatska je u svoje zakonodavstvo implementirala također standard pripravničkog staža kroz studijske programe te se u dogledno vrijeme predmetno očekuje kod svih zdravstvenih profesija. Sada je uveden u studijske programe doktora medicine od 2013. i doktora dentalne medicine.

Pravilnikom o pripravničkom stažu doktora medicine („Narodne novine“, broj 114/13., dalje - PPSDM) propisuju se sadržaj i način provođenja pripravničkog staža doktora medicine osnovom kojih se stječu kompetencije propisane planom i programom pripravničkog staža, uvjeti koje moraju ispunjavati zdravstvene ustanove, trgovačka društva koja obavljaju zdravstvenu djelatnost i privatni zdravstveni radnici kod kojih doktori medicine provode pripravnički staž, obrazac pripravničke knjižice i dnevnika rada doktora medicine na pripravničkom stažu, sadržaj, program i način polaganja stručnog ispita te sadržaj i izgled uvjerenja o položenom stručnom ispitu (PPSDM, čl. 1.). ${ }^{1}$

Pripravnik je doktor medicine na pripravničkom stažu propisanom u Republici Hrvatskoj koji je završio sveučilišni studij medicine u Republici Hrvatskoj ili u državi ugovornici EGP-a, ako ta država propisuje obvezan pripravnički staž (PPSDM, čl. 2.). Pripravnički staž provodi se prema planu i programu koji je sastavni dio PPSDM-a. (PPSDM, čl. 4.), a kojim se utvrđuju ishodi učenja i kompetencije koje stječe pripravnik da bi se osposobio za samostalni rad te raspored i trajanje rada na stručnim poslovima u pojedinim specijalističkim djelatnostima, kojima se pripravnik osposobljava za samostalan rad (PPSDM, čl. 2.).

Pripravnički staž za zdravstvene radnike traje do godinu dana. Iznimno, pripravnički staž doktora medicine koji su završili petogodišnji studij medicine traje dvije godine (ZOZZ, čl. 131.)._Točnije, pripravnički staž doktora medicine traje pet mjeseci (PPSDM, čl. 4.). Pripravnički staž provodi se u punom radnom vremenu bez prekida. Iznimno, opravdani prekid pripravničkog staža može biti bolest dulja od 30 dana u kontinuitetu ili 45 dana s 
prekidima, rodiljni dopust, roditeljski dopust, vojna obveza i stručno usavršavanje u inozemstvu u trajanju duljem od 30 dana te se u tim slučajevima staž produžava za onoliko vremena koliko je prekid trajao, uz dokaz u vidu potvrde koju izdaje ravnatelj zdravstvene ustanove, odgovorna osoba trgovačkog društva ili nositelj privatne prakse (PPSDM, čl. 7.).

Pripravnički staž obavlja se u zdravstvenim ustanovama i trgovačkim društvima koja obavljaju zdravstvenu djelatnost (ZOZZ, čl. 137.), odnosno kod doktora medicine sa završenim sveučilišnim diplomskim studijem koji obavlja privatnu praksu, koji ima važeće odobrenje za samostalan rad i najmanje pet godina radnog iskustva u struci te u vojno zdravstvenoj ustanovi i drugoj pravnoj osobi u kojoj se zdravstvena djelatnost obavlja u skladu sa Zakonom o zdravstvenoj zaštiti i posebnim zakonom, a koja ispunjava propisane uvjete (PPSDM, čl. 6.). Zdravstvene ustanove i trgovačka društva koja obavljaju zdravstvenu djelatnost obvezni su primati zdravstvene radnike na pripravnički staž prema mjerilima koje će pravilnikom odrediti ministar (ZOZZ, čl. 137.).

Nakon obavljenoga pripravničkog staža zdravstveni radnici polažu stručni ispit pred ispitnom komisijom ministarstva (ZOZZ, čl. 132.). Tako nakon uspješno završenog pripravničkog staža $\mathrm{i}$ stečenih kompetencija utvrđenih planom i programom pripravničkog staža, doktori medicine polažu stručni ispit pred ispitnom komisijom Ministarstva (PPSDM, čl. 12.). Stručni ispit je ispit koji polaže doktor medicine pripravnik koji je završio pripravnički staž pred ispitnom komisijom Ministarstva (PPSDM, čl. 2.), s kojim uvjerenjem zdravstveni radnici stječu potvrdu od nadležnog državnog tijela da su stručno osposobljeni obavljati zdravstvenu djelatnost u okviru svoje profesije. Pripravnik osobno podnosi prijavu Ministarstvu najranije 30 dana prije isteka pripravničkog staža (PPSDM, čl. 13.). Ako je pripravnik ispunio sve uvjete propisane ovim Pravilnikom, ministar rješenjem odobrava polaganje stručnog ispita te o datumu i mjestu polaganja stručnog ispita dostavlja obavijest pripravniku pisanim putem najmanje 8 dana prije dana polaganja stručnog ispita (PPSDM, čl. 14.). Troškove stručnog ispita snosi zdravstvena ustanova koja je doktora medicine primila na pripravnički staž (PPSDM, čl. 15.). Stručni ispit za doktore medicine polaže se usmeno, a obuhvaća sljedeće ispitne predmete: 1. Ustavno uređenje Republike Hrvatske, 2. Radni odnosi i mirovinsko osiguranje, 3. Zdravstvena zaštita i obvezno zdravstveno osiguranje, 4. Liječništvo i zaštita prava pacijenata (PPSDM, čl. 17.). Doktoru medicine koji je položio stručni ispit Ministarstvo izdaje uvjerenje o položenom stručnom ispitu koje potpisuje ministar (PPSDM, čl. 24.).

Odredbe ZOZZ-a o obavljanju pripravničkog staža i polaganju stručnog ispita (ZOZZ, čl. 30. do 132.) ne odnose se na državljane država Europskog gospodarskog prostora (u daljnjem tekstu: EGP), niti na državljane Republike Hrvatske koji su završili integrirani curiculum studija medicine, dentalne medicine, farmacije, obrazovanje za medicinsku sestru/medicinskog tehničara u djelatnosti opće njege i primalju, koji su sukladni Zakonu o reguliranim profesijama i priznavanju inozemnih stručnih kvalifikacija (ZZZ, čl. 133.). Državljani država ugovornica EGP-a koji su stekli stručnu kvalifikaciju doktora medicine u trećim državama, uz dokaz o formalnoj osposobljenosti izdan u skladu sa Zakonom o reguliranim profesijama i priznavanju inozemnih stručnih kvalifikacija, a nakon provedbe postupka priznavanja inozemnih stručnih kvalifikacija, obvezni su položiti stručni ispit 
pred ispitnom komisijom Ministarstva. Doktori medicine hrvatski državljani koji su upisali studijski program medicine nakon 1. srpnja 2013. godine i državljani država ugovornica EGP-a, u kojima nije propisana obveza pripravničkog staža, ne provode pripravnički staž i nemaju obvezu polaganja stručnog ispita (PPSDM, čl. 3.).

Rad pripravnika tijekom pripravničkog staža nadzire i prati mentor i odgovoran je za propisano provođenje plana i programa pripravničkog staža. Mentor mora biti u radnom odnosu u zdravstvenoj ustanovi. Mentor je obvezan redovito provjeravati stečena znanja i vještine pripravnika te uspostaviti suradnju s voditeljima ustrojstvenih jedinica i drugim doktorima medicine kod kojih pripravnik provodi dio programa pripravničkog staža (PPSDM, čl. 8.).. Pripravnik je obvezan za vrijeme pripravničkog staža obavljati stručne poslove koje mu povjeri mentor, voditelj ustrojstvene jedinice odnosno doktor medicine specijalist i nositelj privatne prakse koji neposredno prati rad pripravnika u dijelu programa pripravničkog staža i stjecati kompetencije u skladu s planom i programom pripravničkog staža te redovito voditi dnevnik rada. Mentor je obvezan voditi brigu o redovitom vođenju dnevnika rada doktora medicine na pripravničkom stažu te o dokumentaciji za evaluaciju (Upitnik samoprocjene pripravnika i Upitnik procjene profesionalnog ponašanja pripravnika). Dnevnik rada svojim potpisom ovjeravaju mentor i doktori medicine specijalisti koji neposredno prate rad pripravnika u pojedinom dijelu programa pripravničkog staža (PPSDM, čl. 9.).

\section{Primjedbe}

${ }^{1}$ Pravilnikom o pripravničkom stažu doktora dentalne medicine propisuju se sadržaj i način provođenja pripravničkog staža doktora dentalne medicine. Odredbe ovog pravilnika i postupci obavljanja pripravničkog staža i polaganja stručnog ispita doktora dentalne medicine u mnogome su identični Pravilniku o pripravničkom stažu doktora medicine. Za sve druge zdravstvene radnike u primjeni je Pravilnik o pripravničkom stažu zdravstvenih radnika. 


\section{4/ Trajno stručno usavršavanje}

\subsection{Značaj i dužnost stalnog stručnog usavršavanja}

Kadar koji se danas educira prolazi svoje posebnosti i određenu pripremu za profesionalnu odgovornost u zdravstvenom sustavu, od medicinskog fakulteta preko posebnih specijalizacija i užih specijalizacija do osposobljavanja medicinskih kadrova za vršenje najsloženijih dijagnostičkih i terapijskih zahvata i to se najčešće odvija u duljem vremenskom razdoblju. Medicinski fakultet u trajanju od šest godina, godina dana staža, zatim u prosjeku pet godina specijalizacije i dvije godine uže specijalizacije čine ukupno 14 godina neprekidnog učenja i obučavanja. ${ }^{1}$ Kadrovska politika u zdravstvenom sektoru, prema preporukama Svjetske zdravstvene organizacije, podrazumijeva planiranje školovanja odgovarajućeg broja i kvalifikacijske strukture zdravstvenih radnika prema procijenjenim potrebama i njihovu odgovarajuću iskorištenost, uz stalno profesionalno usavršavanje i razvoj. Tako je cjelokupna zdravstvena zaštita podignuta na višu razinu posebno specijalistička, s obzirom na sudjelovanje liječnika specijalista i subspecijalista u ukupnom broju liječnika, kao i drugih zdravstvenih radnika s visokom i višom stručnom spremom u odnosu na ukupan broj zdravstvenih radnika. Zato se danas, u cilju permanentnog podizanja razine kvaliteta zdravstvenog sustava i stručnog usavršavanja i stjecanja novih znanja, sposobnosti i vještina zdravstvenih radnika, posebno ističe značaj formuliranja i realizacija plana razvitka kadrova u zdravstvu. ${ }^{2}$

U vremenu učestalih i masovnih tehničkih i tehnoloških inovacija u kojem jednom stečeno stručno znanje vrlo brzo zastarijeva, kontinuirano obrazovanje i stručno usavršavanje zdravstvenih radnika (zaposlenika) postalo je, između ostalog, i preduvjet uspješnosti poslovanja zdravstvenih ustanova. ${ }^{3} \mathrm{~S}$ razvitkom sustava zdravstvene zaštite, organiziranje i upravljanje zdravstvenom zaštitom postalo je sve više specijalizirana oblast koja zahtijeva specifično, dodatno usavršavanje. Sve analize ukazuju na nedovoljnu razvijenost i osposobljenost kapaciteta za zdravstveni menadžment koji nisu u mogućnosti nositi se s izazovima i zahtjevima koji proizlaze iz reforme zdravstvenog sektora. Ove vještine nužno je poboljšati u svim područjima sektora i na svim razinama zdravstvene zaštite, uključujući sve profile zdravstvenog kadra. ${ }^{4}$

Prema odredbama ZOZZ-a zdravstveni radnici imaju pravo i obvezu stručno se usavršavati radi održavanja i unapređivanja kvalitete zdravstvene zaštite, a sadržaj, rokovi i postupak provjere stručnosti, osim specijalizacije i uže specijalizacije, propisuju se općim aktom nadležne komore (ZOZZ, čl. 138.). Iako to u ZOZZ-u nije izričito propisano drži se da je zdravstveni radnik dužan stečena stručna znanja stalno prenositi na svoje suradnike u zdravstvenoj ustanovi.

Stručno usavršavanje, osim specijalizacije i subspecijalizacije, obuhvaća i posebne oblike stručnog usavršavanja kroz kontinuirano praćenje i usvajanje suvremenih znanja i vještina iz pojedinih oblasti, a kojim se osigurava i unapređuje kvalitetu zdravstvene zaštite. Zdravstvene radnike na neprekidno stručno usavršavanje obvezuje i njihova profesionalna 
etika. Izmijenjeni zahtjevi zdravstvenog sustava postavljaju nove izazove pred zdravstvene radnike koji zahtijevaju njihovo stalno usavršavanje. U skladu s pozitivnim zakonskim propisima stručno usavršavanje radi održavanja i unapređenja kvalitete zdravstvene zaštite je pravo i obaveza svih zdravstvenih radnika, ali je i obaveza poslodavca da im omogući dalje usavršavanje. Trajno usavršavanje provodi se putem stručnih predavanja, tečajeva, seminara, čiji sadržaj danas, uglavnom, organiziraju farmaceutske kuće i sl. $^{5}$ Pod stručnim usavršavanjem zdravstvenih radnika podrazumijevaju se oni oblici obrazovnih aktivnosti s pomoću kojih zdravstveni radnik/zaposlenik stječe dopunska znanja, vještine i navike, u sklopu stečenog stupnja stručnog obrazovanja određenog zanimanja, a u svrhu usavršavanja radnih sposobnosti i uspješnijeg obavljanja posla. Dakle, stručnim usavršavanjem ne stječe se verificirani stupanj stručne spreme. Neposredni razlozi stručnog usavršavanja mogu biti ubrzano uvođenje visoke tehnologije (CT, laparoskopija, , robotska kirurgija, endoskopija, laser, telemedicina, zračenje itd.), unapređenje postojeće organizacije rada, radnih postupaka i sl. ${ }^{6}$ Oblici stručnog usavršavanja mogu biti: specijalizacija u zemlji i inozemstvu; pohađanje seminara, predavanja, savjetovanja i kongresa; polaganje stručnih ispita; obuka za konkretni posao na novoj tehnologiji; usavršavanje na poslu, odnosno usavršavanje na praktičnom radu $\mathrm{i} d{ }^{7}$

Stručno usavršavanje zdravstvenih radnika najčešće se provodi putem sudjelovanja na raznim oblicima edukacija kao što su, primjerice, stručni skupovi (tečajevi, kongresi, simpoziji, online edukacije, stručne radionice i slično), ali ono se može obavljati i stjecanjem nekih stručno-znanstvenih postignuća, kao, primjerice, obranom doktorske disertacije, stjecanjem specijalističkog ili stručnog magisterija, stjecanjem naziva primarius, polaganjem specijalističkog odnosno ispita iz uže specijalnosti i tome slično. Svaki taj oblik stručnog usavršavanja doprinosi kvaliteti rada zdravstvenog radnika. Kontinuirana edukacija zdravstvenih radnika je i uvjet za dobivanje, odnosno obnavljanje licencije. ${ }^{8}$ Osim toga, obveza kontinuiranog učenja jest, istodobno, i pravna. Njezin pravni karakter iskazuje ZOZZ u čl. 120. st. 2. gdje propisuje: ,Zdravstveni radnici imaju pravo i obvezu stručno se usavršavati radi održavanja i unapređivanja kvalitete zdravstvene zaštite." $U$ tom smislu treba navesti, primjerice, i odredbu čl. 1. st. 2. Pravilnika o trajnom medicinskoj izobrazbi liječnika (u nastavku teksta: Pravilnik) prema kojemu su ,liječnici obvezni stručno se usavršavati radi stjecanja uvjeta za produženje odobrenja za samostalni rad na poslovima zdravstvene zaštite." U pravilu, svaki zdravstveni radnik bira sam način na koji dolazi do stručnih saznanja. Njemu se, prije svega, nude organizirani i kolektivni oblici usavršavanja sudjelovanjem na domaćim i međunarodnim kongresima, sudjelovanjem na tečajevima priznatim od Komore i međunarodnim tečajevima, studijskim boravcima, stručnim sastancima i sl. Individualno obrazovanje stječe se pretežito preko stručne literature. Zdravstveni radnik je dužan pratiti i čitati opće dostupnu stručnu literaturu (nedostatak aktualnog knjiškog znanja, ako je ono uzrok štete koju je pretrpio pacijent, smatra se profesionalnim nehajem). Nova saznanja o daljnjem napretku medicinske znanosti dobivaju se osobito čitanjem stručnih časopisa. Liječnik je, primjerice, kriv kad pacijentu propise određeni lijek za umirenje bolova, iako je u stručnim časopisima pisalo da taj lijek izaziva određena štetna djelovanja. Štoviše, smatra se da liječnika ne može opravdati ni činjenica da su podaci o štetnosti lijeka bili objavljeni za vrijeme dok se nalazio na godišnjem odmoru, i da je lijek propisao pacijentu 
odmah po povratku s odmora. Jer, „bolesnik se može pouzdati u to da je liječnik koji obavlja medicinsku praksu uvijek u tijeku stvari““. ${ }^{9}$

\subsection{Postupak trajnog stručnog usavršavanja}

Postupak trajne izobrazbe, ${ }^{10}$ odnosno stručnog usavršavanja nije postupak u formalnom smislu. Radi se zapravo o kontinuiranom učenju, odnosno stjecanju novih znanja i vještina koja nastaju kao rezultat nezaustavljivog, gotovo svakodnevnog, razvoja zdravstvenih znanosti i tehnologija. Stručnim usavršavanjem osigurava se kvaliteta rada zdravstvenih radnika koja dovodi do poboljšanja kvalitete pružanja zdravstvenih usluga. Bez stručnog usavršavanja zdravstveni radnici ne bi mogli obavljati svoju djelatnost jer je stručno usavršavanje nužnost koja proizlazi iz, kako je već spomenuto, nezaustavljivog razvoja struke i tehnologija bez kojih bi svakodnevni rad zdravstvenih radnika bio nezamisliv. Upravo zbog opisane važnosti odnosno nužnosti stručnog usavršavanja, zakonodavac je u svim, ranije navedenim, tzv. strukovnim zakonima, ${ }^{11}$ uveo zakonsku obvezu stručnog usavršavanja za sve zdravstvene radnike te je prepustio komorama u zdravstvu da svojim podzakonskim aktima pobliže propišu uvjete i način stručnog usavršavanja.

Pravilnikom o trajnoj medicinskoj izobrazbi Hrvatske liječničke komore (objavljen na web stranici www.hlk.hr.) propisano je da stručno usavršavanje liječnika obuhvaća kontinuirano praćenje razvoja medicinske struke i znanosti te stjecanje novih znanja i vještina, osobito iz područja za koje su liječniku izdana odobrenja za samostalan rad (licence) (Članak 1. stavak 2. Pravilnika o trajnoj medicinskoj izobrazbi Hrvatske liječničke komore). Također su propisana i načela trajne medicinske izobrazbe, i to: dostupnost izobrazbe svima, odnosno uključivanje svih liječnika u program trajne medicinske izobrazbe, jedinstvenost medicinske doktrine, što znači da medicinska saznanja moraju biti svojina svih liječnika koji obavljaju zdravstvenu djelatnost na primarnoj, sekundarnoj i tercijarnoj razini, znanstvena osnovanost i suvremenost trajne medicinske izobrazbe te informiranost o novim svjetskim dostignućima iz područja medicinske znanosti, osposobljenost hrvatskih liječnika prema svjetskim standardima, slobodan izbor u postupku trajne medicinske izobrazbe, odnosno mogućnost i pravo svakog liječnika na izbor sadržaja i oblika trajne medicinske izobrazbe, osobito iz područja za koje su liječniku izdana odobrenja za samostalan rad (licenca), trajnom medicinskom izobrazbom liječnik treba stalno usavršavati, proširivati i osuvremenjivati svoja znanja i vještine te ih koristiti u dijagnostičkim, terapijskim i rehabilitacijskim postupcima prema pacijentima koji će zbog toga osjetiti poboljšanje kvalitete rada svojih liječnika (Članak 2. stavak 3. Pravilnika o trajnoj medicinskoj izobrazbi Hrvatske liječničke komore). Obveza je liječnika stalno obrazovanje i praćenje napretka u struci (Kodeks medicinske etike i deontologije Hrvatske liječničke komore, „Narodne novine“, br. 55/08., 139/15., pročišćeni tekst od 15. siječnja 2016., dalje - KMED, čl. 9. toč. 9.). Isključivi kriteriji vrednovanja i napredovanja u liječničkoj struci moraju biti stručnost, sposobnost i profesionalne zasluge te osposobljenost i rezultati u obavljanju određene vrste djelatnosti, poslova i zadataka. Znanstveno nepoštenje i prijevara u znanosti oblici su ponašanja nespojivi s liječničkom etikom. Neetično je ako liječnik uz svoje ime koristi titule koje mu ne pripadaju (KMED, čl. 9. toč. 10.). 
Doktori dentalne medicine, dentalni tehničari i dentalni asistenti obvezni su također stručno se usavršavati prema uvjetima koje je propisala Hrvatska komora dentalne medicine. Prema Pravilniku o stručnom usavršavanju člana Komore (Vidi stranicu www.hkdm.hr.), članovi Hrvatske komore dentalne medicine obvezni su u šest godina, za razliku od liječnika, sakupiti 60 bodova u postupku stručnog usavršavanja (Pravilniku o stručnom usavršavanju člana Komore, čl. 16.). Koncept stručnog usavršavanja doktora dentalne medicine, dentalnih tehničara i dentalnih asistenata gotovo je jednak kao i onaj liječnički. Postupak stručnog usavršavanja vrednuje se odgovarajućim brojem bodova koje su članovi Hrvatske komore dentalne medicine dužni sakupljati kako bi mogli obnoviti odobrenje za samostalan rad (licencu).

Hrvatska ljekarnička komora svojim je Pravilnikom o sadržajima, rokovima i postupku stručnog usavršavanja magistara farmacije (Vidi stranicu www.hljk.hr.) propisala uvjete i način stručnog usavršavanja magistara farmacije, a također je odredila načela po kojima se ima provoditi stručno usavršavanje. Ta načela slična su načelima koja vrijede i za stručno usavršavanje liječnika, a odnose se na: dostupnost programa stručnog usavršavanja svim magistrima farmacije, jedinstvenost usavršavanja magistara farmacije u stjecanju i primjeni znanja i vještina ljekarničke djelatnosti što znači da se ljekarnička znanja i vještine trebaju primjenjivati na jedinstven način u obavljanju ljekarničke djelatnosti, znanstvena osnovanost i suvremenost stručnog usavršavanja te informiranost o novim svjetskim dostignućima iz područja farmaceutske i zdravstvene znanosti, osposobljenost ljekarnika prema svjetskim standardima, slobodan izbor u postupku stručnog usavršavanja odnosno mogućnost i pravo svakog magistra farmacije na izbor sadržaja i oblika stručnog usavršavanja (Pravilnik o sadržajima, rokovima i postupku stručnog usavršavanja magistara farmacije, čl. 2.). Magistri farmacije dužni su svakih šest godina sakupiti minimalno 30 bodova u postupku stručnog usavršavanja kako bi obnovili svoje odobrenje za samostalan rad (licencu). Navedenim brojem bodova magistri farmacije dokazuju da su stekli potrebnu razinu stručnosti u okviru postupka stručnog usavršavanja.

Stručno usavršavanje medicinskih biokemičara propisala je Hrvatska komora medicinskih biokemičara u svojem Pravilniku o trajnom usavršavanju magistara medicinske biokemije (Vidi stranicu www.hkmb.hr.). U pogledu načina stručnog usavršavanja medicinskih biokemičara, nema nekih značajnih razlika u odnosu na ostale zdravstvene radnike. I medicinski biokemičari sakupljaju bodove u postupku stručnog usavršavanja sudjelujući u raznim oblicima stručnog usavršavanja kao što su, primjerice, stručno-znanstveni skupovi, organizirana usavršavanja u klinikama, studijski boravci u inozemstvu i slično. Jednako kao i ljekarnici, i magistri medicinske biokemije moraju u šestogodišnjem razdoblju važenja odobrenja za samostalan rad (licence) sakupiti 30 bodova (Pravilnik o trajnom usavršavanju magistara medicinske biokemije, čl. 10. st. 2.).

Zakonska je obveza i medicinskih sestara da stalno obnavljaju stečena znanja i usvajaju nova u skladu s najnovijim dostignućima i saznanjima iz područja sestrinstva. Hrvatska komora medicinskih sestara propisala je Pravilnikom o sadržaju, rokovima i postupku trajnog/stručnog usavršavanja i provjere stručnosti medicinskih sestara (Vidi stranicu www.hkms.hr.) način i uvjete pod kojima su se medicinske sestre dužne usavršavati. Stručno usavršavanje medicinskih sestara nastavlja se na završeno redovno obrazovanje 
i odnosi se na sve medicinske sestre koje pružaju neposrednu zdravstvenu zaštitu u djelatnosti zdravstvene njege (Pravilnik o sadržaju, rokovima i postupku trajnog/stručnog usavršavanja i provjere stručnosti medicinskih sestara, čl. 2.). U svrhu obnove odobrenja za samostalan rad (licence), medicinska je sestra dužna u šestogodišnjem razdoblju važenja licence, sakupiti najmanje 90 bodova u postupku stručnog usavršavanja (Pravilnik o sadržaju, rokovima i postupku trajnog/stručnog usavršavanja i provjere stručnosti medicinskih sestara, čl. 5.).

Stručno usavršavanje primalja, primalja asistentica, primaljskih asistenata, prvostupnika/ca primaljstva i magistara primaljstva propisala je Hrvatska komora primalja u Pravilniku o sadržaju, rokovima i postupku trajnog stručnog usavršavanja primalja, primalja asistentica, primaljskih asistenata, prvostupnika/ca primaljstva i magistara primaljstva (Vidi stranicu www.hkp.hr.). Spomenutim Pravilnikom također su propisana i načela koja se primjenjuju u stručnom usavršavanju, i to: dostupnost izobrazbe svim primaljama odnosno uključivanje primalja u program stručnog usavršavanja, stručna i znanstvena osnovanost i suvremenost u edukaciji što znači da trajna edukacija mora biti stručno i znanstveno osnovana, prenositi svjetska i vlastita dostignuća te osposobiti hrvatske primalje prema odgovarajućim standardima, kompetentna se primalja ističe cjeloživotnim učenjem i profesionalnom naobrazbom koja pridonosi očuvanju i poboljšanju kvalitete primaljske prakse te unaprjeđenju i očuvanju zdravlja, primalje treba poticati na višu i visoku razinu obrazovanja, odnosno na preddiplomski i diplomski studij primaljstva te na najviši profesionalni razvoj u primaljskim i srodnim područjima (Pravilnik o sadržaju, rokovima i postupku trajnog stručnog usavršavanja primalja, primalja asistentica, primaljskih asistenata, prvostupnika/ca primaljstva i magistara primaljstva, čl. 3.). Ujedno, Pravilnikom je propisano da je izobrazba primalja trajni postupak koji ne prestaje završetkom školovanja već se nastavlja kroz program trajnog stručnog usavršavanja i cjeloživotnog obrazovanja. Primalje su dužne tijekom šestogodišnjeg važenja odobrenja za samostalan rad (licence) sakupiti 90 bodova od čega najmanje 45 bodova treba biti iz stručne izobrazbe koja je usko vezana uz primaljsku djelatnost dok preostalih 45 bodova može biti iz srodnih struka, po slobodnom izboru primalje. U tih preostalih 45 bodova uračunavaju se bodovi koji su stečeni na stručnoj izobrazbi iz područja etike, zakonodavstva iz primaljstva ili psihologije te izobrazbi koja nije usko vezana uz primaljsku djelatnost, ali uključuje znanja koja pridonose kvaliteti pružanja primaljske skrbi. Također, svaka je primalja unutar roka od šest godina, dužna prisustvovati i jednoj vrsti izobrazbe na kojoj se minimalno jedna tema odnosi na područje etike u primaljstvu, jedna tema na područje zakonodavstva u primaljstvu, jedna tema na kardiopulmonalnu reanimaciju novorođenčeta i odrasle osobe te jedna tema na područje psihologije (Pravilnik o sadržaju, rokovima i postupku trajnog stručnog usavršavanja primalja, primalja asistentica, primaljskih asistenata, prvostupnika/ca primaljstva i magistara primaljstva, čl. 6.).

Kao i ostali zdravstveni radnici kojima je nadležna komora izdala odobrenje za samostalan rad (licencu), tako su i fizioterapeuti, fizioterapeutski tehničari, radni terapeuti i maseri-kupeljari koji su članovi Hrvatske komore fizioterapeuta, dužni stručno se usavršavati odnosno dužni su stalno obnavljati stečena znanja i usvajati nova znanja u skladu s najnovijim dostignućima i saznanjima iz područja fizioterapije. Stručno usavršavanje fizioterapeuta, fizioterapeutskih tehničara, radnih terapeuta i masera- 
kupeljara propisala je Hrvatska komora fizioterapeuta u Pravilniku o sadržaju, rokovima i postupku provjere stručnosti fizioterapeuta, fizioterapeutskih tehničara, radnih terapeuta i masera-kupeljara (Vidi stranicu www.hkf.hr.). Pravilnikom je propisano da su fizioterapeuti i radni terapeuti dužni u šestogodišnjem razdoblju važenja odobrenja za samostalan rad (licence) sakupiti 120 bodova u postupku stručnog usavršavanja dok su fizioterapeutski tehničari dužni sakupiti 90 bodova, a maseri-kupeljari 60 bodova (članak 5.).

Hrvatska komora zdravstvenih radnika donijela je Pravilnik o sadržaju, rokovima i postupku provjere stručnosti zdravstvenih radnika iz djelatnosti sanitarnog inženjerstva, zdravstvene radiološko-tehnološke djelatnosti, djelatnosti radne terapije i medicinskolaboratorijske djelatnosti (Vidi stranicu www.hkzr.hr.). Spomenutim su Pravilnikom pobliže propisani uvjeti i način na koji se mogu i moraju usavršavati članovi Komore te su propisana i sljedeća načela stručnog usavršavanja: dostupnost izobrazbe svim zdravstvenim radnicima, aktivno uključivanje zdravstvenih radnika u program trajnog stručnog usavršavanja, sustavna briga Komore $u$ provođenju trajnog stručnog usavršavanja zdravstvenih radnika, dužnost Komore kontinuirano provoditi, organizirati i osiguravati uvjete za trajno stručno usavršavanje zdravstvenih radnika, stručna i znanstvena osnovanost i suvremenost u nastavi, što znači da trajna nastava mora biti stručno i znanstveno osnovana, prenositi svjetska i vlastita dostignuća te osposobiti zdravstvene radnike prema svjetskim standardima, kompetitivnost zdravstvenih radnika ističe se doživotnim učenjem i profesionalnom naobrazbom koja pridonosi očuvanju i poboljšanju kvalitete djelatne prakse, zdravstvene radnike treba poticati na visoku razinu obrazovanja, odnosno na najviši profesionalni razvoj i akademsku razinu u predmetnim područjima i djelatnostima, slobodan izbor u postupcima stručnog usavršavanja, što znači da svaki zdravstveni radnik ima pravo izabrati sadržaj i oblik trajnog stručnog usavršavanja koji mu odgovara, kategorizacija oblika, što znači bodovnim sustavom vrednovati oblike stručnog usavršavanja prema kriterijima utvrđenima Pravilnikom, oblici stručnog usavršavanja moraju biti jednaki nastavnom učinku i bodovnoj vrijednosti, sustavan pristup svakom obliku stručnog usavršavanja i vrednovanju istih, vrednovanje oblika i načina stručnog usavršavanja kroz zakonska načela upravnog postupanja (Pravilnik o sadržaju, rokovima i postupku provjere stručnosti zdravstvenih radnika iz djelatnosti sanitarnog inženjerstva, zdravstvene radiološko-tehnološke djelatnosti, djelatnosti radne terapije i medicinsko-laboratorijske djelatnosti, čl. 4.). S obzirom da su članovi Hrvatske komore zdravstvenih radnika zdravstveni radnici nekoliko različitih struka, i spomenutim je Pravilnikom određen različit broj bodova koje svaki zdravstveni radnik mora sakupiti u šestogodišnjem razdoblju na koje mu je izdano odobrenje za samostalan rad (licenca). Shodno tome, magistri sanitarnog inženjerstva, diplomirani sanitarni inženjeri, magistri radiološke tehnologije i magistri medicinskolaboratorijske dijagnostike, moraju sakupiti 120 bodova za obnovu licence. S druge strane, prvostupnici sanitarnog inženjerstva, prvostupnici radiološke tehnologije, prvostupnici radne terapije, prvostupnici medicinsko-laboratorijske dijagnostike, inženjeri medicinske radiologije, viši radni terapeuti, viši fizikalni terapeuti - smjer radne terapije, inženjeri medicinsko-laboratorijske dijagnostike i prvostupnici medicinskolaboratorijske dijagnostike sa završenim tečajem iz citodijagnostike ili sa završenim tečajem iz transfuzijske medicine, moraju sakupiti 90 bodova. Konačno, sanitarni tehničari, zdravstveno-laboratorijski tehničari, zdravstveno-laboratorijski tehničari sa 


$$
\begin{array}{r}
\text { ZDRAVSTVENO STRUKOVNO STALEŠKO PRAVO } \\
\text { Radnici zdravstvene struke: Trajno stručno usavršavanje }
\end{array}
$$

završenim tečajem iz citodijagnostike i zdravstveno-laboratorijski tehničari sa završenim tečajem iz transfuzijske medicine, moraju sakupiti 60 bodova.

\subsection{Trajno stručno usavršavanje na području medicinskog prava}

Zbog svoje interdisciplinarnosti medicinsko pravo je vrlo kompleksno, pa zahtijeva od pravnika barem elementarno poznavanje medicinske problematike, ali i obrnuto. ${ }^{12}$ Posebno se akcent postavlja na poznavanje medicinske prakse i visokih standarda $\mathrm{i}$ dostignuća u području medicinske djelatnosti, jer je to, među ostalim, dovelo i do znatnog širenja instituta odgovornosti zdravstvenih radnika ne samo u pogledu stručnog, lege artis postupanja, nego i u pogledu iskazivanja dužne pažnje i poštivanja tuđih i vlastitih prava tijekom obavljanja zdravstvene djelatnosti. ${ }^{13}$

Kada govorimo o značaju medicinskog prava kao znanstvene discipline i grane prava na uređenje odnosa u području zdravstva, prvenstveno bi trebalo ukazati na edukacijski značaj medicinskog prava. Educiranje (budućih) zdravstvenih radnika na ovom području svakako bi pridonijelo prevenciji pogrešaka, umanjilo bi trend primjene tzv. defensive medicine i omogućilo bi bolju informiranost i bolje ostvarivanje zajamčenih prava pacijenata. Naime, medicinsko pravo je u našem pravu (još uvijek) relativno nova znanstvena disciplina i grana, čiji bi razvitak trebao pridonijeti obrazovanju stručnjaka koji će raspolagati multidisciplinarnim znanjima. Postojanje polivalentno obrazovanih stručnjaka, odnosno stručnjaka koji će imati znanja iz područja prava, medicine i bioetike, korisno je i nužno zbog rješavanja brojnih problema multidisciplinarnog značaja koji se javljaju u obavljanju zdravstvene djelatnosti.

Bez pretenzija da obuhvatimo sve poslove koje bi specijalisti medicinskog prava mogli obavljati, odnosno kompetencije koje bi mogli i trebali steći izobrazbom, slobodni smo nabrojati neka od znanja, odnosno neke od potencijalnih poslova i zadataka specijalista medicinskog prava: znanja o osnovnim izvorima medicinskog prava, o ugovornom aspektu odnosa liječnik ili ustanova ili trgovačko društvo - pacijent, o pretpostavkama odgovornosti za štete u medicini i doživljene nelagodnosti tijekom medicinskog tretmana, o pravnoj regulativi medicinski potpomognutog začeća, doniranja tkiva i organa, o pravnom uređenju uzimanja i presađivanja dijelova ljudskog tijela u svrhu liječenja i medicinski potpomognutog začeća, o pravnom uređenje zaštite osoba s duševnim smetnjama, pravnom uređenje prekida trudnoće, ugovoru o medicinskim uslugama, informiranom pristanku pacijenta, odgovornosti za štete u medicini, osiguranju od odgovornosti, zdravstvenom osiguranje, o pravima i dužnostima liječnika s posebnim naglaskom na liječničku tajnu i vođenje liječničke dokumentacije, o uvjetima provođenja biomedicinskih istraživanja nad ljudima, o kaznenoj odgovornosti liječnika, o zaštiti potrošača kroz kazneno pravo, o odgovornosti za prijevarno postupanje u pružanju zdravstvenih usluga, o etičkim i pravnim problemima kloniranja i pobačaja, o pravnim aspektima intenzivne medicine s posebnim osvrtom na pitanja vezana uz eutanaziju, o pravnoj zaštiti HIV pozitivnih osoba odnosno osoba s AIDS-om, o inkriminacijama vezanim uz ovisnost, o upotrebi biomedicinskih spoznaja u kaznenom pravu i kriminologiji, o kaznenim djelima iz područja zdravstva (nesavjesno liječenje, samovoljno liječenje, nepružanje medicinske pomoći), o problematici pravne odgovornosti u uvjetima timskog rada na relaciji liječnik, medicinska sestara (i drugi 
zdravstveni radnici), pacijent; o liječničkom zvanju i načelima obavljanja liječničke djelatnosti; pravima i obvezama liječnika u obavljanju liječničke djelatnosti; vrednovanju liječničke djelatnosti (sve navedeno analogno vrijedi i za druge zdravstvene radnike); radu i ustroju Hrvatske liječničke komore i drugih komora zdravstvenih radnika; Kodeksima medicinske etike i deontologije te disciplinskoj odgovornosti zdravstvenih radnika, o postupku sudske zaštite i ostvarivanja individualnih prava pacijenata; izvanparničnim, ovršnim i stečajnim postupcima u području zdravstva te ostvarivanju prava pacijenata i udruga za zaštitu pacijenata u postupku pred ustavnim sudom RH i pred Sudom za ljudska prava Vijeća Europe, prisilnoj hospitalizaciji, oduzimanju i vraćanju poslovne sposobnosti, parnicama radi utvrđivanja očinstva i materinstva, značaju medicine u predistražnom postupku, fiksiranju dokaza i donošenju presude, ulozi DNK u istraživanju kaznenih djela, ovlasti policije i tijela kaznenog postupka na tjelesne preglede okrivljenika i drugih osoba, na uzimanje mokraće, krvi, povjerljivih medicinskih uzoraka, analizu genetskog materijala, primjene medicinskih intervencija za potrebe kaznenog postupka, prisilnom liječenju pritvorenika, medicinskim uzrocima nesposobnosti okrivljenika da sudjeluje u kaznenom postupku, pravu na suodlučivanje, na obaviještenost; na prihvaćanje ili odbijanje pojedinoga dijagnostičkog, odnosno terapijskog postupka; na pristup medicinskoj dokumentaciji; na povjerljivost; na održavanje osobnih kontakata; na samovoljno napuštanje zdravstvene ustanove; na privatnost; na naknadu štete; o nastanku i razvoju zdravstvenih sustava kroz povijest, modelima financiranja i upravljanja zdravstvenim sustavima u svijetu, problemima i poteškoćama koje se pri tome javljaju, formalnim i neformalnim organizacijskim strukturama u zdravstvu, stanjem u zdravstvenom sustavu Hrvatske, mogućim mjerama i metodama koje se mogu poduzimati kako bi se osiguralo njegovo pravilno funkcioniranje i ostvario javni interes zbog kojeg i postoji posebna regulacija tog područja društvenog života, o temeljnim institutima radnog i socijalnog prava, o propisima koji reguliraju ispitivanje, registraciju, proizvodnju i promet lijekova a posebno o izumima nebioloških i mikrobioloških postupaka i proizvoda; izumima koji se odnose na element izoliran iz ljudskog tijela ili proizveden tehničkim postupkom, uključujući odsječak ili djelomični odsječak gena; izumima koji se odnose na dijagnostičke ili kirurške postupke ili postupke liječenja koji se primjenjuju neposredno na ljudskom tijelu; postupcima kloniranja ljudskih bića, postupcima za modificiranje genetičkog identiteta zametne loze ljudskih bića, uporabi ljudskih embrija u industrijske ili komercijalne svrhe; patentnoj zaštiti izvedenih bioloških materijala; patentnoj zaštiti proizvoda koji sadrži ili se sastoji od genetičke informacije, ograničenja prava iz patenata, ograničenje učinaka s obzirom na patente iz područja biotehnologije, zaštiti generičkih lijekova, o štetnim zdravstvenim učincima okolišnih čimbenika, uvjeta i načina rada; ovisnosti zdravlja i bolesti o čimbenicima vezanim za neposredni životni i radni okoliš uključujući i izvanredna stanja; o uzrocima i prevenciji ozljeda na radu, profesionalnih bolesti, bolesti u svezi s radom kao i drugih bolesti koje su važne u morbiditetu radnika kao uzrok privremene ili trajne nesposobnosti za rad; o sindikatima i sindikalnom djelovanju u oblasti zdravstva, o osiguranju financiranja javno-zdravstvenih usluga, odnosu javnog i privatnog $u$ zdravstvenom sustavu, ponude i potražnje zdravstvenih usluga, troškova bolničkih programa, poreznih poticaja itd.

Sve to nužno traži i odgovarajući proces naobrazbe polivalentnih stručnjaka koji će moći udovoljiti tim složenim zahtjevima. ${ }^{14}$ 
Osim što bi trebali biti podrobno upoznati s pravnim propisima i pravnom praksom iz područja zdravstva, pravnici bi trebali biti barem na općenitoj razini upućeni u medicinsku problematiku, ${ }^{15} \mathrm{kroz}$ odgovarajući proces naobrazbe polivalentnih stručnjaka koji će moći udovoljiti tim zahtjevima. Temeljne spoznaje o tome pravnici bi mogli steći tijekom studiranja iz kolegija medicinsko/zdravstveno pravo, sudska medicina, sudska psihijatrija/psihopatologija i sl. ${ }^{16} \mathrm{Na}$ žalost, medicinsko/zdravstveno pravo, kao ni bioetika, ${ }^{17}$ ne izučavaju se sustavno kao zasebni obvezni kolegiji na našim pravnim fakultetima, ${ }^{18}$ dok se, suprotno, pod raznim nazivima, s različitim sadržajem i opsegom, te s različitim nastavnim programima, ponegdje nalaze u studijskim programima medicinskih i nekih drugih stručnih, preddiplomskih, diplomskih i poslijediplomskih studija, što držimo iznimno značajnim i pozitivnim. ${ }^{19}$ Međutim, postoji mišljenje da unatoč tome njihova zastupljenost u studijskim programima medicinskih fakulteta nije zadovoljavajuća s obzirom na realno stanje koje se najbolje očituje kroz veliki broj tužbi protiv liječnika, opadanje interesa studenata za studiranje na fakultetima zdravstvenih usmjerenja te malu ili gotovo nikakvu zainteresiranost za kirurške, anesteziološke, ginekološke i druge ,rizične“" specijalizacije. ${ }^{20}$

Usprkos nedostatku (mogućnosti) stjecanja takvih specijaliziranih znanja, pravnici su prisiljeni pisati pravne propise iz područja medicinskog prava i primjenjivati ih u praksi. Nedostatak tih znanja naše pravnike dovodi u podređeni položaj u odnosu na pravnike iz Europske unije i drugih zemalja.

Značajan iskorak na planu izobrazbe stručnjaka iz područja medicinskog prava uradio je Pravni fakultet Sveučilišta u Splitu ustrojavanjem poslijediplomskog specijalističkog studija «Medicinsko pravo», koji ima za cilj obrazovanje specijalista medicinskog prava, kako bi mogli obavljati vodeće i najsloženije poslove u zdravstvenim ustanovama, pravosuđu, visokoškolskim i drugim obrazovnim ustanovama, institutima te državnim i drugim javnim institucijama. Studij mogu upisati pristupnici koji su diplomirali na sveučilišnom studiju prava. Studij mogu upisati i pristupnici koji su diplomirali na medicinskom fakultetu ili na nekom od društvenih fakulteta: nakon upisa navedeni pristupnici moraju prije polaganja drugih ispita odslušati predavanja iz predmeta «Uvod u pravo». Završetkom poslijediplomskog specijalističkog studija «Medicinsko pravo», stječe se zvanje i kompetencije specijalista medicinskog prava, odnosno točnije specijaliste medicinskog prava. Polaznik stječe multidisciplinarno (pravno-medicinskoetičko) znanje i vještine koje omogućuju kritičku analizu i sposobnost primjene stečenih specifičnih znanja iz područja medicinskog prava u praksi. Polaznici koji steknu diplomu moći će obavljati složene i zahtjevne poslove viših razina odgovornosti u: zdravstvu, pravosuđu, javnoj administraciji (lokalnog, regionalnog, nacionalnog i međunarodnog značenja), profesionalnim i strukovnim udruženjima, obrazovnim institucijama, institutima, ustanovama kao samostalni eksperti iz područja medicinskog prava i dr. $\mathrm{Na}$ studiju se izvode obvezni kolegiji: Građansko pravo i medicina, Medicina i kazneno pravo, Liječničko pravo, Medicinsko građansko procesno pravo, Medicina i kazneni postupak, Pravo pacijenata, Sudska medicina, Uprava u zdravstvu, Radno i socijalno pravo u zdravstvu, te izborni kolegiji: Integrativna bioetika, Osobna prava, Zakonodavstvo na području lijekova, Pravno uređenje inventivne djelatnosti u medicini, Zdravstvena ekologija i medicina rada, CSI Split - Medicinska kriminalistika, Sudska psihijatrija, Sindikalno pravo u zdravstvu, Financiranje javnog zdravstva, Zdravstveno 
strukovno staleško pravo, Zdravstvena informatika, Međunarodno medicinsko pravo i Osnove zdravstvenog osiguranja.$^{21}$

Treba kazati da medicinska struka ima znatno veću tradiciju i uspostavljene sustave provođenja i kontrole izobrazbe i usavršavanja zdravstvenih radnika, negoli što je to slučaj s pravnom strukom. Štoviše, načini i dužnost permanentnog usavršavanja zdravstvenih radnika uređeni su i kogentnim normama. Osiguranje odgovarajućeg stupnja profesionalnosti postiže se, između ostalog, i tzv. postupkom trajne medicinske izobrazbe u kojem sudjeluju svi zdravstveni radnici kojima je izdano odobrenje za samostalan rad - licencija.

Osobe koje se u vidu zanimanja bave poslovima iz područja medicinskog prava, ili su im znanja iz tog područja nužna iz drugih razloga (pacijenti, znanstvenici, odvjetnici i sl.), mogućnost specijalizacije i stjecanja tih znanja mogu ostvariti, osim kroz visokoškolski sustav, i sudjelovanjem na specijaliziranim savjetovanjima, radionicama, u radu na znanstvenim i stručnim projektima i bavljenjem znanstvenim radom, članstvom u strukovnim povjerenstvima, radnim skupinama (za izradu propisa) i sl.

Posebno bismo istaknuli nužnost postojanja strukovnih komora koje bi, između ostalog, trebale omogućiti i organizirati stjecanje specijalističkih znanja i kvalifikacija iz područja medicinskog prava (organiziranjem seminara i polaganjem specijalističkih ispita), donositi pravila struke i etičke kodekse, ostvarivati suradnju s drugim sličnim nacionalnim i inozemnim/međunarodnim udrugama (primjerice, udrugama pacijenata, pravnika u zdravstvu, sudsko-medicinskih vještaka i dr.) i komorama (primjerice, odvjetničkom, liječničkom).

Medicinsko pravo i stručnjaci koji posjeduju znanja iz područja medicinskog prava trebali bi imati značajnu ulogu kod izrade i donošenja novih propisa iz područja zdravstva, te kod usklađivanja naših propisa iz područja zdravstva s propisima međunarodnog prava, odnosno s propisima Europske unije, koji su brojni na ovom području. ${ }^{22}$ Možemo kazati da je danas odnos pacijenta i zdravstvenih radnika sve više protkan pravnim pravilima pa se često koristi termin juridizacija medicine, kao kontinuirani postupak kontrole pružanja zdravstvenih usluga s posljedicom povećanja prava pacijenata i smanjenja ovlasti zdravstvenih radnika. ${ }^{23}$

Malo je vjerojatno da će zakonodavac pravnim normama u potpunosti urediti sve, često i prijeporne odnose u obavljanju medicinske djelatnosti, ako sama medicinska profesija jasno ne definira svoje ciljeve i načela. Ovo je posebno značajno zbog trenda zanemarivanja humanističkih u korist znanstvenih ciljeva u medicini. ${ }^{24}$

Konačno, stručnjaci iz područja medicinskog prava trebali bi svojim radom (sudjelovanje u radu strukovnih komora, udruga, ministarstava, HZZO-a, bolnica, domova zdravlja i drugih zdravstvenih ustanova, te rješavanjem sporova u kojima je potrebno njihovo multidisciplinarno znanje, vještačenjem i sl.), znatno pridonijeti uspostavljanju i razvitku sudske i upravne prakse na ovom području, što bi u konačnici trebalo rezultirati i većom pravnom sigurnošću, a značajan doprinos trebali bi dati i razvitku medicinsko pravne znanosti. ${ }^{25}$ 


\section{Primjedbe}

${ }^{1}$ Usp. HALLER, H., Medicinski pogled na liječničku odgovornost, rad u zborniku „Građanskopravna odgovornost u medicini“, HAZU, Zagreb, 2008., str. 18.

${ }^{2}$ Tako PLAVŠIĆ-NEŠIĆ, A., Komore zdravstvenih radnika Srbije, „Pravni život“, 2009., broj 9, TOM I, str. 1018.

${ }^{3}$ Vidi BOŠKOVIĆ, Z., Profesionalno obrazovanje zdravstvenih djelatnika, „Informator“, broj 4987-4990. od 22., 26. i 29. prosinca 2002., str. 61.

${ }^{4}$ Usp. Prijedlog Strateškog plana razvoja zdravstva u Federaciji Bosne i Hercegovine u periodu od 2008. do 2018. godine, Sarajevo, 2008., str. 26.

${ }^{5}$ Vidi Prijedlog Strateškog plana razvoja zdravstva u Federaciji Bosne i Hercegovine u periodu od 2008. do 2018. godine, Sarajevo, 2008., str. 27. Šire kod BODNARUK, S. - ČIZMIĆ, J. - HRABAČ, B. - HUSEINAGIĆ, S., Komentari zdravstvenih zakona, knjiga 1., Privredna štampa, Sarajevo, 2011.,str. 222.-223.

${ }^{6}$ Tako BOŠKOVIĆ, Z., Profesionalno obrazovanje zdravstvenih djelatnika, „Informator“, broj 4987-4990. od 22., 26. i 29. prosinca 2002., str. 61.

${ }^{7}$ Usp. BOŠKOVIĆ, Z., Profesionalno obrazovanje zdravstvenih djelatnika, „Informator“, broj 4987-4990. od 22.,26. i 29. prosinca. 2001. i 2.siječnja. 2002., str. 61.

${ }^{8}$ Vidi PLAVŠIĆ-NEŠIĆ, A., Komore zdravstvenih radnika Srbije, „Pravni život“, 2009., broj 9, TOM I, str. 1019.

${ }^{9}$ Vidi BOŠKOVIĆ, Z., Profesionalno obrazovanje zdravstvenih djelatnika, „Informator“, broj 4987-4990. od 22.,26. i 29. prosinca. 2001. i 2.siječnja. 2002., str. 62.

${ }^{10}$ Epitetom trajna izobrazba želi se naglasiti kako su zdravstveni radnici kroz cijeli svoj radni vijek dužni pratiti nova dostignuća, metode i tehnike u zdravstvenoj djelatnosti kako bi stručnost u pružanju zdravstvenih usluga uvijek bila osigurana i zajamčena.

${ }^{11}$ Članci 14. i 29. Zakona o liječništvu, članak 55. Zakona o dentalnoj medicini, članak 28. Zakona o ljekarništvu, članak 16. Zakona o medicinsko-biokemijskoj djelatnosti, članak 12. Zakona o sestrinstvu, članak 12. Zakona o primaljstvu, članak 13. Zakona o fizioterapeutskoj djelatnosti, članci 9., 27., 44. i 62. Zakona o djelatnostima u zdravstvu.

12 Upravo zbog povezanosti ove dvije struke, liječnicima je u svakodnevnom radu potrebno (prethodno) elementarno poznavanje pravnog aspekta, odnosno mogućih negativnih pravnih posljedica njihova rada, posebno jer često odluke moraju donositi u trenu. Liječnici su sve više izloženi kaznenim prijavama, građanskim tužbama i stegovnim postupcima zbog eventualnih propusta i pogrešaka u njihovom radu.

13 Tako MUJOVIĆ-ZORNIĆ, H., Pravo kao garant vršenja medicine, «Bilten Jugoslovenskog udruženja za medicinsko pravo», septembar/decembar 2001., str. 15.

${ }^{14}$ Podrobnije kod GOSIĆ, N., Pravna perspektiva u bioetičkoj edukaciji u Hrvatskoj, referat održan na 9. bioetičkom okruglom stolu «Bioetika i medicinsko pravo», održanom u Rijeci, 15. i 16. svibnja 2008.

${ }^{15}$ Ibid.

${ }^{16}$ Usp. JELAČIĆ, O., O nastavi iz sudske medicine na pravnim fakultetima, «Zbornik radova Pravnog fakulteta u Splitu», god. XIV, 1997., str. 236.

17 Jedna od najznačajnijih uloga bioetike upravo je njezina edukacijska uloga. Malo je vjerojatno da će zakonodavac pravnim normama u potpunosti urediti sve, često i prijeporne odnose $u$ obavljanju medicinske djelatnosti, ako sama medicinska profesija jasno ne definira svoje ciljeve i načela. Ovo je posebno značajno zbog trenda zanemarivanja humanističkih u korist znanstvenih ciljeva u medicini. Tako BOGDANIĆ, M., Odnos moralnog i legalnog u medicinskoj eticiameričko iskustvo 40 godina povezanosti bioetike i pravnog sustava, referat na 9. bioetičkom okruglom stolu «Bioetika i medicinsko pravo», održanom u Rijeci, 15. i 16. svibnja 2008.

${ }^{18} \mathrm{Na}$ Pravnom fakultetu Sveučilišta u Zagrebu izvodi se izborni kolegij Medicina i pravo, a na Pravnom fakultetu Sveučilišta u Splitu izvodi se izborni kolegij Zdravstveno pravo. 
${ }^{19}$ Primjerice, u svom studijskom programu Madicinski fakultet u Osijeku ima kolegije Pravo na život i Kako primijeniti Hipokratovu prisegu; Visoka zdravstvena škola u Zagrebu, Studij inženjera medicinske radiologije u planu ima (u planu) kolegij Zdravstveno pravo; Medicinski fakultet u Rijeci ima kolegije Medicinska etika i bioetika i Etika zdravstvene skrbi; Medicinski fakultet Sveučilišta u Splitu - Stručni studij Medicinske radiologije izvodi kolegij Zdravstveno pravo i etika i dr. Usto, na Medicinskom fakultetu Sveučilišta u Splitu izvode se i Medicinska etika, Etika u zdravstvu, Filozofija i bioetika u zdravstvenoj njezi.

${ }^{20}$ Usp. ŽUNIĆ, LJ., Značaj poznavanja medicinskog prava za zdravstvene radnike, seminarski rad - neobjavljeno, Split, 2009., str. 8.

${ }^{21}$ Vidi Studijski program poslijediplomskog specijalističkog studija „Medicinsko pravo“, Split, 2008.

22 Tako MUJOVIĆ-ZORNIĆ, H. (2001). Pravo kao garant vršenja medicine, Bilten Jugoslovenskog udruženja za medicinsko pravo, septembar/decembar, str. 16.

${ }^{23}$ Usp. ŽUNIĆ, LJ., Značaj poznavanja medicinskog prava za zdravstvene radnike, seminarski rad - neobjavljeno, Split, 2009., str. 9.

${ }^{24}$ Tako BOGDANIĆ, M., Odnos moralnog i legalnog u medicinskoj etici-američko iskustvo 40 godina povezanosti bioetike i pravnog sustava, referat na 9. bioetičkom okruglom stolu «Bioetika i medicinsko pravo», održanom u Rijeci, 15. i 16. svibnja 2008.

${ }^{25}$ Usp. ČIZMIĆ, J., Specijalisti medicinskog prava, referat na 19. posvetovanju „Medicina in pravo“, na temo Odgovornost v zdravstvu, Maribor, 26. i 27. marec 2010., Zbornik izvlečkov, str. 80.-99. 


\section{5/ Uvjeti i odobrenje za samostalni rad - licencija}

Odobrenje za samostalan rad je javna isprava koju prema posebnome zakonu izdaje nadležna komora nakon dobivenog uvjerenja zdravstvenog radnika o položenom stručnom ispitu. Odobrenjem za samostalan rad zdravstveni radnik stječe pravo samostalno obavljati poslove u svojoj struci (ZOZZ, čl. 134.). Davanje, obnavljanje i oduzimanje odobrenja za samostalan rad zdravstvenih radnika provodi se sukladno posebnome zakonu (ZOZZ, čl. 135.).

Zdravstveni radnici dužni su svojim znanjem, radom i međusobnom suradnjom u postupku pružanja zdravstvene zaštite, osiguravati odgovarajući stupanj zdravstvenog stanja i zaštite zdravlja korisnika zdravstvene zaštite. Svi zdravstveni radnici moraju zadovoljavati odgovarajuće stručne i zakonske kriterije koji su propisani za sve one koji se, kao profesionalnim zanimanjem, bave pružanjem zdravstvenih usluga. Ovdje se ne misli prvenstveno na stručno-obrazovne kriterije, obzirom da je samo po sebi razumljivo da se profesionalnim pružanjem zdravstvenih usluga mogu baviti samo osobe koje su završile odgovarajuće obrazovanje, već se misli i na neke dodatne uvjete koje je zakonodavac postavio kao conditio sine qua non za obavljanje zdravstvene djelatnosti. Najvažniji od tih dodatnih uvjeta bez kojeg se ne može zakonito obavljati zdravstvena djelatnost, jest svakako odobrenje za samostalan rad, odnosno licenca. Donošenjem tzv. strukovnih zakona (ZOL, ZOLJK, ZODM, ZOMBD, ZOP, ZOS, ZODUZ) zakonodavac je odredio da svi zdravstveni radnici - dakle, liječnici, doktori dentalne medicine, dentalni tehničari, dentalni asistenti, magistri farmacije (ljekarnici), medicinski biokemičari, medicinske sestre, primalje, fizioterapeuti, fizioterapeutski tehničari, radni terapeuti, maseri kupeljari, sanitarni inženjeri, radiološki tehnolozi, te zdravstveni radnici medicinsko-laboratorijske dijagnostike, moraju imati odobrenje za samostalan rad koje im izdaje nadležna komora. Spomenuti strukovni zakoni definiraju odobrenje za samostalan rad (licencu) kao javnu ispravu kojom se dokazuje stručna osposobljenost zdravstvenih radnika temeljem koje oni mogu nesmetano obavljati djelatnost za koju su se školovali.

Zdravstveni radnici se, nakon položenog stručnog ispita, obvezno upisuju u registar zdravstvenih radnika kod nadležne komore iz područja zdravstva, ${ }^{1}$ a time stječu pravo na izdavanje odobrenja za rad tj. licencije od navedenih komora. Odobrenje za samostalan rad - licencija javna je isprava kojom se dokazuje stručna osposobljenost za samostalno obavljanje djelatnosti. Svaki zdravstveni radnik koji na području Republike Hrvatske obavlja bilo koju vrstu djelatnosti vezanu za svoju struku, dužan je podnijeti zahtjev za izdavanje licence/odobrenja za rad te ne može obavljati djelatnosti iz svoje struke bez dobivene licence. Licencu izdaje nadležna komora, nakon dobivanja uvjerenja o položenom stručnom ispitu, sa rokom važenja od šest godina i obnavlja se u skladu sa ZOZZ-om, kao i propisom nadležne komore. Tek po završetku naprijed navedenih postupaka i radnji, zdravstveni radnik ostvaruje pravo na samostalan rad u okviru svog stručnog zvanja. ${ }^{2}$ 
Odobrenje za samostalan rad (licencija) temelj je prepoznatljivosti zdravstvenog radnika i njegove pripadnosti predmetne zdravstvene profesije. Bez odobrenja za samostalan rad niti jedan zdravstveni radnik nije u mogućnosti obavljati poslove svoje profesije u okviru obavljanja zdravstvene djelatnosti. Postoje zdravstveni radnici, tj. osobe koje su završile zdravstvene studije dakle formalno zdravstveno obrazovanje ali ne posjeduju odobrenja za samostalan rad, jer obavljaju poslove izvan svoje profesije, odnosno van okvira zdravstvene djelatnosti, odnosno zdravstvene struke.

Odobrenje za samostalan rad (licencije) izdaju nadležne strukovne organizacije (Komore) zdravstvenih radnika. ${ }^{3}$ One svojim podzakonskim aktima propisuju uvjete za ishodovanje, obnavljanje i oduzimanje odobrenja za samostalan rad (licencije). Opći uvjeti $^{4}$ koji su uopćeno propisani kod svih zdravstvenih Komora u izdavanju odobrenja jesu završen obrazovni zdravstveni program propisane razine, obavljen pripravnički staž i položen stručni ispit (ili obavljen staž u okviru integriranog studijskog programa) te ili hrvatsko državljanstvo ili poznavanje hrvatskog jezika kod stranaca koji također imaju mogućnost i ovlaštenje obavljati djelatnost svoje profesije u okviru zdravstvene djelatnosti po posebno propisanim dodatnim uvjetima (postupci priznavanja inozemnih stručnih kvalifikacija). Posebne uvjete obavljanje profesionalne djelatnosti Komore zdravstvenih radnika propisuju izvan gore navedenih općih uvjeta te se odnose u većini slučajeva na specifičnosti pojedinih profesija. Posebni uvjeti u načelu uključuju podnošenje posebnih zahtjeva i ispunjavanje posebnih obrazaca, kao i potreba prethodnog registriranja u članstvo Komore, uplate određenih naknada za izdavanje odobrenja za samostalan rad, pisano prihvaćanje etičkih i deontoloških načela profesije, potpisivanje suglasnosti o ustezanju dijela članarine od plaće ili drugih osiguranja plaćanje obvezne članarine. Opći akti kojim reguliraju izdavanje odobrenja za samostalan rad jesu u pravilu kod svih Komora akti naziva pravilnik o izdavanju, obnavljanju i oduzimanju odobrenja za samostalan rad. $^{5}$

Odobrenje za samostalan rad (licencija) formalna je isprava koja u svojem sadržaju dokazuje da je njen posjedovatelj ovlašten i zadužen samostalno obavljati rad. Licencija zdravstvenom radniku znači da je zdravstveni radnik ovlašten i dužan samostalno obavljati poslove svoje struke tj. profesije. U sustavu zdravstvene zaštite kao normiranih zdravstvenih profesija postoji jedanaest struka. Predmetne struke nomen profesije zaslužile su temeljem jasno utvrđenih i postavljenih standarda koje je potrebno zadovoljiti da bi se određena osoba mogla baviti poslom takve struke. Naime pripadnici zdravstvenih profesija moraju se obrazovati na zdravstvenim učilištima, stručno se osposobiti za obavljanje predmetnog posla, ishodovati licencu za samostalan rad, te se kontinuirano stručno usavršavati. Dakle produkt takvih preduvjeta je pripadnost profesiji. Na važnost zdravstvenih profesija ukazao je i zakonodavac koji je zakonom propisao temeljna utvrđenja obavljanja tih profesija te ustanovio nadležna tijela koja štite interese zdravstvenih profesija (komore), te koja u ime države provode javne ovlasti. Jedan od temeljnih čimbenika ukazivanja važnosti zdravstvenih profesija i obavljanja poslova i djelatnosti pojedinih profesija je odobrenje za samostalan rad. Odobrenje za samostalan rad je formalna javna isprava, a sadržajem predstavlja puno više. Naime, svaka licencija govori i ukazuje pojedinom zdravstvenom radniku ali i svima trećima da je taj zdravstveni radnik, dakle nositelj tog odobrenja samostalan u svom radu, te da je s tog osnova ovlašten ali i obvezan obaviti svoj dio posla koji se odnosi na pružanje zdravstvene zaštite i usluge 
pacijentu. Dakle taj segment posla ne može i ne smije nitko drugi obavljati osim isključivo taj zdravstveni radnik bez obzira obavljala li se zdravstvena djelatnost $\mathrm{u}$ timu, usporedno ili neovisno tj. pojedinačno. Odobrenje za samostalan rad za svakog zdravstvenog radnika preslika je njegovih obveza i odgovornosti u obavljanju poslova profesije. Jako je bitno naglasiti da se u predmetnom smislu govori o poslovima profesije kojoj zdravstveni radnik pripada, što znači da se kroz svako odobrenje za samostalan rad ogleda samostalnost profesije i njenih poslova u okviru i za vrijeme pružanja zdravstvene zaštite. Tim bi trebale biti donekle utvrđene jasne granice što je posao određene profesije i što će i koji posao određeni zdravstveni radnik zaista obavljati u zdravstvenom timu. Tim više što je jasna prefiksacija samostalnog obavljanja poslova. Odobrenje za samostalan rad utvrđuje u svojoj definiciji izrijekom samostalnost, što znači da nema podjele poslova, niti potrebe miješanja poslova u obavljanju predmetnih djelatnosti. Ovdje bi bilo jasno da kroz element tako utvrđenih samostalnih poslova proizlazi i njegovo ovlaštenje i odgovornost obavljati navedeno. Ovlaštenje da ta osoba, zdravstveni radnik zna koji element posla treba obaviti neovisno i samostalno od drugih, poglavito od pripadnika tima i za taj posao je on educiran i zaposlen u sustavu zdravstva. Kako s jedne strane odobrenje za samostalan rad govori o ovlastima opsegu i vrstu posla koji može i treba zdravstveni radnik obavljati s druge strane ono govori i utvrđuje odgovornosti obveze istog zdravstvenog radnika. Jasno je da je zdravstveni radnik ovlašten obaviti upravo taj posao upravo te profesije, ali je on u odnosu na druge pripadnike tima, u odnosu na pacijenta odgovoran i obvezan za isti posao. Nitko drugi ne može i ne bi smio biti odgovaran za element posla za koji je ovlašten taj zdravstveni radnik i za koji ima i posjeduje za to formalnu i sadržajnu potvrdu. Odgovornost mora proizlaziti iz samog ovlaštenja jer se radi o poslovima koji ukazuju na samostalnost i poslovima koji su sadržajno vezani za profesiju kojoj zdravstveni radnik pripada. Stoga je odgovornost takvog zdravstvenog radnika neupitna kako u sadržajnom tako u formalnom smislu. Ako ćemo jasno vezati odgovornost zdravstvenog radnika za poslove koje je on ovlašten i dužan obavljati kao pripadnik profesije u zdravstvenom timu jasna je njegova odgovornost prema pacijentu kao trećoj osobi, pacijentu kao korisniku usluga, društvu kao cjelini i društvenim vrijednostima te svom poslodavcu. Sadržajem zdravstveni radnik odgovora svima za vrstu i opseg svojih poslova koji su jasno postavljeni standardima i zakonskim normama same profesije i djelokruga struke. Formom on odgovara u različitim vrstama odgovornosti kako je zakonodavac propisao (kaznena, građanska, disciplinska, prekršajna, stegovna, moralna itd.) Slijed takvih utvrđenja provocirao bi sasvim druge dimenzije procesnih odgovornosti. Isto bi značilo da je zdravstveni radnik u procesnom smislu odgovoran u svom subjektivitetu. $\mathrm{S}$ tim bi se utvrđivale sve vrste i načini procesnih odgovornosti. Dakle nitko ne bi smio odgovarati za posao i propuste takvog zdravstvenog radnika, a svu štetu bi trebao on pokrivati i naknaditi. Međutim poznato je da $\mathrm{u}$ procesnom smislu zakonodavac propisuje poglavito $\mathrm{u}$ segmentu građanske odgovornosti ,obvezu naknade štete poslodavca ukoliko u svezi s radom ili u radu zdravstvenih radnik počini nekom štetu. Jednako tako zakonodavac propisuje solidarnu odgovornost ukoliko zdravstveni radnici zajednički obavljaju posao. Vjerojatno jesu ova temeljna načela procesne odgovornosti nesukladna s utvrđenjima koji proizlaze iz odobrenja za samostalan rad ali oni predstavljaju postulate i kriterije postupanja utvrđivanja i procesuiranja odgovornosti. Stoga će bez obzira što zdravstveni radnik ima licencu da je ovlašten i odgovoran samostalno obaviti svoj rad, u zakonsko procesnom smislu odgovarati poslodavac za štetu koju je počinio taj zdravstveni radnik u okviru svog 
posla. Ili će više zdravstvenih radnika koji rade u timu ukoliko se procesno utvrdi da su neki posao obavljali zajedno, odgovarati solidarno. Dakle moglo bi se reći da predmetna dva primjera jasno ukazuju da institut licencije u svom sadržaju još nije ,prepoznat“ u procesno-pravnom segmentu pitanja odgovornosti, dakle prvenstveno kao pravnog pojma. Međutim navedeni element ne bi smio ostavljati zdravstvenom radniku prostora da olako shvaća svoj položaj prilikom obavljanja poslova zdravstvene djelatnosti, te onaj položaj i ulogu koja mu namijenjena kao pripadniku zdravstvene profesije temeljem odobrenja za samostalan rad. Olakim shvaćanjem svoje pozicije gubi se smisao posebnosti i specifičnosti zdravstvenih profesija te njenih utjecaja i važnosti po društvo i pojedinca te instituta zaštite zdravlja kao djelatnosti od posebnog interesa za državu. Stoga će pod pritiskom važnosti i značaja zdravstvenih profesija i zdravstvenih radnika i njihovih poslova biti stvarana nova jasna slika odgovornosti zdravstvenog radnika kao pojedinca u okviru njegovih jasno postavljenih i utvrđenih poslova.

Postupak ishođenja odobrenja za samostalan rad je jasno propisana procedura koja se provodi kroz upravni postupak, obzirom da se radi o javnoj ovlasti koju je državna vlast prenijela u nadležnost Komora kao neovisnih strukovnih organizacija. Vidjeli smo da je element pripravničkog staža i stručnog ispita u nadležnosti ministarstva zdravstva, dok je izdavanje odobrenja za samostalan rad u nadležnosti strukovnih zdravstvenih Komora koje odobrenja za samostalan rad izdaju temeljem upravno pravnih rješidbi za koje su nadležne ili službene osobe ili čelnik tijela ovisno o organizacijskoj strukturi pojedinih Komora.

Pravilnik o odobrenju za samostalan rad (licenci) Hrvatske liječničke komore od 10. travnja 2017. (dalje - POL). POL se propisuju uvjeti i postupak izdavanja, obnavljanja ili zamjene odobrenja za samostalan rad (licence) Hrvatske liječničke komore u svrhu obavljanja liječničke djelatnosti na području Republike Hrvatske; način prestanka važenja odobrenja za samostalan rad (licence); način izvršavanja disciplinske mjere privremenog ili trajnog oduzimanja odobrenja za samostalan rad (licence) odnosno ograničenja opsega odobrenja za samostalan rad (POL, čl. 1.). Odobrenje za samostalan rad javna je isprava kojom se dokazuje stručna osposobljenost liječnika - doktora medicine za samostalno obavljanje liječničke djelatnosti iz područja opće medicine, specijalnosti i uže specijalnosti odnosno akreditacijskog područja u Republici Hrvatskoj (POL, čl. 2.).

Uvjeti za izdavanje licence liječnicima državljanima Republike Hrvatske su: 1. stručna kvalifikacija koja obuhvaća formalno obrazovanje i profesionalnu osposobljenost, odnosno priznata inozemna stručna kvalifikacija za obavljanje liječničke djelatnosti koju donosi nadležno tijelo u postupku priznavanja inozemnih stručnih kvalifikacija sukladno posebnom propisu, 2. obavljen pripravnički staž, odnosno priznat pripravnički staž obavljen u inozemstvu, 3. položen stručni ispit, 4. državljanstvo Republike Hrvatske, 5. članstvo u Komori, 6. poznavanje hrvatskog jezika na razini koja je potrebna za nesmetanu i nužnu komunikaciju s pacijentom.

Licenca odnosno rješenje o izdavanju, obnavljanju ili zamjeni licence sadrži sljedeće podatke: 1 . ime i prezime liječnika, 2. datum i mjesto rođenja, 3. profesionalni naziv, akademski stupanj, nastavno zvanje, stručno zvanje, naziv primarius, stručni naziv, 4. 


\section{ZDRAVSTVENO STRUKOVNO STALEŠKO PRAVO \\ Radnici zdravstvene struke: Uvjeti i odobrenje za samostalni rad - licencija}

stručno područje za koje se licenca izdaje - opća medicina, specijalizacija ili uža specijalizacija ili akreditacijsko područje, 5. razdoblje važenja licence, 6. broj licence, 7 . klasa i urudžbeni broj licence, 8. datum i mjesto izdavanja, 9. potpis predsjednika Komore, 10. pečat s grbom Republike Hrvatske. Podaci koju su navedeni na licenci moraju biti prethodno evidentirani odnosno upisani u javne knjige Komore (POL, čl. 11.).

Licenca se izdaje na razdoblje od šest godina, osim ako POL-om nije drukčije propisano (POL, čl. 16.).

Liječnik, državljanin Republike Hrvatske koji je stručne kvalifikacije stekao u Republici Hrvatskoj i koji u Republici Hrvatskoj želi obavljati liječničku djelatnost, dužan je zatražiti upis u Imenik liječnika te izdavanje licence (POL. čl. 17.).

Predsjednik donosi rješenje o izdavanju licence u roku od 30 dana od dana primitka urednog i opravdanog zahtjeva za izdavanje licence. Ukoliko predsjednik utvrdi da zahtjev za izdavanje licence nije opravdan iz razloga koji su predviđeni važećim zakonskim i podzakonskim propisima Republike Hrvatske, donosi rješenje kojim se zahtjev odbija. Protiv rješenja iz stavka 1. i 2. ovoga članka nije dopuštena žalba, već se može pokrenuti upravni spor pred nadležnim upravnim sudom (POL, čl. 22.).

Liječnik je dužan bez odgode podnijeti zahtjev za zamjenu licence u sljedećim slučajevima: a) ako unutar razdoblja važenja licence iz opće medicine položi specijalistički ispit ili stekne status specijalista određene specijalnosti, sukladno posebnim propisima; b) ako unutar razdoblja važenja licence iz specijalnosti položi ispit iz uže specijalnosti ili stekne status specijalista iz uže specijalnosti, sukladno posebnim propisima; c) ako unutar razdoblja važenja licence iz određene specijalnosti i uže specijalnosti položi ispit ili mu bude priznat status specijalista iz druge uže specijalnosti istog specijalističkog područja; d) ako unutar razdoblja važenja licence završi izobrazbu iz akreditacijskog područja (POL, čl. 23.).

Licenciju je moguće izdati zdravstvenom radniku i za višu razinu obrazovanja ili za drugu razinu obrazovanja. Doktori medicine nakon obavljenog specijalističkog usavršavanja po položenom specijalističkom, ili subspecijalističkom ispitu imaju pravo ishodovati licencu u okviru specijalizacije odnosno subspecijalizacije. Time se ovlašćuje doktor medicine obavljati poslove predmetne specijalizacije odnosno pojedine subspecijalizacije. Postoje zdravstveni radnici koje shodno tome posjeduje i više odobrenja za samostalan rad. Naime pojedini doktori medicine mogu biti specijalisti iz više područja, a drugi zdravstveni radnici mogu steći druga obrazovanja iz sustava zdravstva pa time i mogućnosti ishodovanja više odobrenja za samostalan rad. Međutim postoje u praksi i najčešće su situacija da pojedini zdravstveni radnik stekne viši stupanj obrazovanja, ali nema mogućnosti da mu se isti viši stupanj vrednuje te je shodno tome dužan zadržati odobrenje za samostalan rad za postojeći nižu razinu obrazovanja, jer je ono kako smo prethodno naveli temelj radnog mjesta i mogućnosti obavljanja profesionalne djelatnosti.

Liječnik je dužan bez odgode zatražiti zamjenu licence i u slučajevima: kada stekne naziv primarius, akademski stupanj, u slučaju izbora u znanstveno-nastavno ili nastavno zvanje te u slučaju promjene osobnih podataka (POL, čl. 24.). Liječnik koji unutar razdoblja 
važenja licence iz određene specijalnosti položi specijalistički ispit ili stekne status specijaliste iz druge specijalnosti dužan je podnijeti zahtjev za izdavanje licence iz druge specijalnosti (POL, čl. 25.).

Odobrenje za samostalan rad (licencija) ima i svoj "rok trajanja", odnosno, rok na koji se izdaje. Svim pružateljima zdravstvenih usluga odobrenje se, u pravilu, izdaje na vrijeme od šest godina. Nakon isteka roka od šest godina, odobrenje se mora obnoviti. Odobrenja za samostalan rad izdaju se u pravilu kod svih zdravstvenih radnika na vrijeme od šest godina, što znači da se ista odobrenja moraju svih šest godina obnavljati. Institut obnavljanja odobrenja za samostalan rad utvrđen je iz razloga potreba zdravstvenih radnika stalno se stručno i profesionalno usavršavati. Zdravstvo je djelatnost koja iznimno ovisi o tehnološkom napretku i razvoju, te jasno utvrđenim standardima i smjernicama koje ne mogu biti konstanta obzirom na razvoj zdravstveno-medicinskih struka i unaprjeđenja načina obavljanja zdravstvene zaštite, novih načina liječenja dijagnostičkih i terapijskih postupaka. Liječnik kojemu je izdana licencija, dužan je stručno se usavršavati u skladu s posebnim aktom Komore kojim je reguliran postupak, sadržaj i rokovi trajne medicinske izobrazbe liječnika. Liječniku se obnavlja licencija ukoliko je sakupio propisani broj bodova u postupku trajne medicinske izobrazbe, odnosno najmanje 120 bodova u šest godina te ukoliko uredno ispunjava sve članske obveze (POL, čl. 29.). Zdravstveni radnik nakon isteka šestogodišnjeg razdoblja mora imati odgovarajući broj bodova koji će potvrditi da je prošao potrebu edukaciju s ciljem obnove svoje licencije. U većini slučajeva kod zdravstvenih radnika doktora i magistra drugih zdravstvenih profesija bodovni prag je utvrđen na 120 bodova, za tzv. prvostupnike bodovni prag je utvrđen na 90 bodova, a za srednjoškolsko obrazovanje utvrđen je prag od 60 bodova potrebnih za obnovi licencije nakon šestogodišnjeg razdoblja. Komora će najkasnije tri mjeseca prije isteka razdoblja važenja licencije liječnika upozoriti na obvezu obnove licencije, odnosno na uvjete koji moraju biti ispunjeni u svrhu obnove licencije (POL, čl. 31.). Predsjednik Komore donosi rješenje o obnavljanju licencije u roku od 30 dana od dana primitka urednog i opravdanog zahtjeva za izdavanje licencije. Protiv rješenja iz stavka 1. ovoga članka nije dopuštena žalba, već se može pokrenuti upravni spor pred nadležnim upravnim sudom (POL, čl. 36.). Ukoliko zdravstveni radnik ne stekne odgovarajući ovdje predviđen broj bodova dužan je ukoliko želi obnoviti licenciju i samim tim nastaviti raditi u svojoj profesiji položiti posebni ispit provjere znanja i stručnosti ispred povjerenstva koje strukovne organizacije Komore imenuju za takve slučajeve. Tek nakon utvrđivanja da je osoba položila predmeti ispit i samim tim zadovoljila kriterije obnavljanja svojeg znanja ona je u mogućnosti obnoviti svoju licenciju.

Liječniku, državljaninu Republike Hrvatske koji je stručne kvalifikacije stekao u Republici Hrvatskoj, a koji u roku od šest godina od dana položenog stručnog ispita nije zatražio izdavanje licencije Komora će izdati licenciju samo uz prethodnu provjeru osposobljenosti (POL, čl. 38.). U slučaju dostave zahtjeva za provjerom osposobljenosti podnositelju zahtjeva će se odrediti rok od šest mjeseci u kojem je dužan obaviti provjeru osposobljenosti (POL, čl. 39.). Liječniku koji nije sakupio propisani broj bodova na način predviđen posebnim aktom Komore kojim je reguliran postupak, sadržaj i rokovi trajne medicinske izobrazbe, licencija će se obnoviti samo pod uvjetom uspješno završene provjere osposobljenosti (POL, čl. 40.). Nakon uspješno položenog ispita u postupku 
provjere osposobljenosti, liječniku će se izdati odnosno obnoviti licencija s danom položenog ispita radi provjere osposobljenosti (POL, čl. 41.).

Liječnik može zatražiti izdavanje duplikata izdane licencije u slučaju gubitka, otuđenja, oštećenja ili uništenja sukladno posebnom aktu Komore koji uređuje postupak izdavanja duplikata (POL, čl. 42.).

Licencija prestaje važiti: 1 . istekom vremenskog razdoblja na koje je izdana, 2. na osobni zahtjev liječnika, 3. odlukom disciplinskog tijela Komore, 4. brisanjem liječnika iz Imenika liječnika, 5. smrću liječnika -člana Komore (POL, čl. 42.).

Jednom stečena licencija može se i oduzeti. Oduzimanje licence predviđeno je u određenim okolnostima zbog posebno propisanih situacija. Oduzeti se licencija može ili privremeno ili trajno. Na koje će se vrijeme licencija oduzeti ovisi o činjenici koja prethodi i uvjet je oduzimanja licencije. Propisane su komorskim internim aktima različite mogućnosti oduzimanja licencije npr. utvrđivanje nedostojnost za obavljanje profesije, ili utvrđivanje povrede profesionalne dužnosti u disciplinskom postupku ili drugom sudskom postupku, ispisivanjem iz članstva Komore, gubitkom poslovne sposobnosti itd. Oduzeta licencija znači ujedno i nemogućnost obavljanja profesionalne djelatnosti u vremenu za koje je licencija oduzeta.

Odlukom Suda Komore liječniku se može privremeno ili trajno oduzeti licencija. Osim odluke iz prethodnog stavka ovoga članka, Sud Komore može, privremeno ili trajno, liječniku ograničiti licenciju obzirom na opseg i vrstu poslova kojima se liječnik smije baviti (POL, čl. 46.). Liječniku kojem je aktom nadležnog tijela temeljem posebnih propisa odobren djelomičan pristup profesiji izdaje se licencija za djelomičan pristup profesiji (POL, čl. 48.).

Neposjedovanje licencije iz bilo kojeg razloga znači ujedno i nemogućnost obavljanja profesionalne djelatnosti, te svako za kog se na bilo koji način utvrdi da nema licenciju podložen je prekršajnim novčanim kaznama i drugim mjerama predviđenim zakonskim propisima. 


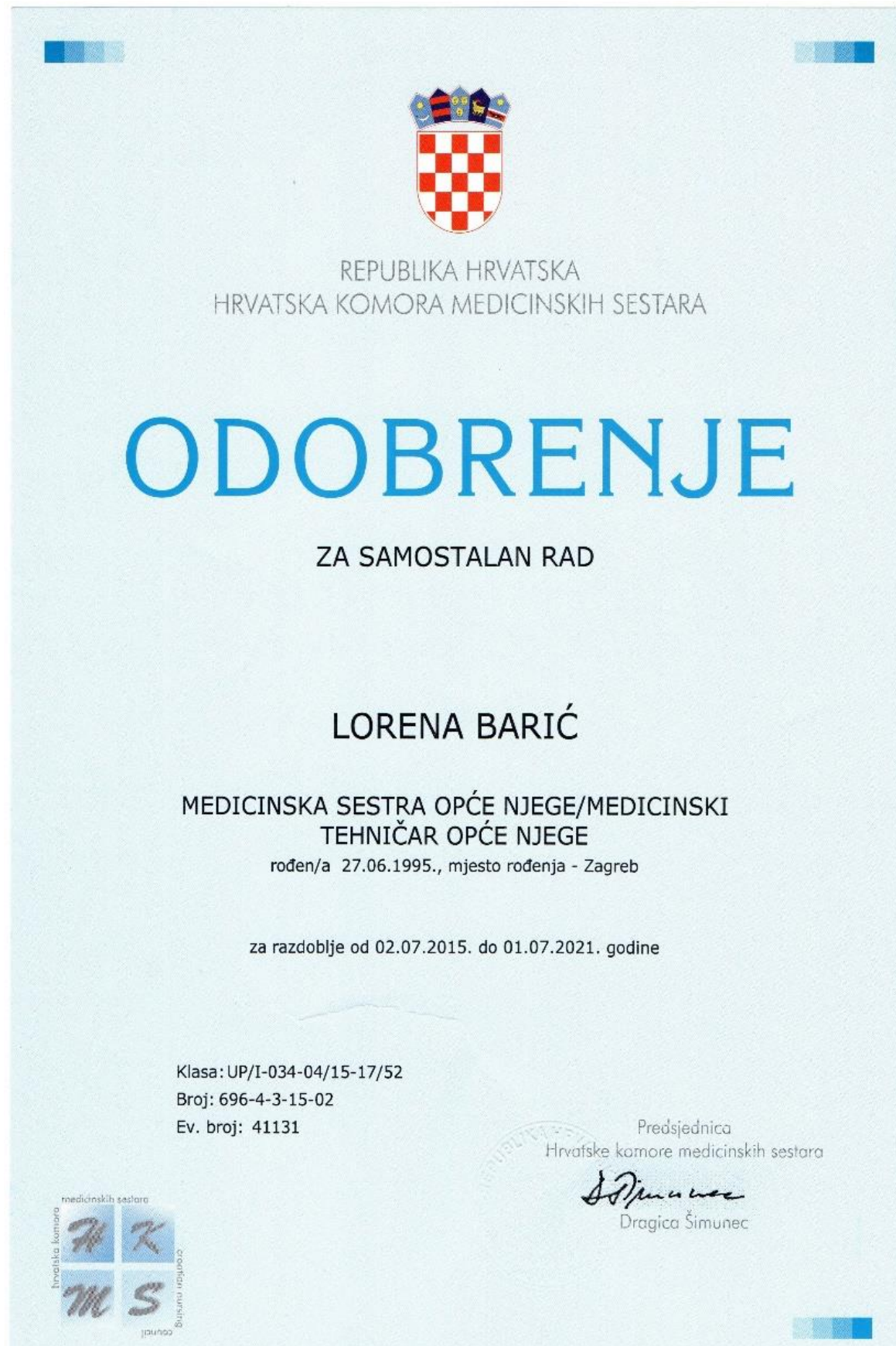

Slika 8: $\mathrm{FN}^{6}$ 


$$
\begin{array}{r}
\text { ZDRAVSTVENO STRUKOVNO STALEŠKO PRAVO } \\
\text { Radnici zdravstvene struke: Uvjeti i odobrenje za samostalni rad - licencija }
\end{array}
$$

\section{Primjedbe}

${ }^{1}$ Uvjeti za upis u Imenik liječnika propisani su posebnim aktom Komore (POL, čl. 9.).Prema odredbi čl. 6. Pravilnika o javnim knjigama Hrvatske liječničke komore, Imenik liječnika je osnovna javna knjiga Komore koja sadrži podatke o liječnicima - članovima Komore, sukladno ovom Pravilniku i drugim općim aktima Komore. Liječnici koji rade na poslovima zdravstvene zaštite u Republici Hrvatskoj upisuju se u Imenik liječnika. Upisom u Imenik liječnika stječe se status člana Komore odnosno sva članska prava i obveze propisane Statutom i drugim općim aktima Komore. Upis u Imenik liječnika obavlja se na zahtjev liječnika koji udovoljava sljedećim uvjetima: - diploma medicinskog fakulteta u Republici Hrvatskoj ili priznata diploma inozemnog medicinskog fakulteta, položen stručni ispit, odnosno specijalistički ispit, ili ispit iz uže specijalizacije za samostalan rad u pojedinim specijalističkim, odnosno strukama uže specijalizacije; - državljanstvo Republike Hrvatske; - znanje hrvatskog jezika. Iznimno, strani državljani mogu obavljati liječničku djelatnost prema propisima koji uređuju rad stranaca u Republici Hrvatskoj te upisati se u Imenik liječnika (Pravilnika o javnim knjigama Hrvatske liječničke komore, čl. 7.).

2 Vidi BODNARUK, S. - ČIZMIĆ, J. - HRABAČ, B. - HUSEINAGIĆ, S., Komentari zdravstvenih zakona, knjiga 1., Privredna štampa, Sarajevo, 2011., str. 219.

${ }^{3}$ Licencija liječnika sadrži: ime i prezime liječnika,datum i mjesto rođenja,akademski stupanj, znanstveno nastavno odnosno nastavno zvanje liječnika, naziv primarijus,stručni naziv stručno područje za koje se licenca izdaje -opća medicina, specijalnost ili uža specijalnost ili akreditacijsko područje,razdoblje važenja licence broj licence,klasa i urudžbeni broj licence, datum i mjesto izdavanja,potpis predsjednika Komore,pečat Republike Hrvatske.

${ }^{4}$ Opći uvjeti za liječnike stručna kvalifikacija koja obuhvaća formalno obrazovanje i profesionalnu osposobljenost za obavljanje regulirane profesije liječnik -doktor medicine, članstvo u Hrvatskoj liječničkoj komori, poznavanje hrvatskog jezika na razini koja je potrebna za nesmetanu i nužnu komunikaciju s pacijentom.

${ }^{5}$ Zahtjevu za ishodovanje licence liječnik dostavlja: 1. dokaz o stručnoj kvalifikaciji koja obuhvaća formalno obrazovanje i profesionalnu osposobljenost izdan u Republici Hrvatskoj ili u državi članici EU/EGP(diploma medicinskog fakulteta), 2.rješenje o priznavanju inozemne stručne kvalifikacije za obavljanje liječničke djelatnosti koju donosi nadležno tijelo u postupku priznavanja inozemnih stručnih kvalifikacija sukladno posebnom propisu, 3.dokaz o obavljenom pripravničkom stažu odnosno o priznavanju pripravničkog staža obavljenog u inozemstvu, 4.dokaz o položenom stručnom ispitu, 5.dokaz o položenom specijalističkom ispitu odnosno rješenje o priznavanju specijalizacije izdano od strane ovlaštenog tijela u Republici Hrvatskoj, 6.dokaz o položenom ispitu iz uže specijalizacije odnosno rješenje o priznavanju uže specijalizacije izdano od strane ovlaštenog tijela u Republici Hrvatskoj, 7.dokaz o završenoj izobrazbi iz akreditacijskog područja, odnosno rješenje o priznavanju završene i zobrazbe iz akreditacijskog područja, 8.dokaz o hrvatskom državljanstvu (domovnica), 9.dokaz o poznavanju hrvatskog jezika na razini koja je potrebna za nesmetanu i nužnu komunikaciju s pacijentom, sukladno članku 6. Pravilnika, 10.izjava o obvezi poštivanja etičkih i deontoloških načela struke, 11.dokaz o stečenom ili priznatom akademskom stupnju, 12.dokaz o izboru u znanstveno nastavno odnosno nastavno zvanje ili rješenje o priznatom znanstveno nastavnom odnosno nastavnom zvanju, 13.dokaz o stečenom ili priznatom nazivu primarijus ili drugom stručnom nazivu.

${ }^{6}$ Podatak na stranici:

https://www.google.hr/search?q=odobrenje+za+samostalni+rad+lije\%C4\%8Dnika+obrazac+slika \&hl=bs\&tbm=isch\&imgil=LzTf3urBsRmqMM\%253A\%253BBRfwxmRyrXo92M\%253Bhttp\%2 5253A\%25252F\%25252Fss-

bedekovcina.skole.hr\%25252F\%25253Fnews_hk\%2525253D1\%25252526news_id\%2525253D8 827\%25252526mshow\%2525253D1155\&source=iu\&pf=m\&fir=LzTf3urBsRmqMM\%253A\%25 2CBRfwxmRyrXo92M\%252C_\&usg=_uBVKz_6Afbf6ozUUXYTXbBIW6wg\%3D\&biw=1920 
Radnici zdravstvene struke: Uvjeti i odobrenje za samostalni rad - licencija

\&bih=971\&ved=0ahUKEwi37fv0t8fVAhXDUBQKHefkCtwQyjcITw\&ei=epOJWbfIOsOhUefJq -AN\#imgrc=LzTf3urBsRmqMM: 


\section{6/ Članska iskaznica}

Zdravstvenom radniku upisanom u registre komore izdaje se članska iskaznica. Komore vode javne registre u kojima čuvaju i pohranjuju sve relevantne podatke o zdravstvenim radnicima: ime i prezime, godina i mjesto rođenja, OIB, adresa stanovanja, stupanj obrazovanja, osposobljavanja, sve edukacije i stručna usavršavanja, ustanova zaposlenja, itd.). ${ }^{1}$ Registri su u većini elektroničke baze podataka, o kojima vode računa posebno osposobljeni i za navedeno educirani zaposlenici Komora. Obzirom da se radi o osobnim pa time i tajnim podacima Komore su propisale posebna pravila čuvanja i korištenja predmetnih podataka. ${ }^{2}$

Liječniku upisanom u Imenik liječnika izdaje se liječnička iskaznica (ZOL, čl. 11.), a oblik i sadržaj liječničke iskaznice te način izdavanja i vođenja upisnika o izdanim iskaznicama propisuje općim aktom Hrvatska liječnička komora, Liječnička iskaznica izdaje se liječniku nakon izdavanja licencije obvezno sadrži: ime i prezime liječnika, članski broj, broj licence, vrijeme važenja licence i znak Komore Liječnička iskaznica izdaje se liječniku upisanom u Imenik liječnika. Liječnička iskaznica je pravokutnog oblika, u pravilu veličine 8,5 x 5,4 cm, plastificirana. Na liječničkoj iskaznici obavezno se nalaze slijedeći podaci: 1. naziv i logo Komore na hrvatskom i engleskom jeziku, 2. ime i prezime liječnika, 3. članski broj, 4. po potrebi i drugi podaci sukladno odluci Izvršnog odbora Komore ili izdavatelja iskaznice (Pravilnik o javnim knjigama Hrvatske liječničke komore VII LIJEČNIČKA ISKAZNICA, članak 34.). ${ }^{3}$ Liječnik je dužan gubitak liječničke iskaznice, bez odgode, prijaviti Komori i izdavatelju iskaznice. Komora gubitak liječničke iskaznice objavljuje u prvom sljedećem broju službenog glasila Komore, a izdavatelj iskaznice treba postupiti sukladno svojim uvjetima poslovanja. Komora, odnosno izdavatelj iskaznice, izdat će liječniku novu iskaznicu, u pravilu, u roku od 30 dana od dana objave gubitka liječničke iskaznice u službenom glasilu Komore (Pravilnik o javnim knjigama Hrvatske liječničke komore (pročišćeni tekst), VII LIJEČNIČKA ISKAZNICA, članak 35.).

Nedavno su liječnicima podijeljene prve tzv. 'pametne' liječničke iskaznice. Projekt izrade novih liječničkih iskaznica s naprednim elektroničkim potpisom, koje će članovima omogućiti siguran način komunikacije s Komorom te brzo i jednostavno ostvarivanje članskih prava i pogodnosti, pokrenut je krajem 2016. u sklopu e-Komore. Ovom iskaznicom članovi HLK-a bit će povezani i sa sustavom e-građanin. Nove pametne liječničke iskaznice omogućit će članovima Komore sigurnu komunikaciju te brzo i jednostavno ostvarivanje članskih prava i pogodnosti. Liječnik će primjerice putem online servisa moći zatražiti ili produžiti licencu ili neku drugu potvrdu. Svaka iskaznica, uz osobne podatke člana imat će i njegovu biometrijsku fotografiju. 


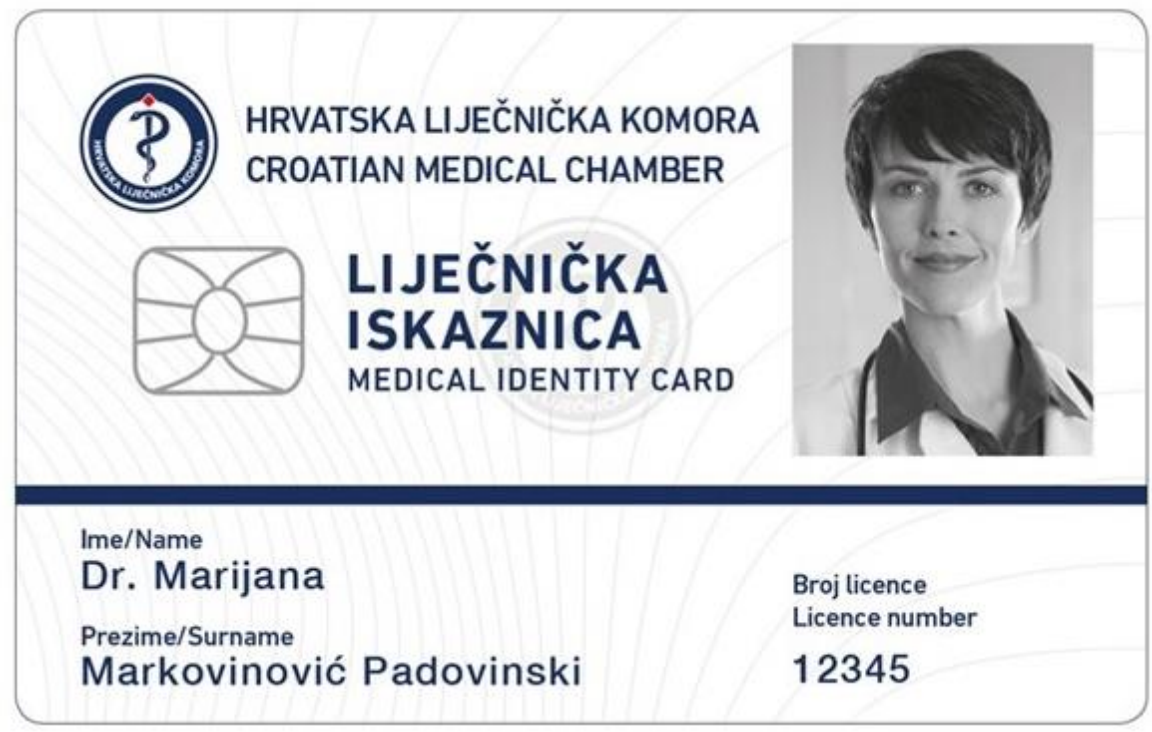

Slika 9: Fotografija nove liječničke iskaznice objavljena je na stranici Hrvatske liječničke komore, https://www.hlk.hr/dostavite-biometrijsku-fotografiju-radiizrade-pametne-lijecnicke-iskaznice.aspx.

\section{Primjedbe}

${ }^{1}$ Vidi Pravilnik o registru članova HKZR(pročišćeni tekst)od 19.5 2016.g., Pravilnik o registrima HKF od 28.12.2011. g. , Pravilnik o vođenju registra HKMS (pročišćeni tekst) od 17 .6.2015. g.,Pravilnik o vođenju registra članova HKMB od 9.4.2005.g., Pravilnik o registrima HKDM od 22.2.2010.g. Pravilnik o uvjetima, načinu upisa, vođenja i sadržaju Registra HLJK- (pročišćeni tekst )od 26.10.2016.g., Pravilnik o postupku upisa u registre HKP od 17.11.2016.g.

${ }^{2}$ Vidi www.hlk.hr. Pravilnik o dužnosti čuvanja poslovne i profesionalne tajne te postupanja s klasificiranom dokumentacijom stupio na snagu 5.5.2017.

${ }^{3}$ Izdavateljem se u smislu ovog Pravilnika smatra Komora, odnosno druga fizička ili pravna osoba ovlaštena od strane Komore za izdavanje liječničkih iskaznica. 


\section{7/ Specijalizacija u grani zdravstvene djelatnosti i specijalistički ispit}

\subsection{Ovlaštenici i svrha specijalističkog usavršavanja}

Pojedine zdravstvene profesije imaju mogućnost specijalističkog usavršavanja. Sukladno pravnim utvrđenima u RH takvu mogućnost imaju doktori medicine, ${ }^{1}$ doktori dentalne medicine, magistri biokemije, ${ }^{2}$ magistri farmacije, ${ }^{3}$, medicinske sestre ${ }^{4}$ dok druge zdravstvene struke takvu mogućnost nemaju iako sve zdravstvene struke imaju mogućnost vertikalnog napredovanje u struci, odnosno stjecanje viših razina edukacije i obrazovanja. Zasigurno je samo pitanje vremena kad će hrvatski zdravstveno - obrazovni sustav omogućiti specijalizacije i drugim zdravstvenim profesijama. Danas u sustavu zdravstva ne postoji praktički liječnička djelatnost koja se može obavljati bez stečene specijalizacije. Nekad su doktori obiteljske medicine, te doktori hitne medicine mogli obavljati predmetnu djelatnost bez stečene specijalizacije.

Specijalizacija zdravstvenih radnika je oblik stručnog osposobljavanja odnosno stručnog usavršavanja osoba koje su već stekle određeni najviši stupanj stručne spreme, kako bi se u što je moguće većoj mjeri stručno osposobili u određenoj grani medicine, odnosno zdravstvene djelatnosti. Specijalizacija je osnova za primjenu novih i usavršavanje postojećih znanja. Specijalističko usavršavanje je pravno uređen institut. ${ }^{5}$

Svrha je specijalizacije da se specijalizantu dadu znatno proširena i produbljena znanja za obavljanje poslova na mjestima za koja se zahtijeva specijalističko znanje. Prepuštanje operacije i drugih zahvata specijalizantima nužno je radi njihova usavršavanja, ali se to ne smije činiti na štetu pacijenta, odnosno pacijent ne smije biti izložen dodatnom riziku što zahvat obavlja neobučen ili nedovoljno obučen zdravstveni radnik te ima pravo na zahvat koji odgovara standardu prosječno iskusnog specijalista. To ne znači da zahvat uvijek moraju obavljati specijalisti, da se uvijek mora jamčiti odgovarajući medicinski standard. ${ }^{6}$ Jedini kvalitetan način da liječnici na specijalizaciji steknu praksu i iskustvo i da budu osposobljeni za polaganje specijalističkog ispita i u konačnici postanu specijalisti iz određenog područja je da prvo promatraju liječnike specijaliste i uče, a zatim da i sami počnu sudjelovati u radu s pacijentima, što svakako znači i da je uključen aktivni praktični rad u trenutku dok ta osoba još nije specijalist nego je samo budući specijalist, još točnije u tom trenutku je ta osoba (samo) in spe specijalist. Problem je, naravno u postavljanju uvjeta u kojima će se praksa stjecati na ,pravim“ pacijentima, a ti uvjeti bi morali u prvom redu zaštititi pacijente, a tek nakon toga specijalizante i ustanove. Idealno bi bilo da postoji pravna norma koja bi najprije propisala opće uvjete rada specijalizanata, a nakon toga bi se propisali posebni uvjeti za pojedine specijalizacije. ${ }^{7}$ Specijalističko usavršavanje osigurava specijalizantu stjecanje znanja i vještina neophodno korisnih za njegov daljnji praktični rad i napredovanje u profesiji. Za stjecanje rečenih znanja i vještina pomaže mentorstvo kojim se potiče, razvija, usmjerava i kontrolira intelektualni rad specijalizanata. ${ }^{8}$ Specijalističko usavršavanje odnosi sa na oblik organiziranog stjecanja kompetencija prema propisanom programu koja se može obavljati samo u 
Radnici zdravstvene struke: Specijalizacija u grani zdravstvene djelatnosti i specijalistički ispit

ovlaštenim zdravstvenim ustanovama, trgovačkim društvima koja obavljaju zdravstvenu djelatnost, odnosno kod ovlaštenih zdravstvenih radnika koji obavljaju privatnu praksu.

Zdravstveni radnici mogu se specijalizirati u određenoj grani zdravstvene djelatnosti te određenim granama uže specijalizacije, a grane specijalizacije, trajanje i program specijalizacija i užih specijalizacija utvrđuje pravilnikom ministar na prijedlog nadležne komore i stručnih društava (ZOZZ, čl. 139.). Nekoć skoro jedinstveni medicinski korpus razdvaja se danas u niz zasebnih područja unutar kojih se sistematiziraju pojedinačna znanja iz pojedinih područja, zbog čega raste broj specijaliziranih i uže specijaliziranih radnika, niču nove ustrojbene jedinice i sve se više inzistira na timskom radu i interdisciplinarnoj suradnji. Takva gibanja zacijelo su neophodna i jamac su daljnjem znanstveno-medicinskom teorijskom i praktičnom napretku. ${ }^{9}$ Uža specijalizacija jest nastavak usavršavanja specijalista određene grane specijalizacije na temelju utvrđenog plana potrebnih kadrova putem stjecanja dodatnih kompetencija prema propisanom programu. Uža specijalizacija jest stručna osposobljenost specijalista određene grane specijalizacije koja se stječe završetkom programa uže specijalizacije.

Program specijalizacije definira sadržaj i trajanje svih dijelova specijalističkog usavršavanja, popis općih i posebnih kompetencija, uvjete koje moraju ispunjavati pravne i fizičke osobe za obavljanje specijalističkog usavršavanja, obrazac praćenja napredovanja u stjecanju kompetencija, obrazac praćenja obavljenih zahvata, a uključuje i poslijediplomski specijalistički studij za grane specijalizacije.

Specijalizacija se može odobriti zdravstvenom radniku kojem je izdano odobrenje za samostalan rad te koji je u radnom odnosu u zdravstvenoj ustanovi ili trgovačkom društvu koje obavlja zdravstvenu djelatnost ili ima privatnu praksu ili radi kod zdravstvenog radnika privatne prakse sa završenim sveučilišnim diplomskim studijem (ZOZZ, čl. 140.). ${ }^{10}$ Odobrenje za specijalizaciju (i užu specijalizaciju) daje ministarstvo rješenjem na temelju godišnjeg plana potrebnih specijalizacija i užih specijalizacija koji donosi na prijedlog zdravstvenih ustanova, Zavoda i nadležne komore (ZOZZ, čl. 140. st. 3.). 
GLASILO HRVATSKE LIJEČNIČKE KOMORE GODINA XVI BR. 153 LISTOPAD 2016.
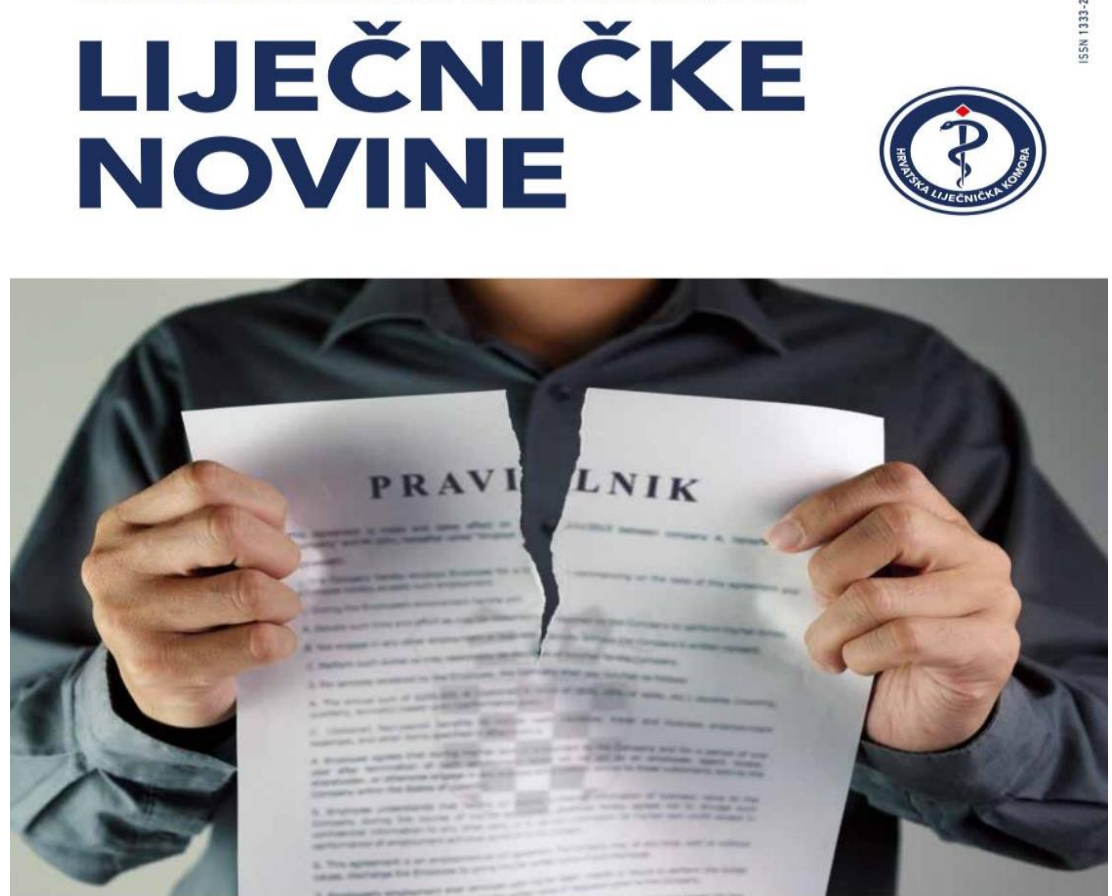

\title{
Specijalizacije u RH vs. EU
}

\author{
Slika 10: $\mathrm{FN}^{11}$
}

\subsection{Specijalizant}

jest zdravstveni radnik kojem je ministar nadležan za zdravstvo izdao rješenje o odobrenju specijalizacije i s kojim je zdravstvena ustanova čiji je osnivač Republika Hrvatska, jedinica područne (regionalne) samouprave ili grad zasnovala radni odnos. Radni odnos specijalizant može zasnovati i u drugoj zdravstvenoj ustanovi, trgovačkom društvu koje obavlja zdravstvenu djelatnost ili kod zdravstvenog radnika privatne prakse. Specijalizanti su liječnici, koji imaju položen stručni ispit, ali i koji još uvijek nisu došli do vrha stručne piramide u svom obrazovanju i strukovnom usavršavanju. Radi se o liječnicima koji još nemaju položen specijalistički ispit, koji nisu specijalisti iz određenog područja, ali su u postupku stjecanja tog statusa i nose naziv specijalizanti. Obzirom na to da oni s jedne strane imaju i titulu (liječnika) doktora medicine, završen vježbenički staž i položen stručni ispit, ali s druge strane rade (samo) pod nadzorom mentora, otvaraju se značajna pravna pitanja, pored ostaloga i na području njihove odgovornosti. ${ }^{12}$ 
Radnici zdravstvene struke: Specijalizacija u grani zdravstvene djelatnosti i specijalistički ispit

Voditelj programa specijalističkog usavršavanja koordinira izvođenje programa specijalističkog usavršavanja određene specijalizacije u Republici Hrvatskoj te nadzire rad svih glavnih mentora i mentora za određenu granu specijalizacije. Voditelj programa specijalističkog usavršavanja koordinira izvođenje programa užih specijalizacija te akreditacijskih područja određene specijalizacije u Republici Hrvatskoj. Glavni mentor je odgovoran za propisano provođenje cjelokupnog programa specijalističkog usavršavanja. Glavni mentor surađuje s mentorima, prati napredak specijalizanta, redovito provjerava znanja specijalizanta putem provjere znanja i vještina najmanje dva puta godišnje te je odgovoran za točnost podataka u knjižici o specijalističkom usavršavanju doktora medicine i dnevniku rada doktora medicine na specijalističkom usavršavanju. Glavni mentor za svoj rad odgovoran je voditelju programa specijalističkog usavršavanja za pojedinu specijalizaciju. Mentor jest doktor medicine specijalist iste specijalističke grane za koju se specijalizant usavršava $\mathrm{s}$ najmanje pet godina specijalističkog staža. Mentora imenuje ministar rješenjem o odobrenju specijalizacije. Mentor mora biti u radnom odnosu u zdravstvenoj ustanovi ili trgovačkom društvu koje obavlja zdravstvenu djelatnost ili mora biti nositelj privatne prakse kojima je dano ovlaštenje ministra. Specijalizant u svakoj zdravstvenoj ustanovi ili trgovačkom društvu koje obavlja zdravstvenu djelatnost ili ordinaciji privatne prakse u kojoj obavlja dio programa specijalizacije ima mentora. Mentor može istovremeno voditi najviše pet specijalizanata. Mentor je odgovoran za propisano provođenje programa specijalističkog usavršavanja, za točnost podataka u knjižici o specijalističkom usavršavanju doktora medicine u koju bilježi napredak specijalizanta u stjecanju kompetencija. Mentor je odgovoran za točnost podataka u dnevniku rada doktora medicine na specijalističkom usavršavanju. Mentor prati napredak specijalizanta, redovito provjerava znanja specijalizanta putem provjere znanja i vještina, surađuje $s$ glavnim mentorom i drugim mentorima, a za svoj rad odgovoran je glavnom mentoru u zdravstvenoj ustanovi. Mentor je obvezan provesti najmanje dva sata tjedno u radu sa specijalizantom. Komentar jest specijalist srodne grane $\mathrm{s}$ najmanje pet godina specijalističkog iskustva ili stručnjak određenog područja koji nadzire dio programa predviđen specijalističkim usavršavanjem. Ovakvim pristupom zdravstvenom radniku omogućeno je da se specijalizira i usko specijalizira za pojedino područje svog profesionalnog rada i djelovanja, te da tim bude ovlaštena i odgovora isključivo za svoj dio posla koji uključuje stečene kompetencije iz specijalističkog odnosno subspecijalističkog usavršavanja. U načelu zdravstvene ustanove raspisuju natječaje po odobrenju nadležnog ministarstva za prijem u program specijalizacije, odnosno subspecijalizacije.

Specijalizacije i uže specijalizacije mogu se obavljati samo u ovlaštenim zdravstvenim ustanovama i trgovačkim društvima, odnosno kod ovlaštenih zdravstvenih radnika koji obavljaju privatnu praksu (ZOZZ, čl. 140. st. 5.). Za potrebe ljekarničke djelatnosti dio specijalizacije može se obavljati kod pravnih osoba koje provode proizvodnju ili kontrolu lijekova (ZOZZ, čl. 140. st. 7.). Zdravstvene ustanove trebaju planirati specijalističko usavršavanje svojih djelatnika i time poticati nova znanja i nova tehnološka rješenja. Specijalizacija, izravno ili neizravno, pridonosi potpunijem ostvarivanju ciljeva ustanove koja specijalistička znanja primjenjuje u praksi. ${ }^{13}$ 
Specijalističko usavršavanje (doktora medicine) nema učinak samo na organizirano stjecanje kompetencija prema propisanom programu, nego utječe i na trajanje obveze rada specijalizanta nakon završenog specijalističkog usavršavanja, a može imati utjecaja i na naknadu štete ovlaštenoj zdravstvenoj ustanovi (poslodavcu) u slučaju da specijalizant ne ostane na radu u zdravstvenoj ustanovi koja mu je omogućila specijalizaciju. ${ }^{14} 15$ Zdravstveni radnik na specijalističkom usavršavanju stupa u radni odnos sa zdravstvenom ustanovom koja je dobila suglasnost od nadležnog ministarstva raspisati natječaj za nove specijalizacije. Pri tom zdravstveni radnik sklapa ugovor o radu i ugovor o tzv. međusobnim pravima i obvezama gdje se definiraju klauzule u prvom redu odgovornosti zdravstvenog radnika prema ustanovi u vidu obveze nastavka rada nakon završene specijalizacije i vraćanja troškova specijalizacije u slučajevima prijevremenog prestanka rada kod istog poslodavca. Pojedini ugovorni odnosi bili su opterećeni potrebama vraćanja primljenih bruto plaća kod prijevremenih prestanaka radnih odnosa specijalizanta i specijalista sa matičnom ustanovom gdje je bila zanemarena činjenica da su specijalizanti za vrijeme stručnog usavršavanja obavljali zdravstvenu djelatnost i pružali potrebnu skrb i zaštitu pacijentima

\subsection{Odgovornost za rad specijalizanata}

Premda je riječ o operaciji koja sa sobom nosi povećani rizik zbog neiskustva liječnika koji je obavlja, prema jednom stavu pacijentu ne treba dati obavijest o tome, osim u slučaju kada on sam pita, ili u slučaju kada izričito traži da ga operira određeni liječnik tada treba, ukoliko je moguće poštovati pacijentovu želju, a ukoliko nije moguće treba ga o tome obavijestiti. Razlog je što bi u protivnom bilo onemogućeno usavršavanje liječnika, jer bi malo tko pristao na to da ga operira specijalizant, pa se smatra da je u javnom interesu da ne postoji obveza informiranja pacijenta o ovom pitanju. ${ }^{16}$ Dodatno opravdanje za ovakav stav se nalazi u tome da u pravilu pacijent sklapa ugovor o liječenju s medicinskom ustanovom, a ne s određenim liječnikom (što ne znači da ne može izričito ugovoriti da ga operira točno određeni liječnik), a smatra se da se standard iskusnog kirurga osigurava kroz nadzor koji vrši liječnik specijalist. ${ }^{17}$ Osim toga, drži se da ukazivanje na činjenicu da će zahvat obaviti početnik - specijalizant, ne bi bilo ni u interesu pacijenta budući da njegovo psihičko stanje treba biti usmjereno na sudjelovanje u vlastitoj terapiji. ${ }^{18}$

Kada je hrvatsko pravo u pitanju (de lege lata ni de lege ferenda) teško se u potpunosti složiti s ovakvim stavom. Premda to otežava učenje specijalizantima i stjecanje potrebne prakse (u smislu dobivanja prilike praktično raditi), smatramo da je informirani pristanak (i to onaj koji uključuje i podatke o osobi odnosno osobama koje operiraju, misleći pri tome u prvo redu na liječnika, ali ne nužno i samo na operatera) jedno od temeljnih prava pacijenata i da je potrebno da pacijent bude o tome informiran i da na to pristane. Da bi pristanak pacijenta na liječenje bio pravno valjan, nužno je da ispunjava određene pretpostavke propisane zakonom, a to su: a/ pristanak mora biti dan od osobe koja je sposobna dati pristanak - čl. 17., st. 1. ZOZPP - u njemu se navodi tko nije sposoban dati suglasnost (za njih suglasnost daje zakonski zastupnik ili skrbnik) i prema njemu su to: osobe koje nisu pri svijesti, pacijenti s težim duševnim smetnjama, poslovno nesposobni (vidi i čl. 21. ZOZZ), maloljetni pacijenti (vidi i čl. 21. ZZZ); b/ 2. mora biti dan u pisanoj 
Radnici zdravstvene struke: Specijalizacija u grani zdravstvene djelatnosti i specijalistički ispit

formi (čl. 21. ZOZZ); c/ ,mora biti dan bez mana volje ${ }^{19}$ (ovo je opća pretpostavka za svaku izjavu volje prema odredbama čl. 279. - 285. ZOO); d/ mora biti dan od osobe koja je informirana (čl. 8.- 18. ZOZPP, čl. 21. st. 6. ZOZZ-a); e/ mora biti dan najkasnije u trenutku poduzimanja zahvata ili početka provođenja terapije - međutim, u slučajevima kada pribavljanje potrebne suglasnosti nije moguće, bilo da je riječ o hitnoj intervenciji, bilo da bolesnik ne može iz objektivnih ili subjektivnih razloga iskazati pristanak, pribjegava se „pretpostavljenom pristanku“ ${ }^{20}$. Između nužnosti i težine zahvata mora postojati izvjestan razmjeran odnos. „Pretpostavljeni pristanak“ ima sve karakteristike pravne osnove za oslobađanje od odgovornosti, ali vrijedi samo u onim slučajevima u kojima bi i stvarni pristanak pravno valjano djelovao i to samo kod hitnih zahvata i drugih hitnih tretmana. ${ }^{21} \mathrm{Tu}$ je riječ o žrtvovanju manjeg dobra (tjelesnog integriteta) da bi se spasilo veće dobro (ljudsko zdravlje ili čak i život). Međutim, nužno je da se ne radi o slučaju u kojem je pacijent liječniku prethodno za istu stvar uskratio pristanak. ${ }^{22} \mathrm{ZOZZ} \mathrm{u}$ čl. 21. st. 6. određuje da u ostvarivanju zdravstvene zaštite svaka osoba ima pravo na točno informiranje i pouku o svim pitanjima koja se tiču njezina zdravlja. Kod nekih autora $^{23}$ nalazimo na objašnjenje pojma "informirani pristanak" na način da to znači da liječnik ne smije liječiti pacijenta dok ga točno ne informira i dade mu pouku o svim pitanjima koja se tiču njegova zdravlja i tretmana koji predlaže, kao i alternativnih tretmana koji predlaže te dok pacijent ne odluči koji tretman želi da se na njega primijeni, odnosno želi li uopće primjenu bilo kakvog tretmana. Potrebno je precizirati na što bi se odnosili objašnjenje i upute, jer postoji velika opasnost od preširokog tumačenja ove definicije, osobito je potrebno precizno definirati što znači davanje uputa - o čemu i koliko opsežne upute. Ako se misli na davanje uputa o ponašanju prije i poslije zahvata i/ili terapije, onda je to prihvatljivo i potrebno, ali ako se misli na detaljno davanje uputa o cijelom zahvatu i sl., smatramo da je nemoguće očekivati od liječnika da može izdvojiti toliko vremena samo na obavještavanje i upućivanje pacijenta.

Čl. 6. i 7. ZOZPP-a uređuju pravo pacijenta na suodlučivanje, koje prema čl. 6. obuhvaća pravo pacijenta na obaviještenost i pravo na prihvaćanje ili odbijanje pojedinoga dijagnostičkog, odnosno terapijskog postupka. Čl. 7. navodi iznimke od prava na suodlučivanje: „može se iznimno ograničiti samo kada je to opravdano njegovim zdravstvenim stanjem u slučajevima i na način posebno određenim ovim Zakonom.“ Prema odredbi čl. 12. ZOZPP-a, pacijent ima pravo biti upoznat s imenima te specijalizacijom osoba koje mu izravno pružaju zdravstvenu zaštitu. Činjenica je da se ova odredba nalazi u zakonu koji je lex specialis i koju u svojem fokusu ima pacijente, ma o kojem dijelu zdravstvene usluge se radilo. To znači da ista vrijedi i za specijalizante, pa makar u pravnoj normi (neovisno što se radi o podzakonskom aktu) koja se posebno bavi specijalizantima o tome nema ni riječi. Iako bi se dalo raspravljati o nomotehničkom standardu bilo kojeg propisa iz korpusa medicinskog prava to ne može dovesti u pitanje navedeni zaključak, što znači da već time što pacijent nije upoznat $s$ tim da je operater specijalizant, njegov pristanak na zahvat nije pravno valjan. Nepostojanje informiranog pristanka samo po sebi znači protupravnost cijelog zahvata i to je jedna vrlo značajna pravna posljedica takvog postupka.

Nedvojbeni je javni interes $u$ tome da se specijalizanti obučavaju na najbolji mogući način, kao i da to uključuje i samostalni rad specijalizanta. Moglo bi se možda 
polemizirati o tome čiji je to javni interes u kontekstu masovnih odlazaka liječnika u inozemstvo, ali smo uvjereni da taj javni interes treba staviti u odnos s jednim drugim javnim interesom, a to je da nitko bez vlastitog (i to ne bilo kakvog nego informiranog) pristanka ne smije biti podvrgnut bilo kakvom medicinskom zahvatu. Nedvojbeno je da apsolutnu prednost nad usavršavanjem specijalizanata ima pravo pacijenta na informirani pristanak. Zamjene ili supstituta za informirani pristanak nema i ne može biti, a potpuno je drukčije kod usavršavanja. Kada se postiglo dragovoljno javljanje pacijenata za testiranje lijekova, kada je unatoč određenim rizicima sve bolji i bolji odaziv potencijalnih davatelja organa za transplantaciju (da o davateljima krvi i ne govorimo) ne vidimo zašto se ne bi mogao ishoditi i pristanak pacijenta na zahvat od strane specijalizanta (tim prije obzirom na nadzor specijalista). ${ }^{24}$

Osim što specijalizant može počiniti liječničku grešku na planu informiranog pristanka i s tim povezanog pristanka pacijenta na zahvat (ili terapiju), daljnja mogućnost greške je izvan područja informiranog pristanka. To predstavlja grešku učinjenu propustom ili činjenjem jednaku kao što je može učiniti i specijalist, ali ipak uz jednu bitnu razliku. Ta razlika proizlazi iz naravi stvari, odnosno iz toga što specijalist smije raditi sam i bez nadzora od sebe stručnije osobe, a specijalizant ipak ne smije. Navedeno znači da pored i izvan same greške koja se dogodi postoji dodatna odgovornost specijalizanta već i samo zato što se odlučio (ili prihvatio tuđu odluku) nešto raditi sam. Taj dio je svakako protupravan i moglo bi se izbjeći tu protupravnost samo u situacijama kao što je krajnja nužda (nema specijalista na raspolaganju, a stvar ne trpi odgodu). Specijalizant je zašao u protupravnu zonu već samim tim što radi samostalno, bez nadzora specijaliste. Međutim, pitanje je je li sama ta protupravnost dovoljna za zaključak da je počinjena liječnička greška, čak i ako daljnjih propusta nije bilo (zahvat je obavljen stručno i bez ikakve štetne posljedice). Držimo da bi se tu moglo raditi samo o protupravnosti za potrebe nekog stegovnog ili sličnog postupka, nikako ne i protupravnosti kao jednom od uvjeta građanskopravne odgovornosti. Međutim, ako ipak dođe do greške u postupanju tada specijalizant svakako odgovara, a činjenica da nije specijalist mu onda može samo biti dodatna otegotna okolnost. Naravno, ako se radilo o nečijem nalogu, takav nalog je nezakonit, a davatelj takvog naloga je zajedno sa specijalizantom u pravnom položaju suodgovornosti. Inače, specijalizant može napraviti baš sve greške kao i specijalist, čak i jednu više koju specijalist objektivno ne može napraviti, a to je lažno prikazivanje sebe kao specijalista. To znači kako greške u dijagnozi, tako i u ostaloj pripremi zahvata, ali i kod samog zahvata te oporavka nakon zahvata.

Liječnik specijalizant nije oslobođen od svake pravne odgovornosti za štetu pacijentu nad kojim je samostalno obavio zahvat. Ne mogu ga opravdati nedovoljno znanje i iskustvo, kao ni činjenica da mu je obavljanje zahvata povjerio rukovodeći liječnik medicinske ustanove u kojoj obavlja specijalizaciju. ${ }^{25}$ Liječnik specijalizant nije odgovoran zato što operaciju nije u stanju obaviti kao prosječan kirurg, ali je odgovoran zato što je pristao na obavljanje takve operacije. To je tzv. krivnja zbog preuzimanja ili prethodna krivnja, koja postoji kod osoba koje obavljaju određeni posao kojemu nisu dorasle ili se dovedu u situaciju koju nisu u stanju kontrolirati - primjer je prouzrokovanje štete u stanju opijenosti (actio libera in causa). ${ }^{26}$ Specijalizant mora biti samokritičan i svjestan svojih mogućnosti, a prekorači li granice svojih sposobnosti koje je znao ili morao znati, on čini 
Radnici zdravstvene struke: Specijalizacija u grani zdravstvene djelatnosti i specijalistički ispit

liječničku grešku. ${ }^{27}$ Specijalizant nema izravni ugovorni odnos s pacijentom, ali je u ugovornom odnosu s ustanovom koja ima ugovorni odnos s pacijentom, ${ }^{28}$ To znači da će se u odnosu na pravnu kvalifikaciju odnosa pacijent - specijalizant ipak u pravilu raditi o ugovornom odnosu i slijedom toga ugovornoj odgovornosti. Inače, pravila o izvan ugovornoj odgovornosti u ZOO-u imaju karakter općih pravila o odgovornosti za štetu, što znači da će se primjenjivati na odgovarajući način na sva pitanja koja nisu posebno uređena pravilima ugovorne odgovornosti. Pri tome se ugovorna pravila primjenjuju i na štete nastale povredom obveze i iz drugih obvezno pravnih odnosa, kao što su stjecanje bez osnove, poslovodstvo bez naloga, jednostrana izjava volje. ${ }^{29}$ Slijedom navedenog specijalizant se mora usavršavati, a ustanova mu mora (kao poslodavac) omogućiti usavršavanje, pri čemu je to (in ultima linea) ipak obveza države (kao onog to stvara pravni okvir svega, pa i ovoga), što je možda nebitna razlika dok je vlasnička struktura ustanova (u prvom redu bolnica i domova zdravlja) ovakva kakva je danas, ali nema jamstava da će tako uvijek biti i ako tako više ne bude ta razlika će postati vrlo bitna. Pacijent mora u skladu s načelom informiranog pristanka biti potpuno obaviješten o sudjelovanju specijalizanta u aktivnoj ulozi u konkretnom zahvatu.

Najosjetljivije pitanje je kako tumačiti određene pravne standarde (npr. „sam“,

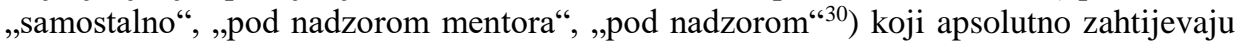
tumačenje, a potpuno je jasno da niti ima objašnjenja za uporabu različitih formulacija, (ponekad čak i alternativno navedenih) niti jasnih smjernica za tumačenje. Držimo da specijalizant nikad ne bi smio raditi samostalno one poslove za koje se zahtijeva specijalizacija, a koji su to poslovi moralo bi biti izrijekom propisano. Ako se zahtijeva specijalizacija, to treba obaviti specijalist, a specijalizant (koji nije specijalist) mora sudjelovati do razine značajnog sudjelovanja, koje nije jednako samostalnom djelovanju (za to mora sačekati da postane specijalist, osim možda u slučaju izričitog pristanka pacijenta, pri čemu ostaje „otvorenim“ pitanje što ako se radi o zahvatu kod kojeg nije moguć popravak ako specijalizant možda pogriješi). Naravno, neovisno o tome što nešto što bi uvijek morao raditi liječnik specijalist radi liječnik specijalizant, moguća je greška i u samom postupku (tu bi se radilo o klasičnoj grešci bez specifičnosti na strani onoga tko je radi). Ako specijalizant odbije raditi potpuno sam, bez ikakvog nadzora (ali nadzor nije teorijska, nego konkretna kategorija, to ne može biti dostupnost na mobitelu i sl.), on radi nešto potpuno zakonito, ali pravnu zaštitu može dobiti samo ako radi odbijanja dobije otkaz kojega uspije osporiti u sudskom postupku, ali ostaje ona tzv. „siva“ zona u kojoj mu se može sprječavati napredovanje i sl., na kojem području je pravna zaštita, nažalost, dosta nekonkretna. Ako ipak specijalizant obavi zahvat kod kojeg dođe do liječničke greške, on se ne može (barem ne potpuno) ekskulpirati pozivajući se na to da nije specijalist. To nije nikakav argument za treće (posebno za oštećenog), a u internom odnosu ustanova - mentor - specijalizant to može biti jedan od argumenata koji mogu dovesti do primjene instituta podijeljene odgovornosti ako do regresa uopće dođe, što je kod pozitivne hrvatske regulative (koja u čl. 1061. ZOO-a uvjetuje regres time da se radilo o namjeri ili krajnjoj nepažnji) i naročito prakse malo vjerojatno.

Odgovornost mentora ili voditelja odjela za pogrešku specijalizanta - Mentor specijalizantu mora biti osoba koja je kvalificirana vršiti nadzor nad obavljanje zahvata od strane specijalizanta, a to može biti samo zdravstveni radnik koji je u stanju takav 
zahvat izvesti samostalno i na vlastitu odgovornost. ${ }^{31}$ Mentor ili voditelj odjela, koji su morali pravilno procijeniti je li specijalizant u stanju obaviti tu operaciju u svakom slučaju snose odgovornost jer su nekome tko nije specijalist (nego specijalizant) naložili neka sam obavi određeni zahvat za koji je formalno potrebna kvalifikacija specijalista, a ne specijalizanta. Jedini način oslobođenja od odgovornosti ili barem smanjenja vlastitog udjela u odgovornosti je situacija krajnje nužde u kojoj nije na raspolaganju niti jedan specijalist. Ali ako bi se radilo o osobi koja je odgovorna za izradu rasporeda onda ni krajnja nužda nije jamac oslobađanja od odgovornosti za onoga tko je takvu krajnju nuždu stvarno prouzročio. Interesantno može biti pitanje oblika krivnje ove osobe u svezi regresa. Sigurno je da na strani te osobe postoji namjera ako pri tome mislimo na svijest o davanju naloga koji je ne samo praeter legem, nego izravno contra legem, pa bi tu osobu bio moguće i izravno tužiti jednako kao i poslodavca. Drukčije je, ipak, ako mislimo na namjeru glede same štete. Što se, pak, regresa tiče, zbog naprijed navedene argumentacije trebalo bi smatrati kako pravo na regres postoji. Ako stručni nadzor nad zahvatom koji izvodi specijalizant obavlja osoba koja nema odgovarajuću specijalizaciju, a zahvat dovede do komplikacija za pacijenta, tada postoji indicija da je tome uzrok nedovoljno iskustvo nadziratelja. ${ }^{32}$

Odgovornost medicinske ustanove za pogrešku specijalizanta - Prema rješenju koje prihvaća ZOO u čl. 1061. poslodavac odgovara, te ima pravo na regres u slučajevima namjere i krajnje nepažnje zaposlenika, odnosno za štetu koju zaposlenik u radu ili u svezi s radom prouzroči trećoj osobi odgovara poslodavac kod kojega je radnik radio u trenutku prouzročenja štete, osim ako dokaže da su postojali razlozi koji isključuju odgovornost zaposlenika. Oštećenik bi imao pravo zahtijevati popravljanje štete i neposredno od zaposlenika ako je štetu prouzročio namjerno. Poslodavac koji je oštećeniku popravio štetu ima pravo zahtijevati od zaposlenika naknadu troškova popravljanja štete, ako je ovaj štetu prouzročio namjerno ili iz krajnje nepažnje, a to pravo zastarijeva u roku od šest mjeseci od dana kad je šteta popravljena. U slučaju da je poslodavac (npr. ravnatelj ustanove) dao nalog specijalizantu ili je dopustio funkcioniranje sustava na način da je uobičajeno i potpuno nezakonito izjednačavanje specijaliste i specijalizanta, snosi odgovornost za takvu praksu i tom slučaju regresa ili ne bi uopće bilo ili bi ga bilo u mjeri određenoj odlukom o podijeljenoj odgovornosti. Ukoliko kod zaposlenika postoji namjera ili krajnja nepažnja poslodavac ima pravo na regres.

U tom smislu za greške specijalizanta koji je u radnom odnosu s medicinskom ustanovom u kojoj obavlja specijalizaciju, odgovara sama ta ustanova. Specijalizant je izravno odgovoran pacijentu samo ako je štetu prouzročio namjerno. Kada medicinska ustanova isplati naknadu oštećenome pacijentu, može se regresirati od specijalizanta samo kada je on štetu prouzročio namjerno ili krajnjom nepažnjom.

Solidarna i podijeljena odgovornost zbog greške specijalizanta - Prema odredbama ZOO-a za štetu koju je više osoba prouzročilo zajedno svi sudionici odgovaraju solidarno. Solidarno odgovaraju za prouzročenu štetu i osobe koje su je uzrokovale radeći nezavisno jedna od druge, ako se ne mogu utvrditi njihovi udjeli u nastaloj šteti. Kad je nedvojbeno da je štetu prouzročila neka od dviju ili više određenih osoba koje su na neki način međusobno povezane, a ne može se utvrditi koja je od njih štetu prouzročila, te osobe 
Radnici zdravstvene struke: Specijalizacija u grani zdravstvene djelatnosti i specijalistički ispit

odgovaraju solidarno (ZOO, čl. 1107.). Potpuno je jasno da postoji solidarnost, ali samo u slučajevima postojanja namjere kod zaposlenika, zato jer bez toga nema ni pasivne legitimacije zaposlenika. Međutim, kada to otklonimo kao problem, treba odgovoriti da solidarnost (između specijalizanta i rukovoditelja, ali i između njih i poslodavca ako postoji njihova namjera) postoji. Glede podijeljene odgovornosti u konačnici bi se trebalo utvrditi utvrdi koliko otpada na pojedinoga od štetnika, odnosno potrebno je utvrditi doprinos svake od tih osoba. U praksi najčešće specijalizanti nakon relativno kratkog vremena praktično rade sami, a ako se ipak dogodi greška mentor (kao specijalist koji je zadužen za specijalizanta) preuzima odgovornost na sebe po nekoj vrsti analogije sa zapovjednom odgovornošću. Obzirom na ozbiljnost angažmana državnih tijela ovaj modus operandi se, ako nije bilo vrlo ozbiljne posljedice, u pravilu nikad ni ne otkrije i dobije se jedno stanje „u papirima“, a drugo u stvarnosti, što dugoročno i objektivno baš nikome ne može i ne smije odgovarati. Pri tome na određeni način svi sudjeluju i svi nekoga ,pokrivaju“ ili štite - specijalizant zna da je bilo nužno da tu cijelo vrijeme bude i mentor, mentor zna da nije na lako dokaziv način izdao nalog neka specijalizant sam radi (a možda je istovremeno obavljao neki drugi zahvat), a ustanova je iz čitavog niza razloga iznimno zainteresirana da sve prođe bez ikakvog skandala i po mogućnosti bez ikakvih postupaka. Država je objektivno zainteresirana slično kao i ustanova, ali iz drugog razloga, zato što nije obavila svoj dio obveza, od osiguranja sredstava za dovoljan broj stručnjaka i sredstava za rad (koja su kod nekih specijalizacija enormno skupa) pa do toga da pravni okvir u kojemu se sve to odvija nije ni približno na potrebnoj razini. ${ }^{33}$

U specijalistički staž za određenu specijalizaciju ili užu specijalizaciju priznaje se vrijeme provedeno na poslijediplomskom studiju u cijelosti ili djelomično, ako program poslijediplomskog studija odgovara programu specijalizacije, odnosno uže specijalizacije. Doktorima medicine koji su završili petogodišnji studij medicine u specijalistički staž rješenjem Ministarstva priznaje se dio pripravničkog staža obavljen kroz sekundarijat, a najmanje šest mjeseci (ZOZZ, čl. 141.).

Specijalistički ispit je završna provjera znanja iz određene specijalizacije, stečenog za vrijeme specijalističkog staža. Nakon uspješno završenoga specijalističkoga staža kandidat polaže specijalistički ispit pred ispitnom komisijom i stječe pravo na naziv specijalista određene specijalnosti. Nakon uspješno završenog programa iz uže specijalizacije kandidat polaže ispit pred ispitnom komisijom i stječe pravo na naziv područja uže specijalnosti. Iznimno, status uže specijalizacije može se priznati pod uvjetima koje pravilnikom utvrđuje nadležni ministar. Nakon položenog ispita zdravstveni radnika može ishodovati odobrenja za samostalan rad za obavljanje poslova specijalista odnosno subspecijalista. Članove ispitne komisije imenuje ministar iz redova priznatih stručnjaka određenih specijalnosti, prvenstveno iz redova nastavnika u znanstvenonastavnom zvanju redovitog profesora, izvanrednog profesora ili docenta. Iako se to u propisima izrijekom ne navodi, članove ispitne komisije ministar bi mogao i prvenstveno bi trebao imenovati iz redova nastavnika u znanstveno-nastavnom zvanju redovitog profesora u trajnom zvanju jer se radi o zasebnom i najvišem znanstveno-nastavnom zvanju.

Ministar pravilnikom utvrđuje mjerila za prijam specijalizanata i način polaganja specijalističkog ispita, odnosno ispita iz uže specijalizacije te određuje ovlaštene 
ZDRAVSTVENO STRUKOVNO STALEŠKO PRAVO

zdravstvene ustanove, trgovačka društva i zdravstvene radnike koji obavljaju privatnu praksu za provođenje specijalističkog staža (ZOZZ, čl. 140. st. 6.).

Ministarstvo može pripravnički staž obavljen u inozemstvu priznati u cijelosti ili djelomično, ako program pripravničkog staža proveden u inozemstvu bitno ne odstupa od programa koji su važeći na području Republike Hrvatske, ali se ova odredba ne odnosi se na državljane država članica Europske unije. Ministarstvo može specijalizaciju, odnosno užu specijalizaciju obavljenu u inozemstvu, uz prethodno pribavljeno mišljenje nadležne komore priznati u cijelosti ili djelomično ako program specijalističkog staža provedenog u inozemstvu bitno ne odstupa od programa važećeg na području Republike Hrvatske (ZOZZ, čl. 143.).

\subsection{Primarijus}

Doktorima medicine specijalistima i doktorima dentalne medicine specijalistima koji imaju deset godina rada u svojstvu specijalista, objavljene znanstvene i stručne radove i uspješne rezultate na stručnom uzdizanju zdravstvenih radnika, može se priznati naziv primarius (ZOZZ, čl. 144.). Primarius (lat. primus - prvi) najviša je profesionalna titula koju liječnička zajednica neke države dodjeljuje iskusnim liječnicima specijalistima. U prošlosti su titulu primariusa nosili pojedini liječnici u velikim bolnicama koji su zahvaljujući svojem znanju, iskustvu i doprinosima bili predvodnici klinika, sanatorija, odjela, odnosno službi.34 Kratica naziva primarius jest »prim.« i stavlja se ispred akademskog stupnja (mr. sc. dr. sc.) prije imena i prezimena osobe, a iza kratice za znanstveno nastavno zvanje (doc., prof., prof. emer.) (Pravilnik o mjerilima za priznavanje naziva primarius, čl. 1.). Pravilnikom o mjerilima za priznavanje naziva primarius („Narodne novine“, broj 28/2012.), utvrđuju se mjerila, postupak i način za priznavanje naziva primarius doktorima medicine - specijalistima i doktorima dentalne medicine - specijalistima, sastav Povjerenstva za priznavanje naziva primarius te način rada Povjerenstva. Postupak za priznavanje naziva primarius provodi Povjerenstvo koje imenuje ministar nadležan za zdravlje. Postupak priznavanja naziva primarius pokreće doktor medicine specijalist ili doktor dentalne medicine specijalist (u daljnjem tekstu: kandidat) podnošenjem pisanog zahtjeva za priznavanje naziva primarius (u daljnjem tekstu: zahtjev). Zahtjevu se prilaže dokumentacija kojom se dokazuje da kandidat ispunjava uvjete i mjerila propisana ovim Pravilnikom (Pravilnik o mjerilima za priznavanje naziva primarius, čl. 2.). Pravo na podnošenje zahtjeva imaju doktori medicine specijalisti ili doktori dentalne medicine specijalisti, državljani Republike Hrvatske koji imaju važeće odobrenje za samostalan rad izdano od Hrvatske liječničke komore ili Hrvatske komore dentalne medicine (u daljnjem tekstu: Komora) te: - imaju najmanje 10 godina rada u svojstvu specijalista na određenom području specijalizacije, imaju objavljene stručne $\mathrm{i} / \mathrm{ili}$ znanstvene radove $\mathrm{i}$ uspješne rezultate na stručnom uzdizanju zdravstvenih radnika, uspješne rezultate u svojoj specijalnosti i u svojem radnom okruženju, - u posljednjih deset godina protiv kandidata nije donesena konačna odluka disciplinskih tijela nadležne Komore kojom ga se proglašava odgovornim za disciplinsku povredu niti se protiv kandidata ne vodi disciplinski postupak pred nadležnim tijelima Komore. Povjerenstvo utvrđuje ispunjenje navedenih uvjeta (Pravilnik o mjerilima za priznavanje naziva primarius, čl. 3.). U zahtjevu mora se iscrpno 
Radnici zdravstvene struke: Specijalizacija u grani zdravstvene djelatnosti i specijalistički ispit

obrazložiti: - čime je točno kandidat stručno pridonio unapređenju zdravstvene zaštite, u čemu je kandidatov doprinos na stručno-organizacijskom i razvojnom području sustava zdravstvene zaštite, - koji su stručni i/ili znanstveni radovi i publikacije kojima je kandidat doprinosio struci, - kako je kandidat sudjelovao u stručnom uzdizanju zdravstvenih radnika, - kako je kandidat doprinosio razvoju svoje struke u svom radnom okruženju, - koje dužnosti i obveze je kandidat obavljao kao član stručnih i strukovnih udruga i institucija, - druge podatke značajne za ocjenu stručnog rada i profesionalne etike kandidata. Uz zahtjev kandidat mora priložiti stručni životopis, popis objavljenih stručnih i/ili znanstvenih radova i posebne otiske tih radova ili časopisa u kojima su objavljeni (Pravilnik o mjerilima za priznavanje naziva primarius, čl. 7.). O priznavanju naziva primarius odlučuje povjerenstvo koje imenuje ministar iz redova nastavnika medicinskog i fakulteta dentalne medicine i istaknutih medicinskih i stručnjaka dentalne medicine (ZOZZ, čl. 144.). Povjerenstvo nakon razmatranja zaprimljene dokumentacije i radova kandidata ocjenjuje ispunjava li kandidat sve propisane uvjete pridržavajući se sljedećih mjerila: a) uspješnost desetogodišnjeg specijalističkog rada s obzirom na doprinos unapređenju struke uvođenjem ili primjenom metoda u dijagnostici, liječenju i rehabilitaciji, pokretanju, organiziranju i sudjelovanju u aktivnostima unapređenja sustava zdravstvene zaštite i zdravlja stanovništva te njegovanja medicinske etike, nesebičnosti i humanosti u odnosu prema pacijentima i suradnicima, b) uspješnost rada na stručnom uzdizanju zdravstvenih radnika sudjelovanjem u srednjoškolskom obrazovnom procesu, dodiplomskom ili poslijediplomskom studiju zdravstvenog usmjerenja, sudjelovanjem u osposobljavanju pripravnika, specijalizanata ili aktivnim sudjelovanjem na stručnim skupovima, c) uspješnost stručno-publicističkog rada - broj objavljenih radova u medicinskim časopisima: - najmanje 10 stručnih i/ili znanstvenih radova, uključivo poglavlja u stručnim knjigama i drugim publikacijama, a od kojih najmanje $5 \mathrm{u}$ međunarodnim indeksnim publikacijama, - najmanje 5 priopćenja na stručnim ili znanstvenim skupovima u kojima je kandidat prvi autor, od kojih najmanje dva na međunarodnim skupovima, d) uspješnost u obavljanju dužnosti i obaveza koje je kandidat obavljao kao član stručnih i strukovnih udruga i institucija: - potvrde odgovarajućih stručnih i strukovnih udruga i/ili institucija, e) dosljednost u pridržavanju odredbi Kodeksa medicinske etike i deontologije, te korektnost u stručnom radu: potvrda nadležne Komore da se pred nadležnim tijelima Komore protiv kandidata ne vodi disciplinski postupak, - potvrda nadležne Komore da protiv kandidata nije donesena konačna odluka disciplinskih tijela, unatrag deset godina (Pravilnik o mjerilima za priznavanje naziva primarius, čl. 8.). Odluku o ispunjavanju uvjeta i mjerila za priznavanje naziva primarius, Povjerenstvo donosi u roku od 90 dana od dana primitka zahtjeva, a odluku dostavlja ministru u roku od 30 dana od dana donošenja odluke. Specijalistima kojima je priznat naziv primarius izdaje se akt o priznavanju naziva kojeg potpisuje ministar najkasnije u roku od 30 dana. Popis osoba kojima je priznat naziv primarius objavljuje se u službenim glasilima nadležne Komore te na internetskoj stranici Komore i Ministarstva (Pravilnik o mjerilima za priznavanje naziva primarius, čl. 12.). 


\section{Primjedbe}

${ }^{1}$ Vidi Pravilnik o specijalističkom usavršavanju doktora medicine („Narodne novine“ br. broj 100/11, 133/11, 54/12, 49/13, 139/14, 116/15, 62/16, 69/16 - Ispravak i 6/17). Popis specijalizacija doktora medicine; 1. Abdominalna kirurgija, 2. Alergologija i klinička imunologija, 3. nesteziologija, reanimatologija i intenzivna medicina, 4. Dermatologija i venerologija, 5. Dječja i adolescentna psihijatrija, 6. Dječja kirurgija, 7. Endokrinologija i dijabetologija, 8. Epidemiologija, 9. Fizikalna medicina i rehabilitacija, 10. Gastroenterologija, 11. Ginekologija i opstetricija, 12. Hematologija, 13. Hitna medicina, 14. Infektologija, 15. Internistička onkologija, 16. Javnozdravstvena medicina, 17. Kardiologija, 18. Kardiotorakalna kirurgija, 19. Klinička farmakologija s toksikologijom, 20. Klinička mikrobiologija, 21. Klinička radiologija, 22. Laboratorijska imunologija, 23. Maksilofacijalna kirurgija, 24. Medicina rada i športa, 25. Nefrologija, 26. Neurokirurgija, 27. Neurologija, 28. Nuklearna medicina, 29. Oftalmologija i optometrija, 30. Onkologija i radioterapija, 31. Opća interna medicina, 32. Opća kirurgija, 33. Ortopedija i traumatologija, 34. Otorinolaringologija, 35. Patologija i citologija, 36. Pedijatrija, 37. Plastična, rekonstrukcijska i estetska kirurgija, 38. Psihijatrija, 39. Pulmologija, 40. Reumatologija, 41. Sudska medicina, 42. Školska i adolescentna medicina, 43. Transfuzijska medicina, 44. Urologija, 45. Vaskularna kirurgija, 46. Pedijatrijska infektologija, 47. Laboratorijska medicina.

Vidi Pravilnik o specijalističkom usavršavanju doktora medicine iz obiteljske medicine („Narodne novine“ br. broj 129/11, 129/12, 120/13 i 31/17)

2 Vidi Pravilnik o specijalističkom usavršavanju magistara medicinske biokemije („Narodne novine“ br.78/03). Njime se utvrđuju grane specijalizacija magistara medicinske biokemije, trajanje i program specijalizacije, način polaganja specijalističkog ispita te mjerila koja moraju ispunjavati zdravstvene ustanove i zdravstveni radnici koji obavljaju privatnu praksu za provođenje specijalističkoga staža za magistre medicinske biokemije. Magistri medicinske biokemije mogu se stručno usavršavati u obliku specijalizacije s nazivom: Medicinska biokemija i laboratorijska medicina ili Analitička toksikologija. Po položenom specijalističkom ispitu stječe se naziv magistar medicinske biokemije, specijalist medicinske biokemije i laboratorijske medicine, odnosno specijalist analitičke toksikologije.

${ }^{3}$ Vidi Pravilnik o specijalističkom usavršavanju doktora stomatologije („Narodne novine“ br. 115/07). Zdravstveni radnici visoke stručne spreme, doktori stomatologije (u daljnjem tekstu: specijalizanti) mogu se stručno usavršavati u obliku specijalizacije. Grane specijalizacija u stomatologiji su: - Dječja stomatologija, - Endodoncija s restaurativnom stomatologijom, - Obiteljska stomatologija, - Oralna kirurgija, - Oralna medicina, - Ortodoncija, - Parodontologija, - Stomatološka protetika.

Specijalizacija jest oblik organiziranog stjecanja teorijskih i praktičnih stručnih znanja i znanstvenih spoznaja, a sukladno planu i programu za obavljanje poslova specijalista iz određenog stomatološkog područja, u trajanju od tri godine. Odobrenje za specijalizaciju daje ministar nadležan za zdravstvo), na temelju godišnjeg plana potrebnih specijalizacija, a koji donosi na prijedlog zdravstvenih ustanova, Hrvatskog zavoda za zdravstveno osiguranje te Hrvatske stomatološke komore.

4 Vidi Pravilnik o specijalističkom usavršavanju medicinskih sestara-medicinskih tehničara („Narodne novine“ br.139/09) Pravilnik o specijalističkom usavršavanju medicinskih sestara medicinskih tehničara u djelatnosti hitne medicinske pomoći ( $N N$ br 28/11)

5 Tako BOŠKOVIĆ, Z., Specijalizacija zdravstvenih djelatnika, „Informator“, broj 4660-4661. od 4. i 7. studenoga 1998., str. 34.

${ }^{6}$ Usp. RADIŠIĆ, J., Ko je odgovoran zbog greške lekara na specijalizaciji, „Pravni život“, 2009., TOM I, broj 9, str. 809.

7 Vidi ČIZMIĆ, J. - KAČER IVANČIĆ, B., Odgovornost za greške doktora medicine specijalizanta, zbornik radova sa II. simpozija s međunarodnim sudjelovanjem „PRAVNI, ETIČKI 
Radnici zdravstvene struke: Specijalizacija u grani zdravstvene djelatnosti i specijalistički ispit

I MEDICINSKI ASPEKTI SUVREMENOG VOĐENJA PORODA“, Šibenik, 11. i 13. svibnja 2017. Godine, str. 51.-67.

${ }^{8}$ Tako BOŠKOVIĆ, Z., Specijalizacija zdravstvenih djelatnika, „Informator“, broj 4660-4661. od 4. i 7. studenoga 1998., str. 34.

9 Usp. BOŠKOVIĆ, Z., Profesionalno obrazovanje zdravstvenih djelatnika, „Informator“, broj 4987-4990. od 22.,26. i 29. prosinca. 2001. i 2.siječnja. 2002., str. 61.

${ }^{10}$ Zdravstvenom radniku koji nije u radnom odnosu u zdravstvenoj ustanovi niti u trgovačkom društvu koje obavlja zdravstvenu djelatnost niti ima privatnu praksu, odnosno ne radi kod zdravstvenog radnika privatne prakse sa završenim sveučilišnim diplomskim studijem, ministar može odobriti specijalizaciju za vlastite potrebe, za potrebe ministarstva, ministarstva nadležnog za obranu, ministarstva nadležnog za pravosuđe, ministarstva nadležnog za unutarnje poslove, ministarstva nadležnog za obitelj i branitelje, ministarstva nadležnog za znanost i obrazovanje, ministarstva nadležnog za okoliš, Državnog zavoda za radiološku i nuklearnu sigurnost, Agencije za lijekove i medicinske proizvode, Agencije za kvalitetu i akreditaciju u zdravstvu, fakulteta zdravstvenog usmjerenja, znanstvenih pravnih osoba, pravnih osoba koje obavljaju proizvodnju i promet lijekova i medicinskih proizvoda, pravnih osoba koje obavljaju poslove zdravstvenog osiguranja te upravnih tijela jedinica područne (regionalne) samouprave nadležnih za zdravstvo (ZOZZ, čl. 140. st. 2.).

${ }^{11}$ Podatak na stranici:

https://www.google.hr/search?q=licenca+lije\%C4\%8Dnika+slika\&hl=bs\&tbm=isch\&imgil=xb 5E54QxI2MM\%253A\%253B-

QdF1QwBjeU8NM\%253Bhttp\%25253A\%25252F\%25252Fwww.index.hr\%25252Fvijesti\%2525 2Fclanak\%25252Fotkrivamo-splitski-lijecnici-karcinome-salji-meni-novac-dijelimo-po-pola-kodmene-nema-

zajeba\%25252F858841.aspx\&source $=\mathrm{iu} \& \mathrm{pf}=\mathrm{m} \& \mathrm{fir}=\mathrm{xb} \quad$ 5E54QxI2MM\%253A\%252CQdF1QwBjeU8NM\%252C_\&usg $=$ umONFtTuEZCtEWSV3LDaAvRcUoA\%3D\&biw $=1920 \&$ bih=971\&ved=0ahUKEwj0naaktsfVAhXF0RQKHSmKCrUQyjcIQw\&ei=xZGJWbSnFcWjU6m UqqgL\#imgrc=OU8CXD_Ao-KmMM:

12 Tako ČIZMIĆ, J. - KAČER IVANČIĆ, B., Odgovornost za greške doktora medicine specijalizanta, zbornik radova sa II. simpozija s međunarodnim sudjelovanjem „PRAVNI, ETIČKI I MEDICINSKI ASPEKTI SUVREMENOG VOĐENJA PORODA“, Šibenik, 11. i 13. svibnja 2017. Godine, str. 51.-67.

${ }^{13}$ Vidi BOŠKOVIĆ, Z., Specijalizacija zdravstvenih djelatnika, „Informator“, broj 4660-4661. od 4. i 7. studenoga 1998., str. 34.

${ }^{14}$ Tako i više o tome kod MILAKOVIĆ, G., Ugovor o specijalističkom usavršavanju doktora medicine i posljedice nepridržavanja ugovornih odredaba, „Informator“, broj 6423. od 20. lipnja 2016., str 15.-17.

${ }^{15}$ Vidi Odluka Ustavnog suda U-II-187/2015 i dr. („Narodne novine“ br, 89/2917)

$\mathrm{Na}$ sjednici održanoj 11. srpnja 2017. godine, u postupku ocjene suglasnosti propisa s Ustavom Republike Hrvatske, Ustavni sud je donio odluku kojom se ukidaju te s danom 31. prosinca 2017. godine prestaju važiti pojedini članci Pravilnika o specijalističkom usavršavanju doktora medicine i Pravilnika o izmjenama i dopunama Pravilnika o specijalističkom usavršavanju doktora medicine. Ustavni sud je zaključio kako ministru nije dana ovlast da Pravilnikom propiše obveze sklapanja ugovora o međusobnim pravima i obvezama specijalizanta i ustanove, najduljeg trajanja obveze ostanka na radu specijalizanta nakon završetka specijalizacije, uvjetovanja otkazivanja ugovora o radu prethodnom suglasnosti ministarstva, obveze zdravstvene ustanove u kojoj se specijalizant ili specijalist zaposlio da naknadi troškove specijalizacije, obveze specijalizanta i specijalista da naknadi taroškove specijalizacije u slučaju otkazivanja radnog odnosa bez suglasnosti ministarstva, kao što ministru nije dana niti ovlast da utvrdi troškove specijalizacije. 
Takvim sadržajem Pravilnika, smatra Ustavni sud, prekoračene su zakonom utvrđene granice te je nadležni ministar propisivanjem spornih odredbi Pravilnika izišao izvan okvira ovlaštenja koja proizlaze iz Zakona o zdravstvenoj zaštiti.

Prema sudskoj odluci ukidaju se i prestaju važiti članci 11., 11a i 12. Pravilnika o specijalističkom usavršavanju doktora medicine („Narodne novine“ br. 100/11, 133/11, 54/12, 49/13, 139/14, 116/15, 62/16, 69/16 i 6/17), te članci 17. i 18. Pravilnika o izmjenama i dopunama Pravilnika o specijalističkom usavršavanju doktora medicine („Narodne novine“ br. 62/16 i 69/16).

U ocjeni Ustavnog suda stoji i kako je Zakonom o zdravstvenoj zaštiti nadležnom ministru dana ovlast za utvrđivanje grana specijalizacija, trajanje i programa specijalizacija i užih specijalizacija te za utvrđivanje mjerila za prijem specijalizanata i načina polaganja ispita, kao i određivanja ovlaštene zdravstvene ustanove, trgovačkog društva ili zdravstvenog radnika koji obavlja privatnu praksu za provođenje specijalističkog staža, i u tom je ista ovlast i ograničena.

Vidi Odluka Ustavnog suda U-II-13/2016, kojom je ukinut članak 24. Pravilnika o specijalističkom usavršavanju doktora medicine (,Narodne novine“ br. 116/15), te odluka Ustavnog suda U-II249/2016 kojom je ukinut članak 12. i 13. Pravilnika o izmjenama i dopunama Pravilnika o specijalističkom usavršavanju doktora medicine (,Narodne novine“ br. 139/14)

${ }^{16}$ Usp. RADIŠIĆ, J., Odgovornost za štetu uzrokovanu operacijom koju je obavio liječnik na specijalizaciji, u zborniku radova skupine autora: Medicinsko pravo i medicinska etika, Univerzizet u Beogradu, Beograd, 1994., str. 176.

${ }^{17} \mathrm{Ibid}$, str. 176. i 177.

18 Tako DEUTSCH, E., Die Anfangeroperation: Autklarung, Organisation, Haftung und Beweislastumkehr, „Neue Juristiche Wochenschrift, 1984., broj 12, str. 650.

${ }^{19} \mathrm{O}$ manama volje vidjeti više u: KLARIĆ, P. - VEDRIŠ, M., Građansko pravo, Narodne novine, Zagreb, 2008. god., str. 140. - 143.

${ }^{20}$ Vidjeti tako u PROSKE, M., Aerztliche Aufklarungspflicht und Einwilligung des Patienten aus strafrechtlicher Sicht, $u$ : Haftung des Arztes in zivil - und strafrechtlicher Sicht unter Einschluss des Arzneimittelrechts, Graz, 1983., str. 111., prema: ĐURĐEVIĆ, N., Pristanak pacijenta na lečenje, Pravni fakultet, Institut za pravne i društvene nauke, Kragujevac, 1997., str. 86. - 90.

${ }^{21}$ Ibid., str. 87.

22 Ibid., str. 88.

${ }^{23}$ Vidjeti tako TURKOVIĆ, K., Prava pacijenta na suodlučivanje prema Zakonu o zaštiti prava pacijenata, Zbornik "Medicina i pravo - sodobne dileme”, Maribor, 2006., str. 101.

${ }^{24}$ Usp. ČIZMIĆ, J. - KAČER IVANČIĆ, B., Odgovornost za greške doktora medicine specijalizanta, zbornik radova sa II. simpozija s međunarodnim sudjelovanjem „PRAVNI, ETIČKI I MEDICINSKI ASPEKTI SUVREMENOG VOĐENJA PORODA“, Šibenik, 11. i 13. svibnja 2017. Godine, str. 51.-67.

${ }^{25}$ Tako RADIŠIĆ, J., Ko je odgovoran zbog greške lekara na specijalizaciji, „Pravni život“, 2009., TOM I, broj 9, str. 815 .

${ }^{26}$ Vidjeti tako u: DEUTSC, E., Unerlaubte Handlungen und Schadensersatz, Ein Grundriss, Köln, 1987., str. 67. i 68., marg. br. 127., prema: RADIŠIĆ, J., Odgovornost za štetu uzrokovanu operacijom koju je obavio liječnik na specijalizaciji, op. cit., str. 180.

${ }^{27}$ To je stav i njemačkih sudova i austrijskog Vrhovnog suda u odluci od 09.09.1986. - vidjeti tako u GIESEN, D., Arzthaftungsrecht, Tübingen, 1990., str. 41.; Juristische Blätter, br. 3-4/1987., str. 104-106., prema: Jakov Radišić, Odgovornost za štetu uzrokovanu operacijom koju je obavio liječnik na specijalizaciji, op. cit., str. 181.

${ }^{28}$ Odnosno to je ugovorni odnos s HZZO, a samo iznimno bi se radilo o izvanugovornom odnosu (npr. kod greške u identitetu i sl.).

${ }^{29}$ Vidjeti tako u: PETAR KLARIĆ, MARTIN VEDRIŠ, op. cit., str. 604.-605.

${ }^{30}$ Pravilnik o specijalističkom usavršavanju zdravstvenih djelatnika (vidjeti detaljno o tome u dijelu Pravna vrela, uz važnu napomenu da se ipak radi o podzakonskom aktu s pravnom snagom ispod zakona) je sadržavao i prilog pod naslovom Plan i program specijalizacija i užih specijalizacija, pa 
se tako kod hematologije spominje formulacija „samostalno izvesti 5 pretraga citološkom punkcijom perifernog limfnog čvora“, kod pedijatrije „pod nadzorom učiniti“ (pored ostalog) totalnu kolonoskopiju $10 \mathrm{x}$, kod pedijatrijske pulmologije ,ultrazvučni pregled $10 \mathrm{x}$ uz nadzor ili samostalno"....

${ }^{31}$ Usp. RADIŠIĆ, J., Ko je odgovoran zbog greške lekara na specijalizaciji, „Pravni život“, 2009., TOM I, broj 9 , str. 810 .

${ }^{32}$ Ibid., str. 810.

${ }^{33}$ Prema rješenju iz poredbenog prava, specijalizant koji je počinio liječničku grešku odgovara po osnovi delikta i to solidarno $s$ medicinskom ustanovom za koju je operirao, a pošto on nije $s$ pacijentom u ugovornom odnosu (već je u ugovornom odnosu s pacijentom medicinska ustanova) riječ je o izvanugovornoj odgovornosti za štetu. Kada namiri pacijenta, može se (specijalizant) u cijelosti regresirati od medicinske ustanove, ali ako je njegova krivnja veća od krivnje medicinske ustanove, on snosi i razmjerni dio štete. Prema pacijentu liječnik specijalizant odgovara kao da je liječnik specijalist, dakle za svaki stupanj krivnje, ali prema poslodavcu (medicinskoj ustanovi) ne bi trebao odgovarati za običnu nepažnju. Medicinska ustanova je u ugovornom odnosu s pacijentom i ona odgovara za svoje zaposlenike. Za specijalizante koji nisu u radnom odnosu u toj medicinskoj ustanovi, odgovara kao za svoje pomoćnike u poslu. Ako medicinska ustanova isplati štetu oštećenome, nema pravo na regres od specijalizanta jer je njen mentor liječnik ili voditelj odjela povjerio obavljanje operacije specijalizantu koji nije bio sposoban za to, osim u slučaju ako je specijalizant počinio veću grešku od nje, ali i tada mora snositi dio štete koji je razmjeran njenoj krivnji (radi se o slučaju podijeljene odgovornosti). Voditelj (šef) odjela ili liječnik mentor koji je pogriješio u procjeni iskustva specijalizanta je u ugovornom odnosu s medicinskom ustanovom i njegova neposredna odgovornost pacijentu je moguća samo ako je štetu prouzročio s namjerom. Vidjeti tako u: RADIŠIĆ, J., Odgovornost za štetu uzrokovanu operacijom koju je obavio liječnik na specijalizaciji, op. cit., str. 178.-183.

${ }^{34}$ Podatak na stranici https://hr.wikipedia.org/wiki/Primarijus. 


\section{8/ Priznavanje inozemnih stručnih kvalifikacija}

\subsection{Pojam i postupak priznavanja inozemnih stručnih kvalifikacija}

Stručna kvalifikacija podrazumijeva kvalifikaciju stečenu: po završetku formalnog obrazovanja kojim je obuhvaćeno i stručno usavršavanje te se dokazuje diplomom, svjedodžbom ili drugom javnom ispravom koju je izdala nadležna obrazovna ustanova, odnosno kvalifikaciju stečenu po završetku formalnog obrazovanja i nakon toga obavljenog stručnog usavršavanja, odnosno stručnim iskustvom, na temelju kojeg je nositelj stručne kvalifikacije stekao pravo obavljanja određene regulirane profesije u državi članici.

Postupak i utvrđivanje uvjeta za priznavanje inozemnih stručnih kvalifikacija, izdavanje rješenja o priznavanju inozemnih stručnih kvalifikacija, davanje informacija o postupku i uvjetima za priznavanje inozemnih stručnih kvalifikacija, te za poduzimanje ostalih radnji provodi nadležna komora sukladno Zakonu o reguliranim profesijama i priznavanju inozemnih stručnih kvalifikacija (»Narodne novine« br. 82/2015.).

Zdravstveni radnici su izrazito mobilna profesionalna skupina na tržištu rada te su vrlo traženi u drugim državama. Zbog velikog međudržavnog protoka profesionalaca zdravstvene struke, nužna je izgradnja što jedinstvenijeg sustava obrazovanja i stečenih kompetencija unutar europskog kvalifikacijskog okvira. U tom smislu donesena je na razini europskog gospodarskog prostora Direktiva 2005/36 koja omogućava mobilnost zdravstvenih radnika temeljem instituta priznavanja stručnih kvalifikacija i definiranja reguliranih profesija. U skladu s tim i u Republici Hrvatskoj jasno su propisani standardi reguliranih profesija i priznavanja stručnih kvalifikacija. Sve zdravstvene profesije u RH jesu regulirane, a Komore kao strukovne organizacije definirane su kao regulatorna tijela zadužena za nadzor i propisivanje standarda profesije. Doktori medicine, doktori dentalne medicine, farmaceuti medicinske sestre, primalje su automatski priznate profesije na području Europskog gospodarskog prostora te radi obavljanja profesionalne djelatnosti pripadnici tih profesija ne moraju prolaziti dodatne posebne uvjete i kriterije verifikacije svoje kvalifikacije u bilo kojoj državi EU.

S druge strane ostale zdravstvene profesije dužne su radi zasnivanja radnog odnosa u drugim državama EU prolaziti posebni postupak priznavanja inozemne stručne kvalifikacija koji uključuje usporedbu studijskih programa i donošenje posebnih rješenje o priznatoj kvalifikaciji. Ista načela vrijede i za zasnivanje radnog odnosa u RH. Sve osobe koje žele zasnovati radni odnos u RH ili nekoj drugoj državi EU, a dolaze iz drugih zemalja (obrazovali su se u trećim državama), bez obzira o kojoj se zdravstvenoj profesiji radilo, dužne su prolaziti opći sustav priznavanja inozemne stručne kvalifikacije.

Postupak priznavanja inozemne stručne kvalifikacije provodi se pred nadležnim tijelima Komore a uključuje provedbu upravnog postupka po posebnom zakonu. Nadležna Komora provodi priznavanje inozemne stručne kvalifikacije (automatsko priznavanje), 
koje se odnosi isključivo na državljane država EGP-a s dokazom o formalnoj osposobljenosti izdanim u državi EGP-a, kojim se priznaje tim dokazima jednaka valjanost kao i dokazima o formalnoj osposobljenosti izdanima u Republici Hrvatskoj. Usto, nadležna Komora provodi i opći sustav priznavanja inozemnih stručnih kvalifikacija koje se odnosi na državljane treće države s dokazom o formalnoj osposobljenosti izdanim u državi EGP-a te na državljane Republike Hrvatske, državljane država EGP-a i državljane trećih država koji su stručne kvalifikacije stekli izvan države EGP-a (ZOZZ, čl. 138.a). Postupak se pokreće podnošenjem zahtjeva za priznavanje inozemne stručne kvalifikacije, a bitan dio postupak čini nužna usporedba studijskih programa. Usporedbu studijskih programa dužni su na zahtjev Komore obaviti stručnjaci zaposleni na učilištima i fakultetima koji sudjeluju aktivno u izobrazbi kadrova predmetne profesije. Usporedbom studijskih programa ukoliko se utvrdi podudarnost programa s programom koji se koristi u RH osoba stječe temeljne preduvjete da joj se predmetne kvalifikacija priznaju te da tim može raditi $u$ RH, pa joj se istom rješidbom utvrđuje i akademski, odnosno stručni naziv kojim će ta osoba u obavljanju profesionalne djelatnosti koristiti. S druge strane ukoliko se usporedbom programa utvrde različitosti programa, ta osoba može ukoliko želi obavljati profesionalnu djelatnost u RH odabrati dvije predviđene mjere: provjere kompetentnosti koja uključuje polaganje ispita razlike programa, ili provedba mjere prilagodbe do tri godine koja uključuje pohađanje razlikovnih kolegija na učilištima ili zdravstvenim ustanovama. ${ }^{1}$

\subsection{Priznavanje inozemnih stručnih kvalifikacija stečenih u državama EU}

Mobilnost je između država EU zajamčena u cijelosti za pet automatski reguliranih profesija, dok za druge profesije ipak još uvijek u potpunosti nije, jer standardi obavljanja profesionalnih djelatnosti za druge profesije nisu ista ili slične na razini EU. Međutim ukoliko se radi o bilo kojoj osobi (državljaninu RH, državljaninu EU, trećim državljanima) koji su stekli obrazovnu ili stručnu kvalifikaciju u trećim državama, on će bez obzira o kojoj se profesionalnoj djelatnosti radi morati proći postupak priznavanja inozemnih stručnih kvalifikacija u Komori. Jednom priznata kvalifikacija vrijedi za sve države EU.

Nakon stečene i priznate kvalifikacije osobi se na njezin zahtjev izdaje odobrenje za samostalan rad, jer bez licence nije moguće ni u kojem pogledu obavljati profesionalnu djelatnosti RH. Rješenje o priznatoj kvalifikaciji je dokaz koji prilikom izdavanja licence potvrđuje stručnu i formalnu kvalifikaciju imenovane osobe

Osim trajnog obavljanja djelatnosti koja uključuje i zasnivanje poslovnog nastana u RH, drugi državljani mogu obavljati profesionalnu djelatnost na privremenoj ili povremenoj osnovi, pri čemu nisu dužni prolaziti postupak priznavanja inozemnih stručnih kvalifikacija, kao ni postupak licenciranja. Za iste se podrazumijeva da su članovi svojih matičnih Komora te da su od strane svojih regulatornih tijela ovlašteni obavljati profesionalnu djelatnost. Kod ovog je bitno naglasiti da su zdravstvene profesije na razini velikog broja europskih država regulirane profesije (profesije čiju regularnost i standarde nadziru ovlaštene organizacije poput Komora) što opravdava činjenicu da su profesije u zdravstvu visoko standardizirane profesije. 
Doktori medicine i doktori medicine specijalisti koji su stručne kvalifikacije stekli u inozemstvu, a žele obavljati liječničku djelatnost na području Republike Hrvatske, dužni su zatražiti priznavanje inozemnih stručnih kvalifikacija. Iznimno, temeljem članka 48. Zakona o reguliranim profesijama i priznavanju inozemnih stručnih kvalifikacija (»Narodne novine« br. 82/2015.), postupku priznavanja ne podliježu stručne kvalifikacije (diploma medicinskog fakulteta, svjedodžbe odnosno uvjerenja o položeno državnom/stručnom ispitu, specijalističkom ispitu i ispitu iz područja uže specijalnosti), koje su doktori medicine stekli prije 8. listopada 1991. godine izvan teritorija Republike Hrvatske na području bivše SFR Jugoslavije. Postupak priznavanja inozemnih stručnih kvalifikacija za doktore medicine i doktore medicine specijaliste, provodi Hrvatska liječnička komora, kao nadležno tijelo u Republici Hrvatskoj, temeljem članka 138. ZOZZ-a. Postupak se provodi sukladno Zakonu o reguliranim profesijama i priznavanju inozemnih stručnih kvalifikacija i Pravilniku o mjerilima za priznavanje inozemnih stručnih kvalifikacija („Narodne novine“ br. 89/2013 od 10.07.2013.). Automatski postupak priznavanja inozemnih stručnih kvalifikacija primjenjuje se na podnositelje zahtjeva koji imaju dokaz o stručnoj kvalifikacije izdan u državi članici Europske unije (EU) odnosno državi ugovornici Ugovora o Europskom gospodarskom prostoru (EGP) ili Švicarskoj konfederaciji. Opći postupak priznavanja inozemne stručne kvalifikacije primjenjuje se na podnositelje zahtjeva koji nemaju dokaz o stručnoj kvalifikacije izdanoj u državi članici Europske unije (EU) odnosno državi ugovornici Ugovora o Europskom gospodarskom prostoru (EGP) ili Švicarskoj konfederaciji, te na sve koji su stručne kvalifikacije stekli u državi koja nije članica Europske unije (EU) odnosno državi koja nije ugovornica Ugovora o Europskom gospodarskom prostoru (EGP) ili u Švicarskoj konfederaciji ( tzv. „treće zemlje“). Temeljem članka 143. ZOZZ-a, Hrvatska liječnička komora dijeli nadležnost u općem postupku priznavanja inozemnih stručnih kvalifikacija s Ministarstvom zdravlja Republike Hrvatske. Zahtjev za priznavanje inozemnih stručnih kvalifikacija doktor medicine i doktor medicine specijalist u svrhu ostvarivanja prava na obavljanje regulirane profesije doktor medicine, na području Republike Hrvatske podnosi se Hrvatskoj liječničkoj komori. ${ }^{2}$

\subsection{Izdavanje potvrda o osposobljenosti za obavljanje profesije}

Nadležna komora provodi provjeru stručnog znanja kandidata radi ocjene osposobljenosti kandidata za obavljanje regulirane profesije. Mjerila za priznavanje inozemnih stručnih kvalifikacija pravilnikom propisuje ministar uz mišljenje nadležnih komora (ZZZ, čl. 138.a). U cilju omogućavanja mobilnosti zdravstvenih radnika Komore su nadležne za izdavanje odgovarajućih potvrda kao što je EU potvrda za neometano pružanje usluga na unutarnjem tržištu Europske unije - potvrda koja se izdaje pravnim i fizičkim osobama u svrhu neometanog obavljanja profesija i pružanja usluga na području drugih država članica, zapošljavanjem i obavljanjem gospodarske djelatnosti, odnosno samozapošljavanjem, poslovnim nastanom, odnosno privremenim i povremenim pružanjem usluga, ili pak potvrda o trenutnom profesionalnom statusu kojima se dokazuje da se protiv članova zdravstvenih radnika ne vode disciplinskih postupci, ili pak potvrda o stupnju sukladnosti obrazovanja kojom se potvrđuje da je obrazovanje zdravstvenog radnika sukladno utvrđenim programima te odredbama direktive i europskih standarda. Prema odredbama ZOZZ-a, zdravstvenom radniku državljaninu Republike Hrvatske koji zakonito obavlja zdravstvenu djelatnost na teritoriju Republike Hrvatske, nadležna 
komora izdaje potvrdu o stvarnom i zakonitom obavljanju te djelatnosti neprekidno tri godine u posljednjih pet godina (ZOZZ, čl. 138.b st. 1.). Nadležne komore izdaju potvrde za državljane Republike Hrvatske čiji dokaz o formalnom obrazovanju za doktora medicine, medicinske sestre u djelatnosti opće njege, doktore dentalne medicine, magistre farmacije i primalje nije sukladan zvanju (tituli) upisanom za Republiku Hrvatsku sukladno Zakonu o reguliranim profesijama $\mathrm{i}$ priznavanju inozemnih stručnih kvalifikacija, a tom potvrdom se utvrđuje da je formalna kvalifikacija izdana na temelju uspješnog završetka obrazovanja sukladno Zakonu o reguliranim profesijama i priznavanju inozemnih stručnih kvalifikacija (ZOZZ, čl. 138.b st. 3.).

\section{Primjedbe}

${ }^{1}$ Bitno različit sadržaj podrazumijeva sadržaj osposobljavanja, odnosno stečene kompetencije odlučujuće za obavljanje profesije, a osposobljavanje pokazuje značajne razlike glede njegova trajanja ili pokrivenih područja od osposobljavanja koja su propisana u Republici Hrvatskoj. U slučaju mjere provedbe razdoblja prilagodbe Komora je dužna u rješenju odrediti i uvjete za njegovo obavljanje $\mathrm{s}$ mogućim dodatnim obrazovanjem ili stručnim usavršavanjem i osposobljavanjem, imenovati kvalificiranog stručnjaka za nadzor te odrediti kriterije za ocjenu uspješnosti obavljanja razdoblja prilagodbe.U slučaju mjere provjere kompetentnosti Komora će u rješenju utvrditi rok za polaganje (praktičnog i/ili teorijskog dijela) ispita provjere kompetentnosti kojim se kandidatu omogućava prvi izlazak na ispit provjere kompetentnosti unutar šest mjeseci od dana donošenja privremenog rješenja te popis obrazovnih sadržaja koji podliježu provjeri kompetentnosti, a nisu obuhvaćeni kandidatovim dokazima o obrazovnoj, odnosno stručnoj kvalifikaciji, ali su bitni za bavljenje reguliranom profesijom u Republici Hrvatskoj.

2 Vidi Priznavanje inozemne stručne kvalifikacije, podatak na stranici https://www.hlk.hr/priznavanje-inozemne-strucne-kvalifikacije.aspx. 


\section{9/ Stalni sudski vještak zdravstvene struke}

\subsection{O pojmu vještačenja i vještaka - Vještačenje}

je parnična radnja u okviru koje se od strane vještaka, kao osobe koja raspolaže posebnim znanstvenim ili stručnim znanjem i iskustvom, primjenjuju znanstvena i stručna znanja, vještine i metode na činjenice koje predstavljaju predmet vještačenja. ${ }^{1}$ Vještačenje je, dakle, parnična radnja kojom se pribavlja posebni dokaz - iskaz vještaka i kao takva pridonosi ostvarenju načela traženja materijalne istine.

Vještaci (engl. expert witness; surveyers, court experts; njem. Sachverstaendige, Gutachter, Gerichtsgutachter; talij. periti, periti giurati.) su, pak, osobe koje sudu na temelju svoga stručnoga znanja iznose svoja zapažanja o predmetu vještačenja (nalaz) i svoje zaključke o određenim činjenicama izvedene na temelju rezultata toga ispitivanja (mišljenje). Vještak je, dakle, osoba pozvana da pred sudom, koristeći se svojim stručnim znanjem, iznese: svoja sadašnja stručna zapažanja potrebna za utvrđenje sadržaja neke relevantne činjenice (NALAZ) i svoje stajalište o značenju, vjerovanju, uzrocima i posljedicama određenih činjenica koje bi mogle biti važne za utvrđivanje istinitosti u dokazivanju (MIŠLJENJE). ${ }^{2}$ Tako, primjerice, vještak medicinske struke pomaže sudu da utvrdi što je prihvatljivo u redovitoj praksi, a što u posebnim okolnostima, osiguravajući da se profesionalno određeni standardi $u$ realnim kliničkim situacijama aktualno potvrde $i$ usporede sa standardima iskazanim u retorici kliničkih vodiča. Drži se da uspostavljeni standardni postupci u okviru protokola i vodiča dobre prakse jesu primarno relevantni, ali ne mogu biti zamjena za vještaka, pogotovo ako postoje suprotstavljeni vodiči razvijeni u različitim bolnicama. ${ }^{3}$

Sud treba izvesti dokaz vještačenjem kad je radi utvrđivanja ili razjašnjenja kakve činjenice potrebno stručno znanje kojim sud ne raspolaže (Zakon o parničnom postupku, „Narodne novine“, broj 53/91, 91/92, 112/99, 88/01, 117/03, 88/05, 2/07, 84/08, 96/08, 123/08, 57/11, 148/11, 25/13, 89/14, dalje - ZPP, čl. 250.). Sud bi, u pravilu, trebao pozvati vještaka uvijek kad je potrebno takvo stručno znanje koje bitno prelazi razinu znanja koje na tom području sudac obično dostigne. ${ }^{4}$ Kriterij je, dakle, stupanj znanja čovjeka koji posjeduje opće obrazovanje i životno iskustvo kao sudac. ${ }^{5}$ Uloga vještaka u parničnom postupku jest u tome da pomoću svoga stručnog znanja utvrde okolnosti na temelju kojih sam sud mora zaključiti o postojanju odnosno nepostojanju odlučnih činjenica. ${ }^{6}$ Tako pitanje je li tuženik osigurao odgovarajuće mjere zaštite na radu predstavlja stručno, a ne obično faktičko pitanje, pa se isto treba razjasniti vještačenjem, a ne samo putem svjedoka. ${ }^{7}$ Izvođenje vještačenja ima prednost pred oslanjanjem na stručno znanje suda jer se nalaz i mišljenje vještaka podvrgavaju diskusiji i kritici na raspravi na kojoj sudjeluju stranke. ${ }^{8}$

ZPP sadrži samo opće odredbe o vještačenju kojima se, ponajviše, propisuje procesni tijek vještačenja, dok se pravilnost samog vještačenja osigurava postupanjem lege artis, 
po pravilima odgovarajuće znanosti, struke ili vještine, pa je zato nepodesna za (procesno)pravnu regulativu i uopće joj ne podliježe. ${ }^{9}$

Vještak treba pomagati sudu isključivo u utvrđivanju činjenica, a nikada prilikom odlučivanja o primjeni pravne norme. Tako sudac ne može odrediti vještaka za pravna pitanja, niti od vještaka tražiti odgovor na pravna pitanja. Vještak se ne može upuštati u pravna pitanja ni na osobnu inicijativu, niti svoje mišljenje može utemeljiti na tumačenju pravnih propisa. Predmet vještačenja ne mogu biti propisi koji se trebaju primijeniti na određeni slučaj, već samo propusti u ponašanju osoba i primjeni tih propisa. ${ }^{10}$ Vještak se ne može izjašnjavati ni o stupnju i postotku krivnje, već, primjerice, samo o propustima sudionika u prometu koji su u uzročnoj svezi s nastankom štete, a zaključak o doprinosu u nastanku štetnih posljedica donosi sud prema slobodnoj ocjeni (arg. iz čl. 223. ZPPa) ${ }^{11}$ Dakle, sud nalaz i mišljenje vještaka koristi samo radi razjašnjenja ili utvrđivanja onih činjenica za koje je potrebno stručno znanje kojim sud ne raspolaže. ${ }^{12}$

Kada sud sudi u vijeću nužno je da svi članovi vijeća mogu sami stručno ocijeniti činjenice koje se utvrđuju. Ako samo jedan član vijeća raspolaže potrebnim stručnim znanjem u određenom slučaju, sud mora za izvođenje dokaza odrediti vještaka. Naime, stručno znanje s kojim eventualno raspolaže samo jedan član vijeća, nije stručno znanje suda.

Ukoliko sam sud može određene činjenice pojasniti, primjerice običnim računskim operacijama, pribavljanjem podataka od određene državne institucije koja je ovlaštena voditi evidencije i podatke, iscrpnim saslušanjem stranaka i svjedoka i sl., tada nema potrebe za vještačenjem. ${ }^{13} \mathrm{U}$ tom smislu parnični sud nije dužan vještačenjem utvrđivati iznos zateznih kamata obračunatih za period kašnjenja u plaćanju glavnog duga, ako je tužitelj priložio obračun iz kojega su vidljivi svi elementi na temelju kojih je sačinjen, a tuženik nije osporio na određeni način ni jedan od elemenata obračuna. U nedostatku prigovora nema razloga ni vještačenju. ${ }^{14}$ Usto, da bi se utvrdilo zdravstveno stanje stranke nije uvijek nužno izvesti dokaz medicinskim vještačenjem. ${ }^{15} \mathrm{I}$ onda kad sud donosi odluku o povjeravanju djece na čuvanje i odgoj, odredit će i način održavanja osobnih odnosa roditelja s djecom. O učestalosti, trajanju i načinu održavanja tih odnosa korisno je pribaviti mišljenje vještaka (psihologa), ali to nije u svakom slučaju potrebno. Takvom vještačenju treba pristupiti ako to iziskuju interesi djeteta odnosno ako na to upućuju neki posebni razlozi. ${ }^{16}$ Možemo kazati da je psihijatrijsko vještačenje svakako odlučan putokaz pri utvrđivanju umne odnosno poslovne sposobnosti neke osobe, ali ne mora biti i jedini dokaz koji sud treba imati u vidu. ${ }^{17} \mathrm{Ali}$, iako je sud u pogledu postojanja kaznenog djela i kaznene odgovornosti vezan za pravomoćnu presudu kojom je tuženik proglašen krivim, u parničnom postupku mogu se vještačenjem utvrđivati činjenice u pogledu okolnosti nastanka štete, koje uvjetuju stupanj krivnje. ${ }^{18}$

Vještaci su zamjenjivi jer, u pravilu, na određenom području (suda) postoji više osoba koje posjeduju stručna znanja kojima mogu pomoći sudu pri utvrđivanju činjeničnog stanja i izvođenju zaključaka na temelju izvršenog zapažanja. ${ }^{19}$ To je i razlog zbog kojeg se prema vještacima koji odbiju dati iskaz ne mogu primijeniti sankcije kojima bi ih se prisililo da dadu iskaz. 
ZDRAVSTVENO STRUKOVNO STALEŠKO PRAVO

Sud ocjenjuje nalaz i mišljenje vještaka kao i sve druge relevantne činjenice, te nije vezan za zaključke vještaka.

\subsection{Uvjeti za obavljanje poslova stalnog sudskog vještaka}

Prema odredbi čl. 29. Zakona o sudovima („Narodne novine“, broj 28/13, 33/15, 82/15, $82 / 16$, dalje - ZS), poslovi sudske uprave obuhvaćaju, među ostalim, i poslove u svezi sa stalnim sudskim tumačima i vještacima. I prema odredbama čl. 17. Sudskog poslovnika („Narodne novine“, broj 37/2014., dalje - SP), poslovi sudske uprave obuhvaćaju osiguranje uvjeta za pravilan rad i poslovanje suda, a, među ostalim, i poslove u svezi sa stalnim sudskim vještacima (vođenje popisa ili registara stalnih sudskih vještaka, tumača i procjenitelja). Tako je ZS-om propisano da stalni sudski vještaci na temelju svoga stručnog znanja pružaju sudu uslugu davanja vještačkog nalaza i mišljenja (vještačenje) kada je to potrebno radi utvrđivanja ili razjašnjenja činjenica koje se utvrđuju u postupku (ZS, čl. 125.). Sudsko vještačenje mogu obavljati pravne ili fizičke osobe. Što se uvjeta za obavljanje sudskog vještačenja tiče, ZS propisuje da fizičke osobe moraju imati najmanje završenu srednju školsku spremu odgovarajuće struke, dok pravne osobe mogu obavljati sudsko vještačenje samo u okviru svoje registrirane djelatnosti i to pod uvjetom da samo vještačenje obavljaju njihovi djelatnici koji ispunjavaju uvjete kao i fizičke osobe (ZS, čl. 126.). Stalne sudske vještake - fizičke osobe i stalne sudske vještake u pravnim osobama imenuje i razrješava predsjednik županijskog ili trgovačkog suda za svoje područje, a postavljaju se na vrijeme od četiri godine i mogu biti ponovno imenovani (ZS, čl. 126.) ${ }^{20}$ Sudski vještaci smiju isticati zvanje sudskog vještaka samo kad daju nalaz i mišljenje na zahtjev suda ili zahtjev stranaka radi ostvarenja njihovih prava, a u drugim slučajevima samo po odobrenju predsjednika suda koji ih je imenovao (ZS, čl. 127.).

Vještaci su dužni čuvati službenu tajnu, bez obzira na način na koji su je doznali, a posebno: sve ono što je kao službena tajna određeno zakonom ili drugim propisom; sve ono što je kao službena tajna, odnosno poslovna tajna određeno općim aktom pravne osobe, drugog tijela, organizacije ili institucije; podatke i isprave posebno označene kao službena, odnosno poslovna tajna od strane državnih tijela ili pravnih osoba, drugih tijela, organizacije ili institucije; te podatke i isprave koje su predsjednik suda ili ovlašteni službenik suda označili kao službenu tajnu (ZS, čl. 130.). I prema odredbama PSSV-a stalni sudski vještak dužan je čuvati kao tajnu sve ono što je saznao prigodom obavljanja poslova stalnog sudskog vještaka. Stalnom sudskom vještaku odnosno pravnoj osobi koja obavlja poslove stalnog sudskog vještaka zabranjeno je isticanje svojstva stalnog sudskog vještaka na javnim i privatnim površinama ili reklamiranje, osim uobičajene oznake na adresi sjedišta stalnog sudskog vještaka (PSSV, čl. 17.).

Sukladno odredbi čl. 139. st. 3. prethodno važećeg ZS-a, ministar pravosuđa bio je dužan propisati pravilnikom način na koji će se utvrditi ispunjava li osoba uvjete za obavljanje poslova stalnoga sudskog vještaka, njihova prava i dužnosti te visinu nagrade i naknade troškova za njihov rad. U tom smislu donesen je Pravilnik o stalnim sudskim vještacima („Narodne novine“", broj 88/08. i 8/09., a kasnije i novi objavljen u Narodnim novinama br. 38/14., dalje - PSSV), prema kojemu za stalnog sudskog vještaka može biti imenovana osoba za koju se u postupku imenovanja utvrdi da, osim općih uvjeta za prijam u državnu službu, ispunjava i sljedeće uvjete: a/ da je državljanin Republike Hrvatske, ${ }^{21}$ b/ da je 
državljanin države članice Europske unije ili neke druge države potpisnice Ugovora o Europskom gospodarskom prostoru, c/ da je zdravstveno sposoban za obavljanje poslova stalnog sudskog vještaka, d/ da je nakon završenog odgovarajućeg studija odnosno odgovarajuće škole radio na poslovima u struci i to: najmanje 5 godina - ako je završio preddiplomski i diplomski sveučilišni studij ili preddiplomski sveučilišni studij i specijalistički diplomski stručni studij odnosno stručni studij i specijalistički diplomski stručni studij; najmanje 8 godina - ako je završio odgovarajući preddiplomski sveučilišni studij ili stručni studij; i najmanje 10 godina - ako je završio odgovarajuću srednju školu. Iznimno, upravo liječnicima specijalistima sposobnost za obavljanje poslova stalnog sudskog vještaka utvrđena je položenim stručnim specijalističkim ispitom nakon provedenog specijalističkog staža, e/ da ima sklopljen ugovor o osiguranju od odgovornosti za obavljanje poslova stalnog sudskog vještaka (PSSV, čl. 2. st. 1.). ${ }^{22} \mathrm{Za}$ stalnog sudskog vještaka ne može se imenovati osoba za koju postoje zapreke za prijam u državnu službu, odnosno osobe protiv kojih se vodi kazneni postupak ili koje su osuđene za kaznena djela za koje je propisana kazna od najmanje dvije godine zatvora prema domaćem ili međunarodnom pravu za kaznena djela protiv života i tijela, čovječnosti, morala, javnog ili privatnog vlasništva, javne uprave i javnog interesa ili zbog pronevjere u javnom sektoru, osim ako je nastupila rehabilitacija prema posebnom zakonu (arg. Zakon o državnim službenicima, čl. 49. st. 1.a), ili osoba kojoj je izrečena sigurnosna mjera dok traju pravne posljedice osude ili joj je izrečena zabrana bavljenja zanimanjem u vrijeme kada traži imenovanje za stalnog sudskog vještaka.

Pravne osobe (poseban zavod ili drugo tijelo znanstvene ustanove ili državno tijelo) ispunjavaju uvjete za sudsko vještačenje: a/ ako se utvrdi da su registrirane za obavljanje vještačenja za odgovarajuću djelatnost što dokazuju potvrdom nadležnog suda, b/ako je utvrđeno da njihovi zaposlenici ispunjavaju uvjete za stalnog sudskog vještaka, što se utvrđuje uvidom u rješenje o imenovanju i popis stalnih sudskih vještaka za područje odgovarajućeg suda, c/ ako za zaposlenike koji su imenovani stalnim sudskim vještacima ima zaključen ugovor o osiguranju od odgovornosti za obavljanje poslova stalnog sudskog vještaka (PSSV, čl. 4.).

Postupak imenovanja stalnih sudskih vještaka pokreće se zahtjevom koji se podnosi predsjedniku županijskog ili trgovačkog suda nadležnog prema prebivalištu podnositelja zahtjeva odnosno sjedištu pravne osobe. Zahtjev može podnijeti i pravna osoba za svog zaposlenika pod uvjetom da je zaposlenik dao svoj pristanak u pisanom obliku. Fizička osoba zahtjevu prilaže životopis, dokaz o državljanstvu i druge propisane dokaze o ispunjavanju uvjeta za imenovanje (o državljanstvu, zdravstvenoj sposobnosti, radu u struci, školskoj spremi, ugovoru o osiguranju od odgovornosti, v. PSSV, čl. 2.). Zahtjevu se može priložiti popis objavljenih znanstvenih i stručnih radova.

Prije odlučivanja o zahtjevu predsjednik odgovarajućeg županijskog, odnosno trgovačkog suda treba uputiti kandidata na stručnu obuku stalnom sudskom vještaku kojeg predloži jedna od strukovnih udruga. Pohađanje stručne obuke može se istovremeno promatrati kao pravo i kao dužnost kandidata. Stručna obuka ne može trajati dulje od jedne godine. Sposobnost kandidata za obavljanje poslova stalnog sudskog vještaka utvrđuje se upravo na temelju izvješća o provedenoj stručnoj obuci kod stalnog sudskog vještaka odgovarajuće struke pod čijim je nadzorom kandidat dužan obaviti 
najmanje pet vještačenja, izraditi nalaz i mišljenje. Ako predsjednik županijskog odnosno trgovačkog suda utvrdi da podnositelj zahtjeva ne ispunjava propisane uvjete ili je zahtjev nepotpun, predsjednik suda će ga odbiti (PSSV, čl. 5.).

Stručna obuka treba se obavljati prema programu što ga za svaku djelatnost odnosno struku izradi odgovarajuća strukovna udruga. Nakon obavljene stručne obuke nadležne udruge dužne su na temelju izvješća stalnog sudskog vještaka kod kojeg je kandidat bio na stručnoj obuci u roku od mjesec dana izraditi mišljenje u pisanom obliku o uspješnosti obavljene obuke i osposobljenosti kandidata za obavljanje poslova sudskog vještačenja i dostaviti predsjedniku odgovarajućeg županijskog odnosno trgovačkog suda.

Stalni sudski vještak nakon proteka vremena na koje je imenovan za sudskog vještaka može biti ponovno imenovan na vrijeme od četiri godine. Zahtjev za ponovno imenovanje i priložene dokaze o ispunjavanju uvjeta vještak mora podnijeti predsjedniku nadležnog suda najkasnije 30 dana prije isteka roka na koje je postavljen, a on bi trebao donijeti rješenje o ponovnom imenovanju kad utvrdi da nema zapreka za imenovanje, odnosno ako prethodno utvrdi da se protiv kandidata ne vodi kazneni postupak i da nije pravomoćno osuđen za kazneno djelo koje je zapreka za prijam u državnu službu ili mu je izrečena sigurnosna mjera, dok traju pravne posljedice osude ili mu je izrečena zabrana bavljenja zanimanjem. Ponovno imenovani stalni sudski vještak ne daje prisegu i nije dužan obaviti stručnu obuku (PSSV, čl. 12.).

Predsjednik odgovarajućeg županijskog odnosno trgovačkog suda treba razriješiti imenovanog stalnog sudskog vještaka: a/ ako to sam zatraži, b/ ako se utvrdi da nisu postojali odnosno da su prestali uvjeti na temelju kojih je imenovan, c/ ako je na temelju pravomoćne odluke nadležnog tijela proglašen nesposobnim za obavljanje djelatnosti ili struke za koju je imenovan, d/ ako mu je na temelju pravomoćne sudske odluke oduzeta poslovna sposobnost, e/ ako je stalnom sudskom vještaku izrečena pravomoćna presuda za kazneno djelo koje je zapreka za prijam u državnu službu ili mu je izrečena sigurnosna mjera, dok traju pravne posljedice osude ili mu je izrečena zabrana bavljenja zanimanjem kada traži imenovanje za stalnog sudskog vještaka, f/ ako nesavjesno ili neuredno obavlja povjerene mu poslove vještačenja, g/ ako ne zaključi ugovor o osiguranju od odgovornosti stalnog sudskog vještaka, te h/ ako povrijedi odredbe o dužnosti čuvanja tajne. Protiv rješenja o razrješenju vještaka dopuštena je žalba Ministarstvu pravosuđa u roku od 15 dana od dostave rješenja, koja se predaje neposredno ili se šalje poštom predsjedniku odgovarajućeg županijskog odnosno trgovačkog suda, u dva primjerka s dva preslika rješenja (PSSV, čl. 13.).

Vještaci medicinske struke - Za vještaka može u načelu biti imenovana i osoba koja ima posebno stručno znanje iz određenog područja medicinske djelatnosti. Liječnik vještak medicinske struke mora se pridržavati etičkih načela struke sadržanih u etičkim kodeksima strukovnih udruga, društava i komora te prisege koju je pri imenovanju položio pred sucem. Liječnik vještak mora imati značajno iskustvo i znanje za područje koje vještači i mora biti upoznat sa suvremenim postignućima u tom području. Etičnost sudskog vještaka medicinske struke očituje se u stalnoj procjeni vlastite praktične i teoretske osposobljenosti za izradu odgovarajućeg vještačkog nalaza (KMED, čl. 9. toč. 16.). Medicinsko vještačenje je postupovna radnja u kojoj se medicinski pojmovi i 
instituti prevode na zakonom zadane institute i kategorije. ${ }^{23}$ Međutim, sama medicinska stručnost nekog liječnika, pa bila ona i iznadprosječna, nikako ne jamči da će on i kao vještak zadovoljiti. ${ }^{24}$ Stoga, svaka osoba koja se namjerava baviti vještačenjem na području medicinske djelatnosti, dužna je ispunjavati sve (druge) uvjete propisane za stalne sudske vještake. Što se stalnih sudskih vještaka medicinske struke tiče, program obavljanja stručne obuke donosi Hrvatska liječnička komora, Hrvatska stomatološka komora odnosno druga strukovna komora. Stručna obuka liječnika specijalista s valjanom licencijom Hrvatske liječničke komore i Hrvatske stomatološke komore ne može trajati dulje od 6 mjeseci, a liječnika specijalista s valjanom licencijom Hrvatske liječničke komore, odnosno Hrvatske stomatološke komore kojom mu je priznato zvanje primariusa ili koji je u znanstveno-nastavnom zvanju, ne može trajati dulje od 3 mjeseca. Liječnik specijalista sudske medicine s valjanom licencijom Hrvatske liječničke komore nije dužan obaviti stručnu obuku (PSSV, čl. 6.).

U tom smislu, na temelju članka 6. PSSV-a i članka 7. točka 8. alineja 20., te članka 19. točke 1. Statuta Hrvatske liječničke komore (Narodne novine, broj 55/08.), Vijeće Hrvatske liječničke komore na sjednici održanoj 08. svibnja 2009. donijelo je Pravilnik o provođenju izobrazbe kandidata za stalne sudske vještake (dalje - Pravilnik), ${ }^{25}$ kojim se uređuje provođenje izobrazbe za liječnike - kandidate za stalne sudske vještake (dalje kandidat), postupak imenovanja mentora liječniku - kandidatu te prava i obveze kandidata i mentora (Pravilnik, čl. 1.).

Za stalnog sudskog vještaka (medicinske struke) može se imenovati osoba koja, pored toga što ispunjava uvjete propisane PSSV-om za sve stalne sudske vještake, ima važeće odobrenje za samostalan rad (licenciju) izdano od Hrvatske liječničke komore (dalje HLK), te prođe izobrazbu koju provodi HLK u skladu s odredbama Pravilnika i Programom koji je sastavni dio Pravilnika. Izobrazba liječnika specijalista - kandidata ne može trajati dulje od šest (6) mjeseci, a liječnika specijalista - kandidata kojemu je priznat naziv primarius ili koji je u znanstveno nastavnom zvanju, ne može trajati dulje od tri (3) mjeseca (Pravilnik, čl. 2. i 3.)

U pravilu zahtjev za provođenje izobrazbe kandidat podnosi HLK nakon podnošenja zahtjeva za imenovanje stalnim sudskim vještakom pred nadležnim sudom, a iznimno izobrazbi mogu pristupiti i liječnici koji nisu podnijeli zahtjev za imenovanje stalnim sudskim vještakom, odnosno liječnici koji pružaju stručnu pomoć pravosudnim tijelima Republike Hrvatske i ostalim ovlaštenim osobama (eksperti, stručni pomoćnici i slično) (Pravilnik, čl. 4.). Nakon primitka zahtjeva za provođenje izobrazbe stručne službe HLK upućuju kandidata na izobrazbu za stalne sudske vještake, koja se sastoji od teorijskog dijela koji se provodi u obliku tečaja i praktičnog dijela koji obuhvaća rad pod nadzorom mentora (Pravilnik, čl. 5. i 6.). Tijekom trajanja izobrazbe kandidat je obvezan pod nadzorom mentora izraditi tri (3) nalaza i mišljenja (Pravilnik, čl. 10.).

Teorijski dio izobrazbe obuhvaća 20 školskih sati, a obavlja se u obliku tečaja čiji je sadržaj propisan Programom koji je sastavni dio ovog Pravilnika. U tijeku tečaja kandidat se upoznaje sa zakonskim i podzakonskim propisima Republike Hrvatske kojima su regulirani poslovi sudskog vještačenja te $s$ načinom izrade nalaza i mišljenja. Po završetku tečaja kandidat polaže ispit provjere znanja (Pravilnik, čl. 7.). ${ }^{26}$ Usmeni ispit iz 
prethodnog stavka ovoga članka obuhvaća usmenu provjeru znanja iz svih pet cjelina (modula) teorijskog dijela izobrazbe koje su predviđene Programom izobrazbe. Pismena provjera znanja provodi se rješavanjem testa u pisanom obliku (Pravilnik, čl. 7a.). ${ }^{27}$

Praktični dio izobrazbe provodi se kroz praktičan rad pod nadzorom mentora, a može obuhvaćati rad na terenu, pristup na glavnu raspravu ili prikupljanje podataka radi izrade nalaza i mišljenja (Pravilnik, čl. 9.).

Mentor kandidata mora biti iste specijalnosti odnosno uže specijalnosti kao i kandidat, te može biti samo liječnik koji je: a/ imenovan stalnim sudskim vještakom rješenjem odgovarajućeg županijskog odnosno trgovačkog suda u Republici Hrvatskoj; b/ član Komore s važećim odobrenjem za samostalan rad (licencom); c/ nakon imenovanja stalnim sudskom vještakom samostalno izradio najmanje deset (10) nalaza i mišljenja d/ da ima najmanje pet godina iskustva u obavljanju poslova sudskog vještačenja (Pravilnik, čl. 11.). Izvršni odbor HLK sastavlja popis mentora pod čijim će nadzorom kandidat obaviti praktični dio izobrazbe na temelju prijedloga stručnih društva i medicinskih fakulteta u Republici Hrvatskoj, ${ }^{28}$ a predsjednik HLK imenuje mentora svakom kandidatu odlukom protiv koje nezadovoljna stranka može uložiti žalbu Izvršnom odboru HLK u roku od 15 dana od dana primitka pismenog otpravka odluke. ${ }^{29}$

Nakon obavljenog praktičnog dijela izobrazbe, mentor podnosi predsjedniku HLK pisano izvješće o provedenoj izobrazbi, ${ }^{30}$ na temelju kojega je predsjednik HLK dužan u roku od mjesec dana po primitku izvješća, izraditi pisano mišljenje o uspješnosti obavljene izobrazbe i osposobljenosti kandidata za obavljanje poslova sudskog vještačenja, koje se dostavlja predsjedniku odgovarajućeg županijskog odnosno trgovačkog suda kod kojeg je kandidat podnio zahtjev za imenovanje stalnim sudskim vještakom. U mišljenju se mora navesti naziv suda i poslovni broj svakog predmeta u kojima je kandidat sudjelovao u izradi mišljenja i nalaza, kao i ime i prezime stalnog sudskog vještaka kod kojega je kandidat obavljao stručnu obuku (Pravilnik, čl. 18.).

Nakon provedenog postupka i prikupljenih dokaza predsjednik odgovarajućeg županijskog odnosno trgovačkog suda treba rješenjem odlučiti o zahtjevu. ${ }^{31}$ Protiv rješenja kojim je zahtjev za imenovanje stalnim sudskim vještakom određene struke odbijen dopuštena je žalba Ministarstvu pravosuđa u roku od 15 dana od dostave rješenja, koja se neposredno predaje ili se šalje poštom predsjedniku županijskog odnosno trgovačkog suda koji je donio rješenje, u dva primjerka s dva preslika rješenja (PSSV, čl. 13.).

\subsection{Određivanje vještaka}

Vještačenje obavljaju vještaci koje određuje parnični sud (ZPP, čl. 251. st. 1.). ${ }^{32}$ Sud je slobodan u odlučivanju hoće li odrediti dokazivanje vještačenjem, a iznimka je pravilo o dužnosti suda da uzme tumača. ${ }^{33}$ Sud treba odlučiti o tome koje struke ili specijalnosti treba biti vještak, a treba donijeti odluku i o osobi vještaka. ${ }^{34}$

Prijedlog za izvođenje dokaza vještačenjem stranke mogu postaviti u tužbi (ZPP, čl. 186. st. 1.), odgovoru na tužbu (ZPP, čl. 285.), u podnescima (ZPP, čl. 106.), na pripremnom 
ročištu (ZPP, čl. 284.) i na ročištu za glavnu raspravu (ZPP, čl. 299.). Značaj nalaza i mišljenja vještaka ima samo nalaz i mišljenje onoga vještaka kojega je u tom svojstvu odredio parnični sud, a ne i nalaz i mišljenje osobe koju je angažirala neka od stranaka. ${ }^{35}$ Stoga sud nije dužan nalaz i mišljenje vještaka koji je tužitelj priložio uz tužbu, te koji je sastavljen po nalogu tužitelja, prihvatiti samo zato što ga je dala osobe koja je stalni sudski vještak. ${ }^{36}$ Nalaz i mišljenje koje jedna od stranaka izradi o svom trošku samo je pomoćna građa u parničnom postupku. ${ }^{37}$ To, pak, ne znači da sud ne može za vještaka odrediti osobu koju je jedna od stranaka bila prethodno angažirala da utvrdi određene činjenice.

Sud može odrediti za vještaka osobu koja je državljanin druge države samo ako takva osoba po propisima Republike Hrvatske može biti imenovana za stalnog sudskog vještaka od strane nadležnog tijela za imenovanje stalnih vještaka. ${ }^{38}$

Protiv odluke suda kojom se određena osoba postavlja za vještaka, kao i drugih rješenja koje je sud donio u svezi s tim, nije dopuštena žalba (v. čl. 262. ZPP-a).

Prije nego što odredi koje će osobe uzeti za vještake sud bi o tome trebao saslušati stranke. U hitnim slučajevima sud može odrediti vještaka iako prije toga stranke nisu saslušane (ZPP, čl. 251. st. 2.).

Sud može odrediti vještačenje i protivno suglasnoj volji stranaka. Sud nije vezan prijedlogom stranaka o tome koga će imenovati kao vještaka, jer su vještaci pomoćnici suda koji popunjavaju njegovo znanje u stručnim pitanjima, pa se stoga sudu mora prepustiti da sam izabere svoje pomoćnike. ${ }^{39}$ Predviđeno prethodno saslušanje stranaka o osobama koje namjerava uzeti za vještaka, nužno je i korisno kako bi se izbjegli eventualni naknadni zahtjevi za izuzeće vještaka i time spriječilo nepotrebno odugovlačenje postupka.

Parnični sud može ovlastiti predsjednika vijeća ili zamoljenog suca da oni odrede vještake ako je njima povjereno izvođenje dokaza vještačenjem (ZPP, čl. 251. st. 3.). Kad je vještačenje povjereno stručnoj ustanovi, ona određuje jednu ili više osoba koje će u njezino ime obaviti vještačenje..$^{40}$

Umjesto određenog vještaka sud može uvijek odrediti drugog vještaka (ZPP, čl. 251. st. 4.). Pri donošenju odluke o imenovanju drugog vještaka umjesto već određenog vještaka, sud mora voditi računa o tome da nesvrsishodna zamjena vještaka može prouzročiti dodatne troškove i odugovlačenje postupka (v. čl. 10. ZPP-a).

\subsection{Obavljanje vještačenja - fizičke i pravne osobe}

Kad sud ocijeni da je vještačenje potrebno, u skladu s načelom ekonomičnosti u postupku vještačenje se mora provesti što brže i sa što manje troškova (ZPP, čl. 10.). Vještačenje, u pravilu, obavlja jedan vještak, a kad sud ocijeni da je vještačenje složeno, može odrediti dva ili više vještaka (ZPP, čl. 252. st. 1.).

Pri izboru vještaka mora se voditi računa o stručnim kvalifikacijama i kvalitetama onoga tko se imenuje vještakom. Tako u jednoj parnici može biti određeno više vještaka 
različitih struka. Tijekom vještačenja može se povećati broj vještaka, u pravilu zbog multidisciplinarnog pristupa utvrđivanju ili ocjeni neke važne činjenice.

Vještaci se određuju, ponajprije, iz reda imenovanih sudskih vještaka za određenu vrstu vještačenja (ZPP, čl. 252. st. 2.), ali sud nije vezan za listu sudskih vještaka, nego može po potrebi za vještaka odrediti i drugu osobu. ${ }^{41}$ Naime, službenu listu stalnih sudskih vještaka treba shvatiti kao pomoćno sredstvo, podsjetnik, adresar osoba prikladnih za obavljanje vještačenja, i ta lista može imati samo značenje preporuke i sugestije, a ne $\mathrm{i}$ obvezatnog izvora. ${ }^{42}$ Za određenu vrstu vještačenja, sud može odrediti vještake i izvan reda stalnih sudskih vještaka. Primjerice, ako za određenu vrstu vještačenja nema stalnog sudskog vještaka, ili je stalni sudski vještak spriječen, ili postoji opasnost od odgađanja. Vođenje popisa ili registara stalnih sudskih vještaka obavljaju se u uredu predsjednika suda (arg. SP, čl. 34.). Popis stalnih sudskih vještaka koji obavljaju sudsko vještačenje za sve sudove objavljuje prema potrebi Ministarstvo pravosuđa $u$ »Narodnim novinama« (ZS, čl. 142.). Popis stalnih sudskih vještaka po pojedinim područjima vještačenja i Popis pravnih osoba za obavljanje poslova vještačenja, moraju voditi uredno i na vrijeme. Imenovani stalni sudski vještaci i pravne osobe unose se na jedinstveni elektronički popis stalnih sudskih vještaka za područje cijele Republike Hrvatske, a za unošenje na popis nadležan je županijski odnosno trgovački sud koji je imenovao vještaka i o tome redovno obavijestiti Ministarstvo pravosuđa. Ako pravna osoba prestane s radom ili prestane obavljati poslove sudskog vještačenja, odnosno ako stalni sudski vještak umre, bude razriješen ili ako nije ponovno imenovan, briše se s popisa stalnih sudskih vještaka (PSSV, čl. 16.). Županijski, trgovački i općinski sudovi objavljuju na oglasnoj ploči obavijest o mogućnosti uvida stranaka u popis stalnih sudskih vještaka u uredu predsjednika suda (PSSV, čl. 17.).

Značaj nalaza i mišljenja vještaka u parnici ima samo nalaz i mišljenje vještaka kojega je u tom svojstvu odredio sud u konkretnoj parnici, bez obzira na to što se radi o stalnom sudskom vještaku. ${ }^{43}$

Vještačenje sud može povjeriti i nekoj stručnoj ustanovi (bolnici, kemijskom laboratoriju, fakultetu i sl.), posebno ako drži da je potrebno vještačenje toliko teško i složeno da na izradi nalaza i mišljenja treba raditi više stručnjaka i/ili se pri izradi nalaza i mišljenja treba koristiti posebna tehnička sredstva i opremu s kojom te ustanove raspolažu. Međutim, nije isključeno da se nekada i u ovim ustanovama vještačenje povjeri samo jednom stručnjaku, koji preuzima i odgovornost za nalaz i mišljenje. Da bi izvršila vještačenje, stručna ustanova mora imati na raspolaganju materijal potreban za vještačenje. U tom je smislu sud dužan toj ustanovi staviti na raspolaganje traženi materijal. Ako postoje posebne ustanove za određene vrste vještačenja (vještačenje lažnog novca, rukopisa, daktiloskopsko vještačenje i sl.), takva vještačenja, a osobito složenija, povjerit će se, u prvom redu, tim ustanovama. Odluka suda kojom se vještačenje povjerava ovim ustanovama, ne može se pobijati žalbom. Popis pravnih osoba (stručnih ustanova) koje obavljaju sudsko vještačenje za sve sudove objavljuje prema potrebi Ministarstvo pravosuđa u »Narodnim novinama« (ZS, čl. 142.). 


\subsection{Dužnost vještačenja}

Svaka osoba koju sud imenuje za vještaka dužna je odazvati se pozivu suda. Određeni vještaci dužni su iznijeti svoj nalaz i mišljenje (ZPP, čl. 253.). U nalazu se daju temeljni podaci o predmetu vještačenja i nađenom stanju, pa je nalaz svojevrsni opis predmeta vještačenja. Iz mišljenja vještaka vidi se na temelju kojih je pravila (svoje) struke vještak izveo zaključak, te je mišljenje, u stvari, odgovor koji je sud tražio od vještaka.

Odredbama čl. 253. st. 2. i 3. ZPP-a, uređuje se pitanje oslobađanja od dužnosti vještačenja. Ako utvrdi da postoje okolnosti navedene u st. 2. čl. 253. ZPP-a, odnosno razlozi zbog kojih bi i svjedok mogao uskratiti svjedočenje ili odgovor na pojedino pitanje, nadležni sud mora donijeti rješenje kojim će osloboditi vještaka od dužnosti vještačenja. Protiv rješenja suda vještak ima pravo na samostalnu suspenzivnu žalbu (v. čl. 378. i 379. ZPP-a).

Iako se to u odredbama st. 2. čl. 253. ZPP-a izričito ne spominje, držimo kako bi određeni vještak, pored postojanja okolnosti iz čl. 237. i 238. ZPP-a, mogao zatražiti da ga se oslobodi dužnosti vještačenja $\mathrm{i}$ onda kad bi vještačenjem povrijedio dužnost čuvanja službene ili vojne tajne (v. čl. 237. ZPP-a).

Sud može vještaka, na njegov zahtjev, osloboditi dužnosti vještačenja i iz drugih opravdanih razloga (ZPP, čl. 253. st. 3.).

Odredbama st. 3. čl. 253. ZPP-a nije poimenice određeno koji su to "drugi opravdani razlozi" zbog kojih sud može vještaka osloboditi dužnosti vještačenja na njegov zahtjev. Držimo kako bi to, u prvom redu, mogla biti činjenica da vještak ne raspolaže potrebnim stručnim znanjem ili tehničkim sredstvima za obavljanje vještačenja. Mogući opravdani drugi razlozi bili bi i zauzetost drugim službenim ili neodgodivim privatnim poslovima, bolest, službena spriječenost, postojanje okolnosti zbog kojih stranke mogu tražiti izuzeće vještaka i sl.

Opravdanost razloga ocjenjuje sud prema svojem uvjerenju na temelju savjesne i brižljive ocjene svih konkretnih okolnosti (v. ZPP, čl. 8.) i pri tome sud nije uvijek dužan uvažiti zahtjev vještaka i kad utvrdi da su izneseni razlozi opravdani. To stoga jer pojedini vještaci mogu, s obzirom na njihovu specifičnu stručnost, biti de facto nezamjenjivi.

Oslobođenje od dužnosti vještačenja može tražiti i ovlaštena osoba tijela ili pravne osobe u kojoj vještak radi. Ustanova može tražiti oslobađanje od dužnosti vještačenja za svoga ovlaštenog djelatnika u pravilu onda kada drži da je zbog poslova u samoj ustanovi spriječen prihvatiti obavljanje vještačenja, a posebno onda ako se predviđa da će vještačenje duže trajati.

Protiv odluke suda kojom se odbija zahtjev vještaka ili ustanove za oslobađanje od dužnosti vještačenja, vještak ima pravo na posebnu suspenzivnu žalbu.

\subsection{Izuzeće vještaka}

Odredbama čl. 254. ZPP-a, uređuju se uvjeti, način i postupak za izuzeće vještaka. 
Vještak može biti izuzet iz istih razloga iz kojih može biti izuzet sudac. Ulogu vještaka ne mogu obavljati član vijeća, zapisničar, stranka i njezin zastupnik. Ali za vještaka može biti određena osoba koja je u istoj parnici saslušana kao svjedok. Za vještaka sud može odrediti i osobu koju je jedna od stranaka bila prethodno angažirala da utvrdi određene činjenice. $^{44}$

Odredbe čl. 254. ZPP-a o izuzeću vještaka primjenjuju se samo onda ako je zahtjev postavila stranka. Stranka je dužna podnijeti zahtjev za izuzeće vještaka čim sazna da postoji razlog za izuzeće, a najkasnije prije početka izvođenja dokaza vještačenjem. Ako je sud prije određivanja vještaka saslušao stranku o osobi vještaka, stranka se dužna tom prilikom izjasniti o izuzeću (ZPP, čl. 254. st. 2.). U zahtjevu za izuzeće vještaka stranka je dužna navesti okolnosti na kojima temelji svoj zahtjev za izuzeće. Stranka se ne može pozivati na nedovoljnu stručnost vještaka kao razlog za njegovo izuzeće.

Iako iz odredaba članka 254. ZPP-a izričito ne proizlazi da se vještak može izuzeti i po službenoj dužnosti, držimo neprijepornim da sud može i po službenoj dužnosti smijeniti vještaka (v. ZPP, čl. 251.), ako utvrdi da okolnosti navedene u čl. 71. ZPP-a dovode u sumnju njegovu nepristranost.

Ako drži da postoje okolnosti iz čl. 71. ZPP-a, vještak može i sam tražiti da bude oslobođen dužnosti vještačenja (arg. iz čl. 253. st. 3. ZPP-a). Ako sam vještak drži da postoji neki od uvjeta iz čl. 71. ZPP-a, zatražit će da ga se, sukladno odredbama čl. 253. ZPP-a, oslobodi od dužnosti vještačenja. Sud može vještaka, također na njegov zahtjev, osloboditi dužnosti vještačenja i iz drugih opravdanih razloga. ${ }^{45}$

Odredbama st. 2. i 6. čl. 254. ZPP-a, određuje se rok u kojemu stranka može istaknuti zahtjev za izuzeće vještaka. Stranka je dužna podnijeti zahtjev za izuzeće vještaka čim sazna da postoji razlog za izuzeće, a najkasnije prije početka izvođenja dokaza vještačenjem. Ako je sud prije određivanja vještaka saslušao stranku o osobi vještaka, stranka se dužna tom prilikom izjasniti o izuzeću. Ako je stranka saznala za razlog izuzeća poslije obavljenog vještačenja i prigovara vještačenju iz tog razloga, sud bi trebao postupiti kao da je zahtjev za izuzeće stavljen prije obavljenog vještačenja. Nakon što je vještačenje obavljeno, stranka može, sukladno odredbama st. 6. čl. 254. ZPP-a, prigovoriti vještačenju samo onda ako je za razlog izuzeća saznala nakon vještačenja.

O zahtjevu za izuzeće odlučuje sud. Sudac zamoljenog suda i predsjednik vijeća odlučuju o izuzeću ako im je povjereno izvođenje dokaza vještačenjem. Kada sud uvaži zahtjev stranke za izuzeće vještaka, postavit će odmah novoga vještaka. Ako sud usvoji zahtjev stranke za izuzeće vještaka zbog okolnosti iz st. 6. čl. 254. ZPP-a, odnosno nakon obavljenog vještačenja, postavit će također novoga vještaka i ponovit će već obavljeno vještačenje.

Eventualno sudjelovanje u postupku vještaka za kojeg je bilo osnove da bude izuzet, ne predstavlja apsolutno bitnu povredu odredaba parničnog postupka (arg. iz čl. 354. st. 2. ZPP-a). 
Protiv rješenja kojim se prihvaća zahtjev za izuzeće nije dopuštena žalba, a protiv rješenja kojim se zahtjev odbija nije dopuštena posebna žalba.

\subsection{Pozivanje vještaka}

Vještaci se pozivaju dostavom pisanog poziva u kojem se navodi ime, prezime i zanimanje pozvanoga, vrijeme i mjesto dolaska, predmet u svezi s kojim se poziva i naznaka da se poziva kao vještak. U pozivu se vještak mora upozoriti na posljedice neopravdanog izostanka (ZPP, čl. 256.) i na pravo na naknadu troškova (ZPP, čl. 257.). Pozivu se moraju odazvati i one osobe koje drže da ne raspolažu stručnim znanjem ili tehničkim sredstvima potrebnim za vještačenje, kao i oni koji smatraju da zbog drugih razloga nisu dužni vještačiti, jer se pozvanome ne može prepustiti da sam ocijeni je li stvarno i pravno u mogućnosti vještačiti. ${ }^{46}$

\subsection{Nalog vještaku i identifikacija vještaka}

Odredbama čl. 258. ZPP-a uređena je tzv. pripremna faza vještačenja, u okviru koje sud mora vještaka upoznati s predmetom vještačenja. U tom će smislu sud pozvati vještaka da predmet vještačenja brižljivo razmotri, da točno navede sve što opazi i nađe i da svoje mišljenje iznese savjesno i sukladno pravilima znanosti i vještine. Određivanje predmeta i opsega vještačenja posebno je značajno jer neprecizno određivanje predmeta i opsega vještačenja ili njihov potpuni izostanak, mogu rezultirati potrebom za brojnim dopunama nalaza i mišljenja, a time i nepotrebnim produženjem trajanja postupka i dodatnim troškovima. ${ }^{47}$

Pritom će sud upozoriti vještaka i na posljedice davanja lažnog iskaza. Vještak koji u postupku pred sudom da lažan iskaz, kaznit će se novčanom kaznom ili kaznom zatvora do tri godine (arg. Kazneni zakon, „Narodne novine”, broj 110/97., 28/98., 50/00, 129/00, 51/01., 111/03., 105/04., čl. 303.). Iskaz vještaka je lažan kada vještak u nalazu ne navede sve ono što je opazio i našao ili navede da je našao i opazio nešto što ne postoji, kao i onda kada u stručnom mišljenju protivno svojoj savjesti i poznavanju znanstvenih pravila, odnosno pravila struke, izvede nepravilne zaključke.

Od vještaka se može tražiti da da samo nalaz, ili i nalaz i mišljenje o predmetu vještačenja. Hoće li sud od vještaka zahtijevati samo davanje mišljenja ili davanje mišljenja i nalaza, zavisi od toga što se utvrđuje vještačenjem. Ako mišljenja vještaka nisu data po traženju suda i u postupku kod suda korištena kao dokazi, ne smatraju se dokazima u smislu ZPPa. ${ }^{48}$

Nakon toga sudac bi trebao vještaka pitati za ime i prezime, ime oca, zanimanje, boravište, mjesto rođenja, godine života i njegov odnos sa strankom (ZPP, čl. 258. st. 2.).

\subsection{Rukovođenje vještačenjem}

U skladu s načelom sudskog upravljanja postupkom, sud rukovodi vještačenjem na način što neposredno prati rad vještaka, postavlja vještaku pitanja, traži razjašnjenja, skreće vještaku pozornost na određene okolnosti, daje mu potrebne informacije o tijeku parnice i 
okolnostima značajnim za vještačenje, daje vještaku mogućnost da prati glavnu raspravu i dr. (ZPP, čl. 259.).

Vještaci su dužni odgovorno, savjesno, profesionalno i etički besprijekorno ispunjavati svoje obveze prema naručitelju uz primjenu načela objektivnosti, nepristranosti, i stručnog znanja (Etički kodeks Statuta Hrvatskog društva sudskih vještaka od 12. veljače 2011., dalje - Kodeks, čl. 2.), te poštivati sve zakonske i druge propise, međunarodna pravila i pravila struke (Kodeks, čl. 3.).

Što se načina i mjesta izvođenja vještačenja tiče, vještačenje se može obaviti u prisustvu suca/vijeća i izvan zgrade suda. Izvan sudske zgrade mogu se obavljati samo one službene radnje koje su na osnovi zakonskih propisa potrebne za rješavanje pojedinih predmeta. U tom smislu, o potrebi izlaska radi obavljanja vještačenja odlučuje vijeće odnosno sudac pojedinac koji rješava taj predmet, a o svakom uredovanju izvan sudske zgrade treba obavijestiti ured predsjednika suda (SP, čl. 86.). Predsjednik suda i suci koji obavljaju službene radnje izvan sudske zgrade trebaju nastojati uredovanja u kojima sudjeluju sudski vještaci pripremiti tako da isti vještak prilikom izlaska u isto ili približno vrijeme, u istom mjestu ili smjeru, obavi više vještačenja ili drugih službenih radnji (SP, čl. 87.). Ako je osiguran predmet vještačenja, vještačenje je moguće obaviti i u sudu, a najčešće vještak obavlja vještačenje na temelju uputstva koja je dobio u rješenju suda kojim je određeno vještačenje, nakon čega dostavlja sudu i parničnim strankama svoj nalaz i mišljenje.

Sud nije vezan ni stručnim nalazom niti mišljenjem vještaka, i može ih, vodeći se pravilima logike, podvrgnuti analizi i kritici.

Rukovođenje vještačenjem ogleda se, među ostalim, i u pokazivanju vještaku predmeta vještačenja. Vještak je vezan uputstvima i zahtjevima suda, jer je sud naredio vještačenje i dobro mu je poznato na koja stručna pitanja traži odgovore. Stoga između suda i vještaka mora postojati stalni kontakt i suradnja, jer to omogućava davanje dopunskih uputa vještaku i smjernica za njegov rad.

Stranke, njihovi zakonski zastupnici i punomoćnici mogu po odobrenju predsjednika vijeća neposredno postavljati pitanja vještaku (v. čl. 311. ZPP-a).

Ako je sud propustio voditi vještačenje, a posebno ako je propustio odrediti vještaku predmet i smjer vještačenja, počinio je bitnu povredu odredaba parničnog postupka. ${ }^{49}$

Uz materijal kojim raspolaže, vještaku su često potrebni i drugi podaci koji su poznati sudu. U tom se smislu vještaku mogu davati pojašnjenja, a može mu se odobriti i razmatranje spisa, o čemu konačnu odluku donosi sud. U praksi, vještaku se uvijek daje spis na razmatranje jer rješenje o vještačenju obično ne sadrži dovoljno podataka o predmetu spora. Usto, uvid u spis je od posebnog značenja kada se nalaz i mišljenje ne mogu dati na temelju pregleda stvari odnosno lica mjesta, jer stvari i tragovi više ne postoji, nego se to može uraditi jedino na temelju pisanih dokaza, iskaza svjedoka ili stranaka, koji se nalaze u spisu. Iz istog razloga predviđa se i ovlaštenje vještaka da strankama postavlja pitanja, a time i dužnost stranaka da vještaku daju potrebna 
razjašnjenja. Ako je u predmetu određeno vještačenje iz različitih područja od strane dva ili više vještaka, oni mogu jedan od drugog tražiti razjašnjenja neophodna za izradu njihovog nalaza i mišljenja. ${ }^{50}$

Vještak može sudu objasniti svrsishodnost da se vještačenje izvrši izvan onoga što je naređeno, ali konačnu odluku o tome donosi sud. Tako, na zahtjev vještaka mogu se izvoditi i novi dokazi da bi se utvrdile okolnosti koje su važne za stvaranje mišljenja vještaka. Primjerice, vještak može predložiti izvođenje dokaza pribavljanjem predmeta da bi se utvrdile okolnosti koje su važne za stvaranje mišljenja vještaka, a može prisustvovati i očevidu. ${ }^{51}$

\section{$9.10 \quad$ Izlaganje nalaza i mišljenja vještaka}

Aktivnost vještaka sastoji se od pripremanja nalaza i mišljenja, te usmenog ili pisanog prezentiranja nalaza i mišljenja sudu. ${ }^{52}$

Sud će odrediti hoće li vještak iznijeti svoj nalaz i mišljenje samo usmeno na raspravi ili će ih podnijeti i pisano prije rasprave (ZPP, čl. 260.). U rješenju kojim se određuje vještačenje sud će, dakle, odrediti i način na koji će vještak iznijeti svoj nalaz i mišljenje, te je uobičajeno da se vještak izjasni neposredno na ročištu za glavnu raspravu ili u pisanoj formi.$^{53}$ Propust suda da vještaka sasluša neposredno na raspravi može biti samo relativno bitna povreda odredaba parničnog postupka. ${ }^{54}$ Nalaz i mišljenje vještaka, koje nije izvedeno po nalogu suda niti je izvedeno na glavnoj javnoj raspravi, nije pravno valjan dokaz te se na takvom dokazu ne može temeljiti sudska presuda. ${ }^{55}$

Vještaci obavještavaju sud o svojim sadašnjim zapažanjima, izvodeći eventualno zaključke o činjenicama koje su se dogodile u prošlosti. Vještačenje se poduzima radi zapažanja činjenica koje postoje u času suđenja i koje bi sud i sam mogao opažati i razjasniti kad bi raspolagao potrebnim stručnim znanjem. ${ }^{56}$

Vještak svoj iskaz daje usmeno na raspravi a može dati i pisano prije rasprave, dakle pisano i usmeno na raspravi, ali ne i samo pisano. ${ }^{57}$ Davanjem samo pisanog nalaza i mišljenja sudu bi bilo onemogućeno postavljanje pitanja i traženje objašnjenja, a isto tako i strankama, a to pravo stranaka propisano je odredbama čl. 302. ZPP-a, gdje se, posebice u st. 2., propisuje da stranka i njezin zastupnik ili punomoćnik mogu po odobrenju predsjednika vijeća neposredno postavljati pitanja vještacima. Kod manje složenih vještačenja, vještak se o nalazu izjašnjava odmah pred sudom i usmeno daje svoje mišljenje. Kad je vještačenje složenije, ili kad je to inače potrebno, sud određuje da vještak svoj nalaz i mišljenje podnese pisano prije glavne rasprave, kao i rok u kojemu to treba učiniti. I pored toga što je sud odredio da vještak pisano podnese svoj nalaz i mišljenje, vještak je dužan odazvati se pozivu na ročište na kojemu će se raspravljati o njegovom nalazu i mišljenju. Time će se njegov nalaz i mišljenje na ročištu bolje raspraviti, a stranke imaju mogućnost od vještaka tražiti razjašnjenje i postavljati mu pitanja.

U zapisniku o vještačenju, pored podataka koje sadrži svaki zapisnik o obavljenoj parničnoj radnji, trebalo bi navesti i podatke o vještaku te njegovu specijalnost, a ti se podaci moraju navesti i u pisanom nalazu i mišljenju. To je primjerice značajno zbog 
eventualnog raspravljanja o isključenju ili izuzeću vještaka, zbog ocjene vrijednosti ili pouzdanosti nalaza i mišljenja, utvrđivanja kaznene odgovornosti vještaka zbog davanja lažnog iskaza i sl.

Činjenice koje vještak sazna istraživanjem u skladu s pravilima svoje znanosti ili struke, predstavljaju nalaz vještaka (visum repertum). U nalazu su, dakle, sadržani podaci o svemu što je vještak zapazio ili otkrio vještačenjem, odnosno podaci o činjenicama koje su od važnosti za parnični postupak. Nalaz mora biti potpun i objektivan navod utvrđenog činjeničnog stanja. Nalaz je vjeran opis stanja i promjena koje su objektivno utvrđene. ${ }^{58}$ Kod izrade medicinskog vještačenja, primjerice, nalaz započinje navođenjem osobnih podataka ozlijeđenog i opisom nastanka i mehanizma nezgode. Sljedeći dio nalaza je popis dijagnoza dokazanih ozljeda iz medicinske dokumentacije. Kronološkim redom navodi se slijed liječenja bolesnika, navodeći pri tome broj lista sudskog spisa na kojemu je napisan neki nalaz. Sastavni dio nalaza vještačenja je obvezni pregled bolesnika i on se nikako ne bi smio izostaviti kod sudskog vještačenja. ${ }^{59}$

Na temelju nalaza vještak, u skladu s pravilima znanosti i struke, daje svoje mišljenje (parere). Riječ je o sažetom tumačenju podataka iz nalaza, iznesenih u skladu sa zakonskim propisima koji se odnose na predmet vještačenja (primjerice, o težini tjelesne ozljede, uzroku smrti, pravu oštećenika na naknadu neimovinske štete i sl.). ${ }^{60}$ Mišljenje vještaka predstavlja, dakle, stručnu ocjenu vještaka o zapaženim činjenicama. Nalaz i mišljenje vještaka čine njegov iskaz i moraju biti utemeljeni na provjerenim činjenicama te izneseni precizno i jasno. Drugim riječima, u nalazu se daju temeljni podaci o predmetu vještačenja i nađenom stanju, pa je nalaz svojevrsni opis predmeta vještačenja. Iz mišljenja vještaka vidi se na temelju kojih je pravila (svoje) struke vještak izveo zaključak, te je mišljenje, u stvari, odgovor koji je sud tražio od vještaka.

Vještak se ne smije upuštati u pravnu ocjenu činjenica, tumačenje pravne norme ili u neku drugu aktivnost koja je u isključivoj nadležnosti suda. ZPP ne isključuje mogućnost da se od vještaka traži samo nalaz ili samo mišljenje, kao što ne zabranjuje da se od jednog vještaka zatraži nalaz, a od drugog mišljenje, ako se primjerice u konkretnom slučaju i za nalaz i za mišljenje traže različite stručnosti i vještine.

Zadatak koji pred vještaka medicinske struke postavlja sud u parničnom postupku, redovito je da se liječnik očituje o tome koje je ozljede pretrpio oštećenik, kakav oblik i jakost oštećenja zdravlja su nastupili, te da izrazi mišljenje kakve posljedice oštećenik zbog tih ozljeda trpi ${ }^{61}$ Vještak medicinske struke treba voditi računa o težini ozljeda, trajanju, kvaliteti i kvantiteti te težini dijagnostičkih i terapijskih postupaka, kojima je oštećeni/tužitelj bio izložen tijekom liječenja, te kvaliteti življenja oštećenika tijekom liječenja i rehabilitacijskog postupka. ${ }^{62}$

Što se parnica za naknadu štete tiče, zadatak vještaka medicinske struke je da medicinski rječnik kvalificiraju u onaj pravni, odnosno u ono što pravo podrazumijeva pod „naknadom štete“ (zakonski izrazi), te da na taj način pomognu i olakšaju sudu u utvrđivanju činjenica o kojima ovisi osnovanost tužbenog zahtjeva. ${ }^{63}$ Posebno je važno da u parnicama za naknadu štete prouzročene pružanjem medicinskih usluga vještaci u svojim ekspertizama jasno predoče sudu i strankama situacije u kojima postoji puka mogućnost uzročne veze, od onih u kojima postoji njezina veća ili manja vjerojatnost, 
odnosno od onih u kojima oni smatraju neupitnim (izvjesnim) postojanje te veze, a jednako tako trebali bi postupati i prigodom zauzimanja stava o vrsti i kvantiteti same štete. ${ }^{64}$ Vještačenje je jedno od najznačajnijih pitanja u parnicama za naknadu štete prouzročene pružanjem medicinskih usluga, među ostalim i zbog teškoća vezanih uz pronalaženje osobe koja je dovoljno stručna, ali i dostatno objektivna za obavljanje te funkcije, primjerice i zbog toga jer je teško pronaći vještake koji (zbog slabije stručne/znanstvene kvalifikacije) kvalitetno mogu vrednovati i ocijeniti rad koji su obavili vrhunski eksperti u određenoj medicinskoj djelatnosti/grani. Usto, otvara se i pitanje objektivnosti vještaka, njihove spremnosti da nadiđu ograničenja koja nameće „profesionalna solidarnost”, „kolegijalnost”, izloženost mogućnosti da se sami nađu u situaciji osoba čiji će se rad ocjenjivati i sl. ${ }^{65}$

Medicinska vještačenja nematerijalne/neimovinske štete najzahtjevniji su i najkompliciraniji segment medicinskih vještačenja uopće. Izmjenama čl. 19. Zakona o obveznim odnosima („Narodne novine”, broj 35/05. od 17. ožujka 2005.), odnosno definiranjem prava osobnosti, ${ }^{66}$ aktualizira se i određivanje uloge sudskih vještaka u postupku pred sudom, a time i njihova uloga dobiva na važnosti, pošto svaka povreda prava osobnosti ne znači bezuvjetno pravo oštećenika na isplatu pravične novčane naknade, nego u slučaju spora oštećenik to pravo može ostvariti samo ako sud nađe da težina povrede i okolnosti slučaja to opravdavaju. ${ }^{67}$ Drugim riječima, težina tjelesne ozljede ne daje sama po sebi pravo na naknadu štete, već isključivo posljedice ozljede zbog kojih oštećenik pati i zbog kojih trpi duševne boli. ${ }^{68} \quad \mathrm{U}$ parnicama za naknadu neimovinske (nematerijalne) štete vještaci imaju ključnu ulogu u utvrđivanju oštećenja zdravlja koje je prouzročilo fizičke bolove, strah, postotak umanjenja životne aktivnosti, naruženost i sl. ${ }^{69} \mathrm{U}$ tim parnicama potrebno je sagledati pravni i medicinski aspekt, odnosno nužan je multidisciplinarni pristup. To upućuje na nužnu i tješnju suradnju između suca i vještaka medicinske struke, uvijek imajući u vidu da je sudac dominus litis.

U slučaju kad pravni poredak oštećeniku priznaje pravo na naknadu neimovinske štete, javlja se kao iznimno složno pitanje utvrđivanja objektivnih medicinskih, a zatim i pravnih kriterija prema kojima bi se ocjenjivalo postoji li uopće pravo oštećenika na takvu naknadu, a onda i u kojem novčanom iznosu. ${ }^{70}$ Sudska praksa trebala bi biti što ujednačenija kako bi građani (oštećeni) u zahtjevima za pravičnu novčanu naknadu kod istih ili sličnih posljedica tjelesnih i duševnih ozljeda dobili približno jednake novčane iznose. Da bi se ovo postiglo, nužno je u praksi primjenjivati orijentacijske medicinske i pravne kriterije. Medicinski i pravni kriteriji međusobno su uvjetovani. ${ }^{71}$ Nepostojanje kriterija omogućava medicinskim laicima, te punomoćnicima stranaka da koriste neargumentirane ili nedovoljno argumentirane podatke, kako bi ciljano poljuljali autoritet vještaka i obezvrijedili njegovo mišljenje, odnosno prisilili ga na određene ustupke. S druge strane, primjena kriterija omogućuje sudu aktivno praćenje izlaganja vještaka i donošenje pravične odluke uz bitno olakšano razumijevanje predmeta i ekspeditivnije uklanjanje eventualnih nejasnoća. Time se izbjegavaju nepotrebni, često isforsirani i neutemeljeni zahtjevi za dodatno vještačenje, pogotovo nekih osiguravateljskih kuća, koje zlorabe procesna ovlaštenja odugovlačenjem postupka. ${ }^{72}$

Pravne kriterije (orijentacijske naravi) donio je Vrhovni sud 29. studenoga 2002. (Orijentacijski kriteriji $i$ iznosi za utvrđivanje visine pravične novčane naknade 
nematerijalne štete), te se redovito primjenjuju na sve parnične postupke za naknadu nematerijalne štete u svim stupnjevima suđenja, kako na štetne događaje koji su se zbili prije, tako i na one koji su se zbili nakon njihovog donošenja.

Što se medicinskih kriterija tiče, nužno je njihovo postojanje, a posebno da se u praksi primjenjuju jedinstveni kriteriji. U nedostatku jedinstvenih, općeprihvaćenih orijentacijskih medicinskih kriterija koje bi vještaci primjenjivali u parničnim postupcima za naknadu nematerijalne štete, vještaci se pozivaju, u nedostatku valjanih argumenata, na nedefiniranu literaturu (u zadnje vrijeme stranu), iskustvo, uobičajenu metodologiju, kao i na uvaženost autora i ustanova te institucija koje iza njega stoje, što je neprihvatljivo. ${ }^{73}$ Drži se da bi u praksi trebalo primjenjivati medicinske kriterije koji su objavljeni u knjizi ZEČEVIĆ, D i drugi, Sudska medicina i deontologija, Medicinska naklada, Zagreb, 2004., jer u cijelosti ispunjavaju tražene uvjete i kompatibilni su s pravnim kriterijima Vrhovnog suda i sukladni su novoj koncepciji neimovinske štete po odredbama ZOO/2005.

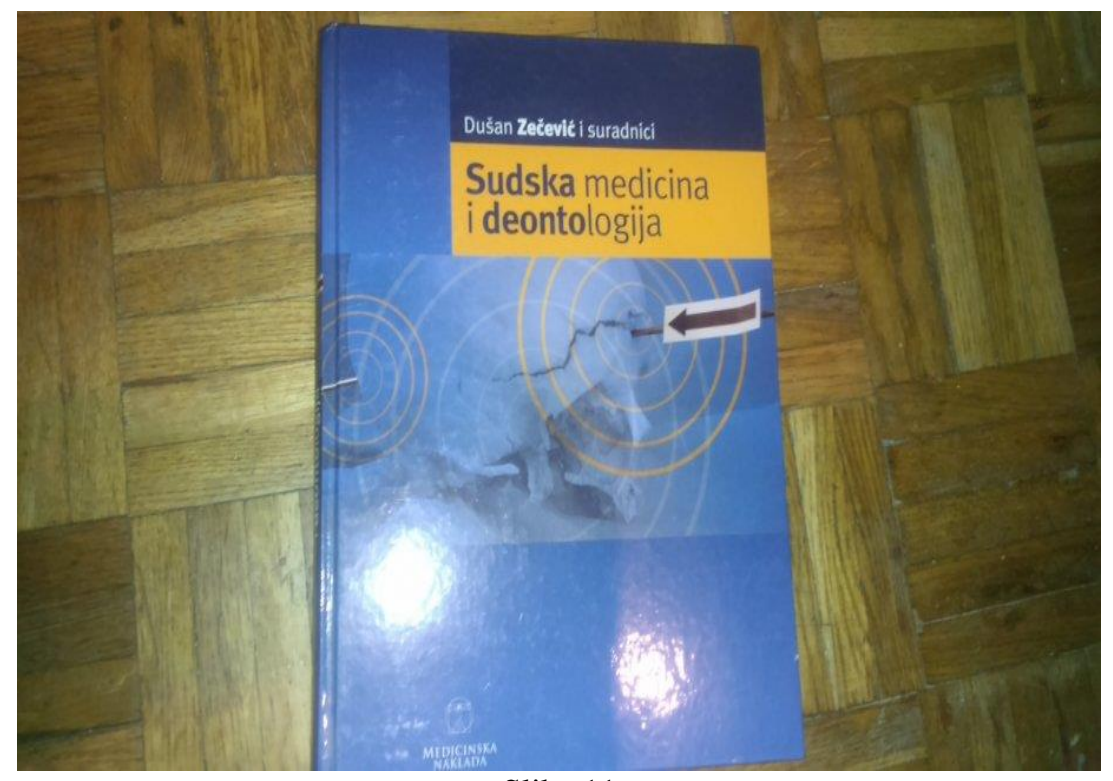

Slika 11

Usto, za psihijatrijski dio, odnosno psihijatrijske kriterije, trebalo bi uvažavati kriterije koji su naknadno doneseni i objavljeni u knjizi GORETA, M., Psihijatrijska vještačenja povrede duševnog integriteta kao oblika neimovinske štete, „Narodne novine“, Zagreb, 2008., koji su prilagođeni ZOO/2005. i spomenutim pravnim kriterijima Vrhovnog suda. 


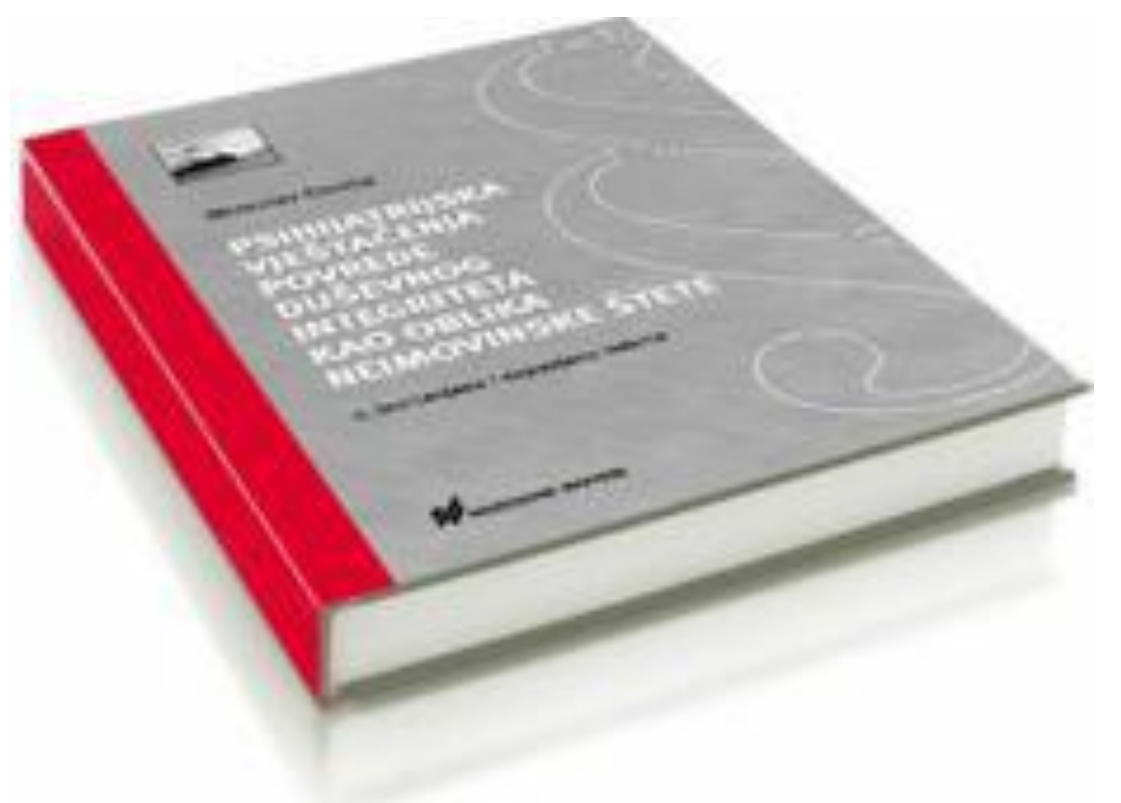

Slika 12

Sve su tablice orijentacijske naravi i svaki stupanj ograničenja ili postotak treba obrazložiti. Vještak može odabrati tablice koje želi. ${ }^{74}$ Ovako kompletirani medicinski kriteriji u cijelosti odgovaraju potrebama zakonodavstva i sudske prakse, te jamče jednakost i sigurnost građanima, a ujedno predstavljaju i zaštitu oštećenicima kod potraživanja neimovinske štete. ${ }^{75}$

Sud će odrediti rok za pisano podnošenje nalaza i mišljenja. Vještak je dužan vještačenje obaviti u pravilu u roku koji mu odredi sud, a u slučaju nemogućnosti ispunjenja roka dužan je o tome obavijestit naručitelja (Kodeks, čl. 7.). Rok u kojem je vještak dužan sudu podnijeti svoj nalaz i mišljenje jest sudski rok dužina kojega zavisi od složenosti predmeta vještačenja, kao i od drugih objektivnih okolnosti koje mogu biti i na strani vještaka. Ovaj se rok, po potrebi, može i produžiti (arg. iz čl. 111. ZPP-a.). Vijeće ne može zaključiti glavnu raspravu ako treba pričekati nalaz i mišljenje vještaka. ${ }^{76}$

Stalni sudski vještaci su dužni pridržavati se rokova određenih odlukom kojom im je vještačenje povjereno. Ako vještak iz objektivnih razloga ne može dovršiti vještačenje $u$ zadanom mu roku dužan je podnijeti sudu najkasnije u roku od 8 dana prije isteka roka, izvješće o razlozima zbog kojih nije u mogućnosti dovršiti vještačenje, kratki prikaz rezultata do tada obavljenih radnji kao i navesti rok do kojega će obaviti vještačenje (PSSV, čl. 15.). U složenijim vještačenjima, u kojima je određen dulji rok za vještačenje, vještak je dužan podnijeti sudu svakog mjeseca od dana povjerenog mu vještačenja kratko izvješće o rezultatima do tada obavljenih radnji (PSSV, čl. 16.). 
Stranka koja prigovara nalazu vještaka dužna je istaknuti konkretne primjedbe, a nije dovoljno ako prigovori samo uopćeno. Navod stranke da je iskaz vještaka nestručan, nedovoljan je jer se time ne dokazuje niti iznosi o čemu se smatra da je nalaz nestručan. Izjašnjenje o nalazu vještaka mora biti izričito, opredijeljeno i u njemu mora biti točno navedeno u čemu se sastoji nestručnost vještaka. ${ }^{77}$ Prilikom ocjene primjedaba stranaka na nalaz vještaka, prvostupanjski sud mora ukazati na činjenice iz kojih proizlazi osnovanost odnosno neosnovanost tih primjedbi, a ne da se isključivo pozove na mišljenje vještaka. ${ }^{78}$ Stranci je onemogućeno raspravljanje pred sudom kad njeni prigovori na nalaz i mišljenje vještaka nisu dostavljeni vještaku, niti je on o njima saslušan na glavnoj raspravi. ${ }^{79}$

Propust suda da vještaka sasluša neposredno na raspravi može biti samo relativno bitna povreda odredaba parničnog postupka. ${ }^{80}$ Okolnost da vještak nije pozvan na raspravu radi usmenog iznošenja nalaza i mišljenja nije bitna povreda odredaba parničnog postupka kad stranke nisu imale primjedbi ni pitanja u svezi s nalazom i mišljenjem koji je on pisano podnio. ${ }^{81}$ Drugim riječima, ako vještak ne pristupi na glavnu raspravu, a na samoj raspravi se utvrdi da su nalaz i mišljenje jasni, potpuni i konzistentni, te da stranke nemaju primjedbi na njih niti imaju pitanja za vještaka, bilo bi protivno načelu procesne ekonomije odlagati raspravu. Zato se i predviđa da se glavna rasprava može održati u odsustvu vještaka, a u tom slučaju, umjesto usmenog izlaganja nalaza i mišljenja od strane vještaka, ovaj dokaz se izvodi čitanjem njegovog pismenog nalaza i mišljenja od strane suda. $^{82}$

Vještak mora uvijek obrazložiti svoje mišljenje (ZPP, čl. 260. st. 2.). Sud je dužan vještaka pozvati na raspravu da obrazloži svoj nalaz i mišljenje i izjasni se o primjedbama stranaka. ${ }^{83}$ Držimo da je vještak dužan, osim mišljenja, obrazložiti i svoj nalaz, jer okolnosti koje je vještak zapazio uz pomoć znanstvenih pravila i pravila struke, nisu uvijek dostupna i zapažanju osoba koje nemaju potrebno stručno znanje. ${ }^{84}$ Dužnost vještaka je da obrazloži svoje mišljenje, te je u skladu s pravom suda i stranaka da rad vještaka podvrgnu analizi i kritici. Svrha je usmenog iznošenja nalaza i mišljenja vještaka da se time omogući strankama da se postavljanjem pitanja vještaku razjasne eventualne primjedbe na vještakov nalaz i mišljenje. ${ }^{85}$ Sud čini (bitnu) povredu odredaba parničnog postupka ako ne omogući jednoj od stranaka da se izjasni o nalazu i mišljenju vještaka. ${ }^{86}$

Nepotpuni nalaz i mišljenje vještak može na zahtjev suda, na prijedlog stranaka ili samoinicijativno naknadno nadopuniti.

Ako vještak svoj nalaz i mišljenje dostavlja samo sudu, dužan je priložiti i dovoljan broj primjeraka za stranke. Sud će ih odmah po primitku dostaviti strankama, odnosno njihovim punomoćnicima. Sud će, po mogućnosti, dostaviti strankama pisani nalaz i mišljenje prije ročišta na kojem će se o njima raspravljati (ZPP, čl. 260. st. 3.). Time će strankama omogućiti da temeljito prouče nalaz i mišljenje vještaka, te da se pravovremeno pripreme za raspravljanje o rezultatima vještačenja i da pripreme eventualne prijedloge radi dopune vještačenja i razjašnjenja nalaza i mišljenja.

Okolnost da je vještačenje izvršeno bez prisustva stranke ne čini, sama po sebi, bitnu povredu odredaba parničnog postupka. Ako se stranka nije složila s nalazom vještaka, 
mogla je staviti primjedbe na nalaz. Sama izjava stranke da ne priznaje vještačenje nije dovoljna osnova da se odredi novo vještačenje. ${ }^{87}$

Stranci je onemogućeno raspravljanje pred sudom kad njezini prigovori na nalaz i mišljenje vještaka nisu dostavljeni vještaku niti je on o njima saslušan na glavnoj raspravi. ${ }^{88}$

Propuštanjem da od vještaka zatraži da se na traženje stranke izjasni o određenoj odlučnoj okolnosti u svezi s njegovim nalazom i mišljenjem, sud toj stranci onemogućuje raspravljanje pred sudom. ${ }^{89}$

\subsection{Proturječnosti i nedostaci u nalazu i mišljenju}

Nalaz i mišljenje vještaka sud vrednuje po pravilima o slobodnoj ocjeni dokaza. Sud mora ocijeniti mišljenje vještaka ne samo u formalnom smislu, već, prije svega, u sadržajnom pogledu.

Odredbama čl. 261. ZPP-a predviđena je i uređena iznimka od pravila iz čl. 252. st. 1. ZPP-a da vještačenje obavlja jedan vještak. Naime, sud radi vještačenja može angažirati više vještaka. Ako je određeno više vještaka, oni mogu podnijeti zajednički nalaz i mišljenje kad se u nalazu i mišljenju slažu. Time se smanjuju troškovi postupka i ne odugovlači se nepotrebno postupak. Ako se, pak, u nalazu i mišljenju ne slažu, svaki vještak posebno iznosi svoj nalaz i mišljenje.

U slučaju sudjelovanja više vještaka, sud nije vezan za mišljenje pojedinih vještaka, pa ni za suglasno mišljenje svih vještaka. Mišljenje vještaka nije obvezno za sud, već predstavlja dokazno sredstvo koje sud cijeni po slobodnom uvjerenju, pa ga može prihvatiti ili odbiti. Ako sud odbije mišljenje vještaka, odluku donosi na temelju drugih dokaza kojima raspolaže, a ako drugih dokaza nema, drži da je činjenica koju je trebalo dokazati vještačenjem ostala nedokazana..$^{90}$

Ali, primjerice, kad o istim činjenicama imaju različito mišljenje medicinski vještak, kojega je u tom svojstvu odredio sud, i liječnik, kojega je pozvala stranka, ne radi se o razlikama u nalazima i mišljenjima dvaju vještaka..$^{91}$

Odredbama st. 2. čl. 261. ZPP-a propisana su ovlaštenja suda u situaciji kada utvrdi da na temelju rezultata izvršenog nalaza ne može utvrditi relevantne činjenice. Odredbama spomenutog stavka predviđeni su slijedeći nedostaci u nalazu vještaka: ako se podaci vještaka o njihovom nalazu bitno razilaze, ako je njihov nalaz nejasan, ako je nalaz nepotpun, ako je nalaz proturječan sam sa sobom ili izvedenim okolnostima. Kada se ti nedostaci ne mogu otkloniti ponovnim saslušanjem vještaka, obnovit će se vještačenje $s$ istim ili drugim vještacima. Svi navedeni nedostaci moraju biti značajni.

Najprije bi se moralo pokušati navedene nedostatke otkloniti ponovnim, pa i višestrukim saslušanjem vještaka (tzv. dopunsko vještačenje), jer je to uvjet da bi se pristupilo ponovnom vještačenju. Otklanjanje nedostataka može se izvesti i ponovnim vještačenjem, s istim ili drugim vještacima, odnosno u istoj ili drugoj stručnoj ustanovi 
(tzv. ponovno vještačenje). Ako se nalazi vještaka bitno razlikuju, sud nije ovlašten sam ocijeniti istinitost neke činjenice u pogledu koje je bio izveden dokaz vještacima tako što će prihvatiti kao točan nalaz jednog od vještaka.

Prema stajalištu sudske prakse, kad sud ne prihvati nalaz i mišljenje vještaka (jer su neobrazloženi i nejasni) pa nakon toga odredi drugog vještaka čiji nalaz i mišljenje ocijeni prihvatljivim, on nije dužan angažirati daljnjeg vještaka da bi utvrdio činjenice zbog kojih je vještačenje određeno. ${ }^{92}$ Usto, kad se podaci o nalazu vještaka bitno razilaze, sud će u skladu s odredbama čl. 261. st. 2. ZPP-a, prvo pokušati ponovnim saslušanjem vještaka otkloniti nedostatke u njihovim nalazima, a ako to ne postigne, zatražit će mišljenje drugih vještaka. ${ }^{93}$ Prema stajalištu dijela sudske prakse, ako se, pak, nalazi i mišljenja vještaka bitno razlikuju u ocjeni događaja i posljedica, tada sud ne može prihvatiti mišljenje jednoga od vještaka, nego mora odrediti saslušanje trećega vještaka, ${ }^{94}$ što bi moglo unedogled odugovlačiti vođenje postupka. ${ }^{95}$ Suprotno, dio sudske prakse zauzeo je stajalište kako je sud, u slučaju kad se vještaci razilaze u mišljenjima, ovlašten formirati svoje stajalište o problemu. ${ }^{96}$

Odredbe st. 3. čl. 261. ZPP-a odnose se na određene nedostatke u mišljenju vještaka, koje također podliježe slobodnoj ocjeni dokaza.

Vještak mora svoj nalaz i mišljenje pred sudom dati u jasnom i jednoznačnom izričaju, kao i obrazložiti i stručno argumentirati svoje mišljenje te navesti izvor podataka kojima se služio (Kodeks, čl. 8.).

Nedostaci u mišljenju vještaka postoje: ako u mišljenju vještaka ima proturječnosti, primjerice između mišljenja i činjenica za koje se saznalo; ako u mišljenju ima nedostataka, primjerice jer je mišljenje nejasno, nepotpuno ili se odnosi na okolnosti koje nisu predmet vještačenja; ili ako se pojavi osnovana sumnja u točnost danog mišljenja. ${ }^{97}$ Nedostaci bilo koje vrste moraju se odnositi na bitne činjenice i okolnosti. Ako se navedene nepravilnosti ne mogu otkloniti ponovnim saslušanjem vještaka, zatražit će se mišljenje drugih vještaka.

Vještak nije tijelo suda niti službena osoba, već se imenuje za svaki pojedini slučaj da bi sudu stavio na raspolaganje svoje stručno znanje, pa država ne odgovara za krivnju vještaka kao za službenu osobu, osim ako vještačenje nije zatraženo od kakve državne institucije. ${ }^{98}$

Ako sud drži da je nalaz ranijih vještaka pravilan, novi će se vještak ograničiti samo na davanje mišljenja. ${ }^{99}$

Protiv rješenje koje sud donosi u primjeni ovoga članka, nije dopuštena posebna žalba.

\subsection{2 Žalba protiv rješenja o određivanju vještaka}

Protiv rješenja suda kojim određuje vještaka, ili kojim određuje vještaka bez prethodnog saslušanja stranaka; kojim ovlašćuje predsjednika vijeća ili zamoljenog suca da odrede vještaka; ili umjesto određenog vještaka odrede drugoga vještaka; kao i protiv rješenja 
kojim ocjenjuje da je vještačenje složeno i određuje dva ili više vještaka, odnosno vještačenje povjerava stručnoj i posebnoj ustanovi za određene vrste vještačenja i kojim se određuje obnavljanje vještačenja s istim ili drugim vještacima ili se traži mišljenje drugih vještaka; nije dopuštena žalba (usp. ZPP, čl. 262.). Prema stajalištu sudske prakse, ZPP-om nije predviđena mogućnost posebne tužbe protiv vještaka u kojoj bi se tražilo poništenje nalaza i mišljenja vještaka donesenog u drugom parničnom postupku. ${ }^{100}$ Stoga tužba s tužbenim zahtjevom kojim se traži poništenje nalaza i mišljenja vještaka danog u drugom parničnom postupku, može se odbaciti, bez obveze prethodnog postupanja po odredbi čl. 109. ZPP-a. ${ }^{101}$

\subsection{Kažnjavanje vještaka}

Predsjednici županijskih odnosno trgovačkih sudova dužni su pratiti rad vještaka. Rad vještaka dužni su pratiti i predsjednici općinskih sudova, kao i dužnosnici drugih tijela koja sudjeluju u sudskom postupku i o svojim zapažanjima obavještavati predsjednika županijskog odnosno trgovačkog suda. Primjedbe na rad vještaka mogu podnijeti i stranke odnosno njihovi punomoćnici, te strukovne udruge. Primjedbe se podnose predsjedniku suda koji je imenovao vještaka (PSSV, čl. 20.).

Za razliku od svjedoka (v. čl. 248. ZPP-a), vještaka se ne može prisilno dovesti pred sud niti mu se može odrediti zatvorska kazna. Nemogućnost određivanja zatvorske kazne vještaku, posljedica je načelne zamjenjivosti vještaka. S druge strane, od vještaka kojega bi prisilio da obavi vještačenje sud ne bi mogao očekivati djelotvornu pomoć.

Sud jedino može kazniti novčanom kaznom od 500,00 do 10.000,00 kuna vještaka koji ne dođe na ročište iako je uredno pozvan, a izostanak ne opravda, kao i vještaka koji bez opravdanog razloga odbije vještačiti, te vještaka koji svoj nalaz i mišljenje bez opravdanog razloga ne podnese u roku koji mu je odredio sud (ZPP, čl. 255.). Međutim, nema mjesta primjeni ni ovih prinudnih mjera prema vještaku ako u pozivu na raspravu nije bilo upozorenja na posljedice neopravdanoga izostanka. ${ }^{102}$ Svrha ovih inkriminacija počiva na društvenom interesu da pojedinci lojalno sudjeluju u postupku, kako bi sud svoje odluke mogao temeljiti na istinitom činjeničnom stanju. ${ }^{103}$

U slučaju kažnjavanja vještaka novčanom kaznom, na odgovarajući način se primjenjuju odredbe članka 10. ZPP-a (ZPP, čl. 255. st. 4.). ${ }^{104}$

Zakonom o izmjenama i dopunama Zakona o parničnom postupku („Narodne novine“, broj 88/08.), proširen je krug razloga za sankcioniranje vještaka koji neuredno obnaša povjerenu mu dužnost, što bi trebalo onemogućiti potencijalna nesavjesna obnašanja vještačkih dužnosti, sve u cilju bržeg okončanja parničnog postupka. ${ }^{105}$ Težište ove izmjene jest na tome da po novome ne ovisi više o diskreciji suda hoće li ili ne kazniti vještaka - on to mora učiniti. ${ }^{106}$

Rješenje o novčanoj kazni sud može opozvati ako vještak naknadno opravda svoj izostanak, a može ga i sasvim ili djelomično osloboditi naknade troškova. Usto, sud može opozvati svoje rješenje o kazni i kad vještak naknadno pristane vještačiti (arg. iz čl. 248. st. 6. ZPP-a). Nadalje, na zahtjev stranke sud može rješenjem narediti vještaku da nadoknadi troškove koje je prouzročio svojim neopravdanim nedolaskom ili 
neopravdanim odbijanjem da vještači, kao i kada vještak svoj nalaz i mišljenje ne podnese u roku koji mu je sud odredio (arg. ZPP, čl. 260. st. 4.). O takvom zahtjevu sud je dužan odlučiti bez odgode, a žalba protiv toga rješenja ne odgađa ovrhu.

Također, vještaku koji ne poštuje sud ili stranke, ne preuzima dodijeljene mu predmete, ne opravda zašto u roku nije dovršio povjereno mu vještačenje, ili iz drugih ozbiljnih razloga, može se privremeno uskratiti vještačenje najmanje tri mjeseca a najdulje godinu dana. Privremenu će uskratu predsjednik suda koji je imenovao vještaka naredbom proslijediti svim sucima suda u kojem je predsjednik kao i predsjednicima općinskih sudova. Vještaku protiv kojega se vodi kazneni postupak predsjednik županijskog odnosno trgovačkog suda izreći će privremenu zabranu obavljanja poslova stalnog sudskog vještaka. Privremena zabrana trajat će pravomoćnog okončanja kaznenog postupka (PSSV, čl. 21.).

\subsection{Naknada i nagrada za vještačenje}

Kao i svjedok, vještak ima pravo na naknadu putnih troškova i troškova za prehranu i prenoćište, te na naknadu izmakle zarade, ali, za razliku od svjedoka, ima pravo i na naknadu troškova vještačenja, kao i pravo na nagradu za izvršeno vještačenje (ZPP, čl. 256.).

Troškovi vještačenja obuhvaćaju izdatke prouzročene promatranjem i ispitivanjem predmeta vještačenja, izradom nalaza i mišljenja, koji bi uključivali putne troškove do predmeta vještačenja i natrag, izdatke za upotrebu tehničkih instrumenata, papira i ostalih sredstava potrebnih za vršenje i izradu nalaza i mišljenja. ${ }^{107}$ Sud je ovlašten ispitati opravdanost i visinu troškova. U slučaju da stranka koja izgubi spor ne namiri po nalogu suda troškove vještaku, vještak na temelju odluke suda stječe pravo tražiti prisilnu naplatu prema toj stranci. ${ }^{108}$ Prema stajalištu sudske prakse, ako je stranka, postupajući po rješenju suda, uplatila iznos potreban za podmirenje troškova vještačenja, a vještak je dostavio svoj pisani nalaz i mišljenje prije rasprave, sud ne može ponovno pozivati stranku radi uplate novog troška vještačenja koji bi se odnosio na vještakovo usmeno iznošenje nalaza i mišljenja na glavnoj raspravi. Ne smatra se dopunskim vještačenjem usmeno obrazloženje nalaza i mišljenja sudskog vještaka na glavnoj raspravi koje je već prije podneseno sudu u pisanom obliku nego su to obrazloženje i eventualni uobičajeni vještakovi usmeni i pisani odgovori na pitanja i primjedbe stranaka sastavni dio vještakova nalaza i mišljenja. ${ }^{109}$ Sud rješenjem određuje visinu predujma za izvođenje dokaza vještačenjem. Taj iznos predujma mora biti dostatan za pokriće troškova izrade pisanog nalaza i mišljenja vještaka te izvođenje dokaza vještačenjem na glavnoj raspravi. Ako po prigovorima jedne od stranaka samoinicijativno napravi novi pisani nalaz i mišljenje, sudski vještak ne može potraživati dodatni trošak za izradu tog nalaza. To on pogotovo ne može učiniti ako su mu zbog vlastita propusta prijašnji nalaz i mišljenje manjkavi. ${ }^{110}$

Nagrađivanje vještaka bio je jedan od razloga za sporije rješavanje predmeta, jer je uvijek bilo teško procijeniti na koji način će se nagraditi vještak za svoj urađeni nalaz. U nedostatku posebnih propisa o nagradama vještaka, visinu nagrade vještaku za izvršeno vještačenje sud je određivao po slobodnoj ocjeni, na temelju istaknutog vještakovog zahtjeva, uzimajući u obzir uloženi trud, složenost predmeta, utrošeno vrijeme i stručnu 
kvalifikaciju vještaka. ${ }^{111}$ Sigurno je sudu bilo veoma teško određivati razumnu nagradu, koja je morala biti različita za različite vrste i različite vrijednosti predmeta vještačenja. ${ }^{112}$ Nešto lakši zadatak sud je mogao imati kod određivanja nagrade vještacima onih profesija čija strukovna udruženja imaju propisane tarife njihovih usluga (primjerice, ovlašteni sudski tumači). Sada je problematika određivanja visine nagrade i naknade troškova za rad vještaka uređena odredbama PSSV-a. U tom smislu, za obavljeno vještačenje vještak ima pravo na nagradu koju utvrđuje nadležni sud prema posebnom cjeniku stalnih sudskih vještaka, koji je sastavni dio PSSV-a. Nagrada se određuje u bodovima a vrijednost boda je 2,00 kune bruto bez PDV-a, a treba se izmijeniti ako se izmijene okolnosti koje su postojale u vrijeme donošenja PSSV-a. Novu vrijednost boda utvrđuje ministar pravosuđa po službenoj dužnosti. Ako je nagrada obračunata u satima vještak je dužan uz račun dostaviti i obrazloženje svake stavke (PSSV, čl. 22).

Nagrada za vještačenje povjerenoj pravnoj osobi pripada toj pravnoj osobi, što vrijedi i onda kada je vještačenje povjereno državnom tijelu, stručnoj ustanovi ili drugoj pravnoj osobi koji to vještačenje ne obavljaju kao svoju registriranu djelatnost (PSSV, čl. 25.). Kad je sud povjerio vještačenje stručnoj ustanovi u skladu s odredbama čl. 252. st. 3. ZPP-a, onda se nagrada i troškovi za izvršeno vještačenje isplaćuju ustanovi, jer u odnosu na sud kao sudionik u postupku pojavljuje se samo ustanova. ${ }^{113}$ Kada za pojedine vrste vještačenja koje obavljaju pravne osobe registrirane za obavljanje vještačenja za odgovarajuću djelatnost postoji cjenik usluga, sud će odrediti nagradu za obavljeno vještačenje prema tom cjeniku (PSSV, čl. 27.).

Ako se vještačenje obavlja pod otežanim uvjetima (noću od 22 do 06 sati, u iznimno nepovoljnim vremenskim uvjetima, na otvorenom prostoru i sl.), te za rad u dane tjednog odmora, državnog blagdana ili neradnog dana, iznos iz cjenika vještačkih nagrada uvećava se za 100\% (PSSV, čl. 26.).

Kada se sredstva za pojedine vrste vještačenja (obdukcije) osiguravaju pravnim osobama koje obavljaju poslove vještačenja unaprijed u državnom proračunu, visina tih sredstava utvrđuje se na osnovi mjerila propisanih u cjeniku vještačkih nagrada. Utvrđena visina sredstava povećava se za $150 \%$.

Putni troškovi obuhvaćaju naknadu za prijevoz sredstvima javnog prometa, a obuhvaćaju izdatke za dolazak iz mjesta prebivališta odnosno boravišta do mjesta gdje treba obaviti vještačenje kao i za povratak u prebivalište odnosno boravište, te izdatke za prijevoz sredstvima javnog prometa u mjestu prebivališta odnosno boravišta. Sredstvima javnog prometa u smislu PSSV-a smatraju se tramvaj, trolejbus, vlak, autobus, brod i zrakoplov (PSSV, čl. 28.). Naknada za prijevoz pripada za putovanje obavljeno najkraćim putem i najekonomičnijim prometnim sredstvom, a obračunava se na temelju urednog i vjerodostojnog putnog naloga i priloženih isprava (računa), kojima se dokazuju prijevozni troškovi i drugi izdaci navedeni na putnom nalogu (PSSV, čl. 28.).

Za vrijeme zadržavanja izvan mjesta prebivališta preko $8-12$ sati vještaku pripada naknada u visini $1 / 2$ dnevnice, a za vrijeme provedeno preko $12-24$ sata cijela dnevnica, koju imaju suci suda koji vodi postupak. Izdaci za smještaj (u daljnjem tekstu: noćenje) 
priznaju se u punom iznosu prema priloženom računu do visine cijene noćenja u hotelu u istom mjestu, a koji se priznaje i sucu (PSSV, čl. 30.).

Treba kazati da PSSV nije preuzeo rješenja prethodnog Pravilnika o stalnim sudskim vještacima (»Narodne novine«, broj 21/98) o naknadi za neostvarenu plaću odnosno zaradu. Naime, prema odredbama čl. 30., 31. i 32. spomenutog Pravilnika, osobama stalno zaposlenim u državnom tijelu, stručnoj ustanovi ili drugoj pravnoj osobi pripadalo je pravo na naknadu za neostvarenu plaću za vrijeme odsustvovanja s rada zbog odazivanja na poziv u svojstvu vještaka, koju je trebalo isplatiti državno tijelo, stručna ustanova ili druga pravna osoba u kojem su zaposleni, a navedeni poslodavci mogli su ostvariti pravo na povrat isplaćene naknade plaće od suda koji je vodio postupak. Međutim, ZPP u čl. 256. st. 1. izričito propisuje da vještak ima pravo i na "naknadu izmakle zarade" pa vjerujemo da ovaj redakcijski propust u PSSV-u ne bi trebao imati štetne posljedice na ostvarivanje ovog prava vještaka.

Što se tiče obračuna i naknade troškova za stalne sudske vještake iz područja, odnosno sekcije medicine dio tih troškova obračunava se i nadoknađuje prema odredbama točke C br. 2. Cjenika stalnih sudskih vještaka (koji je sastavni dio PSSV-a), kao i za vještake iz drugih sekcija (Financijsko-računovodstvene sekcije, Građevinska sekcija, Sekcije Medicina, Sekcije za promet i vozila, Sekcije toksikologije, Sekcije veterinarstva, Geodetske sekcije i dr.). Dodatno, prema odredbi C br. 5. Cjenika, za Sekciju Medicina, u području kliničke medicine naknada troškova za pregled osoba i medicinske dokumentacije iznosi 140 bodova, a za provedbu dodatnih pretraga 80 bodova. U području sudske medicine naknada za davanje nalaza i mišljenja iznosi 160 bodova, za obdukciju 400 do 800 bodova, a za obdukciju na terenu 750 do 1.200 bodova.

Kad vještaci obave naloženi zadatak i izvrše vještačenje, ali ne podnesu izvještaj, imaju pravo na naknadu troškova, tj. na nagradu za obavljeni posao, ali ne i pravo na nagradu za sastavljanje izvještaja. ${ }^{114}$

U pogledu naknade troškova i nagrade vještaka na odgovarajući se način primjenjuju odredbe članka 249. st. 2. i 3. ZPP-a o svjedocima.

Tako bi vještak trebao zatražiti naknadu odmah nakon vještačenja, inače gubi pravo na nju. Sud je dužan na to upozoriti vještaka (arg. iz čl. 249. st. 2. ZPP-a). U rješenju kojim se odmjeravaju troškovi vještaka sud će odrediti da se određena svota isplati iz položenog predujma. Ako predujam nije položen sud će u izreci rješenja narediti stranci da određenu svotu plati vještaku u roku od 8 dana (arg. iz čl. 249. st. 3. Zpp-a). Žalba protiv tog rješenja ne zadržava ovrhu rješenja. Dakle, protiv rješenja o odmjeravanju troškova i nagrade vještaku dopuštena je posebna žalba pa se stoga ono ne može pobijati u žalbi protiv odluke o glavnoj stvari. ${ }^{115}$

\subsection{Umjesto zaključka}

U zadnjih nekoliko godina dogodio se niz aktivnosti koje su dovele do značajnih promjena na području sudskog vještačenja. Navedene aktivnosti bile su nužne jer se utvrdilo da na tom području nisu precizno i sveobuhvatno riješeni status i uvjeti za 
određivanje (stalnih) sudskih vještaka te da u samom postupku vještačenja nisu (bile) rijetke nepravilnosti, nestručnost, neodgovornost, neujednačenost kriterija, nerazumijevanje (između suda i vještaka kod određivanja predmeta i opsega vještačenja te zadatka vještaka), pa i razne zloporabe.

U tom smislu donesen je (novi) PSSV, kojim su uređeni način utvrđivanja uvjeta za obavljanje poslova sudskog vještačenja, njihova prava i dužnosti, te visina nagrade i naknade troškova za rad vještaka.

Nadalje, novelama ZPP-a uvedene su neke izmjene i dopune odredaba o vještacima koje, među ostalim, imaju za cilj pooštriti odgovornost vještaka. Tako je Zakonom o izmjenama i dopunama Zakona o parničnom postupku („Narodne novine“, broj 88/08.), proširen krug razloga za sankcioniranje vještaka koji neuredno obnaša povjerenu mu dužnost, što bi trebalo onemogućiti potencijalna nesavjesna obnašanja vještačkih dužnosti, sve u cilju bržeg okončanja parničnog postupka, a posebno da ne ovisi više o diskreciji suda hoće li ili ne kazniti vještaka.

Treba spomenuti da je Vrhovni sud donio tzv. Orijentacijske kriterije i iznose za utvrđivanje visine pravične novčane naknade nematerijalne štete, koji se redovito primjenjuju na sve parnične postupke za naknadu nematerijalne štete u svim stupnjevima suđenja, kako na štetne događaje koji su se zbili prije, tako i na one koji su se zbili nakon njihovog donošenja.

Značajna je i aktivna uloga Hrvatskog društva sudskih vještaka, kao udruge stalnih sudskih vještaka u koju se, radi unapređenja i osiguranja javnog interesa na području vještačenja, udružuju sudski vještaci koji u Republici Hrvatskoj za područje pojedinog županijskog ili trgovačkog suda povremeno ili stalno obavljaju djelatnosti sudskih vještačenja. Glavne aktivnosti te udruge usmjerene su na sudjelovanje u donošenju propisa koji uređuju položaj sudskih vještaka, kao i permanentno stručno usavršavanje članova. Društvo je donijelo i svoj Etički kodeks koji sadrži moralna načela kao i pravila profesionalne etike kojih se u svom djelovanju trebaju pridržavati svi članovi Društva, kako bi time pridonijeli napretku stručnog i objektivnog pristupa svakom slučaju vještačenja i doprinosili unaprjeđenju i ugledu struke, unutar koje se provode vještačenja. Društvo redovito tiska časopis „Vještak”, u kojemu se objavljuju znanstveni i stručni članci, tematski vezani uz djelatnost vještačenja, vijesti o aktivnostima koje se provode na razini Društva kao i imenik članova. ${ }^{116}$

Što se tiče vještačenja od strane vještaka medicinske struke, svjedoci smo da rješavanje brojnih problema, pa i na području prava i medicine, nužno zahtijeva multidisciplinarni pristup i specijalizacije. U tom smislu bilo bi korisno da i sud i punomoćnici u građanskim postupcima usavrše i steknu posebna stručna znanja iz onih područja znanosti koje je u okviru određene specijalizacije najpotrebnije poznavati, točnije suci iz područja medicine, a liječnici-vještaci iz područja prava. Zbog nedostatka organizirane edukacije vještaka, nepostojanja standarda te nepoznavanja elementarnih pravila procesnog prava i drugih propisa, dugo se zapažala velika razlika u ocjenama vještaka, ${ }^{117}$ što je rezultiralo neujednačenom sudskom praksom, a u krajnjoj liniji i stvaranjem pravne nesigurnosti i povredom načela zakonitosti u parničnom postupku. To se posebno odnosi na parnice u 
kojima je potrebna procjena pravične naknade neimovinske/nematerijalne štete, gdje su medicinska vještačenja nezaobilazna. Specijalizacija bi značajno povećala mogućnost suda da objektivno i pravilno ocjenjuje nalaz i mišljenje vještaka, a bitno bi mu olakšala i izbor vještaka. Suci-specijalisti ne bi morali nekritički i bezrezervno vjerovati vještacima niti stvarati dojmove o logičnosti i stručnosti nalaza, nego bi u najvećem dijelu mogli faktički ocijeniti nalaz i mišljenje vještaka i kao takvog ga prihvatiti ili odbaciti. ${ }^{118}$ Zbog svoje interdisciplinarnosti vještačenje na području medicine vrlo je kompleksno, pa zahtijeva od pravnika (sudaca i odvjetnika) barem elementarno poznavanje medicinske problematike, ali i obrnuto. Posebno se akcent postavlja na poznavanje medicinske prakse i visokih standarda i dostignuća u području medicinske djelatnosti. Osim što bi trebali biti podrobno upoznati s pravnim propisima i pravnom praksom iz područja zdravstva, pravnici (suci i odvjetnici) bi trebali biti barem na općenitoj razini upućeni u medicinsku problematiku. Temeljne spoznaje o tome bi mogli steći tijekom studiranja iz kolegija medicinsko (zdravstveno) pravo, sudska medicina i sudska psihijatrija. Na žalost, medicinsko/zdravstveno pravo, ne izučava se sustavno kao zasebni obvezni kolegiji na našim pravnim fakultetima, dok se, suprotno, pod raznim nazivima, s različitim sadržajem i opsegom, te s različitim nastavnim programima, često nalaze u studijskim programima medicinskih i nekih drugih stručnih, preddiplomskih, diplomskih i poslijediplomskih studija, što držimo iznimno značajnim i pozitivnim. ${ }^{119}$

Nadalje, spoznalo se da je nužno postojanje tzv. (orijentacijskih) medicinskih kriterija, a posebno da se u praksi primjenjuju jedinstveni kriteriji. Tako se u praksi primjenjuju medicinski kriteriji koji su kompatibilni s pravnim kriterijima Vrhovnog suda i sukladni novoj koncepciji neimovinske štete po odredbama ZOO/2005. Usto, za psihijatrijski dio vještačenje, uvažavaju se tzv. psihijatrijski kriteriji, koji su također prilagođeni ZOO/2005. i spomenutim pravnim kriterijima Vrhovnog suda, pa ovako kompletirani orijentacijski medicinski kriteriji u cijelosti odgovaraju potrebama zakonodavstva i sudske prakse, te jamče jednakost i sigurnost građanima, a ujedno predstavljaju i zaštitu oštećenicima kod potraživanja neimovinske štete.

Osnovna načela prema kojima se provodi trajna medicinska izobrazba propisana su člankom 2. Pravilnika o sadržaju, rokovima i postupku trajne medicinske izobrazbe i provjere stručnosti liječnika Hrvatske liječničke komore i njima je, među ostalim, obuhvaćeno i pravo na slobodan izbor u postupku trajne medicinske izobrazbe odnosno mogućnost i pravo svakog liječnika na izbor sadržaja i oblika trajne medicinske izobrazbe. U tom smislu lako je uočiti uzlazni trend izbora usavršavanja zdravstvenih radnika upravo na području tzv. medicinskog prava. Ovu tvrdnju možemo poduprijeti činjenicama da je veliki broj zdravstvenih radnika upisao poslijediplomski specijalistički studij „Medicinsko pravo“, da su bili sudionici ili referenti na nekoliko znanstvenih i stručnih skupova s tematikom iz područja medicinskog prava (kojima je pokrovitelj bio i ministar zdravstva), da se na medicinskim fakultetima izvodi ili se uvodi u studijske programe kolegij „Medicinsko/zdravstveno pravo“ (ili njegove inačice) i sl. Stečena znanja zdravstvenim radnicima omogućit će kvalitetnije pružanje pomoći pacijentima (informed consent), ali će im svakako koristiti kako bi upoznali i kvalitetnije zaštitili svoja prava (građanska i kaznena odgovornost, liječnička tajna, svjedok, itd.), u obavljanju upravljačkih funkcija i znanstvenog rada, pa i obavljanju funkcije stalnog sudskog vještaka. 
Radnici zdravstvene struke: Stalni sudski vještak zdravstvene struke

Konačno, Hrvatska liječnička komora 2009. donijela je Pravilnik o provođenju izobrazbe kandidata za stalne sudske vještake, kojim se uređuje provođenje izobrazbe za liječnike - kandidate za stalne sudske vještake, postupak imenovanja mentora liječniku - kandidatu te prava i obveze kandidata i mentora, što bi, među ostalim, trebalo značajno pridonijeti upoznavanju liječnika kandidata za stalne sudske vještake s pravnim pojmovima i terminologijom, kako bi potpunije i pravilno mogli shvatiti zadatak koji im je postavljen i razumljivo izložiti svoj nalaz i mišljenje za sud i druge sudionike u postupku. ${ }^{120}$ 


\section{Primjedbe}

${ }^{1}$ Tako SIJERČIĆ-ČOLIĆ, H. - VULETA, D. - HADŽIOMERAGIĆ, M., Komentar Zakona o krivičnom postupku, Sarajevo, 1999., str. 310.

${ }^{2}$ Usp. TRIVA, S. - BELAJEC, V. - DIKA, M., Građansko parnično procesno pravo, Zagreb, 1986., dalje - TRIVA, str. 432.

${ }^{3}$ Vidi MUJOVIĆ ZORNIĆ, H., Značaj veštačenja lekarske greške u građanskom postupku, zbornik radova "Aktualnosti građanskog i trgovačkog zakonodavstva i pravne prakse", br. 6, Mostar 2008, str. 393.

${ }^{4}$ Tako u okviru Hrvatskog društva sudskih vještaka djeluju sljedeće sekcije: - za arhitekturu i graditeljstvo, - za balistiku i mehaničke tragove, - za carinsko poslovanje, - za defektologiju, - za drago kamenje, dijamante i zlatarstvo, - za elektroniku, elektrotehniku i automatiku, - za financije, računovodstvo, aktuaristiku, devizno i vanjsko trgovinsko poslovanje, ekonomiku poslovanja i organizaciju rada, - za geodeziju, - za gospodarstvo, - za glazbarstvo, - za informatiku, - za kemiju i toksikologiju, - za krivotvoreni novac, - za medicinu, - za promet vozila, - za rukopise, - za sigurnost i zaštitu na radu, zaštitu od požara i eksplozija, i sigurnost u željezničkom prometu, - za strojarstvo, industrijska i druga postrojenja, fotografiju i tisak, - za telekomnikacije, - za veterinarstvo.

${ }^{5}$ Vidi POZNIĆ, B. -VRŽALIĆ, M. -BAČIĆ, F., Zakon o parničnom postupku sa komentarom, Beograd, 1957., str. 220.

${ }^{6} \mathrm{U}$ tom je smislu odluka VSJ, Rev- 724/58., PŽ 3-4/59.

${ }^{7}$ Usp. odluku VPSS, Sl- 1053/71. od 21. rujna 1979. god. - podatak kod JANKOVIĆ, M. KARAMARKOVIĆ, H. - JANKOVIĆ, Ž. - PETROVIĆ, D., Komentar zakona o parničnom postupku, 3. izdanje, Beograd, 1990., dalje - JANKOVIĆ, str. 289. Napominjemo da se u radu pozivamo na sudsku praksu sudova bivše SFR Jugoslavije, te na praksu sudova zemalja nastalih njezinim raspadom, i to u onim slučajevima kada su sudske odluke utemeljene na odredbama koje su po svom sadržaju istovjetne ili uvelike slične odredbama hrvatskih propisa.

${ }^{8}$ Tako TRIVA, str. 434.

${ }^{9}$ Usp. KULIĆ, R., Upis i status vještaka u sudskom postupku, „Pravni život“, broj 12/1998., str. 229.-230.

${ }^{10}$ Takvo je stajalište zauzeo VSS u odluci Gž- 4259/74. od 2. travnja 1974. god., JANKOVIĆ, str. 290.

${ }^{11}$ Vidi odluku VSS, Gž- 2074/76., podatak kod RISTIĆ, V. - RISTIĆ, M., Praktikum za parnicu, Beograd, 1989., dalje - RISTIĆ, str. 234.

${ }^{12}$ U tom je smislu odluka VSS, Gž- 3174/77., RISTIĆ, str. 235.

13 Tako SALAJ, Š., Uloga vještaka u parničnom postupku, "Pravo i porezi”, XLIX, 2000., br. 10, str. 52.

${ }^{14}$ Vidi odluku Vrhovnog suda Federacije Bosne i Hercegovine (dalje - VSFBiH), Pž- 129/98. od 19. kolovoza 1998. god. - Bilten sudske prakse VSFBiH, br. 2/98-10.

${ }^{15}$ Usp. odluku Vrhovnog suda Republike Hrvatske (dalje - VSH), Rev- 878/88. od 8. veljače 1989. god. - PSP, 44/162.

${ }^{16}$ Takvo je stajalište zauzeo i VSH u odluci Rev- 128/81. od 26. svibnja 1981. god. - PSP, 19/204.

${ }^{17}$ U tom je smislu odluka VSH, Rev- 1522/81. od 23. prosinca 1981. god. - PSP, 20/130.

18 Usp. odluku VSS, Gž- 911/78. - JANKOVIĆ, str. 290. Usto, prema stajalištu sudske prakse, parnični sud nije dužan vještačenjem utvrđivati iznos zateznih kamata obračunatih za period docnje tuženog u plaćanju glavnog duga, ako je tužitelj priložio obračun iz koga su vidljivi svi elementi na osnovu kojih je sačinjen, a tuženi nije osporio na određen način nijedan od elemenata obračuna (VSFBiH, Pž-129/98 od 19. 8. 1998. godine - Bilten sudske prakse VSFBiH, broj 1998/2, odl. br. 10.). Činjenica što je u parnici izostalo dokazivanje očinstva metodom genetske daktiloskopije (ispitivanje strukture i svojstva DNK), sama za sebe, ne znači da su pouzdanost drugih dokaza i istinitost činjenica na kojima je zasnovana presuda sumnjivi, odnosno da ovi dokazi nemaju 
vrijednost (VS Republike Srpske, Rev-302/01 od 19. 4. 2002. godine - Bilten sudske prakse VS RS, broj 2004/I, odl. br. 130; Domaća i strana sudska praksa, broj 2005/7, str. 58.). „Vještak geometar je dužan izjasniti o određenoj relevantnoj činjenici iz oblasti geodezije, pa njegov nalaz i mišljenje ne može biti pouzdan dokaz o tome koja je stranka bila posljednji posjednik sporne nekretnine (Kantonalni sud Zenica, broj: Gž-1076/05 od 13. 12. 2005. godine - Domaća i strana sudska praksa, broj 2006/14, str. 60. i 61.).

19 Zamjenjivost vještaka leži u njegovoj stručnosti, a nezamjenjivost vještaka u njegovom neposrednom zapažanju. KULIĆ, R., Upis i status vještaka u sudskom postupku, „Pravni život“, broj 12/1998., str. 230.

${ }^{20}$ Protiv odluke kojom se zahtjev za imenovanje sudskim vještakom odbija podnositelj ima pravo žalbe Ministarstvu pravosuđa u roku od 15 dana od dostave odluke (ZS, čl. 126.).

${ }^{21}$ Za stalnog sudskog tumača može se imenovati i državljanin države članice Europske unije ili neke druge države potpisnice Ugovora o Europskom gospodarskom prostoru, ako ispunjava uvjete propisane PSSV-om za domaće državljane. Državljanin države članice Europske unije kao dokaz da je ispunio obvezu da ima sklopljen ugovor o osiguranju od odgovornosti za obavljanje poslova stalnog sudskog vještaka (v. PSSV, čl. 2. točka 5.), može priložiti ugovor o osiguranju od odgovornosti za obavljanje poslova stalnog sudskog vještaka koji je zaključen u matičnoj državi (PSSV, čl. 3.). Ova odredba stupa na snagu danom pristupanja Republike Hrvatske u punopravno članstvo Republike Hrvatske (arg. PSSV, čl. 33.).

22 Prije imenovanja za stalnog sudskog vještaka kandidat, odnosno na pravne osobe koje su registrirane za obavljanje vještačenja dužni su predsjedniku županijskog odnosno trgovačkog suda koji je nadležan za njegovo imenovanje dostaviti dokaz o sklopljenom obaveznom osiguranju od odgovornosti radi namirenja zahtjeva za naknadu štete, a koja je nastala uslijed njegovog djelovanja kao stalnog sudskog vještaka. Kandidat mora biti osiguran tijekom cijelog razdoblja na koje je imenovan za stalnog sudskog vještaka. Najniža svota osiguranja iznosi najmanje 200.000,00 kuna. $\mathrm{Na}$ početku svake kalendarske godine imenovani stalni sudski vještak dužan je predsjedniku nadležnog županijskog odnosno trgovačkog suda dostaviti dokaz o zaključenom ugovoru o osiguranju za narednu tekuću godinu (PSSV, čl. 7.).

${ }^{23}$ Tako GNJIDIĆ, Ž. - BILIĆ, R. i dr., Uvod u medicinsko vještačenje u građanskim parnicama, Zagreb, 2008., str. 18.

${ }^{24}$ Vidi ZEČEVIĆ, D i drugi, Sudska medicina i deontologija, Medicinska naklada, Zagreb, 2004., str. 222.

${ }^{25}$ Pravilnik je objavljen na oglasnoj ploči Komore dana 11. svibnja 2009. godine te je stupio na snagu dana 19. svibnja 2009. godine. Na temelju odredbe članka 4. Pravilnika o izmjenama i dopunama Pravilnika o provođenju izobrazbe kandidata za stalne sudske vještake od 29. svibnja 2015. godine stručne službe Hrvatske liječničke komore izradile su 1. srpnja 2015. pročišćeni tekst Pravilnika o provođenju izobrazbe kandidata za stalne sudske vještake, koji obuhvaća: - Pravilnik o provoĎenju izobrazbe kandidata za stalne sudske vještake od 8. svibnja 2009. godine, -Pravilnik o izmjeni Pravilnika o izobrazbi kandidata za stalne sudske vještake od 16. listopada 2009. godine, -Pravilnik o izmjenama i dopunama Pravilnika o provođenju izobrazbe kandidata za stalne sudske vještake od 9. svibnja 2012. godine, -Pravilnik o dopunama Pravilnika o provođenju izobrazbe kandidata za stalne sudske vještake od 1 . veljače 2013. godine, -Pravilnik o izmjenama i dopunama Pravilnika o provođenju izobrazbe kandidata za stalne sudske vještake od 14. studenog 2014. godine i -Pravilnik o izmjenama i dopunama Pravilnika o provođenju izobrazbe kandidata za stalne sudske vještake od 29. svibnja 2015. godine.

${ }^{26}$ Tečaj se boduje i kategorizira u skladu s odredbama Pravilnika o sadržaju, rokovima i postupku trajne medicinske izobrazbe i provjere stručnosti liječnika Hrvatske liječničke komore, a polaznici dobivaju potvrdnice koje mogu koristiti u postupku obnove odobrenja za samostalan rad (licence). ${ }^{27}$ Iznimno od članka 7. ovoga Pravilnika, kandidatu koji iz opravdanih razloga nije u mogućnosti obaviti teorijski dio izobrazbe u trajanju od 20 školskih sati, Predsjednik Komore može odobriti 
pristup usmenom ispitu i pismenoj provjeri znanja. Opravdanost razloga procjenjuje Predsjednik Komore u svakom pojedinom slučaju (Pravilnik, čl. 7a. st. 1.).

${ }^{28}$ Izvršni odbor Komore donosi odluku o iznosu i načinu plaćanja troškova izobrazbe. Troškovi izobrazbe obuhvaćaju kotizaciju za tečaj odnosno teorijski dio izobrazbe te naknadu mentoru za praktični dio izobrazbe. Troškove izobrazbe snosi kandidat (Pravilnik, čl. 19.).

${ }^{29}$ Kandidat ima pravo mentoru postavljati pitanja i tražiti pojašnjenja određenih stručnih problema kao i na drugi oblik stručne pomoći koji proizlazi iz odnosa kandidata i mentora. Odmah po saznanju o imenovanju mentora, kandidat je dužan kontaktirati mentora, surađivati s njime te postupati u skladu s njegovim uputama kroz cijelo vrijeme obavljanja praktičnog dijela izobrazbe (Pravilnik, čl. 14.). Mentor je obvezan prihvatiti provođenje praktičnog dijela izobrazbe dodijeljenog mu kandidata. Iznimno, mentor može odbiti provođenje izobrazbe dodijeljenog kandidata ukoliko za to postoje objektivni ili opravdani razlozi. Opravdanost razloga procjenjuje Izvršni odbor HLJK. Mentor koji iz opravdanih razloga ne može prihvatiti provođenje mentorstva, mora u roku od osam dana (8) od dana primitka odluke o imenovanju, obavijestiti Izvršni odbor HLJK o razlozima neprihvaćanja mentorstva. U slučaju opravdanosti razloga, predsjednik Komore donosi odluku o imenovanju novog mentora (Pravinik, čl. 15.). U praktičnom dijelu izobrazbe, mentor je obvezan kandidata poučiti o načinu obavljanju poslova sudskog vještačenja, uputiti ga u način izrade nalaza i mišljenja, način prouke sudskog spisa odnosno upoznati ga sa svim važnim pitanjima sudskog vještačenja (Pravilnik, čl. 16.).

${ }^{30}$ Pisano izvješće mora sadržavati ime i prezime kandidata, znanstveni stupanj, specijalnost ili užu specijalnost, vrijeme trajanja izobrazbe, mjesto obavljanja izobrazbe, broj izrađenih nalaza i mišljenja te kratki prikaz provedene izobrazbe.

${ }^{31}$ Imenovani vještak daje prisegu (koju treba i potpisati) pred predsjednikom suda koji ga je imenovao za vještaka. Sadržaj prisege glasi: »Prisežem svojom čašću povjerena mi vještačenja obavljati savjesno i prema svom najboljem znanju, a svoje nalaze i mišljenja iznijeti točno, potpuno i objektivno sukladno propisima o vještačenju.«(PSSV, čl. 11.).

32 Prema stajalištu ranije sudske prakse, utemeljene na suđenju u vijeću, okolnost da vještačenje nije obavio vještak kojeg je odredilo raspravno vijeće, već drugi vještak kojem je taj zadatak povjerio predsjednik vijeća, može biti relativno bitna povreda odredaba parničnoga postupka. Vidi odluku VSH, Rev- 575/84. od 17. svibnja 1984. god. - PSP, 25/189.

${ }^{33}$ Usp. TRIVA-DIKA, str. 526. Odredbe članka 251., članka 252. stavka 2, čl. 253. do 257, članka 258. stavka 2. i članka 262. ZPP-a na odgovarajući se način primjenjuju i na tumače (ZPP, čl. 263.). Odredbama ovoga članka izjednačeni su procesni položaj, prava i dužnosti tumača i vještaka. Tumači (njem. Dolmetscher) su vrsta vještaka koji pomažu sudu da se sporazumjeva sa sudionicima u postupku koji ne znaju jezik suda ili koji se normalno ne mogu s drugim sporazumijevati. Tumač može biti samo jedna fizička osoba. Sud mora postaviti tumača kada saslušava svjedoka koji ne zna jezik na kojem se vodi postupak ili je gluh, nijem i nepismen. Saslušavanje svjedoka i stranaka uz sudjelovanje vještaka-tumača obvezno je i kad bi se sud mogao sporazumjeti s njima na njihovom jeziku, jer je dužan i drugim sudionicima u postupku omogućiti praćenje tijeka raspravljanja (Usp. TRIVA, str. 439.). Tumač je na zahtjev suda dužan obrazložiti svoj način prevođenja, odnosno sporazumijevanja (arg. iz čl. 260. ZPP-a.). Tumača je sud dužan upozoriti na dužnost točnog prevođenja, odnosno tumačenja onoga što je saslušani svjedok izjavio, te onoga što sud pita ili priopćava saslušavanom svjedoku. Tumač je svoju funkciju dužan obaviti u skladu s pravilima jezika, odnosno drugim pravilima sporazumijevanja (arg. iz čl. 258. ZPP-a). Tumač je kazneno odgovoran za lažno prevođenje, odnosno objašnjavanje. Tumač koji u postupku pred sudom dade lažan iskaz, kaznit će se novčanom kaznom ili kaznom zatvora do tri godine. Vidi Kazneni zakon čl. 303. Davanje lažnog iskaza kao kazneno djelo obuhvaća dva djela: lažno iskazivanje svjedoka, vještaka, prevoditelja ili tumača u postupku pred sudom (st. 1.), te lažno iskazivanje stranke u postupku (st. 2.). Prema stajalištu sudske prakse, sud nije ovlašten narediti stranci da uplati određenu svotu novca radi podmirenja troškova prevođenja podneska od ovlaštenog sudskog tumača, pa nisu ispunjene pretpostavke za odbacivanje tužbe kad tužitelj nije postupio po nalogu suda (Usp. odluku PSH, Pž- 539/90. od 6. ožujka 1990. god. - PSP, 46/195.). 
34 Tako i šire o tome kod ŠTIMAC, S., Pravni aspekt medicinskog vještačenja nematerijalne/neimovinske štete, „Vještak”, god. XXVIII, 2008., broj 1, str. 181.-192.

35 Vidi odluku VSH, Rev- 797/01. od 26. rujna 2001., IO 2/02-178.

${ }^{36} \mathrm{U}$ tom je smislu odluka ŽS u Varaždinu, Gž- 1652/05. od 3. studenoga 2005., IO- 2/06-254.

${ }^{37}$ Usp. CRNIĆ, I., Zadaće medicinskog vještaka u parničnom postupku za naknadu neimovinske štete, ,Odvjetnik“, 2008., broj 5-6, str. 35.

${ }^{38} \mathrm{U}$ tom je smislu odluka VS FBiH, Rev- 22/99. od 6. srpnja 1999. god. - Bilten sudske prakse Vs FBiH, br. 2/99-17.

${ }^{39}$ Vidi ZUGLIA, S. - TRIVA, S., Komentar zakona o parničnom postupku, Zagreb, 1957., dalje ZUGLIA-TRIVA, str. 580.

40 Takvo je stajalište zauzeo VSH u odluci Rev- 1001/90. od 11. rujna 1990. god. - PSP, 50/136.

${ }^{41}$ Usp. odluku VSH, Rev- 1849/80. od 17. veljače 1981. god. - PSP, 19/205.

42 Tako TRIVA-DIKA, str. 530.

${ }^{43}$ Vidi odluku ŽS u Bjelovaru, Gž- 1473/98. od 4. studenoga 1998. god. - IO, 1/1999-151.

${ }^{44} \mathrm{U}$ tom je smislu odluka VSH, Rev- 2265/85. od 27. veljače 1986. god. - JANKOVIĆ, str. 293.

45 Usp. POGARČIĆ, Z., Dokazi i izvođenje dokaza u parničnom postupku, "Slobodno poduzetništvo", 1999., br. 20, str. 146.

${ }^{46}$ Vidi TRIVA, str. 435. i TRIVA-DIKA, str. 528.

${ }^{47}$ Tako ZEČEVIĆ, E., Komentar Zakona o parničnom postupku, Sarajevo, 2004., str. 150.

${ }^{48}$ Vidi odluku Kantonalnog suda u Sarajevu, GŽ- 13/98.

${ }^{49}$ Usp. odluku VSH, Gž- 1822/77. od 23. svibnja 1978. god. - Inf. Os Zgb., br. 10/81-65.

50 Tako KULENOVIĆ, str. 288.

${ }^{51}$ Vidi DIKA, M -ČIZMIĆ, J., str. 443.-444..

52 Prema mišljenju Trive, funkcija vještaka dvostrukog je značaja. Naime, kada obavještavaju sud o svome nalazu (zapažanjima), oni predstavljaju klasično dokazno sredstvo. Ako, pak, sudu svojom stručnošæu pomažu da izvodi zaključke, odnosno formira mišljenje o zapaženome, oni obavljaju funkciju specifičnog pomagača u obavljanju funkcije suđenja pri utvrđivanju činjeničnog stanja. TRIVA, str. 434.

${ }^{53}$ Zanimljivo je mišljenje Š. Salaj da vještaci gotovo nikada ne daju usmeni nalaz i mišljenje, niti ih sudovi na to pozivaju. SALAJ, Š., Uloga vještaka u parničnom postupku, "Pravo i porezi", XLIX, 2000., br. 10, str. 52.

${ }^{54}$ Tako i u odlukama VSH, Rev. 2449/88 od 15. prosinca 1988.; VSH, Rev. 1482/88 od 24. siječnja 1989. god.

55 Vidi odluku VTSH, Pž-3599/04 OD 8. LIPNJA 2004., Informator, broj 5489 od 14. listopada 2006.

${ }^{56}$ Usp. TRIVA, str. 434.; TRIVA-DIKA, str. 526.

${ }^{57}$ U tom je smislu i odluka ŽS u Bjelovaru, Gž- 125/98. od 20. veljače 1998. god. - IO, 1/1998171.

58 Vidi GNJIDIĆ, Ž. - BILIĆ, R. i dr., Uvod u medicinsko vještačenje u građanskim parnicama, Zagreb, 2008., str. 20.

59 Tako IVEKOVIĆ, R., Izrada medicinskog vještačenja, rad u materijalu „Tečaj izobrazbe kandidata za stalne sudske vještake, Zagreb, 2010., str. 119.

${ }^{60}$ Vidi ŠKAVIĆ, J. - ZEČEVIĆ, D., Načela sudskomedicinskih vještačenja, Zagreb, 2010., str. 15. ${ }^{61}$ Usp. ZEČEVIĆ, D i drugi, Sudska medicina i deontologija, Medicinska naklada, Zagreb, 2004., str. 275.

62 Tako MAROVIĆ, A. - MEDVIDOVIĆ, L. - ŠTIMAC, S., Zaštita prava osobnosti, Split, 2006., str. 82.

${ }^{63}$ Vidi ŠTIMAC, S. - MAROVIĆ, A. - ŠARIĆ, J., Medicinski i pravni kriteriji u postupcima naknade nematerijalne (neimovinske) štete, „Osiguranje“, 2010., broj 10., str. 51.

${ }^{64}$ Usp. DIKA, M., Rješavanje sporova za naknadu štete zbog liječničke greške, referat na savjetovanju"Medicinski, pravni i ekonomski pogledi na profesionalnu odgovornost u zdravstvu i osiguranje od odgovornosti“, Šibenik, listopad 2007., str. 7. 
65 Vidi DIKA, M., Rješavanje sporova za naknadu štete zbog liječničke greške, referat na savjetovanju“Medicinski, pravni i ekonomski pogledi na profesionalnu odgovornost u zdravstvu i osiguranje od odgovornosti“, Šibenik, listopad 2007., str. 7.

${ }^{66}$ Pravo osobnosti raznim sredstvima štiti personalitet čovjeka, pošto osobnost čovjeka nije samo psihološka kategorija, nego je i pravni pojam. Tako RADOLOVIĆ, A., Pravo osobnosti u novom Zakonu o obveznim odnosima, «Zbornik Pravnog fakulteta Sveučilišta u Rijeci», vol. 27., 2006., br. 1, str. 133. Opće je prihvaćeno stajalište da je jedno od subjektivnih prava osobnosti i pravo na tjelesno zdravlje, kao i na privatnost i u okviru toga i na tajnost podataka o stanju čovjekova zdravlja. Podrobnije o pravu osobnosti kod GAVELLA, N., Osobna prava - I. dio, Zagreb, 2000. i BODIROGA, N. - DULČIĆ, K., Zaštita osobnih podataka u europskome i hrvatskome pravu, «Zbornik radova Pravnog fakulteta u Splitu», god. 42, 2005., str. 327.-356.

${ }^{67}$ Tako KAUZLARIĆ, Ž., Stalni sudski vještaci (2. dio), „Informator“, broj 5541. od 14. travnja 2007., str. 9. Vidi i KAUZLARIĆ, Ž., Sudski vještaci i njihova uloga u parničnom postupku - s osvrtom na posebnosti u postupku osporavanja očinstva $i$ vještačenja mobinga, „Hrvatska pravna revija“, broj, 6/07, str. 91.-100.

${ }^{68}$ Neimovinska šteta nastala oštećenjem tjelesnog zdravlja, kao oblik povrede prava osobnosti na tjelesno zdravlje, može se očitovati kao nanošenje tjelesne ozljede ili gubitka nekog tjelesnog organa ili tjelesno oboljenje, te u različitim posljedicama kao, primjerice, fizička bol, duševna bol, smanjenje životne aktivnosti, naruženost, strah i sl. S druge strane, duševno zdravlje, kao pravo osobnosti, može biti ugroženo različitim štetnim postupcima, primjerice tjelesnom ozljedom, šikaniranjem, zastrašivanjem, uznemiravanjem i sl., ali i nepoštivanjem ugovornih obveza, i pri tome je dovoljno da u oštećenika pobude neugodu, nezadovoljstvo, frustraciju, ljutnju, bijes, tj. poremećaj njegovog dotadašnjeg duševnog mira. ŠKAVIĆ, J. - ZEČEVIĆ, D., Načela sudskomedicinskih vještačenja, Zagreb, 2010., str. 210.

${ }^{69}$ Usp. MEDIĆ, D., Značaj vještačenja u parnicama za naknadu nematerijalne štete, „Pravni savjetnik“, god. I, 2001., broj 9, str. 64.

${ }^{70}$ Vidi CRNIĆ, I., Zadaće medicinskog vještaka u parničnom postupku za naknadu neimovinske štete, „Odvjetnik“, 2008., broj 5-6, str. 36.

${ }^{71}$ Tako ŠTIMAC, S. - MAROVIĆ, A. - ŠARIĆ, J., Medicinski i pravni kriteriji u postupcima naknade nematerijalne (neimovinske) štete, „Osiguranje“, 2010., broj 10., str. 51.

${ }^{72}$ Usp. MAROVIĆ, A. - MEDVIDOVIĆ, L. - ŠTIMAC, S., Zaštita prava osobnosti, Split, 2006., str. 83.

73 Tako ŠTIMAC, S. - MAROVIĆ, A. - ŠARIĆ, J., Medicinski i pravni kriteriji u postupcima naknade nematerijalne (neimovinske) štete, „Osiguranje“, 2010., broj 10., str. 51.

${ }^{74}$ Treba ipak kazati da su pojedini orijentacijski kriteriji izazvali polemiku i osporavanja u krugovima sudskomedicinskih vještaka, posebno ako pokazuju tendenciju da budu nacionalni. To se, primjerice, odnosi na nove kriterije objavljene u listu „Vještak”, god. XXX, 2009., br. 2, kod kojih se autori (Davor Strinović, Dušan Zečević, Josip Škavić) pozivaju na Međunarodnu klasifikaciju funkcioniranja invalidnosti i zdravlja, u sudsku praksu uvode pojam SOTDZ koji nije utemeljen ni na kojem pozitivnom propisu u RH i koji ne postoji ni u ZOO/1991, niti u ZOO/2005. U krugu vještaka ovim se tablicama prigovara da su one više teorijske naravi, da su napravljene u drugu svrhu, da su restriktivne u odnosu na zaštitu oštećenika (zbog nepriznavanja postojanja brojnih ozljeda i njihovih posljedica kao i psihičkih smetnji kojima je uzrok štetni događaj, a koje je sudska praksa priznavala) i da nužno uvjetuju promjenu dosadašnje ustaljene sudske prakse. Štoviše, Hrvatsko društvo za medicinska vještačenja Hrvatskog liječničkog zbora raspravljalo je o navedenim kriterijima. Drže da medicinska vještačenja u parničkom postupku gdje se vještači neimovinska šteta pripadaju prvenstveno liječnicima vještacima iz pojedinih grana (specijalizacija) medicine, dakle kliničarima s praktičnim i teoretskim znanjem. S druge strane, smatraju da sudski medicinari (koji vještače najviše neimovinskih šteta) nisu u mogućnosti izvršiti specijalistički pregled, a niti izraditi relevantno mišljenje iz pojedine grane medicine, pa zbog istog razloga nisu u mogućnosti izraditi ni tablice za ocjenu posljedica oštećenja (pa ni navedene), jer ih sudski medicinar na živom, oštećenom čovjeku u praksi ne vidi. U tom smislu ni Tablice sudskih medicinara koje su objavljene u knjizi "Pristup vještačenju naknade za neimovinsku štetu prema ZOO/05" nisu prihvatljive zbog brojnih nedostataka, kao npr. preniskog postotaka za određene posljedice 
oštećenja, prevelikih raspona postotaka stupnjevima kod jedne te iste posljedice, nestručnog i zbog toga neprihvatljivog zbrajanja postotaka i u konačnici zbog zanemarivanja osobnosti oštećene osobe. Drže da je uvođenje ovakvog načina rada i vršenje pritiska na sudske vještake medicinske struke izuzetno štetna radnja za oštećenike, medicinsku struku, a isto tako i za pravni sustav naše zemlje. Zbog toga je odlučeno na sastanku Hrvatskog društva za medicinska vještačenja Hrvatskog liječničkog zbora, da će članovi tog Društva nastaviti vještačiti sukladno svom najboljem stručnom znanju, Etičkom kodeksu sudskih vještaka, Zakonu o parničnom postupku (članci 250- 263), te člancima Zakona o obveznim odnosima (čl. $200 \mathrm{ZOO} / 78$ bol, strah, duševna bol zbog smanjene životne aktivnosti i naruženost) ako je štetni događaj nastao prije 01. siječnja 2006., odnosno po čl. 19. i 1100. ZOO/05 (povreda prava osobnosti) ako je štetni događaj nastao nakon 01. siječnja 2006. Vidi Odluku Hrvatskog društva za medicinska vještačenja Hrvatskog liječničkog zbora od 3. prosinca 2010. Podatak na starnici http://www.hlz.hr/portal/index.php?option=com content\&view=article\&id=62:odluka-hrvatskog-

drutva-za-medicinska-vjetaenja\&catid=4: novosti.

75 Tako ŠTIMAC, S. - MAROVIĆ, A. - ŠARIĆ, J., Medicinski i pravni kriteriji u postupcima naknade nematerijalne (neimovinske) štete, „Osiguranje“, 2010., broj 10., str. 53.

${ }^{76}$ Usp. odluku VSH, Rev. 400/1994 od 2. ožujka 1994. god.

77 Vidi odluku VPSV, Pž- 1281/74. od 7. studenoga 1974. god. - JANKOVIĆ, str. 296.

78 Tako i u odluci VPS, Sl- 1278/73. - JANKOVIĆ, str. 296.

${ }^{79} \mathrm{U}$ tom je smislu odluka VSH, Rev- 54/07. od 5. rujna 2007., IO 2/07-239.

${ }^{80}$ Takvo je stajalište zauzeo VSH u odluci Rev- 2449/88. od 15. prosinca 1988. god. - PSP, 43/107.

${ }^{81}$ U tom je smislu odluka VSH, Rev- 394/87. od 12. ožujka 1983. god. - PSP, 37/65.

${ }^{82}$ Usp. KULENOVIĆ, str. 288.

${ }^{83}$ Vidi odluku VPS, PŽ- 5404/76. - RISTIĆ, str. 118.)

84 Tako ZUGLIA-TRIVA, str. 592.

${ }^{85}$ Usp. odluku VTSRH, Pž- 2274/03. od 17. siječnja 2006., Zbirka odluka VTSH 12/124.

86 Vidi Pravni stav Građanskog odjeljenja Kantonalnog suda u Sarajevu - Bilten sudske prakse Kantonalnog suda u Sarajevu, broj 2000/2, str. 17.

${ }^{87}$ Usp. odluku VPSV, Pž- 262/73. od 19. ožujka 1973. god. - JANKOVIĆ, str. 296.

${ }^{88}$ Takvo je stajalište zauzeo VSH u odluci Rev- 1614/85. od 13. studenoga 1985. god. - PSP, $32 / 154$.

${ }^{89}$ Vidi odluku VSH, Rev- 3073/90. od 31. siječnja 1991. god. - PSP, 51/184.

${ }^{90} \mathrm{U}$ tom je smislu odluka VS BiH, Kž- 1005/77. - podatak kod KREHO, S., Zbirka sudskih odluka iz oblasti Zakona o krivičnom postupku, Sarajevo, 1996., str. 124.

${ }^{91}$ Tako i odluka ŽS u Zagrebu, Gž- 5222/98. od 13. travnja 1999. god., ING PSP 2000-8-39.

${ }^{92}$ Vidi odluku VSH, Rev- 1030/92. od 18. veljače 1993. god. - IO, 1994/292.

${ }^{93}$ Usp. odluku VSS, Rev- 2192/79. - JANKOVIĆ, str. 296.

${ }^{94}$ U tom je smislu odluka VSS, Gž- 510/67. - objavljena u "Glasniku”, br. 9/67.

95 Tako TRIVA, str. 438.

${ }^{96}$ U tom smislu vidi odluku VSSr, Gz- 917/72, PŽ 11/72-76.

${ }^{97}$ Pogrešno ili nepotpuno utvrđeno činjenično stanje razlog je za ukidanje prvostupanjske presude, a, što se tiče vještaka, mogući razlozi su: provođenjendokaza vještačenjem po vještaku neodgovarajuće struke; nepotpun nalaz i mišljenje vještaka (primjerice, vještak nije uzeo u obzir materijalni dokaz koji se nalazi u predmetu; kontradiktoran nalaz i mišljenje (navođenje dvije ili više činjenica koje se međusobno isključuju); nerazumljiv nalaz vještaka (iz kojeg nije moguće zaključiti uz provođenje kojih postupaka je dao svoj nalaz i mišljenje ili vještak koristi stručne izraze koje treba pojasniti); nalaz vještaka je netočan (primjerice, u broju I iznosu). KAUZLARIĆ, Ž., Stalni sudski vještaci (2. dio), „Informator“, broj 5541. od 14. travnja 2007., str. 9.

98 Tako DIKA, M., Rješavanje sporova za naknadu štete zbog liječničke greške, referat na savjetovanju“"Medicinski, pravni i ekonomski pogledi na profesionalnu odgovornost u zdravstvu i osiguranje od odgovornosti“, Šibenik, listopad 2007., str. 6.

99 Zakonodavac ne pravi razliku je li vještak propustio udovoljiti nalogu suda da dostavi, odnosno dopuni ili ispravi nalaz i mišljenje zbog opravdanih razloga ili zbog razloga koji se ne mogu smatrati opravdanim. Postoji mišljenje da, ako je vještak obavijestio sud o razlozima nedostavljanja nalaza 
i mišljenja, pa sud nađe da su ti razlozi opravdani (primjerice, zbog bolesti, složenosti vještačenja, privremene nedostupnosti određenih podataka nužnih za vještačenje i sl.), a to ne bi dovelo do neprimjerenog produženja postupka (primjerice zbog dužeg odsustva iz zemlje ili teške bolesti), sud bi treba produžiti rok za vještačenje i o tome obavijestiti stranke. Suprotno, ako sud nađe da razlog nedostavljanja nalaza i mišljenja ne bi mogao biti opravdan, trebao bi postupiti u u skladu s odredbom ovog stavka, a na isti način sud bi trebao postupiti i ako ga vještak nije obavijestio o razlogu nedostavljanja nalaza, jer sud nije dužan sam pokušati tvrditi te razloge (ZEČEVIĆ, E., Komentar Zakona o parničnom postupku, Sarajevo, 2004., str. 154.; KULENOVIĆ, str. 285.).

100 Tako ŽS u Rijeci u odluci Gž- 2089/03. od 15. listopada 2003., IO 1/04-286.

101 Vidi odluku ŽS u Rijeci, Gž- 2089/03. od 15. listopada 2003., IO 1/04-272.

${ }^{102}$ U tom smislu je odluka VPS, S1- 786/57. - objavljeno u "Glasniku”, br. 12/57.

103 Tako i podrobnije kod BAČIĆ, F. - PAVLOVIĆ, Š., Kazneno pravo - posebni dio, Zagreb, 2001., str. 415.

${ }^{104}$ Novčanu kaznu izriče prvostupanjski sud, a izvan ročišta za glavnu raspravu kaznu izriče sudac pojedinac, odnosno predsjednik vijeća (arg. ZPP, čl. 10. st. 4. u svezi s odredbom čl. 255. st. 4.). Ako sud koji odlučuje o pravnom lijeku posumnja da je određeni vještak teže zlouporabio prava koja mu pripadaju u postupku, dužan je naložiti prvostupanjskom sudu da provjeri je li takva zlouporaba počinjena, pa će u slučaju da se to utvrdi sudac pojedinac, odnosno predsjednik vijeća prvostupanjskoga suda izreći novčanu kaznu, a u suprotnom rješenjem utvrđuje da nije počinjena teža zlouporaba prava. Ako kažnjeni vještak ne plati izrečenu novčanu kaznu u ostavljenom roku, sud će u daljnjem roku od petnaest dana dostavom rješenja o plaćanju novčane kazne, o neplaćenoj novčanoj kazni obavijestiti ispostavu Područnog ureda Porezne uprave Ministarstva financija na čijem je području prebivalište kažnenog vještaka, odnosno sjedište kažnjene stručne osobe kojoj je povjereno vještačenje, radi naplate novčane kazne prisilnim putem, uz naznaku u čiju korist i na koji račun treba naplatiti izrečenu novčanu kaznu, sve uz dostavu obavijesti o neplaćenoj novčanoj kazni kažnjenom vještaku Nakon što primi obavijest i rješenje, nadležna ispostava Područnog ureda Porezne uprave Ministarstva financija na čijem je području prebivalište kažnenog vještaka, odnosno sjedište kažnjene stručne osobe kojoj je povjereno vještačenje dužna je donijeti rješenje kojim je dužan kažnjenom vještaku narediti da u roku od osam dana od dana prijama rješenja plati izrečenu novčanu kaznu, a ako u tom roku ne plati novčanu kaznu, pristupit će se prisilnoj naplati izrečene novčane kazne prema propisima o prisilnoj naplati poreza. Naplaćena novčana kazna uplaćuje se na račun prihoda državnog proračuna Republike Hrvatske, dok se o izvršenoj naplati obaviještava sud. Žalba izjavljena protiv rješenja o novčanoj kazni, ne odgađa provedbu tog rješenja, a ako u roku od godine dana od prijama obavijesti o neplaćenoj novčanoj kazni i rješenja o kažnjavanju ne uspije naplatiti novčanu kaznu, nadležna ispostava Područnog ureda Porezne uprave Ministarstva financija će o nenaplaćenoj novčanoj kazni za fizičku osobu obavijestiti sud koji joj je dostavio obavijest, nakon čega se izrečena novčana kazna treba zamijeniti kaznom zatvora po pravilima kaznenog prava o zamjeni novčane kazne kaznom zatvora, o čemu će odluku donijeti sud koji je izrekao novčanu kaznu. Ako se od kažnjene stručne pravne osoba kojoj je povjereno vještaćenje ne naplati izrečena novčana kazna u roku od godine dana od prijama obavijesti Područnom uredu Porezne uprave radi naplate novčane kazne prisilnim putem, ta se kazna treba prisilno naplatiti po pravilima kaznenog prava (arg. ZPP, čl. 10.).

105 Vidi Nacrt prijedloga Zakona o izmjenama i dopunama Zakona o parničnom potupku $s$ konačnim prijedlogom zakona, Zagreb, lipanj 2008., obrazloženje uz čl. 22.

106 Tako DIKA, M., Zakon o izmjenama i dopunama Zakona o parničnom postupku od 2. srpnja 2008. - Opći pregled, rad u zborniku DIKA, M. i drugi, Novela Zakona o parničnom postupku iz 2008., Zagreb, 2008., str. 6.

${ }^{107}$ Usp. ZUGLIA-TRIVA, str. 589.

108 Tako i u odluci VPSS, P- 2024/72. - JANKOVIĆ, str. 294.

${ }^{109}$ U tom smislu vidi odluku VTSRH, Pž- 7271/03. od 5. rujna 2006., Zbirka odluka VTSH 12/110.

110 Tako VTSH u odluci Pž- 7059/04. od 19. rujna 2007., Zbirka odluka VTSH 14/131. 
${ }^{111}$ Vidi odluku VPS, S1- 242/67., podatak kod KUKOLJAC, M., Parnični postupak, Beograd, 1970., str. 125.

112 Usp. POROBIĆ, M. - POROBIĆ, V. - POROBIĆ, J., Zakoni o parničnom postupku (Federacija BiH, Republika Srpska, Brčko Distrikt BiH) sa komentarom i sudskom praksom, Sarajevo, 2004., str. 571.

${ }^{113}$ U tom je smislu odluka VSV, Gž- 346/81. - JANKOVIĆ, str. 294.

114 Takvo je stajalište zauzeo VPS u odluci Sl- 2633/71. od 3. ožujka 1972. god. - JANKOVIĆ, str. 293.

115 Vidi odluku VSH, Gž- 3885/70. od 9. veljače 1972. god. - JANKOVIĆ, str. 294.

116 Podrobnije na web stranici http://www.sudski-vjestaci.hr/.

117 Tako GNJIDIĆ, Ž. - BILIĆ, R. i dr., Uvod u medicinsko vještačenje u građanskim parnicama, Zagreb, 2008., str. 8.

118 Vidi MAROVIĆ, A. - MEDVIDOVIĆ, L. - ŠTIMAC, S., Zaštita prava osobnosti, Split, 2006. str. 76.

${ }^{119}$ Značajan iskorak na planu izobrazbe stručnjaka iz područja medicinskog prava uradio je Pravni fakultet Sveučilišta u Splitu ustrojavanjem poslijediplomskog specijalističkog studija «Medicinsko pravo», koji ima za cilj obrazovanje specijalista medicinskog prava, kako bi mogli obavljati vodeće i najsloženije poslove u zdravstvenim ustanovama, pravosuđu, visokoškolskim i drugim obrazovnim ustanovama, institutima te državnim i drugim javnim institucijama. Polaznik stječe multidisciplinarno (pravno-medicinsko-etičko) znanje i vještine koje omogućuju kritičku analizu i sposobnost primjene stečenih specifičnih znanja iz područja medicinskog prava u praksi. Polaznici koji steknu diplomu moći će obavljati složene i zahtjevne poslove viših razina odgovornosti u: zdravstvu, pravosuđu, javnoj administraciji (lokalnog, regionalnog, nacionalnog i međunarodnog značenja), profesionalnim i strukovnim udruženjima, obrazovnim institucijama, institutima, ustanovama kao samostalni eksperti iz područja medicinskog prava i dr.

$120 \mathrm{O}$ vještacima zdravstvene struke i sudsko-medicinskom vještačenju kod ČIZMIĆ, J., $O$ vještačenju u parničnom postupku s posebnim osvrtom na vještačenje u području medicine, „Zbornik Pravnog fakulteta Sveučilišta u Rijeci“, (1991) v. 32, 2011., broj 1, str. 473.-510. 



\section{1/ Poslovi zdravstvenih radnika i način obavljanja}

\subsection{Pravno uređenje}

Prema odredbama ZOZZ-a, zdravstvene ustanove koje obavljaju zdravstvenu djelatnost u mreži javne zdravstvene službe obvezne su neprekidno pružati zdravstvenu zaštitu, radom u jednoj, dvije ili više smjena, pomakom radnog vremena, pripravnošću ili dežurstvom u skladu s potrebama stanovništva i oblicima pružanja zdravstvenih usluga (ZOZZ, čl. 162. st. 1.). ${ }^{1}$ Maksimalno ukupno trajanje radnog vremena tjedno uključujući rad u dežurstvu i rad po pozivu ne može biti duže od 48 sati. Iznimno, zbog potrebe posla, maksimalno ukupno trajanje radnog vremena tjedno, uključujući rad u dežurstvu i rad po pozivu, može biti duže od 48 sati uz prethodni pisani pristanak radnika (ZOZZ, čl. 162. st. 5. i 6.). Zdravstveni radnici ne smiju napustiti radno mjesto dok nemaju zamjenu, iako je njihovo radno vrijeme proteklo, ako bi time bila dovedena u pitanje sigurnost pružanja zdravstvene zaštite (ZOZZ, čl. 162.). Početak, završetak i raspored radnog vremena zdravstvenih ustanova i privatnih zdravstvenih radnika u mreži javne zdravstvene službe propisuje pravilnikom ministar, uz prethodno mišljenje nadležne komore (ZOZZ, čl. 162.). U slučajevima izvanrednih okolnosti, katastrofa i epidemija većih razmjera, ministar je ovlašten poduzimati i one mjere i aktivnosti koje nisu utvrđene ovim Zakonom, uključivši i mjere mobilizacije, organizacije i rasporeda rada i radnog vremena, promjene mjesta i uvjeta rada pojedinih zdravstvenih ustanova i radnika, dok te okolnosti traju (ZOZZ, čl. 165.).

Prema Pravilniku o početku, završetku i rasporedu radnog vremena zdravstvenih ustanova i privatnih zdravstvenih radnika u mrě̌i javne zdravstvene službe (,Narodne novine“, broj 4/14., dalje - Pravilnik o radnom vremenu) uređuje se početak, završetak i raspored radnog vremena zdravstvenih ustanova i privatnih zdravstvenih radnika u mreži javne zdravstvene službe (Pravilnik o radnom vremenu, čl. 1.). Raspored radnog vremena, a posebno početak i završetak radnog vremena utvrđuje općim aktom zdravstvena ustanova u skladu s ovim Pravilnikom i drugim propisima, vodeći računa o djelatnosti ustanove, procesu rada u pojedinim njezinim dijelovima, godišnjem dobu te potrebama osiguranih osoba Hrvatskog zavoda za zdravstveno osiguranje (u daljnjem tekstu: Zavod) uz poštivanje načela kontinuiranosti, učinkovitosti i dostupnosti zdravstvene zaštite. Početak i završetak radnog vremena u pojedinim dijelovima zdravstvene ustanove kao i preraspodjelu radnog vremena kada se za to ukaže potreba određuje ravnatelj zdravstvene ustanove (Pravilnik o radnom vremenu, čl. 2.). Zdravstvene ustanove obvezne su pružati zdravstvenu zaštitu radom u jednoj, dvije ili više smjena, pomakom radnog vremena, u turnusima, pripravnošću, dežurstvom i radom po pozivu (Pravilnik o radnom vremenu, čl. 3.).

Raspored radnog vremena od 40 sati tjedno, odnosno odgovarajućeg ukupnog mjesečnog fonda sati u zdravstvenim ustanovama mora biti utvrđen tako da osigurava dostupnost zdravstvene zaštite osiguranim osobama Zavoda tijekom svih dana u tjednu, osim iznimno u ordinacijama primarne zdravstvene zaštite u kojima se ne mora osigurati 
Prava, obveze i odgovornosti radnika u obavljanju djelatnosti: Poslovi zdravstvenih radnika i način obavljanja

redoviti rad nedjeljom i blagdanom ako je zdravstvena zaštita osigurana u okviru djelatnosti hitne medicine (Pravilnik o radnom vremenu, čl. 4.). Prilikom utvrđivanja rasporeda radnog vremena, osim dežurstava i pripravnosti u određenim zdravstvenim ustanovama, ravnatelj zdravstvene ustanove treba uzeti u obzir i strukturu stanovništva s obzirom na dob, spol, vrstu zaposlenja i pobol, prometne i zemljopisne značajke područja te osobitosti sezonskog povećanja broja stanovništva (Pravilnik o radnom vremenu, čl. 5.). Iznimno, u slučaju nastupa posebnih okolnosti koje nalažu drukčiji raspored radnog vremena zdravstvenih ustanova ili radnika, ministar nadležan za zdravlje može odrediti i drukčiji početak i završetak radnog vremena, kao i drukčiju preraspodjelu radnog vremena, do isteka posebnih okolnosti (Pravilnik o radnom vremenu, čl. 15.). Obavijest o početku i završetku radnog vremena pojedinih ustanova, ustrojstvenih jedinica ustanova i ordinacija mora biti vidljivo i čitko označena na ulaznim vratima ustanove, odnosno ordinacije Voditelj ustrojstvene jedinice i ravnatelj ustanove odgovorni su za vođenje evidencije o radnom vremenu i za pridržavanje utvrđenog radnog vremena Iznimno, u slučaju nastupa posebnih okolnosti koje nalažu drukčiji raspored radnog vremena zdravstvenih ustanova ili radnika, ministar nadležan za zdravlje može odrediti i drukčiji početak i završetak radnog vremena, kao i drukčiju preraspodjelu radnog vremena, do isteka posebnih okolnosti (Pravilnik o radnom vremenu, čl. 17.). Nepoštivanje utvrđenog radnog vremena predstavlja težu povredu radne dužnosti zdravstvenih radnika Iznimno, u slučaju nastupa posebnih okolnosti koje nalažu drukčiji raspored radnog vremena zdravstvenih ustanova ili radnika, ministar nadležan za zdravlje može odrediti i drukčiji početak i završetak radnog vremena, kao i drukčiju preraspodjelu radnog vremena, do isteka posebnih okolnosti (Pravilnik o radnom vremenu, čl. 18.).

Prema odredbi čl. 30. Kolektivnog ugovora za djelatnost zdravstva i zdravstvenog osiguranja (Urednički pročišćeni tekst, „Narodne novine“, broj 143/13 i 96/15., dalje Kolektivni ugovor) puno radno vrijeme iznosi 40 sati tjedno. Tjedno radno vrijeme raspoređeno je na pet dana u tjednu, u pravilu od ponedjeljka do petka. Za organizaciju rada u djelatnosti zdravstva i zdravstvenog osiguranja odgovoran je poslodavac. Poslodavac je dužan organizirati rad na način da radnik odradi najmanje ugovoreni puni mjesečni fond radnih sati. U djelatnosti zdravstva i zdravstvenog osiguranja nema dvokratnog radnog vremena. Za posebne poslove koji se obavljaju u smjenskom radu ili poslove koji zahtijevaju drukčiji raspored dnevnog, odnosno tjednog radnog vremena poslodavac može odrediti drukčiji dnevni ili tjedni raspored, a u skladu s pravilnikom o radnom vremenu u zdravstvenim ustanovama koji donosi ministar nadležan za zdravlje, u okviru petodnevnoga radnog tjedna. U slučaju preraspodjele radnog vremena i rasporeda radnog vremena u smjenama, turnusu i dežurstvu, radno vrijeme svodi se na prosječno puno radno vrijeme na razini mjeseca.

Na poslovima na kojima ni uz primjenu mjera zaštite na radu nije moguće zaštititi radnika od štetnog utjecaja, radno vrijeme skraćuje se razmjerno štetnom utjecaju uvjeta rada na zdravlje i sposobnost radnika. Poslovi iz stavka 1. ovoga članka su poslovi:- s otvorenim izvorima ionizirajućeg zračenja,- intravenozna aplikacija citostatika, pod uvjetom da se obavljaju 2/3 radnog vremena.Za poslove iz stavka 1. ovoga članka određuje se opseg skraćenoga radnog vremena na 35 sati tjedno (Kolektivni ugovor, čl. 31.). Sati odrađeni prema redovitom rasporedu radnog vremena na blagdan ili neradni 
dan u smislu Zakona o blagdanima i neradnim danima i dan Uskrsa evidentiraju se kao redovni rad i ubrajaju u redovnu mjesečnu satnicu (Kolektivni ugovor, čl. 52.).

Radniku u djelatnosti zdravstva i zdravstvenog osiguranja na pojedinim radnim mjestima i poslovima kod kojih postoje posebni uvjeti rada pripada pravo na dodatak na plaću. Dodaci se ne mogu se kumulirati (kolektivni ugovor, čl. 57.). Osnovna plaća uvećat će se radnicima po osnovi položajnog dodatka na rukovodećim radnim mjestima i poslovima (Kolektivni ugovor, čl. 55.).

\subsection{Utvrđivanje potrebe za dežurstvom i pripravnošću}

Ravnatelj zdravstvene ustanove utvrđuje potrebu za dežurstvom i pripravnošću radnika prema kriterijima osiguravanja pružanja hitne medicinske pomoći, odnosno potrebe zbrinjavanja životno ugrožavajućih stanja, pri čemu se uzima u obzir kategorija zdravstvene ustanove, vrsta djelatnosti i raspoloživi kapaciteti zdravstvene ustanove (Pravilnik o radnom vremenu, čl. 14.).

\subsubsection{Dežurstvo}

jest oblik rada kada radnik mora biti nazočan u zdravstvenoj ustanovi nakon redovitoga radnog vremena. Dežurstvo počinje iza prve ili druge smjene, a završava početkom rada prve smjene (ZZZ, čl. 162. st. 2.). Dežurstvo je oblik rada kada radnik mora biti nazočan u zdravstvenoj ustanovi nakon redovitoga radnog vremena ustanove, odnosno vrijeme u kojem je spreman (raspoloživ) obavljati poslove prema uputama poslodavca, na mjestu gdje se njegovi poslovi obavljaju ili drugom mjestu koje odredi poslodavac. Vrijeme koje radnik provede u dežurstvu smatra se radnim vremenom. Primopredaja službe nakon dežurstva mora biti unutar 30 minuta po prestanku dežurstva, koje vrijeme se ne računa u radno vrijeme. Ukoliko je dežurstvo određeno unutar redovnog mjesečnog fonda radnih sati, vrijeme provedeno u dežurstvu plaća se kao redovan rad. Vrijeme provedeno u dežurstvu iznad mjesečnog fonda radnih sati plaća se kao prekovremeni rad. Za radnike kojima je u koeficijentu složenosti poslova sadržan položajni dodatak ili taj dodatak ostvaruju temeljem odredbi ovoga Ugovora, plaća za vrijeme dežurstva iznad redovnog mjesečnog fonda radnih sati obračunava se u odnosu na osnovnu plaću radnog mjesta na kojem radnik dežura (Kolektivni ugovor, čl. 53.). Odredbe o dežurstvu odnose se i na radnike koji su upućeni na specijalističku edukaciju ili edukaciju iz uže specijalizacije u drugu zdravstvenu ustanovu.Plaću radniku isplaćuje ustanova u kojoj je u radnom odnosu, a isplaćeni iznos po osnovi dežurstva refundira ustanova u koju je radnik upućen.Ustanova u koju je radnik upućen dužna je o radniku voditi evidenciju radnog vremena i posebno vrijeme provedeno u dežurstvu te istu evidenciju, radi obračuna plaće, dostaviti ustanovi u kojoj je radnik zaposlen, najkasnije do 5. u mjesecu za prethodni mjesec (Kolektivni ugovor, čl. 55). Dežurstvo je definirano kao oblik rada pri kojem radnik mora biti nazočan u zdravstvenoj ustanovi nakon redovitoga radnog vremena, te počinje iza prve ili druge smjene, a završava početkom rada prve smjene. Ima slučajeva da radnik stvarno ne radi, ali za to nije kriv. On je raspoloživ (spreman) za rad i na mjestu koje određuje poslodavac, ali postoje razlozi zbog kojih ne obavlja radne zadatke. U takve slučajeve ubraja se i dežurstvo. Dežurstvo je radno vrijeme. To je rad na mjestu koje 
Prava, obveze i odgovornosti radnika u obavljanju djelatnosti: Poslovi zdravstvenih radnika i način obavljanja

određuje poslodavac bez obzira što radnik de facto ne radi, već dežura. Može i obavljati posao prema naravi i potrebama. Ima dežurstva gdje radnik može na dežurstvu odmarati pa i spavati, ali je raspoloživ za rad kada se ukaže potreba (rad u komunalnom gospodarstvu, zdravstvu i dr.). Dežurstvo počinje iza prve ili druge smjene, a završava početkom prve smjene, a vrijeme provedeno u zdravstvu u dežurstvu smatra se radnim vremenom. Za vrijeme dežurstva može biti i na raspolaganju prostorija za odmor. Plaća se svo vrijeme dežurstva, a ne samo sati de facto (stvarno) odrađeni. Takva je praksa i u Europskoj uniji, po direktivi 93/104/EZ. Radno vrijeme u dežurstvu je radno vrijeme koje se računa puno radno vrijeme od 40 sati tjedno. Može biti preračunato i u preraspodijeli sve drugo je prekovremeni rad. U skladu sa zakonom autonomnim općim aktima (kolektivnim ugovorom, pravilnicima i sl.) treba zaštititi radnika u dežurstvu, zaštititi njegov život i zdravlje uz maksimalno uvažavanje mjera i sredstava zaštite na radu, a pod tim se podrazumijeva i radno vrijeme, odmori i dopusti, a dakako plaćanje toga i takvoga rada. $^{2}$

\subsubsection{Pripravnost}

jest oblik rada kada radnik ne mora biti nazočan u zdravstvenoj ustanovi, ali mora biti dostupan radi obavljanja hitne medicinske pomoći (ZZZ, čl. 162. st. 3.). Pripravnost je vrijeme $u$ kojem je radnik pripravan odazvati se pozivu poslodavca za obavljanje poslova, ako se ukaže takva potreba pri čemu se radnik ne nalazi na mjestu gdje se njegovi poslovi obavljaju niti na drugom mjestu koje je odredio poslodavac. Radnik koji je u pripravnosti obvezan je odazvati se na poziv poslodavca bez odgode i doći na radno mjesto najkasnije u roku od jednog sata. Radnik nadslužbe koji zahtjeva pozivanje na rad radnika koji je u pripravnosti, za potrebu njegova dolaska iz pripravnosti na radno mjesto odgovara pod punom kaznenom i materijalnom odgovornošću. Podaci o broju pripravnosti po radniku kao i o broju dolazaka na rad iz pripravnosti moraju se voditi u posebnoj evidenciji, a evidencija mora sadržavati razlog svakog pojedinačnog poziva na rad, ime i prezime radnika nadslužbe koji je zahtijevao pozivanje radnika na rad te vrijeme provedeno na radnom mjestu po pozivu poslodavca (Pravilnik o radnom vremenu, čl. 14.). Pripravnost jest oblik rada kada radnik ne mora biti nazočan u zdravstvenoj ustanovi, ali mora biti dostupan radi obavljanja hitne medicinske pomoći. Pripravnost je vrijeme u kojem je radnik pripravan odazvati se pozivu poslodavca za obavljanje poslova, ako se ukaže takva potreba, pri čemu se radnik ne nalazi na mjestu gdje se njegovi poslovi obavljaju niti na drugom mjestu koje je odredio poslodavac. Radnik koji je u pripravnosti obvezan je odazvati se na poziv poslodavca bez odgode i doći na radno mjesto, a najkasnije u roku od jednog sata. Pripravnost radnim danom traje 16 sati, a subotom, nedjeljom i blagdanom 24 sata. Za vrijeme provedeno u pripravnosti radniku pripada naknada za pripravnost. Naknada za pripravnost utvrđuje se u odnosu na osnovnu plaću radnika i iznosi:- 16 sati radnim danom -3\%-24 sata subotom, nedjeljom i blagdanom - 5\%. Vrijeme koje radnik, kojem je određena pripravnost, provede na radnom mjestu obavljajući poslove po pozivu poslodavca, smatra se radnim vremenom i plaća kao prekovremeni rad. Za radnike kojima je u koeficijentu složenosti poslova sadržan položajni dodatak ili taj dodatak ostvaruju temeljem odredbi ovoga Ugovora, naknada za pripravnost obračunava se u odnosu na osnovnu plaću radnog mjesta na kojem je radnik pripravan (Kolektivni ugovor, čl. 54.). Zbog nedostatka kadrova, ponekad i zbog racionalizacije službe, u nekim segmentima 
neprekidna zdravstvena zaštita pruža se kroz pripravnost. Potpisnici Kolektivnog ugovora detaljno su ugovorili oblike pripravnosti i način plaćanja. Vrijeme provedeno u pripravnosti ne smatra se radnim vremenom. Radnik u pripravnosti nema pravo na minimalni dnevni odmor nakon provedene pripravnosti i obvezan je redovito javljati se na posao bez obzira u koje vrijeme dana i noći je intervenirao po pozivu. Naknade za rad u pripravnosti sastavni su dio plaće. Pripravnost se dijeli na standardnu pripravnost i pripravnost na bolničkim odjelima i službama gdje nije organizirano dežurstvo. Za rad u pripravnosti poslodavac ne treba pribaviti suglasnost radnika.

Zakon o radu („Narodne novine“, broj 93/14, dalje - ZR) u članku 60. stavak 2. propisuje da se radnim vremenom ne smatra vrijeme u kojem je radnik pripravan odazvati se po pozivu poslodavca za obavljanje poslova, ako se ukaže takva potreba, pri čemu se radnik ne nalazi na mjestu gdje se njegovi poslovi obavljaju niti na drugom mjestu koje je odredio poslodavac. Tijekom razdoblja pripravnosti radnikova obveza obavljanja posla ovisi o slučajnosti i nema kontinuitet, pa u tom slučaju radnik može, iako na ograničeni način, upravljati svojim vremenom, s obzirom na to da ne mora biti prisutan na radnom mjestu. Međutim, vrijeme koje je radnik proveo obavljajući poslove po pozivu poslodavca, smatra se radnim vremenom, neovisno o tome obavlja li radnik te poslove u mjestu koje je odredio poslodavac ili u mjestu koje je odabrao radnik, sukladno članku 60. stavak 4. ZR-a. Vrijeme pripravnosti ne smatra se radnim vremenom pa, stoga, ne će ulaziti u ograničenja broja sati rada na razini tjedna. Pri određivanju obveze radnika na pripravnost valja voditi brigu o članku 60. stavak 3. ZR-a, kojim su utvrđeni uvjeti pod kojima radnik može biti pripravan. Poslodavac može radniku odrediti obvezu pripravnosti samo ako je vrijeme pripravnosti i visina naknade za nju utvrđena ugovorom o radu ili kolektivnim ugovorom. Pritom jasno valja voditi brigu o aktu kojim je obveza pripravnosti utvrđena. Poslodavac, dakle, ne može obvezu pripravnosti radnika utvrditi svojom odlukom, pravilnikom o radu ili sporazumom poslodavca s radničkim vijećem, već se obveza mora ugovoriti, bilo individualno s radnikom kroz ugovor o radu ili kolektivno sa sindikatom kroz kolektivni ugovor. U protivnom radnik nema obvezu biti pripravan. Kao drugi uvjet za uvođenje obveze pripravnosti radnika, ZR utvrđuje i ugovaranje visine naknade za rad u pripravnosti. Prema tome, poslodavac je dužan odgovarajućim aktom utvrditi i visinu naknade na koju radnik ima pravo zbog obveze pripravnosti. Ako pođemo od činjenice da se vrijeme koje radnik provede obavljajući poslove po pozivu poslodavca, smatra radnim vremenom, tada bi - ako je radnik, primjerice, prema rasporedu radnog vremena odradio svoju smjenu, potom je nakon radnog vremena imao obvezu pripravnosti, i tijekom pripravnosti se odazvao pozivu poslodavca za obavljanje poslova (npr. hitna intervencija) - imao pravo na plaću za svoje redovito radno vrijeme, naknadu u vrijeme pripravnosti u visini utvrđenoj kolektivnim ugovorom ili ugovorom o radu, te ako je po pozivu poslodavca obavio posao, i pravo na povećanu plaću po osnovi prekovremenog rada. ${ }^{3}$

\subsubsection{Rad po pozivu}

Pripravnost je definirana kao oblik rada pri kojem radnik ne mora biti nazočan u zdravstvenoj ustanovi, ali mora biti dostupan radi obavljanja hitne medicinske pomoći, a rad po pozivu oblik je rada pri kojem radnik ne mora biti nazočan u zdravstvenoj ustanovi, 
Prava, obveze i odgovornosti radnika u obavljanju djelatnosti: Poslovi zdravstvenih radnika i način obavljanja

ali se mora odazvati na poziv, radi obavljanja djelatnosti. Rad po pozivu jest oblik rada kada radnik ne mora biti dostupan poslodavcu, ali ako primi poziv poslodavca i ako je u fizičkoj mogućnosti, mora se odazvati pozivu radi obavljanja djelatnosti kada nastane problem iz sadržaja rada djelatnosti zdravstvene ustanove koji nazočni radnici ne mogu riješiti, niti se rješavanje problema može odgoditi (ZOZZ, čl. 162. st. 8). Rad po pozivu smatra se prekovremenim radom i tako se plaća. U rad po pozivu, prema stavku 1. ovoga članka, uz efektivni rad, u radno vrijeme koje se računa kao prekovremeni rad, uključeno je i vrijeme potrebno za dolazak na posao i povratak kući. Iznimno od stavka 2. ovoga članka povećanje plaće za rad po pozivu eksplantacijskih i transplantacijskih timova u ovlaštenim transplantacijskim centrima za postupke eksplantacije i transplantacije organa u okviru transplantacijskog programa, ministar zdravlja odredit će posebnom odlukom (Kolektivni ugovor, čl. 55.). Isplata na osnovi rada po pozivu sastavni je dio plaće. ${ }^{4}$

Vidjeli smo, vrijeme provedeno u dežurstvu i rad po pozivu smatra se radnim vremenom (ZOZZ, čl. 162. st. 4.). Evidentirani rad u obliku dežurstva i rada po pozivu, kao što je naprijed navedeno, smatra se radnim vremenom, te njihovo uvođenje potpada pod sustav ograničenosti trajanja radnog vremena, po odluci poslodavca, do 48 sati tjedno. Iznad toga potrebna je pisana suglasnost radnika. To znači da se vrijeme provedeno u dežurstvu ne može uzimati kao prekovremeni rad, kao što je to rad po pozivu. ${ }^{5}$ Isplata na osnovi rada u dežurstvu i rada po pozivu te naknade za rad u pripravnosti sastavni je dio plaće (ZOZZ, čl. 162. st. 7.)._Ako pripravnost i visina naknade za nju nisu uređeni ugovorom o radu, odnosno kolektivnim ugovorom, radnik nije dužan na nalog poslodavca biti u pripravnosti i zbog toga ne smije snositi nikakve posljedice.

\subsubsection{Dodatni rad}

Pravilnik o mjerilima za davanje odobrenja zdravstvenom radniku za sklapanje poslova iz djelatnosti poslodavca stupio je na snagu 27. listopada 2015. i objavljen je na stranicama („Narodne novine“ br. 113/15) Liječnici koji su zaposleni u državnim bolnicama prema Pravilniku o dopunskom radu, mogu legalno raditi kod privatnika, isključivo uz odobrenje za dodatni rad koje mogu dobiti pod određenim uvjetima. Odobrenje izdaje ravnatelj ustanove, a moći će ga dobiti isključivo liječnici koji u svojoj matičnoj zdravstvenoj ustanovi obave više posla i značajno skrate liste čekanja. Odobrenje za dodatni rad dobit će liječnik koji odradi više od svoje prosječne bruto plaće pomnožene s koeficijentom djelatnosti za koju se traži odobrenje. 
Prava, obveze i odgovornosti radnika u obavljanju djelatnosti: Priznavanje inozemnih stručnih kvalifikacija

\section{Primjedbe}

${ }^{1}$ Zdravstvene ustanove svojim općim aktom utvrđuju pružanje zdravstvene zaštite i to:

- u djelatnosti hitne medicine neprekidno 24 sata, te pripravnošću i dežurstvom prema potrebama stanovništva,

- u primarnoj zdravstvenoj djelatnosti organiziranjem rada u jednoj ili dvije smjene, pomicanjem radnog vremena te pripravnošću i dežurstvom prema potrebama stanovništva,

$-\mathrm{u}$ specijalističko-konzilijarnoj zdravstvenoj djelatnosti organiziranjem rada u jednoj ili dvije smjene

te pomicanjem radnog vremena prema potrebama stanovništva,

$-\mathrm{u}$ bolničkoj zdravstvenoj djelatnosti u jednoj ili više smjena te putem dežurstva i pripravnosti prema

potrebama stanovništva i pojedinih oblika bolničkog liječenja te mogućnostima zdravstvene ustanove (ZZZ, čl. 163.).

${ }^{2}$ UČUR, Đ. M., Radno vrijeme u đežurstvu, podatak na stranici https://burza.com.hr/portal/radnovrijeme-u-dezurstvu/9261.

3 Usp. Pitanja $i$ odgovori: Pripravnost $i$ prava radnika iz rada, podatak na stranici http://www.poslovni.hr/tips-and-tricks/pitanja-i-odgovori-pripravnost-i-prava-radnika-iz-rada245330.

${ }^{4}$ Tako BABIĆ, I., Rad u dežurstvu, rad u pripravnosti i rad po pozivu kod zdravstvenih radnika rad po pozivu kod zdravstvenih radnik, PRILOG ČASOPISU RAČUNOVODSTVO, REVIZIJA I FINANCIJE, br. 4/2012., str. 40.-44.

5 Vidi Dežurstvo, pripravnost $i$ rad po pozivu, podatak na stranici http://upuz.hr/aktualnosti/dezurstvo-pripravnost-i-rad-po-pozivu. 
132 | ZDRAVSTVENO STRUKOVNO STALEŠKO PRAVO 


\section{2/ Međusobni odnosi zdravstvenih radnika}

\subsection{Dužnost međusobne suradnje}

Liječnik je svojim ponašanjem i postupkom dužan poštivati čast, dostojanstvo i ugled drugoga liječnika, uvažavajući njegovu stručnost (Zakon o liječništvu, čl. 27.). KMED u Temeljnim načelima, članku 1. točki 5., određuje da je liječnik u svojem djelovanju dužan čuvati ugled i dostojanstvo liječničkog staleža i časno se odnositi prema Kolegama.

U procesu pružanja medicinske usluge uspostavljaju se, pored odnosa liječnika i pacijenta, i međusobni odnosi između samih liječnika, odnosno zdravstvenih radnika. Iako se o tome manje piše negoli o odnosu liječnika prema pacijentima, odnos liječnika prema drugim zdravstvenim radnicima ne treba zanemariti jer ako taj odnos nije dobar, vrlo je upitno i dobro obavljanje posla, odnosno glavne zadaće liječnika, a to je briga za zdravlje bolesnika. ${ }^{1}$ Od liječnika se, kao članova medicinske profesije, tradicionalno očekivalo i očekuje da se jedni prema drugima odnose više kao članovi obitelji, a ne kao stranci ili prijatelji. ${ }^{2}$ Što se odnosa prema drugim liječnicima i struci tiče, KMED propisuje da je častan liječnik dužan odnositi se prema drugim liječnicima onako kako bi želio da se oni odnose prema njemu (KMED, čl. 9. toč. 1.).

Liječnikova je dužnost nastojati s kolegama i suradnicima imati takve odnose koji neće remetiti dobro obavljanje posla. Mogući nesporazumi, bez obzira na to tko ih je skrivio i jesu li se mogli izbjeći i raščistiti, ne smiju ni na koji način opteretiti obavljanje posla. ${ }^{3}$ Iznošenje negativnog mišljenja o drugom liječniku u prisustvu pacijenta, zdravstvenog osoblja ili laičke javnosti je nedopustivo. Uvrede, podcjenjivački komentari i neopravdane kritike kolega liječnika u javnosti predstavljaju sramotnu degradaciju liječničke profesije. ${ }^{4} \mathrm{Ti}$ odnosi su, s jedne strane, regulirani radno pravnim propisima, a s druge strane, normama zdravstvenog prava, pravilima struke i staleškim etičkim normama. Za slučaj da pravne norme ne reguliraju neku situaciju u međusobnim odnosima liječnika, mjerodavne su etičke norme.

Odnose među liječnicima obilježavaju značajke osobnosti samih liječnika stečene rođenjem, odgojem, sredinom u kojoj su odrasli i edukacijom, obilježja sredine u kojoj rade, organizacija posla, zadovoljstvo ili frustracije na radnom mjestu, pozitivno ili negativno radno ozračje s mogućnosti razvitka konfliktnih situacija, te mudrost ili nerazumijevanje nadređenih za nastale probleme. Sustavi koji imaju razvijene mehanizme za uklanjanje potencijalno konfliktnih situacija između zdravstvenih radnika, osobito između liječnika stvaraju poticajnu atmosferu za rad koja dovodi do kvalitetnije zdravstvene skrbi i posljedično boljih rezultata liječenja kao i većeg povjerenja bolesnika u liječnike. ${ }^{5}$ Svi odnosi između liječnika u procesu pružanja zdravstvene usluge pacijentu u jednoj zdravstvenoj ustanovi ili u različitim zdravstvenim ustanovama utemeljeni su na razmjeni stručnog znanja i iskustva, kao i na načelima korektnosti, poštivanja i iskrenosti. U postupku pružanja zdravstvenih usluga i stručnog rada liječnika uspostavlja se međusobna komunikacija liječnika različitih specijalnosti u cilju dijagnosticiranja, 
Prava, obveze i odgovornosti radnika u obavljanju djelatnosti: Međusobni odnosi zdravstvenih radnika

liječenja i rehabilitacije pacijenata te timski rad u tijeku samog pružanja zdravstvene zaštite kada je on nužan. ${ }^{6}$ Svi zdravstveni radnici dužni su međusobno surađivati radi primjene načela činjenja dobra i izbjegavanja nanošenja štete bolesniku, načela pravednosti, načela poštovanja života i načela poštovanja osobnosti bolesnika. Kvalitetna međusobna komunikacija zdravstvenih radnika temelj je uspješnog liječenja. ${ }^{7}$

\subsection{Pružanje stručnih savjeta}

Ako drugi liječnik zatraži od njega stručni savjet i/ili pomoć, izravno ili na drugi način, pružit će mu je nesebično i prema svom najboljem znanju (KMED, čl. 9. toč. 3.). i vještini, a sve u korist bolesnika. Kad liječnik zatraži stručni savjet ili pomoć, drugi liječnik treba mu je pružiti nesebično i prema svom najboljem znanju, u korist bolesnika. Pozvani liječnik ne smije odbiti pružiti traženu stručnu pomoć u vidu konzultacija jer je svaki liječnik dužan svoje stručno znanje ne samo prenositi kolegama nego i primjenjivati suvremene metode dijagnostike i liječenja u skladu sa standardima suvremene medicine, medicinske profesije, etike i humanosti. Ukoliko liječnik procijeni da se radi o kompliciranom slučaju i da mu je u procesu liječenja potreban stručni savjet, dužan je predložiti formiranje liječničkog konzilija. U teškim i kompliciranim slučajevima, ordinirajući liječnik je dužan, bez obzira na njegovo radno mjesto i stručnu osposobljenost, odlučivati konzilijarno. Liječnik ne može odbiti sudjelovanje u konziliju. Smatra se da je poziv na konzilij izraz povjerenja u znanje i sposobnost određenog liječnika. Konzilij čine najmanje dva liječnika. Kada u sastavu konzilija sudjeluje više liječnika, bira se predsjednik konzilija koji je odgovoran za način rada i utvrđivanje mišljenja konzilija koje je nadležno za daljnje postupke i liječenje bolesnika. U konziliju svi liječnici imaju ista prava. ${ }^{8}$

\subsection{Stručna kritika}

To nikako ne znači da u međusobnim odnosima između liječnika nije dopuštena ili da je nepoželjna stručna kritika. Stručna kritika je moguća u okviru struke, u prisustvu liječnika, uključujući i kritiziranog. ${ }^{9}$

Suradnike ili drugo osoblje liječnik je dužan upućivati na učinjene propuste na način koji neće povrijediti njihovo ljudsko i profesionalno dostojanstvo, a nikad u javnosti pred bolesnikom ili njegovim bližnjima, osim u slučaju neposredne izloženosti riziku $s$ mogućim trajnim posljedicama po zdravlje i život. Razlike u stručnim mišljenjima i praksi izrazit će na odgovoran, argumentiran i prikladan način (KMED, čl. 9. toč. 7.). Takav postupak ne bi smio razotkriti u sredstvima javnog priopćavanja. Liječnik koji je u procesu pružanja zdravstvene usluge otkrio propust (zbog kojeg planirana medicinska usluge nije poduzeta ili je završena onako kako nije bilo naloženo ili kako je predviđeno ili je primijenjen pogrešan plan u cilju dijagnosticiranja, liječenja ili terapije) ili stručnu grešku svog kolege liječnika, liječnika suradnika ili liječnika na specijalizaciji i koji je poduzeo mjere da se nastala stručna greška sanira ili otkloni, dužan je ponašati se u skladu s etičkim normama liječničke profesije. Suradniku, specijalizantu ili drugom osoblju liječnik je dužan ukazati na učinjene propuste $\mathrm{i}$ to na način koji ne vrijeđa njihovo dostojanstvo. Liječnik je dužan suradnicima ili specijalizantima ukazati na učinjene 


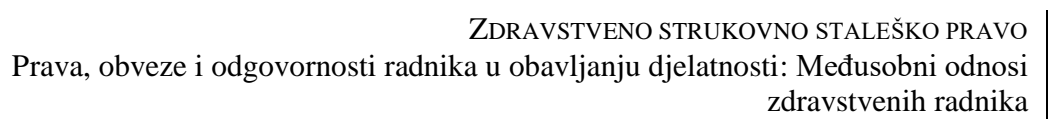

propuste nasamo, a nikad pred bolesnikom ili njegovim bližnjima. ${ }^{10}$ Ocjena mora biti objektivna i argumentirana, bez osobne ostrašćenosti ili drugog subjektivizma. Prilikom ukazivanja na propuste, on je dužan ne vrijeđati, klevetati, omalovažavati ili javno kritizirati suradnika ili specijalizanta kome se potkrao ili dogodio propust ili stručna greška. O stručnim greškama do kojih je eventualno došlo, liječnik ne smije raspravljati sa samim pacijentom, njegovom rodbinom ili o tome obavještavati sredstva javnog informiranja. ${ }^{11}$

Pored zahtijeva za postupanje prema kolegama s uvažavanjem i za rad u suradnji kako bi se načinilo sve potrebno u skrbi za bolesnika, Međunarodni kodeks medicinske etike Svjetskoga liječničkog udruženja (SLU) sadrži tri ograničenja vezana uz međusobne odnose liječnika: (1) nije dopušteno davati ili primati nikakvu novčanu naknadu ili uslugu da bi se određenog bolesnika uputilo nekom određenom liječniku; (2) nije dopušteno pridobivati bolesnika od svojih kolega i (3) postoji obveza prijavljivanja neetičnog i nestručnog ponašanja kolega. ${ }^{12}$

\subsection{Obveza prijavljivanja nestručnog i pogrešnog vođenja bolesnika}

Obveza prijavljivanja nestručnosti, ozljeđivanja ili pogrešnog vođenja bolesnika od strane drugog liječnika naglašena je u kodeksima medicinske etike. U slučaju da liječnik sazna za neetičan, nemoralan ili medicinski neodgovarajući postupak kolege, o tome je obvezan upozoriti kolegu, njemu nadređenu osobu, Hrvatsku liječničku komoru i Hrvatski liječnički zbor (KMED, čl. 9. toč. 8.). Liječnik se ne smije baviti prijavama koje imaju za cilj nekoga povrijediti ili poniziti, a ne zaštititi struku (KMED, čl. 9. toč. 8.). Prvi bi korak trebao biti kontakt s kolegom kojemu bi trebalo priopćiti da njegovo ponašanje smatrate opasnim i neetičnim. Ako se problem može riješiti na toj razini, nema potrebe za poduzimanjem daljnjih koraka. Ukoliko to nije moguće, problem bi trebalo raspraviti s prijestupnikovim nadređenima i odluku o daljnjem postupanju prepustiti njima. Ako ni taj pristup nije urodio plodom treba poduzeti zadnji korak, obavijestiti disciplinska tijela. Prijavljivanje kolega trebalo bi biti zadnjom instancom nakon što su iscrpljene sve ostale mogućnosti. ${ }^{13}$

\subsection{Neovlašteno pridobivanje pacijenata}

Liječnik neće pridobivati pacijente svojih kolega (KMED, čl. 9. toč. 4.), liječnik može preuzeti skrb nad bolesnikom drugog liječnika samo na zahtjev dotičnog liječnika ili pacijenta, o čemu je dužan obavijestiti tog drugog liječnika (KMED, čl. 9. toč. 5.).

\subsection{Upućivanje pacijenta drugom liječniku}

Obveza je liječnika koji upućuje pacijenta drugom liječniku obavijesti ti tog drugog liječnika o pojedinostima koje bi mogle na bilo koji način štetiti, odnosno ugroziti zdravlje ili život liječnika, te dostaviti svu raspoloživu zdravstvenu dokumentaciju (KMED, čl. 9. toč. 6.). 
Prava, obveze i odgovornosti radnika u obavljanju djelatnosti: Međusobni odnosi zdravstvenih radnika

\subsection{Poštivanje učitelja}

Svojim učiteljima iskazivat će poštovanje i zahvalnost za znanje, vještine i odgoj koje je od njih primio (KMED, čl. 9. toč. 2.). U tradicionalnoj Hipokratskoj medicinskoj etici, liječnici su dužni posebno poštivati svoje učitelje. Ženevska liječnička prisega je to ovako odredila: "Svojim ću učiteljima pružiti poštovanje i zahvalnost koje oni zaslužuju". Iako su u današnjem medicinskom obrazovanju odnosi student-nastavnik mnogostruki, a ne jedan-na-jedan kao u prijašnjim vremenima, još uvijek oni ovise o dobroj volji i zalaganju liječnika praktičara koji često ne primaju naknadu za svoje nastavne aktivnosti. Stoga studenti medicine i ostali koji se obučavaju za svoje specijalizacije, duguju duboku zahvalnost svojim nastavnicima bez kojih bi medicinsko obučavanje bilo svedeno na samopodučavanje. Nastavnici imaju posebnu obvezu ne tražiti od studenata da slijede neetičnu praksu. Studenti koji se zanimaju za etička pitanja tijekom svog obrazovanja trebaju biti u mogućnosti iznijeti svoje primjedbe o etičkim pitanjima, a da ih se nužno ne proglasi "zviždačima". Također moraju imati i odgovarajuću podršku za rješavanje određenoga uočenog problema putem formalne procedure. Od studenata se medicine, $s$ njihove strane, očekuje pokazivanje visokih standarda etičkog ponašanja, kako to $i$ dolikuje budućim liječnicima. Oni se trebaju odnositi prema ostalim studentima kao prema kolegama i biti spremni pružiti pomoć kada je ona potrebna, uključujući savjete za ispravljanje neprofesionalnog ponašanja. Također bi trebali sudjelovati u zajedničkim projektima $\mathrm{i}$ ispunjavati određene dužnosti, poput raznih studentskih zadaća i dežurstava. ${ }^{14}$ 


\section{Primjedbe}

1 Vidi ŠMALCELJ, R., Rad u bolnici, poglavlje u knjizi „Medicinska etika 1, urednica ZNIDARČIĆ, Ž., Centar za bioetiku, Zagreb, 2004., str. 139.

2 Ženevska liječnička prisegauključuje obvezu "Moji će mi kolege biti moji braća i sestre". MUSTAJBEGOVIĆ, J., Liječnici i njihove kolege u svjetlu svjetskog liječničkog udruženja, rad u knjizi „Odnosi među liječnicima u Hrvatskoj“, Knjiga izlaganja na XIV. proljetnom simpoziju medicinske etike Hrvatskoga liječničkog zbora, Zagreb, 10. lipnja 2014., urednik Goran Ivanišević, Hrvatski liječnički zbor, Zagreb, 2014., str. 10.

3 Usp. ŠMALCELJ, R., Rad u bolnici, poglavlje u knjizi „Mdicinska etika 1, urednica ZNIDARČIĆ, Ž., Centar za bioetiku, Zagreb, 2004., str. 142.

${ }^{4}$ U tom smislu STOJANOVIĆ, I., Međusobni odnosi lekara, „Pravni život“, 2013., broj 9, TOM I, str. 401.

${ }^{5}$ Pogledaj kod ŽOKALJ, I. - SABLJAR MATOVINOVIĆ, ., Odnosi među liječnicima u radu Povjerenstva za medicinsku etiku i deontologiju Hrvatske liječničke komore, rad u knjizi „Odnosi među liječnicima u Hrvatskoj“, Knjiga izlaganja na XIV. proljetnom simpoziju medicinske etike Hrvatskoga liječničkog zbora, Zagreb, 10. lipnja 2014., urednik Goran Ivanišević, Hrvatski liječnički zbor, Zagreb, 2014., str. 38.

${ }^{6}$ Tako STOJANOVIĆ, I., Međusobni odnosi lekara, „Pravni život“, 2013., broj 9, TOM I, str. 395.396.

${ }^{7}$ Vidi MAHMUTEFENDIĆ, I., Načelo suradnje i dobrih odnosa među zdravstvenim radnicima $u$ svrsi dobrobiti bolesnika, rad u knjizi „Odnosi među liječnicima u Hrvatskoj“, Knjiga izlaganja na XIV. proljetnom simpoziju medicinske etike Hrvatskoga liječničkog zbora, Zagreb, 10. lipnja 2014., urednik Goran Ivanišević, Hrvatski liječnički zbor, Zagreb, 2014., str. 28.

${ }^{8}$ Usp. STOJANOVIĆ, I., Međusobni odnosi lekara, „Pravni život“, 2013., broj 9, TOM I, str. 399. ${ }^{9}$ Ibid., str. 401.

${ }^{10}$ Međutim, primjena tog principa je malokad laka. Naime, liječnik može napasti ugled kolege zbog nedostojnih osobnih motiva, kao što su ljubomora ili osveta. No, istovremeno liječnik može ne biti voljan prijaviti kolegino loše ponašanje zbog prijateljstva ili simpatije. Posljedice, pak, samog prijavljivanja mogu biti vrlo štetne za onog tko prijavljuje, uključujući gotovo sigurnim neprijateljstvo optuženog, a također i onih koji su na strani optuženog. Usprkos tim zaprekama izvješćivanje o krivom radu predstavlja profesionalnu dužnost liječnika. Ne samo da su liječnici odgovorni za održavanje dobrog ugleda profesije, nego su često jedini koji prepoznaju nestručnost, ili pogrešno vođenje bolesnika. Svjetsko liječničko udruženje - Priručnik medicinske etike, Medicinska naklada, Zagreb, 2010., str. 87.; vidi i MUSTAJBEGOVIĆ, J., Liječnici i njihove kolege u svjetlu svjetskog liječničkog udruženja, rad u knjizi „Odnosi među liječnicima u Hrvatskoj“, Knjiga izlaganja na XIV. proljetnom simpoziju medicinske etike Hrvatskoga liječničkog zbora, Zagreb, 10. lipnja 2014., urednik Goran Ivanišević, Hrvatski liječnički zbor, Zagreb, 2014., str. 11.

${ }^{11}$ Vidi STOJANOVIĆ, I., Međusobni odnosi lekara, „Pravni život“, 2013., broj 9, TOM I, str. 400.

${ }^{12}$ Tako MUSTAJBEGOVIĆ, J., Liječnici i njihove kolege u svjetlu svjetskog liječničkog udruženja, rad u knjizi „Odnosi među liječnicima u Hrvatskoj“, Knjiga izlaganja na XIV. proljetnom simpoziju medicinske etike Hrvatskoga liječničkog zbora, Zagreb, 10. lipnja 2014., urednik Goran Ivanišević, Hrvatski liječnički zbor, Zagreb, 2014., str. 10.

${ }^{13}$ Svjetsko liječničko udruženje - Priručnik medicinske etike, Medicinska naklada, Zagreb, 2010., str. 87.; vidi i MUSTAJBEGOVIĆ, J., Liječnici i njihove kolege u svjetlu svjetskog liječničkog udruženja, rad u knjizi „Odnosi među liječnicima u Hrvatskoj“, Knjiga izlaganja na XIV. proljetnom simpoziju medicinske etike Hrvatskoga liječničkog zbora, Zagreb, 10. lipnja 2014., urednik Goran Ivanišević, Hrvatski liječnički zbor, Zagreb, 2014., str. 11. Sukobi trebaju biti riješeni na što je moguće neformalan način, kroz izravan razgovor između osoba koje se ne slažu, 
Prava, obveze i odgovornosti radnika u obavljanju djelatnosti: Međusobni odnosi zdravstvenih radnika

idući prema više formalnim postupcima, samo onda ako su neformalne mjere bile neuspješne. Mišljenja svih izravno uključenih trebaju biti iznesena na vidjelo i treba im se dati odgovarajuća važnost. Ukoliko nakon razumnih napora ne postoji mogućnost postizanja dogovora ili kompromisa kroz dijalog, treba prihvatiti odluku osobe koja ima pravo donošenja odluke. U slučaju da je nejasno ili sporno tko ima pravo donošenja odluke treba tražiti posredovanje drugih. Kod razrješavanja nesuglasica oko postupaka liječenja, pristanak obaviještenog bolesnika ili njegovog zakonskog zastupnika odnosno skrbnika treba biti presudan. Ako se liječnici ne slažu s odlukom o provođenju određenog terapijskog postupka uslijed stručne procjene ili osobnih etičkih vrijednosti, treba im omogućiti da se povuku iz sudjelovanja u donošenju odluka nakon što su se uvjerili da osobi kojoj se pruža medicinska skrb ne prijeti nikakva opasnost od nanošenja štete. MUSTAJBEGOVIĆ, J., Liječnici i njihove kolege u svjetlu svjetskog liječničkog udruženja, rad u knjizi „Odnosi među liječnicima u Hrvatskoj“, Knjiga izlaganja na XIV. proljetnom simpoziju medicinske etike Hrvatskoga liječničkog zbora, Zagreb, 10. lipnja 2014., urednik Goran Ivanišević, Hrvatski liječnički zbor, Zagreb, 2014., str. 11.

${ }^{14}$ Svjetsko liječničko udruženje - Priručnik medicinske etike, Medicinska naklada, Zagreb, 2010., str. 92.; vidi i MUSTAJBEGOVIĆ, J., Liječnici i njihove kolege u svjetlu svjetskog liječničkog udruženja, rad u knjizi „Odnosi među liječnicima u Hrvatskoj“, Knjiga izlaganja na XIV. proljetnom simpoziju medicinske etike Hrvatskoga liječničkog zbora, Zagreb, 10. lipnja 2014., urednik Goran Ivanišević, Hrvatski liječnički zbor, Zagreb, 2014., str. 12. 


\section{3/ Pravila struke - deontologija}

\subsection{Deontologija}

(grčki tò déov: dužnost + -logija) je znanost o dužnostima, a naziv je prvi put upotrijebio engl. filozof J. Bentham u djelu Deontology, 1834. Danas deontologija znači pouku o dužnostima pripadnika pojedinih staleža (npr. liječnika prema bolesnicima), ${ }^{1}$ odnosno objašnjava se kao učenje o ispravnosti i dužnosti pojedinih zanimanja. ${ }^{2}$ Danas se deontologijskima nazivaju svi oni smjerovi u etici koji normativnost i kakvoću ćudorednoga djelovanja izvode iz dužnosti, neovisno o izvanjskim svrhama i posljedicama djelovanja. ${ }^{3}$ Deontologija profesije bi trebala biti samostalni sustav načela i pravila uređenja djelovanja te mogućih vrijednosnih prijepora unutar neke profesionalne skupine i za neku pojedinu profesionalnu skupinu (Primjerice, liječnika, pravnika, novinara i sl. ${ }^{4}$ Deontologija je širi pojam od medicinske etike i govori o normama ponašanja (o pravima i dužnostima liječnika). Ona podrazumijeva pravne propise kojima se uređuje liječničko djelovanje i komplementarna je s medicinskim pravom. ${ }^{5}$ Medicinska deontologija temelji se na dva dijela - medicinskoj etici i medicinskom pravu.

\subsection{Pravila struke}

Kako je medicina profesionalna djelatnost, ona se obavlja u skladu s pravilima struke koja određuje medicinska znanost i praksa. Jedan od aspekata autonomije svake profesionalne djelatnosti jest i činjenica da u takvim djelatnostima postoje utvrđena i priznata pravila ponašanja kao specifičan oblik samoregulative profesije. Radi se o skupu pravila koja je dužan poznavati i poštovati svaki medicinski djelatnik u obavljanju usluga, ali to ujedno znači da ih je i pravni poredak dužan prihvati i respektirati kada procjenjuje (ne)opravdanost pojedinog postupka pripadnika profesije. ${ }^{6}$ Pravila struke su podložna stalnim izmjenama, zbog brzog i kontinuiranog napretka medicinske znanosti i prakse ona se usavršavaju i dopunjuju novim saznanjima. Ponekad se u pojedinim područjima medicinske djelatnosti takva pravila „kodificiraju“ tj. prikupljaju i objavljuju kao protokoli za obavljanje određenih postupaka, standardi medicinske procedure, profesionalni vodiči, smjernice i sl. ${ }^{7}$ U svakodnevnoj kliničkoj praksi diljem svijeta postoji izrazito velika varijabilnost u dijagnostičkom i/ili terapijskom postupku kod pojedinih medicinskih entiteta. Velika većina medicinskih autoriteta smatra da primjena (kliničkih) smjernica, odnosno uputa i preporuka kako postupiti u dijagnostičkom postupku i liječenju pojedinog bolesnika i/ili grupe bolesnika, ne smanjuje niti ograničuje širinu kliničkog promišljanja, već smanjuje neprikladno širok spektar pristupanja određenom medicinskom problemu. Na taj se način izbjegava i smanjuje neprihvatljivo velika varijabilnost u kvaliteti zdravstvene zaštite. ${ }^{8}$ „Smjernice” stručnih medicinskih društava su sistematski izrađene preporuke za liječnike, koje osiguravaju pomoć u donošenju odluka u specifičnim situacijama. Počivaju na aktualnim znanstvenim spoznajama i kliničkim postupcima čija je vrijednost dokazana u svakodnevnoj praksi, a njihov cilj je postići veću sigurnost u odabiru i provođenju medicinskih postupaka uzimajući u obzir ekonomske aspekte. "Smjernice" nemaju pravno-obvezujući karakter 
Prava, obveze i odgovornosti radnika u obavljanju djelatnosti: Pravila struke deontologija

za liječnike, i ne mogu se koristiti kao dokazni materijal u sudsko-medicinskim vještačenjima. ${ }^{9}$ Iako se radi o tehničkim pravilima medicinske znanosti i prakse, ona posredno postaju dio pravnog poretka budući da se pravne norme koje uređuju medicinsku djelatnost pozivaju na takva pravila obvezujući pripadnike profesije da ih poštuju.

Zdravstvenih radnici pri pružanju zdravstvene zaštite dužni su postupati prema pravilima zdravstvene struke, na način da svojim postupcima ne ugroze život i zdravlje ljudi (ZOZZ, čl. 124.). U obavljanju svoga poziva, pripadnici medicinske struke, a prije svega liječnici, nose osobnu, znanstveno opredijeljenu odgovornost za postupanje prema pravilima struke. Pravno gledano, autonomija u struci znači da bavljenje liječničkim pozivom nije subordinirano. Pravo jedino obvezuje liječnike na postupanje u skladu s pravilima struke, ali sama pravila struke donosi liječnički stalež u skladu sa stavovima medicinske znanosti. Zbog toga postoje dvije skupine pravila ponašanja koja obvezuju liječnike: pravila medicinske struke i pravila medicinske etike. ${ }^{10}$ „Pravilo struke“ kao pojam u praksi se često koristi u različitom kontekstu i zapravo ne postoji ujednačena definicija toga pojma. Osim toga, pravila struke u medicini u većini slučajeva obuhvaćaju ,pravila prakse“ koja su se uvriježila kroz dugogodišnje ponavljanje. Velik je problem utvrditi što je to adekvatno pravilo struke unutar neke specijalnosti s obzirom na to da se u ogromnom broju slučajeva isti dijagnostički odnosno teorijski postupak može obaviti na više načina. Nažalost, takva situacija često dovodi do podijeljenih mišljenja disciplinskih sudaca i vještaka koji sudjeluju u postupku. ${ }^{11}$

\subsection{Autonomija u obavljanju profesije}

U vezi načina obavljanja poslova, važno je spomenuti kako zdravstveni radnici kao pružatelji medicinskih usluga uživaju visok stupanj autonomije u obavljanju svog zanimanja. Tu autonomiju zdravstveni radnici imaju na temelju licencije odnosno Odobrenja za samostalni rad koju im izdaje nadležna komora. Autonomija i etimološki znači postupanje koje je vođeno posebnim pravilima, odnosno potčinjeno posebnim pravilima. Ta pravila donose internacionalna i nacionalna udruženja liječnika putem etičkih kodeksa, konvencija, deklaracija, izjava stručno-medicinskih protokola i vodiča za postupanje u različitim specijalističkim područjima i drugih akata kojima na detaljan način uređuju rad zdravstvenih zaposlenika. Za nacionalna zakonodavstva ovi akti nemaju obvezujuću snagu, već samo programski karakter, ${ }^{12}$ jer čine polaznu osnovu zakonodavnoj vlasti da ih putem ustava i zakona, dodatno izgradi i usavrši, da organizacijom i metodologijom rada zdravstvene službe omogući poštivanje načela proisteklih iz ovih dokumenata i da sustavom sankcija uredi obveznost njihove primjene, ako procjeni da postoji takva potreba. ${ }^{13}$ Svaki zdravstveni radnik ovlašten je samostalno obavljati pojedinu zdravstvenu djelatnost u pružanju zdravstvene zaštite. Međutim, ta autonomija pojedinog zdravstvenog radnika determinirana je pravilima struke i dužnošću poštivanja Kodeksa medicinske etike i deontologije, ${ }^{14}$ o čemu će u daljnjem tekstu biti riječi. S time u svezi, zdravstveni radnici u Republici Hrvatskoj imaju obvezu učlanjenja u strukovne organizacije - komore koje im izdaju Odobrenje za samostalni rad (licenciju) i time jamče da posjeduju potrebna stručna znanja i sposobnosti, odnosno daje im pravo na samostalno obavljanja poslova u svojoj struci. Na taj se način istovremeno štiti i interes 
pacijenata, odnosno javni interes i provodi načelo povjerenja javnosti u profesionalnu osposobljenost za obavljanje posebnih znanja i vještina. Suština pojma profesionalne autonomije liječnika pojedinca, koja se još naziva klinička nezavisnost liječnika, očituje se u uvjerenju svakog liječnika da ima potpunu slobodu u obavljanju svojega poziva, točnije da nema obvezu u postupku liječenja pacijenata uvažavati neopravdane utjecaje drugih, bez obzira potiču li oni od politike, stranaka, državne administracije, institucija zdravstvenog osiguranja (u pravcu smanjenja troškova liječenja pacijenata-osiguranika), nevladinog sektora ili pojedinaca uključujući i samog pacijenta, članove njegove obitelji i druge osobe koje se nalaze u bliskom odnosu s pacijentom. Liječnik jedino ima obvezu poštivati volju pacijenta kojom on odbija predloženo liječenje, odnosno uzdržati se od izvođenja medicinskih procedura za koje nije dobio važeći pristanak pacijenta, kao i poštivati ostala prava pacijenta, ali nema obvezu uvažavati pacijentovo uplitanje u profesionalno odlučivanje. Za razliku od pojma kliničke nezavisnosti i profesionalne slobode liječnika koja se suštinski vezuje za liječnika pojedinca, pojam profesionalne nezavisnosti autonomije liječničke profesije vezuje se za liječnički „ceh“ i sastoji se u pravu na samoregulaciju koja pripada liječničkom staležu da sam donosi pravila kojima regulira djelatnost i postupke svojih članova - liječnika. ${ }^{15}$ 
Prava, obveze i odgovornosti radnika u obavljanju djelatnosti: Pravila struke deontologija

\section{Primjedbe}

${ }^{1}$ Podatak kod Hrvatski leksikon, na stranici http://www.hrleksikon.info/definicija/deontologija.html.

${ }^{2}$ Podatak na stranici http://sjedi5.com/sto-je-i-sto-znaci/strana-rijec/deontologija/.

${ }^{3}$ Podatak kod Hrvatska enciklopedija, na stranici http://www.enciklopedija.hr/natuknica.aspx?id=14605.

${ }^{4}$ Vidi MILIČIĆ, V., Deontologija profesije liječnik, život čovjeka i integritet liječnika, ćudoredna raskrižja bioetike, Zagreb, 1996., str, 41.

5 Tako MILETIĆ MEDVED, M., Načela na kojima se temelji medicinska etika, rad u knjizi PUNTARIĆ, D. i dr., Javno zdravstvo“, Medicinska naklada, Zagreb, 2015., str. 536.

${ }^{6}$ Više vidi: CLERK \& LINDSELL, On Torts, Eighteen edition, General Editior: Anthony M. Dugdale; Sweet \& Maxwell, London, 2000., str. 442.

${ }^{7}$ Usp. PETRIĆ, S., Pretpostavke odštetne odgovornosti davatelja zdravstvenih usluga u pravu BiH, zbornik radova „Aktualnosti građanskog i trgovačkog zakonodavstva i pravne prakse“, Mostar, 2005., broj 3, str. 92.-93.

${ }^{8}$ Više o tome kod PULANIĆ, R., Algoritmi u gastrointestinalnoj endoksopiji i endoskopskom ultrazvuku, podatak na stranici http://www.medicinskanaklada.hr/product.aspx?p=4177.

9 Skupina eksperata, Naziv stručnih smjernica, podatak na stranici http://www.hdgo.hr/userFiles/upload/documents/HDGO\%20smjernice/OPCE/Obrazac-Strucne-

Smjernice.pdf.

${ }^{10}$ Tako MALETIĆ, D., Profesionalna sloboda lekara, „Pravni život“, 2011., broj 9, str. 487.

11 Vidi BABIĆ, T., Stegovni (disciplinski) postupak pred tijelima Hrvatske liječničke komore, Hrvatski ljetopis za kazneno pravo i praksu, vol. 15, broj 1/2008, Zagreb, 2008., str. 288.

${ }^{12}$ U tom smislu SUDŽUM R., Pravo na zdravstvenu zaštitu i participacija, Pravna praksa, br. 78/2007, Liber, Beograd 2007., str. 25.

${ }^{13}$ Tako MALETIĆ, D., Profesionalna sloboda lekara, „Pravni život“, 2011., broj 9, str. 486.

${ }^{14}$ Liječnik ima pravo primijeniti način liječenja koji smatra optimalnim, u smislu koristi i cijene. Što učiniti ako bolesnik odbije uobičajenu djelotvornu terapiju (npr. krvni pripravak) koja će mu spasiti život, a eventualno (npr. za neku drugu situaciju) postoji mnogo skuplji, djelotvoran, u pravilu manje dobar način liječenja? Nema mogućnosti davanja općih savjeta koji bi uvijek vrijedili, ali treba naglasiti potrebu da liječnik koliko god to smatra mogućim i razumnim, slijedi bolesnikove želje.

${ }^{15}$ Vidi MALETIĆ, D., Profesionalna sloboda lekara, „Pravni život“, 2011., broj 9, str. 487. 


\section{4/ Medicinska etika}

\subsection{Pojam, načela i pravni izvori}

Značajni predmet zanimanja medicinskog prava predstavlja odnos između liječnika (zdravstvenih radnika) i pacijenata u pogledu pružanja medicinske usluge, a taj odnos nije samo pravni, nego je i etički. U njemu su moralni i pravni obziri pomiješani u znatno većoj mjeri nego što je to slučaj s ostalim pravnim odnosima među ljudima. Moralni stavovi liječnika, baš kao i moralni stavovi različitih pojedinaca, nisu uvijek jednaki. Stoga je neophodno stalno i trajno raspravljati o etičkim pitanjima unutar liječničkih krugova. S jedne je strane potrebno utvrditi stavove a priori, koji će olakšati procjenu etičnosti, dok je s druge neophodno u svakom pojedinačnom slučaju preispitati moralne postulate kojih se situacija dotiče. Tako će odluke o etičnosti sačuvati utemeljenost na općeprihvaćenim načelima, ali i osigurati razinu pojedinačne posebnosti, kako bi se izbjegli površni i pogrešni zaključci.

Medicinska etika dio je opće znanstvene discipline koja se bavi jednim od bitnih područja ljudskog življenja - problematikom morala. ${ }^{1}$ Medicinska je djelatnost zbog specifičnosti svog predmeta i svoje svrhe tradicionalno bila regulirana prvenstveno etičkim postulatima. Kao djelatnost usmjerena na ostvarenje dobrobiti čovjeka, tj. zaštitu njegovog života i uspostavljanje, očuvanje i unapređenje njegovog zdravlja, ona nužno počiva na načelu humanosti i može se objasniti samo kao realizacija etičkih (tj. moralnih) stavova o odnosu pripadnik profesije - pacijent. Medicinska etika je jedna od specijalističkih oblasti etike kao znanstvene discipline, a spada u tzv. profesijske etike. Iako se često izjednačava s tzv. liječničkom etikom, ona je širi pojam jer u sebi sadrži i etičke standarde drugih pripadnika struke (npr. medicinskih sestara, medicinskih biotehničara, stomatologa i sl.). U većini zemalja u svijetu pravila medicinske etike su danas utvrđena kao zasebni tekstovi (tzv. kodeksi medicinske etike) od strane različitih strukovnih udruga pripadnika medicinske profesije. ${ }^{2}$ Medicinska etika predstavlja jedan od brojnih oblika posebne ili područne etike. Predmetno područje na koje se odnosi medicinska etika obuhvaća medicinsku praksu u najširem smislu riječi. ${ }^{3}$ Iako etička pravila i pravila struke nisu po svojoj prirodi pravna pravila, liječnik (zdravstveni radnik) je (pravno) dužan pridržavati se određenih načela medicinske etike. Moralne i pravne dužnosti liječnika toliko su se stopile da ih je u pojedinostima gotovo nemoguće razlučiti. ${ }^{4}$ Jedan od izvora medicinskog prava su i pravila pojedine medicinske profesije, odnosno kodeksa etike i/ili deontologije pojedine profesije.

Etičko povjerenstvo zdravstvene ustanove jest tijelo koje osigurava obavljanje djelatnosti ustanove na načelima medicinske etike i deontologije (ZZZ, čl. 68.).

Načela liječničkog djelovanja do danas su uglavnom ostala ista, a neka važnija od njih su: načelo neškodljivosti - primum nil nocere, činiti samo ono što pridonosi ozdravljenju; dobročinstva - bonum facere; autonomije i pravednosti - autonomia et iustitia. Načela neškodljivosti i dobročinstva potječu još iz doba starih Grka, dok su autonomija i 
pravednost novijeg datuma. Kod načela autonomije staro načelo paternalizma danas je zamijenjeno načelom dogovora ili partnerstva (Voluntas aegroti suprema lex est, poštivanje volje $i$ autonomije pacijenta je na prvom mjestu). ${ }^{5}$ Što se spomenutih načela medicinske etike tiče, prvenstveno bismo spomenuli: $\boldsymbol{a} /$ načelo neškodljivosti - (lat. primum nil nocere) - liječnik ne smije činiti ono što bi bolesniku štetilo, odnosno mora činiti ono što je dobro za njega, što pridonosi ozdravljenju. Ono se zasniva na odnosu povjerenja pacijenta u liječnika, tzv. paternalističkom modelu. To znači da se bolesnik prepusti stručnosti i moralnosti liječnika i da mu vjeruje u pogledu dijagnoze, načina liječenja, propisivanja lijekova i terapije itd. Ono postaje dijelom povijesti, sa stajališta suvremene medicine; $\boldsymbol{b} /$ načelo autonomije - najviše je načelo volja bolesnika. O njoj ovisi postupak zdravstvenog osoblja. Kada, pak, bolesnik nije u stanju sam odlučivati u pogledu terapije koju želi primiti, traži se suglasnost obitelji ili srodnika. S obzirom na složenost medicinskih postupaka potrebna je primjena informiranog pristanka, tj. liječnik je dužan o svemu obavijestiti pacijenta ili njegovu obitelj, a on ili oni na temelju toga daju privolu. U tom smislu nije više riječ o potpunome prepuštanju znanju liječnika, već o ugovornom, pravnom odnosu. Ovo načelo postaje temelj pravila ponašanja u suvremenoj medicini. U novije doba sva se ta načela koriste u prosudbi mogućeg medicinskog postupka i pacijentove očekivane životne kakvoće. ${ }^{6}$

Što se nadležnosti etičkih povjerenstava zdravstvenih ustanova tiče, ono: prati primjenu etičkih i deontoloških načela zdravstvene struke u obavljanju djelatnosti zdravstvene ustanove; odobrava znanstvena istraživanja u zdravstvenoj ustanovi; nadzire uzimanje dijelova ljudskog tijela nakon obdukcije u medicinske i znanstveno-nastavne svrhe; rješava i druga etička pitanja u obavljanju djelatnosti zdravstvene ustanove (ZZZ, čl. 69.).

Formiranje etičkih povjerenstava predviđenih ZOZZ-om od iznimnog značaja je naročito $\mathrm{s}$ aspekta poštovanja utvrđenih prava pacijenata. Uloga etičkog povjerenstava u funkcioniranju zdravstvene ustanove ne smije se zanemariti, što je u praksi često slučaj, obzirom da etičko povjerenstvo, kako smo vidjeli, ima ovlasti odlučivati o vrlo važnim i osjetljivim pitanjima koja se mogu pojaviti prilikom obavljanja zdravstvene djelatnosti i koja mogu biti značajna za kvalitetno i pravilno pružanje zdravstvene zaštite. ${ }^{7}$ Uloga etičkih povjerenstava u suvremenoj medicini sve više dobiva na značaju i neodvojivi je dio zdravstvene zaštite. Po svom obliku etička povjerenstva u medicini predstavljaju institucijki oblik interakcije prava i etike te mjesto na kojemu se od strane članova povjerenstva donose odluke u povodu aktualnih pitanja u medicini. Pravni aspekti rada etičkih povjerenstava ogledaju se u pitanjima medicinske prakse koja traži rješenja u ovom kontekstu, kao i u pogledu utvrđivanja odgovornosti u medicini. ${ }^{89}$

Etičko povjerenstvo imenuje upravno vijeće i čini ga najmanje pet članova, od toga najmanje $40 \%$ članova suprotnog spola, s time da najmanje jedan član etičkog povjerenstva treba biti predstavnik nemedicinskih struka i najmanje jedan član koji nije radnik zdravstvene ustanove. Upravno vijeće imenuje i zamjenike članova etičkog povjerenstva. Broj članova i sastav etičkog povjerenstva uređuje se statutom zdravstvene ustanove. Za obavljanje poslova iz djelatnosti ustanove na načelima medicinske etike i deontologije, zdravstvena ustanova čiji je osnivač pravna i fizička osoba može ovlastiti etičko povjerenstvo druge zdravstvene ustanove. Etičko povjerenstvo donosi poslovnik o svome radu (ZOZZ, čl. 68.). 
Sudovi časti (Court of Honor, Cour d' Honneur) postoje od davnina kao poluslužbeni ili posve interni tribunal koji čuva načela, unutarnju koheziju i časno ime zdravstvene ustanove kojoj pripada. Sud se bira unutar društva iz vlastitih redova, obično između starijih, iskusnih i moralnih članova, kojima dubok osjećaj poštivanja svoje udruge daje moralnu snagu i utanačeno pravo suditi svakom članu, uključujući i čelnike, ako prekrše statut ili etički kodeks udruge. Časni sud HLK ima međutim nekoliko posebnosti, koje mu daju veće mogućnosti utjecaja i respekta, ali je još upitno s kolikim odjekom i kolikom učinkovitošću na deontološko, etičko i profesionalno ponašanje u praksi. Prvo, dok se, u velikoj većini udruga, predsjednik i svi članovi Suda biraju na Skupštini među kolegama, HLK je u skladu sa Zakonom o liječništvu, donijela novi Pravilnik po kojem predsjednik Časnog suda više nije liječnik niti član HLK, nego se imenuje iz redova istaknutih pravnika $\mathrm{s}$ iskustvom u vođenju sudskih parnica. Sudski postupak je tako dobio profesionalni tok, a odluka koju potpisuje sudac u ime Sudskog vijeća dobiva na snazi i smanjuje nelagodu koju su ranije imali predsjednici donoseći presudu kolegi. Uloga liječnika u Sudskom vijeću ostala je i dalje bitna u procjeni kako stručnih propusta i pogrešaka tako i povreda medicinske etike, koje u većini slučajeva prethodno prouči Povjerenstvo za stručna pitanja i stručni nadzor i/ili Povjerenstvo za medicinsku etiku i deontologiju HLK. S druge strane, u raspravama su sve više angažirani odvjetnici, koji predmet razmatraju kroz formalno pravne okvire, u kojima se često ne vide suptilniji medicinski aspekti slučaja. ${ }^{10}$

U Hrvatskom liječničkom zboru (HLZ) je 1992. godine osnovana Komisija za medicinsku etiku i prava čovjeka, koja je 1993. godine donijela etički kodeks HLZ-a. Godine 1996. zajednička Komisija za medicinsku etiku i deontologiju HLZ-a i Hrvatske liječničke komore (HLK), izradila je tekst Kodeksa koji je usvojen na Skupštini HLK-a 4. travnja 1996. godine, a objavljen u „Liječničkim novinama“ br. 126 u svibnju 1996. godine. Donošenjem KMED-a obavljen je jedan od prioritetnih zadataka HLK-a iz samih početaka njenoga rada. KMED-om su bila određena prava i obveze liječnika i pacijenata, uređeni su bili odnosi između liječnika i bolesnika te između liječnika međusobno, a citiranim KMED-om ukazivalo se na nečasne radnje koje su mogle dovesti do narušavanja ugleda staleža. U razdoblju od 2002. do 2006. godine na snazi su bila dva kodeksa, i to KMED te Kodeks HLZ-a. S obzirom na htijenja članova HLK-a i HLZ-a pristupilo se izradi zajedničkog teksta Kodeksa u čijoj su izradi sudjelovali predstavnici Povjerenstva za medicinsku etiku i deontologiju HLK-a i Povjerenstva za medicinsku etiku i deontologiju HLZ-a. Konačno, kao rezultat zajedničkog rada HLK-a i HLZ-a na definiranju i donošenju zajedničkog teksta Kodeksa, na temelju članka 38. ZOL-a te članka 14. Statuta HLK usvojen je jedinstveni tekst Kodeksa medicinske etike i deontologije te je kao takav prihvaćen na Skupštini HLK-a 10. lipnja 2006. godine (isti je prethodno prihvaćen na Skupštini HLZ-a 24. veljače 2006.). Na temelju citiranog članka ZOLJ-a osim što donosi Kodeks medicinske etike i deontologije, HLK putem svog Povjerenstva prati i nadzire njegovo provođenje i sankcionira kršenje. Članak 45. ZOL-a određuje Skupštini HLK-a donositi Kodeks medicinske etike i deontologije. S obzirom da je dinamika promjena i napredovanja u medicini i liječništvu s vremenom zahtijevala promjene i nadopune, Povjerenstvo za medicinsku etiku i deontologiju HLK-a je (uz savjetovanje s analognim povjerenstvom HLZ-a) sastavilo promijenjen i nadopunjen tekst Kodeksa, kojega je Skupština HLK-a prihvatila 29. prosinca 2015. te je stupio na snagu 6. siječnja 2016. godine („Narodne novine“ 139/15). I ovaj je kodeks objavljen i 
u Liječničkim novinama. KMED, polazeći od humanističkih načela i temeljnih vrijednosti društva, utvrđuje načela i pravila kojih se liječnici moraju pridržavati pri obavljanju svog zvanja. U Republici Hrvatskoj značajni su; Kodeks stomatološke etike i deontologije, od 7. lipnja 1996. godine; Kodeks ljekarničke etike i deontologije, od 29. travnja 2009. godine; Etički kodeks medicinskih sestara, od 22. prosinca 2005. godine; Etički kodeks medicinskih biokemičara i medicinske deontologije, 20. Veljače 2009.; Kodeks etike i deontologije djelatnosti sanitarnog inženjerstva, zdravstvene radiološkotehnološke djelatnosti, djelatnosti radne terapije i medicinsko-laboratorijske djelatnosti, od 5. listopada 2012.; Etički kodeks primalja od 27. siječnja 2010. i dr.

Osim KMED-a koji je osnovni dokument etike obvezan za svakog pripadnika liječničke struke u Hrvatskoj, kao i u drugim zemljama, postoje na različitim razinama tijela koja se brinu za etiku. Na Medicinskom fakultetu u Zagrebu postoji Povjerenstvo za etiku koja je ponajprije okrenuta etičnosti istraživanja u svezi s dobivanjem znanstvenih titula. Sabor RH ima posebni odbor za etiku u znanosti i visokom obrazovanju. O njemu se malo zna i rijetko govori. O kliničkim istraživanjima lijekova raspravljaju (lokalna) bolnička etička povjerenstva i od 2004. godine Središnje etičko povjerenstvo za klinička ispitivanja lijekova i medicinskih proizvoda. U travnju 2001. godine Sabor, na prijedlog Ministarstva zdravstva Republike Hrvatske, donio je odluku o osnivanju Nacionalnog bioetičkog povjerenstva (samo) za medicinu. Zadaci su donošenje preporuka, mišljenja, izvješća i smjernica za donošenje Zakona na području biomedicinskih istraživanja na ljudskim bićima, medicinske etike i deontologije, planiranja obitelji i prekida trudnoće, uređenje medicinski potpomognute oplodnje, genske tehnike, ljudskog genoma, zaštite ljudskog zametka, kloniranja, presađivanja ljudskih tkiva i organa, ksenotransplantacije, prisilnoga i obvezatnog liječenja, postupanja s neizlječivim bolesnicima, eutanazije, stručnog usavršavanja na području bioetike.

Važnost etike očituje se u velikom broju međunarodno prihvaćenih dokumenta koji tretiraju medicinsku etiku i neke njezine dijelove. U ovom tekstu spominjemo samo one koji se smatraju temeljnima. Prvi dokument o liječničkoj etici je Hipokratova zakletva, ${ }^{11}$ vjerojatno napisana u 5. st. prije Krista, uz zakletvu Apolonu i Eskulapu koji danas nisu više tako moderni. Sve ono što stoji u Hipokratovoj zakletvi vrijedi još i danas. Spominje se najbolja briga za bolesnika, odustajanje od davanja lijekova koji izazivaju smrt i pobačaj, poštovanje starijih, odustajanje od pogrešnih postupaka, korupcije, zavođenja, čuvanje tajnosti onoga što je liječnik u vršenju svoje dužnosti doznao. Drugi je dokument Međunarodni kodeks medicinske etike koji je usvojila Svjetska zdravstvena udruga, 1947. godine, koji se zove Ženevska deklaracija, a temelji se na međunarodnom kodeksu medicinske etike. 22. svjetska medicinska skupština u Sydneyu 1968. godine dopunila je taj kodeks. Kodeks govori o općenitim dužnostima liječnika, zatim o dužnostima prema bolesniku i o dužnostima prema drugim kolegama. Svjetska zdravstvena udruga tiska od onda do danas, gotovo redovito, materijale koji se tiču pojedinih etičkih pojedinosti. Godine 1964. je 18. svjetska zdravstvena skupština u Helsinkiju prihvatila deklaraciju o biomedicinskim istraživanjima na ljudima. Ova deklaracija bila je bitno ili nebitno dopunjavana od 29. skupštine u Tokiju 1975. od 35. skupštine u Veneciji 1983. i od 41. skupštine u Hong Kongu 1989., Somerset Westu 1996., Edinburghu 2000., s dva razjašnjenja, 2002. u Washingtonu i 2004. u Tokyju te posljednja (VI.) revizija na 59. skupštini 2008. u Seoulu. Helsinška deklaracija sastoji se od temeljnih načela koja govore 
o potrebi ispitivanja potencijalnog lijeka u laboratoriju i na životinjama prije primjene novog lijeka na čovjeku, što osigurava predvidivost opasnosti primjene na čovjeku, pridonosi pažnji na točnost rezultata, informaciji ispitanika (prednost pismenoj), u medicinskim istraživanjima, stručnoj brizi (klinička istraživanja) i dr. Dalje se navodi potreba djelovanja u najboljem interesu bolesnika, pravu bolesnika odbiti ispitivanje i činjenici da je medicinsko istraživanje opravdano samo ako je sukladno dijagnostičkoj odnosno terapijskoj vrijednosti za bolesnika. U trećem dijelu Helsinške deklaracije govori se o nekliničkom biomedicinskom istraživanju, gdje je naglasak na zadatku da liječnik štiti život i zdravlje ispitanika. Ispitivanje treba prekinuti ako se pokaže da će nastavak biti štetan za ispitanika. Znanost $i$ interes društva nikada ne mogu u ovim situacijama biti važniji od interesa ispitanika. U Tokiju je dodana potreba postojanja neovisnog etičkog tijela i potreba pažljivo pripravljenog plana ispitivanja, kao i naglasak na tomu da liječnik ne smije sudjelovati u mučenju zatvorenika i drugim surovim, nehumanim i degradirajućim postupcima. Ne smije davati pomoć u ovakvim postupcima i ne smije biti prisutan kada se oni provode. Tokijska deklaracija potvrđuje neprihvatljivost umjetnog hranjenja. Ako se smatra da odluka o neuzimanju hrane nije donesena od za razumijevanje sposobnog zatvorenika, to mišljenje trebao bi potvrditi još jedan neovisni liječnik. Svjetska medicinska udruga će pomoći i poticati međunarodnu zajednicu te nacionalne medicinske udruge da daju podršku liječniku ili njegovoj obitelji, koji se zbog odbijanja da sudjeluje u surovom, nehumanom, degradirajućem postupku sa zatvorenicima nađe u opasnosti. Godine 1997. prihvaćena je Opća deklaracija o humanom genomu i pravima čovjeka (UNESCO). Spomenuli bismo Međunarodni kodeks medicinske etike, usvojen na 3. generalnoj skupštini Svjetskog medicinskog udruženja u Londonu, 1949. godine, te Načela etike za europske liječnike, Međunarodne konferencije predstavnika liječničkih komora i sličnih liječničkih organizacija iz zemalja članica Europske unije iz 1987. i 2001. Godine; Konvencija Vijeća Europe o zaštiti ljudskih prava i dostojanstva ljudskog bića u pogledu primjene biologije i medicine; Konvencija o ljudskim pravima i biomedicini, koja je stupila na snagu 1. prosinca 1999.; Dodatni protokol uz Konvenciju o zaštiti ljudskih prava i dostojanstva ljudskog bića u pogledu primjene biologije i medicine o zabrani kloniranja ljudskih bića, koji je stupio na snagu 1. ožujka 2001.; Dodatni protokol uz Konvenciju o zaštiti ljudskih prava i dostojanstva ljudskog bića u pogledu primjene biologije i medicine u svezi presađivanja organa i tkiva ljudskog porijekla, sastavljen u Strasbourgu, 24. siječnja 2002. (vidi «Narodne novine - Međunarodni ugovori», broj 13/03.); Deklaracija Svjetske zdravstvene organizacije o promicanju prava pacijenata u Europi iz 1994. godine; Deklaracija ujedinjenih naroda o borbi protiv HIV/AIDS-a iz 2001. godine; Helsinška Deklaracija o etičkim načelima biomedicinskih istraživanja na ljudskim subjektima iz 2000. godine; Madridska deklaracija o etičkim standardima za psihijatrijsku djelatnost iz 1996.; Lisabonska deklaracija o pravima pacijenata iz 1981.; Deklaracija Svjetskog medicinskog udruženja o nezavisnosti i profesionalnoj slobodi liječnika iz 1986.; Deklaracija Svjetskog medicinskog udruženja o ljudskim pravima i osobnoj slobodi medicinskih radnika iz 1985.; Deklaracija Svjetskog medicinskog udruženja o medicinskoj edukaciji iz 1987. i 1991.; Madridska deklaracija Svjetskog medicinskog udruženja o profesionalnoj autonomiji i samoregulaciji iz 1987.; Malteška deklaracija Svjetskog medicinskog udruženja o štrajku glađu iz 1991. i 1992. i dr. Treba napomenuti da međunarodni ugovori koji su sklopljeni i potvrđeni u skladu s Ustavom Republike Hrvatske i objavljeni, a koji su na snazi, čine dio unutarnjega pravnog poretka Republike 
Hrvatske, te su po pravnoj snazi iznad zakona. Njihove se odredbe mogu mijenjati ili ukidati samo uz uvjete i na način koji su u njima utvrđeni, ili suglasno općim pravilima međunarodnog prava (Ustav, čl. 140.).

\subsection{Medicinska etika, bioetika, integrativna bioetika $i$ odnos prema medicinskom pravu}

\subsubsection{Bioetika}

Pojam «bioetika» nastaje u 20. stoljeću, a tek posljednjih desetljeća postaje i opće usvojeni naziv nove grane suvremene etike. ${ }^{12} \mathrm{U}$ Bioetičkoj enciklopediji «bioetika» se definira kao sustavno proučavanje moralnih dimenzija - uključujući moralne poglede, odluke, ponašanje i djelovanje - u sklopu prirodnih znanosti i zdravstvene skrbi, koje se pritom služi različitim etičkim metodologijama u interdisciplinarnom okruženju. ${ }^{13}$ Danas se bioetika nerijetko poistovjećuje $\mathrm{s}$ medicinskom etikom, odnosno $\mathrm{s}$ novom medicinskom etikom, jer se drži da su ti pojmovi sinonimi. ${ }^{14} \mathrm{~S}$ druge strane, postoji i mišljenje da to nije u potpunosti točno jer se tvrdi da je bioetika mnogo više od medicine i medicinskih znanosti, ${ }^{15}$ pošto globalno sagledava dobrobit čovjeka u kontekstu poštivanja prirode, te da pored medicinske etike uključuje i etiku okoliša, religijsku etiku, socijalnu etiku i dr. ${ }^{16}$ I prema mišljenju Callahana, pojam «bioetika» ne podrazumijeva i ne promatra ljudsko zdravlje i kvalitetu života isključivo u medicinskom smislu jer bi takvo shvaćanje bilo preusko da obuhvati šira i sporna pitanja suvremene etike. ${ }^{17} \mathrm{U}$ definiciju bioetike, ponekad se, pored medicinske etike ubrajaju sudska medicina i profesionalna deontologija. ${ }^{18}$

U teoriji i praksi (bio)medicinske etike, često se može susresti pojam klinička bioetika, koji se odnosi na moralno odlučivanje tijekom svakodnevne brige za (konkretnog) pacijenta i etička pitanja koja iz toga proizlaze, a klinička bioetika to čini u okviru šireg interdisciplinarnog područja bioetike koje obuhvaća i filozofiju, teologiju, pravo i dr. ${ }^{19}$

Što se međunarodnih izvora medicinskog prava tiče, njegov izvor su i brojne bioetičke konvencije i deklaracije poput: Konvencije Vijeća Europe o zaštiti ljudskih prava i dostojanstva ljudskog bića u pogledu primjene biologije i medicine; Konvencije o ljudskim pravima i biomedicini, koja je stupila na snagu 1. prosinca 1999.; Dodatnog protokola uz Konvenciju o zaštiti ljudskih prava i dostojanstva ljudskog bića u pogledu primjene biologije i medicine o zabrani kloniranja ljudskih bića, koji je stupio na snagu 1. ožujka 2001.; Dodatnog protokola uz Konvenciju o zaštiti ljudskih prava i dostojanstva ljudskog bića u pogledu primjene biologije i medicine u svezi presađivanja organa i tkiva ljudskog porijekla, sastavljen u Strasbourgu, 24. siječnja 2002. (vidi «Narodne novine Međunarodni ugovori», broj 13/03.); Helsinške Deklaracije o etičkim načelima biomedicinskih istraživanja na ljudskim subjektima iz 2000. godine; Madridske deklaracije o etičkim standardima za psihijatrijsku djelatnost iz 1996. i dr.

\subsubsection{Integrativna bioetika}

Bioetika je nastala kao reakcija na moralne nedoumice koje je donio razvitak suvremene medicine, jer medicinska etika više ne uspijeva pokriti sve sporne slučajeve i odnose, 
posebno odnose zdravstvenih radnika i pacijenata. U novije vrijeme javlja se novi koncept, odnosno model bioetike - integrativna bioetika, čija su osnovna obilježja interdisciplinarnost i pluriperspektivizam. Pretpostavka integrativne bioetike je integriranje različitih (i svih) tema i problema vezanih uz bios, kao i integriranje različitih (i svih) pristupa tim temama i problemima. Glavne karakteristike tako shvaćene bioetike mogu se sažeti kroz pojmove multi-, inter- i transdisciplinarnosti, pluriperspektivnosti, te integrativnosti. Povijesni razvitak bioetike prema stadiju integrativnosti odvijao se na predmetnom planu kao proces širenja, ali i produbljivanja problemskog područja kojim se bioetika bavila, od početnih problema medicinske skrbi i biomedicinskih istraživanja preko problematike ne-ljudskih živih bića i općih uvjeta održanja života (ekologija) do poniranja u dubinsku, filozofijsko povijesnu dimenziju tih problema, u kojoj su se otvorila pitanja svjetsko povijesnih razmjera - naime, pitanja o karakteru znanstveno-tehničke epohe, o metodološkoj konstituciji i povijesnoj ulozi moderne znanosti, o mijenama u temeljnom odnosu čovjeka i prirode - i u kojoj su se, naposljetku, detektirali procesi prelamanja svjetsko-povijesnih epoha. ${ }^{20}$ Model integrativne bioetike, zahvaljujući nastojanju da riješi načelne probleme interdisciplinarnih i interperspektivnih diskusija mogao bi, dakle, poslužiti kao model integrativnog pogleda i na brojne ne-bioetičke probleme, odnosno kao model integrativnih rasprava i u drugim sferama, pa i o onim pitanjima koja nisu bioetička. ${ }^{21}$ Čović drži najvažnijim postignućem koncepta integrativne bioetike izgrađivanje inovativnog koncepta integrativne bioetike, $\mathrm{s}$ prepoznatljivim doprinosom razvoju bioetike u globalnim razmjerima, jer integrativnu bioetiku u predmetnom pogledu karakterizira široko predmetno područje, koje seže od moralnih dilema u medicinskoj praksi i biomedicinskim istraživanjima, preko određivanja moralnog statusa neljudskih živih bića, tematiziranja ekoloških pitanja, uloge znanosti i tehnike u suvremenoj civilizaciji, rasprave o karakteru naše epohe i znakovima prelamanja epoha, sve do teorijskog zasnivanja nove svjetsko povijesne epohe. U metodološkom pogledu integrativnu bioetiku obilježava izrazita interdisciplinarnost, uvažavanje i uključivanje u raspravu relevantnog kruga posebnih znanstvenih disciplina, ali isto tako i kruga neznanstvenih perspektiva koje obuhvaćamo nazivom - kulturne perspektive. ${ }^{22} \mathrm{U}$ tom kontekstu nastao je i pojam pluriperspektivizma kao metodološko određenje integrativne bioetike, pojam koji u sebi objedinjuje znanstvene i kulturne perspektive. Integrativna bioetika određena je u metodološkom pogledu idejom pluriperspektivizma, prema kojoj se »orijentacijsko znanje« može postizati samo interakcijom različitih spoznajnih perspektiva unutar određenog problemskog polja.

Pravna perspektiva u integrativnoj bioetici nužna je za artikuliranje i rješavanje bioetičkih problema, kako u teorijskom tako i u praktičkom smislu, uz korištenje metodologije integrativne bioetike. Neke od istraživačkih tema koje svakako vrijedi istražiti jesu: odnos između bioetike i zdravstvenog prava s posebnim osvrtom na pravne izvore iz područja bioetike (u poredbenom, europskom i međunarodnom pravu), temeljna bioetička načela gledana iz pravne perspektive, prava pacijenata kao ljudska prava (pravo na adekvatno liječenje, zabrana diskriminacije, pravo na humano postupanje, pravo na privatnost, pravo na samoodređenje, selekcija pacijenata u slučajevima nedostatka sredstava i skl.), informirani pristanak (pojam informiranog pristanka, informacija koja treba biti otkrivena pacijentu, sposobnost davanja pristanka, pravo odbijanja liječenja), odgovornost zdravstvenih radnika (građanska, kaznena itd.) - analiza slučajeva, povjerljivost (definicija liječničke tajne, dužnost i iznimke glede čuvanja liječničke tajne, odgovornost 
za kršenje povjerljivosti, neovlaštena uporaba povjerljivih podataka), biomedicinska istraživanja na ljudima (pravni i etički okvir biomedicinskog istraživanja -međunarodni dokumenti i nacionalno zakonodavstvo iz poredbene perspektive), pravni aspekti zaštite okoliša, pravni aspekti zaštite životinja. ${ }^{23} \mathrm{U}$ tom smislu donesen je niz pravnih propisa kojima se artikuliraju i rješavaju bioetički problemi i odnosi iz područja integrativne bioetike, a i Ustav Republike Hrvatske („Narodne novine“, „Narodne novine“ 56/90, 135/97, 8/98, 113/00, 124/00, 28/01, 41/01, 55/01, 76/10, 85/10, 05/14), kao najviša pravna norma, sadrži niz odredbi koje možemo povezati s područjem interesa integrativne bioetike. Poput odredbe o: očuvanju prirodnog i kulturnog bogatstva i korištenju njime (čl. 2.), o pravu svakog ljudskog bića na život (članak 21.), osobitoj zaštiti nekretnine i stvari od ekološkog značenja, za koje je zakonom određeno da su od interesa za Republiku Hrvatsku (čl. 52.), pravu na zdravstvenu zaštitu u skladu sa zakonom svakome (čl. 58), zabrani primanja na rad djece prije zakonom određene dobi i prisiljavana na rad koji štetno utječe na njihovo zdravlje, jamčenju prava na zdrav život svakome, osiguravanju uvjeta za zdrav okoliš od strane države, dužnosti, u sklopu svojih ovlasti i djelatnosti, posvećivanja osobite skrbi o zaštiti zdravlja ljudi, prirode i ljudskog okoliša (čl. 70.).

Treba napomenuti da se (sudska i druga) praksa medicinskog prava često temelji na rješavanju sporova, odnosno problema iz područja bioetike.

\subsubsection{Odnos medicinskog prava i (medicinske, integrativne, bio) etike}

Zbog značenja i aktualnosti bioetike i medicinskog prava kod zaštite i promicanja prava pacijenata, ali i uređenja rada i statusa zdravstvenih radnika, odnos ovih dviju znanstvenih disciplina i znanstvenih područja postao je predmetom brojnih rasprava i istraživanja. ${ }^{24}$

Tako, primjerice, postoji mišljenje da (integrativna) bioetika, kao suvremena interdisciplinarna grana medicinske znanosti, čija je djelatnost utemeljena na zaštiti ljudskih prava u medicini, uključuje u sebi i sudsku medicinu, profesionalnu deontologiju, ali i zdravstveno pravo sensu strictiori i zdravstveno pravo u širem smislu. Drugim riječima, drži se da je zdravstveno/medicinsko pravo, kao sadržajno uži pojam, dio bioetike. ${ }^{25}$ Svakako, postoji i suprotno mišljenje. ${ }^{26}$

Uvažavajući naprijed navedena mišljenja, držimo ipak da niti je medicinsko/zdravstveno pravo dio bioetike, niti je bioetika dio zdravstvenog/medicinskog prava. U Republici Hrvatskoj znanstvena područja, polja i grane uređeni su Pravilnikom o znanstvenim i umjetničkim područjima, poljima i granama („Narodne novine“, broj 118/09, 82/12, 32/13, dalje - PZPPG). Naime, medicinsko pravo i medicinska etika/(integrativna) bioetika dva su zasebna znanstvena područja, polja i grane koja se, svako sa svog aspekta, bave istraživanjem i uređenjem odnosa na području medicine/zdravstva. ${ }^{27}$ Medicinsko pravo je znanstvena disciplina koja pripada znanstvenom području društvenih znanosti (PZPPG, 5.0), polju prava (PZPPG, 5.02), i izučava se u okviru više znanstvenih grana iz polja prava (primjerice, građansko i građansko procesno pravo, kazneno i kazneno procesno pravo, upravno pravo i upravna znanost, ustavno pravo i dr.). S druge strane, medicinska etika pripada znanstvenom području biomedicine i zdravstva, polju kliničkih medicinskih znanosti (PZPPG, 3.02), grani medicinska etika (PZPPG, 3.02.15). Što se bioetike tiče, najbliže bismo je mogli svrstati u znanstveno područje humanističkih 
znanosti (PZPPG, 6.00), polje filozofija (PZPPG, 6.01), grana filozofijska bioetika (PZPPG, C6.01.25). Integrativna bioetika prema PZPPG-u svrstana je, pak, u interdisciplinarno područje znanosti (PZPPG, 8.00), znanstveno polje integrativna bioetika (PZPPG, 8.03, prirodne, tehničke, biomedicina i zdravstvo, društvene, humanističke znanosti).

Držimo neprijepornim da integrativna bioetika može (u budućnosti) postojati kao samostalna znanstvena disciplina, a razlog prije svega treba tražiti u izričaju «interdisciplinarna impostacija», jer je to njezin specifikum. ${ }^{28}$ Naime, vodeći računa o stalnom razvitku i policentričnom sustavu znanstvene djelatnosti i visokog obrazovanja, moguće je i u budućnosti nužno uspostaviti interdisciplinarna znanstvena područja koja će omogućiti suradnju znanstvenika i znanstvenih organizacija iz više različitih znanstvenih područja, polja i grana u ostvarivanju većeg broja problemski povezanih znanstvenih projekata. Ovo područje bilo je donedavno moguće utvrditi samo načelno kao znanstveno područje različitih znanstvenih područja i polja, a znanstvena polja unutar interdisciplinarnog područja mogla su se utvrditi u svakomu pojedinom predmetu (primjerice, znanost o sustavima i kibernetika, kognitivne znanosti, Life Sciences, Behavioural Sciences i sl.). Znanstvena polja unutar interdisciplinarnog područja uspostavljaju se, pak, temeljem obrazloženog zahtjeva, a odluku o utvrđivanju polja donosi Nacionalno vijeće za znanost, visoko obrazovanje i tehnološki razvoj (ex Nacionalno vijeće za znanost) (Arg. PZPPG, čl. 5.). U tom bi pravcu svakako trebalo biti usmjereno i uređenje odnosa medicinskog prava i integrativne bioetike i njihov položaj u sustavu znanstvenih područja, polja i grana. Značajan iskorak u tom smjeru učinjen je svrstavanjem integrativne bioetike u interdisciplinarno područje znanosti, a svakako bi i medicinsko pravo trebalo ispunjavati uvjete za svrstavanje u interdisciplinarno područje znanosti jer ima za predmet izučavanja znanstvena polja i grane iz najmanje tri znanstvena područja - društvenih i humanističkih znanosti te biomedicine i zdravstva.

Medicinsko pravo i (integrativna) bioetika imaju zajednički cilj - humanost, odnosno promicanje i zaštitu temeljnih ljudskih prava u obavljanju medicinske djelatnosti. To je svakako i razumljivo jer te se dvije struke bave najznačajnijim ljudskim vrijednostima, kao što su život i zdravlje čovjeka, svaka na svoj način. ${ }^{29}$

Medicinska etika i (medicinsko) pravo nerijetko se međusobno nadopunjuju. Pojedini odnosi i problemi koji se pojave u području medicinske djelatnosti mogu biti predmetom interesa i medicinskog prava i medicinske etike, odnosno (integrativne) bioetike. Štoviše, nekada je zajednički pristup nužan da bi se navedeni odnosi mogli kvalitetno urediti, odnosno da bi se uočeni problemi mogli kvalitetno riješiti. Spomenuli smo već neke primjere poput: eutanazije, kloniranja, patentiranja gena i matičnih stanica, nepristanka na medicinsku uslugu iz vjerskih razloga, liječničke tajne, priziva savjesti i sl. ${ }^{30}$

Posebno je značajna i nužna suradnja pripadnika ovih znanstvenih područja kod donošenja propisa kojima se uređuju odnosi u području zdravstva. (Integrativna) bioetika sa svojim etičkim sudovima o konkretnom ponašanju pomaže pravu i pravnoj znanosti u artikuliranju adekvatnih zakonskih normativa. ${ }^{31}$ Bioetika, za razliku od etike, insistira da temu svog proučavanja legalno kodificira. ${ }^{32}$ Pravila medicinske etike uobičajeno se kodificiraju u posebnim, nacionalnim i međunarodnim, etičkim odnosno 
deontološkim kodeksima. Kodeksima etike i deontologije u pravilu se utvrđuju načela i pravila ponašanja kojih su se dužni pridržavati zdravstveni radnici, članovi pojedinih komora, pri obavljanju svoje profesionalne djelatnosti, a radi očuvanja dostojanstva i ugleda profesije.

Odnos zdravstvenog radnika i pacijenta povodom pružanja medicinske usluge nije uređen jedino pravnim pravilima, nego su pravila medicinske etike i pravila medicinske struke veliki i iznimno značajan segment medicinskog prava kojim se uređuju obveze (njihov sadržaj i opseg) zdravstvenih radnika prilikom pružanja medicinskih usluga, do te mjere da ih je u našem pravu zakonodavac (primjerice, odredbom čl. 120. ZOZZ-a) digao na razinu pravne norme, za čije se nepoštivanje odnosno kršenje vežu ne samo moralne, nego i stegovne (disciplinske), kaznenopravne i građanskopravne sankcije. ${ }^{33}$ Medicinska etika i pravo međusobno se nadopunjuju, pravilima medicinske etike sudovi priznaju i pravnu snagu jer nepostupanje zdravstvenih radnika po tim pravilima podliježe pravnoj sankciji, pa je neprijeporno da je medicinska etika izvor medicinskog prava. ${ }^{34}$ Kada se etički postulati i pravila ponašanja u području medicine urede pravnim normama, tada dolazi do preklapanja, odnosno svojevrsne simbioze bioetike i medicinskog prava i pri tome je najmanje značajno je li bioetika postala dijelom medicinskog prava ili je, pak, obrnuto.

Treba kazati da medicina u svom ubrzanom razvitku ide, u pravilu, ispred prava, pa se nužno nameće potreba konstantnog pravnog uređenja brojnih pitanja i odnosa iz područja medicine ${ }^{35}$ Danas je uobičajeno da na području medicine pravna regulacija kasni za razvitkom društvenih odnosa na tom području što je ponajviše posljedica ekspanzije znanstveno-tehnoloških inovacija. ${ }^{36}$ Time nastaju i tzv. pravne praznine pa značajni i prijeporni biomedicinski odnosi nisu obuhvaćeni pravnim normama, nego su kontrolirani ponajviše pravilima morala i medicinske etike i deontologije. Tako, na određeni način, bioetika preuzima ulogu prava u uređenju odnosa iz područja medicine, dok se ti odnosi konačno ne urede pravnim normama. S druge strane, pravne norme daju bioetičkim postulatima i teorijama potrebnu praktičnost i opću primjenjivost. ${ }^{37}$ Već od samih početaka bioetike bila je razvidna nužnost i neodgodiva potreba za angažmanom pravne znanosti i prava u tematikama i problematikama koje bioetika prihvaća kao svoj materijalni objekt, a pogotovo se danas javlja potreba ozbiljnog i studioznog pravnoznanstvenog promišljanja o brojnim bioetičkim temama. ${ }^{38}$

Drugim riječima, snažan i ubrzani razvitak medicine i znanosti o životu otvaraju značajna pitanja koja traže i pravnu regulaciju. U pitanjima života i smrti, zdravlja i bolesti, prava pacijenata i dužnosti/odgovornosti liječnika, razumljivo je da se sve više javlja i potreba za uređivanjem tih složenih pitanja putem pravnih normi. ${ }^{39}$ Kašnjenje pravne intervencije na području medicine ima značajne negativne učinke za društvo u cjelini. ${ }^{40} \mathrm{U}$ cilju pravnog uređenja medicinske djelatnosti donose se novi propisi koje nameće medicinska praksa, brojna medicinska etička načela preuzimaju se i daje im se pravna snaga, pristupa se kodifikaciji prava pacijenata i sl.

Treba napomenuti da se (sudska i druga) praksa medicinskog prava često temelji na rješavanju sporova, odnosno problema iz područja bioetike. 
ZDRAVSTVENO STRUKOVNO STALEŠKO PRAVO

Prava, obveze i odgovornosti radnika u obavljanju djelatnosti: Medicinska etika

\section{Primjedbe}

${ }^{1}$ Usp. ZNIDARČIĆ, Z., Medicinska etika 1 - Uvod, Svrha raspravljanja o medicinskoj etici, Zagreb, 2004., str. 11.

${ }^{2} \mathrm{U}$ nazivu ovih akata često se pored ili umjesto termina „etika“ inzistira i na terminu ,deontologija“, no treba naglasiti da je to posljedica promijenjenog odnosa medicinskog prava i medicinske etike kao normativnih sustava u suvremenom društvu. Naime, medicinska deontologija je širi pojam od pojma medicinske etike jer se ona bavi definiranjem i izučavanjem dužnosti (i prava) pripadnika profesije, što znači da naglasak stavlja ne samo na etičku nego i na pravnu dimenziju odnosa. PETRIĆ, S.,

Pretpostavke odštetne odgovornosti davatelja zdravstvenih usluga u pravu BiH, zbornik radova „Aktualnosti građanskog i trgovačkog zakonodavstva i pravne prakse“, Mostar, 2005., broj 3, str. 94.

${ }^{3}$ Vidi kod ČOVIĆ, A., Pojmovna razgraničenja: moral, etika, medicinska etika, bioetika, integrativna bioetika, rad objavljen na starnici http://www.ffzg.unizg.hr/filoz/wp-content/uploads/2011/11/ClanakCOVIC-Bioetika-i-dijete.pdf., str. 16.

${ }^{4}$ Tako RADIŠIĆ, J., Medicinsko pravo u svetu i kod nas, „Pravni informator“, 2002., br. 9. str. 1.

${ }^{5}$ U tom smislu ŠARIĆ, D., Liječnička pogreška - pravni i medicinski aspekti, završni rad na poslijediplomskom specijalističkom studiju „Medicinsko pravo“ na Pravnom fakultetu Sveučilišta u Splitu, Split, 2015., str. 98.

${ }^{6}$ Vidi CERJAN, S., Zakon o zdravstvenoj zaštiti, „Informator“, broj 5176. od 15. listopada 2003., str. 13.

${ }^{7}$ Tako BABIĆ, T. - ROKSANDIĆ, S., Osnove zdravstvenog prava, Zagreb, 2006, str. 59.

${ }^{8}$ Usp. MUJOVIĆ-ZORNIĆ, H., Pravni aspekti etičkih komiteta u medicini, „Pravni život“, broj 9/2007., str. 254.

${ }^{9}$ Tako i više o tome kod BODNARUK, S. - ČIZMIĆ, J. - HRABAČ, B. - HUSEINAGIĆ, S., Komentari zdravstvenih zakona, knjiga 1., Privredna štampa, Sarajevo, 2011., str. 143.

${ }^{10}$ Proces postavljanja dijagnoze ili izbora terapije, medicinska logika i problemi nadležnosti su širi i kompleksniji od onog što se nalazi između članaka internih i pravnih propisa, a značajni su za procjenu inkriminiranog akta. Ne poznavajući dobro medicinsku problematiku, zna se desiti da pravnici ne dozvoljavaju pitanja, koja im se čine da su izvan okvira optužbe. Kad četvero liječnika, optuženih za smrt mlade žene, dođe s četiri odvjetnika, samo čvrsta ruka voditelja rasprave može izvesti slučaj do kraja. Katkad ga nije lako ni svrstati u neki od članaka Pravilnika. Pokazalo se da je odluka o profesionalnom vođenju sudskih rasprava bila nedvojbeno korisna i jedino ispravna, kako zbog same provedbe sudskog procesa, tako još više zbog autoriteta Suda Komore i važnosti koju ima liječničko djelovanje na zdravlje i život ljudi. Izvrstan balans pravnog i medicinskog razmišljanja, s izuzetno dobrim uzajamnim poštivanjem i razumijevanjem, karakterizirao je dosadašnji rad Sudova časti Komore pa su sve odluke donesene bez i jednog izdvojenog mišljenja. Glavna zakonska ovlast Komore leži u davanju i obnovi licence za rad, pa je i odnos prema Časnom sudu baziran na činjenici da je Sud nadležan za sankcioniranje stručnih pogrešaka i etičko-deontoloških povreda sve do oduzimanja licence. GJUROVIĆ, J., Časni sud Komore - osvrt, „Hrvatska liječnička komora 2005-2015“, Hrvatska liječnička komora, Zagreb, 2015., str. 187.

${ }^{11}$ Tako RADIŠIĆ, J., Medicinsko pravo u svetu i kod nas, „Pravni informator“, 2002., br. 9. str. 1.

${ }^{12}$ Tako VISKOVIĆ, N., Kakva bioetika?, poglavlje u knjizi Nikola Visković «Sumorne godine nacionalizam, bioetika, globalizacija», Split, 2003., str. 212.

${ }^{13}$ Usp. Introduction. In: Reich WT, editor. Encyclopedia of Bioethics. 2nd ed., New York, 1995., str. XXI. Tako i opširnije o tome kod HLAĆA, N., O bioetici u povodu potpisa u Vijeću Europe dvaju međunarodnih dokumenata s bioetičkim sadržajima, «Vladavina prava», god. II., 1998., br. 3-4, str. 45.52., SORTA-BILAJAC, I., Od eutanazije do distanazije, Rijeka, 2005., str. 15.-28.; MATULIĆ, T., Bioetika, Zagreb, 2001., str. 76.

${ }^{14}$ Tako i opširnije kod ŠEGOTA, I., Nova medicinska etika (bioetika), Rijeka, 2000., str. 1. i dalje. O pojmu «globalna bioetika» vidi kod MATULIĆ, T., Bioetika, Zagreb, 2001., str. 77.

${ }^{15}$ Vidi JONSEN A. R. - JAMETON A., Medical Ethics, In: Reich WT, editor. Encyclopedia of Bioethics. 2nd ed., New York, 1995., str. 1624., podatak kod SORTA-BILAJAC, I., Od eutanazije do distanazije, Rijeka, 2005., str. 17.

${ }^{16}$ Usp. ŠEGOTA, I., Van Rensselaer Potter II - «otac» bioetike, Bioetički svesci 1999., 6, str. 14.-21. 
${ }^{17}$ Pogledaj kod CALLAHAN, D., Bioethics, In: Reich WT, editor. Encyclopedia of Bioethics. 2nd ed., New York, 1995., str. 1624., podatak kod SORTA-BILAJAC, I., Od eutanazije do distanazije, Rijeka, 2005., str. 18.

${ }^{18}$ Vidi Medicinski leksikon, Zagreb, 1990., str. 106.

${ }^{19}$ Tako SORTA-BILAJAC, I., Od eutanazije do distanazije, Rijeka, 2005., str. 19. Vidi i FLETCHER, J. C. - BRODY, H., Clinical Ethics, In: Reich WT, editor. Encyclopedia of Bioethics. 2nd ed., New York, 1995., str. 399.-402.

${ }^{20}$ Usp. ČOVIĆ, A., Integrativna bioetika i problem istine, rad objavljen na stranici http://epub.ff.uns.ac.rs/index.php/arhe/article/viewFile/1219/1238, str. 186.

${ }^{21}$ Tako JURIĆ, H., Hrvatska uporišta za integrativnu bioetiku u djelu Van Rensselaera Pottera, rad na stranici http://www.ffzg.unizg.hr/filoz/wp-content/uploads/2011/09/45__dok.doc_.pdf, str. 86.

${ }^{22}$ Vidi ČOVIĆ, A., Pojmovna razgraničenja: moral, etika, medicinska etika, bioetika, integrativna bioetika, rad objavljen na starnici http://www.ffzg.unizg.hr/filoz/wp-content/uploads/2011/11/ClanakCOVIC-Bioetika-i-dijete.pdf., str. 23.

${ }^{23}$ Podatak kod Znanstveni program Znanstvenog centra izvrsnosti za integrativnu bioetiku, rad na stranici http://www.bioetika.hr/wp-content/uploads/2016/04/ZCI-IB-znanstveni-program.pdf, str. 7.

${ }^{24}$ Vidi MATULIĆ, T., Bioetika, Zagreb, 2001., str. 45.-461., CAPRON, A. M., Law and Bioethics, Encyclopedia of Bioethics, vol. 3., str. 1329.-1335., ZATTI, P., Bioetica e diritto, «Rivista italiana di medicina legale, 1995., br. 17, str. 11ss. I dr.

${ }^{25} \mathrm{O}$ tome primjerice kod RADOVANČEVIĆ, LJ., (Ko)relacije bioetike i zdravstvenog prava, referat održan na 9. bioetičkom okruglom stolu «Bioetika i medicinsko pravo», održanog u Rijeci, 15. i 16. svibnja 2008., Program i sažeci, str. 15.

${ }^{26}$ Tako, primjerice, postoji mišljenje da profesionalna medicinska etika čini temeljni dio medicinskog prava. Usp. BOŠKOVIĆ, Z., Medicina i pravo, Zagreb, 2007., str. 15. Vidi i MATULIĆ, T., Bioetika, Zagreb, 2001., str. 458.

${ }^{27}$ U tom smislu Matulić drži da: «bioetika i biopravo jesu i ostaju dvije razdvojene stvarnosti, ali intimno povezane i međuovisne, gdje svaka sfera ostaje autonomna i nealterirana u svojoj domeni, ali bezuvjetno legitimira utjecaj jedne na drugu». MATULIĆ, T., Bioetika, Zagreb, 2001., str. 458.

${ }^{28}$ Tako MATULIĆ, T., Bioetika, Zagreb, 2001., str. 76.

${ }^{29}$ Usp. RADIŠIĆ, J., Medicinsko pravo, Beograd, 2004., str. 5.

${ }^{30}$ Tako i više o0 tome kod ČIZMIĆ, J., Bioetika i medicinsko pravo, „,Medicina Fluminensis“, vol. 44, No 2, 2008., str. 171.-185.

${ }^{31}$ Vidi MATULIĆ, T., Bioetika, Zagreb, 2001., str. 453.

32 Tako MUZUR, A. - RINČIĆ LERGA, I., Etika i bioetika: sličnosti i razlike u odnosu prema pravu, referat održan na 9. bioetičkom okruglom stolu «Bioetika i medicinsko pravo», održanog u Rijeci, 15. i 16. svibnja 2008., Program i sažeci, str. 14.

${ }^{33}$ Usp. KLARIĆ, P., Odgovornost za štete u medicini, «Informator», br. 5016-5017. od 3. i 6. travnja 2002., male stranice, str. 3 .

${ }^{34}$ Vidi RADIŠIĆ, J., Medicinsko pravo, Beograd, 2004., str. 24.

${ }^{35}$ Tako JELAČIĆ, O., O nastavi iz sudske medicine na pravnim fakultetima, «Zbornik radova Pravnog fakulteta u Splitu», god. XIV, 1997., str. 236.

${ }^{36}$ Usp. VISKOVIĆ, N., Država i pravo, Zagreb, 1995., str. 219.

${ }^{37}$ Tako BOGDANIĆ, M., Odnos moralnog i legalnog u medicinskoj etici-američko iskustvo 40 godina povezanosti bioetike i pravnog sustava, referat na 9. bioetičkom okruglom stolu «Bioetika i medicinsko pravo», održanom u Rijeci, 15. i 16. svibnja 2008.

${ }^{38}$ Usp. MATULIĆ, T., Bioetika, Zagreb, 2001., str. 452.

${ }^{39}$ Vidi ŠEPAROVIĆ, Z., Granice rizika - Etičkopravni pristupi medicini, Zagreb, 1998., str. 5.

${ }^{40}$ Tako i podrobnije o tome kod VISKOVIĆ, N., Bioetika i biomedicinsko pravo, «Zbornik radova Pravnog fakulteta u Splitu», god. 32, 1995., br. 1-2, str. 78.-82. 


\section{5/ Priziv savjesti}

\subsection{Uvod - pojam i sadržaj ,priziva savjesti“}

Institut „priziv (prigovor) savjesti“ (conscientious objective) u najširem smislu riječi predstavlja pozivanje neke osobe na slobodu savjesti, ${ }^{1}$ kada odbija postupati na uobičajeni, propisani ili ugovoreni način, odnosno kada traži izuzeće od takve obveze ili sl., i to zbog svojih moralnih odnosno vjerskih uvjerenja. ${ }^{2}$ Dakle, priziv savjesti bio bi pravo i odluka pojedinca da izvrši ili odbije izvršiti neku radnju, suprotno zakonu, propisu ili nekoj drugoj odredbi, jer bi se njezino izvršenje protivilo etičkim, moralnim ili vjerskim uvjerenjima - točnije savjesti te osobe. Priziv bi savjesti trebao biti osobno opravdanje (osnova opravdanja) prizivaču u nepostupanju, nesudjelovanju, neprihvaćanju mogućih raznih profesionalnih zahvata, poslova, načina djelovanja i sl. ${ }^{3}$ Pravo na priziv savjesti proizlazi iz slobode savjesti, koja je zajamčena člankom 18. Opće deklaracije o pravima čovjeka. U čl. 47. Ustava Republike Hrvatske („Narodne novine“, pročišćeni tekst, broj 56/90, 135/97, 8/98, 113/00, 124/00, 28/01, 41/01, 55/01, 76/10, $85 / 10,05 / 14$, dalje - Ustav RH), izrijekom se spominje i jamči pravo na priziv savjesti (protiv vojne službe). Implementiranje prava na priziv savjesti u ustavni zakon svake države je najsigurniji način zaštite života, savjesti i dostojanstva ljudskog bića na individualnoj i institucijskoj razini. ${ }^{4}$

Pravo na priziv savjesti je emanacija slobode savjesti i tu prepoznajemo pravo pojedinca da pozivom na naloge svoje savjesti odbije postupati onako kako bi mu inače nalagao pravni poredak. Radi se o konceptu kakav je ustaljen i u pravu, i u znanosti, a također i u katoličkom vjerskom nauku. ${ }^{5}$ Proizašlo je iz temeljnih ljudskih prava na slobodu mišljenja, savjesti i religijskog ili drugog uvjerenja, te prava na autonomiju, identitet, privatnost i dostojanstvo osobe. Najčešće je motiviran religijskim razlozima te drugim moralnim ili etičkim stavovima. Priziv savjesti omogućava pojedincu da čuva svoju koherentnost i slobodu. Drži se kako čovjek prisiljen na postupanje protivno svojoj savjesti gubi samopoštovanje, cjelovitost i puninu svoje osobnosti te trpi ograničavanje svoje slobode. Osobito u slučajevima tzv. religijskog priziva savjesti, mogu biti prisutni i osjećaj straha (od Božje kazne, Pakla, gubitka vječnog spasenja, izopćenja...), krivnje i grijeha. $^{6}$

Klauzula savjesti postala je dio etičkih kodeksa, ali i zakonske regulative. Pozivanje na priziv savjesti definira se i kao zahtjev, motiviran etičkim ili vjerskim uvjerenjima, koji omogućuje njegovom podnositelju da se osobno izuzme kako bi izbjegao uobičajenu dužnost ili kako bi postupio mimo onoga što je zakonom propisano. ${ }^{7} \mathrm{Da}$ bi prigovor savjesti bio legitiman i prihvatljiv mora se zasnivati na moralnim načelima pojedinca, koji upravlja tumačenjem i shvaćanjem pravnih normi ili političkih akata vlasti, a ne na osobnim interesima ili drugim iskonstruiranim oblicima političke lojalnosti. Jer, kad se pojedinac na temelju svojih moralnih načela odluči na otpor, on tada postupa svjesno i savjesno, pa čak i ako nije u pravu, te se na taj način stvara razlika između moralne i pravne sankcije, pošto moralna sankcija djeluje iznutra, a pravna sankcija izvana. ${ }^{8}$ Po 
svojoj naravi priziv savjesti nije pravno pravo, već je moralno pravo ili, točnije, moralna dužnost, jer u području morala egzistira pravo kao korelacija dužnosti. ${ }^{9}$

Iako se drži da priziv savjesti ne predstavlja značajno pravno pitanje, većina pravnih sustava, osobito razvijenih demokratskih zemalja, prepoznala je potrebu pojedinca da postupa u skladu sa zahtjevima savjesti. ${ }^{10}$ Pravo na priziv savjesti temeljno je ljudsko pravo i sastavni je dio slobode mišljenja koje je priznato na međunarodnoj razini, a u praksi se ostvaruje u većini država svijeta. ${ }^{11}$ Zakonodavstva razvijenih zemalja vođena zaštitom ljudske slobode, identiteta, savjesti i dostojanstva dopuštaju priziv savjesti kao pravno dopuštene radnje ograničenog opsega. Teret dokazivanja prigovora u bilo kojem pravnom postupku leži na onome tko ga ističe.

Zahtjev za izuzeće pretpostavlja sukob između opće norme i savjesti, što znači da je to pravilo koje se ne prihvaća strogo, već se odnosi samo na pojedinačnu situaciju. ${ }^{12}$ Drži se kako pojedinac, neovisno o svojoj profesiji, nije dužan poštivati one zakonske odredbe koje su u koliziji s njegovom vlastitom savjesti, ${ }^{13}$ odnosno da ne mora poštivati zakon ili neke njegove odredbe ako iste uključuju postupanje protivno savjesti. ${ }^{14} \mathrm{Da}$ bi priziv savjesti bio legitiman, mora se zasnivati na moralnim načelima pojedinca koji shvaća značenje pravnih normi, a ne na osobnim interesima. S druge strane, bitno je da pravo jednog pojedinca ne ugrožava ili isključuje prava drugih ljudi. ${ }^{15}$

Iako priziv savjesti predstavlja svojevrsni otpor, ipak se klauzula savjesti pojmovno razlikuje od „otpora“ ili „građanske neposlušnosti“ jer ona nije usmjerena na političke razloge ili opće shvaćanje pravičnosti. ${ }^{16}$ Dosadašnja iskustva svjedoče o tome da će kolizija između zahtjeva pravne norme i zahtjeva savjesti biti gotovo uvijek odlučena u korist savjesti. Naime, prizivatelj savjesti ne smatra da je postupio pogrešno kršeći pravnu normu jer je pri tome vođen moralnom odgovornošću (moralnim imperativom). Pojedinac može biti pravno kažnjen, ali ne i kažnjen na autentičan moralni način. Takva, rekli bismo, površna kazna ne stvara motivaciju za korekciju ponašanja, stava ili odnosa prema spornoj pravnoj normi. Moralna sankcija djeluje iznutra, a pravna izvana. Stoga smatramo da ova prva predstavlja autentičnu sankciju. ${ }^{17}$ Pravo na prigovor savjesti, dakle nije contra legem već exceptio legis, jer su zakonodavci u okviru pravnog sustava iskazali tendenciju da to pravo relativiziraju s namjerom da moralni stav pojedinca ne zadire $u$ prava drugih pravnih subjekata. Legalizacija priziva savjesti, odnosno njegova ograničena pravna dopustivost, predstavlja značajan korak u razvitku modernog prava, posebno onoga dijela koji se odnosi na zaštitu najviših ljudskih vrijednosti, od prava na fizički integritet do slobode govora, misli, savjesti i vjeroispovijedi. ${ }^{18}$

Sloboda mišljenja, savjesti i vjeroispovijedi spada u ljudska prava i temeljne slobode zajamčene međunarodnim dokumentima, u prvom redu Općom deklaracijom o ljudskim pravima Ujedinjenih naroda (članak 18.) i Konvencijom za zaštitu ljudskih prava i temeljnih sloboda (članak 9.). Sloboda misli, savjesti i vjeroispovijesti jesu vrednote kojima Ustav RH daje posebno značenje propisujući ih kao temeljne slobode i prava čovjeka i građanina. Ustav RH je posebnim člankom (čl. 47.) predvidio mogućnost priziva savjesti i onima koji zbog svojih vjerskih ili moralnih nazora nisu pripravni sudjelovati u obavljanju vojničkih dužnosti u oružanim snagama. Na sličan način ova je odredba mutatis mutandis uvrštena i u zdravstvene zakone. Stoga priziv savjesti 
predstavlja oživotvorenje ustavnog određenja slobode savjesti svakog čovjeka te kao takvo odnosi prevagu u situacijama kada zdravstveni radnici odluče odbiti pružiti zdravstvenu uslugu koja nije u skladu sa njihovim uvjerenjima. ${ }^{19}$ Značaj ove ljudske slobode ogleda se i u tome što većina demokratskih zemalja daje pojedincu legitimno pravo na priziv savjesti, odnosno dopušta mu da ne postupi po zakonu ili pojedinoj njegovoj odredbi koja propisuje ponašanje protivno njegovoj savjesti. Pri tome je nužno da sloboda savjesti jedne osobe ne ugrožava ili isključuje prava drugih osoba. ${ }^{20}$

Isto tako Ustav RH u članku 40. navodi da se jamči sloboda savjesti i vjeroispovijedi i slobodno javno očitovanje vjere ili drugog uvjerenja. Ova iznimno široka određenja slobode savjesti temelj su za priziv savjesti, ali nisu istovjetna prizivu savjesti, odnosno ne daju automatsko pravo svakoj osobi, u svakoj situaciji i zbog svakog razloga koji ta osoba smatra svojim moralnim ili vjerskim uvjerenjem da krši neke druge propisane ili ugovorene obveze. Kako priziv savjesti u pravili znači kršenje nekih drugih obveza/dužnosti (primjerice, služenja u vojsci, odbijanja izvršavanja ugovorenih poslova i sl.), dakle dolazi u sukob s nekim drugim pravima, on mora na određeni način biti razrađen i ograničen koliko je to moguće procedurom i konkretnijim razlozima, kako ne bi postao temelj za neopravdanu samovolju. Stoga postoji potreba da se priziv savjesti regulira propisima odnosno da mu sudska praksa odredi granice i postupak (iako su to vrlo promjenjive i fleksibilne granice). ${ }^{21}$

Priziv savjesti sve se više u suvremenim demokracijama smatra bitnim kriterijem za ocjenu kvalitete određenog pravnog sustava, kako s aspekta (medicinsko)pravne teorije i njezine evaluacije u pozitivno pravo, tako i s etičkog aspekta, ${ }^{22}$ te njegove deontološke funkcije kritičke evaluacije pozitivnog prava. ${ }^{23} \mathrm{U}$ tom smislu klauzula savjesti može ukazivati i na potrebu izmjene zakona, ali to je, ipak, samo njezina sekundarna svrha. ${ }^{24}$

Malo je poznato da među brojnim praznicima postoji i Međunarodni dan priziva savjesti. Međunarodna mreža priziva savjesti je 1985. odlučila da 15. svibanj postane Međunarodni dan priziva savjesti kako bi se stvorio veći globalni fokus na pitanje priziva savjesti. Međunarodna mreža priziva savjesti sastajala se svake godine od 1981. do 1997. U početku su to bili sastanci prizivatelja savjesti koji su razmjenjivali ideje i iskustva, da bi se kasnije raspravljalo o ozbiljnijim ciljevima i razvijale strategije. U mnogim državama širom svijeta taj dan se obilježava akcijama koje podržavaju pravo na priziv savjesti. ${ }^{25}$ Velik broj razvijenih zemalja priziv savjesti svrstava u kategoriju prava na slobodu, dok neki taj institut smatraju oblikom građanske neposlušnosti, ${ }^{26}$ te kao legalno, međunarodno priznato pravo građana - pravo slobode.

\subsection{Povijesni razvitak instituta ,priziva savjesti“6}

Povijesno gledano, pravni poredci u različitoj su mjeri priznavali pravo na priziv savjesti. Konflikt između onoga što nalaže zakon i savjesti pojedinaca u prošlosti je osobito bio prepoznat u svezi s vojnom obvezom ili medijskim izvještavanjem, putem pozivanja na klauzulu savjesti, odnosno priziv savjesti. ${ }^{27}$

Priziv savjesti kao pojam postoji stoljećima unatrag. Pojam ,savjest" potječe iz antičkokršćanske tradicije. Prema Demokratu oblikovan je od prvotnog pojma „synderesis" ili 
„synteresis" (grč. „su-znanje"), urođene sposobnosti kojom ljudska bića spoznaju moralni zakon, do pojma prema Ciceronu koji je grčku riječ „synderesis" (synteresis) preveo kao „,conscientia" (lat. „,savjest"). ${ }^{28}$ Drevni primjer priziva savjesti nalazimo u antičkoj drami Antigona (5. stoljeće pr. Kr.), gdje Sofoklo prikazuje primjer mlade žene koja odbija poštivati svjetovni zakon koji joj zabranjuje da pokopa braću koja su poginula u pobuni protiv vlastitog kralja - ona se izlaže najvećem riziku jer osjeća da je božanski zakon koji joj nalaže da pokopa najbliže srodnike, obvezuje jače od državnog zakona koji joj to brani. Činjenica da Sofoklo - te, očito, njegova publika u antičkoj Grčkoj - promatra Antigonino rizično i naizgled "neekonomično" ponašanje (ona sama biva osuđena na smrt, zbog brige za ionako mrtva tijela svoje braće) kao dostojno i herojsko, govori nam da je priziv savjesti već u to vrijeme bio kulturalno prepoznat i odobravan. ${ }^{29}$

U 6. i 7. poglavlju biblijske 2. knjige o Makabejcima nalazimo primjere Židova koji su se u 1. stoljeću prije Krista odbijali podvrgnuti helenističkim zakonima koji su od njih tražili, pod prijetnjom smrtne kazne, da prikažu žrtvu na žrtveniku državnog kulta i jedu svinjetinu u znak odricanja od židovskog Zakona i podlaganja zakonu i kultu države. ${ }^{30}$

Savjest koja omogućuje ljudskim bićima spoznaju značenja vlastitog moralnog čina, interpretirana je s teološke perspektive u srednjem vijeku kao ,dvoslojna instancija ljudske duhovnosti". U 18. stoljeću Kant ističe savjest koja je kao glas, amblemičan opis unutarnjeg zakona kojega čovjek samom sebi ne daje, već ga otkriva u sebi, kao preduvjet odnosno temelj za slobodnu, autonomnu moralnu akciju. ${ }^{31}$ U 20. stoljeću Freud definira savjest kao dio super ega (,nad svijesti") koji se razvija pod utjecajem nagrada, zabrana i kazni tijekom odgojnog procesa, odnosno kao odraz volje drugih osoba. U 21. stoljeću, u skladu s mislima svetaca koji savjest identificiraju s „osjećajem za dobro koji je utisnuto u nas" (sv. Augustin), s ,iskrom Božanske ljubavi koja je skrivena u nama" (sv. Pavao) i sa „Zakonom koji je upisan u srcu svakog od nas" (sv. Bazilije), papa Bendikt XVI. riječ „synderesis" zamjenjuje platonskim pojmom ,anamnesis" (grč. spomen) odnosno s ontološkom razinom pojma savjesti. Naša nutarnja otvorenost za apsolutnu istinu ili „anamnesis" u suglasju je sa „conscientia", sa savješću, odnosno drugom razinom koja prosuđuje i odlučuje. ${ }^{32}$

Povijesno je kao ljudsko pravo priziv savjesti priznat nakon Nirnberških procesa, kada se rađa cijela moderna doktrina ljudskih prava i Opća deklaracija o ljudskim pravima. ${ }^{33}$ Od druge polovice 20. stoljeća pravo na priziv savjesti je kroz pravo na mišljenje, savjest i religiju priznato mnogim međunarodnim i nacionalnim pravnim aktima kao i mnogim profesionalnim i etičkim strukovnim kodeksima. Time je prizivačima/cama savjesti zajamčena pravosudna nekažnjivost i zaštita njihovog postupanja. Mogućnost javne osude i/ili stigmatizacije prizivača/ice ostaje prisutna, a ovisi o dominantnim društvenim stavovima i raspoloženjima. ${ }^{34}$

Tijekom XX. stoljeća, u kontekstu opće vojne obveze, nameće se problem priziva savjesti protiv vojne službe. Prizivatelji se opet pozivaju na moralne naloge koji proizlaze iz njihove religije. Makar pravo na priziv savjesti proizlazi iz prava na slobodu savjesti, koja je zajamčena člankom 18. Opće deklaracije UN o pravima čovjeka iz 1948., u praktičnom životu nisu ni danas rijetke situacije u kojima pravni poredak ne priznaje legitimnost prigovora savjesti koje izjavljuju pojedinci. Tako je, s obzirom da vjerski nauk Jehovinih 
svjedoka zabranjuje službu u vojsci, nemali broj pripadnika te vjere je bio izložen zatvorskim kaznama zbog odbijanja vojne službe. ${ }^{35}$ Termin „priziv savjesti““ se je u sudskoj praksi Europskog suda za ljudska prava razvio upravo povodom zalaganja Jehovinih svjedoka da im se prizna priziv savjesti protiv vojne službe. Taj je sud nakon skoro četrdeset godina odbijanja da prizna priziv savjesti u tom iznimno važnom pitanju, tek 2000. takav priziv savjesti priznao u slučaju Thimmenos protiv Grčke. ${ }^{36}$

Kao pojam povezan s medicinskim radnicima pojavljuje se prvi put u Zakletvi za koju se smatra da ju je gotovo sigurno napisao Hipokrat. Scribonius Largus (c. AD 1-50) nam govori da je u njegovo doba Zakletva uobičajeno primjenjivana. ${ }^{37} \mathrm{U}$ srednjem vijeku Zakletva se prvi put spominje kao uobičajena praksa tek u Wittenbergu u Njemačkoj 1508. Oko 1930. samo u 19\% američkih medicinskih škola je polagana Zakletva. Dakle, pojam priziva savjesti preciznije je definiran tek u novije doba. ${ }^{38}$

\subsection{Područja primjene instituta "priziva savjesti"“}

Institut „priziva savjesti" štiti građansku slobodu svake osobe u odnosu na izbor u skladu s vlastitom savjesti. Svatko ima pravo na slobodu mišljenja, savjesti i vjeroispovijedi, a to pravo uključuje slobodu promjene vjeroispovijedi ili uvjerenja i slobodu da pojedinačno ili u zajednici s drugima, javno ili privatno, iskazuje svoju vjeroispovijed ili uvjerenje poučavanjem, bogoslužjem, praktičnim vršenjem i obredima. ${ }^{39}$ Sloboda manifestiranja svoje vjere ili svojih uvjerenja podliježe samo onim ograničenjima predviđenim zakonom i koja su nužna $\mathrm{u}$ demokratskom društvu $\mathrm{u}$ interesu javne sigurnosti, zaštite javnog poretka, zdravlja ili morala ili zaštite prava i sloboda drugih. ${ }^{40}$ Svakako, može se dogoditi da manifestiranje uvjerenja od strane neke osobe dođe u sukob s nekom građanskom ili osobnom dužnošću/obvezom. ${ }^{41}$

Pravo na priziv savjesti najčešće se veže uz medicinu i služenje vojnog roka te nošenje i uporabu oružja.

Vojna obveza i obrana Republike Hrvatske dužnost je svih za to sposobnih državljana. Dopušten je priziv savjesti onima koji poradi svojih vjerskih ili moralnih nazora nisu pripravni sudjelovati u obavljanju vojničkih dužnosti u oružanim snagama. Te su osobe obvezne ispunjavati druge dužnosti određene zakonom (Ustav RH, čl. 47.). ${ }^{42} \mathrm{U}$ takvom slučaju institut „priziva savjesti" omogućuje odustajanje od: služenja vojne obveze, sudjelovanja u ratnim aktivnostima i određenim misijama za koje drže da nisu u skladu s njihovom savješću, odnosno moralnim uvjerenjima, nošenja i upotrebe oružja. Priziv savjesti je odbijanje sudjelovanja u onim radnjama koje savjest prizivatelja ne odobrava, a priziv savjesti na vojnu službu je odbijanje služenja vojnog roka iz političkih, vjerskih, filozofskih, moralnih ili bilo kojih drugih razloga savjesti. U praksi priziv savjesti je pravo svakog da odbije službu u vojnim jedinicama i ustanovama i samim time odbije sudjelovati u bilo kakvom vidu rata ili priprema za rat. ${ }^{43} \mathrm{U}$ tom smislu značajna je i praksa Europskog suda o prizivu savjesti vezano za odbijanje služenja vojnog roka, a posebno je značajna odluka u predmetu Bayatyan protiv Armenije (2011.), u kojemu je podnositelj, inače Jehovin svjedok, odbio služiti vojni rok pozivajući se na priziv savjesti. Sud je smatrao da protivljenje obnašanju vojne službe, ako je motivirano ozbiljnim i nepremostivim sukobom između obveze služenja vojske i savjesti pojedinca ili njegovih 
dubokih i iskrenih vjerskih ili drugih uvjerenja, predstavlja uvjerenje ili vjerovanje dostatne razine uvjerljivosti, ozbiljnosti, kohezije i važnosti da potpadne pod jamstvo čl. 9. Konvencije, što se inače mora utvrditi u svjetlu posebnih okolnosti svakog slučaja. ${ }^{44}$

Primjeri različitih dužnosti vezano za obavljanje medicinske djelatnosti pokazuju da je klauzula savjesti važna u praktičnom radu zdravstvenih radnika. ${ }^{45}$ Institut ,priziva savjesti“ štiti i specifičnu skupinu - liječnike, zdravstvene radnika i znanstvenike, koji mogu odbiti sudjelovanje u znanstvenim istraživanjima, dijagnostičkim i terapijskim postupcima i zahvatima koji nisu u skladu s njihovom savjesti. Mogu isticati priziv savjesti i kod sljedećih usluga: pobačaj/abortus, kontracepcija, osiguranje za pokriće kontracepcije, usluge za planiranje obitelji ili savjetovališta za to, sterilizacija, potpomognuta oplodnja, kloniranje, eksperimentiranje s fetusima, eutanazija, podrška na kraju života, obdukcija, transplatacija organa, transfuzija krvi, medicinski eksperimenti i istraživanja embrionalnih matičnih stanica, etički dvojbeni postupci koji su vezani za slučajeve moždane smrti, odnosno isključivanja aparata koji pacijenta održavaju na životu i sl. ${ }^{46}$ Pravo na priziv savjesti mogli bi istaknuti i indirektni pružatelji zdravstvenih usluga. Primjerice farmaceuti, jer oni nemaju ovlaštenje pisati recepte, nego ih samo provode ili medicinski tehničar koji odbija voziti trudnu ženu na kliniku za abortus. ${ }^{47}$ Poznati su i slučajevi u kojima ljekarnici (farmaceuti) odbijaju izdati lijek za kontracepciju ili lijek koji izaziva prekid trudnoće, ${ }^{48}$ tvrdeći da je takav stav dio njihove profesionalne autonomije i integriteta, da time podržavaju svetost života i da bi drukčije ponašanje bilo suprotno Hipokratovoj zakletvi. ${ }^{49}$ Pri tome drže da se nalaze u analognoj situaciji u kojoj se nalaze liječnici kada pozivom na priziv savjesti odbijaju uraditi prekid trudnoće. ${ }^{50}$ Parlamentarna skupština Vijeća Europe utvrdila je pravo na priziv savjesti u medicini Rezolucijom 1763 iz 2010. godine. U točki 1. ove Rezolucije, među ostalim, stoji da niti jedna pravna ili fizička osoba neće biti podvrgnuta prisili, neće se držati odgovornom niti će se na bilo koji način diskriminirati ako odbije izvršiti pobačaj ili eutanaziju. ${ }^{51}$

Iako se najčešće odnosi na vojnu službu i zdravstvene radnike postoje i druge vrste priziva savjesti. Drži se kako odredba čl. 47. Ustava RH, iako izrijekom spominje samo vojnu obvezu, štiti sve, odnosno pripadnicima svih djelatnosti daje mogućnost da zbog priziva savjesti odbiju određeni posao koji nije u skladu s njihovim stajalištima, uvjerenjima ili svjetonazorom, a zbog toga ne smiju dobiti otkaz. Tako novinar može odbiti napisati tekst koji nije u skladu s njegovim uvjerenjima, članovi pokreta za zabranu eksperimenata nad životinjama imaju pravo na priziv savjesti jer ih smatraju neetičnim, trgovci mogu uložiti priziv savjesti zbog toga što moraju raditi nedjeljom, prodavati pornografiju i štošta drugog što se protivi njihovoj savjesti. ${ }^{52}$ I svećenik, odnosno vjerski ispovjednik, u svojim se duhovnim poslovima ima pravo pozvati na priziv savjesti i odbiti aktivnosti s kojima se ne slaže. Poznat je i primjer kad je jedan sudac odbio zbog svoje savjesti sudjelovati u radu izbornog povjerenstva pri provedbi referenduma o braku, ocjenjujući da se time ugrožavaju prava homoseksualaca, a taj priziv savjesti je uvažen i on je zamijenjen drugim sucem. ${ }^{53}$ Svakako poznati su i primjeri kada je pravo na priziv savjesti bilo neopravdano osporeno, ${ }^{54}$ a i Europski sud za ljudska prava je, primjerice, u slučaju Eveida i dr. protiv Ujedinjenog Kraljevstva 2013. godine zauzeo stajalište da matičari ne bi imali pravo na priziv savjesti protiv obveze da sudjeluju u sklapanju tzv. ,isto spolnog braka“. ${ }^{55}$ 


\section{$5.4 \quad$ „Priziv savjesti“" u medicini}

Primjena novih spoznaja u kliničkoj praksi otvara prostor za mnoštvo konfliktnih situacija gdje se međusobno suprotstavljaju ciljevi istraživanja s medicinskom etikom, zaštitom ljudskih prava i dostojanstva života. Priziv savjesti u medicini je pojam koji označava pravo zdravstvenog radnika da odbije pružiti medicinsku uslugu, pod određenim jasno definiranim uvjetima. Načelno se smatra da uzrok može biti bilo koji subjektivni ili objektivni razlog koji liječnika (zdravstvenog radnika) navodi na zaključak da ne može pružiti uslugu na određenoj, željenoj razini, kao što su: osobna uvjerenja (primjerice, religijska), psihološka (primjerice, liječnik drži da zbog svog stava nije u stanju pružiti uslugu na odgovarajućoj stručnoj razini), tehnički razlozi (medicinska oprema nije ispravna ili nije dostupna), osobna zdravstvena nesposobnost samog liječnika itd. ${ }^{56}$ Osnovanost priziva savjesti liječnika jest u mogućoj (u zamisli i stvarnosti) sučeljenosti vrijednosti, sučeljenosti ćudorednih (moralnih) odabira, vrijednosnih stavova, vrijednosnih prosudbi, u raskrižjima vrsta, stupnjeva, razina odgovornosti. Pri tome bi pravo liječnika na priziv savjesti trebalo biti inače priznato, prihvaćeno, legitimno, pa otuda i liječniku osobno dopušteno, opravdano i legitimno. ${ }^{57}$

Kao pravo koje štiti slobodu mišljenja, savjesti i vjeroispovijesti ono se u medicini najčešće očituje kao pravo na odbijanje činjenja nekih legalnih i standardnih medicinskih postupaka kada su u suprotnosti sa savješću zdravstvenih radnika (liječnici, medicinske sestre, primalje, ljekarnici, radiolozi, fizioterapeuti, laboranti i dr.), odnosno kao tzv. negativni priziv savjesti. S druge strane, savjest zdravstvenog radnika može mu nalagati činjenje nekih medicinskih postupaka u interesu dobrobiti pacijenta, iako su isti protivni važećim odredbama, propisima ili zakonima, kao tzv. pozitivni priziv savjesti. Oba priziva savjesti imaju jednaku vrijednost. U medicini se pretežno raspravlja, istražuje i potiče negativni priziv savjesti (odbijanje činjenja), koji zadnjih desetljeća u svijetu poprima gotovo epidemijske razmjere i značajno utječe na provođenje zdravstvene zaštite. ${ }^{58}$ Drugim riječima, prigovor savjesti može se izraziti aktivno i pasivno, odnosno određenom konkludentnom radnjom može se aktivno suprotstaviti normi ili propustiti činjenje radnje (napuštanje obveznog liječenja pacijenta). Ovo je pitanje bitno u slučaju da prizivatelj ne želi objašnjavati svoje razloge i da pri tome može svoju pasivnost lažno obrazlagati (npr. zbog straha ili srama) ${ }^{59}$ Od ovlaštenog tijela, koje postupa po prigovoru savjesti, očekuje se zbog toga da poduzme sve moguće radnje kako bi utvrdilo prave razloge prizivatelja, pod uvjetom da iz svih činjenica konkretnog slučaja može utvrditi da je određena osoba i stvarno prizivatelj. U slučaju da prizivatelj odbija obrazložiti razloge za priziv savjesti, može biti relevantna i činjenica propisuje li pravna norma dopuštene razloge za priziv savjesti. Kada to nije uređeno propisima, kriterij dopuštenosti priziva savjesti koji nije obrazložen može biti i pretpostavka da se temelji na savjesti prigovaraća. ${ }^{60}$

Pravni izvori - Kao što smo vidjeli, središnji međunarodni dokumenti u kojima se priznaje pravo na priziv savjesti su Opća deklaracija Ujedinjenih naroda o pravima čovjeka iz 1948. godine, koja u čl. 18. priznaje slobodu savjesti, te (Europska) Konvencija za zaštitu ljudskih prava i temeljnih sloboda, koja slobodu savjesti priznaje u čl. 9., a od nacionalnih propisa slobodu savjesti prvenstveno jamči Ustav RH u 
čl. 40. i 47., ${ }^{61}$ a sadrži i neke druge odredbe kojima se na izravan ili neizravan način uređuju i odnosi na području medicinskog prava.

Zakoni predstavljaju temeljni i najznačajniji pravni izvor kojim se uređuje pravo na priziv savjesti zdravstvenih radnika.

Tako je odredbom čl. 20. ZOL-a propisano da liječnik, radi svojih etičkih, vjerskih ili moralnih nazora, odnosno uvjerenja, ima pravo pozvati se na priziv savjesti te odbiti provođenje dijagnostike, liječenja i rehabilitacije pacijenta, ako su ispunjeni propisani uvjeti.

I doktor stomatologije ima pravo, radi svojih etičkih, vjerskih ili moralnih nazora, odnosno uvjerenja, pozvati se na priziv savjesti te odbiti provođenje dijagnostike, liječenja i rehabilitacije pacijenta, ako su ispunjeni propisani uvjeti (ZODM, članak 26.).

Zdravstveni i nezdravstveni radnici koji bi trebali provesti ili sudjelovati u provođenju postupaka medicinski potpomognute oplodnje imaju također pravo pozvati se na priziv savjesti zbog svojih etičkih, vjerskih ili moralnih nazora, odnosno uvjerenja te odbiti provođenje postupka medicinski potpomognute oplodnje ili sudjelovanje u tom postupku (Zakon o medicinski potpomognutoj oplodnji, „Narodne novine“ 86/12., čl. 44.)

I odredbom čl. 124. st. 1. i 3. ZOZZ-a propisano je da su zdravstveni radnici dužni kad pružaju zdravstvenu zaštitu poštivati moralna i etička načela zdravstvene struke, odnosno postupati prema pravilima zdravstvene struke, na način da svojim postupcima ne ugroze život i zdravlje ljudi.

Veliki i iznimno značajan segment medicinskog prava čine pravila etike i pravila medicinske struke, koja sama po sebi, odnosno po svojoj prirodi i nisu pravna pravila, ali ih je zakonodavac, zbog njihovog značaja, dignuo na razinu pravne norme za čije se nepoštivanje, odnosno kršenje ne vežu samo moralne posljedice, nego i stegovne, kaznenopravne, građanskopravne i prekršajne sankcije. ${ }^{62}$ Značajni predmet zanimanja medicinskog prava predstavlja odnos između liječnika (zdravstvenog radnika) i pacijenata u pogledu pružanja medicinske usluge, a taj odnos nije samo pravni, nego je i etički. U njemu su moralni i pravni obziri pomiješani u znatno većoj mjeri nego što je to slučaj s ostalim pravnim odnosima među ljudima. Liječnik (zdravstveni radnik) je (pravno) dužan pridržavati se određenih načela medicinske etike. Moralne i pravne dužnosti liječnika toliko su se stopile $\mathrm{i}$ ispreplele da ih je u pojedinostima gotovo nemoguće razlučiti. ${ }^{63}$ Pravila medicinske etike uobičajeno se kodificiraju u posebnim, nacionalnim i međunarodnim, etičkim odnosno deontološkim kodeksima. Kodeksima etike i deontologije u pravilu se utvrđuju načela i pravila ponašanja kojih su se dužni pridržavati zdravstveni radnici, članovi pojedinih komora, pri obavljanju svoje profesionalne djelatnosti, a radi očuvanja dostojanstva i ugleda profesije. Najstarija kodifikacija liječničke etike je Hipokratova zakletva. ${ }^{64} \mathrm{U}$ Republici Hrvatskoj najznačajniji su KMED koji u čl. 2 točki 15 . određuje da liječnik ima pravo na priziv savjesti, ako time ne uzrokuje trajne posljedice za zdravlje ili ne ugrozi život pacijenta, te da o svojoj odluci mora pravodobno obavijestiti pacijenta i uputiti ga drugom liječniku iste struke. I odredbom čl. 3. toč. 20. Etičkog kodeksa primalja od 27. siječnja 2010., propisano je da primalja ima pravo na priziv savjesti ako time ne uzrokuje trajne 
posljedice za zdravlje ili ne ugrozi život pacijenta/-ice. O svojoj odluci mora pravodobno obavijestiti pacijenta/-icu te ju uputiti drugoj primalji. Primalja koja radi kao član zdravstvenog tima (u primarnoj zdravstvenoj zaštiti ili u bolničkoj zdravstvenoj skrbi) mora u što kraćem roku izvijestiti odgovornu osobu ako postoji bilo kakav priziv savjesti bitan za obavljanje njezine profesionalne djelatnosti. U tom slučaju ne smije prestati pružati primaljsku skrb ako bi time uzrokovala trajne posljedice za zdravlje ili ugrozila život pacijentice. Sukladno čl. 12. Toč. (3) Kodeksa ljekarničke etike i deontologije (Farmaceutski glasnik, broj 4/96.), magistar farmacije ima pravo priziva savjesti samo ako time ne dovodi u opasnost zdravlje i život bolesnika.

Konkretno pitanje priziva savjesti, odnosno transfuzije krvi Jehovinih svjedoka nije nigdje izravno pravno regulirano, kao uostalom mnoga druga životna pitanja, iako je to poseban medicinski, pravni i etički problem. ${ }^{65}$

Prava Jehovinih svjedoka (JS) na zdravstvenu zaštitu u Republici Hrvatskoj (RH) moraju biti jednaka kao za ostalu populaciju. Odbijanje transfuzije krvi (TK) koje nalaže religijski svjetonazor JS-a prepreka je ostvarivanju pojedinih rizičnih oblika liječenja u RH. Krvarenje kao komplikacija nekih oblika liječenja može ugroziti život bolesnika. Izbjegavanje TK postupcima pripreme može u određenom opsegu u pojedinačnim slučajevima spriječiti posljedice, no „zamjenska krv“, zvana tako u laičkim medijima, zapravo ne postoji. U RH je zakonom zajamčeno postupanje u skladu s bolesnikovim pristankom ili odbijanjem određenih postupaka liječenja. U svakome pojedinačnom slučaju potrebno je procijeniti rizik od krvarenja te, ako on nije izrazit, omogućiti bolesniku takvo liječenje. Ako liječnik ili zdravstvena ustanova ne mogu prihvatiti ni manji rizik, potrebno je uputiti bolesnika liječniku ili ustanovi koja može provesti takvo liječenje. Pristanak bolesnika na postupak liječenja bez pristanka na TK ne obvezuje liječnika na sudjelovanje u takvom zahvatu samo kada postoji velik rizik od krvarenja, a bolesnik odbija TK. Zakon o zdravstvenoj zaštiti pacijenata u RH obvezuje liječnika na spašavanje života pa je TK u životno ugroženog bolesnika koji krvari ili je iskrvario u takvoj situaciji jedina opcija, što može dovesti do liječenja protivno volji pacijenta. S obzirom na legislativnu nedorečenost i proturječnost te na obvezu RH prema poštovanju prava Europske unije odnosno slijeđenja Europske konvencije za zaštitu ljudskih prava (EKZLJP), u slučaju, premda etički opravdanog i obveznog TK protiv bolesnikova pristanka u slučaju spašavanja života, možemo i moramo računati da takvim postupanjem EKZLJP može biti povrijeđen. $\underline{\mathbf{6}}$

Treba kazati da je 1995. posebna komisija Ministarstva zdravstva Republike Hrvatske izradila Nacrt prijedloga Zakona o prekidu trudnoće, koji nikad nije stavljen u saborsku proceduru i do danas nije poznato zašto se od Nacrta odustalo. Odredba čl. 20. spomenutog Nacrta predviđala je mogućnost da se pravo na pobačaj ograniči prigovorom savjesti liječnika i drugih zdravstvenih radnika, koji zbog izjavljenog prigovora savjesti ne bi smjeli snositi nikakve štetne posljedice. Stavkom 3. navedenog članka bilo je propisana dužnost ovlaštene bolnice da u takvim slučajevima osigura izvršenje prekida trudnoće. ${ }^{67}$

Dopuštenost pozivanja na „priziv savjesti“ - Zdravstvena djelatnost jedan je od oblika javne službe koja se osniva radi provođenja i osiguranja zdravstvene zaštite građana i za 
koju se zakonom osiguravaju sredstva za provođenje zdravstvene zaštite, kao i za rad i razvitak zdravstvene službe. ${ }^{68}$ Svaka osoba ima pravo na zdravstvenu zaštitu i na mogućnost ostvarenja najviše moguće razine zdravlja, u skladu s odredbama zakona. Svakom pacijentu jamči se opće i jednako pravo na kvalitetnu i kontinuiranu zdravstvenu zaštitu primjerenu njegovom zdravstvenom stanju, sukladno općeprihvaćenim stručnim standardima i etičkim načelima, u najboljem interesu pacijenta uz poštivanje njegovih osobnih stavova (ZOZPP, čl. 2.). Načelo dostupnosti zaštite prava pacijenata podrazumijeva jednaku mogućnost zaštite prava svih pacijenata na području Republike Hrvatske (ZOZPP, čl. 5.). U procesu donošenja odluka i izbora dijagnostike i odgovarajućeg liječenja liječnik je samostalan u postupanju sukladno znanstvenim saznanjima i stručno dokazanim metodama koje odgovaraju suvremenom standardu struke. Liječnik je dužan u obavljanju liječničke djelatnosti osobito: poštovati načela obavljanja liječničke djelatnosti te suzdržavati se od svake aktivnosti koja nije spojiva s ugledom, dostojanstvom i neovisnošću liječničkog zvanja (ZOL, čl. 4.).

Iako bi se možda na prvi pogled moglo učiniti neopravdano dozvoljavanje priziva savjesti u struci čija je osnovna zadaća briga o čovjeku i njegovom zdravlju, ipak ne smije se zaboraviti da i zdravstveni radnici kao subjekti koji sudjeluju u procesu zdravstvene zaštite, imaju svoja prava. Jedno od tih prava jest upravo i pravo na priziv savjesti. ${ }^{69}$ Radi svojih etičkih, vjerskih ili moralnih nazora, odnosno uvjerenja zdravstveni radnik se ima pravo pozvati na priziv savjesti te odbiti provođenje dijagnostike, liječenja i rehabilitacije pacijenta, ako se to ne kosi s pravilima struke te ako time ne uzrokuje trajne posljedice za zdravlje ili ne ugrozi život pacijenta, a o svojoj odluci mora pravodobno izvijestiti pacijenta te ga uputiti drugom zdravstvenom radniku iste struke. Priziv savjesti liječnika visoko je prijeporna, paradoksalna odrednica, ali istodobno i prijeko potrebno načelo koje ima svoje opravdanje. ${ }^{70}$

Značajno je utvrditi kad je priziv savjesti prihvatljiv. Kada se sučele i konfrontiraju liječnikovo pravo na priziv savjesti s njegovom profesionalnom obavezom prema dobrobiti pacijenta/ice, priziv savjesti je prihvatljiv samo onda kada je autentičan i kada će netko drugi na vrijeme i kvalificirano ispuniti profesionalnu dužnost prema pacijentu/ici. Je li priziv savjesti autentičan nije uvijek lako utvrditi. Ipak, najmanje bi trebalo utvrditi: a/ u kojoj su mjeri vrijednosti na koje se prizivač poziva jezgrovna $i$ postojana komponenta prizivačevog identiteta. Primjerice, ako se prizivatelj poziva na vjerski razlog, trebalo bi ispitati kakav je on zapravo vjernik i živi li inače svoju vjeru (je li inače moralna osoba, ide li na nedjeljnu misu, ispovijeda li se, je li u crkvenom braku, je li razveden, ima li više sukcesivnih brakova, ima li izvanbračnu vezu, koliko ima djece, daje li doprinose Crkvi, radi li u vjerskim udrugama, kako dugo ima uvjerenja koja ga sada navode na priziv savjesti - od upisa na medicinu, od početka ili završetka specijalizacije, oduvijek, odnedavno, nije li korumpiran i sl.); b/ kako i koliko bi činjenje protivno savjesti utjecalo na integritet prizivača kao osobe - bi li iskusio krivnju, sram ili gubitak samopoštovanja ili drugu nepodnošljivu emociju; c/ ima li prizivač potpun uvid u medicinski problem o kojem zauzima stav, je li isti utemeljen na stručnim i znanstvenim činjenicama ili na osobnim stavovima, predrasudama i interpretacijama i jesu li s aspekta profesionalnih dužnosti razmotrene implikacije odbijanja za pacijente i društvo; d/ je li priziv savjesti genuin ili je imitacija postupaka drugih u radnom okruženju, ili samoobrana od društvene stigmatizacije, ili rezultat pritiska nadređenih ili okruženja. ${ }^{71}$ 
Treba znati da je pravo na priziv savjesti individualno, a ne kolektivno pravo. Ne može javna ustanova imati pravo na prigovor savjesti. ${ }^{72}$ Nadalje, potrebno je utvrditi u kojem je trenutku moguće pozvati se na priziv savjesti (prije zapošljavanja ili kada se tko sjeti), na koji način se poziva na savjest (telefonom, usmeno, internetom?), te da je apsolutno potrebno da nezavisna povjerenstva utvrđuju autentičnost priziva savjesti. ${ }^{73}$ Pravo na priziv savjesti ne smije se tumačiti preširoko i na način koji bi doveo do onemogućavanja pravodobnog pružanja zdravstvene usluge pacijentu odnosno do zlouporabe primjene tog prava od strane pružatelja (npr. odbijanje radnih naloga nadređenih u bolnicama). Uvijek se mora voditi računa da zdravstvena usluga bude pružena odnosno da pacijent ne trpi nikakve posljedice. Odgovornost leži na liječnicima i doktorima stomatologije koji prije svega moraju dobro procijeniti i dijagnosticirati stanje pacijenta te nakon toga eventualno odlučiti da li je u nastaloj situaciji moguće pozvati se na priziv savjesti ili nije, odnosno da li je moguće, u slučaju pozivanja na priziv savjesti, osigurati trenutnu i adekvatnu zdravstvenu uslugu od strane drugog zdravstvenog radnika. Ako to nije moguće, pravo na priziv savjesti ne može se realizirati (kazneno djelo nepružanja medicinske pomoći). ${ }^{74}$

U svakom slučaju, priziv savjesti u medicini trebalo bi urediti tako da ne potire druga ljudska prava, da ne priječi dostupnost legalne zdravstvene zaštite i da ne izaziva diskriminaciju.

Razlozi za ograničenje prava na ,priziv savjesti“ Pravo na priziv savjesti je, kao i većina drugih prava, ograničeno pravo. Drugim riječima, mogućnost i pravo na priziv savjesti, kao jednog od prava zdravstvenih radnika, ipak nije apsolutno već je podvrgnuto točno određenim ograničenjima te se na nj može pozivati iznimno. Ograničeno je u mjeri koju propisuju zakoni nužni u demokratskom društvu u interesu javne sigurnosti, zaštite javnog reda, zdravlja ili morala, ili za zaštitu prava i sloboda drugih ljudi. Priziv savjesti treba biti ograničen ako: nameće religijske ili druge stavove pacijentu, utječe negativno na zdravlje pacijenta, zasnovan je pogrešnim znanstvenim interpretacijama ili predrasudama te ako proizvodi diskriminaciju i nejednakost. ${ }^{75}$ Olako korištenje ovoga prava predstavljalo bi i etičku i stručnu pogrešku, pogotovo u slučaju ugrožavanja života pacijenta, te bi moglo dovesti i do građanske, disciplinske, prekršajne i kaznene odgovornosti zdravstvenog radnika. ${ }^{76} \mathrm{U}$ tom smislu u postupku utvrđivanja dopustivosti priziva savjesti, pored ograničenja koja izričito utvrđuju pravni propisi, treba uzeti u obzir i neka načelna ograničenja: a/ pravo na priziv savjesti ne odnosi se na razne oblike građanske neposlušnosti; b/ pravo priziva savjesti nije opće pravo; c/ pravo priziva savjesti ne smije zadirati u prava drugih ljudi; d/ pravni položaj i postupanje pojedinca koji ga prisiljavaju na priziv savjesti mora biti prisilno nametnut (vojna obveza), a ne kao rezultat dobrovoljnog i svjesnog ulaska u određenu pravnu situaciju (liječnici, suci i moralno vjerski stavovi); e/ priziv savjesti mora biti rezultat uvjerenja pojedinca da time štiti temeljne i najviše vrednote (život, zdravlje, sloboda pojedinca). ${ }^{77}$ Zakoni i strukovni kodeksi propisuju izrijekom uvjete, koji moraju biti kumulativno ispunjeni, da bi se zdravstveni radnik mogao opravdano i pravovaljano pozvati na priziv savjesti.

Upoznavanje pacijenta/ice sa svojim razlozima odbijanja pružanja tražene/indicirane zdravstvene zaštite zdravstveni radnik ne smije koristiti za nametanje svojih uvjerenja pacijentu/ici. Pri informiranju o postupku kojeg ne želi obaviti, zdravstveni radnik dužan 
je davati samo znanstveno utemeljene podatke i činjenice utemeljene na dokazima, a ne svoje interpretacije ili vlastite prosudbe ili predrasude (primjerice, netočne informacije o povezanosti pobačaja i karcinoma dojke, o mehanizmu djelovanja kontracepcije, o tome kako pobačaj nije medicinski zahvat iako je u MKB pod šifrom 040 i sl.). ${ }^{78}$

Trajne posljedice po zdravlje i život pacijenta - Radi svojih etičkih, vjerskih ili moralnih nazora, odnosno uvjerenja zdravstveni radnik (liječnik, doktor stomatologije, primalja, magistra farmacije) ima se pravo pozvati na priziv savjesti te odbiti provođenje dijagnostike, liječenja i rehabilitacije pacijenta, samo ako time ne uzrokuje trajne posljedice za zdravlje ili ne ugrozi život pacijenta/bolesnika, odnosno samo ako time ne dovodi u opasnost zdravlje i život bolesnika (arg. ZOL, članak 20., ZODM, ranije: Zakon o stomatološkoj djelatnosti, članak 26., KMED, čl. 2. točka 15., Etički kodeks primalja, članak 3. točka 20., Kodeks ljekarničke etike i deontologije, članak 12. točka (3).)

Nesuglasje s pravilima struke - Radi svojih etičkih, vjerskih ili moralnih nazora, odnosno uvjerenja zdravstveni radnika (liječnik, doktor stomatologije, primalja, magistra farmacije) ima se pravo pozvati na priziv savjesti te odbiti provođenje dijagnostike, liječenja i rehabilitacije pacijenta, ako se to ne kosi s pravilima njegove struke (ZOL, članak 20. i ZODM, članak 26.).

Nepravodobna obaviještenost pacijenta o odluci - Svatko tko se želi pozivati na slobodu savjesti i svoja uvjerenja, mora na prikladan način i na vrijeme kazati koji su njegovi stavovi. ${ }^{79}$ Radi svojih etičkih, vjerskih ili moralnih nazora, odnosno uvjerenja zdravstveni radnik (liječnik, doktor stomatologije, primalja, magistra farmacije) ima se pravo pozvati na priziv savjesti te odbiti provođenje dijagnostike, liječenja i rehabilitacije pacijenta, samo ako o svojoj odluci pravodobno izvijesti pacijenta/bolesnika (arg. ZOL, članak 20., ZODM, članak 26., KMED, čl. 2. točka 15., Etički kodeks primalja, članak 3. točka 20.). Što se pravodobnosti obavijesti tiče, priziv savjesti potrebno je izraziti prije obavljanja određenog medicinskog postupka, ali ne neposredno pred samo obavljanje ili tijekom obavljanja medicinskog postupka, jer ne može se više u tom trenutku odustati i ugroziti život i zdravlje pacijenta. Postoji i mišljenje da bi priziv savjesti mogao biti opravdan samo ako je dan prilikom sklapanja ugovora o radu, odnosno nakon usvajanja Ustava RH koji određuje slobodu savjesti, a najkasnije odmah nakon donošenja relevantnog etičkog kodeksa. Drži se da su liječnici i drugi zdravstveni radnici na koje se odnose odredbe drugih strukovnih zakona o prizivu savjesti, trebali o svojem uvjerenju, tj. prizivu savjesti, obavijestiti poslodavca odmah nakon donošenja navedenih zakona, a zdravstveni radnici koji se tek zapošljavaju to bi trebali uraditi prilikom zaključenja ugovora o radu. Iznimno, naknadno isticanje priziva savjesti bilo bi opravdano samo ako bi zdravstveni radnik to opravdavao promjenom vjerskih ili moralnih uvjerenja. U protivnom za poslodavca mogu nastati problemi u organizaciji rada, koje mogu imati i ozbiljne posljedice ${ }^{80}$ Pravodobna obavijest pacijentu od strane prizivatelja značajna je kako bi pacijent mogao na vrijeme izabrati drugog zdravstvenog radnika koji nema problema sa savješću kod obavljanja određenog medicinskog postupka. ${ }^{81}$

Neupućivanje pacijenta drugom liječniku iste struke - Koliziju dva prava, prava na zdravstvenu zaštitu i prava na priziv savjesti, djelomično rješava i obveza zdravstvenog radnika da pravodobno obavijesti pacijenta o svojim moralnim dvojbama i da ga uputi 
drugom zdravstvenom radniku. Ako je priziv savjesti autentičan i prihvatljiv, prizivatelj je dužan osigurati da pacijent pravovremeno dobije traženi (indicirani) medicinski postupak od strane zdravstvenog radnika koji je voljan i kvalificiran obaviti medicinski postupak koji prizivatelj ne želi. Radi svojih etičkih, vjerskih ili moralnih nazora, odnosno uvjerenja zdravstveni radnik (liječnik, doktor stomatologije, primalja, magistra farmacije) ima se pravo pozvati na priziv savjesti te odbiti provođenje dijagnostike, liječenja $\mathrm{i}$ rehabilitacije pacijenta, samo ako pacijenta uputi drugom zdravstvenom radniku iste struke (arg. ZOL, članak 20., ZODM, članak 26., KMED, čl. 2. točka 15., Etički kodeks primalja, članak 3. točka 20.). Ako bi osiguranje odgovarajuće zamjene bilo nemoguće ili otežano, zdravstveni bi radnik svakako trebao pružiti zdravstvenu uslugu usprkos svome prizivu savjesti, naravno pod uvjetom da se radi o ozbiljnoj ugroženosti zdravlja pacijenta ili o opasnosti za njegov život. U tom smislu je zakonodavac ipak posredno odredio da su zdravlje i život pacijenta važniji od prava na slobodu savjesti te na taj način pomirio dva prava - osobno pravo na priziv savjesti zdravstvenog radnika s jedne strane, te pravo pacijenta na zdravstvenu uslugu i zaštitu s druge strane. ${ }^{82}$

Neobavještavanje nadređenog/poslodavca - Radi svojih etičkih, vjerskih ili moralnih nazora, odnosno uvjerenja liječnik se ima pravo pozvati na priziv savjesti te odbiti provođenje dijagnostike, liječenja i rehabilitacije pacijenta, ali ako je liječnik zaposlen u zdravstvenoj ustanovi, trgovačkom društvu, odnosno drugoj pravnoj osobi koja obavlja zdravstvenu djelatnost ili kod drugog liječnika koji obavlja privatnu praksu, mora o svojoj odluci izvijestiti svog nadređenog, odnosno poslodavca (ZOL, članak 20.). I doktor stomatologije ima se pravo pozvati na priziv savjesti te odbiti provođenje dijagnostike, liječenja i rehabilitacije pacijenta radi svojih etičkih, vjerskih ili moralnih nazora, odnosno uvjerenja, ali kada je doktor stomatologije zaposlen kod drugog doktora stomatologije koji obavlja privatnu praksu ili u zdravstvenoj ustanovi, odnosno u drugoj pravnoj osobi, mora o toj svojoj odluci izvijestiti svoga nadređenog, odnosno poslodavca (ZODM, članak 26.). Primalja koja radi kao član zdravstvenog tima (u primarnoj zdravstvenoj zaštiti ili u bolničkoj zdravstvenoj skrbi) mora u što kraćem roku izvijestiti odgovornu osobu ako postoji bilo kakav prigovor savjesti bitan za obavljanje njezine profesionalne djelatnosti. U tom slučaju ne smije prestati pružati primaljsku skrb ako bi time uzrokovala trajne posljedice za zdravlje ili ugrozila život pacijentice (Etički kodeks primalja, čl. 3. točka 20.). Navedeni propisi ne predviđaju preciznu proceduru obavještavanja poslodavca. Zdravstveni radnik ima pravo na priziv savjesti, ako time ne uzrokuje trajne posljedice za zdravlje ili ne ugrozi život. (članak 6. Kodeksa etike i deontologije djelatnosti sanitarnog inženjerstva, zdravstvene radiološko-tehnološke djelatnosti, djelatnosti radne terapije i medicinsko-laboratorijske djelatnosti).

Svakako, u hitnim slučajevima koji ne trpe odgađanje, zdravstveni radnik je u svakom slučaju dužan pružiti pacijentu/ici medicinsku pomoć u skladu s medicinskim pravilima, bez obzira na protivljenje njegove savjesti.

\subsection{Pravo na priziv savjesti u reproduktivnoj medicini}

Priziv savjesti omogućuje zdravstvenim radnicima odbijanje izvođenja pojedinih medicinskih postupaka, što se pokazalo najočitijim na primjeru dostupnosti legalnog prekida trudnoće na zahtjev, odnosno reproduktivne medicine. Ginekolozi su najistureniji 
medicinski profesionalci kad je u pitanju priziv savjesti. Dakle, priziv savjesti predstavlja problem ne samo kod dostupnosti legalnog prekida trudnoće na zahtjev, već i u širem području reproduktivne medicine (kontracepcija, hitna kontracepcija, sterilizacija, pobačaj, prenatalna dijagnostika, izvantjelesna oplodnja, spolno prenosive infekcije i HIV/AIDS, zbrinjavanje bolesnih trudnica, zbrinjavanje silovanih djevojčica i žena, informiranje i edukacija o planiranju rađanja, postavljanju spirale); preventivne medicine (cijepljenje) te u palijativnoj medicini i onkologiji (liječenje boli, unaprijed izražena volja pacijenta). Prizivatelji/ce savjesti također često odbijaju informiranje pacijentica i o drugim mjerama planiranja obitelji (maternični ulošci, sterilizacija i dr.). U konkretnom slučaju radi se o dva jednakopravna ustavna prava koja dolaze u koliziju i to prava na privatnost i pravu na slobodu savjesti, a oba navedena prava se mogu ograničiti. Pritom je važno načelo razmjernosti koje služi balansiranju tih prava. ${ }^{83}$

U reproduktivnoj medicini pretežito se govori o već spomenutom tzv. negativnom prizivu savjesti. Radi se o odbijanju obavljanja (conscientious refusal) nekih medicinskih postupaka koji su dio standardne ginekološko-opstetričke prakse, motiviranom najčcšće religijskim, ali i drugim moralno-etičkim uvjerenjima liječnika/ce i/ili druge zdravstvene radnice ili radnika ${ }^{84}$ Priziv savjesti ovdje služi samozaštiti liječnika i liječnica od činjenja koja bi opteretila njihovu savjest i ugrozila njihov moralni integritet, a ne obazire se na profesionalne obaveze istih prema pacijentima, niti na prava pacijenta/ice na autonomiju, identitet, vlastito mišljenje, savjest i svjetonazor, privatnost te pravo na zdravstvenu zaštitu. Uz ginekologe/inje i medicinske radnike (primalje), kao prizivači/ce savjesti u reproduktivnoj medicini javljaju se i ljekarnici/e, pa čak i paramedicinsko osoblje zaposleno u zdravstvenim ustanovama: spremači/ce, kuhari/ce, serviri/ke, vozači/ce, administrativno osoblje. Moguće je daljnje širenje takve prakse (novinar odbije pisati, sudac odbije suditi, odvjetnik odbije braniti, socijalni radnik odbije pomagati i sl.). ${ }^{85}$ Primjerice, ljekarnik može uložiti priziv savjesti i odbiti prodati ellaOne hitni kontraceptiv koji se i u hrvatskim ljekarnama odnedavno može kupiti bez liječničkog recepta. Pilula "za dan poslije" dosad je bila dostupna isključivo uz recept, no to je promijenila odluka Europske komisije primijenjena ovih dana i u Hrvatskoj. Domaći ljekarnici, međutim, imaju pravo odbiti prodati tabletu uime vlastite savjesti te mogu pozvati kolegu da to učini umjesto njih ili uputiti ženu koja traži ellaOne da ode u drugu ljekarnu. ${ }^{86}$ Dio je to propisanih smjernica Hrvatske ljekarničke komore za izdavanje i prodaju te tablete, za koju će se u toj ustanovi izraditi i poseban standard postupanja pri prizivu savjesti. Radi olakšavanja postupka izdavanja lijeka ellaOne $30 \mathrm{mg}$, uz uvažavanje prava pacijenta na privatnost kao i obvezu ljekarnika da osigura pravilno i sigurno izdavanje lijeka, Hrvatska ljekarnička komora naglašava kako je prvi korak u komunikaciji ispunjavanje upitnika od strane pacijenta. U tom slučaju pacijentica ga sama ispunjava kako bi na temelju istog ljekarnik mogao osigurati opravdano i sigurno izdavanje lijeka. Samostalno ispunjavanje upitnika od strane pacijentice ne isključuje provođenje savjetovanje ljekarnika, u uvjetima koji osiguravaju privatnost. Neovisno o prizivu savjesti, ljekarna mora omogućiti pacijentici pristup lijeku, sukladno protokolu, tako da se u ovom i drugim slučajevima ne može govoriti o nedostupnosti lijeka i bilo kakvom ograničavanju. ${ }^{87}$

Pobačaj ili abortus (lat. abruptio graviditatis) je spontani ili izazvani prekid trudnoće odstranjenjem ili izbačajem embrija ili fetusa iz maternice prije sposobnosti ljudskog 
ploda za samostalni život. Pobačaj može nastati spontano, zbog komplikacija tokom trudnoće ili se može izazvati. Trudnoća se može namjerno prekinuti na mnoge načine. Izabrani način prekida trudnoće ovisi poglavito o gestacijskoj dobi embrija ili fetusa, ali i o legalnosti, regionalnoj dostupnosti i sklonosti liječnika i pacijenta prema određenoj proceduri. Legalnost, učestalost i kulturni pogledi prema pobačaju različiti su u pojedinim državama. U mnogim dijelovima svijeta vode se rasprave između protivnika i pobornika pobačaja o etičkim i pravnim aspektima. Prema zakonu Republike Hrvatske iz 1978. godine prekid trudnoće do 10. tjedna od začeća može se izvršiti na zahtjev trudne žene. O zahtjevu za prekid trudnoće nakon 10. tjedna, na želju same trudnice ili na prijedlog liječnika, ali uvijek uz pristanak trudnice, odlučuju odgovarajuće komisije pri bolničkim ustanovama, odnosno ginekološko-porodničkim odjelima, na temelju medicinskih, eugeničkih i pravno-etičkih indikacija. ${ }^{88}$

$\mathrm{S}$ jedne strane, protivnici/e prava zdravstvenih radnika na priziv savjesti kod pobačaja na zahtjev (ali i na području reproduktivne medicine u najširem smislu riječi), ${ }^{89}$ navode niz argumenata kojima opravdavaju svoje stajalište. Tako se iz feminističkih krugova tvrdi da je trudnoća u potpunoj vlasti žene, a u pogledu djeteta drži se da ono nije osoba dok se ne rodi, jer ne može racionalno razmišljati i donositi odluke, niti je sposobno za samostalan život. ${ }^{90}$ Štoviše, ustavna prava žena u ovim slučajevima nadjačavaju pravo na priziv savjesti te im se mora osigurati odgovarajuća medicinska skrb. U protivnom narušava se njihovo pravo autonomije, dostojanstva, privatnosti, pravo na informirani izbor, nediskriminaciju, slobodno odlučivanje o rađanju djece, pravo na život, zdravlje i uživanje napretka medicine, ${ }^{91}$ što može dovesti ne samo do kršenja ljudskih prava pacijentica, nego i do kršenja stručnih medicinskih standarda. Zdravstveni radnici koji se pozivaju na priziv savjesti pretpostavljaju sebe i svoj religijski interes interesu pacijentice, što je u potpunoj suprotnosti Kodeksu liječničke etike i deontologije. ${ }^{92} \mathrm{Na}$ temelju navedenih (pravnih) činjenica Pravobraniteljica za ravnopravnost spolova zaključuje da jasno slijedi kako bilo kakvo ograničenje pristupa medicinskoj usluzi prekida trudnoće, koja predstavlja legalan medicinski zahvat koji je iz bioloških razloga dostupan isključivo ženama, predstavlja izravnu spolnu diskriminaciju žena u pogledu pristupa uslugama i kao takvo je zabranjeno prije navedenom Direktivom 2004/113/EZ te Zakonom o ravnopravnosti spolova. ${ }^{93}$ Drži se, nadalje, kako priziv savjesti ne može biti selektivan pa ako netko ima priziv savjesti za pobačaj, onda ne može, primjerice, raditi ni amniocentezu ni asistirati u potpomognutoj oplodnji, jer je na taj način priziv savjesti samo za pobačaj nepošten. Liječnicima koji s pozivaju na priziv savjesti kod pobačaja na zahtjev ,poručuju“ da potraže posao u bolnicama koje će financirati Crkva, ${ }^{94}$ a ne u javnim zdravstvenim ustanovama, ili da su mogli izabrati da se ne bave porodništvom. Iznosi se mišljenje da se ispod plašta religijskog ili moralnog uvjerenja kao razloga priziva savjesti, mogu kriti drugi razlozi koji nemaju s njima nikakve veze. Tako drže da dio ginekologa i ginekologinja izjavljuje priziv savjesti zbog toga što su oni koji obavljaju pobačaj u njihovom radnom ili društvenom okruženju stigmatizirani pa izbjegavaju i sami biti stigmatizirani, zbog pritiska šefova posebno kada se radi o konfesionalnim bolnicama, neki u prizivu savjesti nalaze pogodan izgovor da ne moraju raditi zahvate koji su neugodni, neki ginekolozi izjavljuju priziv savjesti samo u javnoj ustanovi gdje primaju mjesečnu plaću, ali ih rade privatno, prizivom savjesti neki nastoje prikrivati svoje medicinsko neznanje i nedovoljnu vještinu za izvođenje pobačaja, dio ginekologa prizivaju se na savjest zbog nedostatka opreme za izvođenje zahvata i sl. ${ }^{95}$ 
Kod prekida trudnoće po zahtjevu trudnice problematični bi mogli biti samo oni zahtjevi trudnice kod kojih nema medicinskih indikacija za nužno obavljanje pobačaja. Sa stajališta trudnice nesporno je da se problematizirati mogu samo oni zahtjevi za prekidom trudnoće koja je za trudnica u tom trenutku neželjena iz različitih subjektivnih i objektivnih razloga koje trudnica smatra opravdanim (nezaposlenost, neimaština, ostvarenje drugih životnih ciljeva, studiranje, trudnoća posljedica silovanja, otac nepoznat ili se ne želi prihvatiti odgovornosti zajedničkog podizanja djeteta, mnogobrojna obitelj, maloljetnost trudnice i sl.). Usvojena filozofija življenja podrazumijeva zadovoljavanje mnogobrojnih, visoko postavljenih i stalno novih potreba i u kvantitativnom i u kvalitativnom smislu. Velika su stremljenja i zahtjevi koje sebi postavljaju i muškarac i žena. Pored težnji vezanih za individualni razvoj i samoostvarivanje, javljaju se i hedonističke težnje i okretanje materijalnim vrijednostima. Pored oportunih prepreka rađanju, osjećaja nedovoljne sigurnosti i u obitelji i u široj zajednici i troškova (cijene) vezanih za usklađivanje roditeljstva i profesionalne aktivnosti kao i roditeljstva i zadovoljenja različitih interesa, i strukturne prepreke, nezaposlenost, neriješeno stambeno pitanje, problemi čuvanja djece, nezadovoljavajući ekonomski standard i druge pojave iz ovog kruga bitna su prepreka za realizaciju stavova o idealnom broju djece. ${ }^{96}$ Prema studijama provedenim u više zemalja svijeta, razlozi zbog kojih se žene odluče prekinuti trudnoću najčešće su: odgoda ili prekid odgajanja djeteta; zabrinutost zbog prekidanja posla ili obrazovanja; pitanja vezana uz financijsku stabilnost ili stabilnost u vezi; osjetna nezrelost. Neke žene su se podvrgle pobačaju radi socijalnih pritisaka. To može uključivati stigmatizaciju nesposobne osobe, preferencija djece određenog spola, neodobravanje samohranog majčinstva, nedovoljna ekonomska potpora obitelji, nedostatak pristupa ili odbijanje kontracepcije ili metode kontrole populacije (kao kineska politika jednog djeteta). ${ }^{97}$

Problematika prava zdravstvenih radnika na priziv savjesti kod pobačaja na zahtjev dodatno je potenciran kada se svi ginekolozi u zdravstvenoj ustanovi pozovu na priziv savjesti. Treba kazati da je pravo na priziv savjesti individualno, a ne kolektivno pravo. Ne može javna ustanova imati pravo na priziv savjesti. Stoga zagovornici zabrane ili ograničenja prava na priziv savjesti drže da, ako neki liječnik ne želi raditi pobačaj i druge postupke koji se protive njegovom vjerskom ili svjetonazornom opredjeljenju, on treba promijeniti struku ili treba otići u privatnu ordinaciju koja to ne radi. Ustanova, ako ima takve liječnike, treba zaposliti nekoga tko nema priziv savjesti, jer ne može cijela bolnica imati prigovor savjesti, pošto bi to bilo protivno svim mogućim standardima i zdravom razumu ${ }^{98}$ Priziv savjesti usko je vezan uz religiozne i moralne stavove pojedinca. Ako je bolnica državna institucija koja se financira iz državnih sredstava, teško bi bilo opravdati pravo na priziv savjesti ako ono stoji na putu ostvarenja prava žene. Prihvatljivost priziva savjesti jača ako bi se radilo o djelatniku bolnice koja se financira fondovima religioznih institucija. ${ }^{99} \mathrm{~S}$ druge strane, u Rezoluciji 1763 iz 2010. godine. U točki 1., između ostalog, stoji da niti jedna pravna ili fizička osoba neće biti podvrgnuta prisili, neće se držati odgovornom niti će se na bilo koji način diskriminirati ako odbije izvršiti pobačaj ili eutanaziju. Dakle, po navedenoj Rezoluciji VE niti pravnu osobu, dakle bolnicu, ne smije se prisiljavati da vrši pobačaje na zahtjev! Pravobraniteljica za ravnopravnost spolova RH naglašava kako se kod isticanja priziva savjesti radi isključivo o osobnoj odluci pojedinca te se stoga ova mogućnost ne može proširiti na čitavu instituciju kao takvu. Svaka medicinska ustanova koja sudjeluje u državnom sustavu zdravstvene zaštite i koja je 
osposobljena i zakonski obvezna pružiti medicinski zahvat prekida trudnoće ima jasnu pravnu obvezu osigurati učinkoviti pristup ovoj vrsti medicinske usluge svim ženama koje su koristeći svoju ustavom zajamčenom slobodu izbora donijele tu nimalo laganu osobnu odluku. Na upravnim tijelima takvih medicinskih ustanova je da uspostave sustav pružanja ove vrste usluge koji će jamčiti da građanke Republike Hrvatske kao i građanke Europske unije u Republici Hrvatskoj u svakom trenutku imaju učinkovit pristup ovoj vrsti medicinskog zahvata u skladu sa uvjetima propisanim Zakonom o zdravstvenim mjerama za ostvarivanje prava na slobodno odlučivanje o rađanju djece. U slučaju da upravna tijela medicinskih ustanova koje su dužne osigurati učinkoviti pristup ovom medicinskom zahvatu nisu sposobna organizirati pružanje ove usluge u skladu sa svojom zakonskom obvezom, tada je na Ministarstvu zdravstva, kao nadležnom tijelu izvršne vlasti, poduzeti sve mjere iz svoje nadležnosti kako bi osiguralo da konkretna ustanova ispuni svoju zakonsku obvezu. ${ }^{100}$

S druge strane, zagovornici prava zdravstvenih radnika na priziv savjesti kod obavljanja pobačaja na zahtjev pozivaju se prvenstveno na relevantne međunarodne dokumente i nacionalne propise u kojima se priznaje pravo na priziv savjesti, kao što su: Opća deklaracija Ujedinjenih naroda o pravima čovjeka, (Europska) Konvencija za zaštitu ljudskih prava i temeljnih sloboda, Ustav RH, ZOL, ZODM, Zakon o medicinski potpomognutoj oplodnji, ZOZZ, KMED, Etički Kodeks ljekarničke etike i deontologije (o čemu je već podrobno pisano u ovom radu pa nema potrebe isto ponovno razlagati), ali i na odluke međunarodnih i domaćih sudova te pravna, etička i teološka stajališta uvaženih fizičkih i pravnih osoba i interesnih skupina.

Primjerice, u prilog prava zdravstvenih radnika na priziv savjesti navodi se kako je Parlamentarna skupština Vijeća Europe utvrdila pravo na priziv savjesti u medicini Rezolucijom 1763 iz listopada 2010. godine. U točki 1. ove Rezolucije, između ostalog, propisuje se kako niti jedna pravna ili fizička osoba neće biti podvrgnuta prisili, neće se držati odgovornom niti će se na bilo koji način diskriminirati ako odbije izvršiti pobačaj ili bilo koji drugi čin koji bi iz bilo kojeg razloga za posljedicu imao smrt ljudskog fetusa ili embrija. Također se navodi kako je većinom glasova Europski parlament odbio glasovati o izvješću zastupnice Edite Estrele (S\&D) o seksualnom i reproduktivnom zdravlju i pravima te je prijedlog ove neobvezujuće rezolucije vratio na matični odbor. Prijedlog rezolucije Edite Estrele izazvalo je oštre polemike u Europskom parlamentu posebice zbog pokušaja sužavanja prava na "priziv savjesti" te definicije pobačaja kao temeljnog ljudskog prava, što je suprotno mišljenju Europske komisije koja je naglasila da EU nije nadležan za uređivanje tog pitanja. ${ }^{101}$ Drže, nadalje, sasvim sigurnim da ljudski život ne počinje sa završetkom 12. tjedna trudnoće, ${ }^{102}$ jer ljudsko biće je genetski posve definirano i jedinstveno, neponovljivo u trenutku začeća. ${ }^{103}$ Njegov DNA se više nikad neće mijenjati. To je ujedno i trenutak u kom su budući mogući roditelji de facto obavili svoj izbor, pa je svaki naknadni "izbor" zapravo vrlo upitan s moralne strane. Da se ne govori o nakaradnosti teze da žene trebaju imati pravo izbora, ali ne i liječnici koji bi trebali izvršiti nešto što osobno smatraju ubojstvom. ${ }^{104}$ Štoviše, ideja o slobodi žene da samostalno odlučuje o pobačaju zasniva se na strahovitom potiranju tuđih prava: u ovom slučaju, prava djece, i također prava zdravstvenih radnika kojima sudbina nerođenog djeteta leži na savjesti. ${ }^{105}$ I Ustav RH u čl. 14. određuje da: "Svatko u Republici Hrvatskoj ima prava i slobode, neovisno o njegovoj rasi, boji kože, spolu, jeziku, vjeri, političkom 
ili drugom uvjerenju, nacionalnom ili socijalnom podrijetlu, imovini, rođenju, naobrazbi, društvenom položaju ili drugim osobinama. Svi su pred zakonom jednaki", a pri tome ne definira eksplicitno što se pod tim „svatko“ podrazumijeva, ali zasigurno ne isključuje prava još nerođenog djeteta. Prava djeteta brižno i smišljeno se prešućuju, a novo ljudsko biće nije samo plod majke, nego i oca. Pravo na abortus pretpostavlja pravo na ubojstvo što je besmisleno. To je kršenje prava na život. ${ }^{106}$ Civiliziranost jednog društva treba prije svega mjeriti stupnjem zaštite najslabijih i najranjivijih pripadnika društva, u što svakako spadaju i nerođena djeca. Postavljaju pitanje kako žena sama može odlučiti o prekidu tog života i zašto se nikad ne uključuju muškarci, jer to je diskriminacija muškaraca, te ako se borimo za pravo žene za odluku, zašto se ne borimo za pravo nerođenog djeteta za život? ${ }^{107}$

Drži se i kako pravo na pobačaj nije ljudsko pravo, nego je riječ o stanovitoj slobodi, gdje jedan broj suvremenih država omogućuje ženama da na organizirani način i bez straha od kazne provedu pobačaj u djelo. Čak i u onim zemljama u kojima je pobačaj dozvoljen, uglavnom se zabranjuje pobačaj u kasnijim stadijima trudnoće. Tako je i u Hrvatskoj predviđena kazna do tri godine zatvora, za pobačaj nakon desetog tjedna trudnoće. ${ }^{108} \mathrm{Sud}$ za ljudska prava donio je 2010. presudu u slučaju $A B C$ v. Ireland, kojom tvrdi da ne postoji pravo na abortus već pravo žene na zaštitu zdravlja i tjelesnog integriteta. ${ }^{109}$

Tvrde kako se prešućuje činjenica da liječnička etika i deontologija ničim ne obvezuju liječnika da obavi pobačaj na zahtjev, jednostavno zato jer trudnoća nije bolest i ukoliko ne ugrožava zdravlje majke ili ploda, ne proizvodi moralnu obvezu liječnika da intervenira. Suprotno tvrdnjama zagovornika neograničenog prava na pobačaj, Hipokrat u svojoj zakletvi, koja je bila i ostala temeljem liječničke etike, jasno kaže: "Nikome neću, makar me za to i molio, dati smrtonosni otrov, niti ću mu za nj dati savjet. Isto tako neću dati ženi sredstvo za pometnuće ploda." Dakle, zaključuju da izvorna Hipokratova zakletva izrijekom zabranjuje liječnicima izvršenje pobačaja na zahtjev. Ta zakletva se kroz stoljeća mijenjala, no i današnja, tzv. “ženevska” iz 1948., je jasna: “Apsolutno ću poštovati ljudski život od samog začetka. Niti pod prijetnjom neću dopustiti da se iskoriste moja medicinska znanja suprotno zakonima humanosti."

Razvidno je da svojevrsna suprotstavljenost dvaju (ljudskih) prava (u pogledu pobačaja na zahtjev), zajamčenih brojnim propisima, teško se može riješiti na individualnoj razini - nedopuštanjem pojedinoj trudnici da traži i obavi pobačaj na njezin zahtjev ili nalogom pojedinom liječniku da obavi pobačaj unatoč njegovom isticanju priziva savjesti u konkretnom slučaju. Za sada je teško nazrijeti i neko kompromisno rješenje, jer su stajališta interesnih skupina u pravilu isključiva. ${ }^{110}$ Nedvojbeno se radi o kompleksnom, multidisciplinarnom problemu (sociološkom, etičkom, medicinskom, pravnom, vjerskom, društvenom, političkom, socijalnom, ekonomskom i dr.) i na tim razinama bi trebalo tražiti i rješenje ovoga problema. ${ }^{111}$

\subsection{Zaključak}

Možemo zaključiti da su u pogledu (ne)dopuštenosti isticanja priziva savjesti (u medicini) stajališta relevantnih aktera rezolutno podijeljena. 
S jedne strane protivnici prava na priziv savjesti, posebno na području porodništva, tvrde kako ta mogućnost u javnom zdravstvu dovodi do neučinkovitosti i nejednakosti, ugrožava kvalitetu i dostupnost zdravstvene usluge, da je nekompatibilan sa zanimanjem liječnika, te da svatko mora preuzeti neke obveze i odgovornosti ako želi postati liječnik (zdravstveni radnik). One su sastavni dio liječničkog zvanja i ne bi bilo u redu da temeljem priziva savjesti liječnik ne pruži uslugu na koju pacijenti imaju pravo, koje su legalne, korisne, koje su izraz pacijentove volje, i koje su dio pravednog sustava zdravstvene skrbi. ${ }^{112}$

$\mathrm{S}$ druge strane, argument koji se navodi $\mathrm{u}$ korist priziva savjesti jest da bi se uskraćivanjem prava zdravstvenim radnicima na priziv savjesti ograničili etički, vjerski ili moralni nazori i uvjerenja zdravstvenih radnika i njihovo pravo zajamčeno međunarodnim konvencijama, Ustavom, zakonima, etičkim i deontološkim kodeksima. Drži se kako institut prigovora savjesti omogućuje liječnicima zadržavanje osobnog integriteta.

Niz je uzroka i razloga koji dovode do navedenog stanja poput: manjkavost zakonske regulative prava na priziv savjesti u medicini; nedostatak sveobuhvatne i opće prihvaćene pravne definicije pojma "priziv savjesti"; nedostatak prakse tzv. ,pozitivnog priziva savjesti“; nenormiranost postupka, forme i trenutka izjavljivanja priziva savjesti, utvrđivanja vjerodostojnosti priziva savjesti i načina sprječavanja njegove zlouporabe; nije propisan način izvještavanja nadređenog, odnosno poslodavca o prizivu savjesti; neodređenost tko može tražiti priziv savjesti - izravni izvršitelj ili i asistenti, neuređeni žalbeni postupak i sl. ${ }^{113}$

U (medicinsko pravnoj) sudskoj praksi i teoriji, javnim raspravama i stajalištima interesnih skupina, publiciranim znanstvenim i stručnim radovima iz raznih znanstvenih područja i polja i dr., može se naći više korisnih prijedloga za ujednačavanje prakse, suprotstavljenih stajališta i pravne regulative na području primjene instituta, ,priziva savjesti“. Drži se, tako, kako je nužno izmijeniti i dopuniti odredbe zakona i podzakonskih propisa kojima se sada uređuje pravo na priziv savjesti na način da se uredi učinkovitost, djelotvornost, jedinstveni sustav standardizirane kvalitete, sigurnost i dostupnost zdravstvene zaštite vezano uz odbijanje obavljanja vršenja nekih standardnih medicinskih postupaka zbog priziva savjesti. Nadalje, posebnim propisom (pravilnikom ministra zdravstva i/ili pravosuđa) trebalo bi regulirati postupak, formu i trenutak izjavljivanja priziva savjesti te isključiti mogućnost selektivnog priziva savjesti. Korisnicima usluga bi trebalo omogućiti da im se u slučaju isticanja priziva savjesti osigura pravovremena usluga drugog stručnjaka istih kvalifikacija (koji se ne poziva na priziv savjesti), te da zbog toga nemaju dodatnih neugodnosti i troškova. Poslodavci bi trebali urediti svoju djelatnost na način da zbog isticanja priziva savjesti njihovih zaposlenika ne dođe u pitanje mogućnost pružanja njihovih usluga, odnosno pada kvalitete njihovih usluga. Svakako bi trebalo posveti pozornost i edukaciji o pravu na priziv savjesti kako tijekom studiranja, tako i kroz cjeloživotno obrazovanje. ${ }^{114}$

Razvidno je da se radi o multidisciplinarnom problemu kod kojeg se rješenje može iznaći samo zajedničkim i istovremenim pristupom više znanstvenih disciplina i struka (medicinara, pravnika, etičara, teologa, sociologa i sl.) kao i interesnih skupina (udruga 
pacijenata i zdravstvenih radnika, komora i sl.), polazeći pri tome od međunarodnih i nacionalnih propisa $u$ najširem smislu riječi, recentne sudske prakse međunarodnih i domaćih sudova, pravila i protokola struke, rješenja iz etičkih kodeksa, nauka vjera i sl. ${ }^{115}$

\section{Primjedbe}

${ }^{1}$ Savjest je svojstena ljudskom biću, koje svjesno opaža, sustavno analizira i preispituje izvor, sadržaj i posljedice svojih misli, svojih namjera, odluka i postupaka slusajući "glas savjesti". Savjest je kompleksna kategorija ljudskog uma, trajno u interaktivnom odnosu s voljom; savjest kao moralna paradigma kreira, oblikuje, prosuđuje i vrednuje postupke, uočava razliku između dobra i zla. MARKELJEVIĆ, J., Savjest i priziv savjesti, predavanje održano 21. siječnja 2015. godine u Domu HKLD-a u Zagrebu.

Savjest zapravo može biti izgovor da bi liječnik izbjegao svoju dužnost, ali itekako može biti i prava, životna dilema, koja će ga proganjati do kraja života. Kada je dužnost prava dužnost, prigovor savesti može biti pogrešan i amoralan. U nekom idealnom svijetu, savjest liječnika ne bi trebala dolaziti u sukob s njegovom medicinskom ulogom; svi liječnici još od studija bi trebali biti svjesni svoje odgovornosti da pruže pomoć u legalnim okvirima, kao i dilema koje se pred njih postavljaju, a za dobrobit pacijenta. Šta je zapravo - prigovor savesti? http://www.respecta.co.rs/2011/09/29/sta-je-zapravo-prigovor-savesti/

2 Tako ROŽMAN, K., O prizivu savjesti, „Primaljski Vjesnik“, 2013., broj 15, str. 19.-21.

Izvor: $\quad$ http://www.ombudsman.hr/hr/reagiranja/priopenja-i-reagiranja/439-pravo-na-prizivsavjesti.html

${ }^{3}$ Vidi MILIČIIĆ, V., Deontologija profesije liječnik-život čovjeka i integritet liječnika-ćudoredna raskrižja bioetike, Zagreb, 1996., str. 38.

${ }^{4}$ Podatak na stranici https://hr.wikipedia.org/wiki/Priziv_savjesti.

5 „U današnjem hrvatskom društvu, ljudska prava - pa tako i pravo na priziv savjesti - omogućuju ostvarivanje ljudske slobode: čovjek u slobodi doista može učiniti mnogo dobrih, lijepih, kreativnih, iskrenih djela. Moramo, međutim, biti svjesni da je sloboda tek jedan potencijal. Sloboda ne služi ničemu, ako nemamo ideje što bismo u toj slobodi poduzeli, i odlučne predanosti da to i postignemo. A ako se nečim ne služimo, možemo slobodno reći da to i ne trebamo: nepoduzetnim ljudima sloboda poduzetništva ne znači mnogo; ljudima koji ne haju za savjest sloboda savjesti ne znači baš ništa“. ČEHIĆ, D., Ljudima koji ne haju za savjest sloboda savjesti ne znači baš ništa, http://zdravstveniodgoj.com/news/-ljudima-koji-ne-haju-za-savjest-slobodasavjesti-ne-znaci-bas-nista.

${ }^{6}$ Vidi ZORNIĆ-MUJOVIĆ., H., Prekid trudnoće - abortus, INSTITUT DRUŠTVENIH NAUKA, Centar za pravna istraživanja, Beograd, 2013., www.ius.bg.ac.rs/.../h.mujovic.prekid\%20trudnoce.

${ }^{7}$ Tako RADIŠIĆ, J., Medicinsko pravo, Beograd, 2008., str. 116.

8 „Iz konstatacije da je prigovor savjesti moralna dužnost pojedinca proizlazi da isti mora prigovoriti zbog neizdržive unutarnje potrebe koja je izazvana kolizijom pravne norme (koju ne može prihvatiti) i njegovog moralnog suda (religiskog, filozofskog i sl.), koja ga dovodi u situaciju da taj konflikt riješi u korist svog morala. Budući da je ljudska savjest neograničena, i ujedno subjektivna, pravna norma, objektiviziranjem kriterija u društvenoj zajednici, nastoji ograničiti tu savjest (u slučaju prigovora savjesti). Tako se pojedinac, vezano za prigovor savjesti, nalazi u pravnoj sferi on prihvaća ili pristaje na pravnu sankciju. Kako se s moralne strane prigovarač savjesti ne smatra odgovornim jer je vođen moralnom dužnošću, dolazi do sutuacije da pojedinac može biti pravno kažnjen, ali ne i kažnjen na autentični moralni način. Moralna sankcija djelujući iznutra, u slučaju prigovora savjesti, predstavlja autentičnu sankciju - pojedinci je sebi nameću u slučaju da su u određenoj situaciji postupili protivno svojoj moralnoj dužnosti. To sve govori u prilog tezi da je prigovor savjesti, osim što je pravno pitanje, i izuzetno značajno etičko pitanje“. ŠEGVIĆ, S., 
Legitimnost građanskog otpora - neki teorijski aspekti, „Zbornik radova Pravnog fakulteta u Splitu“, god. 44, 2/2007., str. 195.

${ }^{9}$ Usp. VUKADIN, D., Pravo prigovora savjesti, „Filozofska istraživanja“, god. 23., 2003., sv. 2, str. 421.

${ }^{10}$ Nismo sigurni da će se takvo stanje zadržati. Naime, krajem prošle godine na razini EU postojali su napori da se ograniči primjena prava na priziv savjesti. Na zasjedanju 7. listopada 2011., Vijeće Europe odlučilo je da priziv savjesti ostaje kao pravo na slobodu mišljenja. Rezolucija u korist priziva savjesti izglasana je s tek 56 glasova za, nasuprot 51 glas protiv. Podatak na stranici http://www.iusinfo.hr/DailyContent/Topical.aspx?id=11891.

${ }^{11}$ Podatak na stranici http://narod.hr/hrvatska/sto-je-institut-priziva-savjesti.

12 Tako MUJOVIĆ-ZORNIĆ, H., Promene u shvatanju klauzule savesti kod pružanja zdravstvenih usluga, „Pravni život“", tematski broj „Pravo i načelo savesnosti i poštenja“, 2014., broj 9, TOM I, str. 283.

${ }^{13}$ Sve učestaliji slučajevi izazivaju zbrku u kojoj se miješaju različita tumačenja prava i zakona. Naročito nakon slučaja sa spikerom Hrvatskog radija, ovdašnja javnost još nije na čistu tko sve ima pravo pozvati se na prigovor savjesti. „Prema Ustavu Republike Hrvatske svatko ima slobodu savjesti odnosno pravo na prigovor savjesti“, izričit je zagrebački odvjetnik Veljko Miljević. Napominje kako je jedina mjerodavna odredba članak 40. Ustava koji kratko i jasno kaže da se jamči sloboda savjesti i vjeroispovijesti. „Ustav pritom jamči i slobodno javno očitovanje toga. To znači ne samo da čovjek ima unutarnju slobodu savjesti, nego i slobodno javno očitovanje vjere ili bilo kojeg drugog uvjerenja“, objašnjava Miljević. No, Miljević upozorava da Ustav ne rješava pitanje same tehnike pozivanja na prigovor ili, kako se u Hrvatskoj još kaže - priziv savjesti. Tako DAVID Udruga građana za zaštitu ljudskih prava, Prijedlozi za cjelovito reguliranje prava na priziv savjesti u medicini/ zdravstvenoj djelatnosti, Inicijativa liječnika/-ca za reguliranje priziva savjesti u medicini i CESI- Centar za edukaciju, savjetovanje i istraživanje, Poruke Okruglog stola „Priziv savjesti u medicini“, Zagreb, Novinarski dom, 21. 01. 2015., http://davidudruga.hr/novosti/2015/02/11/prijedlozi-za-cjelovito-reguliranje-prava-na-priziv-savjesti-umedicini-zdravstvenoj-djelatnosti/.

${ }_{14}$ Poznat je primjer boksača Muhammada Alia koji je zbog prigovora savjesti odbio ratovati u Vijetnamu jer se rat protivio načelima njegove vjere (Islama). Tada je izjavio: „,Niti jedan Vijetkongovac nikada me nije nazvao crnčugom “. Osudila ga je porota, sastavljena isključivo od bijelaca, na pet godina zatvora. Česti su primjeri liječnika koji zbog prigovora savjesti ne žele sudjelovati u postupcima pobačaja, umjetne oplodnje i eutanazije. Usput spomenimo da je pobačaj za osobe kršćanske vjeroispovijesti neprihvatljiv. Izopćenje iz Katoličke crkve kazna je za svakoga tko izazove pobačaj i za svakoga tko se s njime suglasi - ističe kardinal Alfonso López Trujillo. ŠEGVIĆ, S., Legitimnost građanskog otpora - neki teorijski aspekti, „Zbornik radova Pravnog fakulteta u Splitu“, god. 44, 2/2007., str. 116.

${ }_{15}$ Vidi ŠEGVIĆ, S., Legitimnost građanskog otpora - neki teorijski aspekti, „Zbornik radova Pravnog fakulteta u Splitu“, god. 44, 2/2007., str. 116.

${ }^{16}$ Usp. MUJOVIĆ-ZORNIĆ, H., Promene u shvatanju klauzule savesti kod pružanja zdravstvenih usluga, „Pravni život“", tematski broj „Pravo i načelo savesnosti i poštenja“, 2014., broj 9, TOM I, str. 283.

${ }^{17}$ Podatak na stranici http://www.iusinfo.hr/DailyContent/Topical.aspx?id=11891.

18 Tako ŠEGVIĆ, S., Legitimnost građanskog otpora - neki teorijski aspekti, „Zbornik radova Pravnog fakulteta u Splitu“, god. 44, 2/2007., Str. 199.

${ }^{19}$ Vidi BABIĆ, T. - ROKSANDIĆ, S., Osnove zdravstvenog prava, Tipex, Zagreb, 2006., str. 166. 20 Priopćenje Pučkog pravobranitelja RH od $22 . \quad$ kolovoza 2013. http://www.ombudsman.hr/index.php/hr/za-javnost/priopcenja/182-pravo-na-priziv-savjesti.

21 Izvor: http://www.ombudsman.hr/hr/reagiranja/priopenja-i-reagiranja/439-pravo-na-priziv$\underline{\text { savjesti.html, }}$

Primaljski Vjesnik Broj 15, ISSN 1848-5863, listopad 2013., str. 19.-21. 
${ }^{22}$ Usp. ŠEGVIĆ, S., Legitimnost građanskog otpora - neki teorijski aspekti, „Zbornik radova Pravnog fakulteta u Splitu“, god. 44, 2/2007., str. 191.

${ }^{23}$ Tako VUKADIN, D., Pravo prigovora savjesti, „Filozofska istraživanja“, god. 23., 2003., sv. 2, str. 421.

${ }^{24}$ Vidi MUJOVIĆ-ZORNIĆ, H., Promene u shvatanju klauzule savesti kod pružanja zdravstvenih usluga, „Pravni život“, tematski broj „Pravo i načelo savesnosti i poštenja“, 2014., broj 9, TOM I, str. 283.

25 Usp. AZDEJKOVIĆ, P. M., Borba: Prigovor savesti - Muški spas od vojske, http://azdejkovic.com/borba-prigovor-savesti-muski-spas-od-vojske/.

${ }^{26}$ Podatak na stranici http://narod.hr/hrvatska/sto-je-institut-priziva-savjesti.

${ }^{27}$ U tom smislu MUJOVIĆ-ZORNIĆ, H., Promene u shvatanju klauzule savesti kod pružanja zdravstvenih usluga, „Pravni život“, tematski broj „Pravo i načelo savesnosti i poštenja“, 2014., broj 9, TOM I, str. 277.

${ }^{28}$ Tako MARKELJEVIĆ, J., Savjest i priziv savjesti, predavanje održano 21. siječnja 2015. godine u Domu HKLD-a u Zagrebu.

${ }^{29}$ Podatak na stranici https://hr.wikipedia.org/wiki/Priziv_savjesti.

${ }^{30}$ Kulturalni učinak u judeokršćanskoj kulturi osobito daje prikaz uzastopnog svirepog mučenja i ustrajnosti u postupanju prema božanskom zakonu, koje iskazuju sedmorica braće Makabejaca i njihova majke koja gleda kako njeni sinovi bivaju mučeni i ubijani na najokrutnije načine, hrabreći sve manji broj preostalih svojih sinova da ustraju. Taj primjer - podcrtan okolnostima smrti samog Isusa - nasljeduje i prvobitna kršćanske zajednice koja nastaje u Jeruzalemu: u petom poglavlju Djela apostolskim nalazimo da Petar u ime apostola na saslušanju pred Velikim vijećem odbijaju nalog da prestanu propagirati kršćanstvo: "Treba se većma pokoravati Bogu negoli ljudima!" Slijedeći primjer apostola - od njih dvanaestorice, jedanaestorica su poginula mučeničkom smrću znatan broj kršćana je u prvim stoljećima kršćanstva odlučio inzistirati na vjernosti kršćanskoj vjeri sve do mučeništva; uglavnom povodom pritivljenja da u hramu državnog kulta ("Augustov hram") prikažu žrtvu u znak podložnosti Rimskom Carstvu. Podatak na stranici https://hr.wikipedia.org/wiki/Priziv_savjesti.

${ }^{31}$ Vidi MARKELJEVIĆ, J., Savjest i priziv savjesti, predavanje održano 21. siječnja 2015. godine u Domu HKLD-a u Zagrebu.

${ }^{32}$ Ibid.

${ }^{33}$ Vidi stranicu http://narod.hr/hrvatska/sto-je-institut-priziva-savjesti.

34 Tako ZORNIĆ-MUJOVIĆ., H., Prekid trudnoće - abortus, INSTITUT DRUŠTVENIH NAUKA, Centar za pravna istraživanja, Beograd, marta 2013., www.ius.bg.ac.rs/.../h.mujovic.prekid\%20trudnoce.

${ }_{35}$ Prvi slučaj koji se našao pred Komisijom za ljudska prava - tribunalom koji je poslije prerastao u Europski sud za ljudska prava, bio je Grandrath protiv Njemačke (slučaj iz 1964. god., okončan 1966. godine). U tom, kao i u brojnim drugim slučajevima koji su se poslije našli pred Europskim sudom za ljudska prava, priziv savjesti protiv vojne službe je bio odbijan - te je prihvaćen tek u presudi u slučaju Thlimmenos protiv Grčke iz 2000. godine. Vidi stranicu https://hr.wikipedia.org/wiki/Priziv savjesti.

${ }_{36}$ Usp. ČEHIĆ, D., Ljudima koji ne haju za savjest sloboda savjesti ne znači baš ništa, http://zdravstveniodgoj.com/news/-ljudima-koji-ne-haju-za-savjest-sloboda-savjesti-ne-znaci-basnista.

$\overline{37}$ Vidi kod Šta je zapravo - prigovor savesti? http://www.respecta.co.rs/2011/09/29/sta-jezapravo-prigovor-savesti/.

${ }_{38}$ Tako Šta je zapravo - prigovor savesti? http://www.respecta.co.rs/2011/09/29/sta-je-zapravoprigovor-savesti/

${ }^{39}$ OPĆA DEKLARACIJA O LJUDSKIM PRAVIMA, Usvojena i proglašena od Opće skupštine Rezolucijom 217 A (III) od 10. prosinca 1948., članak 18.; (Europska) Konvencija za zaštitu ljudskih prava i temeljnih sloboda, pročišćeni tekst, MU 18/97, 6/99, 14/02, 13/03, 9/05, 1/06, 2/10, čl. 9. st. 1. 
${ }^{40}$ (Europska) Konvencija za zaštitu ljudskih prava i temeljnih sloboda, pročišćeni tekst, MU 18/97, 6/99, 14/02, 13/03, 9/05, 1/06, 2/10, čl. 9. t. 2.

${ }^{41}$ Tako je u predmetu C. protiv Ujedinjenog Kraljevstva (od 15. prosinca 1983., 37 DR 142), koji je pokrenuo pripadnik Društva prijatelja (tj. Kvekera) protiv Ujedinjenog Kraljevstva, pripadnik te religije usprotivio se što dio poreza koji plaća ide u vojne svrhe. Komisija je donijela odluku da opća obveza plaćanjka poreza koju država nameće nema veze s pitanjem savjesti. Vidi HARLAND, C. - ROCHE, R. - STRAUSS, E., Komentar Evropske konvencije o ljudskim pravima prema praksi u Bosni i Hercegovini i Strasbourgu, Sarajevo, 2003., str. 237.

${ }^{42}$ Većina europskih država najčešće prigovaračima savjesti osigurava alternativu služenju vojnog roka u vidu civilne službe, ili vojne službe bez oružja. Civilna služba je alternativna državna služba, u koju se upućuju prigovarači savjesti i koja se obavlja bolnicama, staračkim domovima, vrtićima, organizacijama za pomoć invalidima, spasilačkim organizacijama i svim drugim organizacijama koje su od opšteg javnog interesa. Po međunarodnim standardima ove dvije službe su ravnopravne i oni koji se odluče za civilnu a ne vojnu službu kasnije zbog toga ne gube nikava prava niti smiju na bilo koji način biti diskriminirani. Totalni prigovor savjesti je odbijanje bilo vojne bilo civilne službe. Totalni prigovor savjesti ni u jednoj državi nije zakonski priznat, ali je negdje manje, negdje više toleriran. Prigovor savjesti na vojne troškove se sastoji u odbijanju da se uplati dio poreza namijenjen za vojsku. Takođe, u Švicarskoj je aktivna grupa koja radi na otkrivanju banaka koje imaju posla sa trgovinom oružja i koja poziva građane na bojkot tih banaka. Podatak na stranici https://sr.wikipedia.org/wiki/Prigovor_savesti.

${ }^{43}$ Mnogi prigovarači savjesti su insipirirani mišlju Alberta Ajnštajna: "Ratovi će prestati kada ljudi odbiju da se u njima bore". Vidi https://sr.wikipedia.org/wiki/Prigovor_savesti.

${ }^{44}$ Tako i više o tome kod OMEJEC, J., Konvencija za zaštitu ljudskih prava i temeljnih sloboda u praksi Europskog suda za ljudska prava - Strasbourški aquis, „Informator“, Zagreb, 2013., str. 1051.

${ }^{45}$ Usp. MUJOVIĆ-ZORNIĆ, H., Promene u shvatanju klauzule savesti kod pružanja zdravstvenih usluga, „Pravni život“, tematski broj „Pravo i načelo savesnosti i poštenja“, 2014., broj 9, TOM I, str. 277.

${ }^{46}$ Podatak na stranici http://narod.hr/hrvatska/sto-je-institut-priziva-savjesti

${ }^{47}$ Vidi MUJOVIĆ-ZORNIĆ, H., Promene u shvatanju klauzule savesti kod pružanja zdravstvenih usluga, „Pravni život“, tematski broj „Pravo i načelo savesnosti i poštenja“, 2014., broj 9, TOM I, str. 284.

${ }^{48}$ Tako KNESTOUT, B. P., An Essential Prescription: Why Pharmacist - Inclusive Conscience Clauses Are Necessary, ,Journal of Contemporary Health Law \& Policy“, 2006., broj 2, str. 4.

49 „Ako vas Hipokratova zakletva obvezuje da uvijek služite životu, evanđelje vas još više potiče, da ga uvijek i posvuda volite, ponajviše kada mu je potrebna osobita skrb ... vjernost Evanđelju i poštovanje ljudskoga života ponekad traži hrabri izbor, a u nekim okolnostima i prigovor savjesti“. Papa Franjo: Prigovor savjesti - liječnici, Prigodom 70 godišnjice uspostave Udruge Talijanskog katoličkog liječničkog društva (AMCI), http://www.ika.hr/index.php?prikaz=vijest\&ID=164838.

${ }^{50}$ Tako LAUDE, A., Pharmacie - Actualite juridique, „Revue de droit sanitaire et social“, 1999., broj 1 , str. 86.

${ }^{51}$ Vidi Pravo na priziv savjesti, Priopćenje Pučkog pravobranitelja RH od 22. kolovoza 2013., na stranici http://www.ombudsman.hr/index.php/hr/za-javnost/priopcenja/182-pravo-na-prizivsavjesti.

$\overline{52}$ Također se spominje primjer kako radnika koji je musliman može jako smetati da mu netko u tvorničkoj blagovaonici daje izbor između dva jela, koja su oba načinjena od svinjetine. Vidi na stranici https://sr.wikipedia.org/wiki/Prigovor_savesti.

${ }^{53}$ Unatoč tome u javnosti je bilo komentara kako je riječ o nedopustivu istupu suca čiji je posao provoditi zakon. JURASIĆ, M., SDP-ovski priziv savjesti Peđe Grbina, „Večernji list“ od 8. srpnja 2014., na stranici http://www.vecernji.hr/hrvatska/sdp-ovski-priziv-savjesti-pede-grbina-949048.

${ }^{54}$ Tako Čehić navodi: „Sjećam se iz svoje mladosti (bila je tada komunistička vladavina u Hrvatskoj), da su moji profesori morali držati predavanja u kojima se govorilo protiv vjere, te da 
nikako nisu smjeli pokazati da su vjernici - neki su nedjeljom posjećivali svoje roditelje u selu koje je udaljeno pedeset kilometara, samo kako bi mogli na misu. Da bi se neki profesor prekrižio, ili zaželio učenicima sretan Uskrs, to se uopće nije moglo zamisliti. Kao vojnik, nisam uopće smio razmišljati da bih se ujutro prekrižio, ili da bih nosio križić oko vrata: to je bilo zabranjeno, i bilo bi vrlo opasno da se uopće spomene da bi postojala nekakva ljudska prava tog tipa“. ČEHIĆ, D., Ljudima koji ne haju za savjest sloboda savjesti ne znači baš ništa, na stranici http://zdravstveniodgoj.com/news/-ljudima-koji-ne-haju-za-savjest-sloboda-savjesti-ne-znaci-basnista

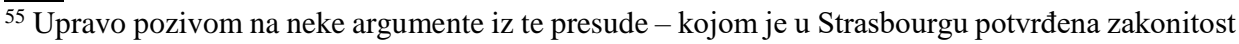
otkaza kojega je dobila londonska matičarka Lilian Ladele koja kao kršćanka nije htjela sudjelovati u ,gay vjenčanjima“ - hrvatska Vlada i Sabor su 2014. godine odbili prijedloge da se u Zakonu o životnom partnerstvu osoba istog spola zajamči pravo na priziv savjesti službenim osobama (matičarima, socijalnim radnicima, sucima i dr.) koji bi trebali sudjelovati u sklapanju takvih partnerstava i dodjeljivanju djece na ,partnersku skrb“ i „roditeljsku skrb“ (kako taj zakon naziva pravne institucije koje su posve ekvivalentne ,posvojenju“ iz Obiteljskog zakona): naime trenutačno-nam-vladajući smatraju da ,službenici imaju obvezu svim građanima osigurati jednako učinkovit pristup svim javnim uslugama“, među kojima je usluga sklapanja istospolnog životnog partnerstva. ČEHIĆ, D., Ljudima koji ne haju za savjest sloboda savjesti ne znači baš ništa, na stranici http://zdravstveniodgoj.com/news/-ljudima-koji-ne-haju-za-savjest-sloboda-savjesti-neznaci-bas-nista.

$56 \quad$ Podatak kod Šta je zapravo - prigovor savesti?, na stranici http://www.respecta.co.rs/2011/09/29/sta-je-zapravo-prigovor-savesti/

57 Vidi MILIČIĆ, V., Deontologija profesije liječnik - život čovjeka i integritet liječnika ćudoredna raskrižja bioetike, Zagreb, 1996., str. 38.

$58 \mathrm{U}$ tom smislu DAVID Udruga građana za zaštitu ljudskih prava, Prijedlozi za cjelovito reguliranje prava na priziv savjesti u medicini/ zdravstvenoj djelatnosti, Inicijativa liječnika/-ca za reguliranje priziva savjesti u medicini i CESI- Centar za edukaciju, savjetovanje i istraživanje, Poruke Okruglog stola „Priziv savjesti u medicini“, Zagreb, Novinarski dom, 21. 01. 2015., http://david-udruga.hr/novosti/2015/02/11/prijedlozi-za-cjelovito-reguliranje-prava-na-prizivsavjesti-u-medicini-zdravstvenoj-djelatnosti/.

${ }^{59}$ Razlikovanje aktivnog i pasivnog izražavanja prigovora savjesti posebice je važno u slučaju kada pojedinac ne želi obrazložiti svoj prigovor savjesti. VUKADIN, D., Pravo prigovora savjesti, „Filozofska istraživanja“, god. 23., 2003., sv. 2, str. 430.

${ }^{60}$ Tako ŠEGVIĆ, S., Legitimnost građanskog otpora - neki teorijski aspekti, „Zbornik radova Pravnog fakulteta u Splitu“, god. 44, 2/2007., str. 197.

${ }^{61}$ Prisila da ljudi postupaju protiv svoje savjesti, može također predstavljati diskriminaciju, u kojoj se govori u čl. 7. Opće deklaracije UN o pravima čovjeka, čl. 14. Konvencije za zaštitu ljudskih prava i temeljnih sloboda, te u čl. 14. Ustava RH. ČEHIĆ, D., Ljudima koji ne haju za savjest sloboda savjesti ne znači baš ništa, na stranici http://zdravstveniodgoj.com/news/-ljudima-koji-nehaju-za-savjest-sloboda-savjesti-ne-znaci-bas-nista.

${ }_{62}$ Vidi BOŠKOVIĆ, Z., Kodeks medicinske etike i deontologije - etika profesije liječnik, „Informator“, broj 5046-5047. od 17. i 20. srpnja 2002., str. 1.

${ }_{63}^{6}$ Tako RADIŠIĆ, J., Medicinsko pravo u svetu i kod nas, „Pravni informator“, 2002., br. 9. str. 1. ${ }^{64}$ Hipokratova zakletva drevni je dokument $\mathrm{i}$ temelj je medicinske etike. Nastala je u V. stoljeću prije Krista. Hipokrat je postavio temelje moderne medicine, oslobađajući je od religije, nametanja kulta čovjeka i uvođenjem znanstvenog načela promatranja čovjeka i prirode. Hipokrat je u zakletvu unio temeljna deontološka načela koja su u to vrijeme važila u Grčkoj. Vidi NIKOLIĆ, S., Etika zdravstvenih radnika danas, «Timočki medicinski glasnik», vol. 28., 2003., broj 3-4, str. 87.-90. Polagali su je prilikom stupanja na dužnost svi liječnici koji su pripadali Hipokratovom društvu Asklepiada. Cjeloviti tekst Hipokratove zakletve objavljen je kod MILIČIĆ, V., Deontologija profesije liječnik, život čovjeka i integritet liječnika - ćudoredna raskrižja bioetike, Zagreb, 1996., Prilog B, str. XXIII. Zdravstveni djelatnici najčešće se susreću sa Ženevskom 
formulacijom Hipokratove zakletve, u kojoj su naglašene obveze koje, prema iskustvima iz prethodna dva svjetska rata, nisu poštivane. Usp. NIKOLIĆ, S., Etika zdravstvenih radnika danas, «Timočki medicinski glasnik», vol. 28., 2003., broj 3-4, str. 87.-90. Usvojena je u Ženevi, 1948. godine, dopunjena na 22. Skupštini Svjetskog liječničkog udruženja u Sydneyu 1968., i 35. skupštini u Veneciji, 1983. godine. Cjeloviti tekst objavljen je kod MILIČIĆ, V., Deontologija profesije liječnik, život čovjeka i integritet liječnika - ćudoredna raskrižja bioetike, Zagreb, 1996., Prilog B, str. XXIII.-XXIV. I Međunarodni kodeks liječničke etike nalaže : "Liječnik je dužan držati u tajnosti sve što zna o bolesniku, čak i nakon njegove smrti". Usvojen je u Londonu 1949. godine, te dopunjavan dva puta: na skupštini Svjetskog liječničkog udruženja u Sydneyu 1986., i Veneciji 1983. godine. Cjeloviti tekst objavljen je kod MILIČIĆ, V., Deontologija profesije liječnik, život čovjeka i integritet liječnika - ćudoredna raskrižja bioetike, Zagreb, 1996., Prilog B, str. XXIV.-XXV. Usp. DOURAKI, T., Ethical and Legal Dimensions of Medical Confidentiality in European Law of Human Rights, «Pravni život», god. LI, 2002., br. 9, str. 183.

65 Tako BOŠKOVIĆ, Z., Odbijanje transfuzije krvi zbog vjerskog uvjerenja - pravni aspekti, „Informator“, broj 4867. od 28. 10. 2000., str. 16.

"66 Vidi ROKSANDIĆ VIDLIČKA S; ZIBAR, L; ČIZMIĆ, J; GRĐAN, K:Pravo jehovinih svjedoka na ostvarivanje kirurške zdravstvene zaštite u RH prema vrijedećim zakonima ( de lege lata) Liječnički vjesnik 2017, 139: 91-98.

${ }^{67}$ Podatak o tome kod RITTOSSA, D., Prijepori o pravu na pobačaj u Republici Hrvatskoj, „Zbornik Pravnog fakulteta Sveučilišta u Rijeci“, v. 26, 2005., broj 2 (1991), str. 980.

${ }^{68}$ Vidi MUJOVIĆ-ZORNIĆ, H., Promene u shvatanju klauzule savesti kod pružanja zdravstvenih usluga, „Pravni život“, tematski broj „Pravo i načelo savesnosti i poštenja“, 2014., broj 9, TOM I, str. 280.

${ }^{69}$ Usp. BABIĆ, T. - ROKSANDIĆ, S., Osnove zdravstvenog prava, Tipex, Zagreb, 2006., str. 167.

${ }^{70}$ Tako BOŠKOVIĆ, Z., Medicina i pravo, Pergamena, Zagreb, 2007., str. 177.

${ }^{71}$ Vidi ZORNIĆ-MUJOVIĆ., H., Prekid trudnoće - abortus, INSTITUT DRUŠTVENIH NAUKA, Centar za pravna istraživanja, Beograd, 2013., www.ius.bg.ac.rs/.../h.mujovic.prekid\%20trudnoce.

${ }^{72}$ Podatak o tome kod Još su žive žene koje su same napravile pobačaj vješalicama, ne želimo da se to ikad ponovi, http://www.vecernji.hr/hrvatska/jos-su-zive-zene-koje-su-same-napravilepobacaj-vjesalicama-ne-zelimo-da-se-to-ikad-ponovi-976203.

${ }^{73}$ Tako BENAČIĆ, A., PRIZIV SAVJESTI ILI OPORTUNIZAM: Prije 20-30 godina najnormalnije su radili abortuse, a sad..., http://lupiga.com/vijesti/priziv-savjesti-ili-oportunizam-prije-20-30godina-najnormalnije-su-radili-abortuse-a-sad.

${ }_{74}^{74}$ Vidi BABIĆ, T. - ROKSANDIĆ, S., Osnove zdravstvenog prava, Tipex, Zagreb, 2006., str. 167. 75 Usp. ZORNIĆ-MUJOVIĆ., H., Prekid trudnoće - abortus, INSTITUT DRUŠTVENIH NAUKA, Centar za pravna istraživanja, Beograd, 2013., www.ius.bg.ac.rs/.../h.mujovic.prekid\%20trudnoce.

${ }_{76}$ Podrobnije kod BABIĆ, T. - ROKSANDIĆ, S., Osnove zdravstvenog prava, Tipex, Zagreb, 2006., str. 167.

77 Tako CERAR, M., Nekateri pravni in moralni vidiki ugovora vesti, „Zbornik znanstvenih rasprav“, Ljubljana, 1993., br. LIII., str. 45.

${ }^{78}$ Vidi ZORNIĆ-MUJOVIĆ., H., Prekid trudnoće-abortus, INSTITUT DRUŠTVENIH NAUKA, Centar za pravna istraživanja, Beograd, 2013., www.ius.bg.ac.rs/.../h.mujovic.prekid\%20trudnoce.

${ }^{79}$ Usp. DAVID Udruga građana za zaštitu ljudskih prava, Prijedlozi za cjelovito reguliranje prava na priziv savjesti u medicini/ zdravstvenoj djelatnosti, Inicijativa liječnika/-ca za reguliranje priziva savjesti u medicini i CESI- Centar za edukaciju, savjetovanje i istraživanje, Poruke Okruglog stola „Priziv savjesti u medicini“, Zagreb, Novinarski dom, 21. 01. 2015., http://davidudruga.hr/novosti/2015/02/11/prijedlozi-za-cjelovito-reguliranje-prava-na-priziv-savjesti-umedicini-zdravstvenoj-djelatnosti/.

80 Vidi stranicu http://www.ombudsman.hr/hr/reagiranja/priopenja-i-reagiranja/439-pravo-napriziv-savjesti.html., ROŽMAN, K., O prizivu savjesti, „Primaljski Vjesnik“, 2013., broj 15, str. 19.-21. 
81 Tako ZORNIĆ-MUJOVIĆ., H., Prekid trudnoće - abortus, INSTITUT DRUŠTVENIH NAUKA, Centar za pravna istraživanja, Beograd, marta 2013., www.ius.bg.ac.rs/.../h.mujovic.prekid\%20trudnoce.

${ }^{82}$ Usp. BABIĆ, T. - ROKSANDIĆ, S., Osnove zdravstvenog prava, Tipex, Zagreb, 2006., str. 167. , vidi i BOŠKOVIĆ, Z., Priziv savjesti u medicini, „Hrvatska pravna revija”, broj 4/2005, str. 92. 93.

${ }^{83}$ Tako BENAČIĆ, A., PRIZIV SAVJESTI ILI OPORTUNIZAM: Prije 20-30 godina najnormalnije su radili abortuse, a sad..., http://lupiga.com/vijesti/priziv-savjesti-ili-oportunizam-prije-20-30godina-najnormalnije-su-radili-abortuse-a-sad.

${ }^{84}$ U 2013. godini smo u medijima mogli pratiti slučaj Jage Stojak: riječ je o primalji koja nikad nije htjela obavljati pobačaje, te je baš zadnjih nekoliko godina imala vrlo velike poteškoće sa svojim pretpostavljenima - možda najviše baš sa glavnom sestrom - primaljom u svojoj bolnici. Makar se u čl. 2. toč. 20. Etičkog kodeksa primalja (kojega donosi Hrvatska komora primalja, prema ovlasti iz čl. 27. Zakona o primaljstvu) izrijekom govori da primalje imaju pravo na priziv savjesti, ta je njezina pretpostavljena, a onda i uprava bolnice uporno tvrdila da zakon priznaje pravo na priziv savjesti jedino liječnicima, a da primalje takve „privilegije“ nemaju. Hrvatska komora primalja (u kojoj je baš ta glavna sestra - primalja bila jedna od članica Etičkog povjerenstva), nije pružila Jagi Stojak (a time, niti drugim svojim članicama koje bi se pozivale na priziv savjesti) baš nikakvu podršku: stoga se morala Jaga Stojak za podršku obratiti drugoj organizaciji koje je član Katoličkoj Crkvi. Zahvaljujući tadašnjem ministru zdravlja poništen je otkaz radnog odnosa kojega je bila dobila gospođa Stojak. ČEHIĆ, D., Ljudima koji ne haju za savjest sloboda savjesti ne znači baš ništa, podatak na stranici http://zdravstveniodgoj.com/news/-ljudima-koji-ne-haju-za-savjestsloboda-savjesti-ne-znaci-bas-nista.

${ }^{85}$ Vidi ZORNIĆ-MUJOVIĆ., H., Prekid trudnoće - abortus, INSTITUT DRUŠTVENIH NAUKA, Centar za pravna istraživanja, Beograd, 2013., www.ius.bg.ac.rs/.../h.mujovic.prekid\%20trudnoce. Manje se govori o tzv. pozitivnom prizivu savjesti (engl. conscientious commitment) u reproduktivnoj medicini. U takvom slučaju liječnike/ce i drugo zdravstveno osoblje njihova savjest motivira da pomažu ženama i omoguće im reproduktivnu zdravstvenu zaštitu. Primarna posvećenost dobrobiti pacijentica omogućava im da potisnu svoja eventualna osobna moralna ili religijska uvjerenje $\mathrm{u}$ interesu pacijentica. Zapaženi primjeri pozitivnog priziva savjesti $\mathrm{u}$ reproduktivnoj medicini su obavljanje besplatnih, medicinski sigurnih pobačaja depriviranim ženama i djevojkama u siromašnim zemljama gdje je pobačaj zabranjen ili jako restringiran, ili povijesno gledano, u zemljama Europe, Amerike i drugdje prije legalizacije pobačaja.

${ }^{86}$ Tako RIMAC-LESIČKI, I., Kod prodaje tablete za „dan poslije“ moguć je - priziv savjesti, „Večernji list“ od 25. travnja 2015., http://www.vecernji.hr/hrvatska/kod-prodaje-tablete-za-danposlije-moguc-je-priziv-savjesti-1002181.

${ }^{87}$ Ljekarnici imaju pravo odbiti provođenje ljekarničke skrbi u slučajevima kad se to kosi sa njihovim osobnim uvjerenjima, moralom ili religijom, te kad vjeruju da će njihova savjest biti povrijeđena tim postupkom. Prigovor treba uputiti pretpostavljenim, a nikako pacijentu ili propisivaču. Ljekarnik koji upućuje prigovor savjesti mora obavijestiti svoje poslodavce na vrijeme, tj. što prije moguće. Poslodavci trebaju prihvatiti prigovor savjesti, omogućiti pacijentu pravo na lijek, a istovremeno izuzeti ljekarnika koji upućuje prigovor savjesti u postupku izdavanja. Takav način izdavanja lijeka ne smije izazvati neugodnost pacijentu. Za stav prema prigovoru savjesti koji upućuju ljekarnici prilikom izdavanja lijeka, nema potrebe utvrđivati čija su prava veća: ljekarnika koji upućuje prigovor ili pacijenta koji ima pravo na zakonom zajamčenu skrb. Moguće je utvrditi postupak izdavanja lijeka koji uvažavaju prava pacijenata na skrb i ljekarnika na prigovor savjesti. Ovakvi postupci su u nekim sredinama već uobičajeni i vrlo učinkoviti. Naputak: Hrvatska ljekarnička komora, podatak na stranici http://www.hljk.hr/Pocetna/tabid/230/ctl/Details/mid/699/ItemID/4016/Default.aspx.

${ }_{88}$ Odrednica Pobačaj, na stranici https://hr.wikipedia.org/wiki/Poba\%C4\%8Daj.

${ }^{89}$ Valjalo bi daleko više naglašavati nekontracepcijske dobrobiti hormonalnih kontraceptiva. Od liječenja nekih dosta čestih bolesti koje mogu značajno ugroziti reproduktivno zdravlje 
(endometrioza), liječenja hormonalnih promjena (sindrom policističnih jajnika), prevencije anemije, pojave cisti na jajnicima, a nakon petogodišnjega uzimanja i značajnoga smanjenja rizika od obolijevanje od raka jajnika itd. Suviše se govori o rizicima koji su za zdravu, mladu ženu zanemarivi u odnosu na dobrobit. U svakom slučaju, prevalencija upotrebe hormonalne kontracepcije je niska, samo oko deset posto žena koristi hormonalnu kontracepciju. SVIRČIĆ, J. - GRUJIĆ, J., Redukcijom prava na pobačaj najviše će biti pogođene mlade i širomašne žene, „Lupiga.com“, od 22. prosinca 2015., podatak na stranici http://lupiga.com/intervjui/intervjupravo-na-pobacaj.

${ }^{90}$ Tako ČEHIĆ, D., Ljudima koji ne haju za savjest sloboda savjesti ne znači baš ništa , na stranici http://zdravstveniodgoj.com/news/-ljudima-koji-ne-haju-za-savjest-sloboda-savjesti-ne-znaci-basnista.

${ }^{91}$ Usp. BENAČIĆ, A., PRIZIV SAVJESTI ILI OPORTUNIZAM: Prije 20-30 godina najnormalnije su radili abortuse, a sad..., http://lupiga.com/vijesti/priziv-savjesti-ili-oportunizam-prije-20-30godina-najnormalnije-su-radili-abortuse-a-sad

${ }_{92}$ Vidi SVIRČIĆ, J. - GRUJIĆ, J., Redukcijom prava na pobačaj najviše će biti pogođene mlade $i$ širomašne žene, „Lupiga.com“, od 22. Prosinca 2015., podatak na stranici http://lupiga.com/intervjui/intervju-pravo-na-pobacaj.

${ }^{93}$ U tom smislu Pravobraniteljica: Pravo na pobočaj je utemeljeno na nadnacionalnim zakonima $E U$, „Indeks“ od 4. studenoga 2014., http://www.index.hr/vijesti/clanak/pravobraniteljica-pravona-pobacaj-je-utemeljeno-na-nadnacionalnim-zakonima-eu/781753.aspx.

94 Vidi Protiv priziva savjesti i Ustava: 'Liječnike koji odbijaju pobačaj izbaciti iz javnog zdravstva', „Dnevno.hr“ od 28. siječnja 2015., http://www.dnevno.hr/vijesti/hrvatska/protivpriziva-savjesti-i-ustava-lijecnike-koji-odbijaju-pobacaj-izbaciti-iz-javnog-zdravstva-143361\#.

95 Tako GJURIĆ, G., Prigovor savjesti $i$ nagovor savjesti u ratu oko pobačaja, http://www.libela.org/sa-stavom/5621-prigovor-savjesti-i-nagovor-savjesti-u-ratu-oko-pobacaja/.

${ }_{96}$ Usp. RAŠEVIĆ. M., Bela kuga i abortus, rad u knjizi „Pomeramo granice“, Institut društvenih nauka, Beograd, 2007., str. 28.-29.

${ }^{97}$ Vidi i podrobnije o tome kod BANKOLE, A. - SINGH, S. - HAAS, T., Reasons Why Women Have Induced Abortions: Evidence from 27 Countries, „International Family Planning Perspectives“, (1998), 24 (3), str. 117-127.

${ }^{98} \mathrm{U}$ tom smislu Još su žive žene koje su same napravile pobačaj vješalicama, ne želimo da se to ikad ponovi, http://www.vecernji.hr/hrvatska/jos-su-zive-zene-koje-su-same-napravile-pobacajvjesalicama-ne-zelimo-da-se-to-ikad-ponovi-976203.

${ }_{99}$ Tako RITTOSSA, D., Prijepori o pravu na pobačaj u Republici Hrvatskoj, ,Zbornik Pravnog fakulteta Sveučilišta u Rijeci“, v. 26, 2005., broj 2 (1991), str. 981.

${ }^{100}$ Vidi Pravobraniteljica: Pravo na pobočaj je utemeljeno na nadnacionalnim zakonima EU, „Indeks“ od 4. studenoga 2014., http://www.index.hr/vijesti/clanak/pravobraniteljica-pravo-napobacaj-je-utemeljeno-na-nadnacionalnim-zakonima-eu/781753.aspx

${ }^{101}$ Usp. EP odbio glasovati o pobačaju kao temeljnom ljudskom pravu, „Večernji list“ od 22.

listopada 2013., http://www.vecernji.hr/eu/ep-odbio-glasovati-o-pobacaju-kao-temeljnomljudskom-pravu-631241

${ }_{102}$ Sud pravde u Luxemburgu, 2011. određuje da ljudski život počinje od samoga začeća.

http://eutopialaw.com/2011/10/21/eu-law-human-dignity-and-the-human-embryo-the-decision-ofthe-cjeu-grand-chamber-in-brustle-v-greenpeace-ev-c\%E2\%80\%913410/

${ }^{103}$ Dijete već od trenutka začeća može steči prava. Tako začeto dijete (nasciturus) ima sposobnost za nasljeđivanje i dijete začeto u času otvaranja nasljedstva smatrat će se rođenim ako se rodi živo (Zakon o nasljeđivanju, „Narodne novine“, broj 48/03, 163/03, 35/05, 127/13, 33/15, čl. 124. st. 2.). Ovo je pravna fikcija i ima za cilj očuvati nasljedna prava ukoliko se dijete kasnije živo rodi. Još od rimskog prava, odnosno, u vremenu kada su znanost i medicina bili na kudikamo nižim granama, dostignućima i spoznajama, rimskim pravnicima nije bilo sporno da se u utrobi majke nalazi živi, još nerođeni čovjek, dakle, čovjek koji čeka svoje vrijeme izlaska, pa su tako odredili zakonsku normu po kojoj su štitili njegova imovinska prava (Nasciturus pro iam nato habetur, 
quotiens de eius commodis agitur). Vidi o tome i šire kod VELČIĆ, B., Nerođeno dijete ima pravo na nasljeđivanje imovine, ali pravo na život - ne!, podatak na stranici http://spiritusmovens.me/zivot/06/13/nerodeno-dijete-ima-pravo-na-nasljedivanje-imovine-ali-pravo-na-zivotnel.

$\overline{104}$ Podatak kod Protiv priziva savjesti i Ustava: 'Liječnike koji odbijaju pobačaj izbaciti iz javnog zdravstva', „Dnevno.hr“ od 28. siječnja 2015., http://www.dnevno.hr/vijesti/hrvatska/protivpriziva-savjesti-i-ustava-lijecnike-koji-odbijaju-pobacaj-izbaciti-iz-javnog-zdravstva-143361\#. ${ }^{105}$ Tako ČEHIĆ, D., Ljudima koji ne haju za savjest sloboda savjesti ne znači baš ništa, podatak na stranici http://zdravstveniodgoj.com/news/-ljudima-koji-ne-haju-za-savjest-sloboda-savjestine-znaci-bas-nista.

${ }^{106}$ Usp. PAVIČIĆ, D., Pozaić o Holy: navodna stranka ekologije propagira kulturu smrti,„Večernji list" od 27. studenoga 2014., http://www.vecernji.hr/hrvatska/biskup-pozaicginekologe-koji-ne-zele-pobacaje-pretvorili-su-u-udbase-976025.

${ }^{107} \mathrm{O}$ tome vidi Protiv priziva savjesti i Ustava: 'Liječnike koji odbijaju pobačaj izbaciti iz javnog zdravstva', „Dnevno.hr“ od 28. siječnja 2015., http://www.dnevno.hr/vijesti/hrvatska/protivpriziva-savjesti-i-ustava-lijecnike-koji-odbijaju-pobacaj-izbaciti-iz-javnog-zdravstva-143361\#. 108 Tako ČEHIĆ, D., Ljudima koji ne haju za savjest sloboda savjesti ne znači baš ništa, podatak na stranici http://zdravstveniodgoj.com/news/-ljudima-koji-ne-haju-za-savjest-sloboda-savjestine-znaci-bas-nista.

${ }^{109}$ Vidi o tome na stranici http://stephenspillane.com/blog/index.php/2010/12/abc-v-irelandeuropean-court-of-human-rights/; http://www.hrlc.org.au/court-tribunal/european-court-ofhuman-rights/s-h-others-v-austria-2011-echr-1879-3-november-2011/.

${ }^{110}$ U Americi je poznat slučaj Jamesa Kopa, člana „Kristovih jaganjaca“, boraca protiv abortusa, koji je došao na FBI-jevu listu deset najtraženijih osoba jer je 1998. godine ubio ginekologa koji je vršio abortuse. U božičnoj poslanici iz 1995. Patrijarh i 35 arhijereja primijetili su da ,žene začinju jer je to skopčano sa uživanjem i zadovoljstvom, ali neće da rađaju i podižu decu, jer je to naporno i tobož ugrožava njihov komoditet“, kao i da „mnoge majke koje nisu želele da imaju više od jednog deteta danas čupaju kose i gorko ridaju nad izgubljenim jedincima u ovim ratnim sukobima, proklinjući zato često Boga i ljude, ali pri tom zaboravljajući da optuže i sebe što nisu rodile još dece da im ostanu kao uteha“. I Mitropolit crnogorsko-primorski je civilizaciju koja ozakonjuje abortus, odnosno čedomorstvo ocijenio kao ,pritajeno nekrofilsku, u suštini nečovečnu civilizaciju“. Podatak kod JOVANOVIĆ, S. - SIMEUNOVIĆ PATIĆ, B., (Ne)dozvoljeni prekid trudnoće, „Pravni život“, 2007., broj 9, str. 160. U Srbiji je 2000. godine Sinod Srpske pravoslavne crkve pred početak uskršnjeg posta javno „umolio“ svećenike da liječnike i primalje koji vrše abortuse, dok se ne pokaju „ne pripuštaju Svetoj tajni Pričešća i da ih liše prava na rezanje slavskog kolača“, jer je čedomorstvo „vapijući greh pred Bogom, osuđen od celokupnog kanonskog i svetootačkog predanja Crkve i kao takvo preti da u dogledno vreme dovede do biološkog istrebljenja srpskog naroda“. Vidi ČIRIĆ, A., Crkva protiv abortusa, „Vreme“, br. 481, 2000., podatak kod JOVANOVIĆ, S. - SIMEUNOVIĆ PATIĆ, B., (Ne)dozvoljeni prekid trudnoće, „Pravni život“, 2007., broj 9, str. 160.

${ }^{111}$ Usp. Rješenje Ustavnog suda Broj: U-I-60/1991 U-I-94/1991 U-I-173/1995 U-I-39/2008 U-I5089/2016 U-I-5639/2016 U-I-5807/2016 o ne prihvaćanju prijedloga za pokretanje postupka za ocjenu suglasnosti s Ustavom Zakona o zdravstvenim mjerama za ostvarivanje prava na slobodno odlučivanje o rađanju djece ("Narodne novine" broj 18/78., 31/86., 47/89. i 88/09.)

Vidi izdvojeno mišljenje u predmetu broj: U-I-60/1991 i dr. Miroslav Šumanović, cit: „Prema tome, osporeni zakonski model suprotan je Ustavu jer zakonska mogućnost disponiranja - dokidanja nerođenog života u smislu čl. 15. osporenog zakona na osnovi ničim limitirane subjektivne volje predstavlja očigledno kršenje ustavne obveze državne vlasti iz čl. 21. st. 1. Ustava. Navedena odredba, naime, obvezuje državu na sveobuhvatnu (uključivo i zakonsku) zaštitu života svakog ljudskog bića, pa tako i nasciturusa. Zahtijeva se zaštitničko postavljanje države u odnosu na život kao vrhunsku vrijednost i to primarno u odnosu na nezakonito zadiranje trećih. S obzirom na 100 
to da je ljudski život ustavna vrijednost najvišeg ranga ova je obveza državne vlasti naročito zahtjevna i ozbiljna. Osporenim zakonom ta je obveza nesumnjivo grubo prekršena “

112 Tako SAVULESCU, J., Prigovor savjesti u medicini, Cijepljenje.info, http://www.cijepljenje.info/julian-savulescu-prigovor-savjesti-u-medicini/. ${ }^{113}$ Usp. GJURIĆ, G., Prigovor savjesti i nagovor savjesti u ratu oko pobačaja, http://www.libela.org/sa-stavom/5621-prigovor-savjesti-i-nagovor-savjesti-u-ratu-oko-pobacaja/ ${ }_{114}$ Vidi DAVID Udruga građana za zaštitu ljudskih prava, Prijedlozi za cjelovito reguliranje prava na priziv savjesti u medicini/ zdravstvenoj djelatnosti, Inicijativa liječnika/-ca za reguliranje priziva savjesti u medicini i CESI- Centar za edukaciju, savjetovanje i istraživanje, Poruke Okruglog stola „Priziv savjesti u medicini“, Zagreb, Novinarski dom, 21. 01. 2015., http://davidudruga.hr/novosti/2015/02/11/prijedlozi-za-cjelovito-reguliranje-prava-na-priziv-savjesti-umedicini-zdravstvenoj-djelatnosti/; i GJURIĆ, G., Prigovor savjesti i nagovor savjesti u ratu oko pobačaja, http://www.libela.org/sa-stavom/5621-prigovor-savjesti-i-nagovor-savjesti-u-ratu-okopobacaja/.

${ }^{115}$ O prizivu savjesti vidi kod ČIZMIĆ, J., Pravo zdravstvenih radnika na ,priziv savjesti “, Zbornik Pravnog fakulteta Sveučilišta u Rijeci, (1991), v. 37, br. 1, 2016., str. 753.-786. 
184 | ZDRAVSTVENO STRUKOVNO STALEŠKO PRAVO 


\section{6/ Odgovornost zdravstvenih radnika i osiguranje od odgovornosti}

\subsection{Liječnička pogreška i građanska odgovornost}

Zdravstvena djelatnost ubraja se u red najznačajnijih ljudskih aktivnosti jer štiti i unaprjeđuje najveće ljudske vrijednosti - život i zdravlje čovjeka. Upravo činjenica što je usmjerena na život i zdravlje čovjeka čini specifičnom i primjenu pravila o odgovornosti za štetu koja može proizaći iz obavljanja ove djelatnosti. ${ }^{1} \mathrm{U}$ svim se profesijama griješi (errare humanum est.). Od toga nije pošteđena ni profesija liječnika odnosno zdravstvenog radnika. Iako je cilj liječenja zaštita zdravlja i života pacijenta, mjere liječenja i poduzete intervencije ponekad ne dovedu do ozdravljenja zbog prirode same bolesti ili zdravstvenog statusa pacijenta, a ponekad mogu prouzročiti povredu i štetne posljedice po zdravlje i život pacijenta. ${ }^{2}$ Pogreške drugih zdravstvenih radnika također mogu dovesti do njihove osobne odgovornosti ili odgovornosti njihova poslodavca za štetu korisniku zdravstvene usluge. ${ }^{3}$ Pogreške mogu prouzročiti prolazne zdravstvene poteškoće, trajne posljedice (neurološke posljedice, invalidnost itd.) ili pak mogu dovesti do smrti (bilo da pogoršaju teško zdravstveno stanje i uzrokuju smrt ili da pogreška izravno dovodi do smrti). Sitne pogreške mogu napraviti veliku štetu ili pak izazvati smrt bolesnika. ${ }^{4}$ Odgovornost liječnika kao jedna vrsta profesionalne odgovornosti, ipak se od nje razlikuje po tome što greška liječnika nikada nije samo tehnička greška kao u drugim profesijama. Liječnička greška ima dvostruku prirodu, medicinsku i pravnu koje se, istovremeno dopunjuju, ali i razmatraju iz dva različita kuta: medicinska definicija se odnosi na pravila medicine dok se pravna definicija odnosi na pitanje protupravnosti čina/propusta. ${ }^{5}$

Čovjeku je svojstveno griješiti u svakom poslu, pa i u medicinskoj djelatnosti. Griješe svi u svome zanimanju ali su liječničke pogreške ${ }^{6}$ izložene osobito budnom oku javnosti, jer se održavaju na najvažnija čovjekova dobra - na život i zdravlje. Problematika koja se tiče liječničkih pogrešaka povezana je s vještinom dijagnosticiranja i liječenja, i praktično je stara isto toliko koliko i sama medicina. Stoga je oduvijek važilo uvjerenje da je liječnik samo čovjek, kojemu se, kao i svakome drugom, može potkrasti greška. ${ }^{7}$ Greška je neraskidivo vezana uz medicinsku djelatnost budući da medicina nije egzaktna znanost $i$ struka poput, primjerice, matematike, pa grešku u radu liječnika nije moguće izbjeći. Doslovno svaki postupak liječnika u odnosu s bolesnikom povezan je s određenim rizikom i mogućnošću nastanka neželjenih posljedica. ${ }^{8}$ Medicinska pogreška je ne samo nesavjesno postupanje liječnika, nego i medicinske sestre/tehničara, ljekarnika, radnog terapeuta, zdravstvene ustanove, ili drugih koji se brinu o zdravstvenoj skrbi. Zdravstveni radnik ili radnici mogu tijekom svoga rada pogriješiti i izazvati pogoršanje zdravstvenoga stanja osobe i/ili smrt osobe o kojoj skrbe i tada govorimo o nesavjesnom liječenju. Ukoliko zdravstveni radnik ne poduzme neku radnju koju je trebao poduzeti u određenom trenutku, a zbog toga dođe do pogoršanja zdravstvenoga stanja osobe ili do smrti, smatra se da je napravljen propust nepoduzimanja nužne radnje i to nesavjesnim postupanjem. Medicinski nesavjestan postupak jest nemar ili nebriga od strane zdravstvenoga radnika bilo kojeg usmjerenja ili bilo koje stručne spreme, koji rezultiraju oštećenjem zdravlja 
Prava, obveze i odgovornosti radnika u obavljanju djelatnosti: Odgovornost zdravstvenih radnika i osiguranje od odgovornosti

bolesnika. Zakonska je dužnost zdravstvenih radnika da u svome radu pruže određeni standard znanja, brige i umijeća prilikom pružanja zdravstvene skrbi. Traži se profesionalan, razborit i human pristup pri liječenju. Suprotno tomu, dakle, neprofesionalan, nerazborit i nehuman pristup smatraju se nemarom, nebrigom, nesavjesnošću zdravstvenoga radnika. ${ }^{9}$

Pojam stručne ili liječničke pogreške nastao je dosta davno, ali se u literaturi pojavio prvi put sredinom devetnaestoga stoljeća. Pojam ,liječničke greške“ pojavio se u (medicinsko pravnoj) literaturi prvi put u drugoj polovici 19. stoljeća. Patolog, njemački klasik medicine i političar Rudolf Virchow ${ }^{10}$ je liječničku grešku nazvao Kunstfehler der Ärzte i definirao je kao kršenje općepriznatih pravila ${ }^{11}$ vještine liječenja zbog pomanjkanja potrebne pažnje ili opreza (Verstoß gegen die allgemein anerkannten Regeln der Heilkunst infolge eines Mangels an gehöriger Aufmerksamkeit oder Vorsicht ${ }^{12}$. To je skrivljeno postupanje contra legem artis (protivno pravilima struke). ${ }^{13}$ Nakon mnogobrojnih prigovora pojam stručne greške (Kunstfehler der Ärzte) napušten ${ }^{14}$ je i u suvremenoj njemačkoj pravnoj literaturi i sudskoj praksi zamijenjen je pojmom greška u tretmanu (Behandlungsfehler). Mijenjanjem naziva željelo se naglasiti da je to širi pojam od pojma stručne greške, jer je riječ o višeznačnom pojmu koji obuhvaća ne samo greške u liječenju, nego i greške u dijagnozi, tijekom provođenja postupka ili tretmana i naknadnoj skrbi. U njemačkoj pravnoj teoriji u početku je vladao stav da liječnici trebaju odgovarati samo zbog težih i ozbiljnih liječničkih grešaka, jer ,da i najvještiji liječnik ne radi sa sigurnošću mašine“. ${ }^{15}$ Takva teorija je davno napuštena tako što je Savezni sud Njemačke zauzeo čvrst stav da liječnik mora odgovarati za svaku (pa i najmanju) grešku. ${ }^{16}$ Premda većina njemačkih pravnika smatra taj stav ispravnim, ima i onih koji nisu suglasni, a među njima je i ugledni njemački teoretičar Erwin Deutsch, koji smatra da liječnička greška postoji samo u slučaju ,kada stručnjak odmahuje glavom“. ${ }^{17}$ Treba istaknuti da je takav stav protivan interesima ne samo potencijalnih oštećenika, nego čak i liječnika koji moraju imati respekt prema mogućim posljedicama, ali one ne smiju biti pretjerane i ne smiju praktično onemogućiti njihov rad niti ih ograničiti samo na tzv. defanzivnu medicinu. Kompromis je pronađen u rješenju da se razlikuju: grube liječničke (medicinske) greške; i obične liječničke (medicinske) greške, pri čemu bi grube liječničke (medicinske) greške bile one koje se liječniku (ili drugom medicinskom djelatniku) nikada ne bi smjele dogoditi - većinom je riječ o zanemarivanju elementarnih znanja i iskustava medicine. ${ }^{18} \mathrm{U}$ slučaju počinjenja grube greške primjenjuje se oboriva predmnijeva da je upravo ona uzrok nastale štete (na pacijentu nije teret dokaza uzročne veze između medicinskog zahvata i nastale štete) i liječnik (ili drugi medicinski djelatnik) mora, da bi se oslobodio od odgovornosti, dokazati da štetu nije izazvala njegova greška, već neki drugi uzrok. ${ }^{19}$

Pojam i institut liječničke pogreške nije pravno uređen i ne nalazi se nigdje u zakonu, pa bi izgledalo da je čisto medicinski pojam. Ipak, nije riječ isključivo o medicinskom pitanju, o vrsti i opsegu liječnikove vještine, nego istovremeno i o pravnom pitanju - o mjerilu koje važi za ispunjavanje obveza što ih liječnik ima prema pacijentu. ${ }^{20}$ Liječnička pogreška kao kategorija proizašla je iz praktične medicine, tj. kodeksa liječničke struke u kojoj su liječnici sami ocjenjivali što je učinjeno dobro, a što loše za bolesnika. Značajno je to što se ona i danas koristi isključivo kao medicinski pojam. U pravnoj legislativi 
(kontinentalnom i u anglosaksonskom pravu) ona se izrijekom nigdje ne spominje. Pravna znanost kao i sudska praksa koriste je za indirektnu ocjenu propusta u radu liječnika. Stoga se još i danas samo posredno na osnovi zakona i sudske prakse može pretpostaviti da je određen loš tretman liječnička pogreška, te kao takav može eventualno biti procesuiran. ${ }^{21}$ Iako naše odštetno pravo ne poznaje pojam pod nazivom liječnička greška ili slični pojam, nema zapreke da se taj naziv ne prihvati u pravnoj teoriji i sudskoj praksi, tim više što je postao svojevrsni tehnički termin za označavanje takvog sadržaja. ${ }^{22}$

Liječnička pogreška osnovni je čimbenik za utvrđivanje odgovornosti liječnika kao i posljedica koje zbog toga nastaju, iako se ni u kaznenom ni u civilnom zakonodavstvu kao pojam izrijekom ne spominju. $\mathrm{S}$ druge strane, ni u medicinskoj struci ne postoji općeprihvaćeno mišljenje o tome kako definirati liječničku grešku. U pravnoj doktrini, zakonodavstvu različitih zemalja, a time i u sudskoj praksi pojam liječničke pogreške različito se određuje (definira): a) kao postupanje suprotno (odnosno koje nije u skladu s) pravilima i metodama odnosno standardima rada zdravstvene struke i/ili znanstvenim saznanjima, kojim se ugrožava život i zdravlje ljudi, ${ }^{23}$ i/ili b) kao nepoštovanje moralnih i etičkih načela zdravstvene struke. Liječnička greška može se počiniti postupanjem opisanim pod a) ili pod b). Nije, dakle, riječ o pretpostavkama koje se moraju istovremeno ispuniti odnosno o kumulaciji pretpostavki. Životno su, dakako, mogući slučajevi u kojima je liječnik počinio obje povrede. ${ }^{24}$ No, ima i dosta drugih, više ili manje različitih definicija, npr. "liječničkom greškom treba smatrati zabludu liječnika u njegovoj profesionalnoj djelatnosti koja u svojoj osnovi ima nepotpunost ili nesavršenost suvremenih načina istraživanja, objektivne vanjske uvjete, kao i neiskustvo samoga liječnika" (Avdjejev), "liječnička greška je povreda liječničkoga umijeća činjenjem nečega što je nedopustivo ili propuštanjem mjera koje su preporučene" (Hansen), „liječnička greška je stručna zabluda bez elementa nesavjesnosti““ (Pejaković). ${ }^{25}$

Definicija liječničke pogreške u današnjem je društvu pretrpjela izmjene. Od prve pomalo rigidne definicije (Arztfehler, Kunstfehler), kojom je njen tvorac (Virchow) označio: „Kršenje opće poznatih pravila umijeća liječenja zbog pomanjkanja dužne pažnje $i$ opreza", zbog opravdanih prigovora od strane liječnika, kako je ovom definicijom stvoren dojam da je medicina znanost sa nepromjenjivim zakonitostima; ista je u suvremenoj sudskomedicinskoj praksi Njemačke napuštena i zamijenjena pojmom Behandlungsfehler, (medical error, malpractise, anglosaksonski, vitium artis latinski). Izmjenom se željelo naglasiti šire značenje pojma liječničke pogreške koji bi obuhvatio ne samo pogreške liječenja, već profilakse, dijagnostike i naknadne skrbi bolesnika, poradi zanemarivanja ili odstupanja od medicinskog standarda ili pravila medicinske struke. ${ }^{26} \mathrm{U}$ Liječničkim novinama iz 2006. mogu se naći i ove definicije: ,medicinska greška obuhvaća sve greške u profilaksi, dijagnostici, liječenju i naknadnoj skrbi zbog zanemarivanja ili odstupanja od medicinskih standarda i medicinske znanosti“ (br. 50) i ,greškom nazivamo nepovoljan ishod bolesti, ozljede ili stanja pacijenta uslijed neprimjerenog medicinskog postupka, neprimjerene ili neispravne opreme, pogrešno primijenjenih medicinskih sredstava ili lijekova ili pak neprimjerene organizacije medicinske službe“ (br. 54). ${ }^{27}$ Postoji mnogo definicija liječničke greške. Neki autori definiraju liječničku grešku kao zanemarivanje ili odstupanje od medicinskog standarda, odnosno standarda medicinske znanosti (Erwin Deutsch), ${ }^{28}$ a drugi kao svaku liječničku 
Prava, obveze i odgovornosti radnika u obavljanju djelatnosti: Odgovornost zdravstvenih radnika i osiguranje od odgovornosti

mjeru koja je prema standardu medicinske znanosti i iskustva izvedena bez dužne pažnje (Laufs - Uhlenbruck). ${ }^{29}$ Neki drže da liječničkom greškom treba smatrati zabludu ${ }^{30}$ liječnika u njegovoj profesionalnoj djelatnosti koja u svojoj osnovi ima nepotpunost ili nesavršenstvo suvremenih načina istraživanja, objektivne vanjske uvjete, kao i neiskustvo liječnika; da je liječnička greška ponašanje zbog kojega planirano liječenje nije završeno kako je bilo predviđeno ili da je riječ o primjeni pogrešnog plana u svrhu liječenja; zatim da je liječnička greška povreda liječničkog umijeća činjenjem nečega što je nedopustivo ili propuštanjem mjera koje su preporučene; da je liječnička greška stručna zabluda bez elemenata nesavjesnosti. ${ }^{31} \mathrm{Sa}$ sudskomedicinskog stajališta liječničkom greškom se označava već sama činjenica da medicinski postupak (zahvat) nije do kraja ispravno obavljen, bez obzira na to zbog čega je do toga došlo. ${ }^{32}$

U angloameričkom pravu taj se pojam (malpractice) definira kao nepažljivo postupanje kojim se uzrokuje šteta, odnosno odstupanje od apstraktnog standarda pažnje dobrog liječnika (reasonably competent doctor) sa sličnim iskustvom i odgovornošću, u sličnim uvjetima rada. ${ }^{33}$ C̆lanak 2236. talijanskog Građanskog zakonika (Codice civile) ograničava odgovornost osoba koje izvršavaju „osobito teške tehničke zadatke na grubu nepažnju“ (Art. 2236. CC „Se la prestazione implica la soluzione d problemi tecnici di speciale difficolta, il prestatore d; opera non risponde dei danni, se non in caso di dolo o di colpa grave"), ali su sudovi ovu odredbu usko tumačili i tu privilegiju priznali među liječnicima samo kirurzima i rendgenolozima. ${ }^{34}$

U nekim definicijama liječničke greške se naglašava objektivni element (odstupanje od standarda medicinske znanosti), a u nekima subjektivni element (povreda obveze dužne pažnje - ein Versto $\beta$ gegen die ärztliche Sorgfaltspflicht). Neki autori smatraju da do liječničke pogreške češće dolazi skrivljeno, najčešće zbog nedovoljne pažnje, ali je moguća liječnička greška i uslijed zablude, neiskustva ili neznanja. ${ }^{35} \mathrm{U}$ hrvatskoj teoriji i zakonodavstvu krivnja je subjektivni element protupravnosti, a unutar krivnje razlikuju se namjera (dolus) i nepažnja (culpa), a unutar nepažnje razlikuju se krajnja ili gruba nepažnja (culpa lata) i obična nepažnja (culpa levis) ${ }^{36}$. Unutar ovih općih kategorija, obzirom na narav stvari kada se radi o liječnicima (ali i drugim stručnjacima medicinske struke), treba upozoriti na čl. 10. ZOO prema kojemu se u ispunjavaju obveza iz svoje profesionalne djelatnosti mora postupati s povećanom pažnjom, prema pravilima struke i običajima (pažnja dobrog stručnjaka). Ukoliko dođe do situacije u kojoj se zahtijevana povećana pažnja ne uloži, bit će to obična nepažnja (culpa levis), a ako se ne postupi ni onako kako bi to učinio svaki prosječni stručnjak, riječ je o gruboj nepažnji (culpa lata). ${ }^{37}$

Liječnička pogreška osim novčanih izdataka stvara nepremostivi jaz narušenog povjerenja između pacijenata i pružatelja usluga, uz rastuće nezadovoljstvo na obje strane. Posljedica je sa strane liječnika provođenje defanzivne medicine i izbjegavanje rizičnih zahvata. ${ }^{38}$

Za ocjenu počinjenja liječničke pogreške isključivo je mjerodavno stanje medicinske znanosti u vrijeme poduzimanja medicinskog zahvata. Odgovornost liječnika uvijek se ocjenjuje ex ante. Kasnija znanstvena dostignuća medicine mogu imati utjecaja samo ako potvrđuju ispravnost poduzetog zahvata, dakle ako idu liječniku u prilog. ${ }^{39}$ Drugim 
riječima, spomenuti pravni standard pravila i metode rada odnosno medicinski standard rada znači da postupke liječnika valja prosuđivati onako kako bi ih, u vrijeme kad je liječnik djelovao, prosudila medicinska struka. Pritom valja imati na umu sve okolnosti slučaja. To znači da valja ocijeniti složenost i rizičnost medicinskog zahvata, vrijeme koje je liječnik imao za pripremu i provedbu zahvata, pri čemu posebno valja imati na umu vrijeme i mogućnost za određivanje dijagnoze i davanje odnosno primjenu terapije, uvjete rada (na terenu ili u prostoru zdravstvene ustanove, opremu, lijekove i slično), potporu suradničkog tima, tj. drugih liječnika i/ili drugih zdravstvenih radnika, primjerice medicinskih sestara, te stručna i znanstvena saznanja koja su mu mogla i morala biti poznata. U okolnostima hitnosti liječnik bi trebao uživati privilegiju smanjenog stupnja pažnje, tj. ne smije se od njega zahtijevati isti stupanj pažnje kao u „normalnim“ okolnostima. Odlučujući o odgovornosti liječnika, sud mora imati na umu da zdravstveni radnik $\mathrm{u}$ ispunjavanju obveza iz svoje profesionalne djelatnosti mora postupati $\mathrm{s}$ povećanom pažnjom, prema pravilima struke i običajima, dakle, pažnjom dobrog stručnjaka (Vidi Zakon o obveznim odnosima, „Narodne novine“, broj 35/05. i 41/08. dalje: ZOO, čl. 10. st. 3.). ${ }^{40}$ Važna novina u definiciji pojma liječničke greške je navođenje odstupanja od standarda medicinske znanosti kao mjerila greške, umjesto dotadašnjeg kršenja općepriznatih pravila medicinske znanosti. ${ }^{41}$ Postupak je liječnik dužan obaviti s „dužnom pažnjom“, u smislu § 276. njemačkog Građanskog zakonika (BGB).. „Općepriznati“" su samo oni medicinski postupci koji su spoznati i prihvaćeni od svih liječnika iste struke ili barem od većine. ${ }^{42}$ Vrlo zahtjevno i kompleksno je pitanje što je to medicinski standard? Nigdje nije precizno određeno što bi se trebalo smatrati medicinskim standardom, a to bi bilo i nemoguće za svaki konkretan medicinski postupak zbog prevelike različitosti i ogromnog broja različitih medicinskih postupaka (uključujući i dijagnostičke i terapijske mjere). Prema jednom objašnjenju, pojam medicinskog standarda svodi se na pitanje je li liječnik postupio onako kako se to od njega očekuje u njegovom profesionalnom krugu. Ne zahtijeva se da sve metode budu općepriznate, dovoljno je da se primjenjuju u više sveučilišnih klinika, ali to se (ipak) ne odnosi na postupke koji su još u eksperimentalnoj fazi. ${ }^{43} \mathrm{U}$ medicinski standard spadaju i novija znanstvena saznanja i mogućnosti, ukoliko su u medicinskoj znanosti već priznati. ${ }^{44}$ Dakle, prihvaćanje ,medicinskog standarda“ je omogućilo da se liječnici ne ustručavaju primijeniti i nove poznate i priznate metode i sredstva, jer kako će nešto novo postati općepriznato, ako se preko liječnika ne uvedu u praksu. 45

Zbog brzog razvitka medicine, liječniku se ne može staviti na teret nesavjesnost, ukoliko se držao klasičnih pravila struke, jer mu objektivno nisu bila dostupna nova dostignuća. ${ }^{46}$ Koliko god je ovo razumljivo, treba priznati i da je to jedan poticaj in favorem defanzivne medicine, što nije baš dobro svojstvo. Pri izboru dijagnostičkih i terapijskih metoda liječnik je potpuno slobodan, ali je u dvojbi dužan držati se načela sigurnijeg puta. Nema dužnost držati se načela sigurnijeg puta ako taj veći rizik ima opravdanje u specifičnostima konkretnog slučaja ili u povoljnijim prognozama izlječenja, jer je ključno u izboru terapije liječnikovo savjesno odmjeravanje koristi i rizika. ${ }^{47}$ Grešku bi učinio jedino ako bi izabrao metodu koja u medicini nije priznata. Ako pak u teoriji postoje različite škole mišljenja o nekoj metodi, preporučuje se osloniti na općeprihvaćenu praksu. ${ }^{48}$ Ukoliko je sporno je li neki medicinski postupak spada u medicinski standard, o tome odlučuje sud uz pomoć sudskog vještaka medicinske struke ${ }^{49}$, ali je za liječnika 
Prava, obveze i odgovornosti radnika u obavljanju djelatnosti: Odgovornost zdravstvenih radnika i osiguranje od odgovornosti

otegotno to što u konkretnom slučaju sigurno nema vremena čekati na to utvrđenje nego kao prvo djelovati, a tek nakon toga čekati kako će to sud ocijeniti. ${ }^{50}$

U praksi je realno jednostavnije utvrđivanje pogreške kod invazivnih intervencija. Operacijski zahvati imaju najveće reperkusije na zdravlje čovjeka jer se praktički radi o agresivnoj metodi liječenja, operacijskom zahvatu. Za određene stručno tehničke pogreške za vrijeme operacijskih zahvata koji se provode u operativnim disciplinama kao što su kirurgija, ginekologija, kardiokirurgija, urologija i vaskularna kirurgija postoje sinonimi koje su uveli sami medicinari. Greškom treba označiti ozljedu organa ili tkivnih struktura, što nije spadalo u programirani zahvat (iako klinička iskustva pokazuju da do toga može doći). Naime, ako tijekom nekog invazivnog postupka dođe do ozljede struktura koje nisu bile cilj zahvata, ne može se zaključiti da je postupak ispravno izveden, bez obzira na okolnosti koje su tome doprinijele. Zapravo je riječ o jatrogenoj ozljedi, što međutim ni u kojem slučaju ne prejudicira da je riječ o liječničkoj odgovornosti. ${ }^{51}$ Pod njom podrazumijevamo nehotimičnu, akcidentalnu ozljedu stanovitog organa ili neku bilo koju štetnu radnju za vrijeme operacijskog zahvata čime nastaje posljedično štetni događaj (Iiatros grč. liječenje). ${ }^{52}$

Medicinske greške u hrvatskom zdravstvu događaju se u dijagnostici, terapiji, njezi, rehabilitaciji, administraciji i sl. One se najčešće u javnoj percepciji i sudskoj praksi nazivaju liječničkom pogreškom, što je kulturološki, a i empirijski uvjetovano. Jesu li medicinske, odnosno liječničke pogreške, pravni, stručno-medicinski, etičko-deontološki ili javni problem ili pak sve to skupa - otvoreno je pitanje. ${ }^{53}$ Pogreške možemo podijeliti na: dijagnostičke, terapijske, preventivne i druge. Dijagnostičke: Postavljanje pogrešne dijagnoze, odgoda postavljanja dijagnoze, propust u traženju potrebnih pretraga - testova, uporaba napuštenih metoda dijagnostike, propust zanemarivanja nalaza i uređaja za praćenje stanja. Terapijske: Pogreške u izvođenju kirurškog zahvata ili drugih postupaka liječenja, pogreške u davanju lijekova (davanje pogrešnog lijeka, davanje odgovarajućega lijeka, ali u pogrešnoj dozi), odgađanje primjene potrebne terapije, neprikladna briga tijekom liječenja. Preventivne: Propust poduzimanja preventivnih postupaka, neodgovarajući nadzor tijekom liječenja ili promatranja bolesnika. ${ }^{54}$

Medicinske greške koje nastaju u toku pružanja zdravstvene zaštite mogu se razvrstati u više skupina i prema raznim kriterijima: - greške koje nastaju činjenjem i greške koje nastaju propuštanjem, - grube ili teže i lakše, - pogreške prema stadijima medicinske intervencije - dijagnostičke, terapijske, profilaktičke, - opće, elementarne, u organizaciji rada, u informiranju itd.; - povreda prava na tjelesni integritet (liječenje bez pristanka pacijenta). ${ }^{55} \mathrm{U}$ slučaju kad su prikupljeni svi potrebni medicinski nalazi ali su pogrešno interpretirani (protumačeni), tada je riječ o grešci u dijagnozi u pravom smislu riječi. ${ }^{56}$ Ako pak potrebni nalazi nisu uopće prikupljeni ili nisu prikupljeni u dovoljnoj mjeri ili blagovremeno, pa zato bude postavljena neispravna ili zakašnjela dijagnoza, tada nije riječ o grešci u dijagnozi nego o grešci u prikupljanju nalaza. ${ }^{57}$ Napredovanjem medicinske znanosti i medicinske tehnologije, te korištenjem u dijagnostici suvremenih medicinskih uređaja s ciljem uspostavljanja konačne dijagnoze sve više je zastupljen, kao treći oblik, pogreške u medicinskoj dijagnostici. Pored navedenih pogrešaka u četvrtu i najzastupljeniju skupinu pogrešaka spadaju one koje nastaju tijekom kirurške intervencije 
(operativnog zahvata) kao neželjena posljedica prouzročena neuspjelom kirurškom intervencijom. Usto, prema kriteriju uzroka, liječničke pogreške su ili tehničke prirode ili se pak sastoje u nepoštivanju prava pacijenata (najčešće se to odnosi na povredu prava informiranog pristanka ili pak povredu liječničke tajne) ${ }^{58}$ Liječničke pogreške tehničke prirode u većini slučajeva odnose se na pogreške u dijagnozi i/ili na greške u terapiji ${ }^{59} \mathrm{U}$ većini slučajeva dijagnoza služi za određivanje terapije. Greške u dijagnozi mogu se pojaviti kao: netočna ili djelomična dijagnoza, propuštena dijagnoza i zakašnjela dijagnoza. Najčešći izvor pogrešaka u dijagnozi proizlazi iz nedovoljne ili neodgovarajuće anamneze, ${ }^{60}$ koja se smatra prvim i najvažnijim stadijem postupka postavljanja dijagnoze. ${ }^{61} \mathrm{~S}$ praktičnog stajališta važno je razlikovanje liječničke greške do koje dolazi prilikom invazivnih intervencija (operacije, pretrage i sl.) od drugih liječničkih postupaka. U praksi je jednostavnije utvrđivanje pogreške kod invazivnih intervencija. Naime, pogreškom valja označiti ozljedu organa ili tkivnih struktura, koja nije spadala u programirani zahvat (iako klinička iskustva pokazuju da do toga može doći). Ako tijekom invazivnog postupka dođe do ozljede struktura koje nisu bile cilj zahvata, ne može se zaključiti da je postupak ispravno izveden, bez obzira na okolnosti koje su tome doprinijele. Zapravo je riječ o jatrogenoj ${ }^{62}$ ozljedi, što međutim ni u kojem slučaju ne prejudicira da je riječ o liječničkoj odgovornosti. Mnogo je teže u praksi utvrditi grešku u ostalim postupcima liječenja (primjerice pri postavljanju dijagnoze, indikacije za operativni zahvat i sl.) zbog činjenice da postoji više načina pristupa medicinskim postupcima. U takvim situacijama kao polazište za utvrđivanje greške treba prilikom vještačenja uzeti u razmatranje okolnosti i činjenice pojedinog slučaja, je li liječnik postupao ispravno i u skladu s onim što je objektivno stanje bolesnika (ozlijeđenog) zahtijevalo. Pri tome valja ocjenjivati mogućnosti djelovanja svakog pojedinog liječnika opće medicine i specijalista odnosno postupka u općoj bolnici i klinici. ${ }^{63}$ Bitno je razlikovati stručnu pogrešku od komplikacije u postupku liječenja. ${ }^{64}$

\subsection{Komplikacija}

U pojmovnom "sukobu" liječnika (kliničara) i pravnika središnji je nesporazum oko tumačenja (shvaćanja) pojma (značenja) „komplikacije“, budući da pod komplikacijom liječnici podrazumijevaju različite oblike nastanka pogoršanja bolesnikova zdravlja pa i jatrogene ozljede. ${ }^{65}$ Medicinski gledano komplikacija je pojam koji znači nepredviđenu teškoću, neželjeni, često neočekivani razvoj i ishod oboljenja, točnije pogoršanje bolesti organizma ili organa koje je postalo još teža i složenije, a manifestira se različitim teškoćama tijekom liječenja kao novo oboljenje ili zatajivanje organskih sustava, pa na kraju može voditi i u smrt. ${ }^{66}$ Kao što je navedeno, liječničku grešku i komplikaciju kao stručni termin ne poznaje ni kazneno ni građansko pravo, iako se kolokvijalno ovi termini u praksi koriste. Problemi su u tome što pojmove medicinske greške i komplikacije liječnici i pravnici različito shvaćaju i tumače. Daljnji je problem što liječnici ne shvaćaju (ili ne prihvaćaju) da za utvrđivanje činjeničnog stanja u sudskom postupku prednost imaju pravne definicije odnosno pravna tumačenja zakonskih propisa. U pravnoj bi struci ovo odgovaralo sintagmi "sudbinski tijek bolesti", što znači da do neželjene posljedice (štete) za bolesnika nije došlo zbog liječničke greške. ${ }^{67} \mathrm{U}$ kliničkoj se praksi vrlo često greške nastale u tijeku liječenja nazivaju komplikacijama zbog čega dolazi do razilaženja u mišljenju izmjenu kliničara i forenzičara. ${ }^{68}$ Iskustva s rada Odbora za sudbena mišljenja 
Prava, obveze i odgovornosti radnika u obavljanju djelatnosti: Odgovornost zdravstvenih radnika i osiguranje od odgovornosti

pokazuju da se s kliničkog stanovišta greška uglavnom shvaća kao sinonim za vitium artis, što apriori znači liječničku odgovornost, prvenstveno kaznenu. Suprotno tome, sa sudskomedicinskog stanovišta greškom se označava samo činjenica da medicinski postupak (zahvat) nije do kraja ispravno obavljen, bez obzira zbog čega je do toga došlo i bez prejudiciranja odgovornosti. Jedan od bitnih razloga ovako različitog shvaćanja pojma liječničke greške vrlo se vjerojatno nalazi u edukaciji liječnika, koja se najvećim dijelom oslanja na englesko i njemačko govorno područje. U SAD, SRNj i većini zemalja zakonodavstva ne predviđaju kaznenu odgovornost za medicinske greške za razliku od hrvatskog Kaznenog zakona (Nesavjesno liječenje), već se problem rješava isključivo u civilnim parnicama za naknadu štete. ${ }^{69}$ Iznimno složeno je pitanje kako činjenično utvrditi je li nepovoljan tijek i rezultat liječenja posljedica pacijentove zlosretne sudbine ili liječničke greške koja je naškodila pacijentovu zdravlju. Za utvrđivanje liječničke odgovornosti osnovni je problem odrediti je li neželjeni ishod liječenja (šteta) posljedica komplikacije ili učinjene greške. Problem je već u navedenoj premisi budući da nema definicije medicinske greške koja bi bila općeprihvaćena. ${ }^{70}$

U medicinskim krugovima, osim pojma liječničke greške, rabi se pojam komplikacije u funkciji negacije liječničke greške. Pojam komplikacija najčešće koriste oni koji se brane od optužbe da su počinili liječnički grešku, pošto se za komplikaciju ne odgovara ni građanskopravno ni kazneno. Razumljivo, jer se za komplikaciju ne odgovara, ni kaznenopravno ni građanskopravno. Kao instrument objektivne analize između ta dva suprotna navoda, odnosno interesa, može poslužiti jedino dobra distinkcija tih dvaju pojmova. Kako medicinsko pravo ne poznaje pojam „komplikacija“, u građanskom pravu koristi se pojmovima viša sila i slučaj, kao razlozima za isključenje odštetne odgovornosti, uz napomenu da se za slučaj ne odgovara samo onda kad se primjenjuju pravila subjektivne odštetne odgovornosti. Slučajem se naziva događaj koji se ne može nikome pripisati u krivnju, premda bi se mogao izbjeći da se mogao predvidjeti. U medicini se njime označava odsutnost liječničke greške i kauzaliteta. Postoji u posebno nepovoljnom stjecanju okolnosti, osobito bolesnikova organizma, npr. alergija na određeni lijek, smrt nakon narkoze dane prema svim zahtjevima anesteziologije. Upravo takva slučajna šteta mogla bi odgovarati onome što se u kolokvijalnom žargonu naziva "komplikacijom". Da bi se utvrdilo je li doista nastupio slučaj, odnosno "komplikacija", u praksi će biti potrebno utvrditi nije li do "komplikacije" došlo nakon što je prethodno učinjena neka liječnička greška, npr. ako je u tijelu zaostao neki predmet (instrument, gaza) ili je nepažnjom presječena krvna žila, živac i sl. ili pak rana nije dovoljno dobro obrana, itd. ${ }^{71} \mathrm{U}$ tim slučajevima rizik pada na pacijenta prema načelu casus sentit dominus. Upravo takva slučajna šteta mogla bi odgovarati onome što se u kolokvijalnom žargonu naziva komplikacija. ${ }^{72}$ Riječ je, dakle, o situaciji kad korisnik zdravstvene usluge (pacijent) trpi neželjene posljedice za svoje zdravlje, koje nisu nastale zbog povrede pravila i metoda odnosno standarda rada zdravstvene struke i/ili znanstvenih saznanja liječnika, tj. nije riječ o liječničkoj pogrešci odnosno pogrešci drugih zdravstvenih radnika, već o neizbježnom životnom tijeku događaja. Za dio tih rizika koji ne prelazi uobičajene granice, tj. za određene tegobe koje korisnik zdravstvene usluge trpi nakon liječničkog zahvata, ne postoji odštetna odgovornost liječnika. Primjer za to su tegobe koje pacijent ima određeno vrijeme nakon kirurškog operativnog zahvata ili bolničke infekcije koje se u primjerenom roku saniraju. Riječ je naprosto o riziku koji sa sobom 
nosi svaki medicinski zahvat. Kad je riječ o događaju koji se ne može dovesti u uzročnu vezu s pogreškom u liječenju, ta bi medicinska komplikacija pravno bila slučaj (casus). Slučaj je takav događaj koji bismo, da smo ga predvidjeli, mogli spriječiti, naspram više sile gdje je riječ o događaju koji, da smo ga i predvidjeli, ne bismo mogli spriječiti. Prema tome, slučaj je takav događaj za koji štetnik čija se odgovornost temelji na načelu krivnje, tj. subjektivne odgovornosti, neće odgovarati. Međutim, osoba koja odgovara za štetu prema načelu objektivne odgovornosti odgovara i za slučajno nastale štete. ${ }^{73}$ Iznimno složeno je pitanje kako činjenično utvrditi je li nepovoljan tijek i rezultat liječenja posljedica pacijentove zlosretne sudbine ili liječničke greške koja je naškodila pacijentovu zdravlju. Do nepovoljnog ishoda liječničke odnosno zdravstvene intervencije može, naime, doći i zbog komplikacije koja se dogodila u postupku liječenja. Komplikacija predstavlja neželjeni rezultat medicinskog postupka koji nastaje unatoč medicinski ispravnom i pravodobno izvedenom postupku, koji je izveden pravilnom uporabom ispravne opreme i sredstava (lijekova, kemijskih tvari i slično), uz optimalnu organizaciju rada. ${ }^{74}$ Nepovoljni ili jatrogeni događaji su događaji u kojima dolazi do nenamjerne i nepoželjne štete za bolesnika (ozljeda ili komplikacija) liječenjem (u 5 $10 \%$ bolnički liječenih). Nepovoljni događaji (engl. adverse evants) su: bolničke infekcije; zaraze kirurških rana; postoperativne plućne embolije; pogreške u primjeni lijekova (3,5\% u Španjolskoj u Velikoj Britaniji, 3,7\% u SAD, 6,5\% u Francuskoj); anesteziološki događaji; pojava dekubitusa. Treba ih razlikovati od komplikacija koje mogu nastati tijekom ispravne primjene liječenja jer su posljedica pogreški. Ovakvi događaji se nazivaju i stražarski (engl. sentinel events) jer kad se pojave tad kao čuvari upozoravaju da nešto nije u redu. ${ }^{75}$

Komplikacija nastaje usprkos medicinski ispravnom i pravodobno provedenom postupku, koji je izveden pravilnom uporabom ispravne opreme i sredstava, uz optimalnu organizaciju rada. ${ }^{76}$ Naime, negativni ishod liječenja u pojedinim slučajevima može se pojaviti i nezavisno od stručne liječničke pogreške, primjerice kao posljedica državnih mjera kojima je cilj smanjivanje troškova liječenja, uštede na lijekovima i medicinskoj opremi, javne nabave koja može prolongirati nužne dijagnostičke procedure i prouzročiti privremeni nedostatak medicinskih sredstava i opreme, neodgovarajućih uvjeta rada zbog smanjenja broja liječnika ili pomoćnog zdravstvenog osoblja i sl. ${ }^{77}$ Prilikom pružanja zdravstvene zaštite i ocjene njezine kvalitete treba uzeti u obzir mjesto, vrijeme, opremljenost i ekipiranost ekipe koja vrši terapijski zahvat. Svaki zahvat u sebi nosi rizik, što je cijena poziva liječničke struke. Niti optimalan terapijski zahvat unaprijed ne jamči pozitivan ishod liječenja - potpuno ozdravljenje. ${ }^{78} \mathrm{U}$ skladu s time za praktičnu primjenu vještačenja komplikacija predstavlja: (a) daljnji razvoj bolesti usprkos ispravnom medicinskom postupku i (b) proširenje patoloških stanja na druge organe ili sustave. ${ }^{79}$ Kad komplikacije prijeđu granice prihvatljivog, uobičajenog rizika, nastaje odgovornost pružatelja zdravstvene usluge, za koju smatramo da ulazi u sferu odgovornosti prema načelima objektivne odgovornosti. ${ }^{80}$

U slučajevima neželjenog ishoda liječenja odnosno nastanka za bolesnika štetnih posljedica, sa sudskomedicinskog stanovišta postoje sljedeće mogućnosti: a/ Kada je neželjeni ishod liječenja posljedica komplikacije bolesti (tzv. sudbinski tijek bolesti), ne postoji odgovornost liječnika a ni bolesnik nema pravo na naknadu štete. Treba naglasiti 
da svaki postupak liječnika od dijagnostičkog preko svih oblika liječenja (konzervativnog i invazivnog) nosi u sebi određeni rizik. Ukoliko zbog postojećeg rizika dođe do štetne posljedice (bez učinjene greške liječnika), i ovo stanje treba shvatiti kao komplikaciju; b/ Kada je štetna posljedica rezultat medicinske greške, za koju ne postoji kaznena odgovornost počinitelja, treba razlikovati dvije odgovornosti u nastanku greške: a) greška je posljedica nekih posebnih okolnosti u tijeku medicinskog tretmana na koje liječnik nije mogao utjecati, zbog čega nema ni njegove odgovornosti, pa bolesnik ne može realizirati pravo na naknadu štete, b) ukoliko za nastalu štetu odgovornost snosi liječnik (bez kaznene odgovornosti), bolesnik ima pravo na naknadu štete; c/ Medicinska je greška posljedica očito nesavjesnog postupka zbog čega postoji kaznena odgovornost počinitelja i bolesnik također ima pravo na naknadu štete. ${ }^{81}$

\subsection{Defanzivna medicina}

Često suočeni s ovakvim stanjem liječnici u većini razvijenih zemalja, a dijelom i kod nas počinju u svojoj rutinskoj praksi koristiti tzv. „defenzivnu medicinu“. Suočeni s mogućnošću da i pored dužne pažnje u profesionalnom radu pogriješe, posebno kad se zakonskim propisima odgovornosti liječnika pretpostavlja i kad ne postoje protokoli liječenja, liječnici spontani i samoinicijativno izlaz iz takve situacije traže u tzv. defanzivnoj medicini. Riječ je o svojevrsnom obrambenom mehanizmu kojeg provode liječnici u svakodnevnoj praksi, a sastoji se u provođenju postupaka koji su sa stanovišta struke „suvišni““ i odgađaju konačnu terapiju ali bez posljedica po zdravlje pacijenta, propisuju se često nepotrebni lijekovi, dolazi do povećanih troškova liječenja koji pogađaju fondove zdravstvenog osiguranja $\mathrm{i} / \mathrm{ili}$ same pacijente. Često se radi o provođenju dodatnih i nepotrebnih testova ili složenih dijagnostičkih pretraga (overtreatment and overdiagnosis), kao i izbjegavanju rizičnih zahvata na pacijentima, a sve zbog straha od moguće liječničke pogreške i posljedične tužbe od strane pacijenta. Dakle, $\mathrm{s}$ jedne strane defanzivna medicina se manifestira kao poduzimanje nepotrebnih mjera i usluga, a, s druge strane, kao odbijanje, izbjegavanje ili odgađanje poduzimanja rizičnih procedura ili zahvata koji su inače indicirani u takvom slučaju. ${ }^{82}$ Ovakvim postupkom liječnici se na neki način ,podsvjesno brane“ od moguće odgovornosti za liječničku pogrešku. Defenzivna medicina je prvenstveno našla primjenu u državama u kojima ne postoji ,,no fault insurance, , model osiguranja od liječničke odgovornosti, što praktički znači u većini zemalja. ${ }^{83}$

\subsection{Uzroci nastanka liječničkih pogrešaka}

Uzroci liječničkih pogrešaka mogu se podijeliti u tri skupine: neznanje, nemar i korist. Pri tome neznanje predstavlja vrlo česti uzrok liječničke pogreške iz više razloga. Medicinska znanost se sve brže razvija i sigurno je da studiji medicine ne omogućuju detaljno teorijsko poznavanje medicinske struke u cijelosti, a pogotovo ne i praktične vještine koje bi liječnik trebao naučiti prije početka rada. Nemar je također vrlo česti uzrok pogreške, odnosno propusta u liječničkoj praksi. Pomanjkanje vremena za rad s bolesnicima može rezultirati površnošću i zanemarivanjem često osnovnih dijelova pregleda bolesnika. Ne smije se zanemariti ni one pogreške i propuste koji su vezani uz bilo kakvu korist za liječnika. Primjerice, sve je veći pritisak brojnih tvrtki na liječnike 
da u svojoj praksi prihvate njihovu skupu opremu i lijekove, što može liječniku donijeti višestruku korist a štetu bolesnicima. Znanstvena istraživanja također sve češće privlače pažnju onih liječnika koji u njima vide mogućnost neke koristi za sebe, a ne samo za bolesnika. ${ }^{84}$ Smatra se da je $2 / 3$ medicinskih propusta u bolnicama uzrokovano neprimjerenom uporabom lijekova. Radi se o davanju krivoga lijeka ili davanju ispravnoga lijeka, ali u pogrešnoj dozi. Pogreške, usto, najčešće nastaju zbog neznanja, nedovoljnog iskustva, opakoga shvaćanja bolesnika, neočekivanih nesretnih okolnosti, očitim nemarom, zbog loše organizacije rada (nepostojanja protokola rada), loše medicinsko-tehničke opremljenosti, loše edukacije i slabe radne discipline. Uzorci su i neispravna oprema, loša komunikacija s bolesnikom, loša komunikacija unutar zdravstvenoga tima ili unutar bolnice, nečitak rukopis kao uzrok pogreške. Najčešće nastaju u jedinicama hitnog prijma, jedinicama intenzivne skrbi, operacijskim dvoranama itd..$^{85}$

\subsection{Vrste građanske odgovornosti zdravstvenih radnika}

Liječničku pogrešku u radu prate četiri vrste odgovornosti, i to: disciplinska odgovornost (na disciplinsku odgovornost, liječnika pozivaju stručne udruge, konkretno tijela Hrvatske liječničke komore, pri čemu je najteža sankcija oduzimanje licencije za obavljanje samostalnog rada); građanska odgovornost (obično traži naknadu štete pri individualnim pogreškama koje su dovele do povrede pacijenata); prekršajna odgovornost (podrazumijeva novčanu kaznu za manje povrede) i kaznena odgovornost (koja se odnosi na zaštitu šireg društvenog interesa). ${ }^{86}$

Osim povrede pravila medicinske struke (liječničke greške), moguće je prilikom obavljanja medicinske djelatnosti počiniti još neke štetne radnje ${ }^{87}$, a to su: a/ povreda prava na tjelesni integritet (liječenje bez pristanka pacijenta), ${ }^{88} \mathrm{~b} /$ povreda obveze pružanja hitne medicinske pomoći ${ }^{89} \mathrm{i}$ c/ povreda obveze sklapanja ugovora o zdravstvenoj usluzi. ${ }^{90}$

Pitanje odgovornosti onih koji pružaju medicinske usluge je vrlo aktualno i složeno, slobodno možemo kazati kako se radi o jednoj od najznačajnijih tema medicinskog prava po kojoj ga mnogi i prepoznaju, a ako se radi o građanskopravnoj odgovornosti, slobodno bi se moglo kazati kako je to svakako temeljna i najvažnija vrsta odgovornosti zdravstvenih radnika. Građanskopravna odgovornost ne isključuje postojanje i drugih oblika odgovornosti zdravstvenih radnika kao što je kaznenopravna odgovornost. ${ }^{91}$ Građanskopravna odgovornost šira je kaznenopravne, prvenstveno zbog toga jer se građanskopravno može odgovarati i bez krivnje i što se najblaži oblik krivnje predmijeva i ne treba ga dokazivati, a temeljni uvjet kaznenopravne odgovornosti je postojanje namjere ili umišljaja ili barem nepažnje ili nehaja kod počinitelja i taj element protivna strana treba dokazati. Moguće je da zdravstveni radnik bude kazneno odgovoran, ali ne i građanskopravno (npr. zato jer nema štete, a šteta je jedan od uvjeta građanskopravne odgovornosti za štetu), ili da je građanskopravno odgovoran, ali ne i kaznenopravno (npr. zato jer se to djelo može učiniti samo umišljajno, ne i iz nehaja). Važno je i naglasiti kako je u građanskoj parnici građanski sud vezan pravomoćnom presudom kaznenog suda, ali samo onom kojom je optuženik oglašen krivim. ${ }^{92}$ 
Prava, obveze i odgovornosti radnika u obavljanju djelatnosti: Odgovornost zdravstvenih radnika i osiguranje od odgovornosti

Unutar područja građanskopravne odgovornosti zdravstvenih radnika razlikuje se posebno odgovornost liječnika od odgovornosti drugih sudionika na strani davatelja zdravstvene usluge (od onih koji vrše prijevoz, pa sve do onih koji skrbe o higijeni, piću i hrani). Koliko je pri tome liječnička odgovornost u prvom planu jasno pokazuje činjenica da postoji pojam liječnička greška, koji u praksi postao tehnički termin za označavanje greški svih zdravstvenih radnika (sestara, medicinskih tehničara, primalja, inženjera radiologije, laboranata i sl.). ${ }^{93}$ Svaka liječnička pogreška nema za posljedicu građanskopravnu odgovornost za nastanak štete. Da bi postojala odgovornost medicinskog osoblja za štetu počinjenu medicinskom greškom, potrebno je da se ispune i određeni uvjeti - postojanje liječničke pogreške, postojanje štete, uzročna veza između učinjene liječničke pogreške i nastale štete (uzročno - posljedična veza, tzv. Kauzalni neksus), krivnja liječnika za počinjenu štetu, te na kraju odgovornost istog za počinjenu štetu. Odgovornost zdravstvenih radnika za počinjenu štetu postoji ako je pogreška prilikom liječenja nastupila zbog nestručnog, nepažljivog i nepropisnog rada zdravstvenog osoblja. ${ }^{94} 95$ Odgovornost liječnika za štetu počinjenu pacijentu zbog liječničke pogreške uvijek se temelji na krivnji. ${ }^{96}$ Općenito gledano, liječnik odgovara samo u slučaju kad je njegova medicinska intervencija bila pogrešna i kad je kriv zbog toga, a ovo načelo postojanja krivnje važi za sve pripadnike tzv. slobodnih profesija: liječnike, odvjetnike, arhitekata, inženjere i slično. ${ }^{97}$ Ako pacijent zahtijeva da mu liječnik ili zdravstvena ustanova naknadi štetu zbog pogrešnog liječenja, on mora uvjerljivo dokazati da je takvo liječenje uzrok njegove primarne štete. ${ }^{98}$ Odgovornost zdravstvene ustanove je subjektivne prirode, i po tom pravnom pravilu zdravstvena ustanova odgovorna je za pričinjenu štetu pacijentu, ako liječnici i drugo medicinsko osoblje te ustanove prilikom medicinskog liječenja nisu postupili u skladu s pravilima medicinske znanosti kao i s odgovarajućom pažnjom pa zbog takvih propusta ili pogrešnih postupanja nastane šteta kod pacijenta. ${ }^{99}$ Navedeno zakonsko rješenje upućuje na jasan zaključak da zdravstvena ustanova kao i zdravstveno osoblje, s jedne strane, kao i pacijent, s druge strane, imaju interes da se pitanje odgovornosti za počinjenu štetu zbog nastanka medicinske pogreške uredi na način koji je odgovarajući i prihvatljiv kako za zdravstvenu ustanovu tako i njezino osoblje, te, s druge strane, da je i pacijent navedenim rješenjem pravično zaštićen kao osoba koja je pretrpjela štetu. Kao prihvatljiv način uređenja odnosa između zdravstvenih ustanova i pacijenta u slučaju nastupanja štetnih posljedica za pacijenta prouzročenih pogreškom u liječenju, jest osiguranje od odgovornosti zdravstvenih ustanova za štetu počinjenu medicinskom pogreškom. ${ }^{100}$

Pružanje zdravstvene zaštite kroz obavljanje zdravstvene djelatnosti može rezultirati neželjenim posljedicama koje se manifestiraju kao određene štete koje pogađaju ili direktno samoga pacijenta ili članove njegove obitelji. ${ }^{101}$ Obzirom da je osnovna svrha odštetnog prava definiranje načina i uvjeta popravljanja odnosno naknađivanja štete od strane štetnika ili druge odgovorne osobe, tako i za štete koje nastanu kao posljedica obavljanja zdravstvene djelatnosti netko mora odgovarati $\mathrm{i}$ to primjenom pravila odgovornosti za štetu. ${ }^{102}$ Svaka je šteta pa tako i neimovinska, predstavlja neugodan događaj, ali se naknadom štete taj neugodan događaj pokušava ublažiti. ${ }^{103}$ Učestali slučajevi teškog stradavanja pacijenata za vrijeme liječenja i, s tim u vezi, odštetni zahtjevi usmjereni protiv zdravstvenih ustanova i samih liječnika, i u Republici Hrvatskoj 
pokrenuli su pitanje rješavanja problema naknade štete žrtvama liječničke greške ili, pak, medicinske nezgode. ${ }^{104}$

Cilj naknade nematerijalne štete je da oštećeni dosuđenom naknadom sebi omogući određeno zadovoljstvo kojim će ublažiti pretrpljeni tjelesni ili duševni gubitak i na taj način uspostaviti poremećenu psihičku ravnotežu. ${ }^{105}$

Liječnik je dužan postupati lege artis (prema pravilima struke), primjenjivati stručna znanja i opće priznata medicinska dostignuća. Postupajući protivno pravilima struke (contraa legem artis) on čini liječničku grešku. Povrede pravila zdravstvene struke (liječničke, stomatološke, ljekarničke itd.) najčešće su štetne radnje na kojima se temelji odgovornost zdravstvenih radnika. No, navedene povrede odnosno greške ipak same po sebi nisu dovoljne da bi prouzročile odgovornosti za štetu, a što proizlazi upravo iz pretpostavaka nastajanja odnosa odgovornosti za štetu. Naime, opće pretpostavke odgovornosti za štetu koje se moraju kumulativno ispuniti da bi se šteta nadoknadila su slijedeće: postojanje subjekata obveznog odnosa odgovornosti za štetu i to štetnika (odgovoran za štetu) i oštećenika (zahtjeva odštetu), štetna radnja štetnika, šteta koja nastaje na strani oštećenika, uzročna veza (kauzalni neksus) između štetne radnje i štete, protupravnost štetne radnje. ${ }^{106}$

Odštetna odgovornost zdravstvenih radnika determinirana je veličinom rizika koji nosi ta profesija, jer je liječnička djelatnost, unatoč temeljnom humanom i plemenitom cilju da se pacijentu očuva ili popravi zdravstveno stanje, ponekad neizbježno povezana s rizikom gubitka života ili pogoršanja zdravlja. ${ }^{107}$ Prilikom utvrđivanja postojanja greške, treba uvijek imati na umu da svaka intervencija koja se poduzima prilikom obavljanja zdravstvene djelatnosti sadrži u sebi određeni stupanj rizika. U većini medicinskih intervencija potencijalno je sadržan i rizik štetnog djelovanja na zdravstveno stanje pacijenta. Zbog toga je indiciranje svake terapije povezano s odmjeravanjem očekivane koristi od nekog terapijskog postupka u odnosu na moguću štetu koju taj isti postupak može donijeti pacijentu. Pri tom se kao osnovno etičko pravilo ističe postulat primum non nocere koji određuje idealnu normu ponašanja liječnika od koje se u praksi ipak najčešće odstupa. U mnogim terapijskim postupcima svjesno prihvaćamo štetne posljedice jer je na drugoj strani mogućnost znatnog poboljšanja zdravstvenog stanja, ponekad i spašavanje života pacijenta (kao npr. U nekim rizičnim operativnim zahvatima, u ordiniranju citostatika, u radio-terapiji i dr.). ${ }^{108}$ Stoga, u slučajevima nastanka štete uslijed poduzimanja takvih intervencija, mora se jasno razdvojiti da li je do štete došlo neželjenim ishodom pojedinog postupka ili je do štete došlo greškom pružatelja zdravstvenih usluga. No greške zdravstvenih radnika mogu se smatrati protupravnima samo kada su nastale kao rezultat postupanja koje nije bilo u skladu s pravilima struke ili ako je do njih došlo jer zdravstveni radnik nije postupao s dužnom pažnjom.

Za štete koje su pacijentima prouzročene u obavljanju zdravstvene djelatnosti odgovara se u skladu s tzv. općim pravilima o odgovornosti za štetu, što u našem pravu znači u skladu s pravilima Zakona o obveznim odnosima. ${ }^{109}$ Odgovornost za štete prilikom obavljanja zdravstvene djelatnosti podrazumijeva u pravilu izvan ugovornu odgovornost. Temeljem iste svaka treća osoba, prema tome i pacijent ima pravo na naknadu štete 
Prava, obveze i odgovornosti radnika u obavljanju djelatnosti: Odgovornost zdravstvenih radnika i osiguranje od odgovornosti

ukoliko do iste dođe, te ukoliko se dokaže da je šteta i nastala istom radnjom zdravstvenog radnika. Olakotna okolnost zdravstvenom radniku koji je počinio štetu može biti da naš pravni sustav poznaje dužnost poslodavca naknaditi štetu ukoliko je ista počinjena prilikom obavljanja rada i u svezi s radom. Oštećenik dakle i pacijent može izravno tražiti naknadu štete od zdravstvenog radnika samo ukoliko je zdravstveni radnik postupao $\mathrm{s}$ namjerom ili iz krajnje nepažnje. ${ }^{110}$

Praksa Republike Hrvatske pokazala je da se u većini slučajeva nastanka štete prilikom pružanja zdravstvenih usluga, najčešće na strani tuženih nalaze zdravstvene ustanove. Naime, oštećeniku je povoljnije tužiti zdravstvenu ustanovu koja je često i osigurana od slučaja nastanka štete, nego pojedinačnog zdravstvenog radnika koji je, kao zaposlenik zdravstvene ustanove, u konkretnom slučaju pružao zdravstvenu uslugu. Međutim, osim gore navedene mogućnosti potraživanja naknade štete od zdravstvene ustanove kao poslodavca štetnika, oštećenik ima pravo zahtijevati naknadu štete odnosno pokrenuti postupak naknade štete i neposredno protiv zdravstvenog radnika, ali samo ako je radnik takvu štetu uzrokovao namjerno što se tada mora i dokazati. ${ }^{111} \mathrm{Za}$ štetu koju radnik zdravstveni radnik u radu ili u vezi s radom prouzroči trećoj osobi odgovara poslodavac (primjerice bolnica) kod kojeg je radnik radio u trenutku prouzročenja štete, osim ako dokaže da su postojali razlozi koji isključuju odgovornost zaposlenika (čl. 1061. st. 1. ZOO-a). Poslodavac će za štetu odgovarati trećima i za druge svoje radnike, tj. one koji nisu zdravstveni radnici (primjerice administrativno i tehničko osoblje i vozači). ${ }^{112}$

Pravo na naknadu štete ne može se unaprijed isključiti ili ograničiti. Liječnik odnosno osoba koja odgovara za štetu, primjerice liječnikov poslodavac, neće odgovarati za štetu: ako se utvrdi da nema uzročne veze (kauzalnog neksusa) između liječnikova postupka i nastale štete; ako se utvrdi da je šteta nastala bez liječnikove krivnje (čl. 1045. st. 1. ZOOa odnosno čl. 154. st. 1. ZOO/91) odnosno da je riječ o slučaju (casus) koji se u medicinskoj frazeologiji označuje kao komplikacija; ako se utvrdi da je šteta nastala 1. višom silom (vis maior), 2. radnjom oštećenika ili 3. radnjom treće osobe, u slučaju kad se odgovornost ocjenjuje prema načelu objektivne odgovornosti (kauzaliteta) (čl. 106. ZOO-a, odnosno čl. 177. ZOO/91.).

Na građanskopravnu odgovornost liječnika primjenjuju se opće odredbe o odgovornosti propisane Zakonom o obveznim odnosima, koji određuje da je sudionik u obveznom odnosu u izvršavanju obveze iz svoje profesionalne djelatnosti dužan postupati s povećanom pažnjom, prema pravilima struke i običajima (pažnja dobrog stručnjaka), što znači da je i liječnik dužan postupati s povećanom pažnjom. Liječnikova odgovornost se, dakle, u našem pravu prosuđuje prema pravilima subjektivne presumirane odgovornosti. ${ }^{113}$

Liječnici odgovaraju osobno za vlastito ponašanje prema kriteriju kompetencija odnosno poslova koje proizlaze iz obrazovanja, ovlaštenja i obveza prema licenci. Liječnik može obavljati svoje zvanje samo u okviru svoje izobrazbe određene odobrenjem za samostalan rad. Tako, liječnik sa specijalizacijom, odnosno užom specijalizacijom, može obavljati samostalan rad za područje specijalnosti ili uže specijalnosti za koju je stručno osposobljen dok liječnik s položenim stručnim ispitom i liječnik na specijalizaciji mogu 
obavljati samostalan rad u području opće medicine. ${ }^{114}$ Odobrenje za samostalan rad je dokument koji u sadržajnom smislu istovremeno jasno propisuje liječniku za koje je poslove ovlašten, ali i koje je dužan obavljati. Dakle, svaki liječnik zna svoju ulogu i poslove koje je dužan samostalno obavljati. Individualna odgovornost za vlastiti čin ili propust danas je općeprihvaćena te svaki liječnik i/ili specijalista snosi odgovornost sam za sve zadatke koji su mu povjereni da ih obavlja samostalno na temelju obrazovanja ili funkcije. ${ }^{115}$ Međutim, kod tzv. vlastite odgovornosti liječnika mogu se pojaviti problemi odgovornosti za sredstva liječenja odnosno za instrumente i lijekove (product liability) te odgovornosti za postupke drugih osoba, u pravilu članova medicinskog tima (vicarious liability). ${ }^{116}$

Liječnička pogreška sama po sebi nije dovoljna da bi liječnik odgovarao. I građanska i kaznena odgovornost liječnika uvjetovane su štetom, koju zbog greške trpi pacijent ili netko treći. Šteta uvjetovana liječničkom pogreškom može biti materijalna i nematerijalna. Materijalna šteta se sastoji, najčešće, od troškova liječenja, putnih troškova i gubitka zarada za vrijeme spriječenosti za rad. Nematerijalnu šteta pojavljuje se najčešće u obliku fizičkih i duševnih bolova zbog umanjenja životnih aktivnosti i naruženosti. ${ }^{117}$ Pri svemu tome pacijent odnosno treća osoba ima pravo na naknadu cjelokupne štete i na naknadu izgubljene koristi kao i na naknadu imovinske i neimovinske štete ${ }^{118}$. Kao što je vidljivo u postupcima i odnosima pružanja zdravstvene zaštite primjenjiva su sva pravila odštetnog prava, pa možemo kazati da ni zdravstvo ni medicina nisu lišeni kompleksnosti procedura zahtjeva za naknadom šteta i načela građanske odgovornosti. Štoviše, svjedoci smo situacija da je sve veći broj postupaka koji se vode pred sudovima upravo u predmetima naknade šteta u obavljanju zdravstvenih djelatnosti.

Svakako je zanimljivo osvrnuti se i na odgovornost za štete koje je pacijent mogao doživjeti zbog određenih doživljenih nelagodnosti tijekom medicinskog tretmana. Naime, fizičke boli ne izazivaju samo ozljede tijela i oštećenje zdravlja, nego im uzrok mogu biti i razne nelagodnosti koje se mogu javiti tijekom liječenja, a ako su te nelagodnosti u uzročnoj vezi sa štetnim događajem, mogu utjecati na odmjeravanje novčane naknade za pretrpljene fizičke boli. U tom smislu i sudska praksa je zauzela pravni stav da nelagodnosti u toku liječenja (npr., kraće nesvjestice, hospitalizacija, vezanost na krevet, razne vrste imobilizacija, fiksacija, rendgensko snimanje, operacije, infuzije, transfuzije, injekcije, previjanje rana, odstranjivanje šavova, upotreba invalidskih kolica, bolovanje, posjećivanje ambulante, fizioterapija itd.) koje trpi oštećeni, razmatraju se u okviru naknade za fizičke bolove. ${ }^{119}$ Dakle, nelagodnosti tijekom liječenja uzimaju se u obzir kao važna okolnost odmjeravanja pravične novčane naknade za pretrpljene fizičke boli ako su vezane uz intenzivnije fizičke boli određenog trajanja. ${ }^{120}$

Kao oštećenik u pravilu se javlja pacijent, tj. osoba koja je zaključila ugovor o pružanju medicinske usluge, ili pak ona koja je bila podvrgnuta medicinskom tretmanu bez izričito ili prešutno zaključenog ugovora. Pod pojmom pacijenta kao oštećenika podrazumijeva se i osoba koja je pretrpjela štetu stoga što joj je medicinska usluga bila uskraćena, iako je postojala pravna obveza da se usluga pruži, a šteta je rezultat takvog propusta. Kao oštećenici mogu se pojaviti i druge osobe, osim pacijenta. Radi se o osobama koje su zbog propusta medicinskog djelatnika u izvršavanju njegovih ugovornih ili zakonskih obveza 
Prava, obveze i odgovornosti radnika u obavljanju djelatnosti: Odgovornost zdravstvenih radnika i osiguranje od odgovornosti

prema pacijentu ili zbog nepravilnog odnosa prema pacijentu i stanju njegovog zdravlja, pretrpjeli štetu na svojim pravno zaštićenim dobrima. U odnosu na treće osobe, odgovornost medicinskih djelatnika uvijek je isključivo deliktna, budući da nema ugovornog odnosa s oštećenikom. U suvremenoj praksi očita je tendencija proširenja odgovornosti pripadnika medicinske struke prema sve većem krugu trećih osoba. U nekim slučajevima postoji odgovornost prema trećima iako pacijentova dobra nisu oštećena propustom liječnika. Pravni temelj ove odgovornosti prema trećima nalazi se u tome što tretirajući pacijenta medicinski djelatnik (ustanova) mora pokazati određeni stupanj pažnje ne samo prema interesima pacijenta nego i prema interesima trećih koji mogu biti povrijeđeni zbog njegovih propusta koji mogu, ali i ne moraju dovesti do štete za pacijenta. ${ }^{121}$

U Republici Hrvatskoj pacijent mora dokazati uzročnu vezu između radnje ili propusta liječnika te štetne posljedice, uz jednu iznimku - šteta nastala u svezi s opasnom stvari, odnosno opasnom djelatnošću smatra se da potječe od te stvari, odnosno djelatnosti, osim ako se dokaže da one nisu bile uzrok štete (oboriva presumpcija) (Vidi čl. 1063. ZOO-a). U slučaju nastale štetne posljedice u tijeku liječenja nema odgovornosti liječnika ukoliko se ne utvrdi uzročna veza između nastale štetne posljedice i postupka liječnika. Uzročnu vezu utvrđuje sud uz pomoć mišljenja vještaka medicinske struke, sudske prakse te pravnih teorija o kauzalitetu. Kako šteta uobičajno nastupa kao posljedica više uzroka, nužno je u okolnostima svakog slučaja cijeniti onaj uzrok koji je pravno relevantan, a pri utvrđivanju uzroka nepovoljnog stanja zdravlja pacijenta to je vrlo složeno i neizvjesno. Drugim riječima, dokaz o uzročnoj vezi u medicini, u nekim je slučajevima, izrazito težak. ${ }^{122}$ Stoga, bitnim za problematiku uzročne veze između liječničke greške i štete za zdravlje pacijenta ukazuju se teret dokazivanja, mjerilo dokaza, prekid uzročnosti i dr. O mjerilu dokaza riječ je kada se raspravlja o stupnju vjerojatnosti koji mora postojati da bi se smatralo da je uzročnost dokazana. U tom pogledu postoje različiti tzv. civilni standardi za dokaz, od pretežne vjerojatnosti te visoke vjerojatnosti ${ }^{123}$ ili vjerojatnosti na granici sigurnosti ${ }^{124}$ dok se u pogledu odabira uzroka koriste pravne teorije ekvivalencije i adekvatnosti. ${ }^{125}$ Nerijetko se i najhitnijim i naj odgovarajućim načinom liječenja štetna posljedica ne može izbjeći, pa ni smrtni ishod za bolesnika. Ovakvi se slučajevi opisuju kao "sudbinski tijek bolesti", jer se krivnja za nastalu štetu ne može nikome pripisati. S pravnog gledišta (ali i sudskomedicinskog) pri utvrđivanju uzročne veze riječ je "ustvari o razgraničenju komplikacija svojstvenih bolesti ili samog liječenja od liječničkih grešaka i njihovih posljedica". ${ }^{26}$ Uzročna veza se ne dokazuje već se predmnijeva kod šteta koje su nastale u svezi sa opasnom stvari ili opasnom djelatnošću. ${ }^{127}$ Teret dokaza postojanja uzročne veze između štetnika i štetne radnje leži na pacijentu koji mora u postupku dokazati da je njegovo zdravstveno stanje posljedica liječničke pogreške, a ne prirodnog toka liječenja, odnosno da njegovo pogoršano zdravstveno stanje nije posljedica prirodnog, sudbinskog tijeka bolesti, nego liječničke greške. Položaj pacijenta u tom pogledu je olakšan ako se primjenjuju pravila objektivne odgovornosti, primjerice ako šteta potječe od nekom medicinskog uređaja kao opasne stvari ili neke dijagnostičke i terapijske mjere koja bi se mogla smatrati opasnom (zračenje i sl.), jer se tada uzročna veza presumira. ${ }^{128}$ 
Odgovornost za štetu može biti subjektivna (kulpozna) i objektivna (kauzalna). O subjektivnoj odgovornosti radi se uvijek ako je za nastanak odgovornosti za štetu potrebna, osim općih pretpostavaka odgovornosti za štetu, još i krivnja štetnika (kao posebna pretpostavka). ${ }^{129}$ Odgovornost za štete temelji se na načelu presumirane krivnje. Tko drugome prouzroči štetu, dužan je naknaditi je ako ne dokaže da je šteta nastala bez njegove krivnje. Tuženi zdravstveni radnik mora u postupku naknade štete dokazivati da nije kriv odnosno da je prilikom pružanja zdravstvene usluge postupao lege artis. ${ }^{130}$ Dva su temeljna oblika namjera i nepažnja: krivnja postoji kad je štetnik zdravstveni radnik prouzročio štetu namjerno ili nepažnjom. Namjerno postupa onaj koji postupa znajući i hotimice, dok s nepažnjom postupa onaj koji ne upotrijebi potreban stupanj pažnje, onu pažnju koju bi upotrijebio prosječan čovjek (krajnja nepažnja) ili onu koju bi upotrijebio dobar gospodarstvenik, odnosno dobar domaćin (obična nepažnja). Predmnijeva se obična nepažnja dakle najblaži oblik i stupanj krivnje štetnika, koji je u većini slučajeva dovoljan za odgovornost. Dakle ovdje se pretpostavlja da je zdravstveni radnik kriv za počinjenje štete jer nije postupao u obavljanju zdravstvene djelatnosti kao dobar stručnjak odnosno profesionalac. Temeljem načela odštetnog prava i odgovornosti za drugog, za ovakav oblik krivnje i počinjenje šteta odgovarati će poslodavac zdravstvenog radnika. S druge strane u pravnoj teoriji egzistira i načelo objektivne odgovornosti koje određuje odgovornost za štetu za što se ne traži krivnja štetnika tj. zdravstvenog radnika. Objektivna odgovornost nastaje odmah kad se ispune pretpostavke: štetna radnja, šteta, uzročna veza između štetne radnje $\mathrm{i}$ štete, te protupravnost štetne radnje. Pravila objektivne odgovornosti primjenjuju se na štete od stvari i djelatnosti od kojih potječe povećana opasnost štete za okolinu. ${ }^{131} \mathrm{Je}$ li obavljanje poslova zdravstvenog radnika, dakle obavljanje zdravstvene djelatnosti, obavljanje opasne djelatnosti odlučivat će sud u svakom pojedinom slučaju. Postavljena zakonska definicija opasne djelatnosti ili opasne stvari nimalo u svom sadržaju ne isključuje oblike i načine obavljanja pojedinih poslova zdravstvenih djelatnosti. Sud bi se u utvrđivanju trebao služiti uglavnom mišljenjem vještaka. Kirurški zahvati, rad s ionizirajućim zračenjem po svojoj temeljnoj definiciji jasno pokazuju da se radi o opasnim djelatnostima ili opasnim stvarima. Navedeno bi značilo da za nju odgovara onaj tko je vlasnik opasne stvari tj. onaj tko obavlja takvu opasnu djelatnost, dakle direktno zdravstveni radnik bez utvrđivanja elementa i stupnja krivnje.

Ne smije se zanemariti i činjenica odgovornosti zdravstvenog radnika prema svom poslodavcu. Poslodavac može regresno zatražiti od takvog zdravstvenog radnika naknadu onoga što je on kao poslodavac isplatio oštećeniku. Poslodavac (pravna ili fizička osoba) koji je oštećeniku popravio štetu ima pravo zahtijevati od radnika naknadu troškova popravljanja štete ako je radnik štetu prouzročio namjerno ili iz krajnje nepažnje (čl. 1061. st. 3. ZOO-a), tijekom rada ili u svezi s radom. Taj propis uređuje, dakle, pravo poslodavca na regres od radnika. Propis se odnosi i na liječnike odnosno druge zdravstvene radnike u odnosu na poslodavce u zdravstvu. Poslodavac nema pravo regresa ako je šteta posljedica obične nepažnje. ${ }^{132}$ Svaki zdravstveni radnik odgovara za svoj dio štete ako je više zdravstvenih radnika počinilo štetu tako da nije primjenjivo načelo kolektivne timske odgovornosti. 
Prava, obveze i odgovornosti radnika u obavljanju djelatnosti: Odgovornost zdravstvenih radnika i osiguranje od odgovornosti

Postupci zdravstvenih radnika podliježu kako medicinskoj tako i sudskoj kontroli. Kontrola nema cilj sputavati slobodu medicinskih radnika koja je u interesu pacijenata, nego ih natjerati da se drže važećeg standarda u svojoj struci i da postupaju pažljivo. ${ }^{133}$

Zbog velikog broja odštetnih zahtjeva sve se veća pažnja posvećuje reformi sustava liječničke odgovornosti za grešku, te je 2005. Svjetsko medicinsko udruženje donijelo „Izjavu o reformi medicinske odgovornosti“" (,Statement on Medical Liability

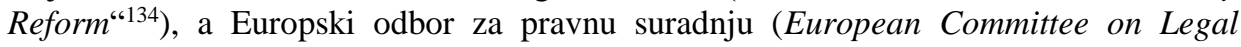
Cooperation) izradio je izvještaj o stanju medicinske odgovornosti u državama Vijeća Europe (Report on Medical Liability in Council of Europe Member States) s ciljem utvrđivanja glavnih problema i unificiranja prakse po tom pitanju. ${ }^{135}$

\subsection{Osiguranje od odgovornosti}

Poslodavac je obvezan sve zdravstvene radnike koji neposredno u vidu zanimanja pružaju zdravstvenu zaštitu stanovništvu osigurati od štete koja bi mogla nastati u provođenju zdravstvene zaštite (ZOZZ, čl. 124.), odnosno od profesionalne odgovornosti. Pojam profesionalne odgovornosti, ${ }^{136}$ nije precizno definiran, ali se veže za profesije u kojima postoje kodeksi ponašanja, strukovna udruženja, itd. ${ }^{137}$

Zdravstvena djelatnost postaje razvojem dijagnostičkih i terapijskih postupaka i svevremenskim tehnološkim napretkom visoko rizična, zdravstveni radnici sve više izloženi mogućnostima pogreške. Uzrok toga je preveliki obim normi u sustavu zdravstva kao i obrambeni stav zdravstvenih radnika u postupcima liječenja. Medicinska znanost razvija se upravo zahvaljujući onim zdravstvenim radnicima koji ulaze u određeni rizik obavljajući neku novu medicinsku metodu i terapiju. Međutim, zbog svakodnevne izloženosti odgovornosti zbog primjene takvih metoda i terapija, zdravstveni radnici traže način kako smanjiti rizike zbog kojih odluke donose pod stresom i pritiskom, a onda su i greške češće. Iako pripadnici svih profesija griješe, greške koje nastaju prilikom pružanja zdravstvenih usluga mogu biti štetne i kobne za konkretnog pojedinca. Zbog straha od greške liječnici su počeli primjenjivati i sve više koriste tzv. defensive medicine. Provodi se čitav niz nepotrebnih dijagnostičkih i terapeutskih zahvata radi osiguranja zdravstvenih radnika od potencijalnih odgovornosti, a to uzrokuje veće troškove liječenja i mogući rizik za pacijenta, u najmanju ruku zbog izloženosti invazivnim zahvatima i kašnjenju s uspostavom dijagnoze i početkom terapije. Zdravstveni radnici u takvom nezavidnom položaju kad svakodnevno brinu o zdravlju i životu ljudi moraju biti sigurni u obavljanju zdravstvene djelatnosti. Sigurnost je najbolje postiže osiguravanjem pozicije zdravstvenog radnika u obavljanju profesionalne djelatnosti. Tako osiguran zdravstveni radnika može bezbrižno i nesmetano pružati zdravstvenu skrb pacijentu. Iz istog razloga propisana je obveze osiguravanja svih zdravstvenih radnika. ${ }^{138}$ Postupno odgovornost za postupak ustupa mjesto odgovornosti za rezultat, a krivnja ili propust liječnika nije više isključivi temelj odgovornosti za štetu koju pretrpi pacijent. Ta promjena prvenstveno je uzrokovana sudskom praksom, čak i kad se pozitivno pravo ne mijenja. Upravo sudska praksa, koja proširuje temelj odgovornosti liječnika, olakšava pacijentu teret dokaza krivnje liječnika, dosuđuje velike odštete u slučaju liječničke greške, ravna opsegom osiguranja od odgovornosti liječnika prema odredbama propisa koji uređuju odgovornost 
liječnika, sa stajališta osiguravatelja predstavlja povećanje rizika, koje, pak, zahtijeva brižljivu ocjenu izloženosti, dostatnosti premije i određivanje osiguranih svota. S druge strane, takva situacija dovodi do teškog položaja zdravstvene ustanove i liječnike profesionalce. Olako pozivanje na odgovornost za štetu od strane pacijenata i veliki izgledi da će tu štetu morati nadoknaditi, odvraća liječnike od obavljanja profesije. ${ }^{139}$ Osiguranje od liječničke odgovornosti ili liječničke pogreške jedan je od oblika osiguranja od profesionalne odgovornosti. Pravilno reguliranje ovog oblika osiguranja je korisno i za liječnike i za pacijente. ${ }^{140}$ Osiguranje od profesionalne odgovornosti je pravni odnos osiguranja koji nastaje na osnovu ugovora ili ako je ono obvezno, na osnovu zakona i zaključenog ugovora između osiguravatelja i osiguranika, odnosno ugovaratelj osiguranja iz koga za njega nastaje obveza da trećoj (oštećenoj) osobi, koja je inače korisnik usluge osiguranika (odvjetnik, liječnik, arhitekt, projektant, geodet, veterinar itd.) isplati odgovarajuću naknadu za pretrpljenu štetu ako ona nastupi kao posljedica ukupne ili određene građanskopravne odgovornosti u obavljanju njegove profesionalne djelatnosti, odnosno pružanju određene usluge za što se sa svoje strane ugovaratelj osiguranja obvezuje osiguravatelju platiti odgovarajuću premiju osiguranja. ${ }^{141}$ Osiguranje od odgovornosti predstavlja elegantan način pokrivanja rizika snošenja financijskih posljedica vlastite građansko-pravne odgovornosti. ${ }^{142}$

Osiguranje od odgovornosti dio je imovinskih osiguranja, dakle osiguranja kojemu je cilj naknada štete. Tim osiguranjem osigurava se od rizika obveze naknade štete trećoj oštećenoj osobi. Umjesto štetnika (odgovorna osoba), štetu će oštećenome naknaditi osiguravatelj. Naknada štete oštećenoj osobi koju bi morao platiti štetnik pogađa imovinu (patrimonium) štetnika. Kod osiguranja od odgovornosti nije riječ o osiguranju za slučaj oštećenja ili uništenja neke stvari, već se osigurava rizik umanjenja imovine, do čega bi došlo zbog obveze naknade štete oštećenoj osobi. To osiguranje javlja se kao jedan od načina upravljanja rizikom koji nam prijeti: transferiranje rizika na osiguravatelja. ${ }^{143}$

Ovu vrstu osiguranja od odgovornosti možemo bliže definirati kao osiguranje od profesionalne odgovornosti. Predmet osiguranja kod osiguranja profesionalne odgovornosti je građanska, odnosno, ugovorna odgovornost za štetu, koja je nastala, prije svega, zbog neispunjenja ili djelomičnog ispunjenja obveze, kao i zbog drugih oblika nastanka štete. Kod profesionalne odgovornosti obveza na naknadu štete nastaje samo kada je do nastanka štete došlo zbog profesionalne greške ili propusta osiguranika u izvršenju obaveza prema trećim osobama, a po zaključenom ugovoru ili donesenoj odluci. ${ }^{144}$ Znači, osiguranje od profesionalne odgovornosti se ugovara za štete zbog profesionalnog propusta koje osiguranik počini u tijeku obavljanja svoga rada. ${ }^{145}$

U pravilu, osiguranje od profesionalne odgovornosti u slučaju nastanka liječničke pogreške ili bilo koje štetne radnje učinjene pacijentu pokriva slijedeća područja: subjektivnu odgovornost; objektivnu odgovornost; djelovanje timskog rada; pružanje prve pomoći i hitne medicinske pomoći; pokriva štete koje su nastale u vrijeme trajanja osiguranja, a prijavljene su nakon prestanka ugovora o osiguranju unutar rokova zastare; pokriva troškove odvjetnika i sudskog postupka u opravdanim, neopravdanim ili pretjeranim zahtjevima za naknadu štete; uključuje isplatu odštetnog zahtjeva do visine osiguranog iznosa uključujući troškove i kamate. Osiguranje od profesionalne 
odgovornosti NE pokriva: štete nastale kod korištenja neispravnih uređaja, ako je osiguraniku to bilo ili trebalo biti poznato; štete koje je počinila osoba na zamjeni, ako klauzulom o zamjeni nije drukčije određeno; štete koje su nastupile prije sklapanje police, a nisu bile ili nisu mogle biti nepoznate osiguraniku; štete nastale iz zakonske odgovornosti članova uprave i drugih odgovornih osoba u obavljanju njihove funkcije. Prilikom ugovaranja profesionalne odgovornosti općenito se treba posvetiti pažnja na: trajanje pokrića - jesu li štetni događaji pokriveni i nakon prestanka trajanja police; opseg pokrića - individualna i/ili objektivna odgovornost, timski rad, primanje naredbi od pretpostavljenih. ${ }^{146}$

Osiguravatelj snosi, u granicama iznosa osiguranja, troškove spora kao i druge opravdane troškove radi utvrđivanja odgovornosti osiguranika. U predmetima naknade štete proizašlim iz greške liječnika, koriste se opća pravila parničnog postupka. Sa druge strane, ovi predmeti sadrže određene specifičnosti koje ih djelomično odvajaju po načinu rješavanja i sadrži odluka od ostalih predmeta naknade šteta. Po općim pravilima parničnog postupka, predviđena su sljedeća dokazna sredstva: uviđaj, isprave, svjedoci, vještaci i saslušanje stranaka. ${ }^{147}$

Poseban interes za osiguranjem od profesionalne odgovornosti za pričinjenu štetu pacijentu u toku liječenja imaju zdravstvene ustanove, jer u slučaju nastupanja štetnog događaja kod pacijenta prouzročenog medicinskom greškom, zdravstvene ustanove odgovaraju za pričinjenu štetu koju je prouzročilo medicinsko osoblje. Od navedenog pravila postoji iznimka kada oštećeni može zahtijevati naknadu štete i od radnika i to samo u slučaju ukoliko je taj radnik štetu prouzročio namjerno. Poseban pravni interes za zaključenje ugovora o osiguranju od odgovornosti ima i pacijent, jer postojanjem takvog ugovora pacijent uživa jaču pravnu zaštitu na način u slučaju izostanka odgovarajuće zdravstvene zaštite, zbog čega za pacijenta nastupe štetne posljedice prouzročene medicinskom pogreškom, pacijent uživa pravnu zaštitu kroz pravo na pravično obeštećenje, unaprijed znajući, u slučaju nastupanja štete, tko je dužan naknaditi štetu.

Svijest o potrebi zaštite žrtava liječničke pogreške/nezgode, slično kao i kod šteta u cestovnom prometu, sili društvo da im osigura nekakvu naknadu štete, bez obzira na to kako je do štete došlo. U svijetu su vremenom razvijali se različiti modeli osiguranja od odgovornosti za štetu pričinjenu medicinskom pogreškom, koji su i danas prisutni kao oblici osiguranja od odgovornosti. Ta razlika mogućih modaliteta osiguranja ogleda se u načinu i obimu saniranja posljedica prouzročenih pričinjenom štetom, te načinu prihvaćanja odgovornosti za pričinjenu štetu. U pravilu modalitete osiguranja od odgovornosti za štetu pričinjenu medicinskom pogreškom možemo razvrstati u tri različite skupine. Drugim riječima, u teoriji i praksi postoje tri sustava osiguranja od odgovornosti zdravstvenog radnika za štetu pacijentu, ${ }^{148} \mathrm{i}$ to:

a) Prvi, tzv. klasični sustav, utemeljen je na krivnji medicinskog profesionalca, koji najčešće nije praćen propisivanjem obveznog osiguranja od odgovornosti i temelji na općim pravilima odštetnog prava. Naknadu štete pacijentu u tom sustavu prati obveza pacijenta da dokaže krivnju liječnika, vođenje dugotrajnog sudskog postupka, trošak odvjetnika itd. ${ }^{149}$. Vezan je sa subjektivnom odgovornosti zdravstvenog radnika koja se 
temelji na krivnji zdravstvenog radnika za grešku koju je skrivljeno počinio. Karakterizira ga apriori provođenje građanske parnice za naknadu štete te $\mathrm{u}$ svezi s time potreba dokazivanja stupnja krivnje zdravstvenog radnika za uzrokovanje nastale štete. Medicinska nezgoda je isključena iz sustava odgovornosti i iz sustava osiguranja. ${ }^{150}$ Takav je sustav na snazi i primjenjuje se u Hrvatskom pravu. Klasični način osiguranja od odštetne odgovornosti zdravstvenih radnika, je prevladavajući u svijetu. Pretežito se primjenjuju pravila subjektivne odgovornosti za štetu kod koje se krivnja presumira, što pacijentu donekle olakšava situaciju, no liječnik mora dokazati, ukoliko se želi ekskulpirati, kako je do greške došlo bez njegove krivnje, odnosno kako je u svemu radio lege artis, prema pravilima i standardima struke. ${ }^{151}$

b) Drugi je no fault sustav odgovornosti za štetu i osiguranja od odgovornosti, kod kojega krivnja nije bitan uvjet naknade štete. Za taj sustav ističu se prednosti, u odnosu na onaj klasični, kao što su: odgovornost bolnice više nego liječnika, odvajanje naknade štete od stegovne ili kaznene odgovornosti liječnika, rješavanje zahtjeva pacijenta u izvan sudskom postupku, koji je brži i puno jeftiniji, naknada za greške koje su se mogle izbjeći, neovisno o krivnji liječnika, korištenje informacija iz nastalih slučajeva radi izbjegavanja sličnih u budućnosti. ${ }^{152}$ Postoji određeni fond iz kojeg se namiruju pacijenti, odnosno osobe kojima je pričinjena šteta bez obzira na krivnju. Ukoliko osobe nisu zadovoljne predloženom naknadom, uvijek im ostaje pokrenuti parnicu pred sudom. Skandinavski „no-fault“ sustav osiguranja od odštetne odgovornosti je specifičan za neke od zemalja u svijetu koje su svojim specifičnim uređenjem materije osiguranja pacijenata za pretrpljene štete stvorile svojevrsnu sponu između zaštite prava pacijenata te osiguranja pacijenata za štete koje bi im profesionalnim radom mogli prouzrokovati liječnici te materije odštetno pravne odgovornosti liječnika i ostalog zdravstvenog osoblja za te iste štete. Njegova ,alternativnost" leži upravo u činjenici da je to sistem koji osigurava pacijente od eventualnih šteta nastalih $u$ toku liječenja bez obzira na odgovornost zdravstvenih radnika. U tom sistemu osiguranja, stavlja se akcenat na nesreće koje se dese na radnom mjestu ili u saobraćaju, kao i u sportu, ali među svim tim slučajevima, nalaze se i nesreće i povrede nastale u medicinskim ustanovama. To su tzv. ,medicinski nesretni slučajevi”, za koje je predviđeno obeštećenje pacijentima, a u te slučajeve spadaju: 1) pozitivne liječničke radnje ili pozitivne liječničke greške koje su uzrokovane nedovoljno visokim i objektivnim stupnjem pažnje; 2) nastupanje teških, neobjektivnih, kao i nepoželjnih i štetnih po zdravlje pojava koje su proizašle iz postupka liječenja; i 3) medicinski nesretni slučajevi nastali kvarenjem medicinskih aparata. ${ }^{153}$ Ovaj model osiguranja uveden je uglavnom u skandinavskim zemljama i to prvo u Švedskoj pa se stoga za taj tip osiguranja veže naziv «skandinavski model».

c) Treći, tzv. "mješoviti“" sustav, po svojim rješenjima negdje je između prethodna dva sustava. Mješoviti“ model osiguranja od odštetne odgovornosti predstavlja kombinaciju klasičnog modela osiguranja i,,no fault” sistema osiguranja. Treći mješoviti sustav ostaje uglavnom na polju odgovornosti po načelu krivnje, a uvodi odgovornost bez krivnje za bolest, medicinsku nezgodu, bolničke infekcije i greške u sanitarnom materijalu, odnosno proizvodu čija je posljedica invalidnost od najmanje $25 \% .{ }^{154}$ Temelji se, dakle, na odgovornosti zdravstvenih radnika po načelu krivnje, ali za određene kategorije nezgoda/šteta u sustavu pružanja zdravstvene zaštite i pod određenim uvjetima uvodi i 
Prava, obveze i odgovornosti radnika u obavljanju djelatnosti: Odgovornost zdravstvenih radnika i osiguranje od odgovornosti

odgovornost bez krivnje, odnosno tzv. " no fault" sustav. Ovaj model osiguranja prisutan je u Francuskoj. Sve do 2002. godine u Francuskoj je bio na snazi klasični način osiguranja odštetne odgovornosti. No, medicinski napredak, razvitak terapijskih metoda i tehnološka unaprjeđenja, ogroman broj sudskih postupaka, uvjetovali su traženje novog načina osiguranja pacijenata, kako bi zaštitili liječnike od povećane odgovornosti, a istodobno zaštitili pacijente i osigurali im naknadu štete koja je posljedica liječničke greške. ${ }^{155} \mathrm{U}$ Francuskom sistemu osiguranja od odštetne odgovornosti prihvaćen je tzv. "no fault" sustav samo u dijelu i samo za slučajeve invalidnosti koji prelaze $25 \%$.

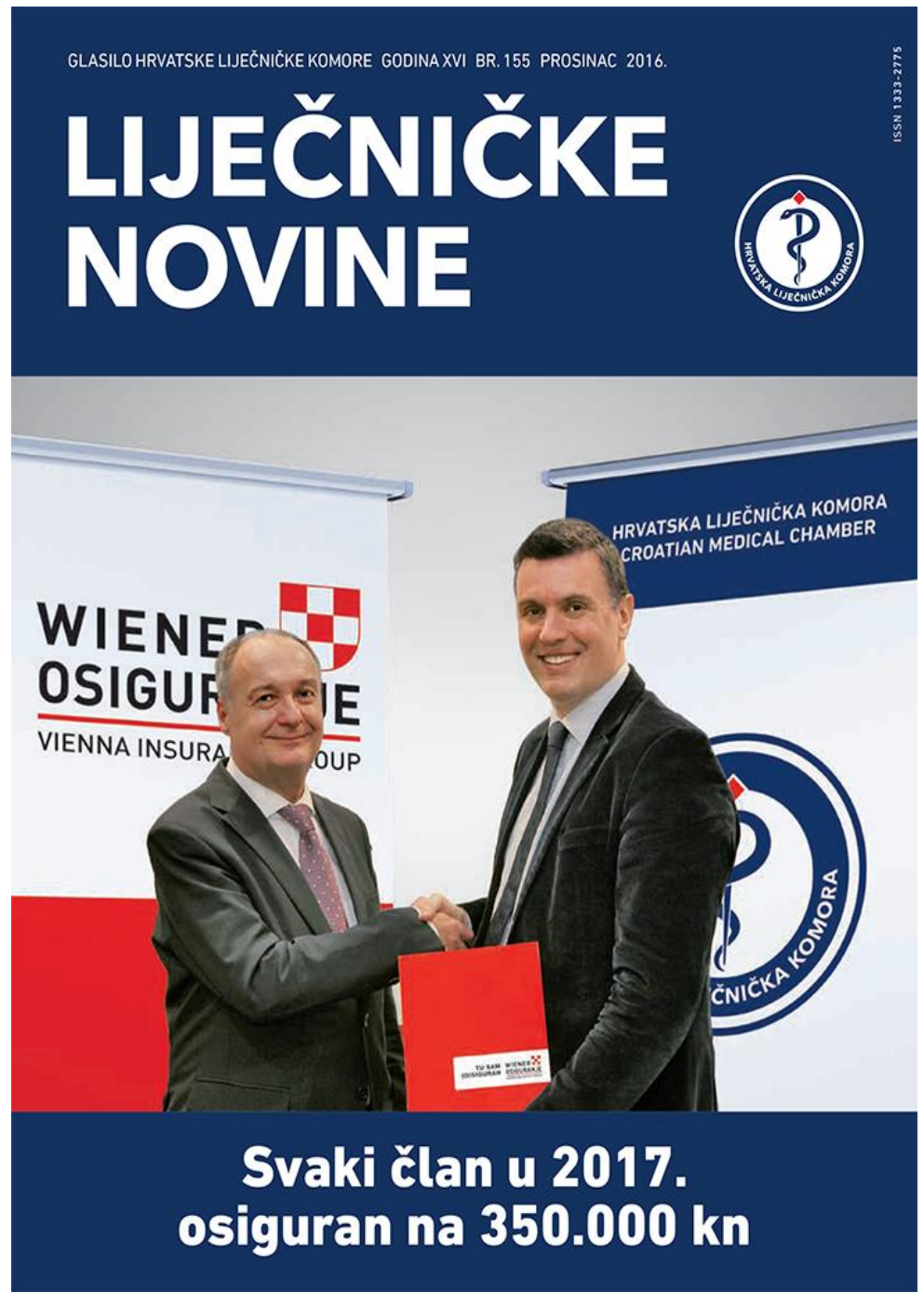

Slika 13 


\subsection{Kaznena odgovornost}

Pravila medicinske struke određuju što je podobno sredstvo i podoban način liječenja, što su odgovarajuće mjere za zaštitu bolesnika. Liječnik mora posjedovati i upotrijebiti znanja i sposobnosti koje iskazuju liječnici njegova profila u sličnim okolnostima. Od liječnika specijalista zahtijeva se viši stupanj sposobnosti kad djeluju u krugu svoje specijalnosti. Pri procjeni nesavjesnosti valja uzeti u obzir lokalne prilike, kao i posebnosti konkretnog slučaja“. ${ }^{156} \mathrm{~S}$ napretkom medicine i povećanjem dijagnostičkih i terapijskih mogućnosti, povećavaju se i pravni zahtjevi prema dužnoj pažnji i profesionalnom umijeću jer onaj tko može više, taj je i više dužan. ${ }^{157}$ Zakonodavac je vodio računa o činjenici da je obavljanje zdravstvene djelatnosti vrlo odgovoran, ali i riskantan posao, kao i o činjenici da zdravstveni radnici svoju djelatnost obavljaju odnosno moraju obavljati sa vrlo visokim stupnjem opreza i odgovornosti, uslijed čega najviše moraju biti svjesni visokog rizika koji se pojavljuje ili se može pojaviti prilikom pružanja zdravstvene zaštite.

Vezano uz liječničku grešku i kaznenu odgovornost, zakonodavac je posebna kaznena djela protiv zdravlja ljudi izdvojio u glavi XIX Kaznenog zakona RH („Narodne novine“ 125/11, 144/12, 56/15, 61/15) kao npr. Širenje i prenošenje zarazne bolesti, Nesavjesno liječenje, Nedozvoljeno uzimanje i presađivanje dijelova ljudskog tijela, Nepružanje medicinske pomoći u hitnim stanjima itd. Grupni zaštitni objekt ove glave jest zdravlje ljudi. Kaznena djela zdravstvenih radnika zakonodavac je normirao posebno i izdvojeno obzirom da kaznena djela protiv zdravlja ljudi štite tjelesni integritet pacijenta, bolesnika, odnosno svake osobe kojoj je potrebna medicinska odnosno zdravstvena pomoć. Potrebno je istaknuti da liječnička greška predstavlja kazneno djelo tek u slučaju kada je utvrđena najgrublja povreda profesionalne dužnosti liječnika koja predstavlja znatno odstupanje od općeprihvaćenih i usvojenih pravila medicinske struke. Osim navedenog, da bi liječnička greška bila kazneno djelo potrebno je ispunjenje i drugih pretpostavki, npr. nastupanje posljedice u vidu pogoršanja bolesti ili naruženja nečijeg zdravlja. U konačnici, da bi se liječnik proglasio krivim zbog počinjenja nekog kaznenog djela protiv zdravlja ljudi, mora postupati s namjerom ili iz nehaja, svjestan ili je bio dužan i mogao biti svjestan da je njegovo djelo zabranjeno. U slučaju postupanja s izravnom namjerom, počinitelj je svjestan obilježja kaznenog djela i hoće ili je siguran u njihovo ostvarenje. U slučaju postupanja s neizravnom namjerom počinitelj je svjestan da može ostvariti obilježja kaznenog djela pa na to pristaje, dakle počinitelj u ovom slučaju ne teži ostvarenju zabranjene posljedice, ali prihvaća realnu mogućnost nastupanja posljedice i unatoč riziku ne odustaje od svojih postupaka. Vezano uz nehaj, počinitelj postupa sa svjesnim nehajem kad je svjestan da može ostvariti obilježja kaznenog djela, ali lakomisleno smatra da se to neće dogoditi ili da će to moći spriječiti. On dakle nepažljivo postupa premda je predvidio mogućnost počinjenja djela. Za razliku od toga, počinitelj postupa s nesvjesnim nehajem kad nije svjestan da može ostvariti obilježja kaznenog djela, iako je prema okolnostima bio dužan i prema svojim osobnim svojstvima mogao biti svjestan te mogućnosti. Počinitelj dakle nije obratio dovoljnu pozornost opasnoj situaciji i nije povezao spoznatu opasnost s opasnošću svoga postupka. ${ }^{158}$ 
Prava, obveze i odgovornosti radnika u obavljanju djelatnosti: Odgovornost zdravstvenih radnika i osiguranje od odgovornosti

Pitanje liječničke greške u Kaznenom zakonu RH povezano je s kaznenim djelom Nesavjesnoga liječenja. Osnovni je kriterij za to kazneno djelo primjena očito nepodobnoga sredstva ili načina liječenja, odnosno uopće nesavjesno postupanje, zbog čega dolazi do pogoršanja bolesti ili naruženja zdravlja neke osobe. Očito nepodobno sredstvo (način) liječenja predstavlja sve ono što je u jasnoj i neporecivoj suprotnosti s medicinskom znanošću i praksom, a koje nije posljedica različitih mišljenja pojedinih medicinskih stručnjaka (medicinskih škola). ${ }^{159}$ Kaznenoga djela neće biti ako zbog primjene očito nepodobnoga sredstva (načina) liječenja nije nastupilo pogoršanje zdravlja neke osobe. Zapravo, riječ je o "drastičnim slučajevima", odnosno o "značajnijem, težem, ozbiljnijem odstupanju od pravila znanosti i liječničke deontologije". ${ }^{160}$ Dakle nesavjesno liječi onaj zdravstveni radnik koji primjeni nepodobno sredstvo ili način liječenja ili na drugi način ne postupi po pravilima struke ili očito nesavjesno postupa. Nepodobno sredstvo (primjerice, propisivanje i uporaba neprovjerenih lijekova) ili nepodoban način liječenja (primjerice, transfuzija neodgovarajuće krvne grupe, propuštanje dezinfekcije ruku), bilo bi svako ono sredstvo ili način liječenja koji je u suprotnosti s dostignućima i pravilima medicinske znanosti. Nesavjesno liječenje može se sastojati i u pogrešnoj dijagnozi bolesti (primjerice, zbog površnog pregleda pacijenta nije utvrđena bolest ili se propustio napraviti potreban klinički pregled pa se zbog pogrešne dijagnoze primjenjuje i pogrešna terapija), propuštanju primjene preventivnih mjera (primjerice, davanje vakcine protiv tetanusa), propuštanje određenih mjera kontrole, zanemarivanju potrebnih higijenskih mjera, nepoduzimanju provjere mogućnosti određenih kontraindikacija (primjerice, ispitivanje alergijske osjetljivosti pacijenta), propuštanje davanja određenog lijeka, kao i drugim postupcima koji su suprotni pravilima medicinske struke. Nesavjesno postupanje tijekom liječničkih postupaka odnosi se na površnost, nemar, brzopletost te svaki nesavjesni postupak pri obavljanju zdravstvene djelatnosti (primjerice, invazivni načini pretrage, pretrage s visokom dozom opasnosti i sl.). Liječnik ili zdravstveni radnik nesavjesno postupa (činjenjem ili nečinjenjem), ako u obavljanju svoje djelatnosti ne poštuje pravila medicinske struke, nema odgovarajuću opremu ili instrumente kako bi se poduzete radnje uspješno obavile, svjesno zanemaruje, ne poštuje ili se upušta u poduzimanje određenih radnji iako zna da za njihovo provođenje nije dovoljno stručan. ${ }^{161}$ Iako su neprimjenjivanje mjera za zaštitu bolesnika, primjena očito nepodobnog sredstva ili načina liječenja i drugi oblici nesavjesnog postupanja pokriveni izričajem nepostupanja po pravilima zdravstvene struke, zakonodavac nije išao za pojednostavljenjem izričaja budući da ovakav prošireni izričaj olakšava vještačenje i služi preciziranju "nepostupanja po pravilima struke". ${ }^{162}$

Kazneno djelo nesavjesnog liječenja spada u kategoriju delicta propria, odnosno mogu ga izvršiti samo one osobe koje vrše zdravstvenu službu, što u širem tumačenju pojma «zdravstvene službe» može obuhvatiti i zdravstvenu administraciju. ${ }^{163}$ Svaki zdravstveni radnik može počiniti kazneno djelo, ali svatko ne može počinit određena kaznena djela, poglavito one iz glave 19. Kaznena djela protiv zdravlja ljudi Kaznenog zakona. Pri tome se može kazati da su zdravstveni radnici „privilegirani“ što samo oni mogu počiniti kaznena djela: - nesavjesno liječenje; - nedozvoljeno uzimanje i presađivanje dijelova ljudskog tijela; - nepružanje medicinske pomoći u hitnim slučajevima. 
Navedena zakonska utvrđenja kaznene odgovornosti predstavljaju nezavidnu poziciju i položaj zdravstvenog radnika u strukturi djelovanja i obavljanja poslova profesije. Element potenciranih statusa koji imaju poseban položaj u okviru kaznene odgovornosti kao niti jedna od drugih profesija rezultira egzistiranjem dodatnog psiho-fizičkog opterećenja pripadnicima zdravstvenih profesija u već dostatnom stresnom okruženju liječenja bolesnika i pružanja usluga zdravstvene zaštite pacijentu. Prezentirani otežavajući element ne može ublažiti ni načelo presumpcije nevinosti (za razliku od građanske odgovornosti) svakog zdravstvenog radnika za kojeg sustav posumnja da je učinio pogrešku prilikom svog rada.

\subsection{Disciplinska (stegovna) odgovornost}

Disciplinska odgovornost liječnika samo je jedna vrsta odgovornosti kojom se nastoji osigurati stručno i zakonito obavljanje liječničke djelatnosti. Naime, liječnici kao zdravstveni radnici, upravo zbog društvene važnosti djelatnosti koju obavljaju, mogu, osim za kaznena djela i prekršaje, odgovarati i za disciplinske povrede koje počine za vrijeme obavljanja liječničke djelatnosti. Disciplinska odgovornost prejudicira disciplinske povrede koje se manifestiraju najčešće kao nestručno obavljanje liječničke profesije ili pak nepoštovanje i nepridržavanje odredaba strukovnog kodeksa, a ono što je najvažnije jest činjenica da postupak za navedene povrede provode pripadnici struke, $\mathrm{i}$ to pred strukovnom komorom čiji je član liječnik kojega se tereti za određenu disciplinsku povredu. ${ }^{164}$ Disciplinska odgovornost može se definirati kao odgovornost liječnika za povredu zakonskih obveza i pravila struke, za koju se u propisanom postupku od strane nadležnog tijela izriče zakonom određena kazna. Disciplinska odgovornost liječnika utvrđuje se za radnje opisane Zakonom o liječništvu, a sama procedura provođenja disciplinskog postupka detaljnije je definirana Pravilnikom o disciplinskom postupku Hrvatske liječničke komore. ${ }^{165}$

Disciplinski postupak je ukupnost pravila kojima se uređuje pokretanje i vođenje postupka utvrđivanja odgovornosti i izricanja kazne liječniku zbog povrede liječničke dužnosti. Precizna regulacija disciplinskog postupka osigurava strankama jasnu poziciju u postupku odnosno stranke tada znaju koje se točne odredbe i na koji se način primjenjuju u postupku što onemogućava bilo kakvu arbitrarnost. ${ }^{166}$

Liječnik je disciplinski odgovoran ako povrijedi odredbe Zakona o liječništvu, povrijedi Kodeks medicinske etike i deontologije Komore, obavlja nestručno liječničku profesiju, svojim ponašanjem prema pacijentu, drugom liječniku ili trećim osobama povrijedi ugled liječničke profesije, ne ispunjava Statutom ili drugim općim aktom određene članske obveze prema Komori ili počini kazneno djelo koje ga čini nedostojnim za obavljanje liječničke djelatnosti. ${ }^{167}$ Dakle liječnik je počinio disciplinsku povredu kada naruši kojih se liječnik dužan pridržavati prilikom obavljanja liječničke djelatnosti, a koja u ukupnosti čine liječničku dužnost. Ovdje valja istaknuti da kaznena i prekršajna odgovornost liječnika ili disciplinska odgovornost u zdravstvenoj ustanovi, trgovačkom društvu ili drugoj pravnoj osobi koja obavlja zdravstvenu djelatnost ne isključuje disciplinsku odgovornost liječnika pred Komorom. U disciplinskim postupcima i u postupku utvrđivanja nedostojnosti pred Hrvatskom liječničkom komorom sudi Časni sud i Visoki 
Prava, obveze i odgovornosti radnika u obavljanju djelatnosti: Odgovornost zdravstvenih radnika i osiguranje od odgovornosti

časni sud Komore, ukoliko drugačije nije određeno postupak se vodi sukladno odredbama Zakona o kaznenom postupku RH, a pri odlučivanju o odgovornosti i izricanju disciplinskih mjera i kazni na odgovarajući način se primjenjuju odredbe Kaznenog zakona. ${ }^{168}$

Uvođenjem disciplinskih mjera kojima se sankcioniraju disciplinske povrede liječnika te nadziranjem stručnosti i etičnosti rada liječnika osigurava se standardizacija kvalitete $u$ obavljanju liječničke djelatnosti te se štite prava i interesi korisnika liječničkih usluga. Cilj nadzora i provedbe disciplinskog postupka u konačnici jest utjecati na poboljšanje i održavanje kvalitete pružanja zdravstvene zaštite. ${ }^{169}$ Pretpostavke disciplinske odgovornosti su okolnosti koje pravni poredak iziskuje kao bitne za postojanje disciplinske odgovornosti, a to su: krivnja, ubrojivost, određenost povrede službene dužnosti i kazne zakonom, protupravnost. ${ }^{170}$ Disciplinske mjere koje se mogu izreći liječniku za disciplinske povrede su opomena, novčana kazna, ukor, javni ukor, privremeno ili trajno oduzimanje odobrenja za samostalan rad, privremeno ili trajno ograničenje opsega odobrenja za samostalan rad te disciplinska mjera dodatne izobrazbe.

Temeljeno pravo svakog čovjeka i građanina sastoji se u tome da zakonom ustanovljeni, neovisni i nepristran sud pravični i u razumnom roku odluči o njegovim pravima $i$ obvezama, ili o sumnji ili optužbi zbog kažnjivog djela, kako to predviđa i članak 29. Ustava RH. Sudska kontrola zakonitosti pojedinačnih akata upravnih vlasti i tijela koja imaju javne ovlasti zajamčena je čl. 19., st. 2. Ustava RH. Odluka Izvršnog odbora Hrvatske liječničke komore kojom se odlučuje u drugom stupnju o povredama dužnosti i ugleda liječničkog zvanja, jest upravni akt. ${ }^{171}$ Stoga stranke u disciplinskom postupku mogu sudsku zaštitu tražiti pred sudbenim tijelima (Upravni, Vrhovni, Ustavni i Europski sud za ljudska prava) redoslijedom (obraćanja sudu) koji moraju pritom poštovati. ${ }^{172}$

Pravni izvori - Zakonom o zdravstvenoj zaštiti propisano je da se zdravstvenim radnicima smatraju osobe koje imaju obrazovanje zdravstvenog usmjerenja i koje neposredno, kao svoje zanimanje, pružaju zdravstvenu zaštitu stanovništvu, pritom obvezno poštujući moralna i etička načela zdravstvene struke. Zakonodavac u istoj odredbi precizira da se zdravstveni radnici obrazuju na medicinskom, dentalnom ili farmaceutsko-biokemijskom fakultetu, studijskom smjeru logopedije te drugom visokom učilištu zdravstvenog usmjerenja, kao i u srednjim školama zdravstvenog usmjerenja, odnosno učilištu ili u srednjim školama koje imaju odobrenje za provođenje obrazovnog programa zdravstvenog usmjerenja. Temeljna je zakonska obveza zdravstvenih radnika da prilikom pružanja zdravstvene zaštite, postupaju prema pravilima svoje struke na način da svojim postupcima ne ugroze život i zdravlje ljudi. Prava i obveze zdravstvenih radnika kao i strukovne organizacije (komore) u koje su se dužni učlaniti (oni zdravstveni radnici koji neposredno pružaju zdravstvenu zaštitu), propisana su tzv. strukovnim zakonima, odnosno Zakonom o liječništvu, Zakonom o dentalnoj medicini, Zakonom o ljekarništvu, Zakonom o medicinsko-biokemijskoj djelatnosti, Zakonom o sestrinstvu, Zakonom o primaljstvu, Zakonom o fizioterapeutskoj djelatnosti te Zakonom o djelatnostima u zdravstvu. Spomenutim je zakonima ujedno propisana i disciplinska odgovornost zdravstvenih radnika u slučajevima povrede pravila struke odnosno povrede temeljnih etičkih i deontoloških načela profesije pa možemo smatrati da osnova 
disciplinske odgovornosti zdravstvenih radnika proizlazi upravo iz odredbi spomenutih, tzv. strukovnih zakona. Odredbe tih zakona zapravo su norme medicinskog prava koje imaju represivan karakter.

Disciplinska (stegovna) odgovornost zdravstvenih radnika samo je jedna vrsta odgovornosti kojom se nastoji osigurati stručno i zakonito obavljanje zdravstvenih djelatnosti. Svi zdravstveni radnici, upravo zbog društvene važnosti djelatnosti koju obavljaju, mogu, osim za kaznena djela i prekršaje, i disciplinski odgovarati. Disciplinska odgovornost najčešće prejudicira disciplinske povrede koje se manifestiraju kao nestručno obavljanje profesije ili nepoštivanje i nepridržavanje odredbi strukovnih kodeksa, a ono što dodaje posebnu „težinu“ disciplinskoj odgovornosti, jest činjenica da postupak za disciplinske povrede provode kolege iz struke kojoj pripada zdravstveni radnik kojeg se tereti za počinjenu disciplinsku povredu. Navedeno konkretno znači da su disciplinski postupak, temeljem zakonskih ovlasti, ovlaštene provoditi strukovne komore čiji je član zdravstveni radnik protiv kojeg se provodi disciplinski postupak. U sustavu zdravstva postoji osam strukovnih komora, i to: Hrvatska liječnička komora, Hrvatska komora dentalne medicine, Hrvatska ljekarnička komora, Hrvatska komora medicinskih biokemičara, Hrvatska komora medicinskih sestara, Hrvatska komora primalja, Hrvatska komora fizioterapeuta i Hrvatska komora zdravstvenih radnika. U nastavku se iznosi sažeti prikaz disciplinske odgovornosti zdravstvenih radnika (liječnika, doktora dentalne medicine, ljekarnika, medicinskih biokemičara, medicinskih sestara, primalja, fizioterapeuta te drugih zdravstvenih radnika) na način kako je to propisao zakonodavac, uz navođenje disciplinskih akata strukovnih komora kojima su pobliže određene disciplinske povrede i kojima su propisana proceduralna pravila disciplinskog sankcioniranja zdravstvenih radnika.

ZOL-om propisana je disciplinska odgovornost liječnika odnosno taksativno su navedena određena ponašanja koja zakonodavac smatra disciplinskim povredama. Dakle, liječnik će disciplinski odgovarati ukoliko: povrijedi odredbe ZOL-a, povrijedi odredbe KMED-a HLK, nestručno obavlja liječničku profesiju, svojim ponašanjem prema pacijentu, drugom liječniku ili trećim osobama povrijedi ugled liječničke profesije, ne ispunjava Statutom ili drugim općim aktom određene članske obveze prema Hrvatskoj liječničkoj komori. Za opisane radnje odnosno ponašanja (povrede) liječniku se mogu izreći disciplinske mjere i novčana kazna ovisno o tome radi li se u konkretnom slučaju o lakšoj ili težoj disciplinskoj povredi. ${ }^{173}$ Hoće li se u konkretnom slučaju raditi o lakšoj ili težoj disciplinskoj povredi, utvrđuje disciplinsko tijelo koje je ovlašteno provoditi postupak, i to u svakom pojedinom slučaju. Karakter disciplinske povrede svakako je bitan jer utječe na vrstu disciplinske mjere koja se liječniku može izreći s obzirom da je zakonodavac propisao kako se za teže disciplinske povrede liječniku mogu izreći sljedeće disciplinske mjere i novčana kazna: ukor, javni ukor, novčana kazna, privremeno oduzimanje odobrenja za samostalan rad (licence) u trajanju od mjesec do godine dana, trajno oduzimanje odobrenja za samostalan rad (licence), privremeno ili trajno ograničenje opsega odobrenja za samostalan rad (licence) (ZOL, čl. 53.). Za lakše disciplinske povrede liječniku se može izreći sljedeća disciplinska mjera i novčana kazna: opomena, novčana kazna. Uz svaku navedenu disciplinsku mjeru i novčanu kaznu (osim uz mjeru trajnog oduzimanja odobrenja za samostalan rad - licence), liječniku se može 
Prava, obveze i odgovornosti radnika u obavljanju djelatnosti: Odgovornost zdravstvenih radnika i osiguranje od odgovornosti

izreći i mjera dodatne izobrazbe dok se disciplinska mjera privremenog oduzimanja odobrenja za samostalan rad (licence), može, osim bezuvjetno, izreći i uvjetno, s rokom kušnje koji ne može biti kraći od šest mjeseci niti duži od dvije godine. Također, zakonodavac je odredio i visinu novčane kazne koja se liječniku može izreći i to u rasponu od 1.000,00 kn pa sve do najvišeg iznosa od 5.000,00 kn. (ZOL, čl. 54.). Disciplinska tijela Hrvatske liječničke komore koja su nadležna za provođenje disciplinskog postupka jesu Časni sud Komore i Visoki časni sud Komore (ZOL, čl. 51.), a zajednički im je naziv Sud Komore. Ta tijela provode disciplinski postupak primjenjujući odredbe Pravilnika o disciplinskom postupku Hrvatske liječničke komore (www.hlk.hr), ali i odredbe Zakona o kaznenom postupku u slučaju kad se pred Sudom Komore pojavi neko pitanje koje nije regulirano Pravilnikom o disciplinskom postupku. Disciplinska tijela sude u vijećima koja su sastavljena od tri člana - predsjednika vijeća koji je pravnik (trenutno tu dužnost obnaša sudac županijskog suda) i dva člana vijeća koji su liječnici. Posebnu vrstu odgovornosti liječnika predstavlja tzv. nedostojnost za obavljanje liječničke djelatnosti. Naime, Zakonom o liječništvu reguliran je institut nedostojnosti liječnika prema kojemu se liječnika koji je pravomoćnom sudskom odlukom proglašen krivim za počinjenje kaznenog djela, može, s obzirom na važnost i prirodu ugroženog dobra ili druge posljedice te s obzirom na okolnosti pod kojima je radnja izvršena odnosno propuštena, smatrati nedostojnim za obavljanje liječničke djelatnosti (ZOL, čl. 8.). Iako zakonodavac nije izričito odredio koja su to kaznena djela za koja se liječnika može proglasiti nedostojnim, iz dosadašnje prakse Časnog suda Komore proizlazi da u obzir dolaze samo kaznena djela koja su počinjena za vrijeme obavljanja liječničke djelatnosti. Ovakav stav ujedno je i logičan ukoliko se uzme u obzir da nedostojnost utvrđuje Hrvatska liječnička komora koja je strukovna organizacija liječnika zadužena, između ostalog, i za brigu o ugledu liječnika te pravilno obavljanje liječničkog zvanja. Nadalje, zakonodavac je također propisao da se liječniku koji je proglašen nedostojnim, može uskratiti davanje odobrenja za samostalan rad (licence) odnosno da mu se licenca može privremeno ili trajno oduzeti kao i da se može ograničiti opseg poslova kojima se liječnik smije baviti. Zakonom je također propisano da se protiv odluke kojom je liječnik proglašen nedostojnim, ne može uložiti žalba već se može pokrenuti upravni spor. S obzirom da bi se tema nedostojnosti liječnika mogla vrlo opširno obraditi u zasebnom stručnom članku, na ovom su mjestu iznesene samo osnovne značajke instituta nedostojnosti liječnika.

Zakonom o dentalnoj medicini propisano je da poslove dentalne medicine obavljaju doktori dentalne medicine i doktori dentalne medicine specijalisti dok djelatnost dentalnih tehničara obavljaju dentalni tehničari prema uputama i nalogu doktora dentalne medicine (članak 36.a stavak 1. ZODM), te dentalni asistenti, također prema uputama i pod nadzorom doktora dentalne medicine (članak 36.n stavak 1. ZODM). S obzirom da doktori dentalne medicine koji neposredno obavljaju djelatnost dentalne medicine, ali i dentalni tehničari te dentalni asistenti, ${ }^{174}$ moraju biti članovi Hrvatske komore dentalne medicine, na njih se primjenjuju odredbe Zakona o dentalnoj medicini kojima je propisana njihova odgovornost kao i odredbe Pravilnika o nadležnosti, ustrojstvu i načinu djelovanja Časnog suda pri Hrvatskoj stomatološkoj komori (www.hkdm.hr). ${ }^{175} \mathrm{Za}$ razliku od Zakona o liječništvu koji je taksativno propisao koja se ponašanja imaju smatrati disciplinskim povredama, Zakon o dentalnoj medicini samo navodi da će se Statutom ili drugim općim aktom Hrvatske komore dentalne medicine odrediti što se 
smatra težom i lakšom povredom pravila ponašanja u obavljanju dentalne medicine, djelatnosti dentalnih tehničara i djelatnosti dentalnih asistenata kao i da će se općim aktom propisati ustrojstvo te način djelovanja Časnog suda pri Komori (članak 51. ZODM). Pravilnikom o nadležnosti, ustrojstvu i načinu djelovanja Časnog suda pri Hrvatskoj stomatološkoj komori ${ }^{176}$ taksativno je određeno koja se ponašanja imaju smatrati težim povredama, a koja lakšim. Tako se težim povredama pravila ponašanja u obavljanju stomatološke djelatnosti imaju smatrati sljedeća ponašanja doktora dentalne medicine: povreda obveze čuvanja profesionalne tajne; povreda obveze čuvanja profesionalne tajne pri čemu je utvrđeno koristoljublje doktora stomatologije (stjecanje financijske koristi, ugleda odnosno znanstvenog ili stručnog naziva i slično); obavljanje stomatološke djelatnosti u suprotnosti s pravilima stomatološke struke slijedom čega dolazi do pogoršanja zdravstvenog stanja ili smrti bolesnika; nepružanje ili odbijanje pružanja hitne medicinske pomoći; primjena postupaka za koje ne postoji odgovarajuća stručnost doktora stomatologije ili koji nisu stručno i znanstveno utemeljeni slijedom čega dolazi do pogoršanja zdravstvenog stanja bolesnika ili nanošenja materijalne štete bolesniku; obavljanje stomatološke djelatnosti bez odgovarajućeg odobrenja nadležnog tijela; pružanje stomatološke usluge po cijeni koja je niža od najniže propisane cijene u Nomenklaturi stomatoloških usluga Komore; oglašavanje rada i isticanje naziva doktora stomatologije na način suprotan aktu Komore; nepridržavanje i neizvršavanje odluka Časnog suda prvog i drugog stupnja; izdavanje lažne potvrde o zdravstvenom stanju bolesnika, osobito ako je vezano uz stjecanje materijalne koristi; primanje mita; spolno iskorištavanje bolesnika koji traži zdravstvenu zaštitu, osobito malodobnih osoba; zlouporaba povjerenja bolesnika koji su u teškom financijskom, zdravstvenom ili psihičkom stanju koje im onemogućava donošenje ispravne odluke; javno iznošenje informacija, navoda i slično, odnosno pokazivanje bolesnika u sredstvima javnog priopćavanja, literaturi ili na drugi način ako se time zlorabi povjerenje i dostojanstvo bolesnika; neodazivanje pozivu za obavljanje stomatološke djelatnosti u slučaju izvanrednih okolnosti; ako je počinjeno kazneno djelo koje dovodi u pitanje dostojnost doktora stomatologije za obavljanje stomatološke djelatnosti (članak 10. Pravilnika o nadležnosti, ustrojstvu i načinu djelovanja Časnog suda pri Hrvatskoj stomatološkoj komori). Pod lakšim povredama pravila ponašanja u obavljanju stomatološke djelatnosti smatraju se sve povrede načela stomatološke etike i deontologije (a koje nisu navedene u katalogu težih povreda) koja su propisana u Kodeksu stomatološke etike i deontologije, a osobito sljedeće: pružanje zdravstvene usluge bez dužnog poštovanja čovjekovog dostojanstva; nepoštivanje prava bolesnika, kolega i ostalih zdravstvenih radnika; nepridržavanje odredaba zakonskih propisa i obveza koje proizlaze iz zakona; odbijanje suradnje, prikrivanje i neprijavljivanje odnosno na bilo koji drugi način omogućavanje rada osobama koje nestručno ili suprotno odredbama zakona obavljaju stomatološku djelatnost; obavljanje stomatološke djelatnosti u suprotnosti s pravilima stomatološke struke; širenje laži i uzrokovanje štete ugledu drugog doktora stomatologije; kršenje pravila Komore; nečasno ponašanje na radnom mjestu (opijanje, uživanje droga i slično); namjerno izbjegavanje sudjelovanja na raspravi pred Časnim sudom Komore; objavljivanje tuđih stručnih radova, rezultata rada i slično, odnosno prisvajanje istih $\mathrm{s}$ namjerom povećavanja vlastitog ugleda; nepodmirivanje troškova postupka određenih u postupku pred Časnim sudom Komore; prešućivanje podataka, informacija ili činjenica koje su bitne u postupku koji se vodi pred Časnim sudom Komore; ponovno činjenje iste 
Prava, obveze i odgovornosti radnika u obavljanju djelatnosti: Odgovornost zdravstvenih radnika i osiguranje od odgovornosti

ili druge povrede pravila ponašanja, ako se o prethodno učinjenoj povredi već vodila rasprava pred Časnim sudom Komore (Članak 11. Pravilnika o nadležnosti, ustrojstvu i načinu djelovanja Časnog suda pri Hrvatskoj stomatološkoj komori). Disciplinske mjere koje se mogu izreći počiniteljima svih gore navedenih disciplinskih povreda također su taksativno određene Pravilnikom o nadležnosti, ustrojstvu i načinu djelovanja Časnog suda pri Hrvatskoj stomatološkoj komori i to su: ukor; javni ukor koji se objavljuje u glasilu Komore; za povrede počinjene objavom u tisku (sredstvima javnog priopćavanja, glasilu Komore i slično) - ispriku oštećenom na način koji je identičan počinjenoj povredi; naknada štete do iznosa visine naknade koju je bolesnik platio doktoru stomatologije za obavljenu stomatološku uslugu; novčana kazna; obvezno podvrgavanje liječenju od ovisnosti; privremena (od šest mjeseci do godine dana) ili trajna zabrana obavljanja stomatološke djelatnosti (članak 13. Pravilnika o nadležnosti, ustrojstvu i načinu djelovanja Časnog suda pri Hrvatskoj stomatološkoj komori). S obzirom da zakonodavac nije odredio visinu novčane kazne koja se može izreći u disciplinskom postupku, Hrvatska komora dentalne medicine to je samostalno odredila tako što je propisala da se za težu povredu pravila ponašanja može izreći novčana kazna u najnižem iznosu od 6.000,00 kn do najviše $30.000,00$ kuna, dok se za lakšu povredu pravila ponašanja može izreći novčana kazna u najnižem iznosu od 1.000,00 kn do najviše $6.000,00$ kn (članak 14. Pravilnika o nadležnosti, ustrojstvu i načinu djelovanja Časnog suda pri Hrvatskoj stomatološkoj komori). Disciplinski postupak Hrvatske komore dentalne medicine provodi Časni sud Komore prvog i drugog stupnja, a stvarna nadležnost i sastav Časnog suda Komore propisana je Pravilnikom o nadležnosti, ustrojstvu i načinu djelovanja Časnog suda pri Hrvatskoj stomatološkoj komori (čl. 4., 8. i 18.). Časni sud Komore prvog i drugog stupnja ima po pet članova. Iako nigdje nije navedeno da Časni sud Komore sudi u vijeću, iz ostalih odredbi Pravilnika o nadležnosti, ustrojstvu i načinu djelovanja Časnog suda pri Hrvatskoj stomatološkoj komori, ipak se može donijeti takav zaključak. Pod istim uvjetima koji vrijede za liječnike, zakonodavac je odredio da se i doktori dentalne medicine te dentalni tehničari također mogu smatrati nedostojnima za obavljanje djelatnosti dentalne medicine odnosno djelatnosti dentalnih tehničara. Od svih zdravstvenih radnika, mogućnost proglašenja nedostojnosti, zakonom je predviđena jedino za liječnike te doktore dentalne medicine odnosno dentalne tehničare. Ostaje nejasno zašto se zakonodavac, kad je u pitanju nedostojnost, odlučio baš za ove dvije profesije, no, s obzirom da će to pitanje vjerojatno ostati bez službenog objašnjenja, preostaju jedino individualne hipoteze o razlozima kojima se u ovim slučajevima rukovodio zakonodavac.

Osnovne odredbe o disciplinskoj odgovornosti magistra farmacije propisane su čl. 36-49. Zakona o ljekarništvu. Kao i kod ostalih do sada opisanih odgovornosti zdravstvenih radnika, i magistri farmacije mogu odgovarati za teže i lakše povrede dužnosti i ugleda ljekarništva pred disciplinskim tijelima Hrvatske ljekarničke komore. Odredbe ZOLJK-a detaljnije su razrađene Pravilnikom o radu i kaznenim mjerama Stegovnog suda Hrvatske ljekarničke komore (www.hljk.hr), a na sva pitanja koja nisu regulirana Pravilnikom, primjenjuju se odredbe kaznenog zakonodavstva. Zakonodavac je propisao da se težim disciplinskim povredama imaju smatrati sva ona ponašanja magistra farmacije koja se odnose na narušavanje dužnosti, ugleda i Kodeksa ljekarničke etike i deontologije, a koja imaju teže značenje s obzirom na ugroženost pacijenta, prirodu povrijeđene dužnosti, 
visinu materijalne štete ili druge posljedice te s obzirom na okolnosti pod kojima je radnja izvršena ili propuštena, dok se lakšim povredama ima smatrati svako narušavanje dužnosti, ugleda i Kodeksa ljekarničke etike i deontologije koje je manjeg značenja (članak 39. ZOLJK). U slučaju odgovornosti za težu disciplinsku povredu, magistru farmacije mogu se izreći sljedeće disciplinske mjere i novčana kazna: opomena koja se objavljuje u glasilu Hrvatske ljekarničke komore; privremeno ili trajno oduzimanje odobrenja za samostalan rad (licence); novčana kazna; upućivanje na dodatno obvezno stručno usavršavanje (članak 40. stavak 2. ZOLJK). Ukoliko se magistra farmacije proglasi odgovornim za lakšu disciplinsku povredu, disciplinsko tijelo Hrvatske ljekarničke komore može mu izreći: ukor; novčana kazna; upućivanje na dodatno obvezno stručno usavršavanje. Iznos novčane kazne odredio je zakonodavac propisavši da se za težu disciplinsku povredu može izreći novčana kazna u iznosu od 3.000,00 $5.000,00$ kn. (članak 40. stavak 1. ZOLJK), dok se za lakšu disciplinsku povredu može izreći novčana kazna u iznosu od 1.000,00 - 2.000,00 kn. (članak 41. ZOLJK). Osim spomenutih disciplinskih mjera i novčane kazne, Pravilnikom o radu i kaznenim mjerama Stegovnog suda Hrvatske ljekarničke komore propisana je i jedna posebna mjera, odnosno mogućnost, i to - Suspenzija, odnosno privremeno oduzimanje odobrenja za samostalan rad (licence) (članak 112. Pravilnika o radu i kaznenim mjerama Stegovnog suda Hrvatske ljekarničke komore). Suspenziju, na prijedlog tužitelja Hrvatske ljekarničke komore, može izreći Stegovni sud prvog stupnja u sljedećim slučajevima: ako je protiv magistra farmacije pokrenut stegovni postupak zbog naročito teške povrede dužnosti i ugleda ljekarničkog zvanja odnosno Kodeksa ljekarničke etike i deontologije; ako je protiv magistra farmacije pokrenut stegovni postupak, a postoji vjerojatnost da bi svojim daljnjim radom ugrozio zdravlje i život korisnika ljekarničkih usluga; ako je protiv magistra farmacije podnesena kaznena prijava zbog kaznenog djela učinjenog na radu ili u vezi s radom; ako je protiv magistra farmacije pokrenut stegovni postupak zbog povrede koje je počinio na radu pod utjecajem alkohola ili opojnih droga. Pravilnikom o radu i kaznenim mjerama Stegovnog suda Hrvatske ljekarničke komore propisana su ponašanja magistra farmacije koja se imaju smatrati povredama zbog kojih je moguće pokrenuti disciplinski (stegovni) postupak (Članak 8. Pravilnika o radu i kaznenim mjerama Stegovnog suda Hrvatske ljekarničke komore). Radi se o ponašanjima koja su protivna pravilima struke farmaceutskog zvanja odnosno koja su protivna odredbama Kodeksa ljekarničke etike i deontologije. ${ }^{177}$ Stegovni sud Hrvatske ljekarničke komore sastoji se od Stegovnog suda prvog i drugog stupnja koji sude u vijećima sastavljenim od predsjednika vijeća i dva člana. Kao i kod disciplinskih tijela Hrvatske liječničke komore, predsjednici Stegovnih sudova prvog i drugog stupnja Hrvatske ljekarničke komore, imenuju se iz redova istaknutih pravnika. Svakako je potrebno naglasiti kako je „kombinirano“ vijeće koje se sastoji od pravnika i predstavnika struke, jamac pravilnog provođenja postupka s obzirom da pravnik profesionalac osigurava pravilnu primjenu propisa dok predstavnici struke osiguravaju pravilnost stručne procjene onih ponašanja koja se, kao disciplinski propust, prijavljenom zdravstvenom radniku stavljaju na teret.

Zakonom o medicinsko-biokemijskoj djelatnosti, odredbama čl. 29.-37., propisana su osnovna pitanja disciplinske odgovornosti medicinskih biokemičara. I medicinski biokemičari također mogu odgovarati za teže i lakše povrede dužnosti i ugleda medicinsko-biokemijske struke pred disciplinskim tijelima Hrvatske komore medicinskih biokemičara. Odredbe ranije spomenutog Zakona o medicinsko-biokemijskoj djelatnosti 
Prava, obveze i odgovornosti radnika u obavljanju djelatnosti: Odgovornost zdravstvenih radnika i osiguranje od odgovornosti

detaljnije su razrađene Pravilnikom o ponašanju i odgovornosti u struci članova Hrvatske komore medicinskih biokemičara (www.hkmb.hr), a na sva pitanja koja nisu regulirana Pravilnikom, primjenjuju se odredbe kaznenog zakonodavstva. Koncept odredbi ZOMBD-a u osnovi je identičan onima iz Zakona o ljekarništvu kojima se regulira disciplinska odgovornost ljekarnika. Dakle, ZOMBD-om propisano je da se težim disciplinskim povredama imaju smatrati sva ona ponašanja medicinskog biokemičara koja se odnose na narušavanje dužnosti, ugleda i Kodeksa medicinsko-biokemijske etike i deontologije koja imaju teže značenje s obzirom na ugroženost pacijenta, prirodu povrijeđene dužnosti, visinu materijalne štete ili druge posljedice te $\mathrm{s}$ obzirom na okolnosti pod kojima je radnja izvršena ili propuštena, dok se lakšim povredama ima smatrati svako narušavanje dužnosti, ugleda i Kodeksa medicinsko-biokemijske etike i deontologije koje je manjeg značenja (Članak 39. Zakona o ljekarništvu). U slučaju odgovornosti za težu disciplinsku povredu, medicinskom biokemičaru mogu se izreći sljedeće disciplinske mjere i novčana kazna: opomena koja se objavljuje u glasilu Komore; privremeno ili trajno oduzimanje odobrenja za samostalan rad (licence) u trajanju do godine dana; novčana kazna; upućivanje na dodatno obvezno stručno usavršavanje; upućivanje na obvezatno liječenje (članak 40. stavak 2. ZOMBD). ${ }^{178}$ Ukoliko se medicinskog biokemičara proglasi odgovornim za lakšu disciplinsku povredu, disciplinsko tijelo Hrvatske komore medicinskih biokemičara može mu izreći: ukor; novčanu kaznu; upućivanje na dodatno obvezno stručno usavršavanje; upućivanje na obvezatno liječenje (članak 30. stavak 1. ZOMBD). Iznos novčane kazne odredio je zakonodavac propisavši da se za težu disciplinsku povredu može izreći novčana kazna u iznosu od 3.000,00 - 5.000,00 kn dok se za lakšu disciplinsku povredu može izreći novčana kazna u iznosu od 1.000,00 - 2.000,00 kn. ${ }^{179}$ Osim spomenutih disciplinskih mjera i novčane kazne, a isto kao i ljekarnicima, i medicinskim biokemičarima Sud komore prvog stupnja može izreći posebnu mjeru, odnosno Suspenziju koja se zapravo odnosi na privremeno oduzimanje odobrenja za samostalan rad (licence) (članak 102. Pravila o ponašanju i odgovornosti u struci članova Hrvatske komore medicinskih biokemičara). Suspenzija se, na prijedlog tužitelja Hrvatske komore medicinskih biokemičara, može izreći u sljedećim slučajevima: ako je protiv medicinskog biokemičara pokrenut postupak zbog naročito teške povrede dužnosti i ugleda zvanja medicinskih biokemičara odnosno Kodeksa etike i deontologije medicinskih biokemičara; ako je protiv medicinskog biokemičara pokrenut stegovni postupak, a postoji vjerojatnost da bi svojim daljnjim radom ugrozio zdravlje i život pacijenta; ako je protiv medicinskog biokemičara podnesena kaznena prijava zbog kaznenog djela učinjenog na radu ili u vezi s radom; ako je protiv medicinskog biokemičara pokrenut postupak zbog povrede koje je počinio na radu pod utjecajem alkohola ili opojnih droga. Pravilima o ponašanju i odgovornosti u struci članova Hrvatske komore medicinskih biokemičara propisana su ponašanja medicinskih biokemičara koja se imaju smatrati povredama zbog kojih je moguće pokrenuti disciplinski (stegovni) postupak (Članak 7. 29. Pravila o ponašanju i odgovornosti u struci članova Hrvatske komore medicinskih biokemičara). Radi se o ponašanjima koja su protivna pravilima struke medicinskih biokemičara odnosno koja su protivna odredbama Kodeksa etike i deontologije medicinskih biokemičara. Sud Hrvatske komore medicinskih biokemičara sastoji se od Suda Komore prvog i drugog stupnja koji sude u vijećima sastavljenima od predsjednika i dva člana. No, za razliku od Časnog i Visokog časnog suda Hrvatske liječničke komore 
te Stegovnog suda Hrvatske ljekarničke komore, predsjednik vijeća Suda Hrvatske komore medicinskih biokemičara nije pravnik.

Odgovornost za teže povrede radnih dužnosti medicinskih sestara propisana je odredbama čl. 18. Zakona o sestrinstvu. Tako je spomenutim Zakonom propisano da medicinska sestra čini težu povredu radne dužnosti ako: zbog nemara ili neznanja nepravilnim postupanjem nanese štetu zdravlju bolesnika; promijeni način i sadržaj od liječnika ordinirane terapije; namjerno prouzroči materijalnu štetu. Kao i u slučajevima odgovornosti ostalih zdravstvenih radnika, i medicinske sestre mogu odgovarati za lakše i teže povrede radnih dužnosti koje su određene ZOS-om i općim aktom Hrvatske komore medicinskih sestara, odnosno Pravilnikom o pravima i odgovornostima medicinskih sestara Hrvatske komore medicinskih sestara (www.hkms.hr). Međutim, u pogledu odgovornosti medicinskih sestara zakonodavac je propisao i jednu specifičnost, odnosno tzv. ekskulpaciju od odgovornosti prema kojoj medicinska sestra neće biti odgovorna za neprovođenje postupaka zdravstvene njege, odnosno za neprovedeni ordinirani postupak u slučaju kada unatoč primjeni najboljeg znanja i vještina, poslodavac nije osigurao ordinirane lijekove, sredstva, minimalno potreban pribor ili tehničku opremu u skladu s minimalnim standardima za provođenje uspješne zdravstvene/sestrinske njege (članak 21. stavak 2. ZOS). Ovakvi izuzeci od odgovornosti propisani su još i ZOP-om, Zakonom o fizioterapeutskoj djelatnosti te ZODUZ-om dok ostali strukovni zakoni ovakve iznimke ne poznaju. Disciplinske povrede za koje medicinska sestra može disciplinski odgovarati pred disciplinskim tijelima Hrvatske komore medicinskih sestara propisane su Pravilnikom o pravima i odgovornostima medicinskih sestara Hrvatske komore medicinskih sestara, a radi se o sljedećim ponašanjima: povredi odredbi ZOS-a; povredi odredbi Etičkog kodeksa medicinskih sestara; nestručnom obavljanju sestrinske djelatnosti; ponašanju prema pacijentu, drugoj medicinskoj sestri ili trećoj osobi koje ima za posljedicu narušavanje ugleda sestrinskog zvanja; neispunjavanju Statutom ili drugim općim aktom članskih obveza prema Komori; počinjenje kaznenog djela koje medicinsku sestru čini nedostojnom za obavljanje sestrinske djelatnosti (članak 5. Pravilnika o pravima i odgovornostima medicinskih sestara Hrvatske komore medicinskih sestara). ${ }^{180}$ Disciplinske mjere koje je moguće izreći medicinskoj sestri koja je proglašena odgovornom, ovise o tome radi li se o težoj disciplinskoj povredi ili o lakšoj. Za teže disciplinske povrede medicinskoj sestri moguće je izreći sljedeće disciplinske mjere i novčanu kaznu: ukor; javni ukor; novčanu kaznu; privremeno oduzimanje odobrenja za samostalan rad (licence) u trajanju od mjesec do godine dana; trajno oduzimanje odobrenja za samostalan rad (licence) (članak 56. stavak 1. Pravilnika o pravima i odgovornostima medicinskih sestara Hrvatske komore medicinskih sestara). Za lakše disciplinske povrede medicinskoj sestri moguće je izreći sljedeću disciplinsku mjeru i novčanu kaznu: opomenu; novčanu kaznu (članak 56. stavak 4. Pravilnika o pravima i odgovornostima medicinskih sestara Hrvatske komore medicinskih sestara). Uz svaku disciplinsku mjeru, osim uz mjeru trajnog oduzimanja odobrenja za samostalan rad (licence), medicinskoj sestri moguće je izreći i mjeru dodatne izobrazbe. Također, mjeru privremenog oduzimanja odobrenja za samostalan rad (licence), moguće je izreći i s rokom kušnje u trajanju od najmanje šest mjeseci do najviše dvije godine. Iako iznos novčane kazne nije određen ZOS-om, Pravilnikom o pravima i odgovornostima medicinskih sestara Hrvatske komore medicinskih sestara propisano je da taj iznos ne 
Prava, obveze i odgovornosti radnika u obavljanju djelatnosti: Odgovornost zdravstvenih radnika i osiguranje od odgovornosti

može biti niži od 1.000,00 kn niti viši od 5.000,00 kn. (članak 56. stavak 7. Pravilnika o pravima i odgovornostima medicinskih sestara Hrvatske komore medicinskih sestara). Sud Komore prvog i drugog stupnja ovlašten je provoditi disciplinski postupak protiv medicinskih sestara. Sudovi sude u vijećima sastavljenima od predsjednika i dva člana no kao član vijeća ne sudjeluje pravnik već su svi članovi vijeća predstavnici struke (članak 6. Pravilnika o pravima i odgovornostima medicinskih sestara Hrvatske komore medicinskih sestara).

Slično kao i za medicinske sestre, odgovornost za teže povrede radnih dužnosti primalja, propisana je odredbama čl. 18. Zakona o primaljstvu. Tako je spomenutim Zakonom propisano da primalja čini težu povredu radne dužnosti ako: zbog nemara ili neznanja nepravilnim postupanjem nanese štetu zdravlju bolesnika; promijeni način i sadržaj od liječnika ordinirane terapije; namjerno prouzroči materijalnu štetu. Kao i u slučajevima odgovornosti ostalih zdravstvenih radnika, i primalje mogu odgovarati za lakše i teže povrede radnih dužnosti koje su određene ZOP-om i općim aktom Hrvatske komore primalja, odnosno Pravilnikom o disciplinskom postupku Hrvatske komore primalja (www.komora-primalja.hr), uz supsidijarnu primjenu Zakona o kaznenom postupku. Međutim, isto kao i kod odgovornosti medicinskih sestara zakonodavac je i u pogledu odgovornosti primalja također propisao tzv. ekskulpaciju od odgovornosti prema kojoj primalja neće biti odgovorna za neprovedeni postupak u slučaju kada unatoč primjeni najboljeg znanja i vještina, poslodavac nije osigurao ordinirane lijekove, sredstva, minimalno potreban pribor ili tehničku opremu u skladu s minimalnim standardima za provođenje primaljske skrbi (članak 21. stavak 1. ZOP). Pravilnikom o disciplinskom postupku Hrvatske komore primalja propisane su teže povrede radnih dužnosti i ugleda primaljstva (članak 5. Pravilnika o disciplinskom postupku Hrvatske komore primalja), osobito teške povrede radnih dužnosti i ugleda primaljstva (članak 6. Pravilnika o disciplinskom postupku Hrvatske komore primalja) te lakše povrede radnih dužnosti (članak 10. Pravilnika o disciplinskom postupku Hrvatske komore primalja). Međutim, spomenutim je Pravilnikom propisano i da će se težom povredom ugleda primaljstva smatrati i ponašanje i postupci te rad primalja u privatnom životu, ako se tim ponašanjem, postupcima i radom narušava ugled primaljstva. Pravilnik precizira da se pod navedenim ponašanjem, postupcima i radom naročito smatraju alkoholiziranost i korištenje droga (članak 9. Pravilnika o disciplinskom postupku Hrvatske komore primalja). Još jedna od specifičnosti disciplinske odgovornosti primalja jest i uvođenje odgovornosti primaljske asistentice koja provodi primaljsku skrb samostalno odnosno bez nadzora primalje, liječnika odnosno specijalista ginekologije i opstetricije (članak 8. Pravilnika o disciplinskom postupku Hrvatske komore primalja). Disciplinske mjere i novčana kazna koja se može izreći primalji za teže disciplinske povrede jesu: ukor; javni ukor; novčana kazna; brisanje iz registra primalja; privremeno oduzimanje odobrenja za samostalan rad (licence) u trajanju od mjesec do godine dana; trajno oduzimanje odobrenja za samostalan rad (licence) (članak 11. Pravilnika o disciplinskom postupku Hrvatske komore primalja). Za lakše disciplinske povrede primalji je moguće izreći: opomenu, novčanu kaznu. Potrebno je primijetiti kako je Pravilnikom o disciplinskom postupku Hrvatske komore primalja također uveden institut nedostojnosti primalje koji nije propisan ZOP-om (članak 11. stavak 2. Pravilnika o disciplinskom postupku Hrvatske komore primalja). Isto tako, spomenutim su Pravilnikom određeni prilično visoki iznosi novčanih kazni pa 
je tako propisano da iznos novčane kazne koji se može izreći u slučaju lakše povrede radnih dužnosti i ugleda primaljstva, ne može biti niži od 1.500,00 kn niti veći od 5.000,00 kn. Za teže povrede radnih dužnosti i ugleda primaljstva, iznos novčane kazne ne može biti niži od $2.500,00 \mathrm{kn}$ niti viši od $15.000,00 \mathrm{kn}$. Za osobito teške povrede radnih dužnosti i ugleda primaljstva može se izreći novčana kazna u rasponu od 5.000,00 kn do 25.000,00 kn. (članak 14. Pravilnika o disciplinskom postupku Hrvatske komore primalja ). Poslovnikom o radu Suda Hrvatske komore primalja (www.komora-primalja.hr) određen je Sud Hrvatske komore primalja kao disciplinsko tijelo koje je nadležno provoditi disciplinski postupak protiv primalja. Sud Komore sudi u prvom i drugom stupnju i to u vijećima koja su sastavljena od tri članice, predstavnice struke.

Disciplinska odgovornost fizioterapeuta propisana je odredbama čl. 18. Zakona o fizioterapeutskoj djelatnosti prema kojemu fizioterapeut čini težu povredu radne dužnosti ukoliko: odbije pružiti pacijentu fizioterapeutsku skrb po uputi liječnika za fizikalnu terapiju; netočno i nepravilno primijeni fizioterapeutske postupke; ne obavijesti liječnika o pogoršanju stanja pacijenta tijekom fizioterapeutskog postupka; ne uputi pacijenta liječniku, kad u okviru fizioterapeutskog postupka ustanovi nalaz koji nije unutar djelokruga fizioterapeutskog znanja; zbog nemara ili neznanja nepravilnim postupanjem nanese štetu po zdravlje pacijenta; primjenjuje metode i tehnike koje nisu u djelokrugu opisa poslova njegovog rada; svojim ponašanjem povrijedi čast i ugled svoje profesije; povrijedi odredbe Zakona o fizioterapeutskoj djelatnosti; povrijedi odredbe Kodeksa fizioterapeutske etike i deontologije. Također, a jednako kao i u pogledu odgovornosti medicinskih sestara i primalja, zakonodavac je i u pogledu odgovornosti fizioterapeuta propisao tzv. ekskulpaciju od odgovornosti prema kojoj fizioterapeut neće biti odgovoran za neprovedeni postupak u slučaju kada unatoč primjeni najboljeg znanja i vještina, poslodavac nije osigurao tehničku opremu, ordinirane lijekove, sredstva i minimalno potreban pribor. Disciplinske povrede koje može počiniti fizioterapeut detaljnije su razrađene odredbama čl. 6.-24. Pravilnika o pravima i odgovornostima fizioterapeuta (www.hkf.hr) te se odredbe toga Pravilnika na odgovarajući način primjenjuju i na odgovornost fizioterapeutskog tehničara kao i na odgovornost maserakupeljara pri čemu se mora uzeti u obzir njihov djelokrug rada (članak 1. stavak 2. Pravilnika o pravima i odgovornostima fizioterapeuta Hrvatske komore fizioterapeuta). Disciplinske povrede koje mogu počiniti fizioterapeuti, fizioterapeutski tehničari te maseri-kupeljari, kao i kod ostalih zdravstvenih radnika, dijele se na teške i lake, a o težini povrede ovisi i težina disciplinske mjere i novčane kazne koja se može izreći. Prema tome, za teške disciplinske povrede može se izreći: opomena koja se objavljuje u glasilu Komore; novčana kazna; privremeno oduzimanje odobrenja za samostalan rad (licence) do godine dana; trajno oduzimanje odobrenja za samostalan rad (licence) (članak 38 . stavak 4. Pravilnika o pravima i odgovornostima fizioterapeuta Hrvatske komore fizioterapeuta). Za lake disciplinske povrede može se izreći: ukor; novčana kazna. Uz svaku disciplinsku mjeru (osim uz mjeru trajnog oduzimanja odobrenja za samostalan rad - licence), može se izreći i mjera dodatne izobrazbe te mjera upućivanja na obvezatno liječenje (članak 38. stavak 3. Pravilnika o pravima i odgovornostima fizioterapeuta Hrvatske komore fizioterapeuta). Slično kao i u Pravilniku o disciplinskom postupku Hrvatske komore primalja, i Pravilnik o pravima i odgovornostima fizioterapeuta Hrvatske komore fizioterapeuta propisuje prilično visok raspon novčanih kazni koje je 
Prava, obveze i odgovornosti radnika u obavljanju djelatnosti: Odgovornost zdravstvenih radnika i osiguranje od odgovornosti

moguće izreći. Tako je Pravilnikom propisano da se za laku povredu može izreći novčana kazna u iznosu od 1.000,00 kn do 3.000,00 kn dok se za tešku povredu može izreći novčana kazna u iznosu od 3.000,00 kn do 10.000,00 kn. (članak 39. stavak 1. Pravilnika o pravima i odgovornostima fizioterapeuta Hrvatske komore fizioterapeuta). Osim spomenutih disciplinskih mjera i novčane kazne, a isto kao i kod ljekarnika te medicinskih biokemičara, Sud komore prvog stupnja može fizioterapeutu izreći i posebnu mjeru, odnosno Suspenziju koja se zapravo odnosi na privremeno oduzimanje odobrenja za samostalan rad (licence) (članak 96. Pravilnika o pravima i odgovornostima fizioterapeuta Hrvatske komore fizioterapeuta). Suspenzija se, na prijedlog tužitelja Hrvatske komore fizioterapeuta, može izreći u sljedećim slučajevima: ako je protiv fizioterapeuta pokrenut postupak zbog naročito teške povrede dužnosti i ugleda zvanja fizioterapeuta odnosno Kodeksa etike i deontologije fizioterapeuta; ako je protiv fizioterapeuta pokrenut postupak, a postoji vjerojatnost da bi svojim daljnjim radom ugrozio zdravlje i život pacijenta; ako je protiv fizioterapeuta podnesena kaznena prijava zbog kaznenog djela učinjenog na radu ili u vezi s radom; ako je protiv fizioterapeuta pokrenut postupak zbog povrede koje je počinio na radu pod utjecajem alkohola ili opojnih droga. Disciplinski postupak protiv fizioterapeuta, fizioterapeutskih tehničara te masera-kupeljara provodi Sud prvog i drugog stupnja Hrvatske komore fizioterapeuta. Sud sudi u vijeću sastavljenom od tri člana, predstavnika struke.

Zakonom o djelatnostima u zdravstvu, odredbama čl. 12.-17., 47.-52. te 65.-71., propisana je disciplinska odgovornost sanitarnih inženjera, stručnih prvostupnika radiološke tehnologije, stručnih prvostupnika radne terapije te stručnih prvostupnika medicinsko-laboratorijske dijagnostike, a odredbe toga Zakona detaljnije su razrađene Pravilnikom o pravima i odgovornostima članova Hrvatske komore zdravstvenih radnika koji se primjenjuje na sve članove Hrvatske komore zdravstvenih radnika (www.hkzr.hr). Prema ZODUZ-a, sanitarni inženjeri, stručni prvostupnici radiološke tehnologije, stručni prvostupnici radne terapije i stručni prvostupnici medicinsko-laboratorijske dijagnostike, čine težu povredu radne dužnosti ako: zbog nemara ili neznanja nanesu štetu korisniku ili bolesniku; svojim ponašanjem naruše ugled struci ili poslodavcu; namjerno prouzroče materijalnu štetu; povrijede dužnost čuvanja profesionalne tajne; ne pridržavaju se mjera zaštite na radu. Međutim, ni sanitarni inženjeri, stručni prvostupnici radiološke tehnologije, stručni prvostupnici radne terapije kao ni stručni prvostupnici medicinskolaboratorijske dijagnostike, neće odgovarati za neprovedeni postupak u slučaju kada korisnik ili bolesnik svjesno odbija primjenu propisanog postupka. Isto tako, navedeni zdravstveni radnici nisu odgovorni niti za neprovedeni postupak u slučaju kada unatoč primjeni najboljeg znanja, poslodavac nije osigurao sredstva, potreban pribor odnosno tehničku opremu neophodnu za rad. Dakle, i ovdje je zakonodavac predvidio iznimke od odgovornosti ove skupine zdravstvenih radnika. Disciplinske povrede za koje mogu odgovarati sanitarni inženjeri, stručni prvostupnici radiološke tehnologije, stručni prvostupnici radne terapije i stručni prvostupnici medicinsko-laboratorijske dijagnostike, mogu biti lakše i teže, a vrsta izrečene disciplinske mjere ovisit će o težini disciplinske povrede. Osim ranije navedenih težih povreda radnih dužnosti, Pravilnikom o pravima i odgovornostima članova Hrvatske komore zdravstvenih radnika propisano je da je član Komore ujedno odgovoran i ukoliko: povrijedi odredbe ZODUZ-a; povrijedi Kodeks etike i deontologije djelatnosti sanitarnog inženjerstva, zdravstveno radiološke- 
tehnološke djelatnosti, djelatnosti radne terapije i medicinsko-laboratorijske djelatnosti te druge opće akte Komore; obavlja nestručno svoju djelatnost odnosno ugrožava zdravlje i život korisnika usluge; svojim ponašanjem prema korisniku usluge, drugom članu Komore ili trećim osobama povrijedi ugled zvanja; ne usavršava se u skladu s Pravilnikom o sadržaju, rokovima i postupku provjere stručnosti Komore; ne ispunjava Zakonom, Statutom ili drugim općim aktom Komore određene članske obveze prema Komori, a što se ne odnosi i na redovito plaćanje članarine Komori (članak 4. Pravilnika o pravima i odgovornostima članova Hrvatske komore zdravstvenih radnika). Za teže povrede dužnosti i ugleda mogu se izreći sljedeće disciplinske mjere i novčana kazna: ukor; javni ukor; novčana kazna; privremeno oduzimanje odobrenja za samostalan rad (licence) u trajanju od mjesec do godine dana; trajno oduzimanje odobrenja za samostalan rad (licence) (članak 56. Pravilnika o pravima i odgovornostima članova Hrvatske komore zdravstvenih radnika). Za lakše povrede mogu se izreći: opomena; novčana kazna. Uz svaku mjeru, osim uz mjeru trajnog oduzimanja odobrenja za samostalan rad (licence), može se izreći i mjera dodatne izobrazbe, a odobrenje za samostalan rad (licenca) također se može i ograničiti s obzirom na opseg i vrstu poslova (članak 56. Pravilnika o pravima i odgovornostima članova Hrvatske komore zdravstvenih radnika). Osim bezuvjetno, mjera privremenog oduzimanja odobrenja za samostalan rad (licence), može se izreći i s rokom kušnje u trajanju od šest mjeseci do dvije godine. Isto tako, Pravilnikom je propisan iznos novčane kazne koji ne može biti niži od 1.000,00 kn niti viši od 10.000,00 kn. (Članak 56. Pravilnika o pravima i odgovornostima članova Hrvatske komore zdravstvenih radnika ). I Hrvatska komora zdravstvenih radnika podzakonskim je propisom uvela tzv. institut nedostojnosti za svoje članove. Sud Komore prvog i drugog stupnja disciplinsko je tijelo Hrvatske komore zdravstvenih radnika koji sudi u vijeću sastavljenom od četiri člana, predstavnika svakog Strukovnog razreda. Zanimljivo je da u radu Suda Komore sudjeluje i pravnik kao pravni savjetnik sudaca, ali on nema pravo glasa.

Disciplinskim mjerama i novčanom kaznom zdravstvenim se radnicima izriče stručni prijekor zbog neodgovarajućeg postupanja učinjenog za vrijeme obavljanja zdravstvene djelatnosti. Dakle, kao profesionalcima im se prigovara što svoj posao nisu obavili stručno niti etički besprijekorno. Za razliku od redovnih sudova gdje suci sude i provode postupak na temelju općih propisa koji jednako vrijede za sve građane, disciplinski postupci kojom se utvrđuje disciplinska odgovornost zdravstvenih radnika, posebna su vrsta postupaka čiji je rezultat, slijedom toga, i posebna vrsta odgovornosti. Takva posebna vrsta odgovornosti pretpostavlja, odnosno trebala bi pretpostavljati s jedne strane, pažnju struke koja je pripremna reagirati svaki put kad je u pitanju neprofesionalno postupanje, a s druge strane, preventivno jamstvo svim osobama kojima se pruža zdravstvena zaštita da će zdravstveni radnici postupati prema svojem najboljem znanju i u skladu s pravilima i etikom vlastite profesije. Povreda pravila profesije u svakom slučaju povlače i disciplinsku odgovornost zdravstvenog radnika. Disciplinski je odgovoran svaki zdravstveni radnik koji se ogriješi na bilo koji način o kodeks profesije, strukovni zakon, koji nestručno obavlja djelatnost profesije, povrijedi ugled profesije, počini kazneno djelo koje ga čini nedostojnim za profesiju itd. Dakle, opis i popis okolnosti koje mogu predstavljati disciplinsku odgovornost je brojan te ne isključuje i druge oblike odgovornosti. Disciplinska odgovornost uz stegovnu odgovornost koju 
ZDRAVSTVENO STRUKOVNO STALEŠKO PRAVO

Prava, obveze i odgovornosti radnika u obavljanju djelatnosti: Odgovornost

zdravstvenih radnika i osiguranje od odgovornosti

može pokrenuti poslodavac prilikom povreda načela radnog mjesta i radnog odnosa predstavljaju zaključni popis vrste i oblika odgovornosti kojima su podložni zdravstveni radnici prilikom obavljanja djelatnosti svoje profesije.

\subsection{Prekršajna odgovornost}

Prekršaji su određene povrede javnog poretka, društvene discipline ili druge društvene vrijednosti koje nisu zaštićene kaznenopravnom prisilom tj. nisu zaštićene Kaznenim zakonom ili drugim zakonima kojima se propisuju kaznena djela. U tom smislu, prekršaji su, prvo, povrede određenih pravnih normi kojima se zabranjuje ili nalaže određeno ponašanje. Prekršaji su ujedno i povrede društvene discipline ili drugih društvenih vrijednosti. Propisivanje određene povrede društvene discipline ili drugih vrijednosti kao prekršaj ima za svrhu otklanjanja mogućnosti ugrožavanja sigurnosti ljudi i imovine, nesmetano obavljanje gospodarskih, kulturnih i drugih društvenih djelatnosti, miran suživot. Obveza poštivanja društvene discipline i drugih društvenih vrijednosti jest obveza koja se mora ispunjavati u civiliziranom i na pravu zasnovanom društvu. Za takva protupravna ponašanja propisuju se i prekršajno pravne sankcije koje se, pod određenim uvjetima izriču počiniteljima prekršaja. ${ }^{181}$

Prekršajna odgovornost je vrsta deliktne odgovornosti liječnika koja proizlazi iz prava građana na zdravstvenu zaštitu u skladu s tzv. zdravstvenim (strukovnim) propisima koji reguliraju obavljanje liječničke djelatnosti i liječničku etiku i deontologiju te obveze liječnika da se pridržavaju tih normi. Kako razvitak medicinske znanosti ima za posljedicu stalnu potrebu pravnog uređenja pojedinih grana i postupaka u medicini, to je danas prekršajna odgovornost propisana s više od dvadeset zakona koji reguliraju zdravstvenu djelatnost i pružanje zdravstvene zaštite. ${ }^{182}$

Prekršajna odgovornost zdravstvenih radnika uređena je odredbama zdravstvenih i strukovnih zakona u kojima su kaznenim odredbama navedena ponašanja koja se smatraju prekršajima i za koje su propisane kazne. Unutar propisa kojima se uređuje ponašanje zdravstvenih radnika prilikom obavljanja svoje profesije te druga prava i dužnosti sadržane su i prekršajne odredbe, a za prekršaje su obično propisane novčane kazne. Za prekršaje mogu biti odgovorne pravne i fizičke osobe. Pravne osobe su zdravstvene ustanove i trgovačka društva koja obavljaju zdravstvenu djelatnost. Fizička osoba koja odgovara za prekršaj je ravnatelj zdravstvene ustanove, privatni zdravstveni radnik, zdravstveni radnik i poslodavac.

Tako je prekršajna odgovornost zdravstvenih radnika propisana kaznenim odredbama: čl. 200-206 ZOZZ-a; čl. 41-42. ZOZPP-a; čl. 58-59. ZOL-a; čl. 51-55. ZOLJK-a; čl. 33. ZOS-a; čl. 65-66. ZODM-a; čl. 33. ZOP-a; čl. 54-58. ZOMBD-a; čl. 32. Zakona o fizioterapeutskoj djelatnosti; čl. 83. ZODUZ-a. Spomenutim sistemskim zakonima za počinjeni prekršaj propisane su, u pravilu, novčane kazne za fizičke osobe i za pravne osobe zbog sljedećih povreda: Za uskraćivanje prava pacijentima-jednakost, slobodan izbor, prvu pomoć i hitnu medicinsku pomoć, informiranje i zdravstvena pouka; Ne osiguravanje hitne medicinske pomoći hitnog prijevoza; Ako započne s radom bez odobrenja ministarstva i komore; Ako prestane obavljati djelatnost bez odobrenja; Ako 
ne primi zdravstvene radnike na pripravnički staž; Ako zdravstvenom radniku ne omogući stručno usavršavanje; Ako protivno odredbama zakona sklopi ugovor sa privatnikom; Ako ne osigura kontinuitet obavljanja zdravstvene zaštite - prijevremeno napuštanje radnog mjesta; Ako dopusti radniku rad izvan punog radnog vremena protivno zakonu; Ako ne provodi unutarnji nadzor nad ustrojbenim jedinicama; Ako onemogući nadzor inspektoratu; Ako ne izvrši mjere koje je inspekcija odredila; Ako ne odredi obdukciju kad se ona mora obaviti; Ako ne postupi po prigovoru kod zaštite prava pacijenta i o tome u roku od 8 dana ga ne izvijesti; Ako ministru jednom godišnje ne podnese izvješće o umrlima u ustanovi i uzrocima njihove smrti; Ako ne obavijesti ministarstvo o nastalim izvanrednim okolnostima kad je ugrožen proces pružanja zdravstvene zaštite ili postoji neposredna opasnost po život i zdravlje osoba; Ako uskraćuje pojedina prava pacijentu određena zakonom; Obavlja zdravstvenu djelatnost za koju nije prijavljen; Obavlja privatnu praksu bez potrebnih odobrenja; Ne obavlja osobno zdravstvenu djelatnost; $\mathrm{Ne}$ osigura zamjenu s ugovorom sa drugim liječnikom; $\mathrm{Ne}$ ispunjava svoje obaveze u svezi pružanja hitne medicinske pomoći i ne podnosi izvješća nadležnoj zdravstvenoj ustanovi i ne daje podatke nadležnim tijelima; Privremeno obustavi rad bez rješenja ministarstva; Obavlja privatnu praksu u djelatnostima u kojima to nije dozvoljeno; Ako bez odobrenja poslodavca sklopi posao iz zdravstvene djelatnosti; Ako ne osigura mjere zaštite na radu i okoliša; Ako ne izvrši obvezu prijavljivanja policiji i državnom odvjetništvu-ozljeda i nasilnih smrti, zapuštanje i zlostavljanje: Ako ne vodi i čuva medicinsku dokumentaciju u skladu s propisima; Ako ne obavijesti drugog liječnika o psihičkom stanju i agresivnosti pacijenta kojega mu upućuje i dr.

\subsection{Odgovornost za rad u timu}

Suvremenu medicinu karakterizira mnoštvo priznatih stručnih oblasti, koje iziskuju specijalizaciju i subspecijalizaciju. Međutim, nasuprot specijalizacije u medicini stoji, ipak, načelna nedjeljivost ljudskog organizma, koja zahtjeva suradnju liječnika različitih struka. Bez te suradnje djelotvorna medicinska pomoć jedva da je još moguća. Predstavnici raznih grana medicine međusobno se dopunjavaju i upućeni su jedni na druge. Liječnici pojedinih struka rade sve više zajedno, kao jedan tim koji opslužuje istog pacijenta. ${ }^{183}$ Znanstveno-tehnološki razvitak medicine nametnuo je liječnicima strategiju timskog rada te je današnja medicina nezamisliva bez zajedničkog rada liječnika različitih specijalizacija i subspecijalizacija. ${ }^{184}$ Kaznena, kao i građanska odgovornost liječnika posebno se komplicira u slučajevima tzv. timskog rada, ${ }^{185}$ jer timski rad ispravlja, ali i kumulira greške. ${ }^{186}$

Zdravstveni tim jezgra je odnosno temelj pružanja zdravstvene zaštite svakom pojedincu korisniku zdravstvenih usluga, pacijentu. Zdravstveni tim čini u pravilu više osoba, zdravstvenih radnika zavisno od činjenice koje je djelatnosti, odnosno poslove pojedinih djelatnosti potrebno poduzeti radi pružanja i davanja konkretne zdravstvene usluge primatelju. Dakle sastav tima ovisi o vrsti i obliku zdravstvenih postupaka koje je potrebno poduzeti prema korisniku usluge. Uloga pojedinih zdravstvenih radnika koji taj isti tim čine je trebala bi biti jednostavna: obaviti svoj dio posla. Međutim može se s druge strane postaviti pitanje koji dio posla, te što se sve podrazumijeva ili zahtjeva pod sintagmom „svog dijela posla“. Mišljenje je da predmetno ne bi trebalo predstavljati 
Prava, obveze i odgovornosti radnika u obavljanju djelatnosti: Odgovornost zdravstvenih radnika i osiguranje od odgovornosti

problem obzirom da bi svaki pojedini zdravstveni radnik u timu trebao biti zadužen za dio posla koji obuhvaća i odnosi sa na djelatnost profesije koju on predstavlja i čiji je on pripadnik. Djelatnosti i poslovi profesija definirane su kako je već navedeno jasnim utvrđenjima koja polaze od pretpostavljenih: definicija djelatnosti koje su predmetne profesije ovlaštene poduzimati; ishodima učenja, tj. kompetencijama pripadnika zdravstvenih profesija nakon završenog zdravstvenog obrazovanja; potvrdom stručnog osposobljavanja; kontinuitetom trajnog usavršavanja te posjedovanja odobrenja za samostalan rad (licence). ${ }^{187}$

Kada govorimo o međusobnom odnosu zdravstvenih radnika, prvenstveno se misli na činjenicu da se zdravstvena djelatnost većinom obavlja u timskom radu. ${ }^{188}$ Zdravstveni tim čini više zdravstvenih radnika iz pojedinih zdravstvenih djelatnosti, a što naravno, ovisi o vrsti zdravstvene usluge koja se pruža pacijentu u konkretnom slučaju. U zdravstvenom timu raspodjela poslova, a s tim u vezi i odgovornosti svakog pojedinog zdravstvenog radnika, ne bi trebala predstavljati problem. Autonomija je zdravstvenom radniku omogućena na temelju licence odnosno Odobrenja za samostalni rad koju mu je izdala nadležna komora. Zdravstveni tim uvijek mora imati jasno definirane granice posla i odgovornosti svakog pojedinog zdravstvenog radnika. Član tima ne može i ne smije biti odgovaran za postupke ostalih članova tima. Stoga se granice odgovornosti, kao i sadržaja njihovog posla u timu, moraju odrediti. Naravno da je problem tim veći što među zdravstvenim radnicima može doći do kolizije i preklapanja kompetencija, postupanja prema nalozima ili zahtjevima drugog zdravstvenog radnika, te u situacijama kada se naslanjaju na pogreške ili štete prilikom prethodno učinjenih štetnih radnji (primjer, odstranjenje zdravog organa na temelju pogrešnog nalaza). Od podjele rada ili funkcija pri timskom liječenju koristi, svakako ima pacijent, ali istovremeno ta podjela može prouzročiti značajne rizike za pacijenta zbog nedostatka koordinacije, komunikacije ili informacija unutar samoga tima. Tako, tipični rizici mogu nastati zbog nedovoljne kvalifikacije i iskustva pojedinih članova tima, zbog nedovoljne komunikacije i suradnje među njima, zbog neusklađenosti poduzetih mjera i nedostataka u razgraničenju nadležnosti članova tima, a također, mogući su i propusti u organizaciji u smislu sigurnosti i kontrole. ${ }^{189}$

Svaki liječnik snosi sam odgovornost za sve zadatke koji su mu na temelju obrazovanja ili funkcije povjereni da ih samostalno obavlja. ${ }^{190}$ Nitko ne bi smio odgovarati za posao i propuste drugog zdravstvenog radnika koji je počinio štetu već bi za štetu trebao odgovarati samo onaj član tima koji ju je i prouzročio. Riječ je na neki način o podjeli odgovornosti u slučaju nepravilnoga medicinskog postupka, o utvrđivanju udjela odgovornosti svakoga pojedinog sudionika u postupku. Kad se govori o timskom radu medicinskih djelatnika, onda to nije samo rad u bolnicama i klinikama već i ambulantna djelatnost, kad u medicinskom postupku oko bolesnika sudjeluje više medicinskih djelatnika raznih struka. S porastom broja članova tima povećava se rizik pogrješke, jer ako pogriješi jedan član tima postoji realna mogućnost da učinjena pogrješka može utjecati na rad drugog člana drugih članova tima. Načelno, u timskom radu postoji mogućnost da se učinjena pogrješka ispravi, ali isto tako da jednu pogrješku slijedi druga ili druge. Kad je riječ o timskom radu, za utvrđivanje odgovornosti načelno vrijedi postulat pojedinačne odgovornosti, a ne odgovornosti svih sudionika u medicinskom 
postupku. Ovo je moguće ako su točno određeni zadatci i nadležnost svakoga člana liječničkog tima, ali zbog specifičnosti medicinske struke ovo nerijetko nije moguće. Zbog ove je činjenice i u medicinskoj i u pravnoj struci opće prihvaćen pojam tzv. ograničene odgovornosti. ${ }^{191}$

Dakle jasno je da liječnik ne može i ne smije, tj. liječnik nije dužan a ni ovlašten obavljati posao drugog zdravstvenog radnika u timu. Svaki zdravstveni radnik ima ovlaštenje obavljati samostalno svoj dio posla u sustavu zdravstvene djelatnosti. Ako je ovlašten za predmetni posao, a ovlaštenje crpi iz sadržaja odobrenja za samostalan rad, ujedno je obvezan obaviti stručno i profesionalno isti posao sukladno pravilima i standardima profesije i zakonitostima predmetne djelatnosti. ${ }^{192}$ Odobrenje za samostalan rad formalna je potvrda kojom se dokazuje da je pojedini zdravstveni radnik ovlašten samostalno obavljati zdravstvenu djelatnost. Osim toga ona je dokument koji u sadržajnom smislu jasno propisuje zdravstvenom radniku koja ovlaštenja imenovani ima, te koje je poslove ovlašten, ali i dužan obavljati u procesu pružanja zdravstvene zaštite. Svaki zdravstveni radnik i unutar zdravstvenog tima temeljem svog odobrenja za samostalan rad zna svoju ulogu i kroz nju poslove koje je zadužen samostalno obaviti. ${ }^{193}$ Zdravstveni tim ima i mora imati, obzirom da ga čini više osoba, definirane odnose između pripadnika tima. U pravilu su to odnosi usmjeravanja i koordinacije od i između pojedinih pripadnika prema drugima kako bi se uspostavila suradnja te adekvatno prihvatila uloga svakog u obavljanju svog samostalnog dijela posla. Upravljački element uvijek dolazi od liječnika koji je u timu odgovoran obavljati prethodno navedene poslove usmjeravanja, koordinacije poslovanja tima i predstavnika tima. Dakle liječnik kreira zadatke, posreduje u obavljanju pojedinih elemenata poslovnog procesa, koordinira aktivnosti unutar poslovanja tima. Tu počinje i prestaje uloga liječnika u odnosima sa drugim zdravstvenim radnicima u timu. Naravno da liječnik osim navedenog obavlja i konkretni posao iz liječničke djelatnosti koji se odnosi ne neposredno pružanje dijela zdravstvene zaštite, kao i što pripadnici drugih profesija kao članovi tima obavljaju svoj dio posla djelatnosti svoje profesije u pružanju zdravstvene zaštite korisniku zdravstvene usluge.

Sa svakim timskim radom povezani su, naime, tipični rizici suradnje. Ti rizici mogu proistjecati iz nedostajuće kvalifikacije i iskustva pojedinih suradnika, iz nedovoljne komunikacije i suradnje, i iz nepotpune usklađenosti poduzetih mjera. Osim toga, mogući su i propusti u organizaciji, tako da se njome ne garantiraju ni sigurnost ni kontrola. Greške koje otuda nastaju mogu se sistematski opisati kao: 1) nedostaci u komunikaciji; 2) nedostaci u koordinaciji; 3) nedostaci u kvalifikaciji; i 4) nedostaci u razgraničenju nadležnosti. Sa porastom broja osoba koja su u konkretnom slučaju uključena u skrb o pacijentu, razjedinjenost među njima biva veća, pa se zato i povećava rizik od grešaka. Stoga se neminovno postavilo pitanje: postoji li pored odgovornosti svakog liječnika zbog vlastitih grešaka i odgovornost zbog grešaka ostalih sudionika, tj. suodgovornost. U načelu, na to pitanje slijedi negativan odgovor. Smatra se da bi bilo nepodnošljivo i nesvrsishodno ako bi svaki od sudionika odgovarao uvijek zbog nepropisnog postupka i nepažnje svakog drugog sudionika, tj. ako bi među njima postojala solidarna odgovornost. Ipak, ima mjesta ograničenoj solidarnoj odgovornosti pojedinca za cjelinu skrbi o pacijentu. Pri utvrđivanju granica te odgovornosti vodi se računa da ona bude razumna i podnošljiva za liječnike, ali da se u istovremeno jamči i potrebna sigurnost 
ZDRAVSTVENO STRUKOVNO STALEŠKO PRAVO

Prava, obveze i odgovornosti radnika u obavljanju djelatnosti: Odgovornost zdravstvenih radnika i osiguranje od odgovornosti

pacijenta. Takvo ograničenje odgovornosti danas je općeprihvaćeno i u medicinskoj i u pravnoj znanosti. Ono se postiže pomoću dva mjerila: načela striktne podjele rada u medicini i načela povjerenja. ${ }^{194}$

U međusobnim odnosima liječnika koji su članovi jedne ekipe uspostavljaju se odnosi između liječnika koji ima ovlaštenje i odgovornost rukovoditelja ekipe i ostalih članova tima. Rukovoditelj radne grupe, bez obzira je li šef ekipe odnosno tima ili predsjednik komore ili nekog radnog tijela ima zadatak rukovoditi grupom i odgovara za njezin i svoj rad i odluke. Rukovoditelj ekipe odgovara i za način i obim rada koji je povjerio suradnicima, a svaki član grupe je osobno odgovoran za svoj rad u grupi. Član jednog tima u tijeku pružanja medicinske usluge može biti i liječnik na specijalizaciji, bez obzira je li u radnom odnosu u toj zdravstvenoj ustanovi ili ne. U tom slučaju uspostavljaju se i odnosi između liječnika koji ima funkciju mentora u stjecanju specijalističkog obrazovanja specijalizanta i između liječnika koji rukovodi radom ekipe (tzv. ovlašteni liječnik) i liječnika - specijalizanta ukoliko on sudjeluje u procesu liječenja u praktičnom dijelu svoje specijalističke obuke. Liječnik na specijalizaciji je zbog nedostatka u znanju i vještini pod stručnim nadzorom starijeg kolege specijaliste - kao mentora i kao ovlaštenog liječnika. U tom međusobnom odnosu liječnika, onaj koji rukovodi u domenu stručnog rada prenosi stečena znanja i vještine i usmjerava i kontrolira rad specijalizanta. ${ }^{195}$

Prva činjenica za utvrđivanje odgovornosti u timskom radu je načelo striktne podjele rada, pri čemu se razlikuje horizontalna i vertikalna podjela rada. Primjer horizontalne podjele rada je slučaj kad dva ili više liječnika raznih specijalizacija ravnopravno sudjeluju u medicinskom postupku. U ovom je slučaju svaki liječnik nadležan u području svoje struke. Međutim, problem utvrđivanja odgovornosti može nastati zbog činjenice što nerijetko postoji „preklapanje“ pojedinih medicinskih struka, što omogućuje nastanak propusta u liječenju. U takvom slučaju može biti teško utvrditi u čijoj je domeni rada došlo do propusta. Druga činjenica utvrđivanja odgovornosti u timskom radu osniva se na načelu povjerenja, što se poglavito odnosi na spomenutu horizontalnu podjelu rada. Osnova je ovog načela da sve svatko „tko sudjeluje u medicinskom tretmanu nad istim pacijentom može pouzdati u to da svi ostali učesnici svoje zadatke izvršavaju znalački i s dužnom pažnjom“ jer bi u suprotnom nastali veliki problemi u liječenju bolesnika. ${ }^{196}$

U međusobnoj komunikaciji liječnika - rukovoditelja ekipe i njegovih suradnika i liječnike na specijalizaciji, ${ }^{197}$ on ima zadatak i dužnost pratiti rad svojih suradnika i nastojati otkloniti njihove propuste ili eventualne stručne greške u dijagnostičkim ili terapijskim postupcima. Ako je nastao propust u dijagnosticiranju ili liječenju, i on bude otkriven, on je dužan bez odlaganja poduzeti potrebne mjere i provesti odgovarajuće postupke u odnosu na druge liječnike koji sudjeluju u procesu dijagnosticiranja ili liječenja i u odnosu na samog pacijenta kome treba pružiti i stručnu i moralnu pomoć. Liječnik koji rukovodi ekipom u pružanju zdravstvene usluge izdaje naloge u pogledu izvršenja pojedinih zadataka ili radova. Članovi ekipe dužni su postupati po dobivenim instrukcijama ili nalozima. Odbijanje izvršenja određenih radova i poslova moguće je samo kad je očigledno da su u suprotnosti s medicinskom etikom. Rukovodeći liječnik je dužan da vodi računa o mišljenjima koja imaju članovi njegove ekipe. Ukoliko se radi o 
nejasnim ili spornim slučajevima, on je dužan članovima svog tima saopćiti međusobno suprotstavljena mišljenja kako bi se nastalo neslaganje u tijeku pružanja zdravstvene usluge eliminiralo na odgovoran način. Između liječnika različitih specijalnosti uspostavlja se međusobna komunikacija u procesu dijagnosticiranja ili liječenja, kako u okviru jedne zdravstvene ustanove, tako i izvan nje. Međusobna komunikacija se uspostavlja da bi se izbjegle moguće stručne greške u dijagnosticiranju i liječenju. Iz tog razloga ordinirajući liječnik dužan je, ako su ispitivanja ili liječenje iznad njegovih profesionalnih ili iskustvenih mogućnosti, ili mu je potrebna stručna pomoć, od drugog liječnika odgovarajuće specijalnosti koji posjeduje odgovarajuće stručno znanje ili odgovarajuće sposobnosti i iskustvo zatražiti stručnu pomoć. Mišljenje liječnika specijaliste kome se liječnik obrati za pomoć ima karakter savjeta, tako da je za postupak daljeg liječenja odgovoran ordinirajući liječnik. ${ }^{198}$

Dužnosti proizlaze iz samog ovlaštenja koje ima svaki zdravstveni radnik u svom segmentu obavljanja zdravstvene djelatnosti. Shodno navedenom svaki zdravstveni radnik ima i odgovornosti da će se predmetni posao obaviti u skladu s ovlaštenjima i dužnostima koja proizlaze iz statusa profesije kojoj pripada, i temeljem toga položaja radnog mjesta kojeg ima svaki pojedini radnik unutar tima. Taj element odgovornosti dio je ukupne dužnosti poslovanja cijelog tima da će se pružiti adekvatna zdravstvena zaštita, odnosno obaviti određeni medicinski postupak, tj. pružiti usluga korisniku. Međutim, istovremeno isti element odgovornosti zaseban je u svojem subjektivitetu i odnosu prema zdravstvenom radniku na kojeg se odnosi. Dakle svaki zdravstveni radnik osobno je odgovoran u okviru i opsegu svog dijela posla u zdravstvenom timu. Odgovornost i dužnost je subjektivna tj. individualna, ovisna o postupanju i shvaćanju pojedinca, te odnosu pojedinca prema samom djelu, odnosno poslu koji obavlja ili je trebao obaviti. Nitko drugi ne može i ne smije biti odgovoran za element posla koji proizlazi iz ovlaštenja samostalnog obavljanja određene aktivnosti od strane pojedinog zdravstvenog radnika unutar tima. Ni zdravstveni radnik koji je u organizacijskom smislu zadužen za koordinaciju i usmjeravanje članova tima ne može odgovarati za pogrešku pojedinog zdravstvenog radnika koja proizlazi iz ovlaštenja samostalnog obavljanja rada. Time bi se kršila načela samostalnog obavljanja rada i samostalnosti svake profesije i svakog pojedinog zdravstvenog radnika pa makar svoje poslove oni koordinirano obavljali u timu. Osoba koja je nositelj zdravstvenog tima, u pravilu liječnik, nije odgovoran za propuste i pogreške koje učini drugi zdravstveni radnik u okviru svog ovlaštenja. Takav zdravstveni radnik i ne smije ugroziti načelo samostalnosti obavljanja poslova pojedine djelatnosti iz profesije kojoj određeni zdravstveni radnik pripada. On može i treba usmjeravati, nadzirati i koordinirati rad pojedinih članova tima, i tu počinje i prestaje njihov međusobni odnos. U tom slučaju može odgovarati samo za pogreške koje proisteknu iz propusta koordinacije i usmjeravanja, ali nikako ne bi smio odgovarati za štete koje proiziđu iz okvira i sadržaja samostalnog obavljanja djelatnosti drugih pripadnika zdravstvenih profesija. ${ }^{199}$

Kod pozivanja na odgovornost kod štete nedvojbeno je bitno utvrditi da je nastala šteta, da je nastala nekom, primatelju usluga, da je postupao pri tom zdravstveni radnik, da je postupao s krivnjom, da je njegovo djelovanje bilo protupravno te da je postojala uzročno posljedična veza između postupanja zdravstvenog radnika i štete. Ali u svemu ovdje je 
Prava, obveze i odgovornosti radnika u obavljanju djelatnosti: Odgovornost zdravstvenih radnika i osiguranje od odgovornosti

bitno utvrditi i dodatni element a to je da je da postoji šteta koja je isključivo i neposredno vezana za konkretno postupanje baš tog zdravstvenog radnika. Naime u zdravstvenom timu više zdravstvenih radnika obavlja djelatnost u segmentu svog odobrenja za samostalan rad i u okviru tog i tim zadanih poslova. Šteta ili posljedica kaznenog djela, odnosno bilo kojeg protupravnog ponašanja može nastupiti kao rezultat rada tima, te pogreškom postupanja jednog, svih ili nekolicine članova tima. Pogreška jednog, nekolicine ili svih članova tima mora se jasno kao takva utvrditi na način da se prije svega utvrde i odrede uzročno posljedične okolnosti. Međutim ni to neće biti dovoljno da se jasno utvrde granice odgovornosti pojedinih zdravstvenih radnika u posljedici pogreške rada tima. Tim više što pogreške rada tima i članova unutar tima mogu biti provocirane prethodnim ili istovremenim pogrešnim radom drugog člana tima. Drugi zdravstveni radnik nije kompetentan niti sposoban sagledati i uvidjeti pogrešku drugog člana tima jer za isti nije ili educiran, ili nema kontrole nad istima, ili je to izvan njegovog ovlaštenja temeljenog na odobrenju za samostalan rad. U takvim situacijama naslanjanje rada pojedinog zdravstvenog radnika na prvotno počinjenu pogrešku prethodnog člana tima rezultira slaganjem pogrešaka domino efektom i nedvojbeno konačno štetom, odnosno protupravnim djelom. Stoga je opravdano pitati je li netko drugi mogao i je li morao ili smio sagledati posljedice pogrešnog rada njegovog prethodnika. Jednako tako opravdano je pitati je li kao takav može i treba odgovarati, i radi li se uopće o krivnji konkretnog zdravstvenog radnika ili se isto može prihvatiti kao slučaj odnosno okolnost na koje isti nije mogao ni na koji način utjecati. Stoga je jedino prihvatljivo u okolnostima nastanke štete ili povrede propisanog dobra utvrđivati u timskom radu odgovornost svakog pojedinog zdravstvenog radnika na osnovu obavljanje djelatnosti za koju je on zadužen te utvrđivati elemente štete $\mathrm{i}$ granice odgovornosti za istu temeljem sagledavanja svih aspekata obavljanja pojedine zdravstvene djelatnosti od strane svakog pojedinačnog zdravstvenog radnika pripadnika zdravstvenog tima. Pravo je konkretno, norma je jasna po predmetnom. Ista u građanskom pravu glasi za štetu: odgovara onaj tko je počinio, ako je više osoba zajednički počinilo istu štetu odgovaraju solidarno. U slučaju kaznene odgovornosti postoji počinitelj kaznenog djela odnosno supočinitelji ako zajedno obavljaju radnju ili ako na drugi način pridonese počinjenu kaznenog djela, tj. pogreške. Kod zdravstvenog radnika i zdravstvenog tima navedeno bi u postupcima odgovornosti za štetu značilo da će zdravstveni radnik odgovarati za štetu koju je nedvojbeno počinio samo u slučaju namjernog postupanja ili postupanja iz krajnje nepažnje, jer u protivnom odgovara poslodavac ako je šteta nastupila u svezi s radom i obavljanjem profesije. Isto je jasno kad u postupke nije involviran tim, odnosno više osoba ovlaštenih zdravstvenih radnika. Sad se može i treba postaviti logično pitanje je li zdravstveni radnici u timu obavljaju zajednički posao, je li to isti posao. Nesustavnim teorijskim i neanalitičkim pristupom moglo bi se potvrdno odgovoriti. Međutim jednako tako s druge strane se može postaviti pitanje je li se može bez dvojbe tvrditi da je posao liječnika i medicinske sestre u svojoj strukturi i sadržaju isti. Rezultati i očekivanje predmetnih poslova obaju zdravstvenih radnika je pružena konačna usluga pacijentu, dakle izlječenje. Ali u tom poslovanju i međuodnosu liječnik obavlja liječničku djelatnost koja je zasnovana na posebnim zakonskim utvrđenjima te standardima i pravilima struke, dok medicinska sestra obavlja djelatnost sestrinske profesije koja je zasnovana na svojim posebnim kriterijima i zakonitostima. Dakle posebitosti profesija, poglavito ako se radi o reguliranim profesijama kao što su liječničke i sestrinska moraju biti jasno vrednovane 
kod utvrđivanje ovlaštenja i odgovornosti. Nezanemariva činjenica je standard posjedovanja odobrenja za samostalan rad koji imaju i liječnici i drugi zdravstveni radnici, a koji omogućava i obvezuju pojedinog zdravstvenog radnika da samostalno obavlja svoj dio posla, dio posla svoje profesije u pružanju zdravstvene zaštite te ostvarivanju rezultata pružene zdravstvene usluge, odnosno izlječenja pacijenta. Cilj i potreban rezultat može i treba biti isti svim zdravstvenim radnicima u timu, kao što treba i građevinaru i arhitektu cilj biti isti a to je izgradnja potrebne zgrade, dok su njihovi poslovi u ostvarenju istog cilja sasvim različiti i posebni te nose posebne odgovornosti i ovlaštenja. Stoga je i kod odgovornosti za štetu zdravstvenog radnika dvojben pristup isključive solidarne odgovornosti, kolektivne kaznene odgovornosti ili s druge strane, isključive zapovjedne odgovornosti samo liječnika, pa svakog radnika i odgovornost treba promatrati u ovitku njegovog ovlaštenja i postupanja. Možda i ovakav stav ne bi bio problematičan niti dvojben kad bi granice postupanja, a samim tim i ovlaštenja i odgovornosti, bilo jednostavnije procesno utvrditi. Problem nastupa u slučajevima: a) kolizija i preklapanja kompetencija zdravstvenih radnika, b) postupanja prema nalozima ili zahtjevima drugog zdravstvenog radnika, te c) u situacijama kad se naslanjaju pogreške ili štete prilikom prethodno učinjenih štetnih radnji (npr. odstranjenje zdravog organa na temelju pogrešnog nalaza). Kolizije i preklapanja kompetencija nisu slučajnost u odnosima među zdravstvenim radnicima. Nedosljednost zakonskih utvrđenja, nepostojanost jasnih smjernica struke, te zastarjelost državnih administrativnih propisa uzrokuju sustavno i kontinuirano preklapanje poslova pojedinih zdravstvenih radnika. Postupanja prema nalozima i zahtjevima nadređenih zdravstvenih radnika, često dijeljena usmenim putem dovode do propusta u obavljanju potrebnih poslova, kao i delegiranje poslova ili provociranje poslova na zamolbu ne mogu utvrditi jasnu odgovornost određenog zdravstvenog radnika.

Situacija prethodnih grešaka stvaraju lanac pogrešnih radnji i postupanja što rezultira krajnjom nepopravljivom pogreškom i štetom. Tko je ,glavi krivac“, odnosno je li naknadni poduzimatelj radnji koji je svoje poslove poduzeo vjerujući u stručnost i profesionalnost postupaka prethodnika, isto tako štetnik i odgovoran za štetu ili pak supočinitelj kaznenog djela, odgovor je u procesno pravnom smislu teško dati. Dakle, zaista je teško utvrditi granice odgovornosti pojedinog zdravstvenog radnika u timu, a još teže je ići linijom manjeg otpora te u predmetnim slučajevima primjenjivati nekritički načelo solidarne odgovornosti kod šteta ili supočiniteljstva kod kaznenih djela. Zdravstveni tim u sadržajnom smislu nesporno uvjetuju postupanja pojedinih zdravstvenih radnika, što posredno utječe na zaduženje tima u cjelini a posebno pojedinaca unutar tima. Je li moguće zdravstvenog radnika gledati kao posebnost i izdvojiti njegovo (ne) postupanje izvan okvira timskog rada. U načelu bez analitičkog pogleda na predmetnu problematiku ne, ali praktično da, jer svaki pojedinac obavlja svoj posao za koji je vlastito odgovaran i ovlašten, a što se reflektira na tim kao cjelinu i mehanizam kroz koji se ukupnošću pojedinačnih poslova i međuodnosa različitih čimbenika stvara i projicira adekvatna i potrebna zdravstvena usluga. Potrebno je dakle $\mathrm{u}$ istom postupku utvrditi kako ovlaštenja tako i odgovornosti za postupanja svakog pojedinog zdravstvenih radnika u čemu svakako treba sagledavati, te uzimati u obzir čimbenike "zajedničkog rada" ali samo kao rezultata istih djelovanja. Utvrditi jasne granice (početak i kraj) gdje počinje ili gdje završava odgovornost postupanja pojedinog 
zdravstvenog radnika unutar tima ostat će i nadalje problem različitih teorijskih rasprava i projekcija. Ali jedno treba biti jasno da nije logično moguće niti zakonski opravdano za (ne) postupanje zdravstvenog radnika utvrđivati odgovornost drugog ili svih. Formalizacija i kogentnom normom usiljeno stvaranje i projiciranje odgovornosti i odgovornih osoba po položaju i statusu ne može biti opravdanje za naknadu prouzročenih šteta, ili saniranje pogrešaka. Svaki zdravstveni radnik treba preuzeti svoj element ovlaštenja, obveza i odgovornosti slijedom svojih kompetencija, stručne osposobljenosti te poglavito ovlaštenja i dužnosti proisteklih iz odobrenja za samostalan rad (koji jasno može oslikati sadržaj, vrste i obim odgovornosti) i standarda profesije, a sustav poglavito onaj represivni treba prepoznavati zdravstvenog radnika kao pojedinca, čimbenika i subjekta unutar tima. ${ }^{200}$

U slučajevima subordinacije otvara se pitanje postupanja prema uputama odnosno pitanje odgovornosti za provedbu pogrešne upute ili za odstupanje od upute. Uz odgovornost liječnika nužna je i odgovornost drugih zdravstvenih radnika, onih koji obavljaju određene poslove prema uputi i pod nadzorom pojedinaca koji samostalno obavljaju poslove zdravstvene zaštite. Zbog prihvaćenog načela da svatko odgovara za svoju radnju i u granicama svoje krivnje, postupanje prema uputi ne isključuje odgovornost u slučaju kad je uputa očigledno nepodobna ili pogrešna. Dvojba između poslušnosti i pameti podređenoga u hijerarhijskim odnosima rješava se postavljanjem određene granice koja važi zbog načela povjerenja i uzajamnog pouzdanja, pa se poslušnost zahtijeva sve dok ne postoje znakovi da se odstupa od standarda struke. ${ }^{201}$

\subsection{Zaključak}

Odštetna odgovornost zdravstvenih radnika determinirana je veličinom rizika koji nosi ta profesija, jer je zdravstvena djelatnost, unatoč temeljnom humanom i plemenitom cilju da se pacijentu očuva ili popravi zdravstveno stanje, ponekad neizbježno povezana $\mathrm{s}$ rizikom gubitka života ili pogoršanja zdravlja. ${ }^{202}$

Iako se navedene vrste odgovornosti preklapaju, nužno je izbjeći dvostruko kažnjavanje liječnika. Nadalje odgovornost zdravstvenog radnika pokriva odgovornost za vlastito ponašanje. Svi oblici odgovornosti jasno se razlikuju kako s aspekta materijalnog, tako i $\mathrm{s}$ aspekta procesnog prava. Iz navedenih razlika proizlaze i mnoge različitosti koje se odnose na vođenje procesa i samu poziciju zdravstvenog radnika unutar procesa. Poznavanje postojećih razlika ključno je za razumijevanje cjelokupnog procesa, te ih zdravstveni radnik u osnovnim crtama mora poznavati kako bi u nekoj eventualnoj budućoj situaciji/pravnoj stvari mogao bolje razumijevati, pratiti te unaprijediti svoj položaj.

U suvremenoj medicinskoj praksi sve se više uvode tzv. algoritmi rada (ili protokoli liječenja) kojima se detaljno normiraju pojedini dijagnostički, terapijski i rehabilitacijski postupci, koji se moraju uzeti u obzir pri ocjeni je li došlo do odstupanja od medicinskog standarda u određenom medicinskom zahvatu. ${ }^{203}$ Protokoli liječenja su propisane obvezne mjere i postupci za određene vrste bolesti koje liječnik treba provesti, a osiguravaju da svaki zdravstveni radnik koji po njima postupa može pokazati i dokazati 
da je uradio sve što predviđa suvremena medicina (znanost i praksa) i najbolja domaća i svjetska iskustva. Pridržavanjem protokola liječenja zdravstveni radnik ne može napraviti stručnu pogrešku jer je postupao savjesno i s dužnom pažnjom, u skladu s pravilima struke. S druge strane protokoli liječenja jamče pacijentima liječenje po medicinskim standardima i u skladu s najboljom medicinskom praksom. ${ }^{204}$

Osnovna je svrha kaznene i prekršajne odgovornosti kazniti počinitelje i spriječiti činjenje kaznenih djela ili prekršaja, dok je zadaća disciplinske odgovornosti prvenstveno zaštiti ugled i dostojanstvo liječnika, te očuvati uredno i učinkovito obnašanje liječničke djelatnosti. Dakle, jedan od bitnih ciljeva procesuiranja pri odgovornosti za liječniku grešku je i prevencija budućih grešaka. Pri tome, međutim, valja istaknuti da odgovornost liječnika nije ni jedini niti najbolji mehanizam zaštite od liječničke greške. U današnje vrijeme postoje razrađeni sustavi upravljanja rizicima i kontrole kvalitete, a tamo gdje je došlo do pogreške potrebno je promijeniti sustav koji je grešku omogućio ili je nije na vrijeme spriječio. Činjenica je da nedostatak timskog rada, nedovoljno postojanje kulture o sigurnosti pacijenta i loša komunikacija predstavljaju jednu od temeljnih barijera u osiguranju sigurnog okružja za pacijente, a da jasna i dvosmjerna komunikacija predstavlja ključni element u prevenciji tužbi za liječničku pogrešku. Polovica svih tužbi zbog liječničke pogreške može se izbjeći sustavnim provođenjem procesa upravljanja rizikom. Reduciranje rizika u kliničkoj praksi bazira se na mnogim elementima, pri čemu vrlo važne elemente čine održavanje adekvatne komunikacije s pacijentom, s članovima tima, vođenje odgovarajuće dokumentacije, briga o neželjenim ishodima te striktno pridržavanje kliničkih protokola i strategija. Jedan od izuzetno bitnih koraka u navedenom predstavlja sustavno upoznavanje svakog liječnika/zaposlenika zdravstvene ustanove s pojmom i institucijom upravljanja rizikom, s liječničkom pogreškom kao vrlo bitnom sastavnicom i pojmom koji vuče mnoge pravne i financijske reperkusije po ustanovu/medicinsko osoblje, te osnovnim stvarima koje mogu sami učiniti kako bi se rizici otklonili, spriječili ili smanjili. Naime, stalna i kvalitetna edukacija liječnika tijekom čitavog profesionalnog života predstavlja conditio sine qua non uspješnog profesionalnog rada i predstavlja jedan od temelja za efikasnu prevenciju liječničke pogreške. ${ }^{205}$

\section{Primjedbe}

1 Usp. MATIJEVIĆ, B., Osiguranje od profesionalne odgovornosti u djelatnosti zdravstva, „Hrvatska pravna revija“, 2008., broj 6, str. 43.

${ }^{2}$ Tako STOJANOVIĆ, I., Pretpostavljena odgovornost lekara i tzv. defanzivna medicina, „Pravni život", knjiga 583, 2016., broj 9., str. 367.

${ }^{3}$ Vidi CRNIĆ, I., Odštetna odgovornost liječnika i zdravstvenih ustanova, zbornik radova sa savjetovanja „Aktualnosti hrvatskog zakonodavstva i pravne prakse“, Godišnjak 15, Organizator, Zagreb, 2008., str. 124.

${ }^{4}$ Tako JUKIĆ, M., Liječničke pogreške - osnovana sumnja, Sudsko-medicinski slučaj,

„Medicinska naklada“, Zagreb, 2014., str. 4.-5.

${ }^{5}$ Usp. MUJOVIC-ZORNIC, M. H., Physician's error: medical or legal concept? Med Law (2010) 29, str. 167. 
Prava, obveze i odgovornosti radnika u obavljanju djelatnosti: Odgovornost zdravstvenih radnika i osiguranje od odgovornosti

${ }^{6}$ Pojam liječničke pogreške potječe od patologa R. Virchowa koji ga je u drugoj polovini 19. st. definirao pod nazivom stručna pogreška liječnika kao ,kršenje općepriznatih pravila umijeća liječenja zbog pomanjkanja dužne pažnje ili opreza“. Smatra se boljim pojam ,pogreška u tretmanu“ jer obuhvaća uz pogreške u liječenju i pogreške u dijagnozi, profilaksi ili naknadnoj skrbi; pojam medicinskog standarda kojim se određuje da li je liječnik postupio kako se to od njega očekuje u njegovom profesionalnom krugu tj. medicinsko mjerilo (ne pravno); isključivo je mjerodavno stanje medicinske znanosti u vrijeme poduzimanja medicinskog zahvata; liječnik je u izboru metode potpuno slobodan, ali je u dvojbi dužan držati se načela sigurnijeg puta.

MIHALIĆ, A., Osiguranje od odgovornosti liječnika pri obavljanju djelatnosti, „Osiguranje“, godina XXXXVII, 2006., broj 7-8, str. 51.

${ }^{7}$ Tako RADIŠIĆ, J., Medicinsko pravo, „Nomos“, beograd, 2004., str. 157.

${ }^{8}$ Usp. STRINOVIĆ, D. - ZEČEVIĆ, D., Komplikacija i greška - sudskomedicinski pristup, rad u knjizi: BOIĆ, V. i dr., Naknada neimovinske štete, Pravno-medicinski okvir, Inženjerski biro, Zagreb, 2009., str. 175.

${ }^{9}$ Vidi JUKIĆ, M., Liječničke pogreške - osnovana sumnja, Sudsko-medicinski slučaj, „Medicinska naklada“, Zagreb, 2014., str. 3.

${ }^{10}$ Vidjeti njegovo djelo Gesammelte Abhandlungen aus dem Gebiete der öffentlichen Medizin und der Seuchenlehre, Philipps-Universität Marburg, Berlin, 1879.

11 „Opće priznatim pravilima“ Virchow je smatrao samo ona načela koja nisu podložna nikakvim teorijskim dilemama, kao što je prekoračenje maksimalne doze lijeka, što će kasnije biti nazvano"apsolutnom stručnom greškom" - vidjeti tako u: Jakov Radišić, Medicinsko pravo, Pravni fakultet Univerziteta Union u Beogradu i „Nomos“, Beograd, 2008., str. 180.

12 Vidjeti tako u: HEINRICH HONSELL, Die zivilrechtliche Haftung des Arztes, Zeitschrift für Schweizerisches Recht, 1990., str. 141.; ANĐELINOVIĆ, Š., Sudsko-medicinski aspekti odgovornosti liječnika, u Zborniku radova skupine autora, Liječnička pogreška - medicinski i pravni aspekti, Split, 2007., str. 87., Petar Klarić, Odštetno pravo, Narodne novine, Zagreb, 2003., str. 398.

${ }_{13}$ Pri čemu je bitno naglasiti da tuženik mora u sudskom postupku dokazati da je njegovo postupanje nije bilo contra legem artis.

${ }^{14}$ Jedan od prigovora je bio da umijeće liječenja, za razliku od npr. građevinskog umijeća, ne može imati „općepriznata pravila“ - vidjeti tako u: HANS JOACHIM MALLACH, GERHARD SCHLENKER, ALFONS WEISER, Ärztliche Kunstfehler, Stuttgart - New York, 1993., str. 2.; njemački liječnici mlađe generacije smatrali su da se kršenje dužnosti liječnika ne može bezuvjetno nazvati „stručna greška“ jer je to krut i višeznačan pojam i da bi ispravnije bilo govoriti o „,nehotičnom nanošenju štete“, o , zanemarivanju dužne pažnje“, o ,grešci u tretmanu“ - vidjeti tako u: Jakov Radišić, Medicinsko pravo, op. cit., str. 180.

${ }^{15}$ Vidjeti tako u: HEINRICH HONSELL, Die zivilrechtliche Haftung des Arztes, Zeitschrift für Schweizerisches Recht, br. 2/1990., str. 141.

${ }^{16} \mathrm{U}$ tom smislu DIETER GIENSEN, Arzthaftungsrecht, Tübingen, 1990., str. 45.; prema: Jakov Radišić, Liječničke greške u svjetlosti pravnih razmatranja, zbornik radova skupine autora: Aktualni pravni problemi u medicini, Univerzitet u Beogradu, 1996., str. 182.

17 Tako u: ERWIN DEUTSCH, Medizinische Fahrlässigkeiten, Neue Juristische Wochenschrift, br. 39/1976., str. 2291. i dalje; prema: Jakov Radišić, Liječničke greške u svjetlosti pravnih razmatranja, op. cit., str. 182.

18 Usp. HARALD I DIETMAR FRANZKI, Waffengleicheit im Arzthaftungsprozess, Neue Juristische Wochenschrifft, br. 49/1975., str. 2228.; prema: Jakov Radišić, Liječničke greške u svjetlosti pravnih razmatranja, op. cit., str. 183.

19 Vidjeti tako u: ERWIN DEUTSCH, Arztrecht und Arzneimittlerecht, 2. Auflage, Berlin - New York, 1991., str. 152.; prema: Jakov Radišić, Liječničke greške u svjetlosti pravnih razmatranja, op. cit., str. 183.

${ }^{20}$ Tako RADIŠIĆ, J., Medicinsko pravo, „Nomos“, beograd, 2004., str. 157. 
Prava, obveze i odgovornosti radnika u obavljanju djelatnosti: Odgovornost zdravstvenih radnika i osiguranje od odgovornosti

${ }^{21}$ Vidi KLARIĆ, P., Odgovornost zdravstvene ustanove i zdravstvenih djelatnika za štetu, Hrvatska pravna revija, 2001., podatak kod ŠARIĆ, D., Liječnička pogreška - pravni i medicinski aspekti, završni rad na poslijediplomskom specijalističkom studiju „Medicinsko pravo“ na Pravnom fakultetu Sveučilišta u Splitu, Split, 2015., str. 9.

${ }^{22}$ Usp. KLARIĆ, P., Građanskopravna odgovornost za liječničku grešku, rad u zborniku radova „Hrestomatija hrvatskoga medicinskog prava“, Pravni fakultet Sveučilišta u Zagrebu, Zagreb, 2016., str. 733.

${ }^{23}$ Povrede pravila zdravstvene struke mogu se dijeliti na: pogreške prilikom dijagnostike, liječenja i naknadne skrbi; pogreške zbog neadekvatno vođene medicinske dokumentacije; pogreške nastale povredom instituta liječničke tajne; pogreške u svezi neadekvatnog informiranog pristanka.

${ }^{24}$ Vidi CRNIĆ, I., Odštetna odgovornost liječnika i zdravstvenih ustanova, zbornik radova sa savjetovanja „Aktualnosti hrvatskog zakonodavstva i pravne prakse“, Godišnjak 15, Organizator, Zagreb, 2008., str. 127.

25 Tako ĆEPULIĆ, E., Profesionalna odgovornost liječnika i skandinavski model osiguranja liječnika, u: Profesionalna odgovornost liječnika, Zagreb, Narodne novine, 2007., str. 5.-8.

${ }^{26} \mathrm{U}$ tom smislu ŠARIĆ, D., Liječnička pogreška - pravni i medicinski aspekti, završni rad na poslijediplomskom specijalističkom studiju „Medicinsko pravo“ na Pravnom fakultetu Sveučilišta u Splitu, Split, 2015., str. 11.

${ }^{27}$ Usp. HALLER, H., Medicinski pogled na liječničku odgovornost, rad u zborniku „Građanskopravna odgovornost u medicini“, HAZU, Zagreb, 2008., str. 23.-24.

${ }_{28}$ O liječničkoj grešci vidjeti u ERWIN DEUTSCH, ANDREAS SPICKHOFF, Medizinrecht, Springer, 2008., str. 107. -162.

${ }^{29}$ Vidjeti tako u: PETAR KLARIĆ, Odštetno pravo, op. cit., str. 398.

${ }^{30}$ Zabluda (lat. error) je pogrešna predodžba o nekoj okolnosti. Ona je oblik nesvjesnog nesklada između volje i očitovanja, jer u trenutku očitovanja volje osoba nije svjesna te nepodudarnosti zbog pogrešne predodžbe o nekoj okolnosti. Kod počinjenja liječničke greške zbog zablude, liječnik može imati pogrešnu predodžbu o svom znanju ili/i iskustvu ili/i o činjenicama o slučaju (pacijentu) kojim se bavi i, misleći da postupa ispravno, počiniti grešku i postaviti pogrešnu dijagozu, ili pogriješiti u nekom medicinskom postupku. Dakle, potrebno je razlikovati situaciju u kojoj je liječnik svjestan svog neznanja i unatoč tome, on riskira i bez konzultiranja djeluje, od situacije u kojoj je liječnik u zabludi da ispravno postupa. U oba slučaja, prema našem mišljenju, postoji odgovornost liječnika (on odgovara za svaki stupanj krivnje), ali je ipak riječ o blažem obliku u slučaju zablude. Vidjeti tako u: PETAR KLARIĆ, MARTIN VEDRIŠ, Građansko pravo, op. cit., str. 155.

${ }^{31}$ Vidjeti tako u: JOSIP ŠKAVIĆ, DUŠAN ZEČEVIĆ, Komplikacija i greška - sudskomedicinski pristup, u Zborniku radova skupine autora: Građanskopravna odgovornost u medicini, Hrvatska akademija znanosti i umjetnosti, Zagreb, 2008., str. 24.

${ }^{32}$ Ibid., str. 25.

${ }^{33}$ Vidjeti tako u: PETAR KLARIĆ, Odgovornost zdravstvene ustanove $i$ zdravstvenih djelatnika za štetu (Prvi dio), Hrvatska pravna revija, br. 8., kolovoz 2008., str. 30.

${ }^{34}$ Više o tome u: ERWIN DEUTSCH, Medizin und Forschung vor Gericht, Heidelberg - Karlsruhe, 1978., str. 12; WOLFGANG - ANDREAS ERTEL, Grundfragen des deutschen und italienischen Arzthaftungsprozess im Vergleich, Konstanz, 1989., str. 31 i 32.; prema: Jakov Radišić, Liječničke greške u svjetlosti pravnih razmatranja, op. cit., str. 183.

${ }^{35}$ Ibid., str. 32.

${ }^{36}$ Vidjeti tako u: PETAR KLARIĆ, MARTIN VEDRIŠ, Građansko pravo, op. cit., str. 596.-598.; ZLATKO ĆESIĆ, VILIM GORENC, HRVOJE KAČER, HRVOJE MOMČINOVIĆ, DRAGO PAVIĆ, ANTE PERKUŠIĆ, ANDREA PEŠUTIĆ, ZVONIMIR SLAKOPER, ANTE VIDOVIĆ, BRANKO VUKMIR, Komentar Zakona o obveznim odnosima, RRIF, listopad 2005., str. 1622. i dalje; KAČER, H., Naknada štete zbog liječničke griješke, u: LIJEČNIČKA POGREŠKA - MEDICINSKI I PRAVNI ASPEKTI, str. 149.-190., Sveučilište u Splitu - Medicinski i Pravni fakultet, ožujak 2007., str. 149.- 
Prava, obveze i odgovornosti radnika u obavljanju djelatnosti: Odgovornost zdravstvenih radnika i osiguranje od odgovornosti

190.; KAČER, H., Jedna novija odluka Ustavnog suda Republike Hrvatske o objektivnoj odgovornosti u medicini, „Hrvatska pravna revija“, broj 4 / 2008., str. 35.-40.; KAČER, H. - IVANČIĆ KAČER, B., Građanskopravna odgovornost za štete nastale zbog liječničke greške - I dio, „Pravo i porezi“ broj 7/2007., str. 12.-18.; KAČER, H. - IVANČIĆ KAČER, B., Građanskopravna odgovornost za štete nastale zbog liječničke greške - II dio, „Pravo i porezi“", broj 8/2007., str. 14.-24.

37 Tako u: PETAR KLARIĆ, MARTIN VEDRIŠ, Građansko pravo, op. cit., str. 599.

${ }^{38}$ Usp. ŠARIĆ, D., Liječnička pogreška - pravni i medicinski aspekti, završni rad na poslijediplomskom specijalističkom studiju „Medicinsko pravo“ na Pravnom fakultetu Sveučilišta u Splitu, Split, 2015., str. 150.

39 Vidi KLARIĆ, P., Građanskopravna odgovornost za liječničku grešku, rad u zborniku radova „Hrestomatija hrvatskoga medicinskog prava“, Pravni fakultet Sveučilišta u Zagrebu, Zagreb, 2016., str. 733.

40 Tako CRNIĆ, I., Odštetna odgovornost liječnika i zdravstvenih ustanova, zbornik radova sa savjetovanja „Aktualnosti hrvatskog zakonodavstva i pravne prakse“, Godišnjak 15, Organizator, Zagreb, 2008., str. 128.

${ }^{41}$ Vidjeti tako u: PETAR KLARIĆ, Odgovornost zdravstvene ustanove i zdravstvenih djelatnika za štetu (Prvi dio), Hrvatska pravna revija, br. 8., kolovoz 2008., str. 29. i 30.

${ }^{42}$ Usp. JAKOV RADIŠIĆ, Medicinsko pravo, op. cit., str. 184.

${ }^{43}$ Vidjeti tako u: PETAR KLARIĆ, Odgovornost za štetu zbog grešaka u medicini, Klub pravnika, Tribina od 19.12.2001., na:

www.pravnadatoteka.hr/pdf/aktualno/hrv/20030211/Odgovornost_za_stetu_zbog_gresaka_u_med icini.doc.

${ }^{44}$ Usp. JAKOV RADIŠIĆ, Medicinsko pravo, op. cit., str. 184.

45 Vidi ČIZMIĆ, J. - KAČER IVANČIĆ, B., Odgovornost za greške doktora medicine specijalizanta, zbornik radova sa II. simpozija s međunarodnim sudjelovanjem ,PRAVNI, ETIČKI I MEDICINSKI ASPEKTI SUVREMENOG VOĐENJA PORODA“, Šibenik, 11. i 13. svibnja 2017. Godine, str. 51.-67.

${ }^{46}$ Tako IVICA CRNIĆ, Odgovornost liječnika za štetu, Organizator, Zagreb, 2009., str. 53.

47 Vidjeti tako u: ADOLF LAUFS, WILHELM UHLENBRUCK, Handbuch des Arztrechts, 3. Auflage, München, 2002., str. 20.; prema: Jakov Radišić, Medicinsko pravo, op. cit. 185.

48 Usp. PETAR KLARIĆ, Odgovornost za štetu zbog grešaka u medicini, Klub pravnika, Tribina od 19.12.2001. na:

www.pravnadatoteka.hr/pdf/aktualno/hrv/20030211/Odgovornost za stetu zbog gresaka u medicini.doc.

${ }_{49}$ Česte su kritike da je prevelika uloga sudskih vještaka u sporovima u kojima se odlučuje o pitanjima povrede pravila medicinske struke, međutim, nemoguće je postići da sudac bude toliko stručan u medicini, i to u svim dijelovima medicine koji se mogu pojaviti kao predmet sudskog postupka pa je uloga sudskog vještaka neizostavno velika. Međutim, ono što smatramo potrebnim postići je da se što više objektiviziraju kriteriji pomoću kojih sudac donosi odluku, da se počne voditi računa o tome da sudske odluke budu što ujednačenije u svim sudovima u državi, te je nužno da pojam liječnička greška nije samo medicinski pojam, već za njega moraju postojati i pravna mjerila, odnosno pravne pretpostavke, koja se primjenjuju u svakom konkretnom slučaju. ${ }^{50}$ Tako ČIZMIĆ, J. - KAČER IVANČIĆ, B., Odgovornost za greške doktora medicinespecijalizanta, zbornik radova sa II. simpozija s međunarodnim sudjelovanjem „PRAVNI, ETIČKI I MEDICINSKI ASPEKTI SUVREMENOG VOĐENJA PORODA“, Šibenik, 11. i 13. svibnja 2017. godine, str. 51.-67.

${ }^{51}$ Vidi HALLER, H., Medicinski pogled na liječničku odgovornost, rad u zborniku „Građanskopravna odgovornost u medicini“, HAZU, Zagreb, 2008., str. 25.

${ }_{52}$ Usp. ŠARIĆ, D., Liječnička pogreška - pravni i medicinski aspekti, završni rad na poslijediplomskom specijalističkom studiju „Medicinsko pravo“"na Pravnom fakultetu Sveučilišta u Splitu, Split, 2015., str. 18. 
Prava, obveze i odgovornosti radnika u obavljanju djelatnosti: Odgovornost zdravstvenih radnika i osiguranje od odgovornosti

${ }^{53}$ Tako BABIĆ-BOSANAC, S. - BOROVEČKI, A., Medicinske pogreške u Hrvatskoj, rad u zborniku radova „hrestomatija hrvatskoga medicinskog prava“, Pravni fakultet Sveučilišta u Zagrebu, Zagreb, 2016., str. 727.

${ }^{54}$ Vidi JUKIĆ, M., Liječničke pogreške - osnovana sumnja, Sudsko-medicinski slučaj, „Medicinska naklada“, Zagreb, 2014., str. 4.-5.

55 Tako MIHALIĆ, A., Osiguranje od odgovornosti liječnika pri obavljanju djelatnosti, „Osiguranje“, godina XXXXVII, 2006., broj 7-8, str. 51.

${ }^{56}$ Usp. SCHULTZE-ZEU, R., Das Vorliegen eines einfachen Befunderhebungsfehlers und die Bevveislastumkehr hinsichtlich der Kausalitat, Versicherungsrecht, br.19/2008, str. 900.

${ }^{57}$ Ibid., str. 900.

${ }^{58}$ Podatak kod Report on Medical Liability in Council of Europe Member States - A Comparative study and Recommendations, European Committee on Legal Co-operation, CDCJ (2005) 3, Strasbourg, 21. ožujka 2005.

${ }^{59} \mathrm{Za}$ definiranje pojma stručne greške neophodno je da struka, u vidu zakona, detaljno definira protokole po kojima se provode određeni postupci u radu, da bi poslužili kao kriteriji za kontrolu. Tek tada se može prosuditi da li je neko prekršio profesionalna pravila rada i napravio grešku ili su posljedice rezultat nepredviđenog i neželjenog tijeka bolesti. ČOLOVIĆ, V., Osiguranje od lekarske odgovornosti, „Strani pravni život“, Institut za uporedno pravo, Beograd, 3/2010., str. 34. ${ }^{60}$ Anamneza (ili tzv. povijest bolesti) je izraz koji u medicini označava skup podataka o bolesniku koji se odnosi na njegove životne prilike, nasljedne osobine, preboljele bolesti ili zadobivene ozljede, odnosno sve okolnosti koje su prethodile njegovom zdravstvenom stanju u trenutku pregleda.

${ }^{61}$ Podatak kod MATIJEVIĆ, B., Osiguranje od profesionalne odgovornosti u djelatnosti zdravstva, „Hrvatska pravna revija“, 2008., broj 6, str. 45.

${ }^{62}$ Izraz koji označuje da je neka posljedica nastala zbog djelovanja liječnika ili drugih zdravstvenih radnika; ozljeda koju pacijentu prouzroči sam liječnik (vidjeti rad JAKOVA RADIŠIĆA u knjizi Medicinsko pravo, str. 121.

${ }^{63}$ Tako CRNIĆ, I., Odštetna odgovornost liječnika i zdravstvenih ustanova, zbornik radova sa savjetovanja „Aktualnosti hrvatskog zakonodavstva i pravne prakse“, Godišnjak 15, Organizator, Zagreb, 2008., str. 129.

${ }^{64} \mathrm{Za}$ definiranje pojma stručne greške neophodno je da struka, u vidu zakona, detaljno definira protokole po kojima se provode određeni postupci u radu, da bi poslužili kao kriteriji za kontrolu. Tek tada se može prosuditi da li je neko prekršio profesionalna pravila rada i napravio grešku ili su posljedice rezultat nepredviđenog i neželjenog tijeka bolesti. ČOLOVIĆ, V., Osiguranje od lekarske odgovornosti, ,Strani pravni život“, Institut za uporedno pravo, Beograd, 3/2010., str. 34. ${ }^{65}$ Vidi STRINOVIĆ, D. - ZEČEVIĆ, D., Komplikacija i greška - sudskomedicinski pristup, rad u knjizi: BOIĆ, V. i dr., Naknada neimovinske štete, Pravno-medicinski okvir, Inženjerski biro, Zagreb, 2009., str. 178.

${ }_{66}$ Podatak kod ŠARIĆ, D., Liječnička pogreška - pravni i medicinski aspekti, završni rad na poslijediplomskom specijalističkom studiju „Medicinsko pravo“ na Pravnom fakultetu Sveučilišta u Splitu, Split, 2015., str. 38.

${ }^{67}$ Tako KLARIĆ, P., Odštetno pravo, Zagreb, Narodne novine, 2003., str. 388.-422. Jedna od prihvatljivijih medicinskih definicija komplikacije jest da je to loš rezultat liječenja koji nastaje usprkos medicinski pravodobno, stručno i ispravno provedenom postupku uz uporabu ispravne $\mathrm{i}$ odgovarajuće opreme uz optimalnu organizaciju rada. "Komplikacije i greške u medicine" Simpozij,; Liječničke novine br. 50/2006. Američki znanstveni medicinski rječnik definira komplikaciju kao: „Neočekivani patofiziološki događaj ili proces koji se javlja tijekom dijagnostičkog postupka, menadžmenta ili tretiranja bolesti i nije esencijalni (važni) dio oboljenja,a proizlazi iz same bolesti ili iz nekog drugog nezavisnog uzroka“. The American Heritage ${ }^{\circledR}$ Medical Dictionary Copyright (C) 2007, 2004 by Houghton Mifflin Company. 
Prava, obveze i odgovornosti radnika u obavljanju djelatnosti: Odgovornost zdravstvenih radnika i osiguranje od odgovornosti

${ }^{68} \mathrm{Na}$ osnovi iskustva i u sudskomedicinskoj je praksi uočeno da ne postoji ni jedinstven stav oko toga što u tijeku liječenja predstavlja komplikaciju, a što treba označiti liječničkom greškom. Prihvatljiva je definicija prema kojoj „komplikacija nastaje usprkos medicinski ispravnom i pravodobnom provedenom postupku koji je izveden pravilnom upotrebom ispravne opreme i sredstva uz optimalnu organizaciju rada“ (Liječničke novine br. 50, 2006.).

${ }^{69}$ Vidi STRINOVIĆ, D. - ZEČEVIĆ, D., Komplikacija i greška-sudskomedicinski pristup, rad u knjizi: BOIĆ, V. i dr., Naknada neimovinske štete, Pravno-medicinski okvir, Inženjerski biro, Zagreb, 2009., str. 177.

70 Ibid., str. 176.

${ }^{71}$ Tako KLARIĆ, P., Odštetno pravo, Zagreb, Narodne novine, 2003., str. 388.-422.

72 Usp. KLARIĆ, P., Građanskopravna odgovornost za liječničku grešku, rad u zborniku radova „Hrestomatija hrvatskoga medicinskog prava“, Pravni fakultet Sveučilišta u Zagrebu, Zagreb, 2016., str. 734. U skladu s navedenim je i presuda Vrhovnog suda RH prema kojoj ne predstavlja (nesretni) slučaj činjenica da je prilikom carskog reza liječnik jednim šavom zahvatio vijugu tankog crijeva uz maternicu. KLARIĆ, P., Odštetno pravo, Zagreb, Narodne novine, 2003., str. 388.-422.

${ }^{73}$ Vidi CRNIĆ, I., Odštetna odgovornost liječnika i zdravstvenih ustanova, zbornik radova sa savjetovanja „Aktualnosti hrvatskog zakonodavstva i pravne prakse“, Godišnjak 15, Organizator, Zagreb, 2008., str. 130.

${ }^{74}$ Predavanje Hrvoja Minige i Zlatka Domljana pod naslovom Medicinska greška ili komplikacija održano 19. svibnja 2006. u Zagrebu. Navedeno prema: ROKSANDIĆ-VIDLIČKA, S., Pružatelji zdravstvenih usluga i najčešće povrede prilikom obavljanja zdravstvene djelatnosti, kod CRNIĆ, I., Odštetna odgovornost liječnika i zdravstvenih ustanova, zbornik radova sa savjetovanja „Aktualnosti hrvatskog zakonodavstva i pravne prakse“, Godišnjak 15, Organizator, Zagreb, 2008., str. 129.

${ }^{75}$ Usp. MIHALIĆ, A., Osiguranje od odgovornosti liječnika pri obavljanju djelatnosti, „Osiguranje“, godina XXXXVII, 2006., broj 7-8, str. 50.

${ }^{76}$ Podatak kod Liječničke novine, Zagreb, 2006., br. 50, str. 15. Neizbježni ishod nastaje usprkos pravodobnom i ispravnom medicinskom postupanju zbog nemogućnosti izlječenja, odnosno smrtonosne bolesti, starosti, otkazivanja više organskih sustava i drugih razloga. ŚARIĆ, D., Liječnička pogreška - pravni i medicinski aspekti, završni rad na poslijediplomskom specijalističkom studiju „Medicinsko pravo“ na Pravnom fakultetu Sveučilišta u Splitu, Split, 2015., str. 11.

77 Tako STOJANOVIĆ, I., Pretpostavljena odgovornost lekara i tzv. defanzivna medicina, „Pravni život", knjiga 583, 2016., broj 9., str. 367.

78 Vidi GJURAŠIN, M. - HALLER, H. - RUMEK ČRNE, R., Zaštita interesa liječnika $i$ bolesnika u Hrvatskoj liječničkoj komori - O radu Povjerenstva za stručna pitanja i stručni nadzor, „Liječničke novine“, godina IX, 2009., broj 77, str. 2.

${ }^{79}$ Usp. STRINOVIĆ, D. - ZEČEVIĆ, D., Komplikacija i greška-sudskomedicinski pristup, rad u knjizi: BOIĆ, V. i dr., Naknada neimovinske štete, Pravno-medicinski okvir, Inženjerski biro, Zagreb, 2009., str. 178.

${ }^{80}$ Podatak kod CRNIĆ, I., Odštetna odgovornost liječnika i zdravstvenih ustanova, zbornik radova sa savjetovanja „Aktualnosti hrvatskog zakonodavstva i pravne prakse“, Godišnjak 15, Organizator, Zagreb, 2008., str. 131.

${ }^{81}$ Tako STRINOVIĆ, D. - ZEČEVIĆ, D., Komplikacija i greška - sudskomedicinski pristup, rad u knjizi: BOIĆ, V. i dr., Naknada neimovinske štete, Pravno-medicinski okvir, Inženjerski biro, Zagreb, 2009., str. 182.

82 Vidi STOJANOVIĆ, I., Pretpostavljena odgovornost lekara i tzv. defanzivna medicina, „Pravni Život“", knjiga 583, 2016., broj 9., str. 372.-373.

${ }^{83}$ Podatak kod ŠARIĆ, D., o. $c$., str. 6. 
${ }^{84}$ Usp. ZNIDARČIĆ, Ž, Pogreške i propusti liječnika i mogućnosti njihova ispravljanja, rad u knjizi Medicinska etika 2, Centar za bioetiku Zagreb, 2006., str. 14.-17.

85 Tako JUKIĆ, M., Liječničke pogreške - osnovana sumnja, Sudsko-medicinski slučaj, „Medicinska naklada“, Zagreb, 2014., str. 4.-5.

${ }^{86}$ Vidi ŽUŽA, Ž., Disciplinska odgovornost liječnika, „Informator“, broj 5863. Od 15. svibnja 2010., str. 9.

${ }^{87}$ Vidjeti tako u: PETAR KLARIĆ, Odgovornost za štetu zbog grešaka u medicini, Klub pravnika, Tribina od 19.12.2001., na:

www.pravnadatoteka.hr/pdf/aktualno/hrv/20030211/Odgovornost_za_stetu_zbog_gresaka_u_med icini.doc

${ }^{88} \mathrm{Da}$ bi se smjelo pristupiti liječenju pacijenta, potrebno je dobiti njegov pristanak i to ne bilo kakav pristanak, već tom pristanku mora prethoditi informiranje pacijenta o postupku, ili tretmanu koji liječnik smatra potrebnim provesti u svrhu liječenja. Takav pristanak se zove informirani pristanak. Informirani pristanak se još naziva i svjesni ili obaviješteni pristanak ili suglasnost. Praktično svi sustavi na svijetu zauzimaju jedinstven stav da liječenje zahtijeva privolu ili suglasnost pacijenta - voluntas aegroti suprema lex (volja pacijenata je iznad zakona). Prema načelu volenti non fit iniuria pristanak pacijenta isključuje protupravnost medicinske intervencije pod uvjetom da je pravno valjan i da su izvedeni oni zahvati za koje je, nakon obavijesti o njima, dan pristanak. C̆ak i ako je sve proteklo u redu, a nije bilo valjanog pristanka, zahvat je protupravan jer se njime krši pravo na tjelesni integritet. Međutim, medicinski neopravdani zahvat i postupanje protiv pravila struke imaju kao posljedicu da pristanak pacijenta postaje nevažeći.

${ }^{89}$ Zakon o liječništvu u čl. 18., st. 2. određuje da je liječnik u hitnim stanjima dužan pružiti pomoć svakom bolesniku bez odlaganja. Hitnim stanjima se, prema st. 3. istog članka, smatraju ona stanja kod kojih bi zbog nepružanja liječničke pomoći mogle nastati trajne štetne posljedice po zdravlje (invalidnost) ili po život bolesnika. St. 4. određuje da liječnik može odbiti pružanje liječničke pomoći osobi koja mu prijeti ili je prema njemu, odnosno drugim zdravstvenim radnicima fizički agresivna, OSIM U HITNIM STANJIMA. Prema ovoj odredbi, liječnik bi trebao riskirati i svoj život, ali samo ako mu je osigurana ZAŠTITA POLICIJE ILI NEKI DRUGI OBLIK ZAŠTITE (čl. 18., st. 5.).

${ }^{90} \mathrm{ZOO}$ u čl. 183. određuje da onaj tko je zakonom obvezan sklopiti neki ugovor, ako ga na zahtjev zainteresirane stranke ne sklopi bez odgađanja, odgovara za štetu.

${ }^{91}$ Više o tome kod ROKSANDIĆ-VIDLIČKA, S., Aktualna pitanja pojedinih kaznenih djela protiv zdravlja ljudi u svijetlu donošenja Nacrta izmjena hrvatskog kaznenog zakona, Godišnjak akademije pravnih znanosti Hrvatske, Vol.1. No 1, prosinac 2010.

92 Članak 12. st. 3. ZPP-a glasi: „U parničnom postupku sud je u pogledu postojanja kaznenog djela i kaznene odgovornosti učinioca vezan za pravomoćnu presudu kaznenog suda kojom se optuženik oglašava krivim. “.), članak 50. Zakona o arbitraži, objavljen u „Narodne novine“ , br. 88/01. (stupio na snagu 19. listopada 2001.), članak 129. Zakona o izmjenama i dopunama Ovršnog zakona, objavljen u „Narodne novine“ , br. 88/05 (stupio na snagu 28. srpnja 2005.), Odluku USRH, br. U-I-1569/04. i dr., objavljena u „Narodne novine“ , br. 2/07 i 96/08. Vidjeti više o tome u: Siniša Triva, Građansko parnično procesno pravo, Narodne novine, Zagreb, 1980., str. 64.-68.

93 Usp. ČIZMIĆ, J. - KAČER IVANČIĆ, B., Odgovornost za greške doktora medicine specijalizanta, zbornik radova sa II. simpozija s međunarodnim sudjelovanjem „PRAVNI, ETIČKI I MEDICINSKI ASPEKTI SUVREMENOG VOĐENJA PORODA“, Šibenik, 11. i 13. svibnja 2017. Godine, str. 51.-67.

${ }^{94}$ Presuda Vrhovnog suda Federacije Bosne i Hercegovine broj: Rev-609/05 od 18.05.2006. godine) - "Zdravstvena ustanova koja vrši medicinsku intervenciju može odgovarati samo za one posljedice intervencije koje nastanu usljed nestručnog, nepažljivog i nepropisnog rada njenih radnika, dakle za posljedice koje se mogu pripisati u krivicu ljekarima I drugom osoblju zbog 
Prava, obveze i odgovornosti radnika u obavljanju djelatnosti: Odgovornost zdravstvenih radnika i osiguranje od odgovornosti

postupanja koje nije bilo u skladu sa pravilima medicinske struke, a oslobađa se odgovornosti ako dokaže da je radnik u datim okolnostima postupao onako kako je to trebalo."

95 „Samo nepropisno postupanje liječnika ne povlači automatski njegovu odgovornost, nego su za to potrebni još neki uvjeti, u te uslove spadaju: krivica lekara, šteta za pacijenta i uzročna veza između lekarske greške i štete”. J. RADIŠIĆ, Građanska odgovornost lekara koja proističe iz njihovog zanimanja, Revija za pravo osiguranja, broj 1/2009., str 16.

${ }^{96}$ Vidi POČUČA, M. - ŠARKIĆ, N. - MRVIĆ PETROVIĆ, N., Lekarska greška kao razlog pravne odgovornosti lekara i zdravstvenih ustanova, Pravni fakultet za privredu i pravosuđe univerziteta Privredna akademija Novi sad, Pravni fakultet univerziteta Union Beograd, Beograd, 2013., str. 209.

97 Ibid., str. 209.

98 Tako RADIŠIĆ, J., Odgovornost lekara u slučaju kad nije dovoljno sigurno da je njegova greška nanela štetu pacijentovom zdravlju, Revija za pravo osiguranja, broj 3/2010, str.48.

99 Presuda Vrhovnog suda Srbije Rev. 2714/92- Odgovornost zdravstvena organizacije je subjektivne a ne objektivne prirode i ona odgovara za štetu prouzrokovanu pacijentu ako njeni ljekari i drugo medicinsko osblje nisu postupili u skladu sa pravilima medicinske nauke i sa odgovarajućom pažnjom, pa iz takvog ponašanja proistekne šteta."

${ }^{100}$ Detaljnije o tome kod ŚABIĆ, S., Osiguranje od odgovornosti za štetu pričinjenu medicinskom greškom kao način pravne zaštite u postupku liječenja, „Anali Pravnog fakulteta Univerziteta u Zenici, god. 9, 2016., broj. 17, str. 335.-356.

101 Za sekundarne štete vidi RADIŠIĆ J., Odgovornost lekara i medicinskih ustanova zbog sekundarnih šteta, u CEKOVIĆ-VULETIĆ, S. et al., Medicinsko pravo, Institut društvenih nauka, Centar za pravna istraživanja, Beograd 1998., str.121. - 143.

102 Tako ROKSANDIĆ, S. - BABIĆ, T. -BUDIĆ, N., Legal Classification of Relations btw Doctors and Patients in Republic of Croatia, 2005, International Congress on Medical law, Seoul, Južna Koreja, kolovoz 2005.

103 Vidi BIKIĆ, A., Obligaciono pravo, Opći dio, Drugo izdanje, Pravni fakultet univerziteta u Sarajevu, Sarajevo, 2007., str. 240.

${ }^{104}$ Podatak kod ĆURKOVIĆ, M., Osiguranje od odgovornosti liječnika, rad u zborniku „Građanskopravna odgovornost u medicini“, HAZU, Zagreb, 2008., str. 111.

${ }^{105}$ Tako JAŠARSPAHIĆ, Š., Nematerijalna šteta, Zbornik radova Jahorina, 20 -22 Oktobar 2011. godine, str. 53.

106 Usp. VEDRIŠ, M., KLARIĆ, P., Građansko pravo, Narodne novine, Zagreb 1998., str. 547. 548.

${ }^{107}$ Vidi KLARIĆ, P., Odštetno pravo, Zagreb, 2003., str. 388.; BOŠKOVIĆ, Z., Zakon o zaštiti

prava pacijenata - reforma zdravstvenog zakonodavstva Republike Hrvatske, „Hrvatska pravna

revija“", god. V., 2005., br. 1, str. 90.

108 Tako GORETA, M., O odgovornosti psihoterapeuta, rad je izložen na V. kongresu

psihoterapeuta Jugoslavije u Sarajevu, 25-29.X 1987., str. 1.

${ }^{109} \mathrm{U}$ svijetu se već dulje vrijeme razvijaju posebni sustavi naknade štete koje, među ostalim, nastaju pacijentima prilikom obavljanja zdravstvene djelatnosti. Riječ je o tzv. no-fault sustavima. Iako su ti sustavi još uvijek u manjini, sve ih se više spominje u vezi s različitim reformama odštetnog prava na području medicine. No-fault sustavi, barem na teorijskoj razini, nisu nužno sustavi u kojima se utvrđuje odgovornost, već je kod njih naglasak na utvrđivanju prava na naknadu štete pa za priznavanje prava na naknadu štete oštećeniku nije potrebno utvrditi odgovornost oosbe koja je prouzročila štetu. NIKŠIĆ, S., Aktualnosti na području odgovornosti za štete u medicini, rad u knjizi DRAKULIĆ, V. i dr., Zdravstvena djelatnost i priprema sustava zdravstvene zaštite za pristupanje Hrvatske Europskoj uniji, TEB poslovno savjetovanje, Zagreb, 2012., str. 72.-73.

${ }^{110}$ Ujedno je potrebno spomenuti i ugovornu odgovornost koja također ima sadržajnog i zakonskog utemeljenja u odnosima i postupcima pružanja zdravstvene zaštite i obavljanja 
Prava, obveze i odgovornosti radnika u obavljanju djelatnosti: Odgovornost zdravstvenih radnika i osiguranje od odgovornosti

zdravstvenih djelatnosti. Naime pacijent je u ugovornom odnosu s pružateljem usluga, ustanovom i/ili zdravstvenim radnikom. U slučajevima kad nije pružena usluga ili je pružena neadekvatna usluga ili je nastupila šteta na bilo koji način pacijent bi imao pravo na naknadu štete i iz ugovorenog odnosa.

${ }^{111}$ Vidi BABIĆ, T. - ROKSANDIĆ, S., Osnove zdravstvenog prava, Zagreb, 2006., str. 207.

112 Tako CRNIĆ, I., Odštetna odgovornost liječnika i zdravstvenih ustanova, zbornik radova sa savjetovanja „Aktualnosti hrvatskog zakonodavstva i pravne prakse“, Godišnjak 15, Organizator, Zagreb, 2008., str. 141.

${ }^{113}$ Usp. BEVANDA, M. - ČOLAKOVIĆ, M., Pravo pacijenta na obaviještenost i pristanak $i$ pravne posljedice liječenja bez pristanka pacijenta, zbornik radova sa 7. međunarodnog savjetovanja „Aktualnosti građanskog i trgovačkog zakonodavstva i pravne prakse“, Neum, 12.14. lipnja 2009., str. 207.

${ }^{114}$ Odobrenje za samostalan rad (licenca) je javna isprava kojom se dokazuje stručna osposobljenost liječnika za samostalno obavljanje liječničke djelatnosti na određenom području. Izdaje se s rokom važenja, a obvezno sadrži i stručno područje za koje se izdaje. ZOL i Pravilnik o izdavanju, obnavljanju i oduzimanju odobrenja za samostalni rad od 14. lipnja 2013. godine. Usp. čl. 20. Zakona o liječništvu FBiH, Službene novine FBiH, 56/13. Dostupno na http://www.fmoh.gov.ba/index.php/zakoni-i-strategije/zakoni/zakon

115 Podatak kod ŽOKALJ, I., SABLJAR-MATOVINOVIĆ, M., Dealing with interpersonal miscommunication problems as presented to the Commission for Medical Ethics and Deontology of Croatian Medical Chamber, Odnosi među liječnicima u Hrvatskoj, Knjiga izlaganja na XIV. proljetnom simpoziju medicinske etike Hrvatskoga liječničkog zbora, Zagreb, 2014.

116 Vidi RADANOVIĆ MIŠIĆ, N., Liječnik kao subjekt deliktne odgovornosti, doktorska disertacija, Mostar, 2017., str. 128.

${ }^{117}$ U tom smislu RADIŠIĆ, J., Medicinsko pravo, „Nomos“, beograd, 2004., str. 173.

${ }^{118}$ Prema ZOO-u povreda prava osobnosti je jedinstveni pravni osnov za određivanje neimovinske štete dok fizičke boli, različiti oblici duševnih boli, naruženosti i dr. su činjenice odnosno kriteriji (kvalifikatorne okolnosti) po kojima sud, uzimajući u obzir težinu povrede i okolnosti slučaja određuje visinu pravične novčane naknade. Pravni temelj povrede prava osobnosti kao neimovinska šteta postaje sama povreda prava osobnosti

119 Zaključak savjetovanja bivšeg Saveznog suda, bivšeg Vrhovnog vojnog suda i bivših vrhovnih sudova republika i autonomnih pokrajina održanog 15. i 16. listopada 1986. godine u Ljubljani. „Pregled sudske prakse“, Prilog naše zakonitosti, broj 33/104.

${ }^{120}$ Detaljnije kod KALADIĆ, I., Nelagodnosti tijekom liječenja i novčana naknada za fizičke boli, „Hrvatska pravna revija“, god. III., 2003., broj 4, str. 15.

${ }^{121}$ U pravilu se radi o tzv. sekundarnim štetama, tj. šteta koju je pretrpio treći posljedica je štete koju je svojim ponašanjem medicinski djelatnik uzrokovao pacijentu. Primjerice, odgovornost za pretrpljene duševne boli zbog smrti bliske osobe, odgovornost zbog neotkrivanja ili neadekvatnog liječenja zaraznog oboljenja kojim je pacijent zarazio treću osobu i sl.. PETRIĆ, S., Pretpostavke odštetne odgovornosti davatelja zdravstvenih usluga u pravu BiH, zbornik radova „Aktualnosti građanskog i trgovačkog zakonodavstva i pravne prakse“, Mostar, 2005., broj 3, str. 113.

122 Tako KLARIĆ, P., Uzročna veza kod odgovornosti za štete u medicini, Zbornik radova II. Znanstvenog skupa „Aktualnosti zdravstvenog zakonodavstva i pravne prakse“, Novalja-Split, 2011 , str. 137.

123 Šire o stupnjevima vjerojatnosti kod uzročnosti RADIŠIĆ, J., Uzročna veza kao osnov i kao mera odgovornosti zbog lekarske stručne greške" Pravni život, 9, 1998., Beograd, str. 239.

${ }^{124}$ U njemačkoj sudskoj praksi neki sudovi zahtijevaju da im vještaci daju odgovor bi li, da je medicinska intervencija poduzeta ili da je na vrijeme poduzeta, pogoršanje zdravlja izostalo $\mathrm{s}$ „vjerojatnošću na granici sigurnosti“" (njem. an Sicherheit grenzende Wahrscheinlichkeit). Međutim takav je zahtjev doživio kritiku kao pretjeran kako s medicinskog, tako i s pravnog gledišta. KLARIĆ, P., Odgovornost zdravstvene ustanove i zdravstvenih djelatnika za štetu, str. 9. 
Prava, obveze i odgovornosti radnika u obavljanju djelatnosti: Odgovornost zdravstvenih radnika i osiguranje od odgovornosti

${ }^{125}$ Podatak kod RADANOVIĆ MIŠIĆ, N., Liječnik kao subjekt deliktne odgovornosti, doktorska disertacija, Mostar, 2017., str. 334.

126 Tako RADIŠIĆ, J., Profesionalna odgovornost medicinskih poslenika, Beograd, Institut društvenih nauka u Beogradu, 1986., str. 123.-167.

${ }^{127}$ Vidi VEDRIŠ, M. - KLARIĆ, P., Građansko pravo, Narodne novine, Zagreb 1998., str. 574.

${ }^{128}$ Usp. KLARIĆ, P., Građanskopravna odgovornost za liječničku grešku, rad u zborniku radova „Hrestomatija hrvatskoga medicinskog prava“, Pravni fakultet Sveučilišta u Zagrebu, Zagreb, 2016., str. 746.

${ }^{129}$ Tako VEDRIŠ, M. - KLARIĆ, P., Građansko pravo, Narodne novine, Zagreb 1998., str. 570.

${ }^{130}$ Vidi BABIĆ, T. - ROKSANDIĆ, S., Osnove zdravstvenog prava, Zagreb, 2006., str. 176.

${ }^{131}$ Pod opasnom stvari razumijeva se svaka stvar koja po svojoj namjeni, osobinama, položaju, mjestu i načinu porabe ili na drugi način predstavlja opasnost nastanka štete za okolinu, pa je zbog toga treba nadzirati s povećanom pažnjom. Jedna djelatnost predstavlja povećanu opasnost kada u njezinu redovnom toku, već po samoj njezinom tehničkoj prirodi i načinu obavljanja, mogu biti ugroženi životi i zdravlje ljudi ili imovina, tako da to ugrožavanje iziskuje povećanu pozornost osoba koje obavljaju tu djelatnost kao i osoba koje s njom dolaze u dodir. Hoće li neka određena stvar ili djelatnost biti kvalificirana opasnom, odlučuje sud u svakom konkretnom slučaju.

${ }^{132}$ Usp. CRNIĆ, I., Odštetna odgovornost liječnika i zdravstvenih ustanova, zbornik radova sa savjetovanja „Aktualnosti hrvatskog zakonodavstva i pravne prakse“, Godišnjak 15, Organizator, Zagreb, 2008., str. 146.

${ }^{133} \mathrm{U}$ tom smislu u svim državama postoji bogata sudska praksa, iz koje smo izdvojili neke karakteristične odluke: "Za naknadu štete nastale poslije hirurške intervencije od značaja je cijeniti i obavezu zdravstvenih radnika da obavještavaju pacijenta o mogućim posljedicama i riziku koji se preuzima pristankom na operativni zahvat" (VSSr, Rev-2714/92 od 8.4.1993., R. Ćosić, Aktuelna sudska praksa iz građansko-materijalnog prava, Beograd, 1996, str., 160-161., odl. 1339; ZSO, 1995, knj. 20, sv. 1, odl. 103). "Prekid trudnoće je opasna delatnost i zato se mora obavljati po svim socijalnim i medicinskim standardima. Za štetu usled smrti pacientkinje nad kojom je, uz njen pristanak, lekar odgovarajuće specijalnosti izvršio abortus, odgovara isključivo štetnik, pa nema uslova za podelu odgovornosti. Tužena je lekar - ginekolog. Njoj su, stoga, bile dobro poznate sve mogućne implikacije abortusa u dvanaestoj nedjelji trudnoće, pa nije smjela pristupiti intervenciji, bez obzira na sve okolnosti slučaja. Ona je to, ipak, učinila i zato snosi isključivu krivicu za tragičan ishod prekida trudnoće. Ona je, i kao lekar i kao čovjek, bila dužna da zaštiti žrtvu od svakog rizika, a pogotovu od mogućnosti tragičnog ishoda" (VSSr, Rev-1048/98 od 18.3.1997., LJ. MILUTINOVIĆ, Naknada štete zbog ljekarske greške..., str. 44; Gasnik pravde, br. 6/2000). „Zdravstvena ustanova odgovara za štetne posledice operativnog lečenja ako pacijentu nije predočila sve mogućne posledice operativnog zahvata na koji je, inače, pristao. Kod tužilje je, kao posledica operacije, došlo i do naruženja. U konkretnom slučaju, tužilja se podvrgla intervenciji u domenu plastične hirurgije, rukoviđena najverovatnije estetskim razlozima, što znači da se nije radilo o hitnom zahvatu, već o zahvatu koji najčešće nema ni terapijsku vrednost. Ovakav zaključak donekle potvrđuje i navod tužilje da ju je tuženi upozorio na rizik kao i mogućnost neuspeha operacije kojoj se izlaže i da se ona sa tim upozorenjem u potpunosti složila i svesno prihvatila rizik, ali uobičajeni jer joj tuženi, prema njenim navodima, ni jednog trenutka nije spomenuo mogućnost ovako katastrofalnog ishoda. Prihvatanje na uobičajeni rizik operativnog zahvata ne znači i prihvatanje mogućih posledica koje, u svakom slučaju, i ne pravdaju preduzimanje zahvata i svakako bi imala bitnog uticaja na odluku tužilje kao pacijenta da mu se podvrgne ili ne" (VSSr, Rev-2714/92 od 8.4.1993., J. Salma, Obligaciono pravo., op. cit., str. 514, bilj. 1730; ZSO, 1995, knj. 20, sv. 1, odl. 103); (VSSr, Rev-2114/92 od 8.5.1993., Lj. Milutinović, Naknada štete zbog ljekarske greške, Bilten VSSr, br. 3/2002, str. 44). „Kad se radi o standardnom medicinskom zahvatu izvršenom u skladu sa suvremenom medicinskom strukom za eventualne štetne posljedice takvog zahvata bolnica odgovara po načelu krivnje, za propuste prilikom njegova poduzimanja, glede izbora zahvata i sredstava kojima se zahvat obavlja (čl. 154. st. 1. ZOO)" (VSRH, Revr- 
6/2002-2 od 3.7.2003. godine). „Bolnica kao imalac opasne stvari (termokautera) odgovara po načelu uzročnosti (čl.173. i 174. ZOO)“ (VSH, Rev-1865/83 od 23.2.1984., P. Klarić, Odgovornost zdravstvene ustanove i zdravstvenih djelatnika za štetu, PuG, br. 4/2001, str. 66, bilj. 67). „Ako pravila medicinske nauke dopuštaju složeniji metod lečenja, uprkos mogućeg rizika u vidu štetnih posledica po zdravlje pacijenta, onda za izuzetno nastupanje štetnih posledica zdravstvena organizacija u kojoj je lečenje vršeno ne može odgovarati po osnovu objektivne odgovornosti. (Savezni sud, broj: Gzs-62/77 16.01.1978., M. Mijačić, Odgovornost za štetu izazvanu medicinskim aparatima, PŽ 11-12/1995., str. 1807, bilj. 15). Sve ovo pod uslovom da je pacijent odnosno njegov staralac upozoren na moguće štetne posljedice i da je pristao na tu vrstu liječenja" (vidi odluku Vrhovnog suda Hrvatske Gž-119/76 11.01.1977.). „Priznaje se pravo na naknadu štete zbog povreda koje je dete pretrpelo u 8 mesecu trudnoće nepažnjom lekara uz uvjet da se dete rodi živo" (Apelacioni sud Orleana (Luizijana) 1923.., Z. Ponjavić, Prenatalna šteta, PŽ 11-12/1995., str. 1815, bilj. 22). „Troškovi roditelja vezanih uz neželjeno rođenje djeteta mogu se tažiti kao odšteta od bolnice ili neke druge medicinske ustanove samo u onom slučaju kad je zaštita od neželjene trudnoće (obrada, savjetovanje...) bila predmet ugovora između bolnice i osobe kojoj se trudnoća dogodila" Savezni sud Njemačke 15.02.2000., VI ZR 135/99., M. Ćurković, Osiguranje 7-8/2000). „Pravilno je sud dosudio naknadu štete (imovinske i moralne) nastale ozljedom fetusa, odnosno primjenom krive metode pri otežanom porodu roditeljima i njihovom djetetu, ali i naknadu za trajne posljedice koje će utjecati na djetetovu radnu sposobnost" (Apelacijski sud Italije., M. Ćurković, Osiguranje 9/2000). „Kod dragovoljnog podvrgavanja prekidu trudnoće suprug i sin nemaju pavo naknade moralne i biološke štete, jer u konkretnom slučaju ne radi se o povredi njihovog subjektivnog prava već o povredi čistog faktičnog interesa (povećanje obitelji), što pravno nije zaštićeno" (Kasacijski sud Italije 3. Građanski odjel 11.02.1998., M. Ćurković, Osiguranje 10/2000). „Uzročna veza kao jedna od pretpostavki odgovornosti za štetu, presumira se i u slučaju kad je medicinska operacija obavljena bez pravno valjanog pristanka bolesnika, ako je nakon nje došlo do pogoršanja zdravlja bolesnika (čl. 154. ZOO)“" (VVSSl, II-Ips-225/97 od 30.9.1998., P. Klarić, Odgovornost zdravstvene ustanove i zdravstvenih djelatnika za štetu, PuG, br. 4/2001, str. 83, bilj. 139; DSP, br. 5/2004, str. 92). „Nema medicinskog dokaza da je prekomjerna doza penicilina koju je tužitelj nepažnjom dobio prilikom liječenja meningitisa, a koji je intezivnim liječenjem spašen ali je ostao gluh, povećala rizik gluhoće kod meningitisa" (Dom Lordova Kay v/s Ayrshire and Arran Health Board 1987.., P. Klarić, Odgovornost za štete u medicini, Novi Informator 5016-5017/2002, Male stranice, str. 21, bilj. 159). „Zahtjev tužiteljice čiji je muž nakon što se potužio na bolove i mučninu u želucu poslan kući a istoga dana i umro od trovanja arsenom odbijen je premda je bolnica priznala da nije postupala promptno. Dokazano je da bi i u slučaju da je hitno postupljeno smrt nastupila zbog trovanja, dakle nije postojala uzročna veza između nepažnje bolnice i smrti pacijenta" (Vrhovni sud SAD Barnett v/s Chelsea and Hensington Hospital Menagement Committee 1969.., P. Klarić, Odgovornost za štete u medicini, Novi Informator 50165017/2002, Male stranice, str. 22, bilj. 163). „Tužitelju koji je pao i ozlijedio kuk zbog kašnjenja liječničke intervencije razvila se avaskularna nekroza na mjestu ozljede. Dokazalo se da je vjerojatnost $75 \%$ da nekroza potječe od prvotne ozljede, što znači da tužitelj nije uspio dokazati uzročnu vezu. Da je pacijent uspio dokazati da uzrok nekroze treba pripisati $51 \%$ kašnjenju liječničke pomoći, bio bi ostvario potpunu naknadu štete" Vrhovni sud SAD Hotson v/s East Berkshire Area Health Authority 1987.., P. Klarić, Odgovornost zdravstvene ustanove i zdravstvenih djelatnika za štetu, PuG 4/2001., str. 84, bilj. 143). „Ne smatra se nesretnim slučajem propust liječnika-operatera koji je za vrijeme operacije carskog reza zbog nedovoljne pažnje kod šivanja operiranog dijela maternice zahvatio jednim šavom i vijugu tankog crijeva" (VSH, Kž2768/65., P. Klarić, Odgovornost zdravstvene ustanove i zdravstvenih djelatnika za štetu, PuG 4/2001., str. 84, bilj. 146). „U slučaju štete koja se dogodila radi ekspolozije aparata za narkozu u tijeku operacije a uslijed čega je pacijent umro, sud je primjenio odredbu iz čl. 1384. Code civil-a o odgovornosti za štete od stvari kod koje se predmnijeva odgovornost čuvara stvari. Takva se predmnjeva može oboriti samo dokazom slučaja, više sile ili vanjskog događaja“" (Kasacijski sud 
Prava, obveze i odgovornosti radnika u obavljanju djelatnosti: Odgovornost zdravstvenih radnika i osiguranje od odgovornosti

Francuske., P. Klarić, Odgovornost zdravstvene ustanove i zdravstvenih djelatnika za štetu, HPR 8/2001., str. 28, bilj. 76). „Prije kozmetičkog zahvata, formularom od strane bolnice pacijentica je samo obaviještena da je moguća retka komplikacija tromboza (formiranje krvnih ugrušaka), sa eventualnom naknadnom embolijom (arterijsko zakrečenje šlepovanim ugrušcima). Ta se opasnost sprečava davanjem sredstava koja koče zgrušavanje i pokretnim vežbama." Do navedenim je komplikacija nakon operacije istinski došlo i, budući da se radi o samo kozmetičkom zahvatu, stoji odgovornost za pretrpljenu materijalnu i nematerijalnu štetu kao i za buduće štete (400 $000 \mathrm{DM}$ ). Naime, ovakav način obavijesti o rizicima operacije nije dovoljan pošto je bolnica bila apsolutno dužna da ukaže na rizik od tromboze i embolije. Zbog propusta liječnika da dovoljno obavijeste pacijenticu o rizicima operacije njezin pristanak na zahvat smatra se nevažećim“ (Vrhovni zemaljski sud Oldenburg 30.05.2000., J. Radišić, Kozmetička operacija i odgovornost operatora, PŽ 9/2002., str. 177). „Pacijentica se, iz čisto kozmetičkih razloga, odlučila na operaciju proširenih vena, jer joj je ordinirajući lekar garantovao da je zahvat potpuno bezazlen i da ona neće zbog toga izgubiti nijedan radni dan. Operacija nije imala uspjeha i došlo je do formiranja bolnog apcesa i do dužeg bolovanja pacijentice. Ni u ovom slučaju nije se radilo o lekarskoj stručnoj grešci. Lekar mora platiti tužilji troškove lečenja i nadoknadi nematerijalnu štetu (bolninu), jer pristanak pacijentice na zahvat nije dobijen na pravilan način, te stoga nije bio punovažan“" (Vrhovni sud Austrije., J. Radišić, Kozmetička operacija i odgovornost operatora, PŽ 9/2002., str. 180). „Bolnica odgovora za skrivljeno postupanje svoga liječnika. Postupanje liječnika je skrivljeno ako nije u skladu s pravilima medicinske znanosti““ (VSSl, Pž-84/76., P. Klarić, Odgovornost za štete nastale uporabom medicinskih tehničkih uređaja..., str. 6, bilj. 30). „Lice koje se podvrgava medicinskoj intervenciji snosi rizik od objektivnih posljedica te intervencije. Zdravstvene organizacije koje vrše takvu intervenciju mogu odgovarati samo za one posljedice intervencije koje nastanu uslijed nestručnog, nepažljivog ili nepropisnog rada njenih radnika, dakle za posljedice koje se mogu pripisati u krivicu” (VSSr - Odjeljenje u Novom Sadu, Gž-356/69 od 15.5.1969., Lj. Milutinović, Naknada štete zbog lekarske greške, Bilten VSSr, br. 3/2002, str. 44). „Liječnik tužene bolnice skrivljeno je postupio kada je bez obavještavanja oštećenog o posljedicama primijenio metodu $\mathrm{s}$ injekcijom pentazola u svrhu utvrđenja boluje li oštećenik od epilepsije, što je prouzročilo reakciju s teškim tjelesnim oštećenjima (prijelom kralježnice i ruke)“ (VSH, Gž-3112/66 od 23.2.1967.). „Bolnica odgovara po načelu krivnje za štete nastale infekcijom koja se ne može smatrati uobičajenim rizikom operacije (čl. 154. st. 1. ZOO). Pogrešno bolnica smatra da je pacijent pristao na rizik operacije potpisom formulara za operaciju jer tada tužitelj nije bio upoznat da postoji mogućnost infekcije kakvu je on dobio. Takav potpis tuženu bolnicu ne oslobađa odgovornosti za tako nastalu štetu i uništeno zdravlje tužitelja. Sigurno je da takva infekcija, koja je uglavnom uzrokovana nedovoljno sterilnim uvjetima u bolnici, ne može spadati u uobičajeni rizik operacije, pa tuženica odgovara za štetu temeljem čl. 154. st. 1. ZOO” (Žs Zagreb, Gž-1938/99-2 od 14.3.2000., I. Crnić, Zakon o obveznim odnosima..., str. 136-137, odl. 28). „Odgovarajućom primjenom odredaba o ugostiteljskoj ostavi bolnica je dužna naknaditi štetu pacijentu koja mu je nastala za vrijeme boravka u bolnici zbog krađe novca (čl. 729. ZOO)" (VSH, Rev-779/89 od 10.10.1990., Pregled VSH, br. 47/1991, str. 80). “Zdravstvena organizacija odgovara po principu objektivne odgovornosti za štete koje pretrpi pacijent uslijed neispravnosti medicinskih instrumenata, pa i kada je ta neispravnost posljedica konstruktivne greške. Odgovornost tuženog ne može se otkloniti ni pozivom na odredbu člana 163. stav 1. Zakona o obligacionim odnosima. Pozivom na tu odredbu otklanja se odgovornost zdravstvene organizacije udruženog rada za uobičajene rizike koje donosi neophodna medicinska intervencija, preduzeta u cilju liječenja oštećenog, izvedena stručno i sa ispravnim instrumentima. Zdravstvena organizacija, međutim, odgovara za štetne posljedice koje nastanu zbog neispravnosti medicinskog pribora (usljed neadekvatne izrade ili istrošenosti) upotrebljenog prilikom medicinske intervencije, po principu uzročnosti i onda kada radnici zdravstvene organizacije nisu bili svjesni ove neispravnosti" (Vrhovni sud BiH, broj: Rev-102/85 od 11.6.1985. godine - Bilten VSBiH, br. 3/1985, odl. 16). "Ne može se istom tužbom zahtijevati naknada stečenog bez osnova od zdravstvene organizacije 
kojoj je Federacija platila cijenu liječenja vojnih osiguranika u većem iznosu od dugovanog i naknada štete od opštine čiji organi nisu uredno kontrolisali fakture zdravstvene organizacije jer se tužba ne zasniva ni na istom ni na bitno istovrsnom činjeničnom i pravnom osnovu u odnosu na tužene" (Vrhovni sud BiH, broj: Pž-23/85 od 27.6.1985. godine - Bilten VSBiH, br. 3/1985, odl. 36). "Bolnica odgovara za štetu prouzrokovanu smrću pacijenta koji je u stanju akutne psihoze iskočio kroz prozor nakon što je smješten u šok sobu bez nadzora medicinskog osoblja. Na osnovu iskaza utvrđeno je da je u šok sobi trebala da dežura medicinska sestra i dežurni ljekar, te da je bila praksa da se bolesnici kod kojih se pojaviljivao nemir kao kod tužitelja, vežu za krevet. Prema tome prvostepeni sud je pravilno primijenio materijalno pravo (član 170. st. 1. Zakona o obligacionim odnosima) kada je ocijenio da je tužena zbog propuštanja ljekara da, s obzirom na uznemireno stanje bolesnika, obezbijedi prisustvo medicinskog osoblja u šok sobi i odgovara za štetu" (Vrhovni sud $\mathrm{BiH}$, broj Gž-60/88 od 16.3.1989. godine - Bilten VSBiH, br. 2/1989, odl. 69). „Bolnica ne odgovara za štetu prouzrokovanu pacijentu medicinskom radnjom koja je izvršena u skladu sa pravilima struke. Iz činjeničnih utvrđenja sadržanih u razlozima nižestepenih presuda proizlazi da je provođenje elektrošokterapije u vrijeme liječenja tužioca kod tužene zdravstvene ustanove obavljeno u skladu sa pravilima medicinske nauke i prakse, koja se u to vrijeme primjenjivala $u$ većini psihijatrijskih ustanova u zemlji. Stoga tužena nije učinila takav propust da bi zbog toga bila odgovorna za štetu zbog teške tjelesne povrede, koju je pretrpio tužilac" (Vrhovni sud BiH, broj: Rev-191/88 od 26.1.1989. godine - Bilten VSBiH, br. 2/1989, odl. 70). „Budući da se liječenje vrši u cilju očuvanja i poboljšanja zdravlja bolesnika to zdravstvene ustanove za štete koje prilikom liječenja budu pričinjene bolesnicima, mogu odgovarati samo po principu krivice. To znači da zahvat preuzet u cilju liječenja, koji je bio indiciran i preduzet po pravilima struke, ostaje pravno besprijekoran i kad ne bude uspješan" (Vrhovni sud BiH, broj: Rev-191/88 od 26.1.1989. godine Bilten VSBiH, br. 2/1989, odl. 70). „,,Okolnost da je nastanku štete zbog smanjenja životne aktivnosti doprinijela i pogreška u liječenju, ne oslobađa odgovornosti vlasnika opasne stvari da oštećeniku naknadi svu štetu (čl. 177. st. 4. ZOO)" (Vrhovni sud Republike Hrvatske, broj: Revr703/07-2 od 20. 12. 2007. godine - Domaća strana sudska praksa, br. 37/2010, str. 87). „Kad je bolnica prilikom liječenja postupala po pravilima struke dajući kao lijek određeni krvni pripravak, ne odgovara za štetu kad je pacijent zbog takvog liječenja zaražen virusom (hepatitisom C). Mnogi medicinski tretmani bilo zbog načina liječenja, bilo upotrebe lijekova ili raznih pomagala predstavljaju određeni rizik za pacijentovo zdravlje, međutim, ako je takvo liječenje prihvaćeno u medicini, onda zbog mogućnosti nastupanja štetnih posljedica ne može zdravstvena ustanova odgovarati po načelu objektivne odgovornosti bez obzira na svoju krivnju“ (Vrhovni sud Republike Hrvatske, Gzz-249/03-2, od 22.01.2004. godine - Domaća i strana sudska praksa, broj 10/2005, strana 76). „Za štetne posljedice inače dopuštenog u medicini i općeprihvaćenog načina liječenja, bolnica odgovra po principu krivnje, a ne na osnovi objektivne odgovornosti (VSH, Rev- 3118/93. od 1. ožujka 1995., objavljena u „Informatoru“, broj 4546. od 1. listopada 1997., str. 4.), primjerice zbog toga što je do kasnije teške infecije došlo zbog toga što je pacijenticu prerano, s tinjajućom infekcijom, otpustila kući nakon poroda“ (VSH, Rev- 859/96. od 5. prosinca 2000.). „Za previd liječnika da je kod pacijenta došlo do prijeloma slabinskog kralješka i vratne kralježnic, pa je pacijent umjesto na operativni zahvat upućen na stacionarnu rehabilitaciju u toplice, odgovorna je zdravstvena ustanova u kojoj su liječnici zaposleni“ (Županijski sud u Bjelovaru, Gž- 139/06-2. od 11. svibnja 2006., objavljeno kod „Sudska praksa ŽS u Bjelovaru“, veljača 2007., str. 32.). „Okrivljena je kao ljekar anesteziolog pri pružanju ljekarske pomoći u toku operacije nesavjesno postupala jer nije obezbijedila dovoljnu količinu kiseonika u toku davanja opšte anestezije, iako je bila svjesna da može prouzrokovati pogoršanje zdravstvenog stanja bolesnice koja je operisana, pa je time prouzrokovala oštećenje moždanih centara, što je dovelo do smrtnog ishoda" (Presuda Okružnog suda u Beogradu Kž. 3053/03 od 17. novembra 2003. i presuda Drugog opštinskog suda u Beogradu K. 551/98 od 30. januara 2003. godine - Domaća i strana sudska praksa, broj 10/2005, strana 78). ,,,Zdravstvena ustanova koja vrši medicinsku intervenciju može odgovarati samo za one posljedice intervencije koje nastanu usljed nestručnog, nepažljivog i nepropisnog rada njenih 
Prava, obveze i odgovornosti radnika u obavljanju djelatnosti: Odgovornost zdravstvenih radnika i osiguranje od odgovornosti

radnika, dakle, za posljedice koje se mogu pripisati u krivicu ljekarima i drugom osoblju zbog postupanja koje nije bilo u skladu sa pravilima medicinske struke, a oslobađa se odgovornosti ako dokaže da je radnik u datim okolnostima postupao onako kako je trebalo. Samo na osnovu utvrđenja da je porod obavljen stručno, nižestepeni sudovi nisu mogli zaključiti da je ljekar koji je porodio tužiteljicu, $u$ datim okolnostima prije porođaja, u toku praćenja trudnoće, postupao onako kako je trebalo. Nije utvrđeno da li je prema specifičnostima trudnoće tužiteljice, njene debljine i težine ploda ljekar bio dužan blagovremeno uputiti tužiteljicu da se porodi u bolnici u kojoj bi se mogao obaviti operativni zahvat, odnosno da li su sve okolnosti predmetnog slučaja upućivale na moguće komplikacije pri porodu koji bi se obavio u samoj ambulanti" (Presuda Vrhovnog suda Federacije Bosne i Hercegovine, broj: Rev-62/04, od 9. 2. 2006. godine - Domaća i strana sudska praksa, broj 17/2006, strana 23; Bilten sudske prakse VS FBiH, broj 2006/1, odluka broj 28). ,,Bolnica odgovara za štetu pacijentu koji je tijekom liječenja putem transfuzije zaražen hepatitisom C. Ne može se prihvatiti kao osnovan revizijski navod da se tužitelju transfuzijom spašavao život i da ponašanje zaposlenika I - tuženika može se tretirati kao postupanje u krajnjoj nuždi jer se I - tužena ne može braniti da u slučaju kada je spašavala život tužitelju nije bila dužna dati tužitelju krv koja nije zaražena" (Vrhovni sud Republike Hrvatske, broj: Rev-1918/01 od 22. 11. 2001. godine Domaća i strana sudska praksa, broj 21/2007, strana 88) - SUPROTAN STAV: Vrhovni sud Republike Hrvatske, broj: Gzz-249/03-2, od 22.01.2004. godine). „Lekar koji je lečio pacijenta ili bio direktor medicinske ustanove u kojoj je pacijent lečen, ne može biti veštak u parnici po tužbi za naknadu štete, protiv druge medicinske ustanove u kojoj je isti pacijent lečen, ako je potrebno utvrđivati uzročno-posledičnu vezu između preduzetih mera lečenja u obe medicinske ustanove i nastale štete“ (Vrhovni sud Srbije, broj: Rev-2316/06, od 18. 10. 2006. godine - Domaća i strana sudska praksa, broj 22/2007, strana 95). „Tuženi zdravstveni centar odgovara tužilji za naknadu nematerijalne štete zbog pretrpljenog straha a zbog greške lekara patologa da je kod tužilje u pitanju karcinom dojke što je dovelo do odstranjenja iste, a potrebnim veštačenjem od najviših medicinskih ustanova Srbije je utvrđeno postojanje dijagnostičke greške lekara tuženog, a shodno čl. 170. i 171. ZOO” (Okružni sud u Čačku, broj: Gž-1361/08 od 27.08.2008. godine). „Svako lice koje se podvrgava medicinskoj intervenciji snosi rizik od objektivnih posljedica te intervencije. Zdravstvena ustanova, koja vrši medicinsku intervenciju, može odgovarati samo za one posljedice intervencije, koje nastanu uslijed nestručnog, nepažljivog i nepropisnog rada njenih radnika, dakle, za posljedice koje se mogu pripisati u krivicu ljekarima i drugom medicinskom osoblju zbog postupanja koje nije bilo u skladu sa pravilima medicinske struke“ (Vrhovni sud Srbije, broj: Rev2066/80 od 14. 1. 1981. godine - M. Mijačić, Odgovornost za štetu izazvanu medicinskim aparatima, Pravni život, br. 11-12/1992, str. 1806, bilj. 15; Lj. Milutinović, Naknada štete zbog ljekarske greške, Bilten sudske prakse VS Srbie, br. 3/2002, str. 43). „Bolnica ne odgovara za štetu prouzrokovanu pacijentu medicinskom radnjom koja je izvršena u skladu sa pravilima struke (čl. 170. st. 1. ZOO)" (Vrhovni sud BiH, broj: Rev-191/88 od 26. 1. 1989. godine - Bilten VSBiH, br. 2/1989, str. 46, odl. 70). „Bolnica ne odgovara za štetu ako se ne dokaže uzročna veza između nestručnog hirurškog zahvata i štetne posljedice (čl. 154. st. 1. i 170. ZOO). U smislu odredbe člana 154. Zakona o obligacionim odnosima, pravni osnov građansko-pravne odgovornosti za štetu je uzrokovanje štete, pa kako u konkretnom slučaju lični živac tužiteljice nije oštećen nestručnim operativnim zahvatom, kako je tužiteljica tvrdila, nego zbog pritiska tumora prije operacije, nižestepeni sudovi su pravilno primijenili navedenu zakonsku odredbu kada su tužbeni zahtjev odbili” (Vrhovni sud BiH, broj: Rev-697/88 od 4. 8. 1989. godine - Bilten VSBiH, br. 4/1989, odl. 119). „Zdravstvena ustanova koja vrši medicinsku intervenciju može odgovarati samo za one posljedice intervencije koje nastanu uslijed nestručnog, nepažljivog i nepropisnog rada njenih radnika, dakle, za posljedice koje se mogu pripisati u krivicu ljekarima i drugom osoblju zbog postupanja koje nije bilo u skladu sa pravilima medicinske struke, a oslobađa se odgovornosti ako dokaže da je radnik u datim okolnostima postupao onako kako je trebalo (čl. 170. st. 1. i 2. ZOO)“ (Vrhovni sud Federacije Bosne i Hercegovine, broj: Rev-62/04 od 9. 2. 2006. godine - Domaća i strana sudska praksa, br. 17/2006, str. 23; Bilten sudske prakse VSFBiH, br. 1/2006, odl. 28). "Za 
previd liječnika da je kod pacijenta došlo do prijeloma slabinskog kralješka i vratne kralježnice, pa je pacijent umjesto na operativni zahvat upućen na stacionarnu rehabilitaciju u toplice, odgovorna je zdravstvena ustanova u kojoj su liječnici zaposleni (čl. 170. st. 1. ZOO)" (Županijski sud u Bjelovaru, broj: Gž-139/06-2 od 11. 5. 2006. godine - H. Bilić-Erić, Domaća sudska praksa, Osiguranje, br. 3/2007, str.75). „Liječnik bolnice nije postupio sukladno pravilima struke kad je prilikom (agresivne pretrage) punkcije jetre propustio uspavati anestezijom nemirnu pacijenticu, što je bilo u vezi sa njezinim ozljeđivanjem (čl. 170. st. 1. ZOO)" (Županijski sud u Zagrebu, broj: Gžn-2983/04-2 od 6. 6. 2006. godine. Isto i Županijski sud u Zagrebu, broj: Gžn-2172/05-2 od 9. 8. 2005. godine). „Kada odlučuje o odgovornosti liječnika, sud je dužan imati u vidu da isti u ispunjavanju obveza iz svoje profesionalne djelatnosti moraju postupati s pažnjom dobrog stručnjaka, zbog čega je za ocjenu odgovornosti liječnika odlučno utvrditi da li je isti postupao suprotno pravilima i metodama rada zdravstvene struke odnosno znanstvenim spoznajama, a kojim se ugrožava život i zdravlje ljudi (čl. 170. st. 1. ZOO)“ (Županijski sud u Varaždinu, broj: Gž1027/08-2 od 10. 6. 2008. godine - Zbirka sudske prakse ŽS u Varaždinu iz oblasti građanskog prava, br. 10, str. 96-97). „Nagodbom o naknadi za štetu koju oštećeni trpi zbog tjelesne povrede obuhvaćena je samo naknada štete za one štetne posljedice koje su za stranku bile predvidive u vrijeme sklapanja nagodbe. Ako je nakon toga došlo do nepredviđenog pogoršanja zdravstvenog stanja oštećenog, on može da traži naknadu štete koju zbog toga trpi bez obzira na to što se nagodbom odrekao prava da traži dalju odštetu u vezi sa istim štetnim događajem" (Pravni stav Građanskog odjeljenja Kantonalnog suda u Sarajevu - Bilten sudske prakse Kantonalnog suda u Sarajevu, br. 3/2000, str. 19). "Kada su se stranke, zaključenom nagodom o naknadi štete zbog pretrpljene tjelesne povrede, sporazumjele o visini naknade kojom su obuhvaćeni oni vidovi štetnih posljedica koji su postojali u momentu zaključenja nagode, ili su bili predvidivi, tada oštećenom pripada pravo da zahtjeva od štetnika veće iznose naknade štete samo za slučaj da je nakon nagodbe došlo do daljeg nepredvidivog pogoršanja njegovog zdravstvenog stanja, pri čemu okolnost da se oštećeni zaključenom nagodom eventualno odrekao svakog daljeg potraživanja iz istog osnova, nije od uticaja za ostvarenje tog oštećenikovog prava (čl. 1092. st. 1. ZOO)" (Okružni sud u Sarajevu, broj: Gž-2304/80 od 16. 12. 1980. godine - Bilten VSBiH, br. 1/1981, str. 14 ). "Kad se radi o standardnom medicinskom zahvatu izvršenom u skladu sa suvremenom medicinskom strukom, za možebitne štetne posljedice takvog zahvata bolnica odgovara prema načelu krivnje za propuste prilikom njegova poduzimanja, glede izbora zahvata i sredstava kojima se zahvat obavlja" (VSH, Rev- 6/02-2. od 3. srpnja 2003., objavljeno kod "Informator", broj 5388. od 26. listopada 2005., str. 5.). "Zdravstvena ustanova odgovara za štetne posljedice zbog pogrešne dijagnoze" (VSRs, Rev-1466/96 od 4.4.1996). "Zdravstvena ustanova odgovara za štetne posljedice operativnog liječenja ako pacijentu nije predočila sve moguće, pa i izuzetno rijetke komplikacije i posljedice operativnog zahvata, na koji je inače pacijent pristao. Tužiteljici je rečeno da se može dogoditi da ne bude potpuno zadovoljna rezultatom operacije ukoliko se ne postigne potpuno zatvaranje oka, što ne zavisi samo od operativnog već i od postoperativnog toka. Tom prilikom tužiteljica nije bila upozorena na posljedicu koja je nastupila jer se pokretljivost očne jabučice kao posljedica ovakve plastične operacije jednostavno ne događa. Obavještenje pacijenta treba da bude pogodno da pacijent stekne osnovna saznanja o onome šta će se sa njim dogoditi ako na intervenciju ne pristane, kao i da mu bude razjašnjena djelotvornost predloženog zahvata, odnosno prognoza o stanju zdravlja poslije intervencije. To prije svega podrazumijeva ukazivanje na mogući neuspjeh zahvata i kada se isti obavi onako kako treba. S obzirom da zahvat nije bio hitan kod tužiteljice, obavještenje je trebalo da bude detaljnije" (VSSr, Rev-1821/05 od 19.5.2005. godine). Vidi kod BODNARUK, S. - ČIZMIĆ, J. - HRABAČ, B. - HUSEINAGIĆ, S., Komentari zdravstvenih zakona, knjiga 1., Privredna štampa, Sarajevo, 2011., str. 408.-418.

${ }^{134}$ Vidjeti na stranici: http://www.wma.net/e/policy/15.htm.

135 Vidjeti tako TURKOVIĆ, K., Novi pogledi u svijetu na odgovornost liječnika za liječničku grešku, na stranici: sretnaobitelj.odlican.net/index.php? 
Prava, obveze i odgovornosti radnika u obavljanju djelatnosti: Odgovornost zdravstvenih radnika i osiguranje od odgovornosti

${ }^{136}$ Za osiguranje od liječničke odgovornosti mogli bismo koristiti i termin osiguranje od liječničke pogreške. Iako se kod oba termina radi o osiguranju od odgovornosti, postoji razlika koja se ogleda u vrsti odgovornosti, vrsti pogreške, odnosno događaju ili događajima koji su doveli do nastanka štete prilikom pružanja liječničke pomoći ili usluga. ČOLOVIĆ, V., Osiguranje od lekarske odgovornosti, „Strani pravni život“, Institut za uporedno pravo, Beograd, 3/2010., str. 34.

${ }^{137}$ Usp. ODAK, V., Obvezna osiguranja, Dani hrvatskog osiguranja, Opatija 15. - 16. 11. 2004., str. 20.

${ }^{138} \mathrm{U}$ RH većina zdravstvenih ustanova nija postupila sukladno zakonskoj odredbi ili je ugovorilo osiguranja koje ne pokriva ni najmanji dio štete koje nastane liječničkom pogreškom.

139 Tako ĆURKOVIĆ, M., Osiguranje od odgovornosti liječnika, rad u zborniku „Građanskopravna odgovornost u medicini“, HAZU, Zagreb, 2008., str. 113.; ĆURKOVIĆ, M., Osiguranje od odgovornosti liječnika, zbornik radova „Aktualnosti građanskog i trgovačkog zakonodavstva i pravne prakse“, Mostar, 2008., broj 6, str. 149.

${ }^{140}$ Analiza ove vrste osiguranja u svijetu pokazuje da efikasno osiguranje od liječničke odgovornosti zavisi i od efikasnog zdravstvenog osiguranja. Da bi osiguranje od liječničke odgovornosti ili pogreške imalo svoje posebno mjesto na tržištu osiguranja ono mora, prije svega, biti zakonski regulirano i to u zakonskom aktu koji regulira zdravstvenu djelatnost. Isto tako, moraju biti definirani posebni uvjeti za ovaj oblik osiguranja koji bi imali svoj osnov u općim uvjetima o osiguranju od odgovornosti. Za pravilno funkcioniranje osiguranja od liječničke odgovornosti trebalo bi pravilno odrediti odnos premija i sume osiguranja, sa jedne strane, i vrste i složenosti ljekarske intervencije, sa druge strane. ČOLOVIĆ, V., Osiguranje od lekarske odgovornosti, „Strani pravni život“", Institut za uporedno pravo, Beograd, 3/2010., str. 33. 141 Vidi SLAVNIĆ, J., Osiguranje od profesionalne odgovornosti danas, Revija za pravo osiguranja, broj 3/2006., str 24.

142 Podatak kod JOVANOVIĆ, S., Osiguranje od odgovornosti -ugovorno pokriće po sistemu nastanka osiguranog uzroka ili datuma postvljanja odštetnog zahtjeva, Revija za prvo osiguranja, broj $1 / 2010$., str 39.

${ }^{143}$ Usp. ĆURKOVIĆ, M., Osiguranje od odgovornosti liječnika, rad u zborniku „Građanskopravna odgovornost u medicini“, HAZU, Zagreb, 2008., str. 111.

144 Vidi ČOLOVIĆ V., Obavezno osiguranje od odgovornosti stečajnog upravnika, Tradicionalno IV savetovanje pravosuđa „Stečaj i privatizacija“, Vršac, 2007., Zbornik radova, str. 132.

${ }^{145}$ Pokriveni su budući, neizvjesni i od volje osiguranika nezavisni štetni događaji koji su nastali kao rezultat liječničke greške, odnosno nesavjesnog ili nestručnog postupka ili propusta liječnika ili ostalog medicinskog osoblja učinjenog protivno važećim propisima i standardima medicinske struke, koji za izravnu posljedicu imaju nepovoljan ishod liječenja i na osnovu kojeg bi treća osoba mogla zahtijevati naknadu štete. Osiguranje se zaključuje na sumu osiguranja koja predstavlja gornju granicu za naknadu štete po jednom štetnom događaju. Osim sume osiguranja po štetnom događaju, postoji i pojam agregatne sume osiguranja koja predstavlja ukupnu obavezu osiguravatelja za cijeli period osiguranja i predmet je ugovaranja. Izbor adekvatne sume osiguranja je vrlo važan, jer predstavlja ujedno iznos do kojeg po pretpostavci mogu ići odštetni zahtjevi trećih osoba. Visina premije osiguranja zavisi od izbora limita pokrića, tj. sume osiguranja kako po štetnom događaju, tako i agregatne, zatim izvora opasnosti i ukupnog prihoda. Jedna od važnih karakteristika ovog oblika osiguranja, odnosi se i na to da obveza osiguravatelja nije samo u isplati štete, odnosno, sume osiguranja, već i u poduzimanju obrane od neosnovanih i pretjeranih zahtjeva za naknadu štete, kao i u naknadi troškova sudskog postupka. Mora se ispuniti uvjet da je osiguranik postupao sa povećanom pažnjom, kao i po zakonu, odnosno po pravilima svoje struke. Oštećena osoba ima pravo na naknadu štete do ugovorene osigurane sume, kao i na zakonsku kamatu (KERETA J., Osiguranje od profesionalne odgovornosti, časopis Sigurnost, vol. 48, br. 3 (01. 10. 2006., str. 323.). Iako se ne bi moglo poistovijetiti zanimanje liječnika s nekim drugim profesijama kao što to navode neki autori, (VASILIĆ J., Osiguranje stečajnog upravnika od građanske odgovornosti za štete učesnicima u stečajnom postupku, Revija za pravo osiguranja, br. 2/2002,

Beograd 2002., str. 46.), nedvojbeno se u svim tim slučajevima radi o osiguranju profesionalne 
Prava, obveze i odgovornosti radnika u obavljanju djelatnosti: Odgovornost zdravstvenih radnika i osiguranje od odgovornosti

odgovornosti.ČOLOVIĆ, V., Osiguranje od lekarske odgovornosti, „Strani pravni život“, Institut za uporedno pravo, Beograd, 3/2010., str. 39.

146 Tako HRANILOVIĆ, A. - ROVIS, D., Pogledi osiguratelja na profesionalnu odgovornost: Što su nam zakoni i praksa donijeli u Hrvatskoj po pitanju profesionalne odgovornosti?; Pravna zaštita liječnika u obavljanju liječničke djelatnosti, Simpozij HLK, Opatija, 2012.

${ }^{147}$ Vidi ČOLOVIĆ, V., Osiguranje od lekarske odgovornosti, „Strani pravni život“", Institut za uporedno pravo, Beograd, 3/2010., str. 41. O dokaznim sredstvima u parničnom postupku vidi više kod ČIZMIĆ, J., Komentar Zakona o parničnom postupku, drugo izmijenjeno i dopunjeno izdanje, "Privredna štampa", Sarajevo, 2016., str. 383.-475.; ČIZMIĆ, J. - BOBAN, M., Elektronički dokazi u sudskom postupku i računalna forenzička analiza, Zbornik Pravnog fakulteta Sveučilišta u Rijeci, (1991), v. 38, br. 1, 2017., str. 23.-50.

${ }^{148}$ Usp. PROSO, M., Sustavi osiguranja od odštetne odgovornosti u zdravstvenoj djelatnosti, Zbornik radova Pravnog fakulteta u Splitu, god. 46, 2/2009., str. 359.-372.

${ }^{149}$ Podatak kod ĆURKOVIĆ, M., Osiguranje od odgovornosti liječnika, rad u zborniku „Građanskopravna odgovornost u medicini“, HAZU, Zagreb, 2008., str. 122.-123.

${ }^{150}$ Tako ĆURKOVIĆ, M., Osiguranje od odgovornosti liječnika, zbornik radova „Aktualnosti građanskog i trgovačkog zakonodavstva i pravne prakse“, Mostar, 2008., broj 6, str. 151.

${ }^{151}$ Sve su doduše češći zahtjevi teorije, u praksi još neprihvaćeni, za što širom primjenom pravila objektivne odštetne odgovornosti kod koje se odgovora po principu cause. PROSO, M., Sustavi osiguranja od odštetne odgovornosti u zdravstvenoj djelatnosti, Zbornik radova Pravnog fakulteta u Splitu, god. 46, 2/2009., str. 363.

152 Vidi ĆURKOVIĆ, M., Osiguranje od odgovornosti liječnika, rad u zborniku „Građanskopravna odgovornost u medicini“, HAZU, Zagreb, 2008., str. 122.-123.

${ }^{153}$ U tom smislu ČOLOVIĆ, V. - PETROVIĆ, Z. - TEŠIĆ, A., Osiguranje profesionalne odgovornosti lekara i ostalih zdravstvenih radnika; Institut za uporedno pravo, Beograd, Srbija; Univerzitet „Sigmund Freud“, Beč ,Austrija; Univerzitet „Privredna akademija“ Novi Sad, Srbija, 2015., str 86.

${ }^{154}$ Tako ĆURKOVIĆ, M., Osiguranje od odgovornosti liječnika, rad u zborniku „Građanskopravna odgovornost u medicini“, HAZU, Zagreb, 2008., str. 122.-123.

${ }^{155}$ Francuski sustav ostaje uglavnom i dalje na polju odštetne odgovornosti po načelu krivnje, po osnovu subjektivne odgovornosti, a kao novinu i specifičnu implementaciju u svoj sustav uvodi, po uzoru na skandinavske zemlje, odgovornost bez krivnje a bolest, medicinsku nezgodu, bolničke infekcije i greške u sanitarnom materijalu, odnosno proizvodu koja ima za posljedicu kod pacijenta invalidnost od najmanje $25 \%$. MAJA PROSO, Sustavi osiguranja od odštetne odgovornosti u zdravstvenoj djelatnosti, Zbornik radova Pravnog fakulteta u Splitu, god. 46, 2/2009., str. 367.

${ }^{156}$ Vidi TURKOVIĆ, K., Kaznena djela protiv zdravlja ljudi, u: Novoselec, P., Posebni dio kaznenog prava, Prvo izdanje, Zagreb, 2007., str. 258.; RADIŠIĆ, J., Medicinsko pravo, IP Nomos, Beograd, 2008., str. 58.

157 Tako MUJOVIĆ-ZORNIĆ, H., Medicinsko pravo - Interdisciplinarnost i suradnja, Beograd, 2013., podatak na stranici

www.ius.bg.ac.rs/pro/Mateirjali/dramar/h.mujovic.medicinsko\%20pravo.pdf. (uvid 27. 11. 2013.).

158 Vidi BAČIĆ, F. - PAVLOVIĆ, Š., Komentar kaznenog zakona, Zagreb, 2004., str. 548.; Tako BAČIĆ, F. - ک̌EPAROVIĆ, Z., Krivično pravo - posebni dio, Zagreb, 1997., str. 111.

159 Usp. RADIŠIĆ, J., Profesionalna odgovornost medicinskih poslenika, Beograd, Institut društvenih nauka u Beogradu, 1986., str. 123.-167.

${ }^{160}$ Tako KLARIĆ, P., Grananskopravna odgovornost za liječničku grešku, u: Građanskopravna odgovornost u medicini, okrugli stol, HAZU, Zagreb, 2008., str. 31.-51.; Liječničke novine,

Zagreb, 2006., br. 50, str. 15. 
Prava, obveze i odgovornosti radnika u obavljanju djelatnosti: Odgovornost zdravstvenih radnika i osiguranje od odgovornosti

161 Tako TURKOVIĆ, K. - ROKSANDIĆ VIDLIČKA, S., Reforma kaznenog zakonodavstva u području zdravstva, Zbornik radova Aktualnosti zdravstvenog zakonodavstva i pravne prakse, II. znanstveni skup, Novalja, 2011., str. 111-136.

162 Usp. TURKOVIĆ, K. i dr., Komentar Kaznenog zakona i drugi izvori novoga hrvatskog kaznenog zakonodavstva, „Narodne novine“, Zagreb, 2013., str. 240.

163 Tako Medicinska enciklopedija, knjiga 4., Zagreb, MCMLXIX, str. 295.

${ }^{164}$ Vidi BABIĆ, T. - ROKSANDIĆ, S., Osnove zdravstvenog prava, Zagreb, 2006., str. 271.

165 Podatak kod ŽUŽA, Ž., Disciplinska odgovornost liječnika, „Informator“", broj 5863. od 15. svibnja 2010., str. 9.

166 Usp. JURAS, D., Disciplinska odgovornost liječnika, ,Zbornik radova Pravnog fakulteta u Splitu“, god. 51., 2014., broj 3, str. 641.

167 Djelo može biti počinjeno činjenjem, npr. primjenom pogrešnog antibiotika kao posljedicom pogrešne dijagnoze, ali i nečinjenjem, npr. nesterilizacijom kirurških instrumenata. Radnja se sastoji u primjeni nepodobnog sredstva ili načina liječenja. Nepodobno je ono sredstvo čija primjena nije u skladu s osnovnom zadaćom zdravstvenih radnika, a to je poštovanje ljudskog života od njegova početka do smrti, promicanje zdravlja te sprečavanje i liječenje bolesti uz poštovanje tjelesnog integriteta pacijenta. Tako bi sredstva bili: različiti lijekovi, instrumenti koji se uvode u tijelo pacijenta, različite kemijske supstance (koje se koriste prilikom anestezije, kemodijalize), rendgen i dr. Načini liječenja su različite vrste medicinskih postupaka poduzetih radi dijagnoze, liječenja, rehabilitacije; kirurški zahvati, kemoterapija, zračenje i dr., koje nije trebalo primijeniti. JURAS, D., Disciplinska odgovornost liječnika, „Zbornik radova Pravnog fakulteta u Splitu“, god. 51., 2014., broj 3, str. 635.-636. Nestručan rad može biti posljedica nemara, lakomislenosti, brzopletosti, površnosti, ali i rezultat objektivnih okolnosti: neiskustva, umora, međuljudskih odnosa u zdravstvenoj ustanovi, preopterećenosti liječnika obvezama na više odjela, nedovoljne opremljenosti uređajima i medicinskim materijalima, nedovoljne edukacije i dr. Uslijed takvog propusta dolazi do pogoršanja bolesti ili narušenja zdravlja pacijenta. ${ }^{41}$ Pogoršanje bolesti pretpostavlja već bolesnu osobu kao pacijenta. Pogoršanje bolesti obuhvaća i produljenje vremena potrebnog za ozdravljenje i slabi uspjeh liječenja. Narušenje zdravlja pretpostavlja zdravu osobu koja je podvrgnuta nekoj liječničkoj intervenciji, primjerice davatelj organa za transplantaciju, dobrovoljni davatelj krvi, cijepljena osoba. JURAS, D.,

Disciplinska odgovornost liječnika, „Zbornik radova Pravnog fakulteta u Splitu“, god. 51., 2014., broj 3, str. 636 .

168 Liječnik može, sukladno posebnim propisima, biti pozvan na odgovornost i pred Sudom časti HLZ-a. Budući da je članstvo u HLZ-u fakultativno, postupak utvrđivanja odgovornosti može se provoditi samo protiv liječnika koji su članovi HLZ-a. Liječnik prema poslodavcu, temeljem Zakona o radu, može odgovarati za kršenje obveza iz radnog odnosa. Ponašanja koja poslodavac smatra povredama radnog odnosa najčešće su propisana pravilnikom o radu. Postupak utvrđivanja odgovornosti u takvim slučajevima nije općenito propisan već je svakom poslodavcu prepušteno da samostalno odredi način na koji će utvrđivati i sankcionirati odgovornost radnika. Propisane povrede često predstavljaju osnovu za izvanredni otkaz, ali mogu biti sankcionirane i eventualnom opomenom, upozorenjem pa čak i novčanom kaznom. JURAS, D., Disciplinska odgovornost liječnika, „Zbornik radova Pravnog fakulteta u Splitu“, god. 51., 2014., broj 3, str. 655 .

169 Vidi ŽUŽA, Ž., Disciplinska odgovornost liječnika, „Informator“, broj 5863. Od 15. Svibnja 2010., str. 9.

170 Tako JURAS, D., Disciplinska odgovornost liječnika, „Zbornik radova Pravnog fakulteta u Splitu“, god. 51., 2014., broj 3, str. 627.

${ }^{171}$ Odluka Upravnog suda Republike Hrvatske, br. Us- 7246/2005. od 30. listopada 2008., „Informator“, Sudska praksa, broj 5885.-5886. od 31. 7. i 4. 8. 2010., str. 4.

${ }_{172}$ Usp. JURAS, D., Disciplinska odgovornost liječnika, ,Zbornik radova Pravnog fakulteta u Splitu“, god. 51., 2014., broj 3, str. 651. 
${ }^{173}$ Zakonodavac je prepustio Hrvatskoj liječničkoj komori da samostalno odredi sadržaj lakše i teže disciplinske povrede pa je tako odredbom članka 4. stavka 3. Pravilnika o disciplinskom postupku Hrvatske liječničke komore ( $\underline{w w w . h l k . h r}$ ) propisano da su teške povrede one koje imaju teže značenje s obzirom na važnost, prirodu povrijeđenog dobra, visinu materijalne štete ili težinu druge posljedice te s obzirom na okolnosti pod kojima je radnja izvršena odnosno propuštena. Odredbom članka 4. stavka 4. citiranog Pravilnika propisano je da su lakše disciplinske povrede one koje imaju lakše značenje s obzirom na važnost, prirodu povrijeđenog dobra, visinu materijalne štete ili težinu druge posljedice te s obzirom na okolnosti pod kojima je radnja izvršena odnosno propuštena. Sličnu definiciju lakih i teških disciplinskih povreda imaju i drugi pravilnici strukovnih komora.

174 Dentalni tehničari učlanjuju se u Strukovni razred dentalnih tehničara, a dentalni asistenti učlanjuju se u Strukovni razred dentalnih asistenata pri Hrvatskoj komori dentalne medicine.

175 Iako je Zakonom o dentalnoj medicini propisana odgovornost doktora dentalne medicine, dentalnih tehničara i dentalnih asistenata, u članku 4. stavku 2. Pravilnika o nadležnosti, ustrojstvu i načinu djelovanja Časnog suda pri Hrvatskoj stomatološkoj komori (na službenoj web stranici Komore moguće je pronaći jedino spomenuti Pravilnik pa je za pretpostaviti da je taj ujedno i važeći), propisano je da Casni sud Komore raspravlja i odlučuje o odgovornosti doktora stomatologije. Ostaje neutvrđeno temeljem kojeg se propisa utvrđuje disciplinska odgovornost dentalnih tehničara i dentalnih asistenata. No, za pretpostaviti je da se njihova odgovornost utvrđuje analognom primjenom spomenutog Pravilnika.

176 Člankom 4. stavkom 2. Pravilnika o nadležnosti, ustrojstvu i načinu djelovanja Časnog suda pri Hrvatskoj stomatološkoj komori propisan je sadržaj odnosno opseg disciplinske odgovornosti koja, dakle, obuhvaća povredu Kodeksa stomatološke etike i deontologije, povredu Statuta Hrvatske komore dentalne medicine te nepravilnosti nastale prilikom obavljanja stomatološke djelatnosti.

177 Zbog ograničenog opsega ovoga rada te zbog brojnosti odredbi kojima su regulirane povrede ljekarničke dužnosti, etike i deontologije, za detaljniji uvid u sadržaj pojedinih povreda vidi odredbe članaka 8. - 37. Pravilnika o radu i kaznenim mjerama Stegovnog suda Hrvatske ljekarničke komore (www.hljk.hr).

${ }^{178}$ Ova mjera, kao dodatna mjera, nije predviđena Zakonom o medicinsko-biokemijskoj djelatnosti već odredbom članka 44. stavka 2. Pravila o ponašanju i odgovornosti u struci članova Hrvatske komore medicinskih biokemičara.

179 Članak 31. Zakona o medicinsko-biokemijskoj djelatnosti; međutim, valja primijetiti da su odredbom članka 45. Pravila o ponašanju i odgovornosti u struci članova Hrvatske komore medicinskih biokemičara, povećani zakonom određeni iznosi novčanih kazni pa je tako propisano da se za lakšu povredu može izreći novčana kazna u visini od 2.000,00 - 5.000,00 kn dok se za tešku povredu može izreći novčana kazna u iznosu od 6.000,00 - 20.000,00 kn - pitanje je da li bi se u disciplinskom postupku doista i mogle izreći kazne u ovim iznosima s obzirom da isti izlaze iz okvira određenog Zakonom o medicinsko-biokemijskoj djelatnosti.

${ }^{180}$ Institut nedostojnosti za medicinske sestre nije propisan Zakonom o sestrinstvu kao što je to slučaj s liječnicima i doktorima dentalne medicine te dentalnim tehničarima. Slijedom toga, ostaje nerazjašnjeno iz kojih je razloga Hrvatska komora medicinskih sestara uvrstila ovu odredbu u svoj Pravilnik o pravima i odgovornostima medicinskih sestara.

${ }^{181}$ Vidi AVIANI, D., Prekršajno pravo, Split, 203., str. 8.

182 Tako JAGIĆ, Z., Prekršajna odgovornost članova komora u zdravstvu, Zbornik radova s međunarodnog simpozija "Medicinsko pravo u sustavu zdravstvene djelatnosti", 2015., str. 279295. Podatak kod RADANOVIĆ MIŠIĆ, N., Liječnik kao subjekt deliktne odgovornosti, doktorska disertacija, Mostar, 2017., str. 59.

${ }^{183}$ Vidi RADIŠIĆ, J., Medicinsko pravo, „Nomos“, beograd, 2004., str. 201.-202.

${ }^{184}$ Podatak kod RODRÍGUEZ-VÁZQUEZ, V., Doctors in Spanish Criminal Law: medical criminal responsibility for deaths and injuries caused by negligence in present-day Spain, 25 Med. \& L., 2006., str. 418. Dostupno na: http://heinonline.org. 
Prava, obveze i odgovornosti radnika u obavljanju djelatnosti: Odgovornost zdravstvenih radnika i osiguranje od odgovornosti

${ }^{185}$ Zdravstveni tim čini više osoba, zdravstvenih radnika, zavisno od činjenice koje je djelatnosti, odnosno poslove pojednih djelatnosti potrebno poduzeti radi pružanja i davanja konkretne zdravstvene usluge. Stoga, sastav tima ovisi o vrsti zdravstvenih postupaka koje je potrebno poduzeti prema pacijentu. Šire KLARIĆ, A. - CVITKOVIĆ, M., Vrste i načini odgovornosti unutar tima, Zbornik radova „2. Hrvatski simpozij medicinskog prava“, Vodice, 2016, str. 217.

186 Tako RADANOVIĆ MIŠIĆ, N., Liječnik kao subjekt deliktne odgovornosti, doktorska disertacija, Mostar, 2017., str. 186.

${ }^{187}$ Usp. KLARIĆ, A. - CVITKOVIĆ, M., Vrste i načini odgovornosti unutar tima, Zbornik radova s međunarodnog simpozija „2. Hrvatski simpozij medicinskog prava“, Vodice, 2016., str. 217.

${ }^{188}$ Ljekari jedne zdravstvene ustanove u tijeku pružanja medicinske usluge vrlo često su grupirani i blisko surađuju. Timski rad u procesu pružanja zdravstvene zaštite postoji na svim nivoima zdravstvene zaštite. Timski rad postoji npr. između kirurga i anesteziologa u tijeku kirurškog zahvata. Timski rad postoji i između glavnog kirurga i ljekara koji mu asistiraju prilikom određenog zahvata i koji su mu podređeni. Pored toga, timski rad postoji i između kirurga i patologa u tijeku operacije iako između njih ne postoji ni prostorna ni organizacijska veza specijalista patolog u tijeku samog operativnog zahvata vrši analizu tkiva ex tempore i na osnovu pregleda operativnog materijala daje svoj nalaz i na taj način usmjerava rad kirurga. Značaj patološko-citološke analize tkiva ima presudan značaj za postavljanje dijagnoze, obim kirurškog zahvata i tijek terapijskog postupka. Patolog, na osnovu kliničkih informacija i neposredno uočenih patoloških karakteristika na biopsijskom materijalu, procjenjuje stanje pacijentovog tkiva, posebno u urgentnim slučajevima, pravovremeno postavlja dijagnozu ili diferencijalnu dijagnozu i stupanj suglasnosti sa svakom od njih. Po potrebi, ljekar patolog sugerira dalje pravde ispitivanja i konzultira, u slučaju potrebe, i druge patologe. U timu koji se formira u tijeku operativnog zahvata između kirurga i dežurnog ljekara patologa odn. citpotaloga ljekari različitih specijalnosti imaju jednak položaj i njihovi međusobni odnosi se zasnivaju na principu suradnje i povjerenja. STOJANOVIĆ, I., Međusobni odnosi lekara, „Pravni život“", 2013., broj 9, TOM I, str. 396.-398.

${ }^{189}$ Vidi RADIŠIĆ J., Građanska odgovornost lekara koja proističe iz njihovog zanimanja, Revija za pravo osiguranja, 2009., br. 1., str. 20.

${ }^{190}$ Usp. ŽOKALJ, I., SABLJAR-MATOVINOVIĆ, M., Dealing with interpersonal miscommunication problems as presented to the Commission for Medical Ethics and Deontology of Croatian Medical Chamber, Odnosi među liječnicima u Hrvatskoj, Knjiga izlaganja na XIV. proljetnom simpoziju medicinske etike Hrvatskoga liječničkog zbora, Zagreb, 2014.

${ }^{191}$ Tako ZEČEVIĆ, D. - ŠKAVIĆ, J., Kaznenopravna i građanskopravna odgovornost liječnika

- Teorija i praksa, ,Medicinska naklada“, Zagreb 2012., str. 20.

192 Podatak kod KLARIĆ, A. - CVITKOVIĆ, M., Vrste i načini odgovornosti unutar tima, Zbornik radova s međunarodnog simpozija „2. Hrvatski simpozij medicinskog prava“, Vodice, 2016., str. 217.

${ }^{193}$ Vidi KLARIĆ, A. - CVITKOVIĆ, M. - MATIJAŠČIĆ ŽUGAJ, P., Komore u zdravstvu, Zbornik Aktualna problematika u zdravstvu, Varaždin (2015), str. 162.-182.

${ }^{194}$ Vidi RADIŠIĆ, J., Medicinsko pravo, „Nomos“, Beograd, 2004., str. 201.-202.

195 Tako STOJANOVIĆ, I., Međusobni odnosi lekara, „Pravni život“, 2013., broj 9, TOM I, str. 396.-398.

196 Usp. ZEČEVIĆ, D. - ŠKAVIĆ, J., Kaznenopravna i građanskopravna odgovornost liječnikaTeorija i praksa, „Medicinska naklada“, Zagreb 2012., str. 21.

${ }^{197}$ Rukovodeći ljekar ne smije da povjeri da pojedini zadatak preuzme ljekar na specijalizaciji koji nije dovoljno stručno obučen ili koji je stručno nepodoban za konkretnu medicinsku usluge. Osim toga i sam ljekar na specijalizaciji ne smije da postupi suprotno svom ljekarskom znanju i uvjerenju i da bez pogovora slijedi nalog nadređenog ljekara. Smatra se da, ukoliko je u pitanju kirurški zahvat, ljekar na specijalizaciji mora da bude samokritičan i da može da odbije da izvrši 
operaciju koja mu je naložena ukoliko to treba da učini bez stručnog nadzora pošto je u pitanju briga za zdravlje i život pacijenta. Ukoliko bi ljekar na specijalizaciji prekoračio granice svog znanja, iskustva i sposobnosti, on bi učinio ljekarsku grešku. J. RADIŠIĆ, Odgovornost za štetu uzrokovanu operacijom koju je obavio ljekar na specijalizaciji, Anali Pravnog fakulteta u Beogradu, br. 6/1993, str. 636.

198 Vidi STOJANOVIĆ, I., Međusobni odnosi lekara, „Pravni život“, 2013., broj 9, TOM I, str. 396.-398.

199 Tako KLARIĆ, A. - CVITKOVIĆ, M., Vrste i načini odgovornosti unutar tima, Zbornik radova s međunarodnog simpozija „2. Hrvatski simpozij medicinskog prava“, Vodice, 2016., str. 218.-220.

${ }^{200}$ Vidi KLARIĆ, A. - CVITKOVIĆ, M., Vrste i načini odgovornosti unutar tima, Zbornik radova s međunarodnog simpozija „2. Hrvatski simpozij medicinskog prava“, Vodice, 2016., str. 222.-224.

${ }^{201}$ Tako HOROVIĆ, S. - RADANOVIĆ MIŠIĆ, N., Kaznenopravna i građanskopravna odgovornost liječnika, Zbornik radova s petnaestog međunarodnog savjetovanja „Aktualnosti građanskog i trgovačkog zakonodavstva i pravne prakse“, održanog u Neumu 16-18. lipnja 2017., Mostar, 2017., str. 46.

${ }^{202}$ Vidi KLARIĆ, P., Odštetno pravo, Zagreb, 2003., str. 388.; BOŠKOVIĆ, Z., Zakon o zaštiti prava pacijenata - reforma zdravstvenog zakonodavstva Republike Hrvatske, „Hrvatska pravna revija“, god. V., 2005., br. 1, str. 90.

${ }^{203}$ Podatak kod KLARIĆ, P., Građanskopravna odgovornost za liječničku grešku, rad u zborniku radova „hrestomatija hrvatskoga medicinskog prava“, Pravni fakultet Sveučilišta u Zagrebu, Zagreb, 2016., str. 733.

${ }^{204}$ U tom smislu STOJANOVIĆ, I., Pretpostavljena odgovornost lekara i tzv. defanzivna medicina, „Pravni život“", knjiga 583, 2016., broj 9., str. 367.

${ }^{205} \mathrm{Kad}$ govorimo o liječničkog greški ista je primjenjiva u svim navedenim segmentima na sve zdravstvene radnike. ŽUŽA, Ž., Disciplinska odgovornost liječnika, „Informator“, broj 5863. Od 15. Svibnja 2010., str. 9. 
252 | ZDRAVSTVENO STRUKOVNO STALEŠKO PRAVO 


\section{7/ Rješavanje sporova (arbitraža)}

\subsection{Pojam i cilj arbitražnog rješavanja sporova}

Izbrano/arbitražno sudovanje je način mirnog rješavanja sporova pred nedržavnim/privatnim tijelom koje stranke same biraju i povjeravaju mu da konačno i autoritativno odluči o njihovim spornim odnosima. ${ }^{1}$ Izbrano sudovanje definira se i kao rješavanje sporova između dvije ili više stranaka od strane treće ili trećih osoba (arbitara), koje svoja ovlaštenja izvode iz sporazuma stranaka i čija je odluka obvezna za njih i ima, u većini pravnih poredaka, učinak kao sudska odluka, ${ }^{2}$ uključujući i osiguranje ovršnosti arbitražnog pravorijeka od strane države. ${ }^{3}$

Arbitražno suđenje pretpostavlja derogiranje ovlaštenja, odnosno nadležnosti državnoga sudstva. U tom smislu arbitraža jest i aktivnost provođenja suđenja u sporu pred arbitražnim sudom. Postupak pred arbitražnim sudom je suđenje, čak i onda kad je po ovlaštenju stranaka sudio po načelu pravičnosti (ex aequo et bono). ${ }^{4}$ Arbitražni postupak karakteriziraju načela: ravnopravnosti stranaka, kontradiktornosti, otvorenog suđenja, autonomije u izboru pravila postupka i mjesta arbitraže, oportuniteta i ekonomije u načinu postupanja, stranačke dispozicije u izboru mjerodavnog prava za bit spora (i arbitražni sporazum), nejavnosti, kolegijalnog odlučivanja i interferencije s državnim sudom (i postupkom pred njim). ${ }^{5}$

Čitav je niz razloga zbog kojih držimo da će mnogi subjekti radije ugovoriti arbitražu kao sredstvo rješavanja sporova, negoli podvrgnuti rješenje njihova spora nadležnom državnom sudu. Među ostalim i zbog povjerenja u stručnost i objektivnost arbitara koje sami izabiru, njezine brzine, učinkovitosti, elastičnosti i tajnosti arbitražnog postupka, velikim dijelom zbog nepovjerenja u državne sudove poslovnog sjedišta druge stranke, zbog nepoznavanja jezika druge stranke i procesnih pravila države protivnika, te međunarodne ovršnosti arbitražnog pravorijeka.

Teorija i praksa arbitražnog prava poznaju brojne klasifikacije arbitraža,${ }^{6}$ ali najpoznatija i najznačajnija podjela je na ad hoc i institucijske arbitraže. Sa stajališta ovlaštenja za suđenje i s obzirom na značenje njihovih odluka, nema nikakve pravne razlike između institucijskih i ad hoc arbitraža, nego su razlike pretežno praktične, organizacijske naravi. ${ }^{7}$ Ad hoc arbitraže su takve arbitraže koje se osnivaju samo za jedan određeni spor i prije spora organizacijski ne postoje, ${ }^{8}$ u pogledu takvih arbitraža na strankama je inicijativa i odgovornost za osnivanje arbitražnog suda koji će riješiti njihov spor, a stranke usto moraju same utvrditi i pravila mjerodavna za vođenje arbitražnog postupka te neposredno sa samim arbitrima dogovoriti o pitanjima kao što su nagrade i troškovi. ${ }^{9}$ S obzirom da se većina poteškoća koje se mogu javiti u svezi s ad hoc arbitražom rješava prema nacionalnom pravu mjesta arbitraže, određivanje sjedišta/države ad hoc arbitraže od iznimnog je značenja. ${ }^{10}$ Ad hoc arbitraža obično se javlja kad stranke u svom arbitražnom ugovoru predvide arbitražu, ali je ne preciziraju kao arbitražnu instituciju, niti se pozivaju na njezina pravila. ${ }^{11}$ Institucijske arbitraže jesu organizacije u okviru kojih 
Prava, obveze i odgovornosti radnika u obavljanju djelatnosti: Rješavanje sporova (arbitraža)

arbitražni sudovi (vijeća ili arbitri pojedinci) rješavaju svoje sporove. ${ }^{12}$ Institucijska arbitraža je permanentni organ, $\mathrm{s}$ ustaljenim pravilima postupka i određenim administrativnim aparatom, ${ }^{13}$ koja, dakle, upravlja arbitražnim postupkom u skladu s njezinim arbitražnim pravilima, a pri tome može uzeti u obzir i želje stranaka. ${ }^{14}$

Izbrano/arbitražno sudovanje je način mirnog rješavanja sporova pred nedržavnim / privatnim tijelom koje stranke same biraju i povjeravaju mu da konačno i autoritativno odluči o njihovim spornim odnosima. ${ }^{15}$ Arbitražno sudovanje definira se i kao rješavanje sporova između dvije ili više stranaka od strane treće ili trećih osoba (arbitara), koje svoja ovlaštenja izvode iz sporazuma stranaka i čija je odluka obvezna za njih i ima, u većini pravnih poredaka, isti učinak kao sudska odluka, ${ }^{16}$ uključujući i osiguranje ovršnosti arbitražnog pravorijeka od strane države. ${ }^{17}$

Cilj arbitražnog postupka ostvaruje se donošenjem meritorne odluke od strane arbitražnog suda. Za razliku od državnog suda, arbitražni sud ne predstavlja stalnu i nepromjenjivu ustanovu, već ga je potrebno konstituirati za svaki pojedini slučaj imenovanjem arbitra ili arbitara koji će biti ovlašteni donijeti odluku o predmetu spora. ${ }^{18}$ Svoj pristanak da sudi u određenom sporu arbitar manifestira sklapanjem (u pravilu konkludentno) ugovora sa strankama (receptum arbitri).

Arbitar/izbrani sudac (engl. arbitrator, njem. Schiedsrichter) jest osoba kojoj je, u skladu sa sporazumom stranaka, povjereno da sama ili u vijeću s drugim arbitrima vodi postupak i odluči u određenom sporu. Arbitar je osoba, koju stranke imenuju sa namjerom da sama ili zajedno sa drugim arbitrima riješi njihov spor, a za koju se pretpostavlja da će u postupku djelovati stručno, samostalno i nepristrano. ${ }^{19}$

Arbitar može biti svaka fizička osoba ${ }^{20}$ koja je potpuno poslovno sposobna. ${ }^{21}$ Kako se arbitar ugovorom obvezuje na izvršenje svoje misije u okviru koje samostalno vrši pravne poslove i poduzima pravne radnje, on mora posjedovati potpunu poslovnu sposobnost. ${ }^{22}$ Od arbitra se očekuje da bude nepristran i sposoban da obavi svoju misiju. Dužnost arbitra je ispunjenje glavnog cilja zbog koga je imenovan - donošenje arbitražne odluke/pravorijeka. Taj cilj arbitar postiže zajedno sa ostalim arbitrima, provođenjem i okončanjem arbitražnog postupka, držeći se pravnih okvira spora iz arbitražnog sporazuma. ${ }^{23}$ Za razliku od državnog suca, arbitru se ne može nametnuti dužnost da spor riješi, on tu obvezu mora dobrovoljno prihvatiti (tzv. receptum arbitri). Njegovi motivi prihvaćanja rješavanja spora mogu biti različiti, a pretpostavlja se da je to danas ponajviše honorar. ${ }^{24}$ Izbor arbitara može ponekad prouzročiti više problema i izazvati zakašnjenje u pokretanju arbitražnog postupka, a time lančano i zakašnjenje u odvijanju cijelog postupka. Nekada su te smetnje rezultat objektivnih teškoća oko pronalaženja odgovarajućeg arbitra ili oko ishođenja njegove suglasnosti za sudjelovanje u arbitraži, ali su češće u pitanju subjektivni problemi izazvani nedovoljnom suradnjom stranaka, najčešće namjernim neizborom arbitra od strane tuženika. Ovome treba dodati i nesuglasnost već imenovanih arbitara u pogledu izbora trećeg arbitra - predsjednika arbitražnog vijeća. ${ }^{25}$ 
Odgovor na pitanje tko može biti izabran za arbitra vezan je za određene zahtjeve/uvjete u odnosu na potencijalnog arbitra, koji mogu biti postavljeni nacionalnim propisima ili pravilnicima institucijskih arbitraža. Zakoni mogu formulirati (opće i posebne) uvjete ili utvrditi određene zabrane za imenovanje arbitara, imajući u vidu njihove osobine kao što su nacionalnost, sposobnost, nezavisnost i nepristranost, objektivnost, moralni dignitet, povjerenje, stručnost te neutralnost arbitra. ${ }^{26}$ Državna pripadnost, spol, etničko podrijetlo, vjera, obrazovni profil (i nepravnici mogu biti arbitri) nisu, u pravilu, od utjecaja na izbor arbitra. S druge strane, sposobnost biti arbitar u nekim se pravnim sustavima ograničava osobama koje su bankrotirale, nositeljima javnih funkcija, kao i osobama koje su osuđene na kaznu zatvora. ${ }^{27}$ Institucijske arbitraže u pravilu raspolažu posebnim listama arbitara s kojih stranke mogu birati arbitre u pojedinom predmetu.

\subsection{Arbitražno rješavanje sporova u zdravstvu}

Danas se veliki broj sporova zdravstvenih radnika rješava pred arbitražnim sudovima zdravstvenih komora i udruga. Sve prednosti arbitražnog sudovanja odavno su tu prepoznate, a tome je, među ostalim, razlog i određena bojazan da ponašanje koje je sastavni dio određene zdravstvene djelatnosti, može pred državnim sudom biti ocijenjeno i proglašeno protupravnim. ${ }^{28}$

Ustrojavanje institucijskih arbitraža u zdravstvu nastalo je zbog potrebe rješavanja sporova koji su izravno ili neizravno vezani za zdravstvenu djelatnost, odnosno zbog potrebe da se ustroji takva arbitražna institucija koja bi bila posebni autoritet i koja bi bila sposobna riješiti najsloženije sporove u zdravstvu i istovremeno ponuditi elastičan, brz, efikasan, nejavan i ne previše skup postupak. ${ }^{29}$

Zdravstvene arbitraže često imaju i obilježja tzv. prisilnih arbitraža (arbitrage obligatore, compulspry arbitration, Zwangsshiedsgericht), kojima se stranke moraju obratiti radi rješavanja određenih sporova. ${ }^{30}$ Sporovi koji se tiču disciplinskih i drugih zdravstvenih pitanja, u pravilu su isključeni iz nadležnosti redovnih sudova. Državni sudovi teško mogu pratiti razvitak i složenost odnosa koji nastaju u zdravstvu, pa su specijalizirane arbitraže sa stručnim i educiranim arbitrima idealno rješenje za ove vrste sporova. Zdravstvene arbitraže imaju i obilježja tzv. unutrašnjih arbitraža, koje se ustrojavaju prije svega zbog brzine i efikasnosti u rješavanju internih sporova unutar neke organizacije.

Pojedinim je strukovnim zakonima propisano da određeni zdravstveni radnici mogu rješavanje međusobnih sporova koji proizađu iz obavljanja njihove djelatnosti, povjeriti na rješavanje arbitražnom tijelu koje se osniva pri nadležnoj komori. ${ }^{31}$ Iz dikcije zakonskih odredbi proizlazi da se arbitražom mogu rješavati samo sporovi između zdravstvenih radnika iste struke koji su članovi komore koja provodi arbitražu.

Mogućnost arbitražnog rješavanja sporova predviđena je odredbama čl. 49. ZOL-a, odredbama čl. 54. ZODM-a, odredbama čl. 48.-50. ZOLJK-a i odredbama čl. 51-53. ZOMBD-a. Navedenim je zakonima propisano da će se pojedina pitanja vezana uz arbitražu pobliže propisati općim aktima nadležnih komora. Osnovna suština arbitražnog rješavanja sporova jest međusobni dogovor stranaka arbitražnog postupka da spor koji je 
Prava, obveze i odgovornosti radnika u obavljanju djelatnosti: Rješavanje sporova (arbitraža)

među njima nastao, povjere na rješavanje odgovarajućem tijelu komore čiji su članovi te da spor riješe mirnim putem pred nepristranim arbitrima. Također, $u$ arbitražnom se postupku nastoji spor riješiti dogovorno, na obostrani interes stranaka bez upotrebe represivnih procesnih mehanizama. Upravo je i zato osnovna karakteristika arbitraže suglasnost stranaka da rješavanje nastalog spora dogovorno povjere arbitražnom sudu.

Liječnici - članovi HLK mogu rješavanje međusobnog spora povjeriti Arbitražnom sudu Hrvatske liječničke komore. Sva pitanja koja se tiču provođenja arbitražnog postupka HLK propisala je Pravilnikom o arbitraži (www.hlk.hr). Arbitražni postupak provodi Arbitražni sud koji sudi u vijeću sastavljenom od tri člana. Svaka stranka imenuje po jednog arbitra s Liste arbitara, a dva imenovana arbitra tada biraju trećeg arbitra (članak 6. Pravilnika o arbitraži). Arbitražni sud može odlučiti samo o onom pitanju koje su pred njega iznijele stranke, a pravorijek koji donese ima prema strankama snagu pravomoćne presude te se može pobijati samo u skladu s odredbama Zakona o arbitraži (članak 4. Pravilnika o arbitraži). Postupak se može pokrenuti podnošenjem sporazumnog ili pojedinačnog zahtjeva za provođenje arbitražnog postupka (članak 9. st. 1. 6. Pravilnika o arbitraži). Ukoliko su ispunjeni svi propisani uvjeti, zakazuje se rasprava pred Arbitražnim sudom na kojoj će se poticati stranke da svoj međusobni spor riješe na obostrano zadovoljavajući način. Arbitražni postupak završava donošenjem pravorijeka ili, eventualno, nagodbe ukoliko su se stranke tako sporazumjele. Sadržaj nagodbe, međutim, ne smije biti u suprotnosti s javnim poretkom Republike Hrvatske (članak 14. Pravilnika o arbitraži).

Iako je Zakonom o dentalnoj medicini propisano da članovi Hrvatske komore dentalne medicine mogu međusobne sporove povjeriti na rješavanje arbitraži Komore, Hrvatska komora dentalne medicine donijela je Pravilnik o mirenju (www.hkdm.hr). Potrebno je naglasiti da su arbitraža i mirenje dva različita postupka koja su i regulirana posebnim zakonima $^{32}$ pa je tako spomenuti Pravilnik o mirenju u većem dijelu usklađen $\mathrm{s}$ odredbama Zakona o mirenju. Postupak mirenja provodi Povjerenstvo za obavljanje vještačenja koje se sastoji se od najmanje pet članova koje imenuje i razrješava Izvršni odbor Komore na prijedlog područnih sjedišta te uz prethodnu suglasnost predsjednika Komore i na prijedlog Upravnog odbora strukovnog razreda dentalnih tehničara i dentalnih asistenata. Također, predsjednika Povjerenstva (izmiritelja) imenuje i razrješava Upravno vijeće Komore, a zamjenika predsjednika biraju članovi Povjerenstva između sebe (članak 3. Pravilnika o mirenju). Provođenje postupka mogu zatražiti domaće i strane fizičke i pravne osobe (članak 10. Pravilnika o mirenju), ${ }^{33}$ a mirenje započinje zaprimanjem prijedloga za provođenje postupka mirenja, zatim pritužbe koja se u postupku mirenja smatra prijedlogom za mirenje ili podneska nadležnog državnog tijela. Postupak je okončan zaključenjem nagodbe ili eventualnim odustankom neke od stranaka od postupka mirenja (članak 14. Pravilnika o mirenju).

Hrvatska ljekarnička komora uredila je arbitražni postupak na gotovo identičan način kao i HLK. Komora je arbitražni postupak propisala Pravilnikom o arbitraži (www.hljk.hr ) kojim su uređena sva postupovna pitanja. Postupak provodi Arbitražni sud koji sudi u vijeću sastavljenom od tri člana. Dva člana imenuju stranke s Liste arbitara, a onda dva imenovana člana biraju trećeg (članak 6. Pravilnika o arbitraži). Postupak započinje 
podnošenjem sporazumnog ili pojedinačnog zahtjeva za provođenje arbitražnog postupka (članak 9. st. 1. Pravilnika o arbitraži), a završava donošenjem pravorijeka ili, eventualno, nagodbe ukoliko su se stranke tako sporazumjele. Sadržaj nagodbe, međutim, ne smije biti u suprotnosti s javnim poretkom Republike Hrvatske (članak 14. Pravilnika o arbitraži).

Arbitražni postupak kojeg provodi Hrvatska komora medicinskih biokemičara ponešto se razlikuje od arbitražnog postupka HLK i Hrvatske ljekarničke komore. Pravilnikom o arbitraži Hrvatske komore medicinskih biokemičara (www.hkmb.hr) propisano je da stranke arbitražnog postupka mogu rješavanje međusobnog spora povjeriti ili arbitražnom vijeću ili arbitru pojedincu (članak 5. stavak 1. Pravilnika o arbitraži Hrvatske komore medicinskih biokemičara). Takvu mogućnost ne poznaju propisi o arbitraži drugih komora. U slučaju da su se stranke sporazumjele povjeriti rješavanje spora arbitražnom vijeću, tada će svaka stranka imenovati arbitra, a imenovani će arbitri izabrati trećeg koji će biti predsjednik arbitražnog vijeća, a ako su se pak sporazumno odlučile povjeriti spor na rješavanje arbitru pojedincu, tada će odrediti arbitra i obavijestiti o tome predsjednika Komore (članak 7. Pravilnika o arbitraži Hrvatske komore medicinskih biokemičara). Arbitražni postupak pokreće se tužbom koja se podnosi Komori (članak 12. Pravilnika o arbitraži Hrvatske komore medicinskih biokemičara). Druga stranka ima pravo podnijeti odgovor na tužbu (članak 13 Pravilnika o arbitraži Hrvatske komore medicinskih biokemičara). Nakon provedenog postupka, donosi se pravorijek koji ima snagu pravomoćne presude (članak 21 Pravilnika o arbitraži Hrvatske komore medicinskih biokemičara). 
Prava, obveze i odgovornosti radnika u obavljanju djelatnosti: Rješavanje sporova (arbitraža)

\section{Primjedbe}

${ }^{1}$ Usp. Arbitraža, SIS-HGK, Zagreb, 1995., str. 7.

2 Vidi SAJKO, K. - DIKA, M., Arbitražno rješavanje međunarodnih trgovačkih sporova, Ljubljana, 1989., str. 1.

3 Tako KNEŽEVIĆ, G., Međunarodna trgovačka arbitraža, Beograd, 1999., str. 20. O pojmu i definiranju arbitraže u pravnoj teoriji, pobliže na str. 17.-19.

${ }^{4}$ Vidi TRIVA, S., Arbitražno ili državno sudovanje, «Pravo u gospodarstvu», god. 43., 2004., br. 2 , str. 10 .

5 Tako GIUNIO, M., Novine u hrvatskom arbitražnom pravu s posebnim osvrtom na ad hoc arbitražu i ulogu državnog suda, referat objavljen u zborniku sa 40. susreta pravnika u Opatiji 2002. godine, str. 218.

${ }^{6}$ Podrobnije o tome kod KNEŽEVIĆ, G., Međunarodna trgovačka arbitraža, Beograd, 1999., str. 23.-25.; TRIFKOVIĆ, M. - OMANOVIĆ, S., Međunarodno poslovno pravo i arbitraže, Sarajevo 2001., str. 511.-515.; GOLDŠTAJN, A. - TRIVA, S., Međunarodna trgovačka arbitraža, Zagreb,1987., str. 12.-14.

${ }^{7}$ Usp. GIUNIO, M., o. c., str. 225.

${ }^{8}$ Tako TRAJKOVIĆ, M., Međunarodno arbitražno pravo, Beograd, 2000., str. 68.

${ }^{9}$ Detaljnije kod Arbitraža i alternativno rješavanje sporova - kako rješavati međunarodne poslovne sporove, Hrvatska gospodarska komora, Zagreb, 2003., str. 36.

${ }^{10}$ Ibid., str. 62.

${ }^{11} \mathrm{U}$ tom smislu TRAJKOVIĆ, M., o. c., 68.

${ }^{12}$ Usp. GOLDŠTAJN, A. - TRIVA, S., Međunarodna trgovačka arbitraža, Zagreb, 1987., str. 13.

${ }^{13}$ Vidi TRAJKOVIĆ, M., o. c., str. 68.

14 Tako kod Arbitraža i alternativno rješavanje sporova - kako rješavati međunarodne poslovne sporove, Hrvatska gospodarska komora, Zagreb, 2003., str. 36.

${ }^{15}$ Usp. Arbitraža, SIS-HGK, Zagreb, 1995. str. 7.

16 Vidi SAJKO, K. - DIKA, M., Arbitražno rješavanje međunarodnih trgovačkih sporova, Ljubljana, 1989., str. 1.

${ }^{17}$ Tako KNEŽEVIĆ, G., Međunarodna trgovačka arbitraža, Beograd, 1999., str. 20. O pojmu i definiranju arbitraže u pravnoj teoriji, pobliže na str. 17.-19.

${ }^{18}$ Usp. PEROVIĆ, J. S., Ugovor o međunarodnoj trgovinskoj arbitraži, Javno preduzeće Službeni list SRJ, Beograd, 2002., str. 162.-163.

19 Tako TRAJKOVIĆ, M., Međunarodno arbitražno pravo, Pravni fakultet Univerziteta u

Beogradu i Udruženje pravnika Jugoslavije, Beograd, 2000., str. 328.- 329.

${ }^{20}$ Pravna osoba također može biti imenovana za arbitra u nekim zemljama, kao što je Francuska, ali u tom slučaju se ova osoba više pojavljuje kao organizator arbitražnog postupka, dok je faktički arbitar njegov predstavnik - fizička osoba. TRAJKOVIĆ, M., Međunarodno arbitražno pravo, Pravni fakultet Univerziteta u Beogradu i Udruženje pravnika Jugoslavije, Beograd, 2000., str. 358.

${ }^{21}$ Vidi ŠAULA, V., Osnovi međunarodnog građanskog procesnog prava Republike Srpske, Banja Luka, 2008., str. 145.; DUKIĆ-MIJATOVIĆ, M., Položaj arbitra u arbitražnom postupku, „Strani pravni život", 2011., broj 1, str. 222.

${ }^{22} \mathrm{U}$ usporednom pravu formulacije u pogledu kvalifikacija arbitara najčešće se odnose upravo na poslovnu sposobnost odnosno starost arbitara. PEROVIĆ, J. S., Ugovor o međunarodnoj trgovinskoj arbitraži, Javno preduzeće Službeni list SRJ, Beograd, 2002., str. 167.

U nekim zemljama se starosna granica nakon koje jedna osoba može biti birana za arbitra diže iznad razine poslovne sposobnosti (punoljetnosti).

${ }^{23}$ U tom smislu TRAJKOVIĆ, M., Međunarodno arbitražno pravo, Pravni fakultet Univerziteta u Beogradu i Udruženje pravnika Jugoslavije, Beograd, 2000., str. 394. 
${ }^{24}$ Tako KNEŽEVIĆ, G., Međunarodna trgovačka arbitraža, Beograd, 1999., str. 16.

${ }^{25}$ Vidi TRAJKOVIĆ, M., Međunarodno arbitražno pravo, Pravni fakultet Univerziteta u

Beogradu i Udruženje pravnika Jugoslavije, Beograd, 2000., str. 349.

${ }^{26}$ Usp. PEROVIĆ, J. S., Ugovor o međunarodnoj trgovinskoj arbitraži, Javno preduzeće Službeni list SRJ, Beograd, 2002., str. 167.; KNEŽEVIĆ, G., Međunarodna trgovačka arbitraža, Beograd, 1999., str. 16.

27 Tako KNEŽEVIĆ, G., Međunarodna trgovačka arbitraža, Beograd, 1999., str. 94. i 95.

${ }^{28}$ Vidi PULJKO, V., Arbitražno rješavanje sporova u nogometu, "Pravni vjesnik", broj 10/2., str. 58.

${ }^{29}$ Više o tome kod KNOL RADOJA, K., Alternativno rješavanje medicinskih sporova, Zbornik radova „Usluge i zaštita korisnika“, Kragujevac, 2016., str. 589.-607.

${ }^{30}$ Više o tome kod MUSA, K., Arbitraža u organizaciji udruženog rada - samoupravni sud, Zagreb, 1982., str. 35.

${ }^{31}$ Treba kazati da u pravnom sustavu Republike Hrvatske egzistiraju i dru pravni propisi kojima je „nametnuta“ arbitraža kao mjesto rješavanja sporova. Spomenuli bismo samo čl. 13. Općih uvjeta ugovora o provođenju zdravstvene zaštite iz obveznog zdravstvenog osiguranja („Narodne novine“, br. 11/07), koji predviđa obvezujuću arbitražu za slučaj spora između Hrvatskog zavoda za zdravstveno osiguranje $\mathrm{s}$ jedne strane i zdravstvenih ustanova, zdravstvenih radnika privatne prakse, te drugih provoditelja zdravstvene zaštite, s druge strane. Više o tome kod LOVIĆ, S., Prisilne arbitraže, ,Pravo u gospodarstvu“, dod. 55, 2016., broj 4, str. 732.-733.

${ }^{32}$ Zakon o arbitraži, Narodne novine, broj 88/2001; Zakon o mirenju, Narodne novine, broj $18 / 2011$.

33 Iako je Zakonom o dentalnoj medicini propisano da članovi Komore mogu rješavanje međusobnog spora povjeriti arbitraži Komore, iz dikcije ove odredbe Pravilnika proizlazi da se postupak mirenja može provoditi između članova Komore, ali i između članova Komore i trećih osoba. 


\section{8/ Nadzor}

Nadzor nad radom zdravstvenih ustanova, trgovačkih društava koja obavljaju zdravstvenu djelatnost, zdravstvenih radnika u zdravstvenim ustanovama te privatnih zdravstvenih radnika obuhvaća: unutarnji nadzor, stručni nadzor komore, zdravstvenoinspekcijski nadzor (ZOZZ, čl. 167.). Različitim vrstama nadzora nad radom zdravstvenih radnika zakonodavac je omogućio nadziranje različitih aspekata postupka pružanja zdravstvene zaštite pa se tako poštivanje propisa koji na posredan ili neposredan način reguliraju zdravstvenu djelatnost osigurava provođenjem zdravstveno-inspekcijskog nadzora, stručnost rada zdravstvenih radnika osigurava se stručnim nadzorom kojeg provode strukovne komore dok se poštivanje prava i obveza koja proizlaze iz radnih odnosa zdravstvenih radnika osigurava unutarnjim nadzorom kojeg provode ovlaštena tijela zdravstvene ustanove. ${ }^{1}$ Svrha nadzora nad radom zdravstvenih radnika nije samo sankcioniranje nepoštivanja pozitivnih zakonskih propisa i pravila struke već ujedno i korekcija postupanja pružatelja zdravstvenih usluga odnosno utjecanje na pružatelje da ubuduće poštuju zakonske propise. ${ }^{2}$

\subsection{Unutarnji nadzor}

Unutarnji nadzor predstavlja neposredan oblik kontrole kvalitete obavljanja rada unutar svake zdravstvene ustanove te je kao takav nužan za osiguranje pružanja kvalitetnih zdravstvenih usluga. Radi se o nadzoru kojeg nad radom svojih ustrojbenih jedinica $\mathrm{i}$ zdravstvenih radnika provode same zdravstvene ustanove i trgovačka društva koja obavljaju zdravstvenu djelatnost. ${ }^{3}$ Unutarnji nadzor od iznimnog je značaja i trebalo bi ga detaljno regulirati kako bi se izbjegle nepravilnosti i pojačala odgovornost direktora $i$ uprave te izvršnih radnika u poslovanju zdravstvene ustanove. ${ }^{4}$ Zdravstvena ustanova i trgovačko društvo koje obavlja zdravstvenu djelatnost obvezno provode unutarnji nadzor nad radom svojih ustrojstvenih jedinica i zdravstvenih radnika. Za stručni rad zdravstvene ustanove, odnosno trgovačkog društva koje obavlja zdravstvenu djelatnost, odgovoran je ravnatelj, uprava ili osoba ovlaštena za vođenje poslova trgovačkog društva (ZOZZ, čl. 168.). Unutarnji nadzor provodi se na temelju općeg akta zdravstvene ustanove, odnosno trgovačkog društva koje obavlja zdravstvenu djelatnost i godišnjeg plana i programa provedbe unutarnjeg nadzora. Općim aktom utvrđuje se način obavljanja unutarnjeg nadzora. Godišnji plan i program provedbe unutarnjeg nadzora zdravstvena ustanova i trgovačko društvo koje obavlja zdravstvenu djelatnost obvezni su dostaviti nadležnom ministarstvu najkasnije do 31. prosinca tekuće godine za sljedeću godinu (ZOZZ, čl. 169.). U okviru unutrašnjeg nadzora predviđeno je i obavljanje poslova i zadataka koji podrazumijevaju uspostavu, razvijanje i održavanje sistema poboljšanja kvaliteta i sigurnosti zdravstvenih usluga, a suglasno zakonskom aktu o sistemu poboljšanja kvaliteta, sigurnosti i o akreditaciji u zdravstvu. Unutarnji nadzor od iznimnog je značaja i trebalo bi ga detaljno regulirati kako bi se izbjegle nepravilnosti i pojačala odgovornost uprave te izvršnih radnika u poslovanju zdravstvene ustanove. ${ }^{5}$ 


\subsection{Stručni nadzor komore}

Temeljem posebnih profesionalnih zakona kojima su u Republici Hrvatskoj uređene regulirane profesije u zdravstvu (doktori medicine, doktori dentalne medicine, ljekarnici, medicinske sestre, primalje, biokemičari, fizioterapeuti, radiološki tehnolozi, sanitarni inženjeri, radni terapeuti te zdravstveni radnici medicinsko laboratorijske djelatnosti) sve strukovne komore imaju javnu ovlast provođenja stručnog nadzora nad radom svojih članova kojima izdaju i odgovarajuće licence. Postupak provođenja stručnog nadzora definiran je odgovarajućim aktima (pravilnicima, poslovnicima i naputcima) svake od komora. Na temelju zakonskog ovlaštenja Komore su donijele akte koji pobliže definiraju proceduru provođenja nadzora kojom bi se na što objektivniji način procijenila kvaliteta i opseg zdravstvenih usluga te ostvarivanje prava korisnika zdravstvenih usluga. Stručni nadzor podijeljen je na dvije vrste - redoviti i izvanredni. Redoviti nadzor obavlja se temeljem godišnjeg plana. Redoviti stručni nadzor nad radom zdravstvenih radnika i zdravstvenih ustanova obavlja se, u pravilu, jednom u razdoblju od 6 godina. Izvanredni nadzor Komisija će obavljati izvan usvojenog godišnjeg plana i to prvenstveno $u$ slučajevima prijetećeg ili postojećeg ugrožavanja života i zdravlja korisnika zdravstvenih usluga. ${ }^{6}$ Stručni nadzor nad radom zdravstvenih ustanova, trgovačkih društava koja obavljaju zdravstvenu djelatnost i privatnih zdravstvenih radnika u pružanju neposredne zdravstvene zaštite građanima s obzirom na kvalitetu i vrstu zdravstvenih usluga provodi nadležna komora. Stručni nadzor provodi se sukladno općim aktima komore na koje daje suglasnost ministar. U slučaju utvrđenoga stručnog propusta zdravstvenog radnika ili povrede načela medicinske etike i deontologije izriču se mjere u skladu s aktima nadležne komore (ZOZZ, čl. 170.). Tako, primjerice, Pravilnikom o stručnom nadzoru Hrvatske liječničke komore od 4. lipnja 2016. (u daljnjem tekstu: Pravilnik) uređuje se način organiziranja i provođenja stručnog nadzora nad radom zdravstvenih ustanova i njihovih ustrojstvenih jedinica, trgovačkih društava koja obavljaju zdravstvenu djelatnost i privatnih zdravstvenih radnika u pružanju neposredne zdravstvene zaštite građanima $\mathrm{s}$ obzirom na kvalitetu i vrstu zdravstvenih usluga. Odredbama Pravilnika uređuje se i obavljanje stručnog nadzora nad radom liječnika radi osiguranja obavljanja liječničkog zvanja u odgovarajućem obimu, kvaliteti i vrsti zdravstvenih usluga te ostvarivanja prava pacijenata (Pravilnik, čl. 1.). Stručni nadzor obavlja se sa svrhom: nadziranja stručnog rada i primjene priznatih metoda i dostignuća medicinske znanosti; nadziranja primjene etičkih i deontoloških načela propisanih Kodeksom medicinske etike i deontologije; praćenja načina ostvarivanja prava pacijenata; nadziranja drugih pitanja značajnih za utvrđivanje i ocjenjivanje kvalitete rada i načina ostvarivanja zdravstvene zaštite, uključujući i organizaciju rada zdravstvenih ustanova i njihovih ustrojstvenih jedinica, trgovačkih društava koja obavljaju zdravstvenu djelatnost i privatnih liječničkih praksi, u dijelu u kojem utječu na kvalitetu pružanja zdravstvene zaštite; savjetovanja i davanja preporuka o unapređenju kvalitete pružanja zdravstvenih usluga i rada liječnika; nalaganje poduzimanja odgovarajućih mjera na temelju obavljenog stručnog nadzora (Pravilnik, čl. 2.).

\section{Z.3 Zdravstveno-inspekcijski nadzor}

Zdravstveno-inspekcijski nadzor nad primjenom i izvršavanjem zakona, drugih propisa i općih akata u djelatnosti zdravstva kao i nadzor nad stručnim radom zdravstvenih 
ustanova, trgovačkih društava koja obavljaju zdravstvenu djelatnost, zdravstvenih radnika te privatnih zdravstvenih radnika obavlja ministarstvo - zdravstvena inspekcija. Zdravstvena inspekcija ministarstva nadležnog za zdravstvo provodi zdravstvenoinspekcijski nadzor nad primjenom i izvršavanjem zakona, drugih propisa i općih akata u djelatnosti zdravstva, te nadzire stručni rad zdravstvenih ustanova, trgovačkih društava koja obavljaju zdravstvenu djelatnost, zdravstvenih radnika te privatnih zdravstvenih radnika. $^{7}$ Poslove zdravstveno-inspekcijskog nadzora obavljaju viši zdravstveni inspektori, zdravstveni inspektori i drugi državni službenici ovlašteni za provedbu nadzora. U slučaju stručnog propusta zdravstvenog radnika ili povrede načela medicinske etike i deontologije, viši zdravstveni inspektor, odnosno zdravstveni inspektor ustupit će predmet na postupanje nadležnoj komori (ZOZZ, čl. 171.). Ministar utvrđuje godišnji program rada zdravstvene inspekcije. Zdravstveno-inspekcijski nadzor nad zdravstvenim ustanovama obvezno se provodi najmanje jednom godišnje (ZOZZ, čl. 175.). Inspektor u provođenju inspekcijskog nadzora pregledava poslovne prostorije, objekte, uređaje i opremu te dokumentaciju i akte zdravstvene ustanove, trgovačkog društva, odnosno zdravstvenog radnika. Inspektor tijekom inspekcijskog nadzora zbog mogućeg prikrivanja dokaza ima pravo privremeno izuzeti predmete i izvornu dokumentaciju, uz potvrdu (ZOZZ, čl. 176.). Zdravstvena inspekcija osobito: 1. prati i proučava obavljanje zdravstvene djelatnosti i poduzima mjere za njezino kvalitetno obavljanje, 2. nadzire zakonitost rada zdravstvenih ustanova, trgovačkih društava i zdravstvenih radnika u obavljanju zdravstvene djelatnosti, 3. razmatra podneske pravnih i fizičkih osoba koji se odnose na nadzor iz utvrđene nadležnosti i o poduzetim radnjama i mjerama pisano obavještava podnositelja (ZOZZ, čl. 178.). U obavljanju inspekcijskih poslova inspektor osobito nadzire: 1. način prijama, liječenja i otpuštanja bolesnika, 2. primjenu sredstava i metoda za prevenciju, dijagnostiku, terapiju i rehabilitaciju, 3. način propisivanja lijekova i medicinskih proizvoda, 4. primjenu sredstava i metoda za obavljanje laboratorijskih analiza i drugih dijagnostičkih metoda, njihove usuglašenosti s odgovarajućim standardima, 5. način vođenja i korištenja odgovarajuće medicinske dokumentacije i evidencije, 6. organizaciju i obavljanje pripravničkog staža i specijalističkog staža zdravstvenih radnika, 7. druga pitanja značajna za utvrđivanje i ocjenjivanje kvalitete rada i način ostvarivanja zdravstvene zaštite (ZOZZ, čl. 179.). U obavljanju inspekcijskih poslova iz članka 179. ovoga Zakona inspektor ima pravo i obvezu: 1. privremeno zabraniti rad zbog otklanjanja utvrđenih nepravilnosti i nedostataka, 2. zabraniti provođenje mjera i radnji koje su protivne zakonu ili drugom propisu, 3. zabraniti rad zdravstvenoj ustanovi, trgovačkom društvu i privatnom zdravstvenom radniku koji više ne ispunjava uvjete u pogledu prostora, radnika i medicinsko-tehničke opreme, 4. zabraniti samostalan rad zdravstvenom radniku koji nema odobrenje za samostalan rad, 5. zabraniti rad zdravstvenoj ustanovi, trgovačkom društvu i zdravstvenom radniku koji ne osigurava kvalitetu i sadržaj zdravstvenih usluga, 6. predložiti nadležnoj komori provođenje postupka u cilju utvrđenja potrebe dodatnoga stručnog usavršavanja zdravstvenog radnika, odnosno potrebu ponavljanja provjere stručne osposobljenosti, 7. zabraniti rad i predložiti komori oduzimanje odobrenja za samostalan rad zdravstvenom radniku, 8. zabraniti obavljanje zdravstvene djelatnosti, ako se ona obavlja bez propisanog odobrenja, 9. uputiti zdravstvenog radnika, odnosno zdravstvenog suradnika na pregled radi ocjene zdravstvene sposobnosti u slučaju sumnje na gubitak zdravstvene sposobnosti za obavljanje zdravstvene djelatnosti, 10. narediti poduzimanje drugih mjera za koje je ovlašten ovim Zakonom i drugim propisom. Ako utvrđeni nedostaci ne budu 
otklonjeni u određenom roku, inspektor će zabraniti obavljanje zdravstvene djelatnosti zdravstvenoj ustanovi, dijelu zdravstvene ustanove, trgovačkom društvu koje obavlja zdravstvenu djelatnost, odnosno privatnom zdravstvenom radniku. Ako inspektor prilikom obavljanja inspekcijskog nadzora uoči nepravilnosti, odnosno povrede propisa, a nije ovlašten izravno postupati obvezan je izvijestiti nadležno tijelo državne uprave o uočenim nepravilnostima, odnosno povredama propisa te tražiti pokretanje postupka i poduzimanje propisanih mjera (ZOZZ, čl. 180.). O obavljenom inspekcijskom nadzoru inspektor obvezan je sastaviti zapisnik (ZOZZ, čl. 181.). Protiv rješenja koje donosi inspektor nije dopuštena žalba već se protiv tog rješenja može pokrenuti upravni spor (ZOZZ, čl. 184.). ZOZZ je dao niz ovlaštenja zdravstvenim inspektorima - od poduzimanja preventivnih aktivnosti u cilju sprječavanja nastupanja štetnih posljedica zbog nedostatka i nepravilnosti u provođenju ovog zakona i propisa donijetih na temelju zakona, do poduzimanja niza drugih upravnih mjera: od zabrane obavljanja poslovanja zdravstvene ustanove, privatne prakse, zabrane rada zdravstvenim radnicima, naređivanje otklanjanja uočenih nedostataka i dr. Ovako široko postavljen spektar mjera koje može izreći zdravstveni inspektor u zdravstveno-inspekcijskom nadzoru, daje jamstvo boljeg poštivanja odredbi ZOZZ-a i drugih propisa u praksi. ${ }^{8}$

\section{Primjedbe}

${ }^{1}$ Vidi BABIĆ, T., Nadzor nad radom liječnika, Zbornik radova sa simpozija „Liječnička pogreška - medicinski i pravni aspekti“, Poslijediplomski tečaj stalnog medicinskog usavršavanja I. kategorije, Medicinski i Pravni fakultet Sveučilišta u Splitu, Split, 2007., str. 191.

${ }^{2}$ Tako BODNARUK, S. - ČIZMIĆ, J. - HRABAČ, B. - HUSEINAGIĆ, S., Komentari zdravstvenih zakona, knjiga 1., Privredna štampa, Sarajevo, 2011., str. 267.

${ }^{3}$ Podatak kod BABIĆ, T. - ROKSANDIĆ, S., Osnove zdravstvenog prava, Zagreb, 2006., str. 313.

${ }^{4}$ Usp. BOŠKOVIĆ, Z., Medicina i pravo, Rijeka, 2007., str. 60.

5 Tako BOŠKOVIĆ, Z., Medicina i pravo, Rijeka, 2007., str. 60.

${ }^{6}$ Vidi BABIĆ, T. - ROKSANDIĆ, S., Osnove zdravstvenog prava, Zagreb, 2006., str. 312.

${ }^{7}$ Ibid., str. 314.

${ }^{8}$ Tako BODNARUK, S. - ČIZMIĆ, J. - HRABAČ, B. - HUSEINAGIĆ, S., Komentari zdravstvenih zakona, knjiga 1., Privredna štampa, Sarajevo, 2011., str. 268. 


\section{9/ Liječnička tajna}

\subsection{Ustavni okvir}

Za ustavno-pravni okvir u području zaštite osobnosti i osobnih podataka u Ustavu Republike Hrvatske ${ }^{1}$ osobito je značajno naglasiti III. dio pod nazivom Zaštita ljudskih prava i temeljnih sloboda. ${ }^{2} \mathrm{U}$ članku 22 . Ustava naglašava se da je čovjekova sloboda i osobnost nepovrediva te da se nikomu ne smije oduzeti ili ograničiti sloboda, osim kada je to određeno zakonom (vidi čl. 22. Ustava). Nadalje Ustav nalaže da je dom nepovrediv (vidi čl. 34. Ustava) te da se svakomu jamči štovanje i pravna zaštita njegova osobnog i obiteljskog života, dostojanstva, ugleda i časti (vidi čl. 35. Ustava).

Također, kao osnovu za razvoj današnjega Zakona o zaštiti osobnih podataka Ustav u čl. 36. st. 1. izrijekom navodi da su sloboda i tajnost dopisivanja i svih drugih oblika općenja zajamčeni (vidi čl. 36. st. 1. Ustava). U istome stavku ustavotvorac navodi i da je ta sloboda nepovrediva. No, stavak drugi istoga članka govori o nužnim ograničenjima koja se mogu propisati u slučaju zaštite sigurnosti Republike i ostvarenja kaznenoga postupka. Primjerice, u čl. 142. Kaznenoga zakona Republike Hrvatske („Narodne novine“ br. $125 / 11,144 / 12,56 / 15,61 / 15$.) nalaze se odredbe koje govore o povredi tajnosti pisama i drugih pošiljaka kao krivičnome djelu. „Tko neovlašteno otvori tuđe pismo ili brzojav ili elektroničku poštu ili kakvo drugo sredstvo dopisivanja ili na drugi način povrijedi njihovu tajnost, ili neovlašteno zadrži, prikrije, uništi ili drugomu preda tuđu zatvorenu pošiljku ili pismo, brzojav elektroničku poštu ili kakvo drugo sredstvo dopisivanja kaznit će se kaznom zatvora do godine dana.... S druge strane, Zakon o kaznenome postupku („Narodne novine“ br. 152/08, 76/09, 80/11 1, 91/12,143/12, 56/13, 145/13, 152/14, 70/17) u članku 339. , kada govori o istražnim radnjama potrebnih u svrhu ostvarenja kaznenoga postupka, određuje potrebnim u svrhu ostvarenja kaznenoga postupka da ,istražni sudac može naložiti da poštanske, telefonske i druge prometne organizacije zadrže i njemu, uz potvrdu primitka, predaju pisma, brzojave i druge pošiljke koje su upućene okrivljeniku ili koje on odašilje ako postoje okolnosti zbog kojih se s osnovom može očekivati da će pošiljke poslužiti kao dokaz u postupku. “3

Najveću važnost glede tematike ovoga rada predstavlja upravo dio Ustava koji eksplicitno navodi da se svakomu jamče sigurnost i tajnost osobnih podataka te da se bez privole ispitanika osobni podaci mogu prikupljati, obrađivati i upotrebljavati samo uz uvjete određene zakonom.(Ustav RH, čl. 37. st. 1.). ${ }^{4}$ Također, Zakonom ${ }^{5}$ se uređuje zaštita podataka te nadzor nad djelovanjem informatičkih sustava u državi (Ustav RH, čl. 37. st. 2.). Ustav također navodi da je zabranjena uporaba osobnih podataka suprotna utvrđenoj svrsi njihova prikupljanja. (Ustav RH, čl. 37. st. 3.). ${ }^{6}$

Nadalje, člankom 38. Ustava jamče se sloboda mišljenja i izražavanja misli, što osobito obuhvaća slobodu tiska i drugih sredstava priopćavanja (vidi šire čl. 38 st. 2. i 3.Ustava RH). Samim time čl. 38 svojim sadržajem predstavlja jedan od najvažnijih članaka Ustava. To je zato što se u njemu govori ne samo o slobodi misli i slobodi izražavanja 
misli nego i o čitavome nizu komunikacijskih prava i sloboda. Ustavotvorac je prihvatio slobodu izražavanja kao temeljno pravo, ali kao ni druga komunikacijska prava, ni ono nije apsolutno. ${ }^{7}$ Budući da postoje različita područja izražavanja (politička propaganda i govor mržnje, zagovaranje ilegalnoga ponašanja, religija, moral, opscenost, pornografija, umjetnost i vrijeđanje suda, mediji, tisak i audio prostor, komercijalni govor...), ono nije ograničeno samo ustavotvorčevom voljom, nego i voljom zakonodavca. ${ }^{8}$

Novim stavkom 4. članka 38. Ustava $\mathrm{RH}^{9}$ jamči se pravo na slobodan pristup informacijama, popularno nazvano pravom javnosti da zna, inače već uvedeno u naš pravni sustav Zakonom o pravu na pristup informacijama („Narodne novine“ br. 25/13, $85 / 15) .{ }^{10}$ Ograničenja prava na pristup informacijama moraju biti razmjerna naravi potrebe za ograničenjem u svakome pojedinom slučaju te nužna u slobodnome i demokratskome društvu, a propisuju se zakonom. (Ustav RH, čl. 38. st. 4.) Također, u članku 38. jamči se pravo na ispravak svakomu komu je javnom viješću povrijeđeno Ustavom i zakonom utvrđeno pravo na pristup informacijama. (Ustav RH, čl. 38. st. 5). ${ }^{11}$ To pravo uključuje i odgovornost novinara ili institucije čijom je informacijom povrijeđeno neko pravo građanina. ${ }^{12}$

Navedene odredbe Ustava RH postavile su temelje za razvoj i kreiranje legislative u području zaštite osobnih podataka i neprikosnovena su smjernica o nužnosti zaštite osobnosti kao temeljnoga ljudskog prava. Nadalje, polazeći od ustavnih tekstova, poznati uglednici iz područja ustavnoga prava rješenje za ključna pitanja iz područja ustavnopravne tematike vide u zainteresiranoj i aktivnoj demokratskoj javnosti, spremnoj na zalaganje i borbu za pravo, a ne u 'konstitucionalnom optimizmu' i ustavnoj propagandi. ${ }^{13}$ Navedeni prikaz Ustava RH čini se najboljim pokazateljem univerzalnosti pitanja ustavnoga uspostavljanja demokratskoga poretka u političkim zajednicama. ${ }^{14}$

\subsection{Zakon o tajnosti podataka}

Pojam klasificiranih i neklasificiranih podataka, stupnjevi tajnosti, postupak klasifikacije i deklasifikacije, pristup klasificiranim ${ }^{15}$ i neklasificiranim ${ }^{16}$ podacima i njihova zaštita u Republici Hrvatskoj uređeni su Zakonom o tajnosti podataka („Narodne novine“, broj 79/07., 86/12., dalje - ZTP) i Zakonom o zaštiti tajnosti podataka („Narodne novine“, broj 108/96., dalje - ZZTP), u onome dijelu koji se odnosi na uređenje poslovne i profesionalne tajne (ZZTP, čl. 19.-27.).

Naime, iako su stupanjem na snagu ZTP-a prestale važiti odredbe ZZTP-a, odredbom čl. 34. ZTP-a propisano je da i nakon njegova stupanja na snagu, odnosno i nakon 8. srpnja 2007., i dalje važe odredbe ZZTP-a navedene u glavi VIII. i IX., odnosno odredbe čl. 19.27. ZZTP-a kojima se uređuju poslovna i profesionalna tajna. Ovo držimo značajnim i stoga što se ZTP-om utvrđuje samo pojam klasificiranih i neklasificiranih podataka te stupnjevi tajnosti, a ne i pojam i vrste tajni, koji su (bili) uređeni ZZTP-om. Stoga ćemo se u objašnjenju pojma i vrsta tajni koristiti, među ostalim, i definicijama iz ZZTP-a, ${ }^{17}$ a osobito o poslovnoj i profesionalnoj tajni. ${ }^{18}$

ZTP-om se utvrđuju pojam klasificiranih i neklasificiranih podataka, stupnjevi tajnosti, postupak klasifikacije i deklasifikacije, pristup klasificiranim i neklasificiranim podacima 
njihova zaštita i nadzor nad njegovom provedbom (ZTP, čl.1., st. 1.). ZTP se primjenjuje na državna tijela, tijela jedinica lokalne i područne (regionalne) samouprave, pravne osobe s javnim ovlastima te pravne i fizičke osobe koje, u skladu s njegovim odredbama, ostvare pristup ili postupaju s klasificiranim i neklasificiranim podacima (ZTP, čl. 1. st. 2).

U samome uvodu u tematiku tajnosti podataka relevantno je determinirati ključne pojmove:

podatak je svaki dokument, odnosno svaki napisani, umnoženi, nacrtani, slikovni, tiskani, snimljeni, fotografirani, magnetni, optički, elektronički ili bilo koji drugi zapis podatka, saznanje, mjera, postupak, predmet, usmeno priopćenje ili informacija koja s obzirom na svoj sadržaj ima važnost povjerljivosti i cjelovitosti za svojega vlasnika (ZTP čl. 2. t. 1.)

klasificirani podatak onaj je koji je nadležno tijelo, u propisanome postupku, takvim označilo i za koji je utvrđen stupanj tajnosti, te podatak koji je Republici Hrvatskoj tako označenoga predala druga država, međunarodna organizacija ili institucija s kojom Republika Hrvatska surađuje (ZTP čl. 2. t. 2.)

neklasificirani podatak je podatak bez utvrđenoga stupnja tajnosti koji se koristi u službene svrhe, te podatak koji je Republici Hrvatskoj tako označenoga predala druga država, međunarodna organizacija ili institucija s kojom Republika Hrvatska surađuje (ZTP čl. 2. t. 3.)

klasifikacija podatka postupak je utvrđivanja jednoga od stupnjeva tajnosti podatka s obzirom na stupanj ugrozbe i područje ovim Zakonom zaštićenih vrijednosti (ZTP čl. 2. t. 4.)

deklasifikacija podatka postupak je kojim se utvrđuje prestanak postojanja razloga zbog kojih je određeni podatak klasificiran odgovarajućim stupnjem tajnosti, nakon čega podatak postaje neklasificirani s ograničenom uporabom samo u službene svrhe (ZTP čl. 2. t. 5.)

vlasnik podatka nadležno je tijelo u okviru čijega je djelovanja klasificirani ili neklasificirani podatak nastao (ZTP čl. 2. t. 6.)

certifikat je uvjerenje o sigurnosnoj provjeri koje omogućava pristup klasificiranim podacima (ZTP čl. 2. t. 7.).

\subsection{Pojam i vrste tajni - Tajnom}

možemo držati podatak koji je poznat i koji smije biti poznat samo određenomu krugu osoba, a pri tome moraju postojati određene društvene norme koje brane iznošenje takvih podataka izvan toga kruga osoba. ${ }^{19}$ Tajna je podatak koji je zakonom, drugim propisom, općim aktom ili drugim aktom nadležnoga tijela donesenim na temelju zakona, određen tajnim. Izraz tajna ima dva značenja. U širem značenju tajnom se naziva sve što je nepoznato, dok se u užem smislu tajna javlja u međuljudskim odnosima i čine je činjenice koje pojedine uže ili šire grupe ljudi ili država čuvaju za sebe, skrivaju od drugih ljudi, 
odnosno od javnosti. Skrivanje činjenica i podataka obavlja se u cilju zaštite nekih interesa i ostvarivanja nekih ciljeva. Tajna je dinamična kategorija, tj. ono što je danas tajna, ne mora biti i sutra. Zaštita poslovnom tajnom može ponekad potisnuti u drugi plan pravno, ali ne uvijek i ekonomski učinkovitiju zaštitu koju pruža pravo industrijskoga vlasništva. ${ }^{20}$ Tajna predstavlja i znanje određenih činjenica koje su doznate u obavljanju poziva ili na neki drugi povjerljiv način i koje ne mogu biti priopćene u javnosti a da se pri tome ne nanese šteta interesima pojedinca ili zajednice. ${ }^{21}$

ZZTP je propisivao pojam, vrste i stupnjeve tajnosti te mjere i postupke za utvrđivanje, uporabu i zaštitu tajnih podataka (ZZTP, čl. 1.). Tako se tajna definirala kao podatak koji je zakonom, drugim propisom, općim aktom ili drugim aktom nadležnoga tijela donesenim na temelju zakona određen tajnim (ZZTP, čl. 2.).

U pojmovno-teorijskome smislu, prema vrsti podataka i osobama koje su ih dužne i ovlaštene štititi tajne bi se mogle i dalje dijeliti na državnu, vojnu, službenu, poslovnu ili profesionalnu tajnu. ${ }^{22} \mathrm{U}$ načelu sve vrste tajni mogli bismo u tome pogledu svrstati u dvije skupine $-\mathrm{u}$ javne i privatne tajne. ${ }^{23}$

U javnu tajnu mogli bismo svrstati podatke koje su u skladu s propisanim uvjetima dužni čuvati: državna tijela, tijela jedinica lokalne i područne (regionalne) samouprave, pravne osobe s javnim ovlastima te pravne i fizičke osobe koje, u skladu s ovim Zakonom, ostvare pristup ili postupaju s klasificiranim i neklasificiranim podacima. Tu svakako po vrsti spadaju državna, vojna, i službena tajna, a možemo ubrojiti i poslovnu tajnu jer je vezana za tajnost podataka pravnih, a ne fizičkih osoba, kao što je to slučaj s privatnim tajnama.

Državnu tajnu predstavljali bi podaci koje su zbog njihove klasifikacije i stupnja tajnosti dužni tajnima čuvati državni dužnosnici. Vojnu tajnu predstavljali bi podaci koje su zbog njihove klasifikacije i stupnja tajnosti dužni tajnima čuvati pripadnici oružanih snaga. Službenu tajnu predstavljali bi podaci koje su zbog njihove klasifikacije i stupnja tajnosti dužni tajnim čuvati državni službenici. Poslovnu tajnu predstavljaju podaci koji su kao poslovna tajna određeni zakonom, drugim propisom ili općim aktom trgovačkoga društva, ustanove ili druge pravne osobe, a koji predstavljaju proizvodnu tajnu, rezultate istraživačkoga ili konstrukcijskoga rada te druge podatke zbog čijega bi priopćavanja neovlaštenoj osobi mogle nastupiti štetne posljedice za njezine gospodarske interese (ZZTP, čl. 19.).

Privatna tajna - predstavljalo bi saznanje određenih podataka jedne osobe od druge na temelju bliskoga odnosa i osobnoga povjerenja koje postoji između njih. ${ }^{24}$ Pojam privatne tajne viši je rodni pojam osobnoj i profesionalnoj tajni. Privatni interesi primaran su predmet pravne zaštite koja se ostvaruje institutima osobne i profesionalne tajne. ${ }^{25}$

Osobna tajna podatak je o osobi koji je zakonom, drugim propisom ili općim aktom nadležnoga tijela donesenim na temelju zakona određen tajnom. Osobni je podatak, pak, svaka informacija koja se odnosi na identificiranu fizičku osobu ili osobu čiji se identitet može utvrditi izravno ili neizravno, osobito na osnovi jednoga ili više obilježja specifičnih 
za njezin fizički, psihološki, mentalni, gospodarski, kulturni ili socijalni identitet (Zakon o zaštiti osobnih podataka, "Narodne novine", br. 103/03., dalje - ZZOP, čl. 2.).

Zaštita osobnih podataka uređuje se ZZOP-om, s ciljem zaštite privatnoga života i ostalih ljudskih prava i temeljnih sloboda. Zaštita osobnih podataka u Republici Hrvatskoj osigurana je svakoj fizičkoj osobi bez obzira na državljanstvo i prebivalište te neovisno o rasi, boji kože, spolu, jeziku, vjeri, političkom ili drugom uvjerenju, nacionalnom ili socijalnom podrijetlu, imovini, rođenju, naobrazbi, društvenome položaju ili drugim osobinama (ZZOP, čl. 1.).

U subjektivnome smislu osobnu tajnu bismo mogli definirati kao podatak koji je poznat samo osobi na koju se odnosi, a koja ne želi da bude poznat drugoj/drugim osobama ili širemu krugu osoba.

Danas je pravo na zaštitu poslovnih i profesionalnih tajni pravo osobnosti. ${ }^{26}$ Pravo je na poslovnu i profesionalnu tajnu osobno, neimovinsko pravo koje nositelju poslovne i profesionalne tajne daje potpunu privatnopravnu vlast glede činjenica i vrijednosnih sudova zaštićenih poslovnom i profesionalnom tajnom i ovlast da svakoga isključi od protupravnoga narušavanja toga njegovog prava osobnosti. ${ }^{27}$ Naime, riječ je o osobnome, neimovinskom dobru imatelja poslovne tajne. Povreda poslovne i profesionalne tajne kao prava osobnosti rezultira, među ostalim, zahtjevom za pravičnom novčanom naknadom zbog pretrpljene neimovinske štete. ${ }^{28}$

\subsection{Profesionalna tajna}

Profesionalna tajna posebna je podvrsta privatne tajne. ${ }^{29}$ Zaštita profesionalne tajne od osobitoga je značenja s obzirom na osobno pravo na privatnost, jer njezino protupravno otkrivanje redovito vrijeđa nečije pravo na privatnost. ${ }^{30}$ Profesionalno povjerenje ne podrazumijeva se samo po sebi. Ono se dokazuje unutar konkretnoga odnosa u konkretnome slučaju. Zato izlazak informacija iz toga odnosa ima svoju konkretnu posljedicu - gubitak povjerenja u konkretnu osobu i predstavnika profesije koju ta osoba predstavlja.

Profesionalna tajna sadrži podatke o osobnome ili obiteljskome životu stranaka koje u obavljanju svojega zvanja i djelatnosti saznaju odvjetnici, branitelji, javni bilježnici, doktori medicine, doktori stomatologije, primalje ili drugi zdravstveni radnici, psiholozi, djelatnici skrbništva, vjerski ispovjednici ${ }^{31}$ te druge osobe u obavljanju svojega zvanja. ${ }^{32}$

Svatko je dužan čuvati profesionalnu tajnu, bez obzira na način saznanja tajnih podataka ili pribavljanja, odnosno stjecanja mogućnosti uvida u tajne podatke, ako je nedvojbeno da se radi o tajni (ZZTP, čl. 28. st. 1.). Tajna ne mora potjecati isključivo od osobe na koju se podaci i činjenice odnose, već može biti saznata i na neki drugi način, a da bi se neki povjerljivi podatak ili činjenica mogao smatrati saznatim u obavljanju poziva, mora postojati uzročna veza između saznanja te činjenice i samoga obavljanja poziva. ${ }^{33}$

Profesionalna je tajna tuđa tajna, a ne tajna pripadnika određenih profesija. Pripadnik slobodne profesije dužan je čuvati tuđe tajne kao svoje profesionalne tajne, tajne svojih 
klijenata s kojima dolazi u doticaj i s kojima svakodnevno radi. Već sama činjenica da netko obavlja takve složene profesije nameće obvezu i pripadniku slobodnih profesija da čuva tajnu svojih klijenata, da dopusti svojim klijentima da mu se s povjerenjem obrate kako bi i oni na taj način mogli razvijati svoje pravo osobnosti u ispravnome smjeru. ${ }^{34}$

ZTP-om se utvrđuju pojam klasificiranih i neklasificiranih podataka, stupnjevi tajnosti, postupak klasifikacije i deklasifikacije, pristup klasificiranim i neklasificiranim podacima, njihova zaštita i nadzor nad provedbom njegovih odredbi u državnim tijelima, tijelima jedinica lokalne i područne (regionalne) samouprave, pravnim osobama s javnim ovlastima te pravnim i fizičkim osobama koje, u skladu sa ZTP-om, ostvare pristup ili postupaju s klasificiranim i neklasificiranim podacima (ZTP, čl. 1.).

Odredbom čl. 32. ZZTP-a stupnjevi tajnosti određeni međunarodnim ugovorima koje je Republika Hrvatska potvrdila prije njegova stupanja na snagu, stupnjevi tajnosti podataka dobivenih međunarodnom razmjenom prije njegova stupanja na snagu te stupnjevi tajnosti podataka koji su utvrđeni prije njegova stupanja na snagu prevedeni su na način:

a/ „DRŽAVNA TAJNA“ u „VRLO TAJNO“, b/ „SLUŽBENA TAJNA - VRLO TAJNO“ i „VOJNA TAJNA - VRLO TAJNO“ u „TAJNO“, c/ „SLUŽBENA TAJNA TAJNO“ i „VOJNA TAJNA - TAJNO“ u „POVJERLJIVO“, d/ „SLUŽBENA TAJNA - POVJERLJIVO“ $i$, „VOJNA TAJNA - POVJERLJIVO“ u „OGRANIČENO“. Tako su se u sadržajnome smislu, s aspekta klasificiranosti i stupnja tajnosti, prestali upotrebljavati pojmovi „vojna“ i „državna“ tajna. ${ }^{35}$ Time se uređuje područje tajnosti podataka određivanjem pojmova klasificiranih i neklasificiranih podataka $\mathrm{i}$ novih stupnjeva tajnosti podataka usklađenih sa suvremenim standardima tajnosti podataka zemalja EU-a i NATO-a te drugih razvijenih demokratskih zemalja.

Međutim, do stupanja na snagu novoga ZOO-a tumačenje profesionalne i poslovne tajne bilo je otežano zbog nedovoljno jasnoga položaja prava osobnosti, osobito prava osobnosti pravnih osoba. ${ }^{36} \mathrm{I}$ danas treba priznati određene razlike u privatnopravnome $\mathrm{i}$ kazneno-pravnome tretmanu poslovne i profesionalne tajne, a one proizlaze iz različite pravno-političke logike privatnoga i kaznenoga prava. ${ }^{37}$ Prema nekima današnje suvremeno društvo, odnosno pojedini njegovi subjekti u okviru svojih funkcija i ovlaštenja postaju ,depozitari“ osobnih tajni. ${ }^{38}$ Riječ je, kao što je već ranije navedeno, o „profesionalcima" koji zbog prirode svojega zanimanja, odnosno svojih specifičnih nadležnosti imaju mogućnost spoznaje raznih vrsta tajni svojih klijenata (ovisno o prirodi zanimanja). ${ }^{39} \mathrm{Te}$ tzv. profesionalne tajne razlikuju se od dosad navedenih oblika tajni (o osobnim podacima i intimnome životu) po jednome svojem subjektivnom elementu predstavljenom specifičnošću kvalifikacija osoba koje su ih u prilici saznati. Naime, da bi se nešto kvalificiralo kao profesionalna tajna, nužna je prisutnost „profesionalca“ i činjenica da je podatak - tajna povezana s profesijom. Stoga je pravo na profesionalnu tajnu predstavljeno ne samo kao očuvanje nečije privatnosti spram profesionalaca nego i kao očuvanje te tajne od profesionalaca spram svih drugih. Onaj tko povrijedi svoju obvezu čuvanja profesionalne tajne nije samo povrijedio nečiju privatnost nego je povrijedio i svoju profesiju. ${ }^{40}$ Profesionalnu tajnu u svezi s obavljanjem pojedinih (in concreto) zanimanja reguliraju posebni propisi ovisno o vrsti profesionalne tajne. 
Tijekom obavljanja svoje profesije liječnik može otkriti ili utvrditi određene činjenice kod pacijenta koje nisu općepoznate i za koje pacijent ne želi da ih drugi doznaju. Saznanje takvih činjenica naziva se i predstavlja liječničku tajnu (engl. medical professional secret, franc. secret professionnel des medecins, secret medical, tal. segreto medico, njem. artzliches Berufsgeheimnis). Liječnička tajna je vrsta pozivne ili profesionalne tajne koja je vezana za obavljanje liječničkog poziva. ${ }^{41}$

Pojam «čuvanja tajne» uvijek je pratio i uvijek će neminovno pratiti zdravstvenu struku, a sam će se sadržaj pojma prilagođavati razvitku znanosti i društva. ${ }^{42}$ Sve ono što je liječnik obavljajući svoju dužnost saznao smatra se liječničkom tajnom (Kodeks medicinske etike i deontologije, «Narodne novine», broj 47/04., čl. 2. st. 13.), a posebno sve ono što liječnik sazna o pacijentu koji mu se obrati za liječničku pomoć, a u svezi s njegovim zdravstvenim stanjem, mora čuvati kao liječničku tajnu (ZOL, čl. 19.). ${ }^{43} \mathrm{Da}$ bi neki podatak, odnosno činjenica imala karakter tajnosti, nije potrebno da pacijent posebno i izričito napomene njezinu povjerljivost, nego liječnik mora sam prosuditi stupanj povjerljivosti pojedinih činjenica. ${ }^{44}$

Korist od čuvanja liječničke tajne ne bi trebalo procjenjivati po objektivnom kriteriju (kako bi se netko drugi na pacijentovom mjestu prema njoj odnosio), nego prema subjektivnom kriteriju, bez pravnog i moralnog vrednovanja, ${ }^{45}$ odnosno osoba na koju se tajna odnosi mora i sama željeti da podatak bude nedostupan trećima.

Prije je prevladavalo stajalište da je liječnička tajna jedinstvena, tj. da postoji samo u odnosu između pacijenta i određenog liječnika, u skladu s praksom tzv. individualne medicine. Uvođenjem u medicinu suvremene i sofisticirane tehnologije i medicinske prakse, bez čega bi medicina bila znatno neučinkovitija, formulirano je stajalište o tzv. podijeljenoj tajni. Drugim riječima, tajna koja je povjerena jednom liječniku može biti prenesena drugim zdravstvenim radnicima koji sudjeluju u liječenju, a često i drugim osobama koje obavljaju zdravstvenu funkciju. ${ }^{46} \mathrm{~S}$ promjenama u obavljanju zdravstvene djelatnosti i sve većim brojem sudionika u zdravstvenoj zaštiti, obveza čuvanja liječničke tajne proteže se i na sve druge zdravstvene radnike te na sve druge osobe koje u obavljanju svojih dužnosti dođu do podataka o zdravstvenom stanju pacijenta. Upravo zbog toga držimo da bi danas za ovu vrstu tajne bilo primjerenije koristiti pojam ,medicinska tajna“ ili ,zdravstvena tajna“, jer bi se na taj način obuhvatile sve osobe koje dolaze u doticaj s pacijentima i koje na taj način doznaju podatke koje su dužne čuvati kao (pacijentovu) tajnu. ${ }^{47}$ Pojam ,medicinska tajna“ koristi se i u poredbenom pravu (engl. medical professional secret, franc. secret professionnel des medecins, secret medica) za označavanje ove vrste tajne.

Međutim, u radu ćemo za označavanje ove vrste tajne koristiti pojam „liječnička tajna“, iako sadržajno ne odgovara stvarnom sadržaju ove tajne i krugu osoba koje su dužne tu tajnu čuvati, jer je kod nas postao svojevrsni tehnički termin i kao takav se u pravilu koristi u zakonodavstvu i (medicinsko)pravnoj teoriji. $U$ tom smislu, pored liječničke tajne, u našem pravu postoje i posebnim propisima su uređene stomatološka (profesionalna) tajna ${ }^{48}$ ljekarnička (profesionalna) tajna, ${ }^{49}$ sestrinska (profesionalna) tajna $^{50} \mathrm{i}$ dr. 
Liječnička tajna je načelo medicinske etike koja se odnosi na ono što je bolesnik povjerio svom liječniku. ${ }^{51}$ Koncept liječničke tajne star je nekoliko tisuća godina i naznake toga instituta mogu se naslutiti još u Hamurabijevu zakoniku, a kasnije i u Hipokratovoj zakletvi. ${ }^{52}$ Hipokratova zakletva drevni je dokument i temelj je medicinske etike. Nastala je u V. stoljeću prije Krista. Hipokrat je postavio temelje moderne medicine, oslobađajući je od religije, nametanja kulta čovjeka i uvođenjem znanstvenog načela promatranja čovjeka i prirode. Hipokrat je u zakletvu unio temeljna deontološka načela koja su u to vrijeme važila u Grčkoj. ${ }^{53}$ Polagali su je prilikom stupanja na dužnost svi liječnici koji su pripadali Hipokratovom društvu Asklepiada. ${ }^{54}$ Tekst koji se odnosi na liječničku tajnu glasi: Što pri svojem poslu budem saznao ili vidio, pa i inače, u dodiru s ljudima, koliko se ne bude smjelo javno znati, prešutjet ću i zadržat ću tajnu. Hipokrat liječničku tajnu definira po sadržaju znatno široko jer pod njom podrazumijeva i sve činjenice saznate i viđene u kući bolesnika. Zdravstveni radnici najčešće se susreću sa Ženevskom formulacijom Hipokratove zakletve, u kojoj su naglašene obveze koje, prema iskustvima iz prethodna dva svjetska rata, nisu poštivane. ${ }^{55}$ Usvojena je u Ženevi, 1948. godine, dopunjena na 22. Skupštini Svjetskog liječničkog udruženja u Sydneyu 1968., i 35. skupštini u Veneciji, 1983. godine. ${ }^{56} 57$

Čuvanje liječničke tajne bilo je prije XIX. stoljeća samo moralna dužnost liječnika, ${ }^{58}$ pa iako je shvaćanje o isključivo etičkom karakteru liječničke tajne imalo svojih prednosti, slabost je bila u teškoći da se na siguran i dostojan način primjene sankcije protiv prekršitelja. ${ }^{59}$ Treba ipak napomenuti da je, primjerice, u francuskom zakonodavstvu, iako nije bilo propisa kojima je liječnička tajna bila izričito uređena nego se ona priznavala prešutno, kao ustaljena norma ponašanja, bilo propisa temeljem kojih se otkrivanje liječničke tajne odobravalo u posebnim slučajevima. Tako je Luj XI. 1447. godine odobrio povredu liječničke tajne u slučajevima prijestupa «uvrede Veličanstva», a Luj XIV. 1666. godine za slučajeve dvoboja i zločina. Revolucionarni zakon od 17. ventoza, X godine (805.), dodatno je odobrio otkrivanje liječničke tajne kad su u pitanju interesi države. ${ }^{60} \mathrm{Za}$ otkrivanje tajne od strane zdravstvenog personala po prvi put je bila utvrđena kazna u Pruskom općem zemaljskom pravu iz 1794. godine. ${ }^{61}$ Po prvi put je dužnost čuvanja liječničke tajne zaštićena autoritetom države u francuskom Kaznenom zakoniku iz 1810. godine, na način da je povreda liječničke tajne okvalificirana kao kazneno djelo protiv osobe. ${ }^{62}$ 


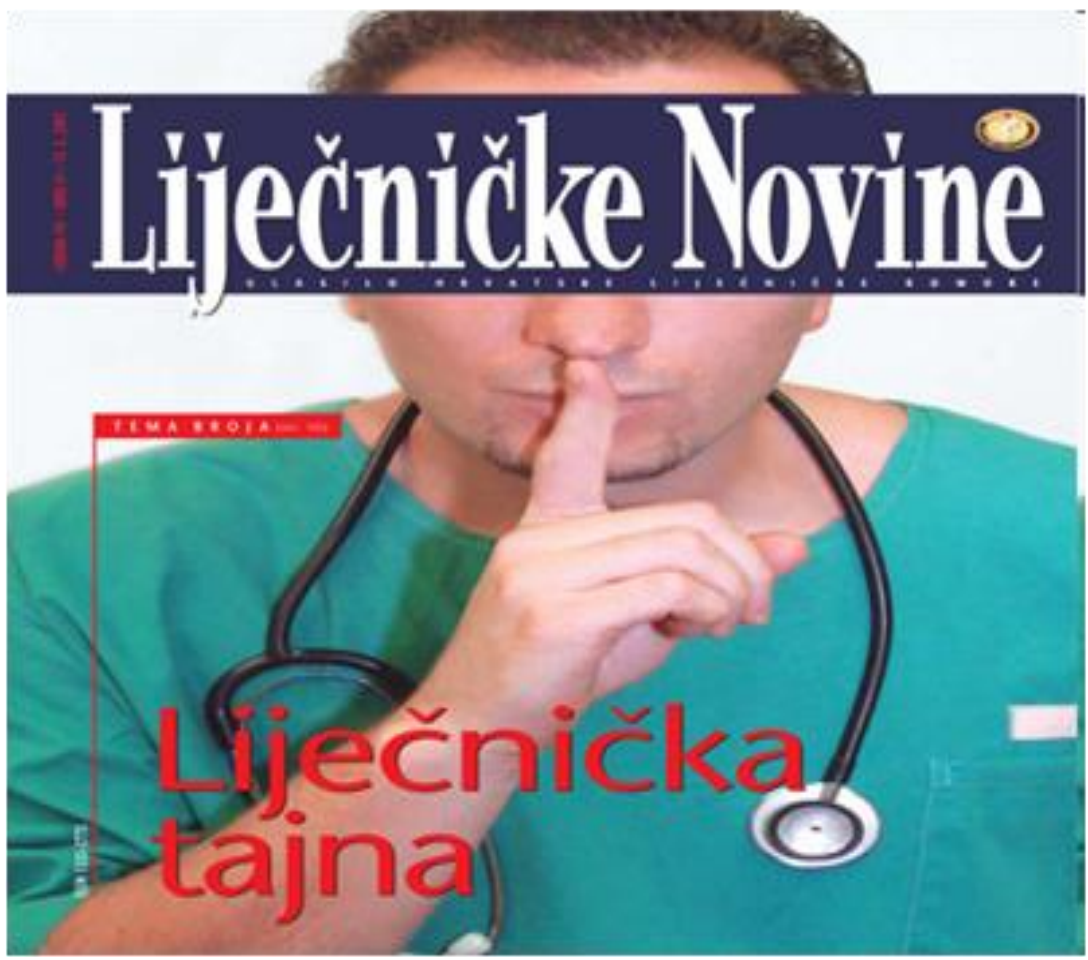

Slika 14

\subsection{Sadržaj liječničke tajne}

Pod zaštitu liječničkom tajnom potpadaju svi podaci o pacijentu i njegovoj okolini koji su liječniku povjereni ili koje je on spoznao prilikom obavljanja svoga poziva, kao i pisana priopćenja pacijenta, bilješke o pacijentu i svi nalazi do kojih se došlo medicinskim ispitivanjem. ${ }^{63} \mathrm{U}$ pravilu se smatra da liječnička tajna obuhvaća samo činjenice koje liječnik saznaje u obavljanju svoga poziva, ponajviše od samoga bolesnika i u vezi s bolešću. Svakako to nisu samo činjenice koje mu bolesnik usmeno priopći, nego i sve ono što liječnik sam opazi ili na bilo koji način sazna prilikom pregleda bolesnika i pri drugim medicinskim aktivnostima. ${ }^{64}$ Međutim, postoji mišljenje da liječnička tajna sadržajno obuhvaća i znatno širi krug podataka. Tako, Pidelievre u pojam tajne uključuje i eventualna zapažanja u kući bolesnika koja se ne odnose neposredno na bolest, mjesto pregleda, dijagnozu i prognozu bolesti, svu medicinsku dokumentaciju, kao i podatke o osobnom životu bolesnika (primjerice obiteljsku neslogu, izvanbračne veze, siromaštvo koje obitelj prikriva i sl.), jer drži da, iako ti podaci nemaju izravne veze s bolešću koja se liječi, njihovo bi otkrivanje svakako škodilo bolesniku ili bi mu u najmanju ruku bilo nelagodno i pokolebalo bi njegovo povjerenje u liječnika. ${ }^{65}$ Tajna se, dakle, ne mora ticati samoga pacijenta, već se može odnositi i na druge osobe.

Obveza čuvanja liječničke tajne proteže se i na čuvanje tajnosti medicinske dokumentacije o pacijentu, jer upravo medicinska dokumentacija sadrži podatke o 
zdravstvenom stanju pacijenta. Tako se, primjerice, čuvanje liječničke tajne proteže i na informatičke sustave u kojima se pohranjuju podaci (KMED, čl. 2. st. 13.). Liječnik ili druga odgovorna osoba koja obavlja zdravstvenu djelatnost, dužni su medicinsku dokumentaciju koja se čuva na elektronskom mediju osigurati od mijenjanja, prijevremenog uništenja ili nedopuštenog korištenja (ZOL, čl. 23. st. 2.). Kod pretrage liječničke ordinacije ne smije biti povrijeđena tajnost liječničke dokumentacije i predmeta na štetu pacijenata. Prema odredbama Zakona o zaštiti osoba s duševnim smetnjama («Narodne novine», broj 111/97., 27/98., 128/99., 79/02., dalje - ZZODS), liječnička dokumentacija o liječenju osobe s duševnim smetnjama može biti dostupna sudu isključivo za potrebe postupka koji je u tijeku, i smije sadržavati samo one podatke koji su prijeko potrebni za ostvarenje svrhe zbog koje se zahtjeva njezina dostava (ZZODS, čl.. 18. st. 1. i 2.). Izjave osobe s duševnim smetnjama sadržane u liječničkoj dokumentaciji koje se odnose na počinjenje nekoga kaznenog djela ne mogu se koristiti kao dokaz u sudskom postupku (ZZODS, čl.. 18. st. 3.). Podaci iz liječničke dokumentacije koji su potrebni za ostvarenje zdravstvene, socijalne, obiteljsko pravne ili mirovinske zaštite mogu se dati za službene svrhe na zahtjev tijela nadležnih za tu zaštitu samo uz suglasnost osoba s duševnim smetnjama, a ako one nisu sposobne dati suglasnost uz suglasnost zakonskog zastupnika (ZZODS, čl.. 18. st. 4.).

Ipak, nemaju sve činjenice koje liječnik sazna od bolesnika karakter tajnosti, nego takvo značenje imaju samo one činjenice koje na takav način zadiru u interese ili intimne osjećaje pacijenta da ih on ne želi objaviti drugim osobama ili bi mu njihovo objavljivanje štetilo. ${ }^{66}$ Liječnička tajna ne bi trebala obuhvaćati banalne podatke, primjerice je li pacijent bio prehlađen, jer se otkrivanjem takvih podataka ne nanosi šteta interesu koji je dostojan zaštite. ${ }^{67}$ Dakle, hoće li se neka bolest smatrati liječničkom tajnom zavisi, primjerice, od toga drži li se prema shvaćanju okoline ta bolest sramotnom (spolne bolesti, psihoze, impotencija i sl.) što umanjuje status i ugled pacijenta u očima sredine u kojoj žive, je li prenosiva ili ne, kakav je uspjeh liječenja te bolesti i sl. ${ }^{68}$

\subsection{Uzroci i načini povrede liječničke tajne}

Apsolutna obveza čuvanja liječničke tajne mogla se zahtijevati i poštivati dok je postojao samo neposredni odnos između liječnika i pacijenta. Sa socijalizacijom medicine pored liječnika u liječenju bolesnika sudjeluje čitav niz osoba kao što su medicinske sestre, ljekarnici, stomatolozi, laboranti, bolničari, studenti, pa i administrativno osoblje, i sve su te osobe na neki način upućene u određenu tajnu. Zaštita liječničke tajne postaje sve teža i zbog kompjuterizacije medicinske dokumentacije, tele-medicine i elektroničke obrade podataka, ${ }^{69}$ obavljanja medicinske intervencije u različitim ustanovama, sudjelovanja u pružanju medicinske usluge sve većeg broja osoba i sve više vrsta zdravstvenih radnika, ali i zbog sve većeg opravdanog ili neopravdanog interesa javnosti i medija za informiranjem o zdravstvenom stanju pojedinih pacijenata (javnih osoba, mogućih zaraznih bolesti i sl.). Usto, medicinski podaci danas služe i potražuju ih primjerice osiguravatelji (zbog ocjene rizika na strani osiguranika), poslodavci, ${ }^{70}$ proizvođači lijekova (u marketinške svrhe), banke (ocjena rizika kreditiranja), državna tijela ${ }^{71}$ kao i u (druge) komercijalne svrhe. ${ }^{72}$ Zbog svega navedenog danas bi mogli govoriti i o službenoj, a ne samo o pozivnoj tajni. 
Odavanje liječničke tajne ima svoje uzroke i pojavne oblike. Do povrede liječničke tajne dolazi najčešće usmeno ili pisanim putem, ali postoje i drugi načini povrede čuvanja liječničke tajne kao primjerice objavljivanje fotografskih snimaka, neopreznim objavljivanjem podataka o pojedinim bolesnicima u stručnoj literaturi i sl. ${ }^{73}$ Do odavanja liječničke tajne može doći nepažnjom, iz neznanja (o pravu na privatnost i o propisima kojom je to pravo zaštićeno) ili namjerno (primjerice, zbog samoisticanja ili koristoljublja). Kao psihološki uzroci koji dovode do odavanja liječničke tajne mogu se navesti lakoumnost, zabluda, prinuda, strast za saznavanjem i odavanjem tajne, koristoljubivi uzroci i psihološka neuračunljivost, ljutnja, tuga i sl. ${ }^{74}$ Pri tome je nebitno na koji je način izvršeno otkrivanje tajne, je li tajna otkrivena jednoj ili više osoba, je li otkrivanje podataka objektivno moglo prouzročiti ili je prouzročilo neke štetne posljedice i sl., a ove okolnosti mogu, u pravilu, biti ocjenjivane kao otegotne okolnosti. ${ }^{75}$

Kontakti sa službama i profesijama nastalih radi zadovoljavanja egzistencijalnih potreba ljudi u velikom broju slučajeva dovode čovjeka u situaciju nužnog odavanja tajnih dijelova osobnosti. ${ }^{76}$ Primjerice, pri izlasku iz bolnice bolesnik dobije otpusnicu u kojoj je ispisana dijagnoza, koju je dužan pokazati poslodavcu radi pravdanja izostanka i odobravanja bolovanja. ${ }^{77}$ Do otkrivanja liječničke tajne može doći i posredno, na zahtjev sudova ili drugih državnih tijela. Primjerice, sud može zahtijevati povijest bolesti nekog pacijenta radi sudsko-medicinskog vještačenja. Međutim, u povijesti bolesti i drugoj dokumentaciji mogu se pored relevantnih nalaziti i takvi podaci koji za sud nisu važni i potrebni u pogledu rješavanja konkretnog spora, a koje je liječnik saznao, utvrdio i zaveo u povijest bolesti i koji kao takvi predstavljaju liječničku tajnu. Otkrivanje i tih podataka zasigurno predstavlja nedopušteno otkrivanje liječničke tajne. ${ }^{78} \mathrm{U}$ bolnicama na krevetu svakog bolesnika izvješene su tzv. temperaturne lite s velikim brojem podataka o bolesniku (ime i prezime, godina rođenja, dijagnoza, zabilješke o temperaturi, pulsu, krvnom tlaku, ordiniranim lijekovima, datumima kirurških intervencija i raznih laboratorijskih pretraga i sl., a te liste stoje otvoreno i pristupačne su svakome tko dođe posjetiti toga ili drugog bolesnika u sobi. ${ }^{79}$ Radnja otkrivanja može se obaviti primjerice i tako što liječnik razgovara telefonom o tajnim podacima u prisustvu treće osobe koja može identificirati pacijenta na kojega se podaci odnose. ${ }^{80}$

Otkrivanje liječničke tajne može se izvršiti i nečinjenjem, odnosno propuštanjem, primjerice ako liječnik pacijentovu medicinsku dokumentaciju ne pohrani na propisani način i time omogući neovlaštenim trećim osobama da je razgledaju ili odnesu. ${ }^{81}$

\subsection{Neovlašteno ${ }^{82}$ odavanje liječničke tajne}

Povreda podataka o zdravstvenom stanju osobe može se odraziti i na njezin privatni život. Čuvanje liječničke tajne je etička i pravna obveza liječnika, odnosno zdravstvenih radnika. ${ }^{83}$ Dužnost čuvanja liječničke tajne postoji bez obzira na činjenicu liječi li liječnik pacijenta slučajno (primjerice, kao žrtvu prometne nesreće), dragovoljno ili prinudno, te ne prestaje s prestankom liječničke djelatnosti, nego traje doživotno. ${ }^{84}$ Tako je, primjerice, liječnik dužan čuvati liječničku tajnu i pred bolesnikovim bližnjima, ako to bolesnik želi, a i nakon njegove smrti, osim u slučaju kad bi čuvanjem liječničke tajne ugrozio život i zdravlja drugih ljudi (KMED, čl. 2. st. 13.). Pravo čovjeka na privatnost ne gasi se njegovom smrću. ${ }^{85}$ Usto, nakon smrti pacijent nije više u stanju liječnika 
osloboditi obveze čuvanja tajne, a postoji mišljenje da to ne mogu ni njegovi nasljednici ni njemu bliske osobe. ${ }^{86}$ U slučaju sumnje, liječnik se uvijek treba odlučiti za postmortalnu obvezu čuvanja tajne. ${ }^{87}$ Mogućnost da se tajni podaci otkriju nakon pacijentove smrti zavisi od raznih okolnosti, primjerice od prirode tih podataka, jesu li te informacije već postale dostupne javnosti, koliko je prošlo od pacijentove smrti, postoji li sukob interesa vezan za te podatke, kojim se osobama otkrivaju ti podaci (rodbina, ovlaštena tijela) i sl. ${ }^{88}$

Liječnik, pak, nije dužan čuvati tajnu odnosno podatke koje je doznao nezavisno od svog zanimanja (primjerice, u privatnom razgovoru) ili samovoljno, odnosno na ilegalan način (primjerice, čitanjem zatvorenog pisma adresiranog na pacijenta), ali može naknadno biti dužan čuvati i takvu tajnu ako bi kasnije liječio osobu o čijoj se tajni radi. ${ }^{89}$

Neovlašteno odavanje liječničke tajne može za osobu koju je povrijedila liječničku tajnu imati različite posljedice i odgovornosti.

Moralne i psihološke posljedice - Nepoštivanje liječničke tajne ima ponajviše štetne psihološke i moralne posljedice. Nepridržavanje etičkih načela od strane liječnika može dovesti do njegove stegovne i kaznene odgovornosti, ali je ono ipak najviše podvrgnuto sudu vlastite savjesti. ${ }^{90} \mathrm{Za}$ razliku od ostalih pravila medicinskog prava, etička su pravila redovito kodificirana u posebnim etičkim, odnosno deontološkim kodeksima, ${ }^{91} \mathrm{u}$ našem pravu u KMED-u.

Kaznena odgovornost - Moralna obveza liječnika da čuva liječničku tajnu pojačana je pravnim normama koje propisuju kaznenu odgovornost liječnika ako neovlašteno otkrije tajnu koju je saznao u obavljanju svoga poziva. ${ }^{92} \mathrm{KZ}$ propisuje da se će doktor medicine, doktor stomatologije, primalja ili drugi zdravstveni radnik koji neovlašteno otkrije tajnu koju je saznao u obavljanju svoga zvanja, kazniti novčanom kaznom ili kaznom zatvora do 1 godine (KZ, čl. 145. st. 1.), a kazneni postupak za navedeno kazneno djelo pokreće se povodom prijedloga (KZ, čl. 145. st. 3.). Ovom inkriminacijom osigurava se kaznenopravna zaštita podataka osobnog značaja, odnosno podataka koji se tiču određenog pojedinca, njegovog intimnog područja života. ${ }^{93}$

Kazneno djelo odavanja liječničke tajne spada u kategoriju delicta propria, odnosno mogu ga izvršiti samo one osobe koje vrše zdravstvenu službu, što u širem tumačenju pojma «zdravstvene službe» može obuhvatiti i zdravstvenu administraciju. ${ }^{94}$ Tajna saznana pri obavljanju poziva nije pristupačna širem krugu osoba. Interes i volja njezina vlasnika je da ostane u diskreciji, da ne postane dostupna i da ju ne sazna neovlaštena osoba. ${ }^{95}$ Uvijek se radi o tajnama koje se tiču pojedinca, a ne i o onima koje se tiču ustanova, trgovačkih društava, organizacija i sl., jer su one obuhvaćene posebnim kaznenim djelima, kao što su djela otkrivanja službene, vojne, poslovne ili državne tajne. ${ }^{96}$ Tajna se ne mora ticati samoga pacijenta, već se može odnositi i na sasvim druge osobe. ${ }^{97}$ Zaštitni objekt je pravo građana na osobnu tajnu, odnosno podaci saznati u vršenju određenog poziva. ${ }^{98}$ Štiti se intimnost osobe, a preko nje i potreba pravilnog funkcioniranja određenih javnih poziva i djelatnosti, jer se odnos djelatnika ovih službi i građana temelji na međusobnom povjerenju, uključujući jamstvo da će osobna tajna biti poštovana.${ }^{99}$ Radnja počinjenja je svako ponašanje liječnika kojom se tajna stavlja do 
znanja, kojom se prenosi, iskazuje nekoj trećoj, neovlaštenoj osobi. Da bi ovo kazneno djelo postojalo mora se raditi o neovlaštenom otkrivanju liječničke tajne, a u protivnom djelo neće postojati jer neće biti protupravno. ${ }^{100}$ Ovo kazneno djelo neće postojati ako su otkriveni podaci čije držanje u tajnosti nije važno za očuvanje pacijentova intimiteta (objektivno beznačajni podaci). Kao poseban temelj isključenja protupravnosti ovog kaznenog djela jest slučaj dopuštenog otkrivanja liječničke tajne, neovisno o stajalištu pacijenta, u općem interesu ili interesu druge osobe koji je pretežniji od interesa čuvanja liječničke tajne. Pod općim interesom može se primjerice smatrati slučaj potrebe otkrivanja kaznenog djela, sprječavanja zaraze i sl. Dopušteno otkrivanje liječničke tajne $\mathrm{u}$ interesu druge osobe postojalo bi, primjerice, ako roditelju treba kazati da mu dijete boluje od teške bolesti, dakle osobi čiji je interes otkrivanja veći od interesa ne otkrivanja. ${ }^{101} \mathrm{Ne}$ bi se radilo o ovom djelu ni onda ako bi, primjerice, liječnik obavijestio suprugu o spolnoj bolesti muža ili kad bi o određenoj bolesti profesionalnog vozača obavijestio nadležnu ustanovu. ${ }^{102}$ Djelo neće biti protupravno ni onda ako je tajna odana uz pristanak pacijenta, a takav učinak mogu imati i opći razlozi isključenja protupravnosti, kao primjerice krajnja nužda ili pretpostavljeni pristanak. ${ }^{103}$

Prekršajna odgovornost - Zbog odavanja liječničke tajne liječnik može odgovarati i prekršajno. Tako se liječnik, ako ne poštuje obvezu čuvanja liječničke tajne, može za prekršaj kazniti novčanom kaznom u iznosu od 5.000,00 do 10.000,00 kuna (ZOL, čl. 59. t. 3.). Novčanom kaznom u iznosu od 10.000,00 do 50.000,00 kuna može se za prekršaj kazniti i zdravstvena ustanova ako povrijedi pravo na povjerljivost podataka (ZOZPP, čl. 41. st. 1. t. 8.), te odgovorna osoba u zdravstvenoj ustanovi s novčanom kaznom u iznosu od 5.000,00 do 10.000,00 kuna. ${ }^{104}$ Psihijatrijska ustanova može se kazniti novčanom kaznom u iznosu od 5.000,00 do 300.000,00 kuna za prekršaj ako povrijedi obvezu čuvanja profesionalne odnosno službene tajne, a za navedeni prekršaj može se kazniti novčanom kaznom u iznosu od 1.000,00 do 10.000,00 kuna i osoba čijom je radnjom ostvaren navedeni prekršaj, kao i odgovorna osoba u psihijatrijskoj ustanovi (ZZODS, čl. 64. t. 5.).

Stegovna (disciplinska) odgovornost - Kaznena i prekršajna odgovornost liječnika ili disciplinska odgovornost u zdravstvenoj ustanovi, trgovačkom društvu ili drugoj pravnoj osobi koja obavlja zdravstvenu djelatnost ne isključuje disciplinsku odgovornost liječnika pred Hrvatskom liječničkom komorom (ZOL, čl. 50. st. 2.). Povreda čuvanja profesionalne, liječničke tajne teža je povreda obveze iz radnog odnosa (ZOZZ, čl. 122. st. 3.). Za povredu liječničke tajne liječniku se mogu izreći sljedeće disciplinske mjere i kazne: ukor, javni ukor, novčana kazna, privremeno oduzimanje odobrenja za samostalan rad od mjesec dana do godine dana, trajno oduzimanje odobrenja za samostalan rad. Uz svaku navedenu mjeru i kaznu, osim uz mjeru trajnog oduzimanja odobrenja za samostalan rad, liječniku se može odrediti disciplinska mjera dodatne izobrazbe. Disciplinska mjera oduzimanja odobrenja za samostalan rad, može se izreći uvjetno s rokom kušnje od 6 mjeseci do dvije godine. Iznos novčane kazne određen Statutom Komore, koji ne može biti niži od 1.000,00 kn niti veći od 5.000,00 kn, određuje Sud Komore u svakom pojedinom slučaju (arg. Pravilnik o disciplinskom postupku Hrvatske liječničke komore, čl. 56.). ${ }^{105}$ 
Građanska odgovornost - Pacijent ima pravo na povjerljivost podataka koji se odnose na stanje njegova zdravlja sukladno propisima o čuvanju profesionalne tajne i zaštiti osobnih podataka (ZOZPP, čl. 25.), a u slučaju povrede toga njegovoga prava, pacijent ima pravo na naknadu štete sukladno općim propisima obveznog prava (ZOZPP, čl. 29.). Dakle, osobi čije je pravo osobnosti, ${ }^{106}$ odnosno pravo na privatnost povrijeđeno protupravnim odavanjem liječničke tajne, pripada pravo da protiv osobe koja je izvršila povredu stavlja i ostvaruje odgovarajuće građanskopravne zahtjeve, ${ }^{107} \mathrm{i}$ to zahtjev za prestanak povrede (kvazinegatorijski zahtjev), zahtjev za popravljanje neimovinske (nematerijalne) štete nenovčanim i/ili novčanim zadovoljenjem, zahtjev za utvrđenje, kao i zahtjev zbog stjecanja bez osnove. ${ }^{108}$ Odštetna odgovornost zdravstvenih radnika determinirana je veličinom rizika koji nosi ta profesija, jer je liječnička djelatnost, unatoč temeljnom humanom i plemenitom cilju da se pacijentu očuva ili popravi zdravstveno stanje, ponekad neizbježno povezana s rizikom gubitka života ili pogoršanja zdravlja. ${ }^{109}$

\subsection{Ovlašteno odavanje liječničke tajne}

Ovlast osobe da može isključiti svakoga od neovlaštenog saznavanja, prikupljanja, daljnjeg širenja i objavljivanja podataka o njoj i njezinu životu, njezino je pravo na to da ti podaci ostanu za svakoga tajna, osim za onoga koji bi bio ovlašten te podatke saznati, baratati s njima i sl. ${ }^{110}$ Međutim, dužnost čuvanja liječničke tajne nije apsolutna, pa liječnik ne postupa neovlašteno, odnosno protupravno ako tajnu otkrije iz opravdanih razloga. Tako liječnik nema obvezu čuvanja tajne: ako su ga pacijent ili njegov zakonski zastupnik oslobodili te obveze; ako okolnosti konkretnog slučaja opravdavaju pretpostavku da je ovlaštena osoba (pacijent ili njegov zakonski zastupnik) suglasna $\mathrm{s}$ otkrivanjem tajne; ako podatke koji predstavljaju liječničku tajnu radi liječenja pacijenta treba odati drugom liječniku; ako čuvanje tajne bitno ugrožava život ili zdravlje pacijenta, ili život, zdravlje ili neki drugi pretežniji interes trećih osoba; ako ga na odavanje tajne obvezuju zakonski propisi (i u tom slučaju liječnik o tome treba izvijestiti pacijenta); ako podatke koji predstavljaju liječničku tajnu treba dostaviti ovlaštenim tijelima; ako podatke koji predstavljaju liječničku tajnu objavljuje na predavanjima ili u znanstvenim publikacijama (uz zaštitu identiteta pacijenta); te ako čuvanje tajne bitno ugrožava neki pretežniji interes samog liječnika.

Ovlaštenje od strane pacijenta - Liječnik ili drugi zdravstveni radnik oslobođen je šutnje o podacima koji predstavljaju liječničku tajnu u svim slučajevima u kojima pacijent pristaje na iznošenje njegovih podataka privatne naravi. Sve što liječnik sazna o pacijentu koji mu se obrati za liječničku pomoć, a u svezi je s njegovim zdravstvenim stanjem, mora čuvati kao liječničku tajnu i može je otkriti, ako posebnim zakonom nije drukčije propisano, samo uz odobrenje pacijenta, roditelja ili skrbnika za malodobne osobe, a u slučaju njegove psihičke nesposobnosti ili smrti, uz odobrenje uže obitelji, skrbnika ili zakonskog zastupnika (ZOL, čl. 19.). ${ }^{111}$ Pacijent može osloboditi liječnik od dužnosti čuvanja tajne koja se odnosi na toga pacijenta, ali ga ne može prisiliti na odavanje tajne. ${ }^{112}$ Naime, liječnik može odlučiti da ne otkrije podatke koji predstavljaju liječničku tajnu, iako ga je pacijent na to ovlastio, ako drži da pacijent nije bio svjestan negativnih posljedica koje bi mu moglo prouzročiti otkrivanje liječničke tajne, ako smatra da pacijent želi da se podaci otkriju iz nekih posebnih razloga koji ne bi bili u skladu s njegovim ugledom i liječničkom etikom i sl. ${ }^{113}$ 
Temeljnu pretpostavku za obznanjivanje podataka čini kompatibilnost pacijenta, odnosno pristanak za odavanje vlastitih podataka bit će valjan ako je pacijent koji ga je dao bio svjestan, punoljetan i duševno zdrav. Ovaj vid odavanja tajne svoje uporište ima u pravu svakog čovjeka da raspolaže svojim vlastitim dobrom. ${ }^{114}$

Pacijent ima pravo dati usmenu ili pisanu izjavu o osobama koje mogu biti obaviještene o njegovu prijemu u stacionarnu zdravstvenu ustanovu kao i o njegovom zdravstvenom stanju, a isto tako može i imenovati osobe kojima zabranjuje davanje tih podataka (ZOZPP, čl. 25. st. 2.).

Osobe koje obavljaju djelatnosti zaštite i liječenja osobe s duševnim smetnjama mogu otkriti ono što su saznale ili primijetile glede duševno oboljelih osoba tijekom obavljanja svoje djelatnosti, samo uz pristanak tih osoba ili njihovoga zakonskog zastupnika, ako ona sama nije sposobna dati pristanak (ZZODS, čl. 17. st. 2.). Ako se, pak, tajna odnosi na neku drugu osobu, a ne na samoga pacijenta, za otkrivanje tajne potreban je pristanak te osobe. ${ }^{115}$ Da bi pristanak osobe s duševnim smetnjama bio valjan, ona mora biti sposobna procijeniti opravdanost, svrhu, korist ili štetu od davanja informacije, te stoga prethodno mora biti informiran o svom stanju i posljedicama koje proizlaze iz davanja informacije određenoj osobi i/ili ustanovi. ${ }^{116}$ U slučaju kad osoba s duševnim smetnjama nije sama sposobna dati pristanak na otkrivanje tajne, pa kad u njezino ime pristanak daje njihov zakonski zastupnik, liječnik smije otkriti podatke samo ako je njihovo otkrivanje u najboljem interesu osobe duševnim smetnjama, a pri tome treba obrazložiti, odnosno dokumentirati razloge zbog kojih se osoba s duševnim smetnjama smatra nesposobnom sama dati pristanak. ${ }^{117}$

Pretpostavljena suglasnost pacijenta - Izjava volje pacijenta koja znači pristanak na otkrivanje tajne od strane liječnika može se dati u bilo kojem obliku, na izričit način ili prešutno, konkludentnim radnjama. Pretpostavljeni pristanak pacijenta značajan je posebno u slučaju kad se pacijent nije sam u stanju izjasniti, primjerice ako je izgubio svijest ili zbog toga što je mentalno bolestan, kao i onda kad se iz okolnosti može zaključiti da pacijent nema interesa za čuvanjem njegove tajne. ${ }^{118} \mathrm{U}$ dvojbi liječnik treba polaziti od pretpostavke da pacijent ima volju da se njegovi podaci drže u tajnosti. ${ }^{119}$ Primjerice, ako pacijent u sudskom postupku imenuje svoga liječnika kao svjedoka, smatra se da ga je prešutno oslobodio obveze čuvanja liječničke tajne. ${ }^{120}$ Ili, ako pacijent po uputi svoga izabranog liječnika (opće prakse, obiteljskog liječnika) ode specijalisti na pregled, drži se da prešutno pristaje da u nalaze koje utvrdi specijalist može imati uvid i njegov liječnik. ${ }^{121}$

Osobe koje obavljaju djelatnosti zaštite i liječenja osobe s duševnim smetnjama mogu otkriti ono što su saznale ili primijetile glede duševno oboljelih osoba tijekom obavljanja svoje djelatnosti, i bez pristanka osobe s duševnim smetnjama ili njezinog zakonskog zastupnika, službenim osobama u centrima za socijalnu skrb i drugim državnim tijelima, koje su te podatke dužne čuvati kao službenu tajnu, kada je to nužno da bi one mogle postupati u svezi s osobom s duševnim smetnjama na temelju i u okviru svojih ovlasti, i to samo onda kad osobe s duševnim smetnjama nisu sposobne dati svoj pristanak, a osobe koje obavljaju djelatnosti zaštite i liječenja osobe s duševnim smetnjama nemaju osnove vjerovati da bi se osoba s duševnim smetnjama protivila otkrivanju takvih podataka, 
(ZZODS, čl. 17. st. 3.). Pri tome se smiju otkriti samo oni podaci koji su značajni za ostvarivanje navedene svrhe i ti podaci ne smiju se, bez posebnog pristanka pacijenta, koristiti u druge svrhe osim onih za koje su dani (ZZODS, čl. 17. st. 4.). Drži se, dakle, da bi se navedenim tijelima trebalo priopćiti minimum informacija o pacijentu koje bi navedenim tijelima i službama bile dostatne za realizaciju postupka u okviru njihova djelokruga rada. ${ }^{122}$

Odavanje tajne drugom liječniku pacijenta - Ako više liječnika istovremeno ili jedan za drugim liječe istoga pacijenta, oni nemaju međusobnu obvezu čuvanja tajne, svakako ukoliko je pacijent $\mathrm{s}$ time suglasan ili se njegova suglasnost može pretpostaviti. ${ }^{123} \mathrm{~S}$ obzirom da moderna medicinska praksa u liječenju uobičajeno uključuje liječničke timove i druge zdravstvene radnike, kao i osobe izvan toga kruga, liječnik mora biti siguran da pacijent razumije zašto i kada podaci koji predstavljaju liječničku tajnu mogu biti dostavljeni drugim članovima tima, kao i da drugi članovi tima razumiju da te podatke moraju čuvati kao liječničku tajnu. ${ }^{124}$

Osobe koje obavljaju djelatnosti zaštite i liječenja osobe s duševnim smetnjama mogu otkriti ono što su saznale ili primijetile glede duševno oboljelih osoba tijekom obavljanja svoje djelatnosti i bez pristanka osobe s duševnim smetnjama ili njezinoga zakonskog zastupnika drugom psihijatru ili doktoru medicine ako je to nužno za pružanje liječničke pomoći toj osobi, koji je te podatke dužan čuvati kao profesionalnu tajnu (ZZODS, čl. 17. st. 3.). Pri tome se smiju otkriti samo oni podaci koji su značajni za ostvarivanje navedene svrhe i ti podaci ne smiju se koristiti u druge svrhe osim onih za koje su dani (ZZODS, čl. 17. st. 4.). Postoji mišljenje da liječnik koji je liječio osobu s duševnim smetnjama ipak ne bi smio ni u svrhu liječničke pomoći ove podatke otkriti drugom psihijatru ili doktoru medicine, ako se duševno bolesna osoba ili njezin zakonski zastupnik izrijekom protivi otkrivanju tajne, osim iznimno u slučajevima hitnje te ako je riječ o osobi s težim duševnim smetnjama prisilno smještenoj u psihijatrijskoj ustanovi, a otkrivanje tajne je nužno za provođenje liječničkog postupka bez kojeg bi nastupilo teško naruženje zdravlja te osobe (arg. ZZODS, čl. 8., 9. st. 1. i 3. u svezi s čl. 17.). ${ }^{125}$

Liječnik koji upućuje bolesnika drugom liječniku dužan je obavijesti ga o pojedinostima koje bi mogle na bilo koji način naškoditi odnosno ugroziti zdravlje ili život liječnika (KMED, čl. 9. st. 4.). Tako, kada liječnik upućuje drugom liječniku ili u drugu ustanovu, trgovačko društvo, odnosno drugu pravnu osobu koja obavlja zdravstvenu djelatnost pacijenta koji bi zbog svog stanja ili ponašanja mogao ugroziti zdravlje, odnosno život liječnika, drugih zdravstvenih radnika ili drugih pacijenata, obvezan ih je o tome pravodobno obavijestiti telefonom, elektroničkim putem ili na drugi odgovarajući način (ZOL, čl. 28.).

Odavanje liječničke tajne na temelju (zakonskih) propisa - Liječnik nije povrijedio dužnost čuvanja liječničke tajne ako je podatke koji predstavljaju liječničku tajnu obznanio, odnosno učinio dostupnim trećim osobama zbog toga što su ga na odavanje tajne obvezali zakonski (ili drugi) propisi. U tom slučaju liječnik o tome treba izvijestiti pacijenta. Zakonska dopuštenja za zadiranje u privatnost treba, kao iznimku, tumačiti restriktivno. Zdravstveni interesi drugih osoba mogu liječnika dovesti u moralnu dvojbu treba li odati ili prešutjeti neku tajnu, kao primjerice kod postojanja zarazne bolesti. U 
takvim je slučajevima, u pravilu, dužnost liječnika jasno (zakonski) definirana, jer je on u prvom redu čuvar javnoga zdravlja. ${ }^{126}$

U smislu kaznenopravne odgovornosti, KZ zaštitu ne postavlja apsolutno, jer određuje da kazneno djelo neovlaštenog otkrivanja profesionalne (liječničke) tajne ne postoji ako je otkrivanje tajne počinjeno u općem interesu ili interesu druge osobe koji je pretežniji od interesa čuvanja tajne. ${ }^{127}$ Tako liječnik i drugi zdravstveni radnici ne mogu kao svjedoci uskratiti iskaz o onome što su u obavljanju svoga zanimanja saznali od okrivljenika, odnosno o liječničkoj tajni (Zakon o kaznenom postupku, «Narodne novine», broj 152/08., 76/09., 80/11., 121/11., 91/12., 143/12., 56/13., 145/13, 152/14, 70/17., dalje ZKP, čl. 285. t. 5.), a liječnici, zubari, ljekarnici i primalje i drugi zdravstveni radnici ne mogu kao svjedoci uskratiti iskaz o onome što su u obavljanju svoga zanimanja saznali od okrivljenika ako postoji zakonska osnova po kojoj su te osobe oslobođene dužnosti čuvanja tajne.

Liječnik je dužan podnijeti prijavu policiji ili državnom odvjetništvu kada tijekom obavljanja liječničke djelatnosti posumnja da je malodobnoj ili nemoćnoj osobi zdravstveno stanje ozbiljno ugroženo zapuštanjem ili zlostavljanjem (ZOL, čl. 22.). Liječnik je dužan obavijestiti policiju i o zlostavljanju djece od strane pacijenta, a posebno kad postoji opasnost da se ono ponovi, a o tome je dužan upozoriti i odgovorna tijela, obazrivo čuvajući privatnost i interes djeteta, odnosno malodobne osobe općenito (KMED, čl. 2. st. 4.).

Liječnik dužan podnijeti prijavu policiji ili državnom odvjetništvu kada tijekom obavljanja liječničke djelatnosti posumnja da je smrt ili tjelesna ozljeda osobe nastala nasilnim putem (ZOL, čl. 22.), bez obzira na to što bi time odao liječničku tajnu.

Prema odredbama Zakona o zaštiti pučanstva od zaraznih bolesti („Narodne novine“ br. 79/07, 113/08, 43/09) dalje - ZZPZB), obvezi prijavljivanja zaraznih bolesti podliježu: a/ svako oboljenje ili smrt od zarazne bolesti navedene u čl. 3. ZZPZB-a ili od zarazne bolesti koju odredi Vlada Republike Hrvatske; b/ svaka sumnja na oboljenje od BrillZinsserove bolesti, kolere, kuge, pjegavca, žute groznice ili virusnih hemoragijskih groznica; c/ svaka epidemija zaraznih bolesti; d/ svako izlučivanje klica trbušnog tifusa; e/ svako nošenje antigena virusne žutice tipa B i C i antitijela na virus sindroma stečenog nedostatka imuniteta (ZZPZB, čl. 16. st. 1.). Prijavu treba podnijeti organizacija zdravstva i zdravstveni radnik koji obavlja poslove zdravstvene zaštite samostalno osobnim radom, nadležnom organu odnosno ovlaštenoj organizaciji (ZZPZB, čl. 16. st. 2.). Štoviše, liječnik ili drugi zdravstveni radnik koji utvrdi oboljenje, sumnju da postoji oboljenje, ozljeda ili smrt od zarazne bolesti iz stavka 1. ovoga članka, a ne nalazi se na dužnosti u organizaciji zdravstva, dužan je o tome bez odlaganja izvijestiti najbližu organizaciju zdravstva (ZZPZB, čl. 16. st. 3.). Prema odredbi čl. 72. ZZPZB-a, novčanom kaznom od 5.000 do 25.000 kuna kaznit će se za prekršaj liječnik ili drugi zdravstveni radnik ako organizaciju zdravstva ne izvijesti o oboljenju, ozljedi ili smrti od zarazne bolesti (ZZPZB, čl. 16. st. 3.), a prema odredbi čl. 70. ZZPZB-a, novčanom kaznom od 10.000 do 100.000 kuna kaznit će se za prekršaj zdravstveni radnik koji obavlja poslove zdravstvene zaštite samostalno osobnim radom ako ne obavlja prijavljivanje zaraznih 
bolesti, na način predviđen zakonom i propisima donesenim na temelju zakona (ZZPZB, čl. 16.).

Odavanje liječničke tajne na zahtjev ovlaštenog tijela - Dužnost čuvanja liječničke tajne može prestati i na temelju odluka sudova ili javnim izjavama predstavnika službi koje brinu o javnoj sigurnosti zajednice. Budući da navedene institucije iznose samo jedan dio privatnosti i tajnosti pacijenata, onaj najnužniji vezan uz odgovarajuću odluku ili izjavu, za očekivati je da će sve ono što nije izrečeno, a ima razinu zaštite privatnosti i neodavanja tajne, ostati obvezom šutnje medicinskih i zdravstvenih radnika. ${ }^{128}$

Tako je liječnik, odnosno drugi zdravstveni radnik, dužan podatke o zdravstvenom stanju pacijenta priopćiti na zahtjev ministarstva nadležnog za zdravstvo, drugih tijela državne uprave u skladu s posebnim propisima, nadležne komore ili sudbene vlasti (ZOZZ, čl. 122. st. 4.). Isto tako, liječnik je dužan medicinsku dokumentaciju na zahtjev predočiti ministarstvu nadležnom za zdravstvo, tijelima državne uprave u skladu s posebnim propisima, Hrvatskoj liječničkoj komori ili sudbenoj vlasti (ZOL, čl. 23. st. 1.).

Liječnik nije dužan čuvati liječničku tajnu prema trećoj (pravnoj) osobi u čije bi ime, uz pristanak pacijenta, vršio pregled. Primjerice, liječnik osiguravajućeg društva nije vezan tajnom prema svojem nalogodavcu. Tako liječnik nije vezan liječničkom tajnom ako treba dati obavijest nadležnom tijelu o teškom oboljenju pacijenta koje ga čini nesposobnim za vožnju automobila i opasnim po ostale sudionike u prometu. ${ }^{129}$ Slično, liječnik koji je na zahtjev roditelja obavio pregled djevojke pa je utvrdio da je trudna, smije im priopćiti rezultate pregleda, što ne bi smio ako je pregled obavio na zahtjev same djevojke. ${ }^{130}$

Odavanje liječničke tajne zbog pretežnijeg interesa trećih osoba - Ponekad su u pogledu čuvanja liječničke tajne u sukobu interesi pojedinca (očuvati tajnu) i interesi javnosti (primjerice, saznati o nekoj zaraznoj bolesti). Javni interes u pravilu je u drugom planu i dolazi do izražaja u prosudbi pretežnijeg interesa (načelo vaganja dobara). ${ }^{131}$ Ocjena o tome koji je interes pretežniji predstavlja quaestio facti u svakom kokretnom slučaju. ${ }^{132}$

Liječnik je liječničku tajnu dužan čuvati osim u slučaju kad bi čuvanjem liječničke tajne ugrozio život i zdravlje drugih ljudi (KMED, čl. 2. st. 13.). Naime, postoje situacije u kojima šutnja i neodavanje podataka o pojedincima, odnosno pacijentima predstavlja opasnost i rizik za zajednicu. To su slučajevi u kojima zaštita zajednice ima prednost pred privatnosti pacijenta. Međutim, važno je naglasiti da i u tim slučajevima medicinski i zdravstveni radnici ne smiju odavati podatke izravno u javnost nego se moraju obraćati odgovarajućim institucijama i službama koje mogu pomoći u rješavanju određenog problema. ${ }^{133} \mathrm{U}$ smislu kaznenopravne odgovornosti, KZ zaštitu liječničke tajne ne postavlja apsolutno, jer određuje da kazneno djelo neovlaštenog otkrivanja profesionalne (liječničke) tajne ne postoji ako je otkrivanje tajne počinjeno u općem interesu ili interesu druge osobe koji je pretežniji od interesa čuvanja tajne (KZ, čl. 132. st. 2.). ${ }^{134} 135$

Postoje i slučajevi u kojima bi šutnja, odnosno neodavanje liječničke tajne nanijelo štetu trećim osobama. Dio tih slučajeva uređen je zakonskim odredbama (primjerice, prenošenje spolnih i zaraznih bolesti). ${ }^{136}$ Tako se drži da ne predstavlja povredu dužnosti 
čuvanja liječničke tajne obavijest supruzi da je njezin suprug zaražen HIV virusom (a vrijedi i za ostale zarazne bolesti), jer su život i zdravlje žene vrjedniji od dužnosti čuvanja tajne. Pored bračnog druga liječnik bi trebao biti ovlašten o tome izvijestiti i druge osobe koje su bliske pacijentu, a posebno ako je prethodno bez uspjeha pokušao uvjeriti pacijenta da sam poduzme mjere zaštite. ${ }^{137}$

Osobe koje obavljaju djelatnosti zaštite i liječenja osobe s duševnim smetnjama mogu otkriti ono što su saznale ili primijetile tijekom obavljanja svoje djelatnosti glede duševno oboljelih osoba i bez pristanka osobe s duševnim smetnjama ili njezinoga zakonskog zastupnika ako je to nužno učiniti u općem interesu ${ }^{138}$ ili interesu druge osobe koji je važniji od interesa čuvanja tajne (ZZODS, čl. 17. st. 3.). Pri tome se smiju otkriti samo oni podaci koji su značajni za ostvarivanje navedene svrhe i ti podaci ne smiju se koristiti u druge svrhe osim onih za koje su dani (ZZODS, čl. 17. st. 4.).

Otkrivanje liječničke tajne u znanstvenim publikacijama - Posebno pitanje upotrebe identifikacijskih podataka i saznanja koja imaju težinu tajne postavlja se u upotrebi tih podataka i saznanja u znanstveno-nastavno-obrazovne svrhe, a pri tome je posebno upitna količina identifikacijskih i drugih podataka koji omogućuju prepoznavanje određenog pacijenta ili dovođenje u svezu s njim. ${ }^{139}$ Iznošenje konkretnih slučajeva u stručnim društvima ili stručnoj literaturi sa navođenjem imena bolesnika ili njegovom fotografijom smatra se neovlaštenim odavanjem liječničke tajne. ${ }^{140}$

Klinički i drugi materijali koji se koriste u predavanjima ili znanstvenim tiskovinama moraju prikriti identitet osoba (s duševnim smetnjama) o kojima govore (ZZODS, čl. 17. st. 7.). Dakle, ako podatke o pacijentu iznosi u znanstvenim publikacijama, na predavanjima i u stručnim priopćenjima, liječnik je dužan onemogućiti identifikaciju pacijenta na kojega se objavljeni podaci odnose. ${ }^{141}$

Otkrivanje liječničke tajne zbog zaštite opravdanih interesa liječnika - Otkrivanje podataka o bolesti i o liječenju pacijenta od strane njegova liječnika može biti opravdano ako bi na taj način liječnik branio vlastite interese. U literaturi se navodi primjer kada pacijent ne želi liječniku platiti honorar pa ga liječnik mora tužiti ili kada pacijent tuži liječnika i traži naknadu štete prouzročene liječenjem tvrdeći da poduzete medicinske mjere nisu bile indicirane. Drži se da u takvim situacijama ne bi trebalo očekivati da liječnik i dalje mora poštivati profesionalnu tajnu, nego se smatra opravdanim da može izložiti tajne podatke kako bi se suprotstavio neutemeljenim zahtjevima pacijenta, odnosno kako bi ostvario svoje pravo na honorar. ${ }^{142} \mathrm{U}$ takvom slučaju, u namjeri da dokažu privrženost svojoj profesiji, da su učinili sve što je bilo u njihovoj moći, te da umanje važnost učinjene štete pred licem javnosti, zdravstveni radnici brane sebe i svoju profesiju upravo onim podacima koje bi duboko u sebi trebali čuvati kao tajnu. ${ }^{143}$

Svakako, liječnik ne bi trebao biti dužan čuvati liječničku tajnu ako bi to bitno ugrozilo njegovo zdravlje i život, odnosno ako i kada mu prijeti izravna opasnost od pacijenta. U takvom slučaju liječnik bi mogao, u ograničenom opsegu, odati podatke o pacijentima, odnosno u onoj mjeri koja je potrebna za zaštitu njegova zdravlja i života. ${ }^{144}$ 


\subsection{Umjesto zaključka - odnos liječnika i pacijenta - pravo na povjerljivost (privatnost)}

U ostvarivanju zdravstvene zaštite svaka osoba ima pravo na povjerljivost svih podataka koji se odnose na stanje njezina zdravlja (ZOZZ, čl. 21. st. . t. 9.). Pravo na povjerljivost podataka koji se odnose na stanje zdravlja pacijenta proizlazi iz prava osobnosti koje raznim sredstvima štiti personalitet čovjeka, pošto osobnost čovjeka nije samo psihološka kategorija, nego je i pravni pojam. ${ }^{145}$ Opće je prihvaćeno stajalište da je jedno od subjektivnih prava osobnosti i pravo na privatnost, odnosno zaštitu privatnog života, koje pak jamči i tajnost podataka o čovjekovom privatnom životu, pa time i o stanju njegova zdravlja. ${ }^{146}$

U većini slučajeva pacijent ulazi u odnos s liječnikom s povjerenjem kako u osobu, tako i u njegovo znanje. ${ }^{147} \mathrm{Za}$ obavljanje liječničke djelatnosti značajno je da se njezin uspjeh temelji na uzajamnom povjerenju liječnika i pacijenta, te da društveni razlozi traže da im se osigura uspjeh jamstvom diskrecije. ${ }^{148}$ Povjerenje je temelj na kojem počiva odnos pacijenta i liječnika te etički i profesionalni kodeks medicine. Suvremenu medicinu karakterizira nadilaženje tradicionalnog liječničkog paternalizma pošto su danas liječnik i pacijent jednakopravni subjekti u kliničkom okruženju. ${ }^{149}$ Izričito i dosljedno poštivanje obveze čuvanja tajne od strane liječnika ohrabruje pacijente da mu se obraćaju za pružanje medicinske pomoći. ${ }^{150} \mathrm{~S}$ druge strane, liječnička tajna koristi, neizravno, i liječniku jer on svoju stručnu djelatnost može kvalitetno obavljati samo ako od pacijenta dobije informacije koje su mu nužne za dijagnozu i terapiju. ${ }^{151}$ Već iz toga može se zaključiti da se profesionalno povjerenje ne podrazumijeva samo po sebi. Ono se dokazuje unutar konkretnog odnosa u konkretnom slučaju. Zato i izlazak informacija iz tog odnosa ima svoju konkretnu posljedicu - gubitak povjerenja u konkretnu osobu i predstavnika profesije koju ta osoba predstavlja. ${ }^{152}$ Odnos pružatelja i korisnika zdravstvenih usluga, gledajući s pravnoga aspekta, najčešće je (neimenovani, neformalni) ugovorni odnos, pa zdravstveni radnici trebaju i s toga osnova poštivati privatnost povjerenih podataka vezanih uz pružanje usluga koje su im povjerene. ${ }^{153}$ Povjerenje na kojem se temelji liječnička tajna nije vezano za konkretnu fizičku osobu liječnika, nego za liječnika kao obnašatelja liječničke funkcije. ${ }^{154}$

Pravo na privatnost, koje je temelj prava na tajnost liječničkih podataka, zajamčeno je i odredbama čl. 9. Opće deklaracije o ljudskim pravima (Universal Declaration on Human Rights), odredbama čl. 17. Međunarodnog pakta o građanskim i političkim pravima (International Convenant on Civil and Political Rights), odredbama čl. 8. Europske konvencije za zaštitu ljudskih prava, ${ }^{155}$ odredbama čl. 8. Povelje o temeljnim ljudskim pravima Europske unije i u Smjernici 95/46/EZ Europskog parlamenta i Vijeća o zaštiti fizičkih osoba s obzirom na postupanje s osobnim podacima, te o slobodnom prometu tih podataka. ${ }^{156}$

Pravo na povjerljivost/privatnost $\mathrm{i}$ tajnost podataka $\mathrm{u}$ odnosu između liječnika (zdravstvenih radnika) i pacijenata, uređeno je i zajamčeno u više domaćih propisa. Liječnik je dužan u odnosu prema pacijentima postupati primjenjujući i poštujući odredbe posebnih zakona koji reguliraju prava pacijenata te odredbe Kodeksa Hrvatske liječničke komore. Svi postupci medicinske prevencije, dijagnostike i liječenja moraju se planirati i 
provoditi tako da se očuva ljudsko dostojanstvo, integritet osobe i prava pacijenata, a posebno pravo na informiranost i samostalno odlučivanje (ZOL, čl. 19.).

Odredbama Ustava Republike Hrvatske svakom se jamči sigurnost i tajnost osobnih podataka. Bez privole ispitanika, osobni se podaci mogu prikupljati, obrađivati i koristiti samo uz uvjete određene zakonom (Ustav, čl. 37. st. 1.). ${ }^{157}$ Uporaba osobnih podataka suprotna utvrđenoj svrsi njihovoga prikupljanja zabranjena je (Ustav, čl. 37. st. 3.). Svakom se jamči i pravo na zdravstvenu zaštitu u skladu sa zakonom (Ustav, čl. 58.).

ZOZZ-om je propisano da su zdravstveni radnici dužni čuvati kao profesionalnu tajnu sve što znaju o zdravstvenom stanju pacijenta (ZOZZ, čl. 122. st. 1.). Profesionalnu tajnu dužni su čuvati i drugi radnici u zdravstvu koji za nju saznaju u obavljanju svojih dužnosti, te studenti i učenici škola zdravstvenog usmjerenja, koji u praktičnom dijelu nastave dolaze u doticaj s pacijentom, ${ }^{158}$ kao i sve druge osobe koje u obavljanju svojih dužnosti dođu do podataka o zdravstvenom stanju pacijenta. Tako je, primjerice, i zdravstveni inspektor prilikom obavljanja inspekcijskog nadzora dužan postupati tako da ne ugrozi čuvanje profesionalne tajne (ZOZZ, čl. 171. st. 1.).

I Zakonom o zaštiti prava pacijenata uređuje se i promiče pravo na privatnost i povjerljivost informacija o pacijentovom zdravstvenom stanju, medicinskom statusu, prognozi i liječenju te svim drugim informacijama osobne prirode koje moraju ostati povjerljive. ${ }^{159}$ Načelo humanosti zaštite prava pacijenata ostvaruje se, među ostalim, i zaštitom osobnosti pacijenta uključujući poštivanje njegove privatnosti, svjetonazora te moralnih i vjerskih uvjerenja (ZOZPP, čl. 4.). Pacijent ima pravo na povjerljivost podataka koji se odnose na stanje njegova zdravlja sukladno propisima o čuvanju profesionalne tajne i zaštiti osobnih podataka (ZOZPP, čl. 25. st. 1.).

ZOL-om je određeno da je liječnik zdravstveni radnik sa završenim medicinskim fakultetom i stečenim nazivom doktor medicine, te je temeljni i mjerodavni nositelj zdravstvene djelatnosti koju obavlja poštujući, među ostalim, i načela održavanja i promicanja povjerenja između liječnika i pacijenata te članova njihovih obitelji, kao i poštivanja prava pacijenata, propisa, pravila struke te Kodeksa medicinske etike i deontologije (ZOL, čl. 2.).

ZZODS-om su, uz zaštitu privatnosti koju uživaju temeljem odredbi čl. 32. ZOZZ-a, stvoreni i dodatni okviri za zaštitu privatnog života pacijenata s duševnim smetnjama. Do stupanja na snagu ZZDOS-a zaštita profesionalne, liječničke tajne bila je tek moralna obveza za osobe uključene u liječenje i brigu oko duševnih bolesnika, što bolesniku nije jamčilo primjerenu zaštitu njegova privatnog života. ${ }^{160}$ Osobe koje obavljaju djelatnosti zaštite i liječenja osobe s duševnim smetnjama dužne su čuvati kao profesionalnu tajnu sve što saznaju ili primijete tijekom obavljanja tih djelatnosti (ZZODS, čl. 17. st. 1.). ZZODS je lex specialis u odnosu na ZOZZ te odredbama čl. 17. ZZODS-a, kad je u pitanju čuvanje liječničke tajne u svezi s postupanjem osoba koje obavljaju djelatnost zaštite i liječenja osoba s duševnim smetnjama, uvijek treba dati prednost u odnosu na općenitije odredbe ZOZZ-a. ${ }^{161}$ 
Odredbom čl. 17. st. 1. Zakona o krvi i krvnim sastojcima („Narodne novine“ br. 76/06, 124/11), dalje - ZOK), propisuje se da u obavljanju transfuzijske djelatnosti ovlaštene zdravstvene ustanove obvezne su voditi evidencije čiji obrazac i sadržaj pravilnikom propisuje ministar. Podatke iz evidencija ovlaštene zdravstvene ustanove obvezne su dostaviti Hrvatskom zavodu za transfuzijsku medicinu na način i u rokovima propisanim pravilnikom. Hrvatski zavod za transfuzijsku medicinu obvezan je podatke iz evidencija čuvati najmanje 15 godina. ${ }^{162}$

\section{Primjedbe}

${ }^{1}$ Kada govorimo o Ustavu RH mislimo na dokument koji je donio hrvatski parlament (Sabor). U ovome slučaju govorimo o užem značenju pojma ustava. No, samo čitanje Ustava RH ne uvodi nas u cjelovito područje pravila ustavnoga prava. Ustav RH kao temeljni dokument samo naznačava osnove na kojima se gradi struktura koja uključuje ostale dokumente, odnosno i druge izvore ustavnoga prava. Ustav predstavlja temeljni okvir kojemu sadržaj čine pravna pravila i tuemačenja koja, kao ishodišna točka, utječu na formiranje i oblikovanje cjelovite strukture ustavnoga prava. U tome smislu ustavno pravo, kao jedna posebna pravna grana, predstavlja realnu i vitalnu snagu hrvatskoga prava i društva. Potonje nas vodi zaključku da se hrvatsko ustavno pravo više od bilo koje druge grane prava oblikovalo prema našim vlastitim idealima, težnjama i potrebama. Tako i šire: BAČIĆ, A., Komentar Ustava Republike Hrvatske, Pravni fakultet Sveučilišta u Splitu, Split, 2004., str. 9.

2 Usp. USTAV RH, III. dio, „Narodne novine” br. 56/90, 135/97, 8/98 - pročišćeni tekst, 113/2000,124/2000 - pročišćeni tekst, 28/2001, 41/2001 - pročišćeni tekst, 85/2010 - pročišćeni tekst.

${ }^{3}$ Op . cit., BAČIĆ, A., Komentar Ustava..., str. 107.

${ }^{4}$ Ustav Republike Hrvatske pridružuje se onim ustavima koji štite osobne podatke. Svakomu se jamči sigurnost i tajnost osobnih podataka. Ustavotvorac tvrdi da će se osobni podaci prikupljati, obrađivati i upotrebljavati samo uz uvjete određene zakonom. Jedan je od takvih zakona, primjerice, i Zakon o državnim maticama („Narodne novine“ 96/94), koji evidentira osobna stanja građana. Zakon predviđa da se pravo uvida u državne matice dopušta (uz nazočnost matičara) osobi na koju se ti podaci odnose, članovima uže obitelji ili usvojitelju, odnosno skrbniku, a drugoj osobi samo kada za to ima na zakonu zasnovan pravni interes. Kazneni zakon u čl. 86. govori o podacima iz kaznene evidencije. U čl. 86. st. 1. stoji da se podaci iz kaznene evidencije mogu dati samo sudovima i državnim odvjetnicima kada se radi o kaznenome postupku protiv osobe za koje se traže podaci ili kada je u tijeku postupak za njezino pomilovanje...Op. cit., BAČIĆ, A., Komentar Ustava..., str. 108.

${ }^{5} \mathrm{U}$ ovome se slučaju prvenstveno misli na Zakon o zaštiti osobnih podataka („Narodne novine“ 103/03).

${ }^{6}$ Usp. Ustav RH čl. 37. Vidi i Bačić, A., Komentar Ustava Republike Hrvatske, Pravni fakultet Sveučilišta u Splitu, Split, 2002.

7 Ustavnu slobodu izražavanja razrađuje i Zakon o medijima („Narodne novine“ br. 59/04, 84/11,81/13) dalje - ZM), u kojem je zakonodavac legalizirao brojna pitanja. Tako se tim Zakonom uređuju pretpostavke za ostvarivanje načela slobode medija, prava novinara $i$ drugih sudionika $u$ javnome informiranju na slobodu izvješćivanja i dostupnost javnim informacijama, prava i obveze nakladnika, javnost vlasništva, ostvarivanje prava na ispravak i odgovor, način obavljanja distribucije tiska, način zaštite tržišnoga natjecanja te prava i obveze drugih pravnih i fizičkih osoba koje djeluju na području javnoga informiranja. (ZM čl. 1.).

Također, prema čl. 3. ZM:

„(1) Jamči se sloboda izražavanja i sloboda medija. 
(2) Sloboda medija obuhvaća osobito: slobodu izražavanja mišljenja, neovisnost medija, slobodu prikupljanja, istraživanja, objavljivanja i raspačavanja informacija u cilju informiranja javnosti; pluralizam i raznovrsnost medija, slobodu protoka informacija i otvorenosti medija za različita mišljenja, uvjerenja i za raznolike sadržaje, dostupnost javnim informacijama, uvažavanje zaštite ljudske osobnosti, privatnosti i dostojanstva, slobodu osnivanja pravnih osoba za obavljanje djelatnosti javnoga informiranja, tiskanja $i$ raspačavanja tiska $i$ drugih medija iz zemlje $i$ inozemstva, proizvodnju i objavljivanje radijskoga i televizijskoga programa i drugih elektroničkih medija, autonomnost urednika, novinara i ostalih autora programskih sadržaja u skladu $s$ pravilima struke.

(3) Slobode medija dopušteno je ograničiti samo kada je i koliko je to nužno u demokratskome društvu radi interesa nacionalne sigurnosti, teritorijalne cjelovitosti ili javnoga reda i mira, sprječavanja nereda ili kažnjivih djela, zaštite zdravlja i morala, zaštite ugleda ili prava drugih, sprječavanja odavanja povjerljivih informacija ili radi očuvanja autoriteta i nepristranosti sudbene vlasti samo na način propisan zakonom.

(4) Zabranjeno je prenošenjem programskih sadržaja u medijima poticati ili veličati nacionalnu, rasnu, vjersku, spolnu ili drugu neravnopravnost ili neravnopravnost na temelju spolne orijentacije i ideološke i državne tvorevine nastale na takvim osnovama, te izazivati nacionalno, rasno, vjersko, spolno ili drugo neprijateljstvo ili nesnošljivost, neprijateljstvo ili nesnošljivost na temelju spolne orijentacije, poticati nasilje $\mathrm{i}$ rat. Usp. ZM čl. 1 i čl. 3.

8 Tako Zakon o javnome priopćavanju („Narodne novine“ br. 83/96, 69/2003) govori o slobodi javnoga priopćavanja (čl. 3. st. 1.), odnosno o slobodi informiranja, koja obuhvaća osobitu slobodu izražavanja misli, slobodu prikupljanja, istraživanja, objavljivanja i širenja informacija, slobodu tiskanja $i$ raspačavanja tiska $i$ drugih javnih glasila, te proizvodnje $i$ emitiranja radijskoga $i$ televizijskoga programa, slobodu primanja ideja i informacija te slobodu osnivanja pravnih osoba za obavljanje djelatnosti javnoga priopćavanja. Čl. 4. Zakona određuje zabranu ograničavanja slobode javnoga priopćavanja, odnosno slobode izražavanja. Naime, nitko nema pravo prisilom ili zloupotrebom položaja utjecati na sadržaj ili tijek javnoga priopćavanja, odnosno slobode izražavanja. (čl. 4. st. 1.) Ipak, o odgovornosti za zloupotrebu ove slobode govori nekoliko zakona. Tako, primjerice, ako se slobodom izražavanja netko koristi u namjeri da javno iznosi ili pronosi zamisli o nadmoćnosti jedne rase nad drugom, ili širi rasnu mržnju, ili potiče na rasnu diskriminaciju, Kazneni zakon odrđuje u čl. 174. st. 3 da će se takva osoba kazniti zatvorom od 3 mjeseca do 3 godine. Op. cit., BAČI Ǐ̆, A., str. 111.

9 Tijekom promjene Ustava dodan je novi stavak 4. u čl. 38 Ustava RH. Vidi Ustav Republike Hrvatske, Novi informator, Zagreb 2010., str. 23. Odbor za Ustav, Poslovnik i politički sustav na temelju članka 57. Poslovnika Hrvatskoga sabora na sjednici 6. srpnja 2010. godine utvrdio je pročišćeni tekst Ustava Republike Hrvatske, koji obuhvaća: Ustav Republike Hrvatske (Nar. Nov., br. 56/90, 135/97, 8/98 - proč. tekst, 113/00, 124700 - proč. tekst, 28/01, 41/01 - proč. tekst, 55/01 - ispr.) te Promjenu Ustava Repbulike Hrvatske objavljenu u Nar. Nov., br. 76/10, 5/14u kojima je naznačeno vrijeme njihova stupanja na snagu.

${ }^{10}$ Ovaj stavak glasi: Jamči se pravo na pristup informacijama koje posjeduju tijela javne vlasti. Ograničenja prava na pristup informacijama moraju biti razmjerna naravi potrebe za ograničenjem u svakome pojedinom slučaju te nužna u slobodnome i demokratskome društvu, a propisuju se zakonom., Usp. Ustav RH čl. 38. st. 4.

${ }^{11}$ Pravo na ispravak služi cilju samoobrane. Ono se temelji na načelu ravnopravnosti, koje zahtijeva da građanstvo, jednostrano informirano o činjenicama iznesenima u medijima, čuje i odgovor osobe koje se napis, vijest i tomu slično tiče, tako da nakon obostrana saslušanja uzmogne stvoriti pravedni sud o samome predmetu. Tako i šire u: BAČIĆ, A., Komentar..., str. 120 Također, zakonodavac u Zakonu o medijima predviđa u čl. 40. st. 1. da svatko ima pravo od glavnoga urednika zahtijevati da bez naknade objavi ispravak objavljene informacije kojom su bila povrijeđena njegova prava ili interesi. Pravo na ispravak imaju i pravne osobe i druge organizacije i tijela ako su informacijom bila povrijeđena njihova prava i interesi. Svrha ispravaka ispravljanje je netočne ili nepotpune informacije. Rok za objavu ispravka može se zahtijevati u roku od 30 dana od objave informacije 
kako stoji u st. 2. toga članka. Također, prema članku 41. st. 1. ZM-a ispravak se mora objaviti bez promjena i dopuna na istome ili istovrijednome mjestu programskoga prostora $i$ na isti ili istovrijedan način na koji je bila objavljena informacija na koju se ispravak odnosi. Ispravak ne smije biti nerazmjerno dulji od informacije, odnosno od dijela informacije na koji se odnosi. Ispravak se može objaviti u izmijenjenome obliku samo ako na to pristane podnositelj zahtjeva. Ispravak se mora objaviti na način da je iz naslova vidljivo da se radi o ispravku. Ispravak se bez suglasnosti podnositelja zahtjeva ne smije objaviti među reagiranjima ili pismima čitatelja, odnosno gledatelja ili slušatelja. Usp. ZM čl. 40. i čl. 41. (,Narodne novine“ br 163/2003., „Narodne novine“ br. 59/2004.)

12 Vidi SMERDEL, B., Ustavna osnova prava javnosti na informaciju, Informator, br. 5527, 2007. str. 1.-2.

${ }^{13}$ Usp. SMERDEL, B., Temeljne značajke ustavnoga poretka Republike Hrvatske na dvadesetu obljetnicu Božićnoga Ustava, Novi informator, 16. izmijenjeno i dopunjeno izdanje, Zagreb, 2010., str. 155.

${ }^{14}$ Tako i više o tome kod ČIZMIĆ, J. - BOBAN, M. - ZLATOVIĆ, D., Nove tehnologije, intelektualno vlasništvo i informacijska sigurnost, Pravni fakultet Sveučilišta u Splitu, Split, 2016., str. 682.-695.

${ }^{15}$ Prema čl. 2 ZTP-a klasificirani podatak je onaj koji je nadležno tijelo u propisanome postupku takvim označilo i za koji je utvrđen stupanj tajnosti i podatak koji je Republici Hrvatskoj tako označenoga predala druga država, međunarodna organizacija ili institucija s kojom Republika Hrvatska surađuje. Sam pustupak klasifikacije podataka predstavlja postupak utvrđivanja jednoga od stupnjeva tajnosti podatka s obzirom na stupanj ugrobze i područje ovim Zakonom zaštićenih vrijednosti. S druge strane, deklasifikacija podatka postupak je kojim se utvrđuje prestanak postojanja razloga zbog kojih je određeni podatak klasificiran odgovarajućim stupnjem tajnosti, nakon čega podatak postaje neklasificirani s ograničenom uporabom samo u službene svrhe. Vlasnik je podatka nadležno tijelo u okviru čijega je djelovanja klasificirani ili neklasificirani podatak nastao. Dakle, pristup klasificiranim podacima obavlja se putem certifikata - uvjerenja o sigurnosnoj provjeri koje omogućava pristup klasificiranim podacima. Usp. ZTP, čl. 2, „Narodne novine“ br. 79/2007. Pristup klasificiranim podacima bez certifikata imat će u okviru obavljanja poslova iz njihova djelokruga saborski zastupnik, ministar, državni tajnik središnjega državnog ureda, sudac i Glavni državni odvjetnik. Navedene osobe dužne su, prije pristupanja klasificiranim podacima, potpisati izjavu Uredu Vijeća za nacionalnu sigurnost kojom potvrđuju da su upoznati s odredbama ovoga Zakona i drugih propisa kojima se uređuje zaštita klasificiranih podataka te se obvezuju raspolagati klasificiranim podacima sukladno navedenim propisima.Vidi ZTP čl. 20. Više o tome kod ČIZMIĆ, J. - BOBAN, M. - ZLATOVIĆ, D., Nove tehnologije, intelektualno vlasništvo i informacijska sigurnost, „Sveučilište u Splitu Pravni fakultet“, Split, 2016., str. 682.725.

${ }^{16}$ Prema čl. 2. ZTP-a neklasificirani podatak je podatak bez utvrđenoga stupnja tajnosti, koji se upotrebljava u službene svrhe, te podatak koji je Republici Hrvatskoj tako označenoga predala druga država, međunarodna organizacija ili institucija s kojom Republika Hrvatska surađuje.

${ }^{17}$ Stupanjem na snagu Zakona o tajnosti podataka 2007. godine člankom 34. ZTP-a ukida se Zakon o zaštiti tajnosti podataka, Narodne novine br. 108/1996, s iznimkom Glave VIII. (Poslovna tajna) i Glave IX. (Profesionalna tajna) Zakona o zaštiti tajnosti podataka, Narodne novine 108/1996 (u daljnjem tekstu - ZZTP). Usp. ZTP čl. 34. NN 79/07.

${ }^{18}$ Podrobnije o tome u: ČIZMIĆ, J., Zaštita prava iz područja industrijskoga vlasništva poslovnom tajnom, „Pravo u gospodarstvu“, god. 38, 1999., br. 2, str. 236.-237. i ZLATOVIĆ, D., Zaštita $i$ čuvanje poslovne tajne, „Slobodno poduzetništvo“, god IV, 1997., br. 8. str. 150.

${ }^{19}$ Usp. ZABEL, B. Poslovna tajna, Beograd, 1970., str. 9.

${ }^{20}$ Ibid., str. 98.

${ }^{21}$ Vidi: JOVANOVIĆ, LJ., Lekarska tajna, Beograd, 1959., str. 11. Jelačić drži da bi bilo točnije kazati ne da „tajna predstavlja znanje određenih činjenica“, nego da „same činjenice saznate u obavljanju poziva predstavljaju tajnu“, jer znanje o tim činjenicama predstavlja pojam posjedovanja 
tajne budući da je objekt zaštite sama činjenica koja se ne smije otkriti, a znanje kao takvo ne može biti objektom zaštite. JELAČIĆ, O., „Liječnička tajna u našem zakonodavstvu“, Zbornik radova Pravnoga fakulteta u Splitu, god X, 1973., str. 14.

${ }^{22}$ Podrobnije o tome u: ČIZMIĆ, J., Zaštita prava iz područja industrijskoga vlasništva poslovnom tajnom, „Pravo u gospodarstvu”, god. 38, 1999., br. 2, str. 236.-237. i ZLATOVIĆ, D., Zaštita i čuvanje poslovne tajne, „Slobodno poduzetništvo”, god IV, 1997., br. 8. str. 150.

${ }^{23} \mathrm{O}$ tome vidi šire u: ČIZMIĆ, J. - PERDIĆ, A., Neka zapažanja o profesionanoj tajni, Zbornik radova Pravo na tajnost podataka, Znanstveni skup, Novalja - Split, 2008., str. 60.

${ }^{24}$ Tako JOVANOVIĆ, LJ., Lekarska tajna, Beograd, 1959., str. 11.

${ }^{25}$ Vidi CVRCIĆ, R., Poslovna, profesionalna i službena tajna, Pravo i porezi, god. XV, 2006., br. 9 , str. 50.

26 O tim slučajevima vidi: WILLIAMS, P.L., How to keep trade secrets ... secret, Seattle/Washington, 1993., str. 1.-2.

${ }^{27} \mathrm{~S}$ druge strane nemamo iste koncepte i na poredbeno pravnoj razini. U anglo-američkim sustavima o poslovnoj tajni razmatra se u okviru prava industrijskoga vlasništva. I u Hrvatskoj se često u žargonu, pa i stručnim pravnim krugovima, ističe da je poslovna tajna u biti intelektualno vlasništvo imatelja poslovne tajne. U pravnim odnosima s međunarodnopravnim obilježjima bitno je odrediti mjerodavno pravo, jer o tome može ovisiti ishod spora. Pravo na poslovnu tajnu snažno se razlikuje od patentne zaštite po tome što je ratio legis patentne zaštite upravo u tome da se u što je moguće većoj mjeri suzbiju tvorničke poslovne tajne te da se one posredno, registriranim patentima, stave na raspolaganje i drugim poduzetnicima, a na dobrobit ukupnoga gospodarstva. $\mathrm{O}$ tome vidi pobliže u: MILADIN, P., Temeljni pravni i ekonomski okvir privatnoga upravljanja imovinom, Zbornik radova / Drugi skopsko-zagrebački pravni kolokvij, Skopje, 2009.; str. 121.142. Vidi: ČIZMIĆ, J., Intelektualno vlasništvo, Slobodno poduzetništvo, god. VIII., 2001., br. 6, str. 73.-87. O tome vidi i: ČIZMIĆ, J., Intelektualno i industrijsko vlasništvo, Pravo i porezi, godina XI., 2002., br. 8, str. 26.-30.

${ }^{28}$ Vidi šire u: MILADIN, P., Poslovna i profesionalna tajna kao prava osobnosti, Zbornik radova znanstvenoga skupa Pravo na tajnost podataka, Novalja - Split, 30. i 31. svibnja, 2008. godine, str.107.-124.

${ }^{29}$ Zanimljiv je pristup problematici tajnosti koji zastupa teologija. Ona, naime, razlikuje tri temeljne vrste ili tri stupnja tajni: a) obećana tajna - secretum promissum, koja obvezuje snagom danoga obećanja. Obveza čuvanja proizlazi iz slobodno danoga „obećanja”; b) naravna tajna secretum naturale, koja se odnosi na područja gdje sama narav činjenice o kojoj je riječ zahtijeva diskreciju, oprez i šutnju; c) ugovorna tajna - secretum commisum, secretum officiale, koja se odnosi na znanje priopćeno na temelju ugovora, izričitoga ili predmnijevanoga, da se ne će obznaniti. Takva tajna obvezuje snagom izražene volje onoga tko je priopćio i sklopljenoga ugovora kojim se obvezuje onaj tko prihvaća da znanje ne objavi. S tim u svezi ističe se da se $u$ cijelosti od drugih vrsta tajni razlikuje strukovna sakramentalna poznatija pod imenom ispovjedna tajna. Po svojoj naravi ona je božansko-ljudskoga prava, a obvezatnost je bezuvjetna, bez izuzetka, apsolutna, pa se naziva i pečatom - sigillum. Tako u: POZAIĆ, V., „Teološki vidici liječničke tajne“, Zbornik radova Medicinska etika 1, Znidarčić, Ž., (ur.), Centar za bioetiku, Zagreb, 2004., str. 130.

${ }^{30}$ Usp. GAVELLA, N., Osobna prava - I. dio, Zagreb, 2000., str. 222.

${ }^{31}$ Kada se govori o potrebi i obvezi čuvanja profesionalne tajne možemo reći da su već više od dvije tisuće godina kršćanski svećenici bili obvezni čuvati tajnost podataka do kojih su došli obnašajući svoju svećeničku dužnost (u tome se smislu osobito apostrofiraju podaci do kojih svećenici dolaze tijekom ispovijedi (ispovjedna tajna), kao jedne od sedam sakramenata). Sakramentalna tajna je nepovrediva: stoga je ispovjedniku apsolutno zabranjeno izdati pokornika bilo u čemu, riječima ili na drugi način, i iz bilo kojega razloga. (KKC, 2490). Vidi o tome: LINIĆ, Z., Ispovijed grijeha pred svećenikom, Glas Koncila, 12 (1709), 21. 3. 2007.

${ }^{32}$ ZZTP određuje da profesionalnu tajnu predstavljaju podaci o osobnome ili obiteljskome životu (stranaka) koji saznaju svećenici, odvjetnici, zdravstveni i socijalni djelatnici, i druge službene 
osobe u obavljanju svojega poziva (ZZTP, čl. 27.). Kazneni zakon (Narodne novine, 125/11, $144 / 12,56 / 15,61 / 15$, dalje - KZ) propisuje, pak, da je profesionalna tajna podatak o osobnome ili obiteljskome životu stranaka koji saznaju odvjetnici, branitelji, javni bilježnici, doktori medicine, doktori stomatologije, primalje ili drugi zdravstveni djelatnici, psiholozi, djelatnici skrbništva, vjerski ispovjednici i druge osobe u obavljanju svojega zvanja (KZ, čl. 145.).

${ }^{33}$ Vidi RAJIĆ, Z. - TOMIĆ, M. - MILJKO, Z., Komentar Kaznenog zakona, Mostar, 2000., str. 217.

${ }^{34}$ Tako MILADIN, P., autorizirano izlaganje na 113. Tribini Pravnoga fakulteta u Zagrebu i Kluba pravnika grada Zagreba, održanoj 19. travnja 2006., s temom Poslovna, profesionalna $i$ službena tajna, Bilten br. 42, str 6 .

35 Već smo ranije konstatirali da se pojmovima „vojna“ i „državna“ tajna može koristiti kada se vrste podataka koji se štite tajnom navode pojmovno-teorijskom smislu, primjerice prema osobama koje su ih dužne i ovlaštene štititi tajnima, a ne i u smislu klasificiranosti ili stupnja tajnosti tih podataka jer je to područje sada uređeno odredbama ZZTP-a na drugi način. Ovi se pojmovi u navedenom smislu još uvijek rabe u javnoj komunikaciji, zadržani su i u nekim propisima (vidi, primjerice, Zakon o proizvodnji, remontu i prometu naoružanja i vojne opreme, pročišćeni tekst zakona, „Narodne novine“ br. 33/02, 173/03, 146/08., čl. 13.).

${ }^{36} \mathrm{O}$ tome vidi MILADIN, P., Kritika zakonskog uređenja poslovne tajne, op. cit.,. str. 338-339.

37 Šire u MILADIN, P., „Odnos između privatnopravnog $i$ kazneno pravnog uređenja poslovne $i$ profesionalne tajne “, Pravo u gospodarstvu, br. 4, 2000., str. 236 i nadalje.

38 Vidi MATIJEVIĆ, B., Prava osobnosti: pravo na privatnost osobnoga i obiteljskoga života, Hrvatska pravna revija, god. VI., br. 5, svibanj 2006., str. 39.

$39 \mathrm{O}$ tome vidi SCALISI., A., Il valore della persona nel sistema e nei nuovi diritti della personalita, Giuggre Ed., 1990., str. 167.

${ }^{40}$ O tome vidi: GAVELLA, N., Osobna prava, I dio, Filozofski fakultet u Zagrebu, Zagreb, 2000., str. 223.

${ }^{41}$ Usp. Medicinska enciklopedija, knjiga 4., Zagreb, MCMLXIX, str. 294.

42 Vidi BABIĆ, T. - ROKSANDIĆ, S., Osnove zdravstvenog prava, Zagreb, 2006., str. 161.

${ }^{43}$ Usp. IVANČEVIĆ, N., Zakon o liječništvu, rad u zborniku «Zbirka zdravstvenih zakona s obrazložnjem, Zagreb, 2003., str. 91.

44 Tako Medicinska enciklopedija, knjiga 4., Zagreb, MCMLXIX, str. 294.

${ }^{45}$ Usp. ULSENHEIMER, K., Die arztliche Schweigpflicht, objavljen u LAUFS-UHLENBRUCK, Handbuch des Arztrechts, Munchen, 2002., str. 551. (dalje - ULSENHEIMER), podatak kod RADIŠIĆ, J., Dužnost čuvanja medicinske tajne, „Anali Pravnog fakulteta u Beogradu“, god. L., 2002., broj 3-4, str. 328.

46 Vidi BOŠKOVIĆ, Z., Profesionalna liječnička tajna, „Informator“, broj 5329. od 2. travnja 2005., str. 11.; Medicinska enciklopedija, knjiga 4., Zagreb, MCMLXIX, str. 295. Tako, prema odredbama ZOZZ-a, liječničku, odnosno profesionalnu tajnu dužni su čuvati i drugi radnici u zdravstvu koji za nju saznaju u obavljanju svojih dužnosti, te studenti i učenici škola zdravstvenog usmjerenja, koji u praktičnom dijelu nastave dolaze u doticaj s pacijentom, kao i sve druge osobe koje u obavljanju svojih dužnosti dođu do podataka o zdravstvenom stanju pacijenta. Primjerice, i zdravstveni inspektor prilikom obavljanja inspekcijskog nadzora dužan je postupati tako da ne ugrozi čuvanje profesionalne tajne (ZZZ, čl. 171. st. 1.).

${ }^{47}$ Tako i ŠEPAROVIĆ, Z., Granice rizika, Zagreb, 1998., str. 30.

48 Prema odredbama bivšeg Zakona o stomatološkoj djelatnosti («Narodne novine», broj 12/03., dalje - ZOSD), doktor stomatologije dužan je čuvati kao profesionalnu tajnu sve što sazna o zdravstvenom stanju pacijenta. Profesionalnom tajnom smatraju se svi podaci koje doktor stomatologije sazna pri obavljanju svoje struke o pacijentu, njegovim osobnim, obiteljskim i socijalnim prilikama kao i podaci vezani uz otkrivanje i liječenje bolesti. Doktor stomatologije obvezan je na čuvanje profesionalne tajne o pacijentu i prema članovima obitelji pacijenta, čak i nakon njegove smrti (ZOSD, čl. 27. st. 1.). Doktor stomatologije obvezan je voditi računa o tome da profesionalnu tajnu čuvaju i druge osobe koje rade u njegovoj ordinaciji ili su na bilo koji drugi 
način saznali podatke o zdravstvenom stanju pacijenta (ZOSD, čl. 27. st. 2). Pruža li više doktora stomatologije istovremeno, ili jedan nakon drugog, istom pacijentu neki oblik stomatološke usluge, obveza čuvanja tajne ne primjenjuje se između doktora stomatologije (ZOSD, čl. 27. st. 3.). Iznošenje profesionalne tajne dopušteno je samo uz pristanak pacijenta te u skladu s Kodeksom stomatološke etike i deontologije. Iznošenje profesionalne tajne dopušteno je i u slučaju ako bi se čuvanjem profesionalne tajne ugrozio život i zdravlje drugih ljudi (ZOSD, čl. 27. st. 4.). Odavanjem profesionalne tajne ne smatra se: iznošenje podataka o pacijentu u svrhu znanstvenih istraživanja, predavanja ili publikacija, neodavajući identitet pacijenta i uz njegov pisani pristanak, davanje podataka za statističku obradu, neodavajući identitet pacijenta, davanje podataka društvu za zdravstveno osiguranje s kojim pacijent ima sklopljen ugovor o osiguranju te davanje podataka istražnoj ili sudbenoj vlasti, ako bi tajenje podataka moglo utjecati na bit istražnog ili sudskog postupka ili naškoditi trećoj osobi (ZOSD, čl. 27. st. 5.). Doktor stomatologije dužan je podnijeti prijavu policiji ili državnom odvjetništvu, kada tijekom obavljanja stomatološke djelatnosti posumnja da je smrt ili tjelesna ozljeda osobe nastala nasilnim putem, kao i onda kada posumnja da je malodobnoj ili nemoćnoj osobi zdravstveno stanje ozbiljno ugroženo zapuštanjem ili zlostavljanjem (ZOSD, čl. 28.). Novčanom kaznom u iznosu od 5.000,00 do 10.000,00 kuna kaznit će se za prekršaj doktor stomatologije ako ne poštuje obvezu čuvanja profesionalne stomatološke tajne (ZOSD, čl. 66. st. 3.). Usp. POLIĆ, J., Zakon o stomatološkoj djelatnosti, rad u zborniku «Zbirka zdravstvenih zakona s obrazložnjem», Zagreb, 2003., str. 117.-118.

${ }^{49}$ Prema odredbama ZOLK-a u obavljanju ljekarničke djelatnosti magistri farmacije dužni su poštivati Kodeks ljekarničke etike i deontologije i Pravila dobre ljekarničke prakse (ZOLK, čl. 25.). U tom smislu sve što magistar farmacije pri obavljanju ljekarničke djelatnosti sazna o korisniku, a u vezi s njegovim zdravstvenim stanjem, mora čuvati kao ljekarničku tajnu i može je otkriti, ako posebnim zakonom nije drukčije propisano, samo uz odobrenje korisnika, roditelja ili skrbnika za malodobne osobe, a u slučaju njegove psihičke nesposobnosti ili smrti, uz odobrenje uže obitelji, skrbnika ili zakonskoga zastupnika (ZOLK, čl. 26.).

${ }^{50}$ Prema odredbama ZOS-a, medicinska sestra je kao profesionalnu tajnu dužna čuvati sve podatke o zdravstvenom stanju pacijenta (ZOS, čl. 3. i 16. st. 3.). Novčanom kaznom u iznosu od 3.000,00 do 10.000,00 kuna kaznit će se za prekršaj medicinska sestra ako ne ispuni obvezu čuvanja profesionalne tajne (ZOS, čl. 33.). I prema odredbi čl. III. Etičkog kodeksa hrvatske udruge medicinskih sestara (Zagreb, 1994.), sestra mora čuvati sve podatke o čovjeku koje je dobila tijekom provođenja zdravstvene njege i zaštite. Tajnom se smatra sve što je sestri povjereno osobno. C̆uvanje profesionalne tajne je za sestru moralna dužnost i zakonska obveza. Odavanje profesionalne tajne i prenošenje tajne dopušteno je u određenim okolnostima samo unutar tima zdravstvenih djelatnika i smatra se podijeljenom tajnom. Nedopustivo je prepričavanje profesionalnih tajni izvan zdravstvenog tima. Pravo svake sestre je da tijekom provođenja zdravstvene njege i zaštite kontrolira dobivene osobne podatke o čovjeku. Razgovor o zdravstvenoj njezi i zaštiti obvezatan je radi kvalitetnog provođenja. Pri tome se mora posebno paziti na zaštitu anonimnosti bolesnika. Sestra je dužna intervenirati ukoliko drugi djelatnici zdravstvenog tima ne poštuju obvezu čuvanja profesionalne tajne. Sestra je oslobođena čuvanja profesionalne tajne ukoliko je to u interesu druge osobe, ili je od općeg interesa, ili je interes za dobrobit drugih jači od čuvanja tajne.

${ }^{51}$ Donald's Medical Dictionary, 28. ed., 1994., str. 368.

52 Podrobnije o starijoj povijesti liječničke tajne kod JOVANOVIĆ, LJ., Lekarska tajna krivičnopravna razmatranja, Beograd, 1959., str. 5.-12.

53 Vidi NIKOLIĆ, S., Etika zdravstvenih radnika danas, «Timočki medicinski glasnik», vol. 28., 2003., broj 3-4, str. 87.-90.

${ }^{54}$ Cjeloviti tekst Hipokratove zakletve objavljen je kod MILIČIĆ, V., Deontologija profesije liječnik, život čovjeka i integritet liječnika - ćudoredna raskrižja bioetike, Zagreb, 1996., Prilog B, str. XXIII.

${ }^{55}$ Usp. NIKOLIĆ, S., Etika zdravstvenih radnika danas, «Timočki medicinski glasnik», vol. 28., 2003., broj 3-4, str. 87.-90. 
${ }^{56}$ Cjeloviti tekst objavljen je kod MILIČIĆ, V., Deontologija profesije liječnik, život čovjeka $i$ integritet liječnika - ćudoredna raskrižja bioetike, Zagreb, 1996., Prilog B, str. XXIII.-XXIV. I Međunarodni kodeks liječničke etike nalaže : "Liječnik je dužan držati u tajnosti sve što zna o bolesniku, čak i nakon njegove smrti". Usvojen je u Londonu 1949. godine, te dopunjavan dva puta: na skupštini Svjetskog liječničkog udruženja u Sydneyu 1986., i Veneciji 1983. godine. Cjeloviti tekst objavljen je kod MILIČIĆ, V., Deontologija profesije liječnik, život čovjeka $i$ integritet liječnika - ćudoredna raskrižja bioetike, Zagreb, 1996., Prilog B, str. XXIV.-XXV.

${ }^{57}$ Usp. DOURAKI, T., Ethical and Legal Dimensions of Medical Confidentiality in European Law of Human Rights, «Pravni život», god. LI, 2002., br. 9, str. 183.

58 Primjerice, dok njemačko pravo pruža apsolutnu zaštitu od otkrivanja liječničke tajne, neke zemlje nisu prihvatile čuvanje liječničke tajne kao zakonsku obvezu, već je ona i dalje ostala samo kao moralno pravo, kao osobna stvar koja se tiče samo liječnika i bolesnika, ali ne i države. Ovakovo je stajalište zastupljeno u angloameričkom pravu. JOVANOVIĆ, LJ., Lekarska tajna krivičnopravna razmatranja, Beograd, 1959., str. 13. U Velikoj Britaniji Generalni medicinski savjet izdao je smjernice koje upućuju na zabranu otkrivanja tajne i okolnosti pod kojima se ta zabrana ne mora poštivati. Vidi o tome kod STAUCH, M. - WHEAT, K., Sourcebook on Medical Law, London-Sydney, 1999., str. 221.-273. Američko pravo uređuje institut liječničke tajne uvažavajuči ponajviše pravo na privatnost, a pri tome se posebno vodi računa o anonimnosti tužitelja (pacijenta) tijekom sudskog postupka. PETROVIĆ-ŠKERO, V., Lekarska tajna $i$ veštačenje, «Svet rada», vol. 1, 2004., br. 4, str. 449.-450.

${ }^{59}$ Tako Medicinska enciklopedija, knjiga 4., Zagreb, MCMLXIX, str. 294.

${ }^{60}$ Usp. JELAČIĆ, O., Liječnička tajna u našem zakonodavstvu, «Zbornik radova Pravnoga fakulteta u Splitu», god X, 1973., str.13.

${ }^{61}$ Vidi JAHNKE, Leipziger Kommentar zum Strafgesetzbuch, 10. Auflage, 5. Band, Leipzig, 1988., par. 203., podatak kod RADIŠIĆ, J., Medicinsko pravo, Beograd, 2003., str. 133.,

${ }^{62}$ Usp. Medicinska enciklopedija, knjiga 4., Zagreb, MCMLXIX, str. 294.

63 Tako MUJOVIĆ ZORNIĆ, H. - SJENČIĆ, M., Kodeks lekarske etike kao izraz staleške samoregulative u medicini, «Pravni informator», 2003., str. 9.

${ }^{64}$ Usp. Medicinska enciklopedija, knjiga 4., Zagreb, MCMLXIX, str. 294.; usp. ZEČEVIĆ, D. i dr., Sudska medicina i deontologija, Zagreb, 2004., str. 318.

${ }^{65}$ Vidi kod PIEDELIEVRE, R. - FOURNIER, E., Medicine legale, Paris, 196., podatak kod JELAČIĆ, O., Liječnička tajna u našem zakonodavstvu, «Zbornik radova Pravnoga fakulteta u Splitu», god X, 1973., str. 14.

${ }^{66}$ Usp. Medicinska enciklopedija, knjiga 4., Zagreb, MCMLXIX, str. 294.

${ }^{67}$ Tako RADIŠIĆ, J., Medicinsko pravo, Beograd, 2003., str. 135.

${ }^{68}$ Vidi JOVANOVIĆ, LJ., Lekarska tajna - krivičnopravna razmatranja, Beograd, 1959., str. 18.

${ }^{69} \mathrm{O}$ tome podrobnije kod BOŠKOVIĆ, Z., Profesionalna liječnička tajna, „Informator“, broj 5329. od 2. travnja 2005., str. 12.

${ }^{70}$ Usp. RISTIĆ, J., Medicina i društvo, Beograd, 1975., str. 82.-84.

${ }^{71}$ Vidi VRHOVAC, B., Liječnička tajna, «Liječničke novine», 2001., broj 5, str. 19.-20.

72 Tako SANDOR, J., Data Protection in Health Care, Beyond Biomedical Use, „Frontiers of European Health Law“, Yearbook 2002., str. 76.

${ }^{73}$ Usp. Medicinska enciklopedija, knjiga 4., Zagreb, MCMLXIX, str. 294.-295.

${ }^{74}$ Ibid., str. 295.

75 Vidi RAJIĆ, Z. - TOMIĆ, M. - MILJKO, Z., Komentar Kaznenog zakona, Mostar, 2000., str. 217.

76 Tako GOSIĆ, N., Privatnost i povjerenje u medicinskoj etici i bioetici, «Sestrinski edukacijski magazin», god. II, 2005., broj 2, str. 5.

77 Usp. JELAČIĆ, O., Liječnička tajna u našem zakonodavstvu, «Zbornik radova Pravnoga fakulteta u Splitu», god X, 1973., str. 21.

78 Tako MARIĆ, J. - LUKIĆ, M., Pravna medicina, Beograd, 1998., str. 344. 
${ }^{79}$ Vidi JELAČIĆ, O., Liječnička tajna u našem zakonodavstvu, «Zbornik radova Pravnoga fakulteta u Splitu», god X, 1973., str. 21.

80 Tako REHBERG, J., Handbuch des Arztrechts, Zurich, 1994., (dalje - REHBERG), str. 345.

${ }^{81}$ Usp. RADIŠIĆ, J., Dužnost čuvanja medicinske tajne, „Anali Pravnog fakulteta u Beogradu“, god. L., 2002., broj 3-4, str. 329.

${ }^{82}$ Pojam „neovlašteno“ trebalo bi izjednačiti s pojmom „neopravdano“ i ,protupravno“ otkrivanje tajne. RADIŠIĆ, J., Medicinsko pravo, Beograd, 2003., str. 139.

${ }^{83}$ Tako CRUZ, P., Medical Law, London, 2002., str. 90.

${ }^{84}$ Usp. RADIŠIĆ, J., Medicinsko pravo, Beograd, 2003., str. 134.

${ }^{85}$ Vidi podrobnije o tome kod PLOEM, C., Medical confidentiality after patient's death, ,Medicine and Law", vol. 20, 2001., br. 2, str. 215.-220.

${ }^{86}$ Usp. RADIŠIĆ, J., Dužnost čuvanja medicinske tajne, „Anali Pravnog fakulteta u Beogradu“, god. L., 2002., broj 3-4, str. 330.

87 Tako ULSENHEIMER, str. 554.

${ }^{88}$ Vidi STAUCH, M. - WHEAT, K., Sourcebook on Medical Law, London-Sydney, 1999., str. 224.

${ }^{89}$ Tako ULSENHEIMER, str. 551.

${ }^{90}$ Usp. ZEČEVIĆ, D. i dr., Sudska medicina i deontologija, Zagreb, 2004., str. 320.

${ }^{91}$ Tako BOŠKOVIĆ, Z., Kodeks medicinske etike i deontologije, «Informator», broj 5046.-5047. od 17. i 20. srpnja 2002. godine, str. 1.

92 Vidi BOŠKOVIĆ, Z., Profesionalna liječnička tajna, „Informator“, broj 5329. od 2. travnja 2005., str. 11.

${ }^{93}$ Usp. RAJIĆ, Z. - TOMIĆ, M. - MILJKO, Z., Komentar Kaznenog zakona, Mostar, 2000., str. 217.

${ }^{94}$ Tako Medicinska enciklopedija, knjiga 4., Zagreb, MCMLXIX, str. 295.

${ }^{95}$ Vidi BAČIĆ, F. - PAVLOVIĆ, Š., Komentar kaznenog zakona, Zagreb, 2004., str. 548.

${ }^{96}$ Tako BAČIĆ, F. - ŠEPAROVIĆ, Z., Krivično pravo - posebni dio, Zagreb, 1997., str. 111.

${ }^{97}$ Ibid., str. 111.

${ }^{98}$ Vidi RAJIĆ, Z. - TOMIĆ, M. - MILJKO, Z., Komentar Kaznenog zakona, Mostar, 2000., str. 217.

${ }^{99}$ Usp. BAČIĆ, F. - PAVLOVIĆ, Š., Komentar zaznenog zakona, Zagreb, 2004., str. 548.

100 Tako BAČIĆ, F., Krivično pravo - Posebni dio (I), Zagreb, 1979., str. 205.

101 Vidi BAČIĆ, F. - PAVLOVIĆ, Š., Komentar kaznenog zakona, Zagreb, 2004., str. 549.

102 Usp. BAČIĆ, F. - ŠEPAROVIĆ, Z., Krivično pravo - posebni dio, Zagreb, 1997., str. 111.; ŠEPAROVIĆ, Z., Granice rizika, Zagreb, 1998., str. 32.

${ }^{103}$ Vidi BAČIĆ, F. - ŠEPAROVIĆ, Z., Krivično pravo - posebni dio, Zagreb, 1997., str. 112.

104 Za navedeni prekršaj kaznit će se novčanom kaznom u iznosu od 10.000,00 do 50.000,00 kuna i trgovačko društvo koje obavlja zdravstvenu djelatnost sukladno Zakonu o zdravstvenoj zaštiti, kao i odgovorna osoba u trgovačkom društvu koja obavlja zdravstvenu djelatnost i to novčanom kaznom u iznosu od 5.000,00 do 10.000,00 kuna, a također će se kazniti novčanom kaznom u iznosu od 5.000,00 do 10.000,00 kuna i privatni zdravstveni radnik (ZOZPP, čl. 41.).

105 Podrobnije o disciplinskoj/stegovnoj odgovornosti liječnika i radu Suda časti HLJK vidi kod RUMEK ČRNE, R. - ROKSANDIĆ, S., Sud Hrvatske liječničke komore - pravni aspekti, objavljen u Hrvatska liječnička komora 193-1995-2005., Zagreb, 2005., str. 237.-244.; BABIĆ, T. - ROKSANDIĆ, S., Osnove zdravstvenog prava, Zagreb, 2006., str. 223.-226.

106 Detaljnije o tome kod RADOLOVIĆ, A., Pravo osobnosti u novom Zakonu o obveznim odnosima, «Zbornik Pravnog fakulteta Sveučilišta u Rijeci», vol. 27., 2006., br. 1, str. 129.-170.

${ }^{107}$ Usp. GAVELLA, N., Osobna prava - I. dio, Zagreb, 2000., str. 219.

108 Ibid., str. 241.

109 Vidi KLARIĆ, P., Odštetno pravo, Zagreb, 2003., str. 388.; BOŠKOVIĆ, Z., Zakon o zaštiti prava pacijenata - reforma zdravstvenog zakonodavstva Republike Hrvatske, „Hrvatska pravna revija“, god. V., 2005., br. 1, str. 90. 
${ }^{110}$ Tako GAVELLA, N., Osobna prava - I. dio, Zagreb, 2000., str. 219.

${ }^{111}$ Vidi IVANČEVIĆ, N., Zakon o liječništvu, rad u zborniku «Zbirka zdravstvenih zakona s obrazložnjem», Zagreb, 2003., str. 91.

${ }^{112}$ Usp. Medicinska enciklopedija, knjiga 4., Zagreb, MCMLXIX, str. 295.

113 Tako JOVANOVIĆ, LJ., Lekarska tajna - krivičnopravna razmatranja, Beograd, 1959., str. 37.

114 Vidi POZAIĆ, V., Teološki vidici liječničke tajne, «Obnovljeni život», (56), 2001., broj 4, str. 447.-449.

115 Usp. TURKOVIĆ, K. - DIKA, M. - GORETA, M. - ĐURĐEVIĆ, Z., Zakon o zaštiti osoba s duševnim smetnjama - s komentarom i prilozima, Zagreb, 2001., str. 107.

${ }^{116} \mathrm{Ibid}$., str. 107.

117 Ibid., str. 108.

118 Tako ULSENHEIMER, str. 556. Usp. STAUCH, M. - WHEAT, K., Sourcebook on Medical Law, London-Sydney, 1999., str. 224.

${ }^{119}$ Usp. REHBERG, str. 135.

${ }^{120}$ Vidi DEUTSCH, E. - SPICKHOFF, A., Medizinrecht, Munchen, 2003., str. 318.

121 Tako REHBERG, str. 349.

122 Usp. TURKOVIĆ, K. - DIKA, M. - GORETA, M. - ĐURĐEVIĆ, Z., Zakon o zaštiti osoba s duševnim smetnjama - s komentarom i prilozima, Zagreb, 2001., str. 110.

123 Vidi MUJOVIĆ ZORNIĆ, H. - SJENČIĆ, M., Kodeks lekarske etike kao izraz staleške samoregulative u medicini, «Pravni informator», 2003., str. 9.

124 Tako STAUCH, M. - WHEAT, K., Sourcebook on Medical Law, London-Sydney, 1999., str. 223.

${ }^{125}$ Vidi TURKOVIĆ, K. - DIKA, M. - GORETA, M. - ĐURĐEVIĆ, Z., Zakon o zaštiti osoba s duševnim smetnjama - s komentarom i prilozima, Zagreb, 2001., str. 109.

${ }^{126}$ Usp. Medicinska enciklopedija, knjiga 4., Zagreb, MCMLXIX, str. 295.

127 Tako BABIĆ, T. - ROKSANDIĆ, S., Osnove zdravstvenog prava, Zagreb, 2006., str. 163.

${ }^{128}$ Usp. GOSIĆ, N., Privatnost i povjerenje u medicinskoj etici i bioetici, «Sestrinski edukacijski magazin», god. II, 2005., broj 2, str. 10.

${ }^{129}$ Vidi RADIŠIĆ, J., Medicinsko pravo, Beograd, 2003., str. 140.

${ }^{130}$ Tako Medicinska enciklopedija, knjiga 4., Zagreb, MCMLXIX, str. 295.

${ }^{131}$ Vidi ŠEPAROVIĆ, Z., Granice rizika, Zagreb, 1998., str. 31.

${ }^{132}$ Usp. RAJIĆ, Z. - TOMIĆ, M. - MILJKO, Z., Komentar Kaznenog zakona, Mostar, 2000., str. 219.

${ }^{133}$ Najčešće je riječ o socijalnoj skrbi (primjerice u slučaju zlostavljanja djece i žena), policiji (slučajevi prometnih nesreća, izazvanih konzumiranjem alkohola ili nekih drugih opojnih droga, prijetnja ubojstvom, predoziranje ovisnika o drogama i sl.), odvjetništvu, sudovima (za slučajeve u kojima medicinski i zdravstveni djelatnici nisu postigli pristanak s pacijentima ili članovima njihove rodbine, a riječ je o intervencijama koje mogu spasiti život, medicinski i zdravstveni djelatnici - kako praksa nekih zemalja pokazuje - mogu se obratiti sudu za pomoć), institucijama i službama čije članove isto tako obvezuje profesionalna tajna. Na taj način u zaštiti zajedničkog dobra, na poziv medicinskih i zdravstvenih djelatnika, sudjeluju i svi oni koji su od društva zaduženi za zaštitu zajedničkog i društvenog dobra. POZAIĆ, V., Teološki vidici liječničke tajne, «Obnovljeni život», (56), 2001., broj 4, str. 447.-449.

${ }^{134}$ Usp. BABIĆ, T. - ROKSANDIĆ, S., Osnove zdravstvenog prava, Zagreb, 2006., str. 163.

135 Postoji mišljenje da u određenim slučajevima liječnička tajna može postojati i prema samom pacijentu. Drži se, primjerice, da bi u slučaju teške, neizlječive bolesti pacijenta njegovo upoznavanje sa stvarnim stanjem bolesti moglo dovesti do pogoršanja njegova zdravlja i ubrzavanja smrti. Suprotno, prikrivanje takvog stanja predstavlja posebnu vrstu liječenja, psihoterapije. Ipak, pretežito je mišljenje da liječnička tajna djeluje samo prema trećim oobama, a ne i prema pacijentu. JOVANOVIĆ, LJ., Lekarska tajna - krivičnopravna razmatranja, Beograd, 1959., str. 42.

${ }^{136}$ U tom smislu Pozaić navodi i primjer osobe koja je nasilna i predstavlja opasnost na radnom mjestu i u obitelji, odnosno kojoj psihofizičke sposobnosti ne dopuštaju dalje obavljanje javne 
djelatnosti te dovodi u pitanje živote drugih ljudi (primjerice, vozači javnog prijevoza, osobe čije radno mjesto zahtijeva rukovanje različitim kemijskim tvarima, otrovnim supstancama $\mathrm{i}$ eksplozivom), te drži da i za te slučajeve važi isto profesionalno pravilo odavanja privatnih podataka kao i u slučajevima prijetnje zajedničkog dobra. POZAIĆ, V., Teološki vidici liječničke tajne, «Obnovljeni život», (56), 2001., broj 4, str. 447.-449.

137 Tako SCHLUND, G., Specifische arztliche Mitteilungsmoglichkeiten, objavljen kod LAUFSUHLENBRUCK, Handbuch des Arztrechts, Munchen, 2002., str. 581., podatak kod RADIŠIĆ, str. 141.

138 Općim interesom ili interesom koji je važniji od interesa čuvanja liječničke tajne u smatra se: (a) otkrivanje saznanja da osoba s duševnim smetnjama priprema počinjenje kaznenog djela za koje je zakonom propisana kazna zatvora od pet godina ili teža kazna, (b) otkrivanje ili suđenje za najteža kaznena djela ako bi ono bilo znatno usporeno ili onemogućeno bez otkrivanja inače zaštićenih podataka, (c) zaštita javnog zdravlja i sigurnosti, (d) sprječavanje izlaganja druge osobe neposrednoj i ozbiljnoj opasnosti za njen život ili zdravlje (ZZODS, čl. 17. st. 5.). Podrobnije o tome kod TURKOVIĆ, K. - DIKA, M. - GORETA, M. - ĐURĐEVIĆ, Z., Zakon o zaštiti osoba $s$ duševnim smetnjama - s komentarom i prilozima, Zagreb, 2001., str. 110.-112.

${ }^{139}$ Vidi GOSIĆ, N., Privatnost i povjerenje u medicinskoj etici i bioetici, «Sestrinski edukacijski magazin», god. II, 2005., broj 2, str. 10.

${ }^{140}$ Usp. JELAČIĆ, O., Pravni i deontološki aspekt lekarske delatnosti, «Jugoslavenska revija za kriminologiju i krivično pravo», god. IX, 1971., br. 3, str. 472.

141 Tako MUJOVIĆ ZORNIĆ, H. - SJENČIĆ, M., Kodeks lekarske etike kao izraz staleške samoregulative u medicini, «Pravni informator», 2003., str. 9.; STAUCH, M. - WHEAT, K., Sourcebook on Medical Law, London-Sydney, 1999., str. 250.

142 Tako RADIŠIĆ, J., Dužnost čuvanja medicinske tajne, „Anali Pravnog fakulteta u Beogradu“, god. L., 2002., broj 3-4, str. 334.-335.

${ }^{143}$ Vidi GOSIĆ, N., Privatnost i povjerenje u medicinskoj etici i bioetici, «Sestrinski edukacijski magazin», god. II, 2005., broj 2, str. 9.

144 Usp. MUJOVIĆ ZORNIĆ, H. - SJENČIĆ, M., Kodeks lekarske etike kao izraz staleške samoregulative u medicini, «Pravni informator», 2003., str. 9.; GOSIĆ, N., Privatnost i povjerenje u medicinskoj etici i bioetici, «Sestrinski edukacijski magazin», god. II, 2005., broj 2, str. 10.

145 Tako RADOLOVIĆ, A., Pravo osobnosti u novom Zakonu o obveznim odnosima, «Zbornik Pravnog fakulteta Sveučilišta u Rijeci», vol. 27., 2006., br. 1, str. 133.

${ }^{146}$ Ibid., str. 150. Podrobnije o pravu osobnosti kod GAVELLA, N., Osobna prava - I. dio, Zagreb, 2000. i BODIROGA, N. - DULČIĆ, K., Zaštita osobnih podataka u europskome i hrvatskome pravu, «Zbornik radova Pravnog fakulteta u Splitu», god. 42, 2005., str. 327.-356.

147 Usp. BLAŽEVIĆ, D. - CIVIDINI STRANIĆ, E. - BECK DVORŽAK, M., Medicinska psihologija, Zagreb, 1979., str. 130.

148 Tako TRIVA, S. - DIKA, M., Građansko parnično procesno pravo, Zagreb, 2004., str. 520.

149 Vidi BOŠKOVIĆ, Z., Zakon o liječništvu - reforma zdravstvenog zakonodavstva Republike Hrvatske, „Hrvatska pravna revija“, god. III., 2003., br. 9, str. 79.

${ }^{150}$ Usp. PETROVIĆ-ŠKKERO, V., Lekarska tajna $i$ veštačenje, «Svet rada», vol. 1, 2004., br. 4, str. 449.

151 Tako REHBERG, J., str. 340.

${ }^{152}$ Primjerice, otkrivanje liječničke tajne može prouzročiti šutnju, izbjegavanje osobe koja je dovela $\mathrm{u}$ pitanje privatnost, iskazivanje razočarenja u odnos u kojem je privatnost povrijeđena, strah od povjerenja u drugu osobu te povlačenje u vlastitu osobnost. Zato od medicinskih djelatnika kojima izlažu dijelove svoje privatnosti, primjerice, od identifikacijskih podataka, materijalnog stanja, adrese stanovanja, broja telefona do informacije u vezi zdravlja i bolesti do kojih treba doći pomoću različitih postupaka i intervencija pacijenti trebaju, u njihovom uzajamnom odnosu, dobiti uvjerenje i točne upute o tome kako će se ti podaci prikupljati, koristiti i štititi te koja su pravila profesije u vezi s njima. U situacijama u kojima treba govoriti o fiziološkim potrebama i funkcijama, tjelesnim izlučevinama, pokazati neki dio tijela, razgovarati o povijesti bolesti, 
rezultatima dijagnostičkih pretraga, težini stanja i svemu onome što bi se trebalo poduzeti da bi se to stanje promijenilo - u prostoru u kojem osoba treba biti zaštićena od pogleda drugih - pitanje povjerenja dobiva svoje puno značenje. GOSIĆ, N., Privatnost i povjerenje u medicinskoj etici $i$ bioetici, «Sestrinski edukacijski magazin», god. II, 2005., broj 2, str. 11.

${ }^{153}$ Usp. BABIĆ, T. - ROKSANDIC, S., Osnove zdravstvenog prava, Zagreb, 2006., str. 162.

154 Tako JOVANOVIĆ, LJ., Lekarska tajna - krivičnopravna razmatranja, Beograd, 1959., str. 16. 155 Vidi DOURAKI, T., Ethical and Legal Dimensions of Medical Confidentiality in European Law of Human Rights, «Pravni život», god. LI, 2002., br. 9, str. 186.-190.; SANDOR, J., Data Protection in Health Care, Beyond Biomedical Use, „Frontiers of European Health Law“, Yearbook 2002., str. 79.-80.; Van DIJK, P. - Van HOOF, G. J. H., Teorija i praksa Evropske konvencije o ljudskim pravima, Sarajevo, 2001., str. 459.-508.; HARLAND, C. - ROCHE, R. - STRAUSS, E., Komentar Evropske konvencije o ljuskim pravima prema praksi u Bosni $i$ Hercegovini $i$ Strasbourgu, Sarajevo, 2003., str. 219.-223.

156 Vidi podrobnije o tome kod BODIROGA, N. - DULČIĆ, K., Zaštita osobnih podataka u europskome i hrvatskome pravu, «Zbornik radova Pravnog fakulteta u Splitu», god. 42, 2005., str. 327.-356. Prema odredbi čl. 8. st. 3. Smjernice, iznimno u svrhu ostvarivanja uspješnog liječenja, podaci iz liječničkog kartona ispitanika dostupni su svim liječnicima koji liječe ili trebaju liječiti ispitanika, odnosno svim drugim osobama koje su uključene u liječenje i koje su obvezane na čuvanje profesionalne (liječničke) tajne. Vidi i HERVEY, T. - McHALE, J. V., Health Law and the European Union, Cambridge, 2004., str. 169.-172.; SANDOR, J., Data Protection in Health Care, Beyond Biomedical Use, „Frontiers of European Health Law“, Yearbook 2002., str. 76.-79.; LEHTONEN, L., Protection of patient data and right to privacy in Finland - recent implementation of the Directive on the protection of personal data and centralized registries containing sensitive health data, referat u zborniku 13th World Congress on Medical Law, 6-10 August 2000, Helsinki, str. 633.-639.

${ }^{157}$ U tom smislu treba napomenuti da su u Republici Hrvatskoj doneseni Zakon o zaštiti osobnih podataka i Zakon o pravu na pristup informacijama kojima se uređuje zaštita osobnih podataka i pravo na pristup informacijama o osobama koje posjeduju javna tijela, gdje svakako pripadaju i podaci o zdravlju određene osobe (tzv. sensitive medical data). Treba napomenuti da se radi o podacima koji su zabilježeni u određenim dokumentima, odnosno evidencijama, dok liječnička tajna uključuje i one podatke koje je zdravstveni djelatnik doznao o pacijentu i nije ih zabilježio u pisanom obliku. Usp. SANDOR, J., Data Protection in Health Care, Beyond Biomedical Use, „Frontiers of European Health Law“, Yearbook 2002., str. 79.

ZZOP uređuje se zaštita osobnih podataka o fizičkim osobama te nadzor nad prikupljanjem, obradom i korištenjem osobnih podataka u Republici Hrvatskoj, u svrhu zaštite privatnog života i ostalih ljudskih prava i temeljnih sloboda u prikupljanju, obradi i korištenju osobnih podataka (čl. 1.). U smislu odredbe čl. 2. t. 1. ZZOP-a, osobni podatak je svaka informacija koja se odnosi na identificiranu fizičku osobu ili fizičku osobu koja se može identificirati (u daljnjem tekstu: ispitanik), a osoba koja se može identificirati je osoba čiji se identitet može utvrditi izravno ili neizravno, posebno na osnovi jednog ili više obilježja specifičnih za njezin fizički, psihološki, mentalni, gospodarski, kulturni ili socijalni identitet. Prema odredbi čl. 8. ZZOP-a, zabranjeno je prikupljanje i daljnja obrada osobnih podataka koji se, među ostalim, odnose na zdravlje ispitanika. Iznimno, ovi podaci mogu se prikupljati i dalje obrađivati: uz privolu ispitanika (privola ispitanika je slobodno dano i izričito očitovanje volje ispitanika kojom on izražava svoju suglasnost s obradom njegovih osobnih podataka u određene svrhe); u svrhu izvršavanja zakonskih obveza voditelja zbirke osobnih podataka; u svrhu zaštite života ili tjelesnog integriteta ispitanika ili druge osobe u slučaju kada ispitanik fizički ili pravno nije u mogućnosti dati svoj pristanak; ako je ispitanik sam objavio te podatke; ili ako se obrada provodi u okviru djelatnosti ustanove, udruženja ili bilo kojeg drugog neprofitnog tijela s političkom, vjerskom ili drugom svrhom te pod uvjetom da se obrada isključivo odnosi na njihove članove te da podaci ne budu otkriveni trećoj strani bez pristanka ispitanika. 
Zakonom o pravu na pristup informacijama ("Narodne novine", br. 25/13, 85/15., dalje - ZOPPI), uređuje se pravo na pristup informacijama koje posjeduju, raspolažu ili nadziru tijela javne vlasti, propisuju načela prava na pristup informacijama, izuzeci od prava na pristup informacijama $\mathrm{i}$ postupak za ostvarivanje i zaštitu prava na pristup informacijama u cilju omogućavanja i osiguranja ostvarivanja prava na pristup informacijama fizičkim i pravnim osobama putem otvorenosti i javnosti djelovanja tijela javne vlasti, sukladno ovom i drugim zakonima (ZOPPI, čl. 1. i 2.). Sve informacije koje posjeduju, raspolažu ili nadziru tijela javne vlasti moraju biti dostupne zainteresiranim ovlaštenicima prava na informaciju (ZOPPI, čl. 4. st. 1.). Iznimno, tijela javne vlasti uskratit će pravo na pristup informaciji ako je informacija zakonom ili na osnovi kriterija utvrđenih zakonom proglašena, među ostalim, profesionalnom tajnom ili ako je zaštićena zakonom kojim se uređuje područje zaštite osobnih podataka, u slučaju da postoje osnove sumnje da bi njezino objavljivanje izazvalo ozbiljnu štetu za život i zdravlje ljudi (ZOPPI, čl. 8. st. 1. i 2.).

158 Vidi JADRO, D. - HRABRIĆ, M. - KRAMARIĆ, D., Zakon o zdravstvenoj zaštiti, rad u zborniku «Zbirka zdravstvenih zakona s obrazložnjem, Zagreb, 2003., str. 26.

${ }^{159}$ Tako BOŠKOVIĆ, Z., Zakon o zaštiti prava pacijenata - reforma zdravstvenog zakonodavstva Republike Hrvatske, „Hrvatska pravna revija“, god. V., 2005., br. 1, str. 90.

${ }^{160}$ Usp. DROPULIĆ, J., Pravo na privatni život i duševni integritet, Zagreb, 2002., str. 124.

${ }^{161}$ Vidi TURKOVIĆ, K. - DIKA, M. - GORETA, M. - ĐURĐEVIĆ, Z., Zakon o zaštiti osoba s duševnim smetnjama - s komentarom i prilozima, Zagreb, 2001., str. 106.

162 O liječničkoj tajni tako i više kod ČIZMIĆ, J., Pravno uređenje instituta liječničke tajne u hrvatskom pravu, «Pravo i porezi», god. XVI., 2007., br. 2., str. 12-25. 


\section{0/ Medicinska dokumentacija}

\subsection{Uvod}

Podaci o zdravstvenom stanju pacijenta nesumnjivo spadaju u osobne podatke, ne smiju se u pravilu otkrivati trećim osobama, a pravila o njihovoj zaštiti moraju poštivati svi subjekti. ${ }^{1}$ Zdravstvene ustanove i drugi organizacijski oblici obavljanja zdravstvene djelatnosti vode razne evidencije koje služe kao izvor podataka za statistička istraživanja u području zdravstva, a koriste se za praćenje i proučavanje zdravstvenog stanja stanovništva, za programiranje i planiranje zdravstvene zaštite, odnosno poduzimanje potrebnih mjera zdravstvene zaštite, za potrebe društvene zajednice, obrane, za izvješćivanje javnosti, za izvršavanje međunarodnih obveza te za druge službene svrhe. Evidencija u području zdravstvene zaštite vodi se upisivanjem podataka na sredstvima za vođenje evidencije - medicinskoj dokumentaciji (medical documentation). ${ }^{2}$

Medicinska dokumentacija je svaki dokument koji je nastao u zdravstvenoj ustanovi, potpisan od zdravstvenog radnika, najčešće liječnika. ${ }^{3}$ Po svom sadržaju medicinska dokumentacija je skup svih pisanih ili na drugi način priređenih dokumenata (na elektronskom mediju i sl.), ${ }^{4}$ u kojima su sadržani stručno relevantni podaci o pacijentovoj bolesti i o njegovu zdravstvenom stanju, te upute o liječenju i upute dane u svrhu ostvarivanja pacijentovih prava na zdravstvenu zaštitu (ZOZPP, čl. 3. t. c/). Medicinska dokumentacija može se definirati i kao dokument o tijeku pacijentove bolesti i liječenja, ${ }^{5}$ odnosno svaki zapis koji sadrži podatke o zdravstvenom stanju pacijenta, kao i o načinu rada na mjestu pružanja te zaštite. ${ }^{6}$

Medicinska dokumentacija nije nužno istovjetna zdravstvenom kartonu (medical record) pacijenta, a posebno to nije u onim zemljama u kojima se liječenje u pravilu odvija na različitim mjestima. ${ }^{7}$

U medicinsku dokumentaciju bi svakako trebalo ubrojiti i podatke, odnosno dokumentaciju o zdravstvenom stanju pacijenta s kojom raspolaže i koju čuva sam pacijent. Naime, ponekad je korisno (primjerice, zbog mogućeg gubitka ili zamjene pojedinih podataka ili priloga iz medicinske dokumentacije, ili eventualne zaštite prava pacijenta pred drugim tijelima) ili, čak, nužno da se takva dokumentacija nalazi kod pacijenta, štoviše uz pacijenta (npr., knjižica dijabetičkih bolesnika, trudnička knjižica; razni lančići, značke, narukvice i sl., koji upozoravaju na postojanje neke bolesti, preosjetljivost na neke lijekove, krvnu grupu i sl.). ${ }^{8}$

$\mathrm{Na}$ žalost, problematika medicinske dokumentacije i njezina pravnog značenja vrlo se rijetko ili nikako tumači studentima prava i pravnicima, a neprijeporno zaslužuje njihovu punu pozornost i poznavanje vrsta, sadržaja i forme medicinske dokumentacije, posebno zbog njezina značenja za pravosuđe gdje predstavlja izvor važnih podataka. ${ }^{9}$ 
ZDRAVSTVENO STRUKOVNO STALEŠKO PRAVO

Prava, obveze i odgovornosti radnika u obavljanju djelatnosti: Medicinska dokumentacija

\subsection{Svrha i cilj medicinske dokumentacije}

Medicinska dokumentacija ima višestruku svrhu. U prvom redu, zadatak joj je omogućiti pravilno liječenje pacijenta i znanstveno istraživanje, pa mora biti tako vođena da može u svakom trenutku drugim liječnicima i pacijentu dati točne podatke o poduzetim dijagnostičkim i terapijskim mjerama, a ti su podaci značajni i onima koji u konačnici snose troškove liječenja. ${ }^{10}$ Cilj medicinske dokumentacije je, dakle, praćenje i utvrđivanje tijeka bolesti u postupku liječenja bolesnika, koje provode određeni zdravstveni radnici i zdravstvene ustanove odgovorni za liječenje konkretnog pacijenta. ${ }^{11}$

Na temelju medicinske dokumentacije pišu se dnevna i periodična izvješća za potrebe evidencija, a izdaju se i financijski dokumenti za plaćanje zdravstvenih usluga. ${ }^{12}$

Medicinska dokumentacija (bilješke i prilozi) liječniku služi da bi se podsjetio na rezultate pretraga, situaciju, svoja razmišljanja i namjere, kad se sretne s istim bolesnikom nakon nekog vremena. ${ }^{13}$

Uredno vođena dokumentacija ne služi samo kao oslonac liječniku za podsjećanje, nego je i u interesu pacijenta da ima urednu medicinsku dokumentaciju. ${ }^{14}$ Naime, zbog loše, odnosno nepravilno vođene medicinske dokumentacije, pacijenti često ne mogu dokazati i ostvariti svoja prava. ${ }^{15}$ Primjerice, magistar farmacije ne smije bez recepta ili medicinske dokumentacije izdati lijek koji ima odobrenje za stavljanje u promet na recept sukladno posebnome zakonu (ZOLJK, čl. 22.). ${ }^{16}$ Magistar farmacije u dežurstvu obvezan je izdati samo lijek na recept koji ima oznaku hitnosti, odnosno samo lijek na temelju drugoga relevantnog medicinskog dokumenta koji ima oznaku hitnosti (ZOLJK, čl. 23.). Tijekom rada magistar farmacije dužan je uskratiti izdavanje lijeka ili medicinskoga proizvoda u slučaju neispravne medicinske dokumentacije (ZOLJK, čl. 24.).

Uredno vođena medicinska dokumentacija od osobite je važnosti za zaštitu prava pacijenata pred sudom, ${ }^{17}$ ali isto tako ona može poslužiti i liječnicima za obranu ako pacijent protiv njih pokrene sudski postupak. ${ }^{18}$

\subsection{Sadržaj i vrste medicinske dokumentacije}

Medicinsku dokumentaciju sačinjavaju različiti dokumenti, kao što su: otpusno pismo, liječničko uvjerenje, rendgenološki snimci, laboratorijske pretrage, temperaturno terapijsko dijetetske liste, ${ }^{19}$ uputnice (drugim specijalistima, laboratorijima, ustanovama), operacijske liste, CT nalazi, anamneze, potvrda o smrti i sl. $^{20}$ Što je medicinska dokumentacija potpunija, to je i kvalitetnija. ${ }^{21} 22$

Medicinska dokumentacija sastoji se ponajviše od liječnikovih zabilješki o nalazima glede pacijentovog zdravstvenog stanja i o poduzetim terapijskim mjerama. Medicinska dokumentacija treba sadržavati podatke o onome što je liječniku pacijent priopćio, onome što je liječnik sam uočio, dijagnosticirao, zaključio i proveo (primjerice, plan liječenja, stupanj uključenosti samoga pacijenta u njegovo liječenje, detalje o primijenjenim metodama liječenja i lijekovima, koji su lijekovi i koliko često davani, kakva je bila 
reakcija pacijenta na njih, informacije koje su dane pacijentu glede liječenja i njegovih prava, usmene ili pisane pristanke koje je davao pacijent tijekom liječenja, ocjene njegove sposobnosti za davanje pristanka i sl.). ${ }^{23}$ Usto, liječnik je dužan u pacijentovom zdravstvenom kartonu čuvati i laboratorijske nalaze, razne tehničke pokazatelje, kao i svoje osobne dojmove i zapažanja, a obvezno anamnezu, tegobe pacijenta, dijagnostičke mjere i dijagnozu, terapiju i rezultate terapije, savjete date pacijentu i datume. ${ }^{24}$ Dakle, posebnost medicinske dokumentacije jest $\mathrm{u}$ tome što ona, pored objektivnih nalaza, sadrži i subjektivne ocjene liječnika koje objašnjavaju njegove postupke. ${ }^{25}$

Osim pisane dokumentacije, prikupljaju se i brojni (tehnički) zapisi druge vrste, primjerice rendgenske slike, laboratorijski nalazi, EKG i drugi biosignali te ostala pomoćna dijagnostička sredstva. ${ }^{26}$

U medicinsko pravnoj teoriji postoji klasifikacija medicinske dokumentacije na: osnovnu medicinsku dokumentaciju; pomoćna sredstva za vođenje evidencije (dnevna evidencija o radu i posjetima, registar kartoteke, primjerice); te na izvještaje individualne (prijava porođaja, pobačaja, profesionalnih oboljenja, nesreća na poslu, zaraznih bolesti, primjerice) i periodične/zbirne (izvješća službe medicine rada; specijalističkih službi; o broju i vrsti izvršenih operacija po odjelima, primjerice). Osnovna medicinska dokumentacija predstavlja primarno registriranje podataka o svakoj osobi kojoj je pružena zdravstvena zaštita, a vodi se u svim zdravstvenim ustanovama i na svim radnim mjestima na kojima se ostvaruje kontakt s korisnicima zdravstvenih usluga. ${ }^{27} \mathrm{U}$ tu bi dokumentaciju mogli, primjerice, svrstati: zdravstveni karton, protokol bolesnika, protokol umrlih, protokol operiranih; protokol intervencija, protokol kućne njege i liječenja; matičnu knjigu osoba smještenih u stacioniranoj zdravstvenoj ustanovi, povijest bolesti; temperaturno-terapijske liste; dijetetske liste; otpusne liste s epikrizom; liste anestezije; karton o potrošnji lijekova; razne knjige evidencije itd. ${ }^{28}$

U bivšoj SFR Jugoslaviji propisi su predviđali i uređivali različite vrste medicinske dokumentacije. Tako se medicinska dokumentacija dijelila s obzirom na mjesto nastanka (bolnička, ambulantna, zavodska); s obzirom na sadržaj i značaj za državu (onu koja je namijenjena za određene evidencije/registre, koja je namijenjena za medicinske svrhe, odnosno liječenje, te ona koja služi pacijentu za ostvarivanje određenih njegovih prava); s obzirom na njezino vremensko važenje (aktivna i pasivna, odnosno ona u uporabi i arhivirana); s obzirom na nosač sadržaja zdravstvenih podataka (papir, rendgenske snimke, biozapisi, informatički zapisi, elektronske osobne kartice, magnetski i laserski nosači i sl.); te na primarnu i sekundarnu dokumentaciju (nastalu u neposrednom odnosu liječnika i pacijenta, odnosno nastalu kao sinteza različitih primarnih dokumenata). ${ }^{29}$

Iako se pod pojmom „medicinska dokumentacija“ misli prvenstveno na liječničku dokumentaciju, medicinska dokumentacija po svom izvoru nastanka svakako obuhvaća i dokumentaciju koju su priredili i drugi zdravstveni radnici. Tako medicinska dokumentacija u ljekarničkoj djelatnosti obuhvaća: očevidnike koji se vode pri obavljanju ljekarničke djelatnosti; medicinsku dokumentaciju za propisivanje i izdavanje lijekova i medicinskih proizvoda (ZOLJK, čl. 30.). Način propisivanja, vrstu i sadržaj recepta, doznake i medicinskoga dokumenta korisnika na temelju kojeg magistar 
farmacije može izraditi, odnosno izdati lijek ili medicinski proizvod te postupak izdavanja propisuje se posebnim pravilnikom na prijedlog nadležnih komora ministar nadležan za zdravstvo. ${ }^{30}$ Stomatološka dokumentacija sastoji se od kartona sa statusom, povijesti bolesti, rendgenskih snimaka te fotografija (bivši Zakon o stomatološkoj djelatnosti, „Narodne novine“, broj 121/03., dalje - ZOSD, čl. 29. st. 3.).

Vođenje sestrinske dokumentacije, kojom se evidentiraju svi provedeni postupci tijekom 24 sata, jedna je od dužnosti medicinske sestre (ZOS, čl. 16.). Sestrinska dokumentacija sadrži: sestrinsku listu; ${ }^{31}$ sažetak praćenja stanja pacijenta tokom hospitalizacije; sažetak trajnog praćenja postupaka trajno praćenje stanja pacijenta (decursus); plan zdravstvene njege; lista provedenih sestrinskih postupaka; evidencija ordinirane i primijenjene terapije; unos i izlučivanje tekućina; procjena bola; lista za praćenje dekubitusa; nadzorna lista rizičnih postupaka u zdravstvenoj njezi; izvješće o incidentu (spriječenom ili nastalom); otpusno pismo zdravstvene njege; sestrinske dijagnoze proizašle iz obrazaca po Gordonovoj; lista okretanja pacijenta; Braden skala za procjenu sklonosti dekubitusu; Knoll skala; Norton skala; Glagow koma skala; trauma score; Morseova ljestvica za procjenu rizika za pad; upute o vođenju sestrinske liste. ${ }^{32}$ Primjena sestrinske dokumentacije osigurava mogućnost praćenja kvalitete i količine provedenih postupaka, a posebno naglašavamo mogućnost trajnog praćenja stanja bolesnika. Bez evidencije sestrinskog rada izuzetno je teško evaluirati zdravstvenu njegu provedenu u bolničkoj skrbi, a gotovo nemoguće planirati potreban broj medicinskih sestara. Sestrinska dokumentacija također predstavlja zbir podataka koji mogu služiti u istraživačke i statističke svrhe. Dijelovi sestrinske dokumentacije osiguravaju kontinuitet skrbi i pravovremeno uključivanje patronažne službe i djelatnosti zdravstvene njege u kući. Važno je također naglasiti da kroz dokumentiranje sestrinskog rada bolesnik postaje partner u skrbi, čime se uvažavaju odredbe ZOZPP-a. Uvođenje sestrinske dokumentacije predstavlja veliki doprinos poboljšanju bolničke skrbi i njezina primjena može donijeti samo pozitivne učinke kako za pacijente tako i za nadležno ministarstvo. ${ }^{33}$ 
Prava, obveze i odgovornosti radnika u obavljanju djelatnosti: Medicinska dokumentacija

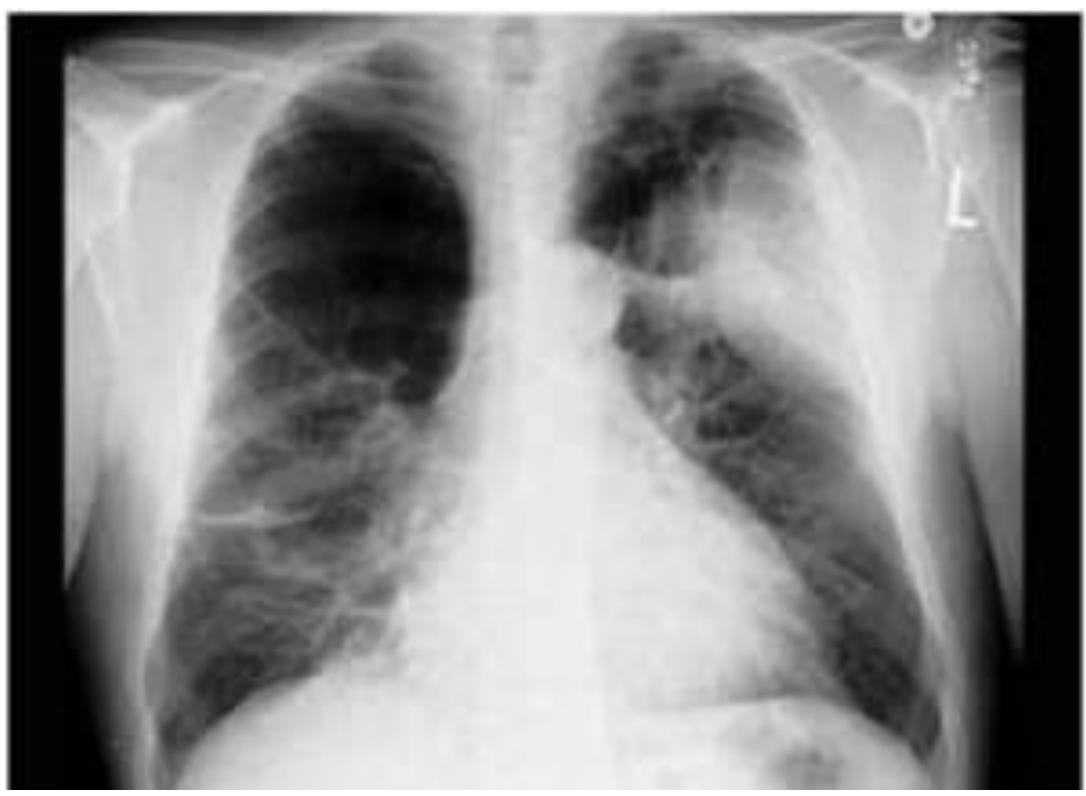

Slika 15

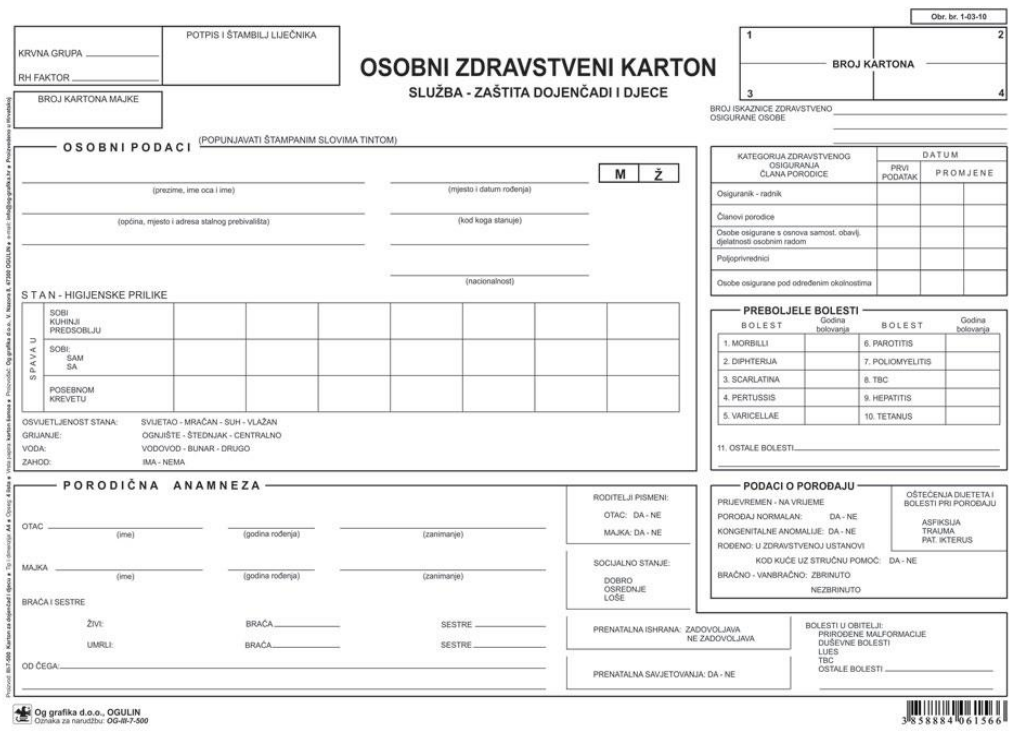

Slika 16 
ZDRAVSTVENO STRUKOVNO STALEŠKO PRAVO

Prava, obveze i odgovornosti radnika u obavljanju djelatnosti: Medicinska dokumentacija

\begin{tabular}{|c|c|c|c|}
\hline Naziv pretrage & Rezultat & Jedinica & Ref. interval \\
\hline Leukociti & 13.3 & $G / L$ & $6.0-16.0$ \\
\hline Neutrofilni granulociti & 5.9 & $G / L$ & $2.0-7.5$ \\
\hline Limfociti & $6.6 \mathrm{H}$ & $G / L$ & $1.40-5.00$ \\
\hline MIO & 0.8 & $G / L$ & $0.2-0.8$ \\
\hline Neutrofilni granulociti $(\%)$ & $45 \mathrm{~L}$ & $\%$ & $50-75$ \\
\hline Limfociti (\%) & 49 & $\%$ & $15-55$ \\
\hline MID (\%) & 6 & $\%$ & $5-8$ \\
\hline Eritrociti & 4.92 & $T / L$ & $4.00-5.00$ \\
\hline Hemoglobin & 134 & $g / L$ & $109-138$ \\
\hline Hematokrit & $0.41 \mathrm{H}$ & $1 / 1$ & $0.320-0.404$ \\
\hline Prosjeèni volumen eritrocita & 83.1 & $\mathrm{fl}$ & $73.8-89.4$ \\
\hline Prosjeèni sadrżaj hemoglobina u eritroci & 27.3 & pg & $24.3-29.2$ \\
\hline Prosjeèna koncentracija hemoglobina u & 327 & $g / L$ & $300-350$ \\
\hline ROW-CV & 13.4 & $\%$ & \\
\hline Trombociti & 309 & $\mathrm{G} / \mathrm{L}$ & $150-450$ \\
\hline Prosjeèni volumen trombocita & 8.1 & fL. & $6.9-11.3$ \\
\hline
\end{tabular}

Slika 17:FN ${ }^{34}$

\subsection{Dužnost vođenja medicinske dokumentacije}

Ranije, dok se držalo da medicinska dokumentacija ima isključivo privatni karakter te da služi liječnicima kao podsjetnik o poduzetim dijagnostičkim i terapijskim mjerama, njezino vođenje nije bilo obvezno. Danas je, pak, prevladavajuće stajalište, a u tom smislu su i brojna zakonodavna rješenja, da je vođenje medicinske dokumentacije opća (javnopravna) dužnost liječnika, odnosno zdravstvenih radnika i zdravstvenih ustanova. Štoviše, ako između pacijenta i liječnika, odnosno zdravstvene ustanove postoji ugovor o medicinskim uslugama, dužnost vođenja medicinske dokumentacije ima istovremeno i zaseban obvezno pravni karakter. ${ }^{35}$ Upisivanje podataka u medicinsku dokumentaciju je dužnost nadležnih osoba $\mathrm{i}$ organa $\mathrm{i}$ obavlja se na temelju rezultata pregleda $\mathrm{i}$ dokumentacije zdravstvene ustanove odnosno na temelju javnih i drugih isprava, te na temelju izjave osobe od koje se uzimaju podaci koji se upisuju u dokumentaciju (Zakon o evidencijama u oblasti zdravstva (Urednički pročišćeni tekst, «Službeni list» broj 22/78 i 18/88 ( ZEOZ), čl. 20.).

Liječnik je dužan voditi točnu, iscrpnu i datiranu medicinsku dokumentaciju u skladu s propisima o evidencijama na području zdravstva, koja u svakom trenutku može pružiti dostatne podatke o zdravstvenom stanju pacijenta i njegovu liječenju (ZOL, čl. 23. st. 1.). U slučaju preseljenja pacijenta, odnosno ako pacijent izabere drugog liječnika, liječnik, zdravstvena ustanova, trgovačko društvo, odnosno druga pravna osoba koja obavlja zdravstvenu djelatnost, dužni su novoizabranom liječniku predati svu zdravstvenu dokumentaciju o pacijentu te sukladno propisima o vođenju i čuvanju medicinske dokumentacije pohraniti potpisanu izjavu o preuzetoj medicinskoj dokumentaciji. (ZOL, čl. 25.). 
I zdravstveni radnici privatne prakse dužni su voditi zdravstvenu dokumentaciju i drugu evidenciju o osobama kojima pružaju zdravstvenu zaštitu i podnositi izvješće o tome nadležnoj zdravstvenoj ustanovi u skladu s propisima o evidencijama u djelatnosti zdravstva (ZOZZ, čl. 149. st. 1. t. 3.).

Doktor stomatologije dužan je voditi točnu, iscrpnu i datiranu stomatološku dokumentaciju o stanju pacijenta i njegovu liječenju u skladu s propisima o evidencijama na području zdravstva, te je dužan tu dokumentaciju na zahtjev predočiti ministarstvu nadležnom za zdravstvo, tijelima državne uprave u skladu s posebnim propisima, Komori ili sudbenoj vlasti (ZODM, čl. 29. st. 1.).

Medicinski biokemičar dužan je voditi točnu, iscrpnu i datiranu medicinsku dokumentaciju u skladu s propisima o evidencijama na području zdravstva, koja u svakom trenutku može pružiti dostatne podatke (ZOMBD, čl. 18. st. 1.). Ova odredba posebno je značajna u medicinsko-biokemijskoj djelatnosti, jer je dijagnostika temelj za postavljanje dijagnoza i daljnje liječenje. ${ }^{36}$

Sanitarni inženjer, radiološki tehnolog, zdravstveni radnik medicinsko laboratorijske djelatnosti odgovoran je za vođenje uredne dokumentacije o izvršenim poslovima, radni terapeut dužan je voditi urednu radno-terapijsku dokumentaciju ${ }^{37}$

Primalja je dužna voditi primaljsku dokumentaciju kojom se evidentiraju svi provedeni postupci tijekom 24 sata (članak 16 Zakona o primaljstvu „Narodne novine“ br. 120/08, $145 / 10)$

Dužnost fizioterapeuta je vođenje točne iscrpne i datirane medicinske dokumentacije sukladno usuglašenim standardima ne europskoj razini kojom se evidentiraju svi provedeni postupci i koja u svakom trenutku može pružiti dostatne podatke o stanju pacijenta u svima fazama fizikalne terapije. Fizioterapeut je dužan evidentirati sve postupke na fizioterapeutskom kartonu. Obvezan sadržaj kartona je početna procjena i dokumentacija za svakog pacijenta, periodična evaluacija i njezino dokumentiranje za svakog pacijenta, dokumentirano otpuštanje pacijenta, datum i vrijeme pružene usluge, plan terapije i cilj terapije.

\subsection{Uredno vođenje medicinske dokumentacije}

Potpuna, precizna, jasno i uredno vođena medicinska dokumentacija najznačajniji je činitelj za dobivanje relevantnih podataka o kakvoći obnašanja liječničke djelatnosti. ${ }^{38}$ Medicinska dokumentacija je uredno vođena i onda ako zabilježeni podaci nisu jasni medicinskom laiku, jer je bitno da budu razumljivi stručnjaku.

Medicinska dokumentacija koja se uručuje pacijentu po završenom liječničkom pregledu, odnosno po završenom liječenju, propisuje se posebnim zakonom/zakonima kojim(a) se uređuju vrste i sadržaj te način vođenja, čuvanja, prikupljanja i raspolaganja medicinskom dokumentacijom (ZOL, čl. 23. st. 3.). Način vođenja, čuvanja, prikupljanja i raspolaganja 
Prava, obveze i odgovornosti radnika u obavljanju djelatnosti: Medicinska dokumentacija

medicinskom dokumentacijom treba podrobnije pravilnikom propisati ministar nadležan za zdravstvo (ZOZZ, čl. 122. st. 5.).

Zbog nevođenja ili neurednog vođenja medicinske dokumentacije pacijent može doživjeti značajnu štetu. Primjerice, zbog nedostatka podataka ili pogrešnih podataka u medicinskoj dokumentaciji liječnik može steći pogrešnu predstavu o zdravstvenom stanju pacijenta, može postaviti pogrešnu dijagnozu i odrediti neodgovarajuću terapiju, a zbog nedostataka u vođenju ili nevođenja medicinske dokumentacije pacijentu može biti onemogućeno i da dokaže svoje pravo na naknadu štete zbog liječničke pogreške. Uvidom u praksu u (stacioniranim) zdravstvenim ustanovama mogu se naći brojni primjeri neurednog vođenja dokumentacije, s puno grješaka, mijenjanja dokumentacije, dodavanja podataka i sl., pa se donošenjem ZOZPP-a nastojalo otkloniti navedene propuste. ${ }^{39}$

Za točnost i potpunost upisanih podataka odgovoran je (zdravstveni) radnik koji podatke upisuje, kao i osoba od koje se podaci uzimaju i koja je dala izjavu o podacima koji se upisuju u medicinsku dokumentaciju (ZEOZ, čl. 22.). ${ }^{40}$

Ako pacijenta liječi više zdravstvenih radnika ${ }^{41}$ zajedno (primjerice, kod obavljanja operativnog zahvata), svaki od njih bi trebao zasebno sačiniti zabilješku o svojim radnjama, svakako ako se te radnje mogu odvojiti (primjerice, anesteziolog i operater). U protivnom, odgovorni liječnik treba upisati i radnje svojih suradnika. ${ }^{42}$

U slučaju preseljenja pacijenta, odnosno ako pacijent izabere drugog liječnika, tada liječnik, zdravstvena ustanova, trgovačko društvo, odnosno druga pravna osoba koja obavlja zdravstvenu djelatnost, obvezni su novoizabranom liječniku predati svu zdravstvenu dokumentaciju o pacijentu te sukladno propisima o vođenju i čuvanju medicinske dokumentacije pohraniti potpisanu izjavu o preuzetoj medicinskoj dokumentaciji (ZOLJ, čl. 25.).

Liječnik je ovlašten izdavati liječničke svjedodžbe samo nakon liječničkog pregleda i uvida u postojeću medicinsku dokumentaciju osobe za koju se izdaje svjedodžba i nakon točno utvrđenih činjenica koje treba potvrditi u svjedodžbi, prema svom najboljem znanju i savjesti. (ZOL, čl. 24.)

Liječnik je dužan medicinsku dokumentaciju voditi pravovremeno. Liječnik bi trebao sukcesivno unositi zabilješke u medicinsku dokumentaciju, neposredno nakon poduzetih dijagnostičkih i terapijskih mjera, dok su mu još svježe impresije o pojedinostima liječenja pacijenta. Dužnost pravovremenog vođenja medicinske dokumentacije svakako uključuje i dužnost pravovremenog izdavanja dokumentacije pacijentu. Primjerice, pravovremenog izdavanja otpusnog pisma pacijentu radi ostvarenja preporučene daljnje zdravstvene zaštite.

Osim što mora biti pravovremena, medicinska dokumentacija mora biti potpuna i istinita, odnosno točna. ${ }^{43}$ 
Pacijentu se mora priznati pravo da od liječnika koji ga je liječio zatraži da sačini, ispravi ili dopuni medicinsku dokumentaciju. ${ }^{44}$ Dakle, pacijent svakako ima pravo tražiti ispravak, dovršenje, poništenje i ažuriranje osobnih i medicinskih podataka koji se odnose na njega, a koji nisu točni, dovršeni, jasni i ažurirani ili nisu bitni za dijagnozu, liječenje i skrb. ${ }^{45}$ Pogrešni podaci o zdravstvenoj skrbi ne smiju se brisati nego ih se ispravlja tako da je uvijek moguće rekonstruirati podatke koji su prvotno bili uneseni.

Prema stajalištu sudske prakse, u pravilu se drži da je ono što je upisano u medicinskoj dokumentaciji istinito, odnosno stvarno i učinjeno, a da se ono o čemu nema pisanog traga nije ni dogodilo. ${ }^{46}$

Medicinska dokumentacija mora biti pisana čitkim i razumljivim stilom (najbolje je da bude pisana pisaćim strojem ili na računalu) i mora biti adekvatan odraz tretmana koji je pacijentu pružen. ${ }^{47}$

Odredbama čl. 12. st. 5. ZOZZ-a određeno je da će se način vođenja, čuvanja, prikupljanja i raspolaganja medicinskom dokumentacijom propisati pravilnikom kojeg treba donijeti ministar nadležan za zdravstvo. ${ }^{48}$ Ova je odredba u suprotnosti s odredbom čl. 23. st. 3. ZOZPP-a prema kojoj se medicinska dokumentacija koja se uručuje pacijentu po završenom liječničkom pregledu, odnosno po završenom liječenju propisuje treba propisati posebnim zakonom kojim se uređuju vrste i sadržaj te način vođenja, čuvanja, prikupljanja i raspolaganja medicinskom dokumentacijom.

Koliko nam je poznato zakonodavac, odnosno ministar nadležan za zdravstvo nisu još donijeli niti posebni zakon niti (sveobuhvatni) pravilnik ${ }^{49}$ kojim bi se uredilo vrste i sadržaj, te način vođenja, čuvanja, prikupljanja i raspolaganja medicinskom dokumentacijom. Treba ipak napomenuti da su doneseni i neki provedbeni pravilnici kojima se izravno ili posredno uređuje i problematika medicinske dokumentacije, ali samo za pojedina područja zdravstvene djelatnosti, ${ }^{50}$ o čemu će se detaljnije elaborirati u nastavnom poglavlju VII/. Do donošenja ovih posebnih propisa, vođenje i sadržaj medicinske dokumentacije u Republici Hrvatskoj još uvijek je uređen, među ostalim, i preuzetim ZEOZ-om. Naime, Republika Hrvatska preuzela je ZEOZ kao republički zakon Zakonom o preuzimanju saveznih zakona iz oblasti zdravstva koji se u Republici Hrvatskoj primjenjuju kao republički zakoni («Narodne novine», br. 53/91, v. čl. 1. točka 1.). ${ }^{51}$ ZEOZ propisuje da pri vođenju evidencije treba primjenjivati jedinstvena metodološka načela i statističke standarde (definicije, klasifikacije, nomenklature - v. ZEOZ, čl. 4.). Zdravstvene ustanove, trgovačka društva za obavljanje zdravstvene djelatnosti i zdravstveni radnici koji obavljaju privatnu praksu dužni su voditi evidenciju o posjetima, zdravstvenim uslugama, utvrđenim bolestima, stanjima i ozljedama (ZEOZ, čl. 1. t. 7.), koja treba sadržavati podatke o: 1/ datumu posjeta i vrsti pružene usluge; 2/ rezultatu pregleda, dijagnozi odnosno utvrđenom stanju; 3/ terapiji; 4/ komplikacijama za vrijeme liječenja; 5/ rehabilitaciji; 6/ uzroku privremene nesposobnosti odnosno spriječenosti za rad; 7/ trajanju privremene nesposobnosti odnosno spriječenosti za rad; 8/ ocjeni radne sposobnosti; 9/ uzroku smrti. Usto, zdravstvene ustanove koje pružaju stacionarnu zdravstvenu zaštitu, trebaju, pored navedenih podataka, voditi i evidenciju koja sadrži podatke o: 1/ trajanju i ishodu stacionarnog liječenja; 2/ datumu i vrsti 
Prava, obveze i odgovornosti radnika u obavljanju djelatnosti: Medicinska dokumentacija

izvršenih kirurških zahvata (v. ZEOZ, čl. 12.). Osim navedenih, u medicinskoj dokumentaciji treba evidentirati i opće podatke o pregledanim, oboljelim, ozlijeđenim, liječenim i drugim osobama kojima je pružena zdravstvena zaštita, i to: 1/ ime, prezime i jedinstveni matični broj; 2/ spol; 3 / dan, mjesec i godina rođenja; 4/ bračno stanje; 5/ zanimanje; 6 / mjesto i adresu stalnog boravka; 7 / oblik zdravstvene zaštite; 8 / registarski broj i šifru djelatnosti; 9/ kategoriju zdravstvenog osiguranja; 10/ osobni broj osiguranika (ZEOZ, čl. 18.).

Obveza čuvanja liječničke tajne odnosi se i proteže i na čuvanje tajnosti medicinske dokumentacije, jer upravo medicinska dokumentacija sadrži najviše podataka o zdravstvenom stanju pacijenta.

Tijekom obavljanja svoje profesije liječnik može otkriti ili utvrditi određene činjenice kod pacijenta koje nisu općepoznate i za koje pacijent ne želi da ih drugi doznaju. Saznanje takvih činjenica naziva se i predstavlja liječničku tajnu (engl. medical professional secret, franc. secret professionnel des medecins, secret medical, tal. segreto medico, njem. artzliches Berufsgeheimnis). Liječnička tajna je vrsta pozivne ili profesionalne tajne koja je vezana za obavljanje liječničkog poziva. ${ }^{52}$ Pojam «čuvanja tajne» uvijek je pratio i uvijek će neminovno pratiti zdravstvenu struku, a sam će se sadržaj pojma prilagođavati razvitku znanosti i društva. ${ }^{53}$ Sve ono što je liječnik obavljajući svoju dužnost saznao smatra se liječničkom tajnom (KMED, čl. 2. st. 13.), a posebno sve ono što liječnik sazna o pacijentu koji mu se obrati za liječničku pomoć, a u svezi s njegovim zdravstvenim stanjem, mora čuvati kao liječničku tajnu (ZOL, čl. 19.). ${ }^{54}$ Da bi neki podatak, odnosno činjenica imala karakter tajnosti, nije potrebno da pacijent posebno i izričito napomene njezinu povjerljivost, nego liječnik mora sam prosuditi stupanj povjerljivosti pojedinih činjenica. ${ }^{55}$ Korist od čuvanja liječničke tajne ne bi trebalo procjenjivati po objektivnom kriteriju (kako bi se netko drugi na pacijentovom mjestu prema njoj odnosio), nego prema subjektivnom kriteriju, bez pravnog i moralnog vrednovanja, ${ }^{56}$ odnosno osoba na koju se tajna odnosi mora i sama željeti da podatak bude nedostupan trećima. Apsolutna obveza čuvanja liječničke tajne mogla se zahtijevati i poštivati dok je postojao samo neposredni odnos između liječnika i pacijenta. Sa socijalizacijom medicine pored liječnika u liječenju bolesnika sudjeluje čitav niz osoba kao što su medicinske sestre, ljekarnici, stomatolozi, laboranti, bolničari, studenti, pa i administrativno osoblje, i sve su te osobe na neki način upućene u određenu tajnu. Zaštita liječničke tajne postaje sve teža i zbog kompjuterizacije medicinske dokumentacije, telemedicine i elektroničke obrade podataka, ${ }^{57}$ obavljanja medicinske intervencije u različitim ustanovama, sudjelovanja u pružanju medicinske usluge sve većeg broja osoba i sve više vrsta zdravstvenih radnika, ali i zbog sve većeg opravdanog ili neopravdanog interesa javnosti i medija za informiranjem o zdravstvenom stanju pojedinih pacijenata (javnih osoba, mogućih zaraznih bolesti i sl.). Usto, medicinski podaci danas služe i potražuju ih primjerice osiguravatelji (zbog ocjene rizika na strani osiguranika), poslodavci, ${ }^{58}$ proizvođači lijekova (u marketinške svrhe), banke (ocjena rizika kreditiranja), državna tijela, ${ }^{59}$ kao i u (druge) komercijalne svrhe. ${ }^{60}$ Zbog svega navedenog danas bi mogli govoriti i o službenoj, a ne samo o pozivnoj tajni. Odavanje liječničke tajne ima svoje uzroke i pojavne oblike. Do povrede liječničke tajne dolazi najčešće usmeno ili pisanim putem, ali postoje i drugi načini povrede čuvanja liječničke 
tajne kao primjerice objavljivanje fotografskih snimaka, neopreznim objavljivanjem podataka o pojedinim bolesnicima u stručnoj literaturi i sl. ${ }^{61}$ Do odavanja liječničke tajne može doći nepažnjom, iz neznanja (o pravu na privatnost i o propisima kojom je to pravo zaštićeno) ili namjerno (primjerice, zbog samoisticanja ili koristoljublja). Kao psihološki uzroci koji dovode do odavanja liječničke tajne mogu se navesti lakoumnost, zabluda, prinuda, strast za saznavanjem i odavanjem tajne, koristoljubivi uzroci i psihološka neuračunljivost, ljutnja, tuga i sl. ${ }^{62}$ Pri tome je nebitno na koji je način izvršeno otkrivanje tajne, je li tajna otkrivena jednoj ili više osoba, je li otkrivanje podataka objektivno moglo prouzročiti ili je prouzročilo neke štetne posljedice i sl., a ove okolnosti mogu, u pravilu, biti ocjenjivane kao otegotne okolnosti. ${ }^{63}$ Kontakti sa službama i profesijama nastalih radi zadovoljavanja egzistencijalnih potreba ljudi u velikom broju slučajeva dovode čovjeka u situaciju nužnog odavanja tajnih dijelova osobnosti. ${ }^{64}$ Primjerice, pri izlasku iz bolnice bolesnik dobije otpusnicu u kojoj je ispisana dijagnoza, koju je dužan pokazati poslodavcu radi pravdanja izostanka i odobravanja bolovanja. ${ }^{65}$ Do otkrivanja liječničke tajne može doći i posredno, na zahtjev sudova ili drugih državnih tijela. Primjerice, sud može zahtijevati povijest bolesti nekog pacijenta radi sudsko-medicinskog vještačenja. Međutim, u povijesti bolesti i drugoj dokumentaciji mogu se pored relevantnih nalaziti i takvi podaci koji za sud nisu važni i potrebni u pogledu rješavanja konkretnog spora, a koje je liječnik saznao, utvrdio i zaveo u povijest bolesti i koji kao takvi predstavljaju liječničku tajnu. Otkrivanje i tih podataka zasigurno predstavlja nedopušteno otkrivanje liječničke tajne. ${ }^{66} \mathrm{U}$ bolnicama na krevetu svakog bolesnika izvješene su tzv. temperaturne liste s velikim brojem podataka o bolesniku (ime i prezime, godina rođenja, dijagnoza, zabilješke o temperaturi, pulsu, krvnom tlaku, ordiniranim lijekovima, datumima kirurških intervencija i raznih laboratorijskih pretraga i sl., a te liste stoje otvoreno i pristupačne su svakome tko dođe posjetiti toga ili drugog bolesnika u sobi. ${ }^{67}$ Radnja otkrivanja može se obaviti primjerice i tako što liječnik razgovara telefonom o tajnim podacima u prisustvu treće osobe koja može identificirati pacijenta na kojega se podaci odnose. ${ }^{68}$ Otkrivanje liječničke tajne može se izvršiti i nečinjenjem, odnosno propuštanjem, primjerice ako liječnik pacijentovu medicinsku dokumentaciju ne pohrani na propisani način i time omogući neovlaštenim trećim osobama da je razgledaju ili odnesu. ${ }^{69}$

Zdravstveni radnici dužni su čuvati kao profesionalnu tajnu sve što znaju o zdravstvenom stanju pacijenta. Na čuvanje profesionalne tajne obvezni su i drugi radnici u zdravstvu koji za nju saznaju u obavljanju svojih dužnosti, te studenti i učenici škola zdravstvenog usmjerenja, kao i sve druge osobe koje u obavljanju svojih dužnosti dođu do podataka o zdravstvenom stanju pacijenta. Iznimno, navedene osobe dužne su podatke o zdravstvenom stanju pacijenta priopćiti na zahtjev ministarstva nadležnog za zdravstvo, drugih tijela državne uprave u skladu s posebnim propisima, nadležne komore ili sudbene vlasti (ZOZZ, čl. 122.). ${ }^{70}$ Svi ovlaštenici koji ne bilo koji način dođu u posjed medicinske dokumentacije dužni su je čuvati poštivajući odredbe o tajnosti podataka. Tako na primjer nadležno ministarstvo može doći na posredan ili neposredan način do medicinske dokumentacije pa se odredbe o dužnosti čuvanja tajne odnose i na one službenike koji imaju neposredan uvid u sadržaj medicinske dokumentacije. Nadležne Komore zdravstvenih radnika također su dužne poštivati odredbe o čuvanju tajne iz medicinske 
ZDRAVSTVENO STRUKOVNO STALEŠKO PRAVO

Prava, obveze i odgovornosti radnika u obavljanju djelatnosti: Medicinska dokumentacija

dokumentacije i slučajevima kada poduzimaju određene mjere i aktivnosti iz svoje nadležnosti.

Kod pretrage liječničke ordinacije ne smije biti povrijeđena tajnost liječničke dokumentacije i predmeta na štetu pacijenata. Pregled liječničke ordinacije treba se ograničiti na pregled samo onih dokumenata i predmeta koji su u izravnoj svezi s kaznenim djelom zbog kojeg se vodi postupak. (ZOL, čl. 26. st. 4.). U suprotnom, pribavljeni dokazi ne mogu se upotrijebiti u postupku protiv liječnika i njegovih pacijenata. (ZOL, čl. 26. st. 5.) ${ }^{71}$

Kako ne postoji idealna zaštita digitalnih podataka, posebne mjere zaštite treba posvetiti medicinskoj dokumentaciji, odnosno podacima o zdravstvenom stanju pacijenta pohranjenim na elektronskim nosačima podataka, jer su posebno podložni i izloženi zlouporabama, ponajviše u obliku neovlaštenog korištenja podataka od strane drugih osoba. ${ }^{72}$ Liječnik ili odgovorna osoba zdravstvene ustanove, trgovačkog društva ili druge pravne osobe koja obavlja zdravstvenu djelatnost dužni su dokumentaciju koja se čuva na elektronskom mediju osigurati od mijenjanja, prijevremenog uništenja ili nedopuštenog korištenja. (ZOL, čl. 23. st. 2.)

Podatke koji se unose u evidenciju o posjetima, zdravstvenim uslugama, utvrđenim bolestima, stanjima i ozljedama treba čuvati kao podatke trajne vrijednosti (ZEOZ, čl. 23.), a mogu se čuvati i na mikrofilmu. ${ }^{73}$ Primjerice, javno arhivsko gradivo koje se odnosi na osobne podatke, pa tako i na liječničku dokumentaciju, dostupno je za korištenje 70 godina nakon svoga nastanka, odnosno 100 godina od rođenja osobe na koju se odnosi (Zakona o arhivskom gradivu i arhivima, »Narodne novine«, br. 105/97., dalje - ZAGA, čl. 21. st. 1.) ${ }^{74}$ a pravo na njezino korištenje imaju svi korisnici pod jednakim uvjetima (ZAGA, čl. 18.). Medicinska dokumentacija, kao javno arhivsko gradivo u arhivima, daje se na korištenje u službene svrhe, za znanstveno istraživanje i u publicističke svrhe, za potrebe nastave, za izložbe i objavljivanje, radi ostvarenja ili zaštite osobnih prava i u druge opravdane svrhe (ZAGA, čl. 19.).

Čuvanje medicinske dokumentacije ne može, ipak, trajati beskonačno. Usto, svi oblici medicinske dokumentacije nemaju trajnu vrijednost i vrijeme za koje ih treba čuvati različito je i nedovoljno precizno određeno. U medicinsko pravnoj teoriji postoji mišljenje da bi medicinsku dokumentaciju, kao dokazno sredstvo, trebalo čuvati najmanje do isteka roka zastare gonjenja zbog kaznenog djela nesavjesnog liječenja i potraživanja za naknadu štete zbog liječničke pogreške. ${ }^{75}$

Posebno značajna odredba ZOL-a jest ona o dužnosti čuvanja medicinske dokumentacije koju bi svaki liječnik morao dobro proučiti i primjenjivati u svome radu. ${ }^{76}$ Naime, liječnik ili odgovorna osoba zdravstvene ustanove, trgovačkog društva ili druge pravne osobe koja obavlja zdravstvenu djelatnost dužni su čuvati podatke o ambulantnom liječenju bolesnika deset godina nakon završenog liječenja, a nakon toga roka obvezni su postupiti prema propisima o čuvanju dokumentacije. (ZOL, čl. 23. st. 4.). Ako pacijent preseli, odnosno ako pacijent izabere drugog liječnika, tada su liječnik ili odgovorna osoba zdravstvene ustanove, trgovačkog društva ili druge pravne osobe koja obavlja 
zdravstvenu djelatnost, dužni novoizabranome liječniku predati svu medicinsku dokumentaciju o pacijentu te sukladno propisima o vođenju i čuvanju medicinske dokumentacije pohraniti propisanu izjavu o preuzetoj medicinskoj dokumentaciji. ${ }^{77}$

Doktor stomatologije obvezan je čuvati podatke o liječenju pacijenta deset godina nakon završenog liječenja, a nakon toga roka obvezan je postupiti prema propisima o čuvanju dokumentacije (bivši ZOSD, čl. 29. st. 5.). ${ }^{78}$ Kod pretrage stomatološke ordinacije ne smije biti povrijeđena tajnost stomatološke dokumentacije i predmeta na štetu pacijenata, a pregled stomatološke ordinacije treba ograničiti samo na one dokumente i predmete koji su u izravnoj vezi s kaznenim djelom zbog kojeg se vodi postupak (bivši ZOSD, čl. 29. st. 4.). Dokazi pribavljeni u protivnosti s ovim odredbama ne mogu se upotrijebiti u postupku protiv doktora stomatologije i njegovih pacijenata. ${ }^{79}$

ZOMBD ne određuje rok čuvanja medicinsko-biokemijske dokumentacije, ali bi taj rok trebao biti jednak kao i za čuvenje dokumentacije u ostalim zdravstvenim djelatnostima, odnosno deset godina. ${ }^{80}$ Kod pretrage medicinsko-biokemijskog laboratorija ne smije biti povrijeđena tajnost medicinsko-biokemijske dokumentacije i predmeta na štetu pacijenata. Pregled medicinsko-biokemijskog laboratorija treba ograničiti samo na pregled onih dokumenata i predmeta koji su u izravnoj svezi s kaznenim djelom zbog kojeg se vodi postupak (ZOMBD, čl. 19. st. 4.). Dokazi pribavljeni u protivnosti s ovim odredbama ne mogu se upotrijebiti u postupku protiv medicinskog biokemičara i njegovih pacijenata.

Liječnička dokumentacija o liječenju osobe s duševnim smetnjama dostupna je isključivo sudu za potrebe postupka koji je u tijeku i sadržava samo one podatke koji su prijeko potrebni za ostvarenje svrhe zbog koje se zahtjeva njezina dostava (Zakon o zaštiti osoba s duševnim smetnjama, „Narodne novine“, broj 111/97., 128/99., dalje ZZODS, čl. 18. st. 1. i 2.). Izjave osobe s duševnim smetnjama sadržane u liječničkoj dokumentaciji koje se odnose na počinjenje nekoga kaznenog djela ne mogu se koristiti kao dokaz u sudskom postupku. Podaci iz liječničke dokumentacije koji su potrebni za ostvarenje zdravstvene, socijalne, obiteljsko pravne ili mirovinske zaštite mogu se dati za službene svrhe na zahtjev tijela nadležnih za tu zaštitu samo uz suglasnost osoba $\mathrm{s}$ duševnim smetnjama, a ako one nisu sposobne dati suglasnost onda samo ukoliko se osnovano vjeruje da se osoba s duševnim smetnjama ne bi protivila davanju navedenih podataka (ZZODS, čl. 18. st. 4.). Dakle, za službene svrhe na zahtjev tijela nadležnih za tu zaštitu mogu se dati samo podaci iz liječničke dokumentacije koji su potrebni za ostvarenje zdravstvene, socijalne, obiteljsko pravne ili mirovinske zaštite, a ne i cijela medicinska dokumentacija. ${ }^{81}$

Prema stajalištu medicinsko pravne teorije, greške, odnosno propusti u vođenju medicinske dokumentacije mogu se, u pravilu svrstati u nekoliko skupina: a/ greške i propusti nastali zbog nepoznavanja vrsta povreda; b/ greške i propusti nastali zbog nenavođenja točne lokalizacije povreda; c/ greške i propusti nastali zbog nepotpunog opisivanja povreda; d/ greške i propusti nastali zbog nekritičnog postavljanja dijagnoze. ${ }^{82}$ 
Prava, obveze i odgovornosti radnika u obavljanju djelatnosti: Medicinska dokumentacija

Pacijenti najčešće imaju pritužbe na nemogućnost dobivanja medicinske dokumentacije, te na naknadno mijenjanje, brisanje i dodavanje podataka, ovisno o potrebi onoga od koga se traži medicinska dokumentacija. ${ }^{83}$ Greške se, primjerice, očituju i u tome što se ne navode sve povrede koje je pacijent imao prilikom prijema, nego samo one opasne po život, što nije prepoznata vrsta povrede, ili je pogrešno upisana lokalizacija povrede. ${ }^{84}$ Veličine povreda mjere se uspoređivanjem s nekim predmetima, kao dječji dlan, orah, jaje i sl., a lokalizacija se navodi krajnje neprecizno. ${ }^{85}$ Ponekad su recepti nečitljivi, a uputnice specijalistu ne sadrže sve potrebne podatke. ${ }^{86}$

Jedan od uzroka loše kvalitete medicinske dokumentacije leži i u neafirmativnom (nemarnom, nehajnom, površnom) pristupu liječnika u vođenju medicinske dokumentacije. ${ }^{87}$ Uzrok pogreškama treba tražiti i u tome što liječnik koji pruža prvu pomoć pacijentu ponekad mora prvenstveno misliti na to da mu hitno pomogne i da ga eventualno spasi od smrti, a pri tome ne misli da mu treba osigurati i mogućnost da kasnije ostvari neka svoja prava. ${ }^{88}$

\subsection{Pravo pacijenta na uvid u svoju medicinsku dokumentaciju}

Jedno od pacijentovih prava u ostvarivanju zdravstvene zaštite jest i pravo na pristup medicinskoj dokumentaciji, koje se temelji na pravu pacijenta na obaviještenost o svom zdravstvenom stanju, zajamčenu odredbama čl. 8-15. ZOZPP-a.

Pravo pacijenta na pristup medicinskoj dokumentaciji je strogo osobno pravo pa je pacijent jedini ovlašten koristiti se ovim pravom - pravom na povjerljivost podataka koji se odnose na stanje njegova zdravlja, uz mogućnost da ovo ovlaštenje može prenijeti i na druge osobe. ${ }^{89}$

Svaki pacijent ima pravo uvida u svu medicinsku dokumentaciju koja se tiče njegova zdravstvenog stanja. Pravo na pristup, odnosno uvid pacijenta u svoju medicinsku dokumentaciju odnosi se kako na dokumentaciju koja se uručuje pacijentu nakon završenog liječničkog pregleda, tako i na njegovu cjelokupnu medicinsku dokumentaciju. ${ }^{90}$

Problemi koji se tiču zaštite pacijentove privatnosti i prava pacijenta na pristup i kopiranje medicinske dokumentacije predmet su i posebnog uređenja i ulaze u sadržaj tzv. ugovora o medicinskom tretmanu, temeljem kojega je liječnik, kao davatelj zdravstvene usluge, dužan unijeti u medicinsku dokumentaciju podatke koji se tiču zdravlja pacijenta i postupaka izvršenih nad njim, uključujući i druge dokumente koji sadrže informacije nužne za potrebni standard pažnje. Pacijent, pak kao principal, primatelj zdravstvene usluge, ima pravo na pristup medicinskoj dokumentaciji, ali ne i onda kada bi time bila povrijeđena privatnost drugih osoba. ${ }^{91}$

Pravo na uvid, odnosno na pristup osobnoj medicinskoj dokumentaciji pridonosi odnosu povjerenja između liječnika i pacijenta. Kada bi liječnik pacijentu odbio dopustiti razgledavanje njegove medicinske dokumentacije, to bi moglo dovesti u sumnju kvalitetu $i$ ispravnost pružene zdravstvene zaštite, što bi svakako štetilo i ugledu liječnika. ${ }^{92}$ 
Liječnik je dužan na zahtjev dati na uvid pacijentu svu medicinsku dokumentaciju koja se odnosi na dijagnostiku i liječenje njegove bolesti (ZOLJ, čl. 23. st. 3.). ${ }^{93}$ Pacijent ima pravo na pristup cjelokupnoj medicinskoj dokumentaciji koja se odnosi na dijagnostiku i liječenje njegove bolesti (ZOZPP, čl. 23. st. 1.). Dakle, pravo na pristup medicinskoj dokumentaciji ne odnosi se na podatke o trećim osobama.

Međutim, bez obzira na postojanje propisa, u praksi još uvijek postoje poteškoće oko davanja i dobivanje dokumentacije na uvid, ponajviše zbog toga jer još uvijek nije eksplicitno riješeno pitanje vlasništva medicinske dokumentacije, odnosno je li ta dokumentacija vlasništvo pacijenta ili liječnika (zdravstvenog radnika) koji mu pruža zdravstvenu uslugu/zaštitu, odnosno zdravstvene ustanove u kojoj mu se ta zaštita pruža. ${ }^{94}$

Odredbe ZOZZ-a i ostalih zakona iz područja zdravstva kojima se jamči pravo pacijentima na pristup svojoj medicinskoj dokumentaciji utemeljene su, među ostalim, i na rješenjima utvrđenim Konvencijom o zaštiti ljudskih prava i dostojanstva ljudskog bića u pogledu primjene biologije i medicine ("Narodne novine - Međunarodni ugovori", br. 13/03., 18/03., 3/06., objavom stupila na snagu u odnosu na Republiku Hrvatsku 1. ožujka 2003.), ${ }^{95}$ koja u članku 10. jamči pravo na privatni život i informaciju u pogledu svoga zdravlja. Naime, svatko je ovlašten znati za svaku prikupljenu informaciju o svome zdravstvenom stanju, ali ipak treba uvažiti želje pojedinaca da ne budu informirani, a usto, u iznimnim slučajevima, zakonom se mogu postaviti ograničenja u korištenju navedenog prava $u$ interesu pacijenta. ${ }^{96}$ Zaštita osobnih prava, kao jednog od temeljnih ljudskih prava, zajamčena je i konvencijom Vijeća Europe Convention for the Protection of Individuals with regard to Automatic Processing of Personal Data iz 981. godine (European Treaty Series, No. 108). Konvencija za zaštitu određenih vrsta podataka predviđa dodatne stroge uvjete, među ostalim i za podatke o zdravstvenom stanju pacijenta koji ne smiju biti predmetom automatske obrade podataka ako nacionalnim propisima nije zajamčena učinkovita zaštita. Osoba na koju se medicinski podaci odnose ne bi imala pravo neposrednog pristupa podacima koji su elektronski pohranjeni, nego bi to pravo mogla ostvariti posredstvom liječnika ili druge osobe koja radi u zdravstvenoj ustanovi. ${ }^{97}$ I Europska deklaracija o unapređenju prava pacijenata jamči pacijentima pravo na pristup svojoj medicinskoj dokumentaciji, tehničkim zapisima i svim drugim podacima i zapisima koji se odnose na njihovu dijagnozu, liječenje i njegu, te im jamči i pravo na primjerak njihova dosjea (zdravstvenog kartona) i zapisa ili njihovih dijelova. ${ }^{98}$

Pacijent ima pravo o svome trošku zahtijevati presliku svoje medicinske dokumentacije (ZOZPP, čl. 23. st. 1.). Pravo pacijenta na pristup njegovoj medicinskoj dokumentaciji sadrži, pored prava na uvid i preslikavanje izvorne medicinske dokumentacije, i pravo na obavijest o bitnim aspektima medicinskog tretmana koji je nad njim obavljen, uključujući i imena zdravstvenih radnika koji su sudjelovali u njegovom liječenju kao i podatak o tome gdje se, odnosno kod koga nalazi medicinska dokumentacija i njegovi drugi osobni podaci. ${ }^{99}$ 
ZDRAVSTVENO STRUKOVNO STALEŠKO PRAVO

Prava, obveze i odgovornosti radnika u obavljanju djelatnosti: Medicinska dokumentacija

Treba napomenuti kako je ponekad davanje dokumentacije na uvid u koliziji s dužnosti čuvanja profesionalne tajne, što zdravstvene radnike često dovodi u dvojbu. ${ }^{100}$

Pravo pacijenta na pristup njegovoj medicinskoj dokumentaciji, zajamčeno odredbom čl. 23. ZOZPP-a, ipak može biti podložno određenim ograničenjima. Prema stajalištu medicinsko pravne teorije, liječnik bi mogao pacijentu, primjerice, uskratiti uvid u dokumentacije koja sadrži podatak da boluje od neizlječive bolesti, ${ }^{101}$ uvid u bilješke o subjektivnim dojmovima liječnika o pacijentu i njegovim srodnicima, o privremenoj dijagnozi koja je kasnije odbačena kao pogrešna, o neopravdanim primjedbama pacijenta tijekom liječenja i sl., a ograničenje prava na pristup (uvid) medicinskoj dokumentaciji posebno je izraženo u odnosu na pacijente koji se liječe od psihičkih bolesti. Liječnici bi trebali odrediti koji dijelovi medicinske dokumentacije podliježu navedenim ograničenjima. ${ }^{102}$

Prema odredbama Convention for the Protection of Individuals with regard to Automatic Processing of Personal Data iz 981. godine, pravo na uvid u medicinsku dokumentaciju može biti ograničeno samo u onim slučajevima u kojima je to određeno zakonom, odnosno kada to nalažu razlozi državne i javne sigurnosti ili sprječavanja kaznenih djela; te ako bi pristup medicinskoj dokumentaciji štetio zdravlju osobe na koju se ti podaci odnose i koja zahtjeva uvid u dokumentaciju; ako bi uvid u medicinsku dokumentaciju štetio drugim osobama. ${ }^{103}$

Kao što pacijent ima pravo dati usmenu ili pisanu izjavu o osobama koje mogu biti obaviještene o njegovu prijemu u stacionarnu zdravstvenu ustanovu kao i o njegovom zdravstvenom stanju, tako pacijent može imenovati i osobe kojima zabranjuje davanje tih podataka (ZOZPP, čl. 25. st. 2.). Pristup medicinskoj dokumentaciji ograničen je na određeni krug ovlaštenih osoba koje moraju biti upoznate sa zakonskom regulativom i ograničenjima koja postoje u svezi s pristupom medicinskoj dokumentaciji. ${ }^{104}$

Nakon smrti pacijenta njegova medicinska dokumentacija ne može biti dostupna trećim osobama, nego se mora čuvati kao profesionalna (liječnička) tajna. Ipak, u određenim se slučajevima odstupa od ovako strogog pravila, ponajviše u korist bliskih srodnika i nasljednika. Tako u slučaju smrti pacijenta pravo na uvid u njegovu medicinsku dokumentaciju ima bračni drug pacijenta, izvanbračni drug, punoljetno dijete, roditelj, punoljetni brat ili sestra te zakonski zastupnik, odnosno skrbnik pacijenta (ZOZPP, čl. 24. st. 1.). Svakako, ako to pacijent nije za života izrijekom zabranio. Protivljenje uvidu u medicinsku dokumentaciju tom krugu osoba, pacijent je dužan dati pisanom izjavom solemniziranom od strane javnog bilježnika (ZOZPP, čl. 24. st. 3.). Javni bilježnik je tada dužan cjelovito informirati pacijenta o značenju takve izjave. ${ }^{105}$ Navedene osobe imaju pravo o svom trošku zahtijevati i presliku medicinske dokumentacije. Bliskim srodnicima se priznaje pravo na uvid u medicinsku dokumentaciju umrlog pacijenta primjerice i zbog toga da bi mogli dokazati pogrešku liječnika i/ili drugih zdravstvenih radnika koji su pacijenta liječili, kao bi ostvarili pravo na naknadu štete, a to pravo izvode iz osobnog prava pacijenta koje ne prestaje ni nakon njegove smrti. ${ }^{106}$ 
Liječnik je dužan medicinsku dokumentaciju na zahtjev predočiti ministarstvu nadležnom za zdravstvo, tijelima državne uprave u skladu s posebnim propisima, Hrvatskoj liječničkoj komori ili sudbenoj vlasti (ZOL, čl. 23. st. 1.). Kada ovlaštena osoba sukladno posebnome zakonu preuzme medicinsku dokumentaciju dužna je izdati liječniku, odgovornoj osobi zdravstvene ustanove, trgovačkog društva, odnosno pravne osobe koja obavlja zdravstvenu djelatnost, službenu potpisanu potvrdu o preuzimanju s popisom preuzete medicinske dokumentacije (ZOL, čl. 23. st. 5.)

\subsection{Podzakonski propisi}

Dužnost vođenja, sadržaj i čuvanje medicinske dokumentacije, kao i posljedice nepridržavanja navedenih dužnosti, uređeni su, osim navedenim ZOZZ-om, ZOL-om, ZOZPP-om, svim strukovnim zakonima i brojnim podzakonskim propisima. U pravilu se radi o propisima kojima se uređuje usko specijalizirano područje djelovanja pojedinih zdravstvenih službi, pri čemu se koristi i medicinska dokumentacija, kako ona koju stvara ta zdravstvena služba, tako i ona nastala izvan nje. U pojedinim propisima vođenje, sadržaj i čuvanje medicinske dokumentacije podrobno su uređeni, dok se u drugima medicinska dokumentacija tek uzgredno spominje.

Spomenuli bi samo neke od tih propisa.

\section{Uredba o medicinskom vještačenju u mirovinskom osiguranju}

(«Narodne novine», broj 12/13., dalje - UOMV), kojom se utvrđuje među ostalim način i postupak medicinskog vještačenja u mirovinskom osiguranju te opseg i sadržaj medicinske dokumentacije koju je izabrani doktor medicine primarne zdravstvene zaštite koji je liječio osiguranika dužan prethodno pripremiti i sa svojim nalazom i mišljenjem dostaviti Hrvatskom zavodu za mirovinsko osiguranje radi vještačenja. Pod navedenom medicinskom dokumentacijom podrazumijeva se izvješće s nalazom i mišljenjem izabranog doktora liječnika, otpusno pismo, prijepis povijesti bolesti zdravstvene ustanove u kojoj se osiguranik liječi, specijalističke i laboratorijske nalaze. U iznimnim slučajevima, kada to ovlašteni vještak smatra potrebnim, može se zatražiti od doktora medicine primarne zdravstvene zaštite i prijepis povijesti bolesti, prijepis zdravstvenog kartona, nalaze prethodnog pregleda, sistematskih i periodičnih pregleda (UOMV, čl. 6.).

Pod opsegom medicinske dokumentacije, koja je potrebna za verifikaciju dijagnoze glavne bolesti, podrazumijeva se medicinska dokumentacija koja sadržava podatke: o početku bolesti ili ozljede, uzroku i okolnostima pod kojima je nastala bolest ili ozljeda; o tijeku liječenja osiguranika s naznakom dana do kojeg se liječio, pod kojom dijagnozom i s kakvim uspjehom; te o tijeku medicinske rehabilitacije s naznakom zdravstvenih ustanova u kojima se osiguranik rehabilitirao, razdoblje u kojem je obavljena rehabilitacija, pod kojom dijagnozom i s kakvim uspjehom. Navedena medicinska dokumentacija treba sadržavati i sve podatke o postojećem zdravstvenom stanju, a posebno podatke: o opsegu anatomskog oštećenja; o opsegu funkcionalnog oštećenja; te o prognozi bolesti, odnosno, očekuje li se s vremenom poboljšanje zdravstvenog stanja, nepromijenjeno ili progredijentno pogoršanje zdravstvenog stanja. Medicinska 
Prava, obveze i odgovornosti radnika u obavljanju djelatnosti: Medicinska dokumentacija

dokumentacija potrebna za verifikaciju drugih bolesti koje utječu na radnu sposobnost treba dokazati postojeće stanje, tj. stanje anatomskog i funkcionalnog oštećenja (UOMV, čl. 9.).

Medicinska dokumentacija mora biti jasna i precizna, te sadržavati sve podatke iz pretraga i nalaza koji omogućavaju postavljanje dijagnoze bolesti. Nalaz i mišljenje liječnika mora biti napisano, čitko s iscrpnom anamnezom koja daje uvid u obiteljske, nasljedne i ranije bolesti, u početak, tijek i trajanje sadašnjih tegoba i bolesti. Opis nalaza liječnika mora biti precizan i iscrpan i ne smije sadržavati samo dijagnozu bolesti. Otpusno pismo ili prijepis povijesti bolesti zdravstvene ustanove u kojoj se osiguranik liječio, a koje se prilaže izvješću liječnika, mora sadržavati podatke o svim nalazima i pretragama koje su obavljene prije dolaska u zdravstvenu ustanovu tijekom liječenja ili nakon završenog liječenja, kako bi se verificirala dijagnoza bolesti osiguranika. Specijalistički nalazi moraju biti ispisani čitko, na propisanim obrascima a osim utvrđene dijagnoze moraju biti opisane i anatomske i funkcionalne promjene utvrđene pri specijalističkom pregledu. Klinički nalazi (EKG, spirometrija, B.M., scintigrafija, endoskopija itd.) prilažu se samo ako su učinjeni ambulantno i ako su potrebni za verifikaciju dijagnoze glavne bolesti. Laboratorijski nalazi prilažu se također ako su učinjeni ambulantno i ako su važni radi verifikacije dijagnoze bolesti (UOMV, čl. 10.).

Dakle, pod cjelokupnom medicinskom dokumentacijom podrazumijeva se medicinska dokumentacija koju je liječnik pripremio držeći se odgovarajućih odredaba UOMV koje se odnose na konkretni slučaj, podrazumijevajući pod tim realizaciju medicinskih pretraga samo u onom opsegu koji je potreban za utvrđivanje zdravstvenog stanja. Treba napomenuti da medicinska dokumentacija ne obuhvaća: medicinsku dokumentaciju koju vještak u tijeku vještačenja naknadno pribavlja, a koja UOMV-em nije utvrđena kao obvezna; medicinsku dokumentaciju koju vještak pribavlja u iznimnim slučajevima.(UOMV, čl. 11.).

Pravilnikom o provedbi zakona o evidencijama u oblasti zdravstva za primarnu $i$ specijalističko-konzilijarnu zdravstvenu zaštitu («Narodne novine», broj 4/95.) propisuju se obrasci za izvješćivanje u primarnoj zdravstvenoj zaštiti i specijalističkokonzilijarnoj zdravstvenoj zaštiti prilagođeni desetoj reviziji Međunarodne klasifikacije bolesti i srodnih zdravstvenih problema, ${ }^{107}$ koji se objavljuju kao prilog Pravilniku i čine njegov sastavni dio (Pravilnik, čl. 2.). Hrvatski zavod za javno zdravstvo dužan je sačiniti upute o popunjavanju i primjeni objavljenih izvještajnih obrazaca (Pravilnik, čl. 3.). Propisane obrasce dužne su ispunjavati te dostavljati u propisanim rokovima sve zdravstvene ustanove i zdravstveni radnici privatne prakse. ${ }^{108}$

Pravilnikom o provedbi zakona o evidencijama u oblasti zdravstva na području zdravstvene zaštite gerijatrijskih bolesnika («Narodne novine», broj 82/02.), propisuju se obrasci za izvješćivanje na području zdravstvene zaštite gerijatrijskih bolesnika, tj. bolesnika starijih od 65 godina života. 
Na području zdravstvene zaštite gerijatrijskih bolesnika popunjavaju se: a/ Evidencijska lista za praćenje zdravstvenih potreba starijih osiguranih osoba specifične zdravstvene zaštite u domovima za starije i nemoćne osobe te drugim ustanovama socijalne skrbi (Evidencijska lista br. 1); b/ Evidencijska lista za praćenje zdravstvenih potreba gerijatrijskih bolesnika u gerijatrijskim ustanovama (Evidencijska lista br. 2); te c/ Evidencijska lista za praćenje zdravstvenih potreba starijih osiguranih osoba opće medicine (Evidencijska lista br. 3). Propisani obrazac Evidencijske liste br. 1 obvezni su popunjavati domovi za starije i nemoćne osobe te druge ustanove socijalne skrbi u kojima su smješteni gerijatrijski bolesnici, a propisani obrazac Evidencijske liste br. 2 dužni su popunjavati gerijatrijske zdravstvene ustanove u kojima su smješteni gerijatrijski bolesnici. Propisani obrazac Evidencijske liste br. 3 obvezni su popunjavati doktori opće medicine u ordinacijama primarne zdravstvene zaštite. Popunjeni propisani obrasci dostavljaju se Centru za gerontologiju Zavoda za javno zdravstvo Grada Zagreba.

Prema odredbi čl. 7. Pravilnika o uvjetima i postupku ostvarivanja prava iz obveznog zdravstvenog osiguranja s osnove ozljede na radu i profesionalne bolesti («Narodne novine», broj 75/14, 154/14, 79/13, 139/15, 105/15, 40/17 66/17.), prijava o ozljedi na radu, odnosno profesionalnoj bolesti podnosi se na tiskanicama koje, u pogledu prijave o ozljedi na radu, sadrži: podatke o Zavodu i radnjama područnog ureda Zavoda; podatke o ozlijeđenoj osobi; podatke o ozljedi na radu, podatke o neposrednom rukovoditelju, podatke o osobi koja je popunila tiskanicu, prijave, potpis podnositelja, izvješće izabranog doktora opće/obiteljske medicine

Što se prijave o profesionalnoj bolesti tiče, pored podataka o Zavodu i radnjama područnog ureda Zavoda; osnovnih podataka o podnositelju prijave; osobnih podataka oboljeloj osobi; podataka o prezimenu, imenu te funkciji radnika pod čijim neposrednim rukovođenjem je obavljan rad pri kome je nastao događaj na radu; podataka o prezimenu, imenu i funkciji te vlastoručnog potpisa ovlaštenog radnika - poslodavca koji podnosi prijavu, prijava treba sadržavati i podatak o bližoj oznaci mjesta na kojem je radnik obolio od profesionalne bolesti; podatak o nazivu ovlaštene zdravstvene ustanove odnosno ovlaštenog specijalista medicine rada u privatnoj praksi koji su utvrdili profesionalno oboljenje; podatak o datumu kada je utvrđeno da je radnik obolio; podatak o nazivu profesionalne bolesti utvrđene Zakonom o listi profesionalnih bolesti i druge propisane podatke.

Prema odredbama Pravilnika o pravima, uvjetima $i$ načinu ostvarivanja prava iz obveznog zdravstvenog osiguranja («Narodne novine», broj 49/14, 51/14, 11/15, 17/15, 123/16.), kojim se uređuju uvjeti i način ostvarivanja prava osiguranih osoba Hrvatskog zavoda za zdravstveno osiguranje iz obveznog zdravstvenog osiguranja te obveze osiguranih osoba u ostvarivanju tih prava, osigurana osoba primarnu zdravstvenu zaštitu ostvaruje kod izabranog doktora primarne zdravstvene zaštite - obiteljske (opće) medicine, ginekologa, dentalne medicine i pedijatra, kojeg bira na način propisan općim aktom Zavoda o izboru doktora primarne zdravstvene zaštite. Iznimno osigurana osoba koja privremeno boravi izvan mjesta prebivališta, odnosno boravišta (npr. službeni put, godišnji odmor) ima pravo u slučaju npr. traume, akutne upalne i zarazne bolesti, akutnog poremećaja koji zahtijeva terapijsko zbrinjavanje i sl. koristiti primarnu zdravstvenu 
Prava, obveze i odgovornosti radnika u obavljanju djelatnosti: Medicinska dokumentacija

zaštitu, osim utvrđivanja privremene nesposobnosti za rad, kod bilo kojeg ugovornog doktora primarne zdravstvene zaštite $u$ mjestu privremenog boravišta, $\mathrm{u}$ istom opsegu kao i kod izabranog doktora primarne zdravstvene zaštite (lijekove propisane na e-recept i primarnu laboratorijsku dijagnostiku propisanu na e-uputnicu za primarni laboratorij). Ugovorni doktor nakon pružene zdravstvene zaštite izdaje osiguranoj osobi povijest bolesti na tiskanici Povijest bolesti iz ordinacije primarne zdravstvene zaštite, koju ovjerava svojim potpisom i pečatom ordinacije. Tiskanica Povijesti bolesti iz ordinacije primarne zdravstvene zaštite mora sadržavati podatke o: doktoru primarne zdravstvene zaštite i ordinaciji, osiguranoj osobi, utvrđenom zdravstvenom stanju na dan izdavanja povijesti bolesti i ordiniranoj terapiji (Pravilnik čl. 20) . Osigurana osoba specijalističkokonzilijarnu zdravstvenu zaštitu te bolničku zdravstvenu zaštitu ostvaruje na osnovi izdane uputnice, a samo iznimno u slučajevima pružanja hitne medicinske pomoći bez uputnice. Uputnicu za specijalističko-konzilijarnu i bolničku zdravstvenu zaštitu izdaje izabrani doktor primarne zdravstvene zaštite: - obiteljske (opće) medicine - pedijatar ginekolog - dentalne medicine. O potrebi upućivanja na specijalističko-konzilijarnu zdravstvenu zaštitu osim izabranog doktora odlučuje doktor specijalist školske medicine, doktor specijalist epidemiolog, odnosno doktor specijalist javnog zdravstva (članak 40). Osigurana osoba u okviru prava na zdravstvenu zaštitu ostvaruje pravo na ortopedska i druga pomagala koja su utvrđena osnovnom i dodatnom listom pomagala pod uvjetima i na način propisan Zakonom i posebnim općim aktom Zavoda o ortopedskim i drugim pomagalima (Pravilnik čl. 42.) . Osigurana osoba u okviru prava na zdravstvenu zaštitu ima pravo na dentalna pomagala koja su utvrđena osnovnom i dodatnom listom dentalnih pomagala Zavoda pod uvjetima i na način propisan Zakonom i posebnim općim aktom Zavoda o dentalnoj zdravstvenoj zaštiti (Pravilnik čl. 43.) . Osigurana osoba u okviru prava na zdravstvenu zaštitu ima pravo na lijekove koji su utvrđeni osnovnom i dopunskom listom lijekova Zavoda, pod uvjetima i na način propisan Zakonom, ovim Pravilnikom i drugim općim aktima Zavoda Osigurana osoba ima pravo u cijelosti na teret sredstava obveznog zdravstvenog osiguranja ostvariti lijekove s osnovne liste lijekova ako su joj na osnovi propisanih medicinskih indikacija propisani na recept $\mathrm{u}$ primarnoj zdravstvenoj zaštititi (Pravilnik čl. 44). Osiguraniku za vrijeme privremene nesposobnosti/spriječenosti za rad pripada pravo na naknadu plaće u slučajevima, pod uvjetima i na način propisan Zakonom i ovim Pravilnikom (članak 45).

Pravilnikom o ortopedskim $i$ drugim pomagalima («Narodne novine», br. 7/12, 14/12, 23/12, 25/12, 45/12, 69/12, 85/12, 92/12, 119/12, 147/12, 21/13, 38/13, 93/ $13,119 / 13,125 / 13,129 / 13,136 / 13,141 / 13,154 / 13,11 / 14,12 / 14,22 / 14,34 / 14,45 / 14$, 54/14, 59/14, 86/14, 92/14, 119/14, 129/14, 149/14, 17/15, 29/15, 77/15, 86/15, 124/15, $129 / 15,132 / 15,139 / 15,25 / 16,30 / 16,106 / 16,108 / 16)$, propisuju se uvjeti i način ostvarivanja prava osiguranih osoba Hrvatskog zavoda za zdravstveno osiguranje iz obveznog zdravstvenog osiguranja na: 1. proteze za ruke, proteze za noge, ortoze, ortoproteze i elektroničke uređaje, ortopedske cipele, pomagala za kretanje, antidekubitalna pomagala, pomagala kod šećerne bolesti, pomagala za probavni sustav i stoma pomagala, pomagala za urogenitalni sustav, obloge za rane, pomagala za disanje, materijal za hemodijalizu i peritonejsku dijalizu kod kuće, očna i tiflotehnička pomagala, slušna i surdotehnička pomagala, pomagala za govor i druga pomagala 2. popravak pomagala 3. rezervne dijelove za pomagala 4. potrošni materijal za pomagala 
Osigurana osoba ostvaruje pravo na pomagala koja su utvrđena Popisom pomagala koji je sastavni dio ovog Pravilnika, a na osnovi medicinske indikacije utvrđene za svako pojedino pomagalo u skladu s Pravilnikom, te odgovarajuće medicinske dokumentacije kojom se dokazuju te indikacije. Pomagala mogu, kao nadležni doktori predlagati, odnosno propisivati: doktori specijalisti određene specijalnosti, odnosno izabrani doktori opće/obiteljske medicine, pedijatri i ginekolozi koji su radnici ugovorne zdravstvene ustanove, odnosno koji su ugovorni doktori privatne prakse s kojima je Zavod sklopio ugovor o pružanju zdravstvene zaštite Nadležni doktor pomagalo propisuje na odgovarajućoj tiskanici potvrde o pomagalu Pomagala, rezervni dio i potrošni materijal, u pravilu se propisuju u količini i za period utvrđen u Popisu pomagala Ako je za ostvarivanje prava na pomagalo potrebno odobrenje liječničkog povjerenstva Zavoda ili liječničkog povjerenstva za ortopedska i druga pomagala Direkcije Zavoda nadležni doktor propisuje pomagalo na odgovarajućoj tiskanici, koju zajedno s medicinskom dokumentacijom i potankim obrazloženjem medicinske indikacije za pomagalo, te tehničkom dokumentacijom osigurana osoba dostavlja radi dobivanja odobrenja područnom uredu Zavoda, odnosno ispostavi područnog ureda Zavoda. Iznimno osigurana osoba može na osnovi odobrenja liječničkog povjerenstva za pomagala Direkcije Zavoda ostvariti pravo na pomagala utvrđena u Popisu pomagala, za koja ne ispunjava propisanu medicinsku indikaciju, ako je prema prijedlogu nadležnog doktora primjena tog pomagala nužna za liječenje i rehabilitaciju osigurane osobe. Za pojedine vrste pomagala, za koja je to utvrđeno u Popisu pomagala, ispunjenje uvjeta za njihovo ostvarivanje utvrđuje i odobrenje za pomagalo daje ovlašteni radnik Zavoda, te kada utvrdi da osigurana osoba ispunjava propisane uvjete za određeno pomagalo ovjerava potvrdu o pomagalu i dodjeljuje joj broj potvrde (Pravilnik čl. 6)

Osigurana osoba ostvaruje pravo na pomagalo, popravak ili rezervni dio, te potrošni materijal za pomagalo iz Popisa pomagala na propisanoj tiskanici potvrde o pomagalu. Potvrda je: 1 . potvrda o ortopedskim i drugim pomagalima 2. potvrda o pomagalima za šećernu bolest 3. potvrda o pomagalima za obloge za rane 4. potvrda o očnim i tiflotehničkim pomagalima 5. potvrda o slušnim i surdotehničkim pomagalima Potvrde ujedno su i računi za isporučeno pomagalo, odnosno popravak pomagala koje ugovorni isporučitelji dostavljaju Zavodu na naplatu. Tiskanice potvrda o pomagalu tiskane su uz Pravilnik i čine njegov sastavni dio (Pravilnik čl. 13)

Potvrde ispunjava nadležni doktor prema kliničkom statusu i medicinskoj dokumentaciji sukladno djelatnosti za koju je sklopio ugovor sa Zavodom te prema prijedlogu nadležnog doktora specijaliste odgovarajuće specijalnosti za pomagala Ako pomagalo kao nadležni doktor propisuje izabrani doktor, pri propisivanju pomagala tiskanici potvrde o pomagalu dodjeljuje četrnaestoznamenkasti broj potvrde. Ako pomagalo propisuje nadležni doktor specijalist određene specijalnosti, tiskanici potvrde o pomagalu broj potvrde dodjeljuje Zavod u postupku utvrđivanja opravdanosti propisivanja pomagala na teret sredstava Zavoda. (Pravilnik čl. 14)

Djelatnost hitne medicine obuhvaća provođenje mjera i postupaka hitnog izvanbolničkog medicinskog zbrinjavanja na mjestu događaja ili u prostoru za reanimaciju/ambulanti 
ZDRAVSTVENO STRUKOVNO STALEŠKO PRAVO

Prava, obveze i odgovornosti radnika u obavljanju djelatnosti: Medicinska dokumentacija

zavoda za hitnu medicinu jedinica područne (regionalne) samouprave ili tijekom prijevoza oboljelih i ozlijeđenih osoba prijevoznim sredstvima hitne medicinske službe u odgovarajuću zdravstvenu ustanovu te provođenje mjera i postupaka hitnog bolničkog medicinskog zbrinjavanja u bolničkoj zdravstvenoj ustanovi. Prema odredbi čl. 19. Pravilnika o uvjetima, organizaciji i načinu obavljanja hitne medicine («Narodne novine», broj 71/16), o radu prijavno dojavne jedinice i timova izvanbolničke hitne medicine vodi se dokumentacija na tiskanim obrascima: obrazac za prijam poziva, obrazac o kretanju timova na terenu, obrazac za primopredaju cestovnog vozila hitne medicine i medicinske opreme, obrazac o izvanrednom događaju, obrazac za trijažu kod većih nesreća, obrazac medicinske dokumentacije o pacijentu Lista A za doktore medicine Tim 1 i Lista B za medicinske sestre - medicinske tehničare Tim 2, obrazac za praćenje postupka oživljavanja (Utstein obrazac) O radu Objedinjenog hitnog bolničkog prijama vodi se evidencija na obrascima: obrazac trijaže, obrazac o izvanrednom događaju, obrazac primarna procjena pacijenta - opservacija u Objedinjenom hitnom bolničkom prijemu s Uputama za primjenu sestrinske dokumentacije u opservaciji Objedinjenog hitnog bolničkog prijama (Pravilnik čl. 19.) Obrasci su sastavni dio medicinske dokumentacije.

Pravilnikom o načinu pregleda umrlih te o utvrđivanju vremena i uzroka smrti («Narodne novine», broj 46/11., 6/13,63/14) utvrđuje se način pregleda umrlih osoba te način utvrđivanja vremena i uzroka smrti (Pravilnik, čl. 1.).

Pri pregledu mrtvozornik utvrđuje smrt, odnosno mrtvorođenost te vrijeme i uzrok smrti. Nakon što je utvrdio smrt, odnosno mrtvorođenost, mrtvozornik treba ispitati okolnosti pod kojima je nastupila te utvrditi uzrok smrti. Podatke o mjestu, vremenu i uzroku smrti umrle osobe prikuplja od ukućana i drugih osoba, koristeći za to i medicinsku dokumentaciju o liječenju umrlog. Građani su obvezni dati mrtvozorniku podatke koji su im poznati i omogućiti mu nesmetano obavljanje pregleda, a doktor medicine koji je u posljednjoj bolesti prije smrti liječio umrlu osobu, dužan je na traženje mrtvozornika dati izvješće radi lakšeg utvrđivanja uzroka smrti (Pravilnik, čl. 8.i 9.).

Pravilnikom o utvrđivanju uvjeta zdravstvene sposobnosti članova posade pomorskih brodova $i$ brodica $i$ jahti («Narodne novine», broj 93/07,107/14) utvrđuju se uvjeti i način obavljanja liječničkih pregleda radi utvrđivanja zdravstvene sposobnosti članova posade pomorskih brodova, brodica i jahti, uvjeti kojima moraju udovoljavati zdravstvene ustanove, odnosno trgovačka društva koja u svom sastavu imaju djelatnost medicine rada ili privatne ordinacije medicine rada za liječničke preglede članova posade; uvjeti kojima mora udovoljavati doktor medicine specijalist medicine rada; uvjeti i način stjecanja i obnavljanja valjanosti Svjedodžbe o zdravstvenoj sposobnosti članova posade pomorskih brodova, brodica i jahti , način vođenja upisnika obavljenih liječničkih pregleda i izdanih Svjedodžbi o zdravstvenoj sposobnosti i čuvanje medicinske dokumentacije (Pravilnik, čl. 1.). 
Prilikom svih liječničkih pregleda ovlašteni specijalist medicine rada može zatražiti uvid u zdravstvenu dokumentaciju osobe na pregledu, a koja je pohranjena kod njegovog izabranog doktora primarne zdravstvene zaštite, drugih doktora medicine ili u drugim zdravstvenim ustanovama. Izjavu o pristanku pristupu medicinskoj dokumentaciji kao i o pristanku na obavljanje probiranog testa na opojne droge i testa na alkohol, osoba na pregledu potpisuje u karton liječničkog pregleda Pravilnik čl. (članak 6.)

Ocjena zdravstvene sposobnosti člana posade upisuje se u »Svjedodžbu o zdravstvenoj sposobnosti članova posade pomorskih brodova, brodica i jahti« koju izdaje zdravstvena ustanova ili ordinacija ovlaštena za pregled članova posade. Svjedodžba iz ovoga članka ima valjanost koja je propisana zakonom i provedbenim propisima. (Pravilnik čl. 33) U zdravstvenoj ustanovi ili ordinaciji ovlaštenoj za liječničke preglede članova posade vodi se upisnik obavljenih liječničkih pregleda i pohranjuju kartoni liječničkih pregleda članova posade.

(Pravilnik čl. 34.) Medicinsku dokumentaciju zdravstvena ustanova ili ordinacija ovlaštena za pregled članova posade, obvezna je čuvati u skladu s propisanim rokovima (Pravilnik čl. 35).

Pravilnikom o poslovima na kojima radnik može raditi samo nakon prethodnog utvrđivanja zdravstvene sposobnosti («Narodne novine», broj 70/10.), utvrđuju, među ostalim, i poslovi na kojima radnik može raditi samo nakon prethodnog utvrđivanja zdravstvene sposobnosti za obavljanje tih poslova, te način utvrđivanja zdravstvene sposobnosti, rokovi u kojima se mora ponoviti utvrđivanje zdravstvene sposobnosti, sadržaj i način izdavanja svjedodžbe o zdravstvenoj sposobnosti (Pravilnik, čl. 1.).Nakon obavljenog zdravstvenog pregleda izdaje se uvjerenje o zdravstvenoj sposobnosti radnika za obavljanje određenih poslova Uvjerenje o zdravstvenoj sposobnosti radnika izdaje zdravstvena ustanova, odnosno trgovačko društvo koje u svom sastavu ima djelatnost medicine rada te specijalist medicine rada u privatnoj praksi (Pravilnik čl. 6.)

Radnik, odnosno poslodavac, imaju na ocjenu zdravstvene sposobnosti pravo žalbe u pisanom obliku, u roku od 15 dana od dana primitka svjedodžbe o zdravstvenoj sposobnosti radnika, komisiji pri Hrvatskom zavodu za medicinu rada koju imenuje ravnatelj Hrvatskog zavoda za medicinu rada za svaki pojedini slučaj podnošenja žalbe. Komisija može donijeti konačnu ocjenu zdravstvene sposobnosti bez ponovnog zdravstvenog pregleda radnika, samo na temelju priložene medicinske dokumentacije i to u roku od 30 dana od dana primitka žalbe. Komisiji mora biti dostupna i medicinska dokumentacija o prethodnim zdravstvenim pregledima radnika, a po potrebi i medicinska dokumentacija od izabranog liječnika primarne zdravstvene zaštite o čijoj se zdravstvenoj sposobnosti odlučuje. Ocjena zdravstvene sposobnosti komisije je konačna i dostavlja se pregledanoj osobi, poslodavcu i Hrvatskom zavodu za medicinu rada (Pravilnik, čl. 7.).

Pravilnikom o načinu vođenja evidencije o izvršenim laboratorijskim ispitivanjima («Narodne novine», broj 23/94.), propisuje se način vođenja evidencije o izvršenim laboratorijskim ispitivanjima i način dostavljanja izvješća o uzročnicima zaraznih bolesti odnosno epidemije zaraznih bolesti (Pravilnik, čl. 1.). Evidenciju su dužne voditi 
Prava, obveze i odgovornosti radnika u obavljanju djelatnosti: Medicinska dokumentacija

zdravstvene ustanove u kojima se obavlja laboratorijsko ispitivanje uzročnika zaraznih bolesti, odnosno epidemije zaraznih bolesti i provjera (verifikacija) laboratorijskog ispitivanja uzročnika zaraznih bolesti radi utvrđivanja dijagnoze (Pravilnik, čl. 2.), te su dužne voditi i knjigu bolesničkih uzoraka za bakteriološku obradu koja mora sadržavati: redni broj pod kojim je zaprimljen uzorak; datum primitka uzorka; ime i prezime bolesnika čiji je uzorak zaprimljen; naziv zdravstvene ustanove iz koje je uzorak poslan; vrstu uzorka; rezultat laboratorijskog ispitivanja (Pravilnik, čl. 3.). Zdravstvene ustanove dužne su dostaviti rezultat laboratorijskog ispitivanja doktoru medicine odnosno doktoru medicine specijalisti koji je zatražio pretragu, te su dužne dostavljati i izvješće o uzročnicima zaraznih bolesti odnosno epidemije zaraznih bolesti, svakih šest mjeseci Hrvatskom zavodu za javno zdravstvo (Pravilnik, čl. 4. i 5.).

Pravilnikom o načinu $i$ rokovima provedbe neposrednog nadzora nad izvorima ionizirajućih zračenja, načinu mjerenja ozračenja djelatnika i bolesnika koji su izloženi ionizirajućim zračenjima, vođenju $i$ sadrz̆aju evidencija $i$ registara te načinu izvješćivanja u vezi s tim zračenjima («Narodne novine», broj 63/00.), propisuju se način i rokovi provedbe neposrednog nadzora nad izvorima ionizirajućih zračenja, način mjerenja osobnog ozračenja djelatnika i bolesnika koji su izloženi ionizirajućim zračenjima, obvezatan sadržaj izvješća o nadzoru i mjerenjima, način vođenja i rokovi čuvanja potrebitih evidencija, te postupak izvješćivanja nadležnih tijela (Pravilnik, čl. 1.).

Hrvatski zavod za zaštitu od zračenja dužan je, na obrascima čiji oblik i sadržaj utvrđuje ravnatelj Hrvatskog zavoda za zaštitu od zračenja i/ili elektroničkim putem, voditi evidencije o ovlaštenim pravnim osobama, o pravnim i fizičkim osobama koje obavljaju djelatnosti s izvorima ionizirajućih zračenja, izvorima ionizirajućih zračenja, o djelatnicima i njihovom ozračenju tijekom rada s izvorima ionizirajućih zračenja i drugim podacima u svezi s ionizirajućim zračenjima. Podaci upisani u evidenciju koja se vodi na elektroničkom računalu upisuju se na odgovarajući medij kao sigurnosna kopija nakon upisa ili nakon upisa promjene (Pravilnik, čl. 37.). Hrvatski zavod za zaštitu od zračenja dužan je voditi i evidencije o pravnim ili fizičkim osobama koje obavljaju djelatnosti s izvorima ionizirajućih zračenja (Pravilnik, čl. 38.), te evidenciju rendgenskih uređaja, akceleratora i drugih uređaja i postrojenja koji proizvode ionizirajuće zračenje, a koriste se u medicini i stomatologiji, gospodarstvu, istraživanjima i javnim djelatnostima, koja sadrži ove podatke (Pravilnik, čl. 39.).

\subsection{Umjesto zaključka - odgovornost za vođenje medicinske dokumentacije}

Svaki liječnik, odnosno zdravstveni radnik koji zabilježi određene podatke u medicinsku dokumentaciju snosi odgovornost za ono što je zabilježio. ${ }^{109}$ Loše vođena i neodgovarajuća medicinska dokumentacija može se smatrati oblikom nesavjesnog liječenja. ${ }^{110}$

Dužnost vođenja medicinske dokumentacije zdravstveni radnici mogu povrijediti na različite načine - propuštanjem (ako dokumentaciju uopće ne vode ili je ne vode potpuno i pravovremeno, odnosno ako je ne čuvaju i pohranjuju u skladu s propisima) ${ }^{111}$ i 
činjenjem (unošenjem netočnih podataka, oštećenjem ili uništenjem, preinakom ili prikrivanjem podataka iz medicinske dokumentacije), a povredu svakako predstavlja i nedopusstanje pacijentu da se upozna sa svojom medicinskom dokumentacijom. ${ }^{112}$ Zbog propusta u vođenju medicinske dokumentacije zdravstveni radnici i zdravstvene ustanove mogu odgovarati prekršajno, stegovno, kazneno i građanskopravno.

U obavljanju inspekcijskih poslova inspektor osobito nadzire i način vođenja i korištenja odgovarajuće medicinske dokumentacije i evidencije (ZOZZ, čl. 173. t. 5.). Zdravstvene ustanove, trgovačka društva i privatni zdravstveni radnici kod kojih se obavlja inspekcijski nadzor dužni su zdravstvenom inspektoru omogućiti obavljanje nadzora i pružiti potrebne podatke i obavijesti. Inspektor u provođenju inspekcijskog nadzora pregledava, među ostalim, i medicinsku dokumentaciju zdravstvene ustanove, trgovačkog društva odnosno zdravstvenog radnika, a inspektor tijekom inspekcijskog nadzora zbog mogućeg prikrivanja dokaza ima pravo privremeno izuzeti predmete i izvornu dokumentaciju, uz potvrdu (ZOZZ, čl. 170.).

Liječnik se može kazniti za prekršaj novčanom kaznom u iznosu od 5. 000, 00 do 10. 000, 00 kuna ako ne vodi i ne čuva medicinsku dokumentaciju u skladu s odredbama čl. 23. ZOL-a (ZOL, čl. 59. t. 5.). Novčanom kaznom u iznosu od 5.000,00 do 10.000,00 kuna može se kazniti za prekršaj magistar farmacije ako bez recepta ili propisane medicinske dokumentacije izda lijek koji ima odobrenje za stavljanje u promet na recept sukladno posebnome zakonu (ZOLK, čl. 53. t. 4.). ${ }^{113}$ Novčanom kaznom u iznosu od $5.000,00$ do $10.000,00$ kuna kaznit će se za prekršaj doktor stomatologije ako ne vodi i ne čuva stomatološku dokumentaciju u skladu s odredbama ZODM-a.

\section{Zdravstvena ustanova i trgovačko društvo koje obavlja zdravstvenu djelatnost} mogu se kazniti za prekršaj novčanom kaznom u iznosu od 10. 000, 00 do 50. 000, 00 kuna ako pacijentima i drugim ovlaštenim osobama uskrati pravo na informiranje o pitanjima koja se tiču njihova zdravlja, što svakako uključuje i pristup medicinskoj dokumentaciji, a odgovorna osoba u zdravstvenoj ustanovi i trgovačkom društvu, te privatni zdravstveni radnik mogu se za navedeni prekršaj kazniti novčanom kaznom u iznosu od 5. 000, 00 do 10. 000, 00 kuna (v. ZOZZ, čl. 192. i 195.). I prema odredbama ZOZPP-a, zdravstvena ustanova i trgovačko društvo koje obavlja zdravstvenu djelatnost mogu se kazniti za prekršaj novčanom kaznom u iznosu od 10. 000, 00 do 50. 000, 00 kuna ako uskrati pacijentu i drugoj ovlaštenoj osobi uvid u medicinsku dokumentaciju protivno odredbama čl. 23. i 24. ZOZPP-a, a za isti prekršaj mogu se kazniti novčanom kaznom u iznosu od 5. 000, 00 do 10. 000, 00 kuna i odgovorna osoba u trgovačkom društvu koje obavlja zdravstvenu djelatnost te privatni zdravstveni radnik (ZOZPP, čl. 41.). Psihijatrijska ustanova treba se kazniti novčanom kaznom u iznosu od 5.000,00 do 300.000,00 kuna za prekršaj ako vodi i postupa s medicinskom dokumentacijom suprotno čl. 18. i 19. ZZOSD-a (ZZOSD, čl. 64. st. 1. t. 6.), a za navedene prekršaje kaznit će se novčanom kaznom u iznosu od 1.000,00 do 10.000,00 kuna osoba čijom je radnjom ostvaren navedeni prekršaj, kao i odgovorna osoba u psihijatrijskoj ustanovi (ZZOSD, čl. 64. st. 2.). 
Prava, obveze i odgovornosti radnika u obavljanju djelatnosti: Medicinska dokumentacija

Eventualna kaznena i prekršajna odgovornost liječnika ili disciplinska odgovornost u zdravstvenoj ustanovi, trgovačkom društvu ili drugoj pravnoj osobi koja obavlja zdravstvenu djelatnost zbog nepoštivanja odredbi kojima se uređuje medicinska dokumentacija, ne isključuje disciplinsku odgovornost liječnika pred Hrvatskom liječničkom komorom. Naime, liječnik je disciplinski odgovoran ako: povrijedi odredbe ZOL-a, povrijedi Kodeks medicinske etike i deontologije Komore, kada svojim ponašanjem prema pacijentu povrijedi ugled liječničke profesije, te ako ne ispunjava Statutom ili drugim općim aktom određene članske obveze prema Komori (ZOL, čl. 50.).

Ako se osobni podaci iz medicinske dokumentacije koriste suprotno zakonom dozvoljenoj svrsi njihova prikupljanja, može se raditi i o kaznenom djelu nedozvoljene uporabe osobnih podataka (KZ, čl. 146.). ${ }^{114}$. U širem smislu može se raditi i o kaznenim djelima neovlaštenog odavanja profesionalne tajne, ili odavanja poslovne ili odavanje službene tajne, odnosno odavanje tajnih podataka (KZ čl. 145.,262., 300., 347. ).

Kako vođenje medicinske dokumentacije nije samo javnopravna, nego i građanskopravna obveza, ispunjenje ove dužnosti moralo bi biti osigurano i sankcijama iz domene građanskog prava - tužbom za ispunjenje i naknadu štete zbog neispunjenja. ${ }^{115}$ 116 


\section{Primjedbe}

${ }^{1}$ Tako i opširnije kod JELENC PUKLAVEC, A., Zdravstvena dokumentacija, zasebnost in kazenski postopek, zbornik «Medicina in pravo», god. 1996.-1998., Maribor, 1998., str. 219.-220.

${ }^{2}$ Usp. TIMOTIĆ, B. - ANĐELSKI, H., Zdravstveno zakonodavstvo, Beograd, 2004., str. 174.-175.

${ }^{3}$ Vidi ČUKIĆ, D., Pravo na medicinsku istinu preko medicinske dokumentacije-teškoće, greške, predlog mjera za njihovo otklanjanje, «Pravni život», vol. LI, 2002., br. 9, str. 260.

${ }^{4}$ Dokument (lat.) jest isprava, odnosno pisani dokaz, a dokumentacija jest materijal koji služi za dokumentiranje. Leksikon JLZ, Zagreb, 1974., str. 222., odnosno pisani ili službeni podaci o nekom predmetu. FILIPOVIĆ, M., Rječnik stranih riječi, Zagreb, 1988., str. 88.

${ }^{5}$ Tako TURKOVIĆ, K. - DIKA, M. - GORETA, M. - ĐURĐEVIĆ, Z., Zakon o zaštiti osoba s duševnim smetnjama s komentarom i prilozima, Zagreb, 2001., str. 116.

${ }^{6}$ Vidi PETROVIĆ, F. - STANOJEVIĆ, S. - MARČETIĆ, LJ., Zaštita i valorizacija medicinske dokumentacije, Beograd, 1995., str. 16.

${ }^{7}$ Zakon o evidencijama u oblasti zdravstva (,"Službeni list SFRJ“, broj 22/78., 18/88., dalje - ZEOZ) na posredan način definira oblik «osnovne medicinske dokumentacije» kao individualni karton, registar knjiga, povijest bolesti, sredstva za automatsku obradu podataka te druga sredstva za vođenje evidencije određena propisom nadležnog organa (ZEOZ, čl. 3. st. 1.).

${ }^{8}$ Vidi JAKŠIĆ, Ž. Medicinska dokumentacija. U: Jakšić, Ž. i sur., Socijalna medicina. Praktikum II. 5. izd., Zagreb, Medicinski fakultet Sveučilišta u Zagrebu, 1989., str. 355.-372.

${ }^{9}$ Usp. JELAČIĆ, O., O nastavi iz sudske medicine na pravnim fakultetima, «Zbornik radova Pravnog fakulteta u Splitu», XIV, 1977., str. 235.

${ }^{10}$ Tako RADIŠIĆ, J., Medicinsko pravo, Beograd, 2004., str. 144.-145.

${ }^{11}$ Vidi OPDERBECKE, H. W. - WEISSAUER, W., Aerztliche Dokumentation und Pflege dokumentation, «Medizinrecht», 1984., br. 6, str. 211.

${ }^{12}$ Tako i podrobnije kod JAKŠIĆ, Ž. Medicinska dokumentacija. U: Jakšić, Ž. i sur., Socijalna medicina.

Praktikum II. 5. izd., Zagreb, Medicinski fakultet Sveučilišta u Zagrebu, 1989., str. 355.-372.

${ }^{13}$ Ibid., str. 355.-372.

${ }^{14}$ Potanje o tome kod MUJOVIĆ-ZORNIĆ, H. - SJENIČIĆ, M., Kodeks lekarske etike kao izraz staleške samoregulative u medicini, «Pravni informator», 2003., str. 6.

${ }^{15}$ Vidi ČUKIĆ, D., Pravo na medicinsku istinu preko medicinske dokumentacije - teškoće, greške, predlog mjera za njihovo otklanjanje, «Pravni život», vol. LI, 2002., br. 9, str. 259.; NIKOLIĆ, K., Krivično-pravna odgovornost ljekara zbog neurednog vođenja medicinske dokumentacije, «Pravni život», 1998., br. 9., str. 268.

${ }^{16}$ Tako RADIĆ, M., Zakon o ljekarništvu, u knjizi Zbirka zdravstvenih zakona s obrazloženjem, Zagreb, 2003., str. 188.

${ }^{17}$ Usp. BOŠKOVIĆ, Z., Zakon o zaštiti prava pacijenata - Reforma zdravstvenog zakonodavstva Republike Hrvatske, «Pravo u gospodarstvu», vol. 44., 2005., br. 1, str. 90.

${ }^{18}$ Vidi kod TURKOVIĆ, K. - DIKA, M. - GORETA, M. - ĐURĐEVIĆ, Z., Zakon o zaštiti osoba s duševnim smetnjama s komentarom i prilozima, Zagreb, 2001., str. 116.

${ }^{19}$ Svrha je temperaturne liste definiranje svakodnevnih terapijskih postupaka, a davanje lijekova mora biti identično zapisu na listi. Liječnik mora upisivati na temperaturnu listu sve lijekove i njihove doze, infuzijske otopine, transfuzije itd., a ti podaci moraju biti sadržani i u otpusnom pismu.

${ }^{20}$ Usp. ČUKIĆ, D., Pravo na medicinsku istinu preko medicinske dokumentacije - teškoće, greške, predlog mjera za njihovo otklanjanje, «Pravni život», vol. LI, 2002., br. 9, str. 261.

${ }^{21}$ Tako TURKOVIĆ, K. - DIKA, M. - GORETA, M. - ĐURĐEVIĆ, Z., Zakon o zaštiti osoba s duševnim smetnjama s komentarom i prilozima, Zagreb, 2001., str. 116.

${ }^{22} \mathrm{U}$ pogledu sadržaja medicinske dokumentacije, Weed je u stručnu literaturu i praksu uveo pojam tzv. «problemima orijentirane dokumentacije». Naime, držao je da se zbog velikog broja nalaza i drugih priloga, te zbog uključenosti u liječenje pacijenta većeg broja zdravstvenih djelatnika, može ponekad izgubiti iz vida temeljni problem zbog kojeg je pacijent pristupio liječenju. Zbog toga je nužno sustavno urediti medicinsku dokumentaciju, pa drži da se ona mora sastojati od 4 temeljna dijela: a/temeljnih podataka o bolesniku (generalije, socijalne prilike, psihološki profil i sl.); b/ lista problema (svi medicinski problemi u užem smislu i socijalnomedicinski problemi); c/ plan za rješenje svih problema (dijagnostički, terapijski, pouke bolesniku, druge aktivnosti za ispunjenje plana); d/ bilješke o praćenju stanja. WEED, L. L., Medical record that guide and teach, N. Eng. J. Med., 1968, str. 593.-600. Vidi o tome podrobnije kod JAKŠIĆ, Ž. Medicinska 
dokumentacija. U: Jakšić, Ž. i sur., Socijalna medicina. Praktikum II. 5. izd., Zagreb, Medicinski fakultet Sveučilišta u Zagrebu, 1989., str. 355.-372.

${ }^{23}$ Podrobnije kod TURKOVIĆ, K. - DIKA, M. - GORETA, M. - ĐURĐEVIĆ, Z., Zakon o zaštiti osoba s duševnim smetnjama s komentarom i prilozima, Zagreb, 2001., str. 116.

${ }^{24}$ Vidi MUJOVIĆ-ZORNIĆ, H. - SJENIČIĆ, M., Kodeks lekarske etike kao izraz staleške samoregulative u medicini, «Pravni informator», 2003., str. 6.

${ }^{25}$ Usp. RADIŠIĆ, J., Medicinsko pravo, Beograd, 2004., str. 143.

${ }^{26}$ Tako i podrobnije kod JAKŠIĆ, Ž. Medicinska dokumentacija. U: Jakšić, Ž. i sur., Socijalna medicina. Praktikum II. 5. izd., Zagreb, Medicinski fakultet Sveučilišta u Zagrebu, 1989., str. 355.-372. Vidi i BOCKELMANN, P., Die Dokumentationspflicht des Arztes und ihre Konsequenzen, Berlin, 1985., str. 700.

${ }^{27}$ Vidi TIMOTIĆ, B. - ANĐELSKI, H., Zdravstveno zakonodavstvo, Beograd, 2004., str. 175.

${ }^{28}$ Ibid., str. 175.-176.

${ }^{29}$ Tako i podrobnije kod FLIS, V., Medicinska dokumentacija in pravice bolnikov, zbornik ,Medicina in pravo“, god. 1996.-1998., Maribor, 1998., str. 234.-235.

${ }^{30}$ Vidi detaljnije kod BABIĆ, T. - ROKSANDIĆ, S., Osnove zdravstvenog prava, Zagreb, 2006., str. 133.

${ }^{31}$ Medicinska sestra obvezna je evidentirati sve provedene postupke na sestrinskoj listi za svakog pojedinog pacijenta na svim razinama zdravstvene zaštite. Sestrinska lista jest skup podataka koji služe kontroli kvalitete planirane i provedene zdravstvene njege, a sadržaj i obrazac sestrinske liste na prijedlog Hrvatske komore medicinskih sestara propisuje ministar nadležan za zdravstvo (ZOS, čl. 17.). Sestrinska lista je jedna od novosti u našem zdravstvenom sustavu, a u Europi i svijetu gdje već postoji pokazala se vrlo korisnom za pacijente, medicinske sestre i zdravstvene ustanove, jer se na temelju nje u svakom trenutku može utvrditi je li planirana zdravstvena njega stvarno i provedena. Vidi RADIĆ, M., Zakon o sestrinstvu, u knjizi Zbirka zdravstvenih zakona s obrazloženjem, Zagreb, 2003., str. 166. Sestrinska lista predviđena je za upotrebu na bolničkim odjelima, za pacijente koji borave duže od 24 sata. Sestrinska skrb dokumentira se na različite načine, ovisno o organizaciji sestrinske službe, kategoriji pacijenta, potrebama tih pacijenata, vrsti odjela, razini zdravstvene zaštite te o obrazovanosti medicinskih sestara. Primjenom Sestrinske liste, što neće biti nimalo jednostavno ni lako, bitno će se poboljšati kvaliteta zdravstvene skrbi, a time i zadovoljstvo pacijenata. Dokumentiranje sestrinskog rada učiniti će sestrinski rad vidljivim. Dobiveni podaci poslužiti će i za izračunavanje broja medicinskih sestara potrebnih za provođenje 24 - satne zdravstvene njege, a medicinske sestre će poticati na istraživački rad. STUŽIĆ, V., Sestrinska dokumentacija, «Sestrinski list KB Merkur», 2006., br. 4 , str. 6 .

${ }^{32}$ Hrvatska komora medicinskih sestara objavila je Sestrinsku dokumentaciju u službenom glasilu Komore „Plavom fokusu“, čime je ispunila obavezu koja proizlazi iz članka 27., točke 3. ZOS-a.

${ }^{33}$ Usp. ŠIMUNEC, D., vms, predsjednica HKMS, izvadak iz dopisa ministru zdravstva i socijalne skrbi, 03. srpanj 2006. (Klasa: 011-02/06-02/03Ur. broj: 381-1-06-02.). Podatak na stranici www.hkms.hr/.

Sestrinska dokumentacija pokazatelj je kvalitete i kontinuiteta zdravstvene skrbi. Važnost dokumentiranja isticale su i F. Nightingale i V. Henderson, a naročito dolazi do izražaja primjenom procesa zdravstvene njege 70- tih godina prošlog stoljeća u SAD- u. Sestrinska dokumentacija je: 1. dio odgovornosti medicinske sestre za pruženu skrb, osigurava prikupljanje podataka o pacijentovim potrebama, ciljevima sestrinske skrbi, provedenim intervencijama i učinkovitosti, 2. služi za pravnu zaštitu, osigurava najbolje dokaze o pacijentovu stanju, 3. sadržava kronološki pregled skrbi, osigurava kontinuitet, olakšava komunikaciju među članovima tima, 4. utječe na troškove u zdravstvu, omogućava sestrama da uz što manje troškova udovolje sve većim zahtjevima i očekivanjima, da pružaju visokokvalitetnu zdravstvenu skrb na najučinkovitiji način, 5. standard sestrinske prakse, potiče na sestrinska istraživanja, služi u obrazovne svrhe. STUŽIĆ, V., Sestrinska dokumentacija, «Sestrinski list KB Merkur», 2006., br. 4, str. 6.

${ }^{34}$ Podatak na stranici:

https://www.google.hr/search?safe=off\&hl=bs\&biw=1920\&bih=971\&tbm=isch\&sa=1\&q=laboratorijski+nala z\&oq=laboratorijski+nalaz\&gs $\mathrm{l}=$ psy-ab.3...4624.4624.0.5380.0.0.0.0.0.0.0.0..0.0...0...1.1.64.psyab..0.0.0.w3a6f6Ue05U\#imgrc=XIM9vbPoRJuXTM:

${ }_{35}$ Tako RADIŠIĆ, J., Medicinsko pravo, Beograd, 2004., str. 145.

${ }^{36}$ Usp. RADIĆ, M., Zakon o medicinsko-biokemijskoj djelatnosti, u knjizi Zbirka zdravstvenih zakona s obrazloženjem, Zagreb, 2003., str. 142.

${ }^{37}$ Vidi članak 13., 31., 47., 66., Zakona o djelatnostima u zdravstvu („Narodne novine“ br. 87/09),

38 Vidi NIKOLIĆ, K., Krivično-pravna odgovornost ljekara zbog neurednog vođenja medicinske dokumentacije, «Pravni život», 1998., br. 9. str. 263.

${ }^{39}$ Podrobnije kod BOŠKOVIĆ, Z., Zakon o zaštiti prava pacijenata-Reforma zdravstvenog zakonodavstva

Republike Hrvatske, «Pravo u gospodarstvu», vol. 44., 2005., br. 1, str. 90. 


\title{
ZDRAVSTVENO STRUKOVNO STALEŠKO PRAVO Prava, obveze i odgovornosti radnika u obavljanju djelatnosti: Medicinska \\ dokumentacija
}

\begin{abstract}
${ }^{40}$ Vidi šire o tome kod IVANJKO, Š., Medicinska dokumentacija pri opravljanju zavarovalne djelatnosti, zbornik „Medicina in pravo“, god. 1996.-1998., Maribor, 1998., str. 257.-258.

${ }^{41}$ Zdravstveni djelatnik je doktor medicine ili stomatologije te svaki drugi stručno obrazovani medicinski djelatnik koji je uključen u sustav pružanja zdravstvene zaštite i koji temeljem posebnih zakona ima odgovarajuća prava, obveze i odgovornosti, a zaposlen je u zdravstvenoj ustanovi/privatnoj praksi. Kada se ostvarivanje određenih pacijentovih prava odnosi na nemedicinske usluge koje su mu potrebne tijekom pružanja zdravstvene zaštite, tada se odredbe ZOZPP-a odnose i na djelatnike cije obrazovanje nije medicinsko, ali su zaposleni u zdravstvenoj ustanovi (ZOZPP, čl. 3. t. e/).

${ }^{42}$ Tako SCHMID, H., Ueber den notwendigen Inhalt arztlichen Dokumentation, «Neue Juristische Wochenschrift», 1987., br. 12, str. 682., podatak kod RADIŠIĆ, J., Medicinsko pravo, Beograd, 2004., str. 148.

${ }^{43}$ Usp. MUJOVIĆ-ZORNIĆ, H. - SJENIČIĆ, M., Kodeks lekarske etike kao izraz staleške samoregulative u medicini, «Pravni informator», 2003., str. 6.

${ }^{44}$ Tako RADIŠIĆ, J., Medicinsko pravo, Beograd, 2004., str. 152.

${ }^{45}$ Vidi Europsku konvenciju o unapređenju prava pacijenata, Amsterdam 1994., podrobnije kod GOSIĆ, N., Privatnost i povjerenje u medicinskoj etici i bioetici, «Sestrinski edukacijski magazin», god. II, 2005., br. 2, str. 4.

${ }^{46}$ Usp. TURKOVIĆ, K. - DIKA, M. - GORETA, M. - ĐURĐEVIĆ, Z., Zakon o zaštiti osoba s duševnim smetnjama s komentarom i prilozima, Zagreb, 2001., str. 116.

${ }^{47} \mathrm{Ibid} .$, str. 116.

${ }^{48}$ Treba napomenuti da je ovaj st. 5. čl. 122. ZOZZ-a promijenjen, odnosno formuliran odredbom čl. 47.

Zakona o izmjenama i dopunama Zakona o zdravstvenoj zaštiti («Narodne novine», br. 85/06.). Dotadašnji st. 5. čl. 122. propisivao je da će se način vođenja, čuvanja, prikupljanja i raspolaganja medicinskom dokumentacijom urediti posebnim zakonom. U javnosti su se povodom ove izmjene pojavile određene dvojbe i neslaganja zbog toga što se drži da ovako osjetljivu materiju ne bi trebalo uređivati podzakonskim propisom (pravilnikom kojeg treba donijeti ministar nadležan za zdravstvo) jer to nije u skladu s jačanjem čovjekove (pacijentove) osobnosti i čini se suprotnim ustavnom načelu pravne sigurnosti. Tako i podrobnije kod
\end{abstract}

BOŠKOVIĆ, Z., Zakon o izmjenama i dopunama Zakona o zdravstvenoj zaštiti, «Informator», br. 5475-5476. od 26. i 30. kolovoza 2006.

49 Vidi primjerice Pravilnik o načinu vođenja, čuvanja prikupljanja i raspolaganja medicinskom dokumentacijom pacijenata u centralnom informacijskom sustavu zdravstva RH (,Narodne novine“ br. 82/10), Pravilnik o načinu vođenja osobnog zdravstvenog kartona u elektoničkom obliku („Narodne novine“ br. 82/10) ${ }^{50}$ Vidi primjerice Pravilnik o provedbi zakona o evidencijama u oblasti zdravstva za primarnu i specijalističko-konzilijarnu zdravstvenu zaštitu («Narodne novine», br. 4/95.) i Pravilnik o provedbi zakona o evidencijama u oblasti zdravstva na području zdravstvene zaštite gerijatrijskih bolesnika («Narodne novine», br. $82 / 02$.).

${ }^{51}$ Treba napomenuti da su se neke odredbe ZEOZ-a izmijenile odredbama Zakona o izmjenama i dopunama zakona kojima su određene novčane kazne za privredne prijestupe i prekršaje («Narodne novine», br. 26/93.), na način da se spomenutim Zakonom, radi povećanja novčanih kazni, mijenjaju i dopunjuju odredbe ZEOZ-a koje sadrže novčane kazne za privredne prijestupe i prekršaje, i to: u članku 25. stavku 1. riječi: "200.000 do 2.000.000 dinara" zamjenjuju se riječima: "u dinarskoj protuvrijednosti 250 do 1200 DEM". U stavku 2. riječi: "40.000 do 400.000 dinara" zamjenjuju se riječima: "u dinarskoj protuvrijednosti 120 do 300 DEM". U članku 26. riječi: "100.000 do 400.000 dinara" zamjenjuju se riječima: "u dinarskoj protuvrijednosti 120 do 250 DEM". U članku 27. riječi: "40.000 do 200.000 dinara" zamjenjuju se riječima: "u dinarskoj protuvrijednosti 50 do 120 DEM". U članku 28. riječi: "40.000 do 400.000 dinara" zamjenjuju se riječima: "u dinarskoj protuvrijednosti 50 do 120 DEM".

${ }_{52}^{52}$ Usp. Medicinska enciklopedija, knjiga 4., Zagreb, MCMLXIX, str. 294.

${ }^{53}$ Vidi BABIĆ, T. - ROKSANDIĆ, S., Osnove zdravstvenog prava, Zagreb, 2006., str. 161.

${ }^{54}$ Usp. IVANČEVIĆ, N., Zakon o liječništvu, rad u zborniku «Zbirka zdravstvenih zakona s obrazložnjem, Zagreb, 2003., str. 91.

${ }^{55}$ Tako Medicinska enciklopedija, knjiga 4., Zagreb, MCMLXIX, str. 294.

${ }^{56}$ Usp. ULSENHEIMER, K., Die arztliche Schweigpflicht, objavljen u LAUFS-UHLENBRUCK, Handbuch des Arztrechts, Munchen, 2002., str. 551., podatak kod RADIŠIĆ, J., Dužnost čuvanja medicinske tajne, „Anali Pravnog fakulteta u Beogradu“, god. L., 2002., broj 3-4, str. 328.

${ }^{57} \mathrm{O}$ tome podrobnije kod BOŠKOVIĆ, Z., Profesionalna liječnička tajna, „Informator“, broj 5329. od 2. travnja 2005., str. 12.

${ }^{58}$ Usp. RISTIĆ, J., Medicina i društvo, Beograd, 1975., str. 82.-84. 
Prava, obveze i odgovornosti radnika u obavljanju djelatnosti: Medicinska dokumentacija

${ }^{59}$ Vidi VRHOVAC, B., Liječnička tajna, «Liječničke novine», 2001., broj 5, str. 19.-20.

${ }^{60}$ Tako SANDOR, J., Data Protection in Health Care, Beyond Biomedical Use, ,Frontiers of European Health Law“, Yearbook 2002., str. 76.

${ }^{61}$ Usp. Medicinska enciklopedija, knjiga 4., Zagreb, MCMLXIX, str. 294.-295.

${ }^{62}$ Ibid., str. 295.

${ }^{63}$ Vidi RAJIĆ, Z. - TOMIĆ, M. - MILJKO, Z., Komentar Kaznenog zakona, Mostar, 2000., str. 217.

${ }^{64}$ Tako GOSIĆ, N., Privatnost i povjerenje u medicinskoj etici i bioetici, «Sestrinski edukacijski magazin», god. II, 2005., broj 2, str. 5.

${ }^{65}$ Usp. JELAČIĆ, O., Liječnička tajna u našem zakonodavstvu, «Zbornik radova Pravnoga fakulteta u Splitu», god X, 1973., str. 21.

${ }^{66}$ Tako MARIĆ, J. - LUKIĆ, M., Pravna medicina, Beograd, 1998., str. 344.

${ }^{67}$ Vidi JELAČIĆ, O., Liječnička tajna u našem zakonodavstvu, «Zbornik radova Pravnoga fakulteta u Splitu», god X, 1973., str. 21.

${ }^{68}$ Tako REHBERG, J., Handbuch des Arztrechts, Zurich, 1994., str. 345.

${ }^{69}$ Usp. RADIŠIĆ, J., Dužnost čuvanja medicinske tajne, „Anali Pravnog fakulteta u Beogradu“, god. L., 2002., broj 3-4, str. 329.

${ }^{70}$ Podrobnije o liječničkoj tajni vidi kod ČIZMIĆ, J., Pravno uređenje instituta liječničke tajne u hrvatskom pravu, «Pravo i porezi», god. XVI., 2007., br. 2., str. 12-25.

${ }^{71}$ Druga državna tijela i pravne osobe dostavit će podatke koje je od njih zatražio državni odbejtnik osim onih koje predstavljaju zakonom zaštićenu tajnu (ZKP članak 206.g). Ovdje se može predpostaviti i medicinska dokumentacija u predmetnom pogledu.

${ }^{72}$ Usp. BOŠKOVIĆ, Z., Zakon o liječništvu - Reforma zdravstvenog zakonodavstva Republike Hrvatske, «Hrvatska pravna revija», god. III, 2003., br. 9, str. 80.

${ }^{73}$ Vidi Zakon o izmjenama i dopunama ZEOZ-a («Službeni list SFRJ», br. 18/88.), čl. 1.

${ }^{74}$ Navedeno arhivsko gradivo, odnosno medicinska dokumentacija, može se koristiti i prije predviđenoga roka, ako je od nastanka namijenjena javnosti ili ako na to pristane osoba na koju se ona odnosi, odnosno njezin bračni drug, djeca ili roditelji poslije njezine smrti (ZAGA, čl. 21. st. 2.).

${ }^{75}$ Tako i podrobnije kod DEUTSCH, E. - SPICKHOFF, A., Medizinrecht, Berlin, 2002., str. 303.

${ }^{76}$ Vidi kod IVANČEVIĆ, N., Zakon o lječništvu, u knjizi Zbirka zdravstvenih zakona s obrazloženjem, Zagreb, 2003., str. 91.

${ }^{77}$ Usp. BABIĆ, T. - ROKSANDIĆ, S., Osnove zdravstvenog prava, Zagreb, 2006., str. 107.

${ }^{78}$ Vidi POLIĆ, J., Zakon o stomatološkoj djelatnosti, u knjizi Zbirka zdravstvenih zakona s obrazloženjem, Zagreb, 2003., str. 118.

${ }^{79}$ Podrobnije kod BABIĆ, T. - ROKSANDIĆ, S., Osnove zdravstvenog prava, Zagreb, 2006., str. 114.

${ }^{80}$ Ibid., str. 120.

${ }^{81}$ Tako TURKOVIĆ, K. - DIKA, M. - GORETA, M. - ĐURĐEVIĆ, Z., Zakon o zaštiti osoba s duševnim smetnjama s komentarom i prilozima, Zagreb, 2001., str. 114.

${ }^{82}$ Usp. NIKOLIĆ, K., Krivično-pravna odgovornost ljekara zbog neurednog vođenja medicinske dokumentacije, «Pravni život», 1998., br. 9. str. 265.-266.

${ }^{83}$ Vidi Pacijent danas, 2004., br. 11-12, str. 15.

${ }^{84}$ Tako ČUKIĆ, D., Pravo na medicinsku istinu preko medicinske dokumentacije - teškoće, greške, predlog mjera za njihovo otklanjanje, «Pravni život», vol. LI, 2002., br. 9, str. 260.

${ }^{85}$ Vidi JELAČIĆ, O., Sudsko-medicinski aspekt kvalifikacije tjelesnih povreda, «Zbornik Pravnog fakulteta u Splitu», god. XVII, 1980., str. 87.

${ }^{86}$ Usp. JAKŠSIĆ, Ž. Medicinska dokumentacija. U: Jakšić, Ž. i sur., Socijalna medicina. Praktikum II. 5. izd., Zagreb, Medicinski fakultet Sveučilišta u Zagrebu, 1989., str. 355.-372.

${ }^{87}$ Tako NIKOLIĆ, K., Krivično-pravna odgovornost ljekara zbog neurednog vođenja medicinske dokumentacije, «Pravni život», 1998., br. 9, str. 267.

${ }^{88}$ Vidi JELAČIĆ, O., Sudsko-medicinski aspekt kvalifikacije tjelesnih povreda, «Zbornik Pravnog fakulteta u Splitu», god. XVII, 1980., str. 86.

${ }_{89}^{89}$ „Pacijent je svaka osoba, bez obzira na dob, spol, rasnu, vjersku i drugu pripadnost, imovno stanje, vrstu i stupanj zdravstvenih potreba, bolesna ili zdrava, koja u bilo kojoj zdravstvenoj ustanovi i/ili privatnoj praksi zatraži odredenu uslugu ili nastoji zadovoljiti svoju zdravstvenu potrebu. U tom smislu pacijenti u najširem smislu riječi jesu svi građani s obzirom na svoju obvezu podvrgavanja mjerama primarne prevencije, odnosno, onog dijela zdravstvene zaštite koji je od najšireg nacionalnog interesa i kojim su obuhvaćeni svi građani Republike Hrvatske koji su to rođenjem i državljanstvom. U uvjetima utvrđenima ZOZPP-om, drugim zakonima i međunarodnim ugovorima, pacijentima se smatraju i strani državljani koji koriste bilo koji oblik 
zdravstvene zaštite u zdravstvenim ustanovama i/ili privatnim praksama na području Republike Hrvatske“ (ZOZPP, čl. 3. t. a/).

${ }^{90}$ Usp. GRBČIĆ, Ž., Kakva prava pruža Zakon o zaštiti pacijenata, «Informator», god. LII, 2005., br. 5145, str. 41.

${ }_{91}$ Vidi MUJOVIĆ-ZORNIĆ, H., Ugovor o medicinskom tretmanu, «Strani pravni život», 2001., br. 1-3, str. 260.-261.

${ }^{92}$ Tako RADIŠIĆ, J., Medicinsko pravo, Beograd, 2004., str. 149.

${ }^{93}$ Primjerice, i doktor stomatologije obvezan je na zahtjev pacijenta dati mu na uvid svu stomatološku dokumentaciju koja se odnosi na dijagnostiku i liječenje njegove bolesti (ZOSD, čl. 29. st. 4.).

${ }^{94}$ Usp. BABIĆ, T. - ROKSANDIĆ, S., Osnove zdravstvenog prava, Zagreb, 2006., str. 114. Postoji, suprotno, mišljenje da je liječnička dokumentacija kao pisani dokument vlasništvo bolnice, odnosno liječnika privatne prakse, te da oni imaju dužnost osigurati povjerljivost, privatnost i sigurnost te dokumentacije. Vidi

TURKOVIĆ, K. - DIKA, M. - GORETA, M. - ĐURĐEVIĆ, Z., Zakon o zaštiti osoba s duševnim smetnjama s komentarom i prilozima, Zagreb, 2001., str. 113.

${ }^{95}$ Podrobnije o ovoj Konvenciji vidi kod: HERVEY, T. K. - McHALE, J. V., Health Law and the European

Union, Cambridge, 2004., str. 164.-65.; HLAČA, N., O bioetici u povodu potpisa u Vijeću Europe dvaju međunarodnih dokumenata s bioetičnim sadržajima, «Vladavina prava», god. II, 1998., br. 3-4, str. 45.-52.; MUJOVIĆ ZORNIĆ, H., Perspektive medicinskog prava u svjetlosti Evropske konvencije o ljudskim pravima i biomedicini, zbornik radova „Aktualnosti građanskog i trgovačkog zakonodavstva i pravne prakse“, Neum Mostar, 2004., str. 137.-145.;

${ }^{96}$ Vidi o tome kod JADRO, D. - HRABRIĆ, M. - KRAMARIĆ, D., Zakon o zdravstvenoj zaštiti, u knjizi Zbirka zdravstvenih zakona s obrazloženjem, Zagreb, 2003., str. 16.-17.

${ }^{97}$ Tako i podrobnije o tome kod ČEBULJ, J., Načela varstva osebnih podatkov na području medicine, zbornik «Medicina in pravo», god. 1996.-1998., Maribor, 1998., str. 212.-215.

${ }^{98}$ Podrobnije o tome kod MUJOVIĆ ZORNIĆ, H., Perspektive medicinskog prava u svjetlosti Evropske konvencije o ljudskim pravima i biomedicini, zbornik radova „Aktualnosti građanskog i trgovačkog zakonodavstva i pravne prakse“, Neum - Mostar, 2004., str. 137.; DRAŠKIĆ, M., Prava pacijenata - kraj paternalističkog koncepta medicine, „Pravni život“, 1998., br. 9, str. 254.-256.; BOŠKOVIĆ, Z., Prava pacijenata na primjerenu obaviještenost i odlučivanje, „Informator“, br. 5343. od 21. svibnja 2005., str. 18.; URLEP, F., Pojasnilna dolžnost v splošni medicini, rad u zborniku «Medicina in pravo - pojasnilna dolžnost», Maribor, 1995., str. 129.-131.

${ }^{99}$ Usp. DEUTSCH, E. - SPICKHOFF, A., Medizinrecht, Berlin, 2002., str. 310.

${ }^{100}$ Tako BABIĆ, T. - ROKSANDIĆ, S., Osnove zdravstvenog prava, Zagreb, 2006., str. 114. Dužnost čuvanja liječničke tajne nije apsolutna, pa liječnik ne postupa neovlašteno, odnosno protupravno ako tajnu otkrije iz opravdanih razloga. Tako liječnik nema obvezu čuvanja tajne: ako su ga pacijent ili njegov zakonski zastupnik oslobodili te obveze; ako okolnosti konkretnog slučaja opravdavaju pretpostavku da je ovlaštena osoba (pacijent ili njegov zakonski zastupnik) suglasna s otkrivanjem tajne; ako podatke koji predstavljaju liječničku tajnu radi liječenja pacijenta treba odati drugom liječniku; ako čuvanje tajne bitno ugrožava život ili zdravlje pacijenta, ili život, zdravlje ili neki drugi pretežniji interes trećih osoba; ako ga na odavanje tajne obvezuju zakonski propisi (i u tom slučaju liječnik o tome treba izvijestiti pacijenta); ako podatke koji predstavljaju liječničku tajnu treba dostaviti ovlaštenim tijelima; ako podatke koji predstavljaju liječničku tajnu objavljuje na predavanjima ili u znanstvenim publikacijama (uz zaštitu identiteta pacijenta); te ako čuvanje tajne bitno ugrožava neki pretežniji interes samog liječnika. Tako i podrobnije kod ČIZMIĆ, J., Pravno uređenje instituta liječničke tajne u hrvatskom pravu, «Pravo i porezi», god. XVI., 2007., br. 2., str. 19.-23. ${ }^{101}$ Ovo je stajalište u skladu i s odredbom čl. 2. t. 9. Kodeksa medicinske etike i deontologije (stupio na snagu 14. prosinca 2003.), kojom se propisuje da bolesnik ima pravo saznati istinu, kao i dobiti na uvid cjelokupnu medicinsku dokumentaciju o svojoj bolesti, ali, iznimno od ovog pravila, ako liječnik ocijeni da će time bolesnik doći u težu zdravstvenu situaciju, nije dužan bolesniku reći istinu niti mu dati na uvid medicinsku dokumentaciju. Isto tako treba uvažiti želju bolesnika da ne bude obaviješten o svojoj bolesti.

${ }^{102}$ RADIŠIĆ, J., Medicinsko pravo, Beograd, 2004., str. 149.

${ }^{103}$ Tako i podrobnije o tome kod ČEBULJ, J., Načela varstva osebnih podatkov na području medicine, zbornik «Medicina in pravo», god. 1996.-1998., Maribor, 1998., str. 214.-215.

${ }^{104}$ Vidi TURKOVIĆ, K. - DIKA, M. - GORETA, M. - ĐURĐEVIĆ, Z., Zakon o zaštiti osoba s duševnim smetnjama s komentarom i prilozima, Zagreb, 2001., str. 113.

${ }^{105}$ Usp. JADRO, D. - KRAMARIĆ, D. - KATIĆ BUBAŠ, J., Zakon o zaštiti prava pacijenata, Zagreb, 2005., str. 9.

${ }^{106}$ Tako LAUFS, A. - UHLENBRUCK, Handbuch des Arztrechts, Munchen, 2002., str. 492. 
Prava, obveze i odgovornosti radnika u obavljanju djelatnosti: Medicinska dokumentacija

${ }^{107}$ Primjena desete revizije Međunarodne klasifikacije bolesti i srodnih zdravstvenih problema stupila je na snagu 1. sijećnja 1995. godine Odlukom Ministarstva zdravstva, Klasa 950-01/94-01/02 Urbroj 534-02-20-9402 od 12. srpnja 1994. godine.

${ }^{108}$ Stupanjem na snagu Pravilnika o načinu vođenja, čuvanja, prikupljanja i raspolaganja medicinskom dokumentacijiom pacijenata u centralnom informacijskom sustavu zdravstva Republike Hrvatske (,Narodne novine“ $b r$. 82/10) prestale su važiti odredbe Pravilnika o provedbi zakona o evidencijama u oblasti zdravstva za primarnu i specijalističko-konzilijarnu zdravstvenu zaštitu u dijelu koji se odnosi na način izrade izvješća tima opće/obiteljske medicine, dentalne medicine, zdravstvene zaštite dojenčadi, predškolske djece, zdravstvene zaštite žena i specijalističko konzilijarnu zdravstvenu zaštitu

${ }^{109}$ Usp. MUJOVIĆ-ZORNIĆ, H. - SJENIČIĆ, M., Kodeks lekarske etike kao izraz staleške samoregulative u medicini, «Pravni informator», 2003., str. 6.

${ }^{110}$ Vidi TURKOVIĆ, K. - DIKA, M. - GORETA, M. - ĐURĐEVIĆ, Z., Zakon o zaštiti osoba s duševnim smetnjama s komentarom i prilozima, Zagreb, 2001., str. 116.

${ }^{111}$ Primjerice, ako ne upiše, odnosno priloži u medicinsku dokumentaciju podatak o namjeri pacijenta da napusti zdravstvenu ustanovu ili ne upiše, odnosno priloži u medicinsku dokumentaciju podatak o samovoljnom napuštanju zdravstvene ustanove bez najave pacijenta (ZOZPP, čl. 42. t. 4. u svezi čl. 27.).

${ }^{112}$ U tom smislu RADIŠIĆ, J., Medicinsko pravo, Beograd, 2004., str. 151.

113 Tako i podrobnije kod JAKŠIĆ, Ž. Medicinska dokumentacija. U: JAKŠIĆ, Ž. i sur., Socijalna medicina. Praktikum II. 5. izd., Zagreb, Medicinski fakultet Sveučilišta u Zagrebu, 1989., str. 355.-372.

${ }^{114}$ Usp. TURKOVIĆ, K. - DIKA, M. - GORETA, M. - ĐURĐEVIĆ, Z., Zakon o zaštiti osoba s duševnim smetnjama s komentarom i prilozima, Zagreb, 2001., str. 115.

115 Vidi RADIŠIĆ, J., Medicinsko pravo, Beograd, 2004., str. 152.

116 Tako i više o medicinskoj dokumentaciji kod ČIZMIĆ, J., Medicinskopravna dokumentacija, zbornik radova „Aktualnosti zdravstvenog zakonodavstva i pravne prakse“, Novalja-Split, 2011., str. 65.-97. 



\section{1/ Pojam, povijesni razvitak i svrha osnivanja zdravstvenih komora}

\section{Uvodne napomene o komorama u zdravstvu}

Komora (lat. iz grč.) je organizacija ili ustanova koja zastupa interese neke profesionalne ili društvene skupine (primjerice, liječnička, odvjetnička, trgovačka). ${ }^{1}$ Komore su i udruženja pojedinih vrsta zdravstvenih radnika u koje su uključeni svi zdravstveni radnici koji obavljaju praksu u javnom ili privatnom sektoru. Komora je staleška organizacija trajnog karaktera čije postojanje ne zavisi od promjene sastava njezinih članova. Kao udruženje javnog prava komora ima određene obveze prema svojim članovima, ali i prema društvu, odnosno državi. ${ }^{2}$ HLK, Hrvatska komora dentalne medicine, Hrvatska ljekarnička komora, Hrvatska komora medicinskih biokemičara, Hrvatska komora medicinskih sestara, Hrvatska komora primalja, Hrvatska komora zdravstvenih radnika, Hrvatska komora fizioterapeuta i ostale komore u zdravstvu (u daljnjem tekstu: komore) strukovne su organizacije zdravstvenih radnika sa statusom pravne osobe (ZOZZ, čl. 197.). ZOZZ u poglavlju XIX „Komore“ uređuje način organiziranja i rada komora iz područja zdravstva. Naime, radi očuvanja i zaštite interesa svoje profesije, ${ }^{3}$ zadovoljavanja svojih stručnih i osobnih potreba, osiguravanja uvjeta za organizirani nastup zdravstvenih radnika istih profesionalnih grupa, kao i zaštite zdravlja građana, zdravstveni radnici zavisno od stručnog naziva obvezno se udružuju u komore kao strukovna udruženja. ${ }^{4}$

\subsection{Povijesni razvitak komorskog sustava u zdravstvu}

Institut Komora u zdravstvu ima svoje početke u pokušajima pojedinaca da zaštite svoje interese na tržištu rada u pružanju usluga međusobnim grupiranjem i intencijom stvaranja pravilnosti i standarda u obavljanju djelatnosti takvih struka. Kroz povijest prepoznata su bila razna cehovska udruženja ${ }^{5} \mathrm{u}$ tom pogledu. Dakle pojedinci pripadnici određene struke grupirali su se i formalno organizirali s ciljem zaštite svojih pojedinačnih prava, a tako i posredno prava i interesa cijele struke. Moć organizacije u tom pogledu dovela je do potrebe utvrđivanja strogih kogentnih pravila unutar nje same, te između pripadnika pojedine struke, kao i jasnih kriterija djelovanja takve zajednice na društveno-političkom, odnosno tržišnom prostoru. Za to je trebalo donijeti i utvrditi niz zakonitosti djelovanja koje je reproduciralo norme i standarde djelatnosti kojima se ta ista struka bavi, kao i jasne kriterije kojima moraju udovoljiti pripadnici te struke i novi članovi zajednice da bi mogli nesmetano i opravdano obavljati svoju djelatnost. Pripadnici zdravstvenih struka kroz institucije su neposredno ili posredno djelovale na jasno definiranje pojma, sadržaja i oblika djelatnosti, te uvjete i načine, ovlaštenja i odgovornosti pripadnika struke u obavljanju djelatnosti.

Pojam komore kao strukovne organizacije definiran je davnih dana u prošlosti. Određene staleške grupacije i/ili udruženja radi zaštite svojih interesa te promicanja istih, formalno su započele definirati i utvrđivati svoja statusna pitanja u društvu, odnosno na prostoru tržišta rada. Dakako da pojedinac svaki zasebno nije mogao egzistirati i funkcionirati u 
društveno političkom okruženju i situaciji brojnih tržišnih i profesionalnih odnosa, a što je dovelo do pokušaja i želje za grupiranjem i formalnim utvrđivanjem određenih pozicija pojedinih skupina, odnosno bolje rečeno struka. Radi potreba konkurentnosti na tržištu rada i prepoznavanja njih samih kao relevantnih čimbenika društva, pokušali su na utvrditi jasne kriterije onima koje će zastupati, odnosno definirati standarde same struke, kao i utvrditi normative koje moraju poštovati oni sami, ali i svi drugi čimbenici društveno političkog života. Takva strukovna udruženja imala su dovoljno moći da podignu značaj svojih organizacija na najvišu razinu, na način da zakonodavac, dakle najviše tijelo jedne državne vlasti, određuje kriterije kojima moraju udovoljavati svi članovi, pod formom definiranja i utvrđivanja standarda struke, odnosno profesije. Tako su profesije dobile definiran pojam i značaj u današnjem društvu. S jedne strane sada profesiju sustavno štite Komore kao strukovne i profesionalne organizacije, a s druge strane poziciju u društvu im daje zakonodavac utvrđujući ih u formalnom smislu kao profesije koje imaju jasno definirane standarde djelatnosti i normative kojima moraju udovoljavati svi koji se bave ili bi se bavili određenom djelatnošću.

Prva poznata i osnovana Komora u zdravstvu je Hrvatska liječnička komora. Liječnička komora osnovana je 1903. g. za područje Splita i okolice. Liječnička komora je osnovana 1923. godine za područje Hrvatske, Slavonije i Međimurja sa sjedištem u Zagrebu. Od godine 1929. Komora obuhvaća i Dalmaciju, a djeluje pod imenom Liječnička komora za Savsku banovinu. Od godine 1939. Komora djeluje pod imenom Liječnička komora Banovine Hrvatske. Od godine 1941. Komora djeluje kao Liečnička komora Nezavisne Države Hrvatske. Godine 1945. Komora mijenja ime u Liječnička komora Federativne države Hrvatske. Iste godine zabranjen je rad Komore. Godine 1995. Komora obnavlja svoj rad na temelju članka 43. stavka 1. Ustava Republike Hrvatske (»Narodne novine« br. 56/90) i članka 171. stavka 1. Zakona o zdravstvenoj zaštiti (»Narodne novine« br. 75/93., 11/94., 1/97 - pročišćeni tekst, 117/97., 95/00. i 129/00) pod novim imenom Hrvatska liječnička komora. Po uzoru na Hrvatsku liječnički komoru osnivane su temeljem istog Zakona redom: Hrvatska komora medicinskih biokemičara, Hrvatska ljekarnička komora, Hrvatska komora dentalne medicine (prije Hrvatska stomatološka komora). Temeljem ZZZ-a osnovana je potom Hrvatska komora medicinskih sestara, Hrvatska komora primalja, Hrvatska komora fizioterapeuta, te Hrvatska komora zdravstvenih radnika kao posljednja komora u sustavu zdravstva. 


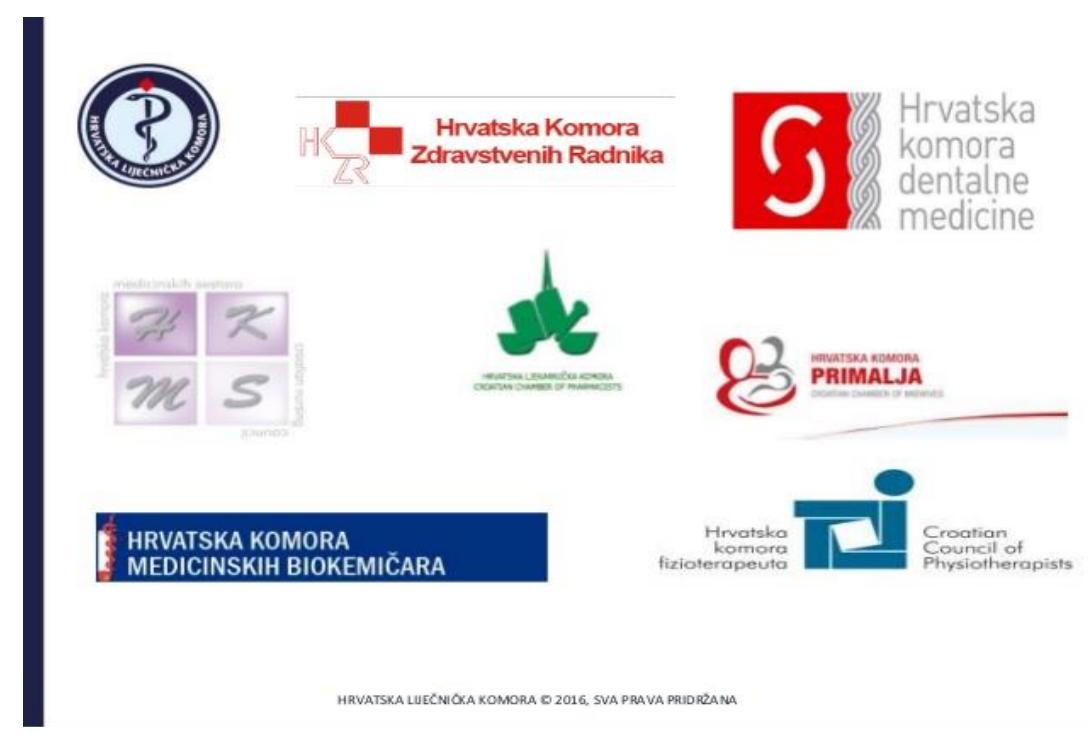

Slika 18

Današnja situacija pokazuje da u sustavu zdravstva postoje jasno definirane djelatnosti koje se mogu nazvati zdravstvenima, te da postoje jasno utvrđeni i pozicionirani pripadnici raznih zdravstvenih struka koji mogu i trebaju obavljati iste djelatnosti na jasan i nedvojbeno definiran i pravnim normama utvrđen način. Posljedica tako organiziranog stanja jest da sustav zdravstva funkcionira na svakodnevnom i kontinuiranom provođenju zdravstvene djelatnosti koje obavljaju zdravstveni radnici pripadnici više zdravstvenih profesija. ${ }^{6}$ Inicijativu potrebe postojanja profesionalizma u sustavu zdravstva prepoznao je zakonodavac ne samo na prostoru Hrvatske već i u cijelom modernom svijetu, ${ }^{7}$ na način da je pravila strukovnih organizacija podigao i na razinu državne vlasti, te je zakonskom regulativom utvrdio načelne kriterije organiziranja profesije i načina obavljanja zdravstvene profesije. Osim tako postavljenih načelnih i okvirnih stručnih poslova, zakonodavac je tako organiziranim profesijama delegirao dio javne vlasti, povjerivši određene državne poslove strukovnim zdravstvenim organizacijama. Tako su formalno i faktički kreirane moderne strukovne organizacije, tj. Komore ${ }^{8} \mathrm{u}$ sustavu zdravstva.

\subsection{Svrha osnivanja zdravstvenih komora}

Komore su profesionalne i nezavisne organizacije, koje imaju status pravne osobe, s pravima, obvezama i odgovornostima utvrđenim Zakonom i statutom komore. Osnivaju se radi unapređenja uvjeta za obavljanje profesije zdravstvenih radnika, zaštite njihovih profesionalnih interesa, organiziranog sudjelovanja na promicanju i provođenju zdravstvene zaštite i zaštite interesa građana u ostvarivanju prava na zdravstvenu zaštitu. ${ }^{9}$ U tom cilju Komore donose opće akte kojima se detaljno i precizno uređuju i propisuju svi elementi strukovnog medicinskog prava: način, uvjeti, djelokrug, kriteriji za obavljanje pojedine zdravstvene djelatnosti, obveze, prava, odgovornosti zdravstvenih radnika, Kodeks postupanja zdravstvenih radnika u obavljanju djelatnosti, tj. Kodeks etike i deontologije, način evidentiranja članova, vođenje svih podatka o članovima 
bitnim za obavljanje djelatnosti, način suradnje s nadležnim tijelima u utvrđivanju standarda obavljanja djelatnosti i poslova u okviru istih djelatnosti.

Komore su ustanove čija je osnovna svrha i zadaća štititi prava i zastupati interese svojih članova, ali i brinuti se o poštivanju etičkih i deontoloških načela struke te, u tom smislu, izricati odgovarajuće mjere onima koji u svojem profesionalnom radu ne poštuju ta načela i kao takve su bitan element, čimbenik u definiranju zdravstvene politike. Ipak, navedeno ne predstavlja osnovnu i jedinu svrhu osnivanja i postojanja komora. Naime, komore, pored svojih ovlasti koje imaju kao staleške ustanove, imaju još i javne ovlasti što ih, mutatis mutandis, čini dijelom državnog mehanizma. ${ }^{10} \mathrm{Na}$ taj način, komore, djelomično «rasterećuju» izvršnu vlast (tj. nadležno ministarstvo) tako što obavljaju poslove koji su rezultat specifičnosti svake pojedine zdravstvene djelatnosti, a koji su, kao takvi, propisani i određeni zakonom. Osim toga, komore kao staleške organizacije, u okviru svoje nadležnosti, na neposredan način osiguravaju i provedbu zakonskih propisa u oblasti zdravstva donošenjem podzakonskih akata kojima se detaljnije razrađuju pojedine zakonske odredbe. Strukturno, komore su samostalne i neovisne strukovne organizacije koje imaju svojstvo pravne osobe i koje, između ostalih, obavljaju i javne ovlasti, a u pravnom prometu s trećim osobama, nastupaju samostalno. ${ }^{11}$ 


\section{Primjedbe}

${ }^{1}$ Pogledaj Hrvatski leksikon, podatak na stranici

http://www.hrleksikon.info/definicija/komora.html.

${ }^{2}$ Vidi RADIŠIĆ, J., Medicinsko pravo, Beograd, 2004., str. 34.

${ }^{3}$ Profesija kao izraz i pojam označava nečiji posao, vokaciju ili zanimanje za čije je obavljanje potrebno specifično stručno obrazovanje i osposobljavanje. Osobe koje obavljaju takve poslove nazivaju se profesionalcima. Dakle upravo činjenica specifičnog stručnog obrazovanja i osposobljavanja je element koji određenoj djelatnosti daje za pravo nazivati se profesijom. Specifičnosti obrazovanja i osposobljavanja utvrdio je zakonodavac na prijedlog i na temelju iskustva interesnih skupina, a njihove staleške organizacije tj. Komore dužne su osigurati i brinuti se o provedbi utvrđenih kriterija. U ovako naznačenom slijedu ovlasti i odgovornosti jasno je da se intervencijom zakonodavca uspjelo postići da zaista svi predstavnici određene struke moraju zadovoljavati kogentnom normom utvrđene kriterije da bi se i oni dok obavljaju svoju djelatnost mogli definirati kao profesionalci određene profesije. Zasigurno je globalno gledajući predmetno uspjeh staleških organizacija, jer uključivanje zakonodavca i njegovih normi u slijed stjecanja statusa profesiji je točka na i osiguranja relevantnog položaja i jasnog pozicioniranja određenje profesije, struke u društveno političkom okruženju, odnosno tržištu rada. Ovakvim pristupom profesijama, i zanimanja u okviru pojedinih djelatnosti počinju imati smisla, jer se sada ne može dogoditi da jedno zanimanje može obavljati više profesija. Dakako isto bi trebalo biti pravilo, dakle jasno utvrđena profesija koja je ovlaštena kogentnom normom obavljati određene djelatnosti može biti jedino zastupljena kao nositelj određenog zanimanja. Tako struka štiti svoj krajnji cilj-rezultat, zanimanje kao objekt neposrednog obavljanja poslova, odnosno položaj u međuljudskim i međudruštvenim odnosima, kao i ovlast i obvezu poduzimati određene poslove i radnje u tržišnim odnosima i odnosima rada. Zanimanje bi trebalo biti stoga usko vezano uz profesiju, pa je tendencija svih struka koje su profesioinalno vezane svim profesijama kroz staleške organizacije da zanimanja i definiranja standarda zanimanja budu krajnji rezultat ovlasti profesija i njihovih djelatnosti. Uz to , iznimno je bitno naglasiti da se poslovi u okviru tako postavljenih zanimanja mogu i moraju iz razloga kompleksnosti, složenosti, ovlasti i odgovornosti, obavljati isključivo samostalno. Element samostalnosti ključ je osposobljenosti predstavnika, člana određene profesije, dakle njegova mogućnost ali i odgovornost samostalno obavljati poslove jedne djelatnosti kogentnom normom utvrđene profesije, a sve u cilju zaštite i promicanja interesa i standarda struke. Vidi KLARIĆ, A. - CVITKOVIĆ, M. - MATIJAŠČIĆ ŽUGAJ, P., Komore u zdravstvu, Zbornik „Aktualna problematika u zdravstvu“, Varaždin (2015), str. 162.-182.

4 Vidi BODNARUK, S. - ČIZMIĆ, J. - HRABAČ, B. - HUSEINAGIĆ, S., Komentari zdravstvenih zakona, knjiga 1., Privredna štampa, Sarajevo, 2011., str. 280.

${ }^{5}$ Usp. TUCAK, A. - FATOVIĆ FERENČIĆ, S, Povijesni razvoj Medicinskog fakulteta Osijek, Osijek 2010.

${ }^{6}$ Usp. KNEŽIĆ-POPOVIĆ, D., Istorija slobodnih profesija od Artes Liberales do savremenog doba, Strani pravni život 2/2008, Beograd, str. 7-28.; MATULIĆ, T., Identitet, profesija i etika sestrinstva, BS 77 (2007.), br. 3, str. 727-744.

Popis reguliranih profesija u RH (temeljem članka 72. stavka 1. Zakona o reguliranim profesijama i priznavanju inozemnih stručnih kvalifikacija - „Narodne novine“ 124/09, 45/11), Vlada RH 2013. - Zdravstvo: Doktor medicine, Doktor medicine specijalist, Doktor dentalne medicine, Doktor dentalne medicine specijalist, Dentalni tehničar, Dentalni asistent, Ljekarnik, Ljekarnik specijalist, Farmaceutski tehničar, Prvostupnik primaljstva, Primalja, Primalja - asistentica, Medicinska sestra opće njege, Medicinska sestra-medicinski tehničar, Prvostupnik sestrinstva, Diplomirana medicinska sestra/medicinski tehničar, Magistar sestrinstva, Medicinska sestra/medicinski tehničar specijalist, Prvostupnik sestrinstva specijalist, Medicinski biokemičar, Medicinski biokemičar specijalist, Prvostupnik fizioterapije, Diplomirani fizioterapeut, Fizioterapeutski tehničar, Maser - kupeljar, Prvostupnik sanitarnog inženjerstva, Diplomirani 
sanitarni inženjer, Magistar sanitarnog inženjerstva, Sanitarni tehničar, Prvostupnik medicinskolaboratorijske dijagnostike, Zdravstveno laboratorijski tehničar, Inženjer medicinskolaboratorijske dijagnostike, Inženjer medicinske radiologije, Prvostupnik radiološke tehnologije, Prvostupnik medicinske radiologije, Radiološki tehničar, Prvostupnik radne terapije.

${ }^{7}$ Usp. BUKOVČAN, T., Želim odabrati koga ću voljeti $i$ kamo ići na liječenje, aktivizam u istraživanju

komplementarne i alternativne medicine u Hrvatskoj, Etnološka istraživanja/Ethnological Researches, FF Zagreb, Zagreb. 2008., 12/13, str. 63-76.

${ }^{8}$ Zakonom o liječništvu formalno je definirana Hrvatska liječnička komora kao samostalna i neovisna strukovna organizaciju sa svojstvom pravne osobe i javnim ovlastima. Komora u okviru svojih djelatnosti predstavlja liječnike u Republici Hrvatskoj i u inozemstvu; Zakonom o medicinsko-biokemijskoj djelatnosti Hrvatska komora medicinskih biokemičara samostalna je i neovisna strukovna organizacija sa svojstvom pravne osobe i javnim ovlastima, Zakonom o ljekarništvu Hrvatska lijekarnička komora samostalna je i neovisna strukovna organizacija sa svojstvom pravne osobe i javnim ovlastima, koja u okviru svoje djelatnosti predstavlja magistre farmacije u RH i inozemstvu; Zakonom o sestrinstvu Hrvatska komora medicinskih sestara je strukovana samostalna organizacija medicinskih sestara sa svojstvom pravne osobe i javnim ovlastima, koja promiče, zastupa i uskađuje interese medicinskoih sestara pred državnim i drugim tijelima u RH i u inozemstvu; Zakonom o primaljstvu Hrvatska komora primalja jest strukovna samostalna organizacija primalja sa svojstvom pravne osobe i javnim ovlastima. Komora promiče, zastupa i usklađuje interese primalja pred državnim i drugim tijelima u Republici Hrvatskoj i u inozemstvu; Zakonom o fizioterapeutskoj djelatnosti Hrvatska komora fizioterapeuta jest samostalna i neovisna strukovna organizacija sa svojstvom pravne osobe i javnim ovlastima. Komora predstavlja i zastupa interese fizioterapeuta, fizioterapeutskih tehničara, radnih terapeuta i masera-kupeljara koji obavljaju poslove u fizikalnoj terapiji na području Republike Hrvatske; Zakonom o djelatnostima u zdravstvu Hrvatska komora zdravstvenih radnika jest samostalna i neovisna strukovna organizacija sa svojstvom pravne osobe i javnim ovlastima. Komora predstavlja i zastupa interese magistara sanitarnog inženjerstva, diplomiranih sanitarnih inženjera, sveučilišnih prvostupnika sanitarnog inženjerstva, stručnih prvostupnika sanitarnog inženjerstva, sanitarnih tehničara, stručnih prvostupnika radiološke tehnologije, stručnih prvostupnika radne terapije, stručnih prvostupnika medicinsko-laboratorijske dijagnostike, inženjera medicinske radiologije, viših radnih terapeuta, viših fizikalnih terapeuta - smjer radne terapije, inženjera medicinskolaboratorijske dijagnostike, zdravstveno-laboratorijskih tehničara, zdravstveno-laboratorijskih tehničara sa završenim tečajem iz citodijagnostike-citoskrinere, zdravstveno-laboratorijskih tehničara sa završenim tečajem iz transfuzijske medicine, stručnih prvostupnika medicinskolaboratorijske dijagnostike sa završenim tečajem citodijagnostike-citotehnologe ili sa završenim tečajem iz transfuzijske medicine.

${ }^{9}$ Vidi PLAVŠIĆ-NEŠIĆ, A., Komore zdravstvenih radnika Srbije, „Pravni život“", 2009., broj 9, TOM I, str. 1011.

${ }^{10}$ Npr. izdavanje odobrenja za samostalan rad (licence) jedna je od najvažnijih javnih ovlasti komora obzirom da bez odobrenja za samostalan rad (licence) zdravstveni radnik uopće ne bi mogao obavljati zdravstvenu djelatnost.

11 Tako BABIĆ, T. - ROKSANDIĆ, S., Osnove zdravstvenog prava, Zagreb, 2006., str. 241. 


\section{2/ Članstvo u komori}

Osim ishodovanja odobrenja za samostalan rad (licence) zdravstveni radnik ima obvezu biti članom svoje strukovne organizacije Komore, koja u tom slučaju raspolaže svim potrebnim podacima svog člana a koji su nužni i važni za obavljanje profesionalne djelatnosti. Zdravstveni radnici za završenim sveučilišnim diplomskim studijem, prvostupnici te zdravstveni radnici srednje stručne spreme koji obavljaju zdravstvenu djelatnost na području Republike Hrvatske, ako posebnim zakonom nije drukčije određeno, obvezno se učlanjuju u odgovarajuće zdravstvene komore (ZOZZ, čl. 198.). Njihova obveza je i poduzimanje aktivnosti s ciljem formiranja i registracije komore, a što uključuje: imenovanje inicijativnog odbora za formiranje komore, održavanje osnivačke skupštine, donošenje odluke o osnivanju komore, poslovnika o radu skupštine, statuta komore, kao i poduzimanje radnji s ciljem upisa komore u registar nadležnog općinskog suda. ${ }^{1}$

Odnos članova prema komori uređen je zakonom, statutom i ostalim propisima komore. Značajno je što komora nastupa kao organ vlasti, jer su članovi dužni odazivati se njenim pozivima i povinovati njezinim odlukama. Točnije rečeno, odluke komore imaju karakter upravnih akata, protiv kojih se može voditi spor pred upravnim sudom. Članovi komore posebno su dužni plaćati komorski doprinos (članarinu), tj. svoj udio u pokriću troškova rada udruženja. Iznos doprinosa zavisi od stvarnih izdataka komore koji su u skladu sa njezinim zadacima. Članovi komore imaju pravo sudjelovati u izboru vijećnika skupštine komore i sami biti birani za skupštinske vijećnike. Pored toga, oni mogu zahtijevati od komore da štiti njihove zajedničke, profesionalne, društvene i ekonomske interese. Svaki član komore može tražiti pomoć iz potpornog fonda, ukoliko ispunjava uvjete utvrđene odgovarajućim pravilnikom. ${ }^{2}$

Obveza članstva postoji za sve zdravstvene radnike koji obavljaju zdravstvenu djelatnost na području RH, dok je članstvo dobrovoljno za sve druge zdravstvene radnika, one koje ne obavljanju zdravstvenu djelatnost, ili su nezaposleni ili rade izvan $\mathrm{RH}$, ili su u mirovini. Članstvom u Komori ostvaruje se mogućnost kontrole zdravstvenih radnika koji obavljaju profesionalnu djelatnost, te se istima omogućava zaštita njihovih interesa u svakom pogledu. Članstvom u Komori zdravstveni radnici dužni su plaćati članarinu kojom dijelom se njihova strukovna organizacija financira a čime je omogućen rad Komori i njenim tijelima kako bi se na potreban i zakonski propisan način mogla ostvarivati uloga Komoru u zaštiti interesa svojih članova i profesije u cjelini. Ne trebaju svi članovi plaćati članarinu koja se u pravilu plaća mjesečno, redovnim ustezanjem od plaće određenog postotka ili se uplaćuje na isti način u fiksnom iznosu. Oslobođeni plaćanja članarine jesu oni članovi koji su nezaposleni, ili su na bolovanju duljem od 42 dana, ili su na služenju vojnog roka ili su na porodiljinome dopustu. Svi ostali zdravstveni radnici mogu biti članovi Komore, ali nisu dužni. Međutim većina njih zaista i jest, iz razloga što kroz svoje članstvo mogu ostvariti sve benefite i zaštititi svoje interese kao pripadnika predmetne profesije. Kao dokaz članstva u Komori članovi dobivaju članstvene iskaznice ${ }^{3}$ koje u većini slučajeva služe kao i identifikacijske iskaznice i kojom 
se prijavljuju na određene stručna usavršavanja. Gubitak članske iskaznice i licence dužni su članovi prijaviti Komori kako bi im se izdale nove licence i iskaznice u smislu jasne identifikacije pojedinog zdravstvenog radnika kao člana. Ostvarivanjem zakonskih uvjeta član može zatražiti i brisanje iz članstva Komore. Brisanjem iz članstva automatski se poništava izdana licenca tako da brisani član nakon gubitaka članstva nije ni u mogućnosti obavljati profesionalnu djelatnost. Članstvom zdravstveni radnik ostvaruje pravo sudjelovati u svim tijelima Komore i na taj način participirati u kreiranju i utvrđivanju standarda profesije i zaštiti interesa članova i profesije. Članstvom u Komori zdravstveni radnik daje istoj strukovnoj organizaciji ovlast disponirati i raspolagati svim njenim profesionalnim i osobnim podacima. ${ }^{4}$

Zdravstveni radnik koji je poslovno nastanjen u državi članici EU/EGP -a, može privremeno ili povremeno obavljati djelatnost na području Republike Hrvatske, te je dužan o tome izvijestiti Komoru, izjavom u pisanom obliku. Komora će temeljem podnesene izjave izvršiti njegovu privremenu registraciju. Privremenom registracijom, on ne stječe članska prava niti preuzima članske obveze. Iznimno, protiv zdravstvenog radnika koji je privremeno registriran koji u Republici Hrvatskoj obavljaju djelatnost na privremenoj i povremenoj osnovi, može se po krenuti i voditi disciplinski postupak pred tijelima Komore sukladno odredbama propisa Komore kojima je određena disciplinska odgovornost i disciplinski postupak. Zdravstvenom radniku se izdaje se potvrda o obavljaju djelatnosti na privremenoj i povremenoj osnovi odnosno upisu u koji na toj osnovi obavljaju djelatnost.

\section{Primjedbe}

${ }^{1}$ Usp. BODNARUK, S. - ČIZMIĆ, J. - HRABAČ, B. - HUSEINAGIĆ, S., Komentari zdravstvenih zakona, knjiga 1., Privredna štampa, Sarajevo, 2011., str. 282.

${ }^{2}$ Podatak kod RADIŠIĆ, J., Medicinsko pravo, „Nomos“, beograd, 2004., str. 34.-35.

${ }^{3}$ Vidi Pravilnik o javnim knjigama HLK. Članska iskaznica sadrži: 1.naziv i logo Komore na hrvatskom i engleskom jeziku, 2.ime i prezime liječnika, 3.naznaku da je liječnik član Komore, 4.sjedište Komore, 5.članski broj, 6.broj odobrenja za samostalan rad (licence), 7.po potrebi i drugi podaci sukladno odluci Izvršnog odbora Komore ili izdavatelja iskaznice.

${ }^{4}$ Pravilnik o javnim knjigama HLK. Imenik liječnika sadrži: ime i prezime, djevojačko prezime, spol, OIB, datum rođenja, mjesto i država rođenja, državljanstvo, mjesto i adresa stanovanja, kontakt podaci (telefon, mobitel, e-mail), podatak o obrazovnom stupnju (medicinski fakultet mjesto i država, broj diplome i datum diplomiranja), broj i datum rješenja o priznavanju inozemne stručne kvalifikacije, broj i datum uvjerenja o položenom stručnom ispitu, broj i datum uvjerenja o položenom specijalističkom ispitu/užoj specijalizaciji, podatak o završenom poslijediplomskom studiju, podatak o akademskim ili stručnim nazivima, podatak o znanstveno nastavnom zvanju, datum i broj rješenja o upisu u Imenik liječnika, datum i broj rješenja o brisanju iz Imenika liječnika te razlog brisanja, datum izdavanja odobrenja za samostalan rad, datum obnove odobrenja za samostalan rad, podatako zaposlenju (naziv subjekta, mjesto i adresa, kontakt podaci), podatak o obavljanju privatne prakse/grupne privatne prakse(naziv subjekta, mjesto i adresa, kontakt podaci), podatak o ugovornom odnosu s HZZO-om, podatak o pokretnom disciplinskom postupku, podatak o izrečenim disciplinskimmjeramainjihovom trajanju te podatak o iznosu izrečene novčane kazne, podatak o karitativnom radu, podatak o posebnim osposobljenostima (znanjima i vještinama), podatak o poznavanju stranih jezika, podatak o statusu sudskog vještaka, podatak o članstvu u domaćim i iznozemnim stručnim društvima/komorama. 


\section{3/ Nadležnost i zadaci komora}

Osnivanje komora zdravstvenih radnika predstavlja značajan instrument i oblik strukovnog i profesionalnog organiziranja, odnosno udruživanja zdravstvenih radnika, kao i afirmiranja zdravstvene struke. Komore bi trebale, u koordinaciji i suradnji s relevantnim institucijama zdravstvene djelatnosti, svojim autoritetom pridonijeti promicanju i razvitku svih segmenata zdravstvene zaštite i zdravstvenog sektora u cjelini. ${ }^{1}$

Komora je staleška organizacija trajnog karaktera, čije postojanje ne zavisi od promjene sastava njezinih članova. Za razliku od dobrovoljnih udruženja, koja se oslanjaju na privatnu autonomiju, komora je zakonski predstavnik i zastupnik interesa svojih članova. Svoj pravni osnova ima u suverenom državnom aktu, tj. zakonu. To su obično tzv. sistemski zakoni iz područja zdravstva, u kojima su određeni zadaci komore i načini na koje se oni ostvaruju, kao i organi komore i njihove nadležnosti. Po svojoj naravi, komora je samoupravno tijelo, oblik decentralizirane posredne uprave u stvarima koje se tiču zdravstvene djelatnosti i njezinih zaposlenika. Država je na komoru prenijela dio svojih javnih ovlasti i zadataka, zato što smatra da će ona bolje i lakše kontrolirati stručne usluge koje njezini članovi pružaju građanima. ${ }^{2}$

Komore iz područja zdravstva trebaju zauzimati značajno mjesto u sustavu zdravstva svojim radom moraju se nametnuti tijelima vlasti kao strateški partneri u kreiranju politika i propisa iz ovog područja.

Kao udruženje javnog prava komora ima određene obaveze prema svojim članovima, ali i prema državi. Njezin je glavni zadatak utvrditi profesionalne dužnosti svojih članova i kontrolirati je li se oni njih pridržavaju. U tom cilju komora donosi tzv. kodeks etike i deontologije, koji predstavlja neposredno važeće pravo za sve njezine članove. Tu su još i razne smjernice, uputstva i direktive koje se tiču pojedinih grana medicine i medicinskih postupaka. Jedan od važnih zadataka komore je obveza skrbi o stručnom usavršavanju svojih članova. Radi toga ona donosi odgovarajući pravilnik, surađuje s medicinskih fakultetima i drugim zdravstvenim i znanstvenim ustanovama, izdaje stručne publikacije i sl. ${ }^{3}$ Komore imaju presudan i odlučujući utjecaj u kreiranju strukovnog prava, tako da je normativna djelatnost i međunarodna aktivnost komora temeljni izvor strukovnog prava. Kao posredan i nimalo nebitan izvor strukovnog prava jesu i procesne odluke i rješenja koje donose komorska tijela, te pravna tumačenja i stavovi komorskih tijela kod tumačenja i utvrđivanja standarda obavljanja djelatnosti profesije. ${ }^{4}$ Komore, dakle, daju stručna mišljenja kod izrade propisa koji su od utjecaja za razvoj zdravstvene struke, sudjeluju pri utvrđivanju standarda i normativa zdravstvenih usluga. ${ }^{5}$ Komore su dužne na zahtjev nadležnog ministarstva ili tijela pravosuđa dostaviti potrebne podatke o činjenicama o kojima državna tijela imaju saznanje. Također, komore po osobnoj inicijativi ili po zahtjevu zainteresirane osobe, obavještavaju ministarstvo nadležno za poslove zdravlja, druga državna tijela, nadležna tijela regionalne uprave i lokalne samouprave i organizaciju obveznog zdravstvenog osiguranja, o problemima u svezi s 
obavljanjem zdravstvene djelatnosti članova komora, kao i o problemima građana u ostvarivanju zdravstvene zaštite te predlažu mjere za njihovo rješavanje. Najmanje jednom godišnje, daju mišljenja o radu komora, koje razmatraju skupštine komora. ${ }^{6}$ Dužnost komore je brinuti o međusobnim odnosima svojih članova, suzbijati nelojalnu konkurenciju među njima i čuvati ugled i dostojanstvo profesije. Prvenstveno u javnosti zastupati staleške interese članova. Radi izvršenja tog zadatka komora ima pravo i podnositi tužbe sudu (primjerice, da bi zaštitila svoje članove od nekvalificirane konkurencije osoba izvan staleža). Međutim, u nadležnost komore ne spada zastupanje privatnih interesa pojedinaca, nego zajedničkih interesa članova koji su povezani s njihovim zanimanjem. Komora je dužna nadzirati ponašanje svojih članova, a naročito motriti kako oni ispunjavaju svoje profesionalne dužnosti. To, u stvari, znači kontrolu kvalitete medicinskih usluga, koja služi zaštiti interesa pacijenata. Stoga su neke komore dobrovoljno preuzele na sebe zadatak da rješavaju sporove između članova i pacijenata zbog eventualnih pogrešaka u radu njihovih članova. Tom cilju služe, primjerice, komorska povjerenstva za vještačenje i službe za nagodbe. ${ }^{7}$

\section{Primjedbe}

${ }^{1}$ Vidi PLAVŠIĆ-NEŠIĆ, A., Komore zdravstvenih radnika Srbije, „Pravni život“, 2009., broj 9, TOM I, str. 1016.

${ }^{2}$ Usp. RADIŠIĆ, J., Medicinsko pravo, „Nomos“, beograd, 2004., str. 34.-35.

${ }^{3}$ Tako RADIŠIĆ, J., Medicinsko pravo, ,Nomos“, beograd, 2004., str. 34.-35.

${ }^{4}$ Kao posredne izvore strukovnog prava u širem smislu prava mogu se spomenuti i svi drugi propisi, odnosno pravni akti kojima zakonodavac, ili druga nadležna tijela pod utjecanjam državne moći utvrđuju pojedine elemente i institute vezano za uvjete i načine obavljanja zdravstvenih djelatnosti

${ }^{5}$ Usp. BODNARUK, S. - ČIZMIĆ, J. - HRABAČ, B. - HUSEINAGIĆ, S., Komentari zdravstvenih zakona, knjiga 1., Privredna štampa, Sarajevo, 2011., str. 283.

${ }^{6}$ Podatak kod PLAVŠIĆ-NEŠIĆ, A., Komore zdravstvenih radnika Srbije, „Pravni život", 2009., broj 9, TOM I, str. 1015.

${ }^{7}$ Tako RADIŠIĆ, J., Medicinsko pravo, „Nomos“, beograd, 2004., str. 34.-35. 


\section{4/ Pravni izvori}

Ustrojstvo, nadležnost i način rada komora iz članka 197. ovoga Zakona uređuje se posebnim zakonom (ZOZZ, čl. 199.).

Glavom XIX „Komore“ ZOZZ-a sve zdravstvene komore dobile su potvrdu legitimiteta, a svi zdravstveni radnici koji obavljaju zdravstvenu djelatnost na području RH, obvezu učlanjenja u Komore. Predmetnim aktom, tj. zakonskom odredbom zakonodavac je želio jasno urediti i definirati profesije u sustavu zdravstva, dajući im iznimnu važnost ali i odgovornost i težinu. Dakle, sustav zdravstva prepoznao je kroz inicijativu staleških grupacija značaj obavljanja zdravstvene djelatnosti kroz sustav profesija, te da osobe koje će obavljati navedene djelatnosti ispunjavaju jasne kriterije i standarde u sadržaju i obliku obrazovanja i stručne osposobljenosti. Zato je omogućeno ali i zadužio sve zdravstvene radnike da samostalno obavljaju svoj posao u okviru vlastitih profesija. Sustav je prilagodio odnose na isti način i kod vrednovanja zanimanja, jer su svi koji obavljaju djelatnosti u sustavu zdravstva, a koje se ne tiču istih profesija, nezdravstveni radnici koji nemaju dužnost, ali ni ovlast staleških komorskih učlanjenja i tako postavljenih kriterija. Još veća razina značaja komorskog ustroja očitovala se kroz donošenje tzv. strukovnih zakona koji su precizno i jasno definirali osim komorskih ovlasti i njihov način rada, odnosno obavljanja pojedinih zdravstvenih djelatnosti. Zdravstvene djelatnosti kao djelatnosti od općeg interesa definirane su odredbama ZOZZ-a uopćeno i nedvojbeno i to na različitima razinama zdravstvene zaštite kao osnova pružanja iste u cilju zaštite zdravlja. Zdravstvene djelatnosti obavljaju se u zdravstvenim ustanovama, trgovačkim društvima ili je obavljaju privatni zdravstveni radnici, dakle u različitim organizacijskim oblicima u kojima zdravstveni radnici mogu relevantno, stručno i zakonski obavljati tu djelatnost u okviru svojih ovlasti i odgovornosti utvrđenim posebnim zakonskim i podzakonskim propisima i općim aktima staleških organizacija.

Ti posebni zakoni koji su temeljni izvori komorskih prava jesu: ZOL kojim se uređuje pojam, ustrojstvo i uvjeti za obavljanje liječničkog zvanja te djelovanje liječnika kao temeljnog, samostalnog i odgovornog nositelja zdravstvene djelatnosti koja je od posebnog interesa za Republiku Hrvatsku i koja osigurava zdravstvenu zaštitu svakom pojedincu i cjelokupnom pučanstvu u Republici Hrvatskoj. ZOL-om formalno je definirana HLK kao samostalna i neovisna strukovna organizaciju sa svojstvom pravne osobe i javnim ovlastima. Komora u okviru svojih djelatnosti predstavlja liječnike u Republici Hrvatskoj i u inozemstvu; ZOMBD kojim se uređuju načela, način organiziranja i provođenja medicinsko-biokemijske djelatnosti, kao dijela zdravstvene djelatnosti od interesa za Republiku Hrvatsku koja se obavlja kao javna služba i koju obavljaju magistar medicinske biokemije pod uvjetima i na način propisan istim Zakonom. Hrvatska komora medicinskih biokemičara samostalna je i neovisna strukovna organizacija sa svojstvom pravne osobe i javnim ovlastima; ZOLJK kojim se uređuje način provođenja i organiziranja ljekarničke djelatnosti kao dijela zdravstvene djelatnosti od interesa za Republiku Hrvatsku koja se obavlja kao javna služba i koju obavljaju magistri farmacije pod uvjetima i na način propisan istima Zakonom Hrvatska ljekarnička 
komora samostalna je i neovisna strukovna organizacija sa svojstvom pravne osobe i javnim ovlastima, koja u okviru svoje djelatnosti predstavlja magistre farmacije u RH i inozemstvu; ZOS kojim se uređuje sadržaj i način djelovanja, standard obrazovanja, uvjeti za obavljanje djelatnosti, dužnosti i kompetencije, kontrola kvalitete i stručni nadzor na radom medicinskih sestara. Hrvatska komora medicinskih sestara je strukovna samostalna organizacija medicinskih sestara sa svojstvom pravne osobe i javnim ovlastima, koja promiče, zastupa i usklađuje interese medicinskih sestara pred državnim i drugim tijelima u RH i u inozemstvu; ZOP kojim se uređuju sadržaj i način djelovanja, standard obrazovanja, uvjeti za obavljanje djelatnosti, dužnosti, kontrola kvalitete i stručni nadzor nad radom primalja u Republici Hrvatskoj. Hrvatska komora primalja jest strukovna samostalna organizacija primalja sa svojstvom pravne osobe i javnim ovlastima. Komora promiče, zastupa i usklađuje interese primalja pred državnim i drugim tijelima u Republici Hrvatskoj i u inozemstvu; Zakon o fizioterapeutskoj djelatnosti („Narodne novine“ br. 120/08) kojim se uređuju sadržaj i način djelovanja, standard obrazovanja, uvjeti za obavljanje djelatnosti, dužnosti, kontrola kvalitete i stručni nadzor nada radom fizioterapeuta u Republici Hrvatskoj. Hrvatska komora fizioterapeuta jest samostalna i neovisna strukovna organizacija sa svojstvom pravne osobe i javnim ovlastima. Komora predstavlja i zastupa interese fizioterapeuta, fizioterapeutskih tehničara, radnih terapeuta i masera-kupeljara koji obavljaju poslove u fizikalnoj terapiji na području Republike Hrvatske; ZODUZ kojim se uređuje sadržaj i način djelovanja, standard obrazovanja, uvjeti za obavljanje djelatnosti, dužnosti, kontrola kvalitete i stručni nadzor nad radom zdravstvenih radnika djelatnosti sanitarnog inženjerstva, zdravstvene radiološko tehnološke djelatnosti, djelatnosti radne terapije i medicinskolaboratorijske djelatnosti. Hrvatska komora zdravstvenih radnika jest samostalna i neovisna strukovna organizacija sa svojstvom pravne osobe i javnim ovlastima. Komora predstavlja i zastupa interese magistara sanitarnog inženjerstva, diplomiranih sanitarnih inženjera, sveučilišnih prvostupnika sanitarnog inženjerstva, stručnih prvostupnika sanitarnog inženjerstva, sanitarnih tehničara, stručnih prvostupnika radiološke tehnologije, stručnih prvostupnika radne terapije, stručnih prvostupnika medicinskolaboratorijske dijagnostike, inženjera medicinske radiologije, viših radnih terapeuta, viših fizikalnih terapeuta - smjer radne terapije, inženjera medicinsko-laboratorijske dijagnostike, zdravstveno-laboratorijskih tehničara, zdravstveno-laboratorijskih tehničara sa završenim tečajem iz citodijagnostike-citoskrinere, zdravstvenolaboratorijskih tehničara sa završenim tečajem iz transfuzijske medicine, stručnih prvostupnika medicinsko-laboratorijske dijagnostike sa završenim tečajem citodijagnostike-citotehnologe ili sa završenim tečajem iz transfuzijske medicine.

Svi gore navedeni tzv. strukovni zakoni utvrdili su Komore kao nadležna tijela za obavljanje djelatnosti navedenih profesija. Time su Komore u punom smislu riječi dobile legitimitet kao regulatorna tijela profesija u zdravstvu. ${ }^{1}$

\section{Primjedbe}

${ }^{1}$ Vidi KLARIĆ, A. - CVITKOVIĆ, M. - MATIJAŠČIĆ ŽUGAJ, P., Komore u zdravstvu, Zbornik „Aktualna problematika u zdravstvu“, Varaždin (2015), str. 162.-182. 


\section{5/ Javne ovlasti komora}

Komore moraju svojim aktima urediti način i postupak obavljanja poslova iz svoje nadležnosti, posebno onih koji su određeni kao javna ovlaštenja. Komore su ustanove čija je osnovna svrha i zadaća štititi prava i zastupati interese svojih članova, ali i brinuti se o poštivanju etičkih i deontoloških načela struke te, u tom smislu, izricati odgovarajuće mjere onima koji u svojem profesionalnom radu ne poštuju ta načela. Ipak, navedeno ne predstavlja osnovnu i jedinu svrhu osnivanja i postojanja komora. Naime, komore, pored svojih ovlasti koje imaju kao staleške ustanove, imaju još i javne ovlasti što ih, mutatis mutandis, čini dijelom državnog mehanizma. Na taj način komore djelomično «rasterećuju» izvršnu vlast (tj. nadležno ministarstvo) tako što obavljaju poslove koji su rezultat specifičnosti svake pojedine zdravstvene djelatnosti, a koji su, kao takvi, propisani i određeni zakonom. Osim toga, komore kao staleške organizacije u okviru svoje nadležnosti na neposredan način osiguravaju i provedbu zakonskih propisa u oblasti zdravstva donošenjem podzakonskih akata kojima se detaljnije razrađuju pojedine zakonske odredbe. ${ }^{1}$

Komori se povjeravaju određena javna ovlaštenja ${ }^{2}$ koja podrazumijevaju, primjerice: izdavanje, obnavljanje i oduzimanje licence za rad zdravstvenim radnicima; davanje mišljenja o opravdanosti izdavanja, produženja ili oduzimanja odobrenja za rad u privatnoj praksi, davanje mišljenja u svezi početka, proširenja, promjene i prestanka rada zdravstvenih ustanova; certificiranje članove komore za upravljanje zdravstvenim tehnologijama; propisivanje načina oglašavanja i način isticanja naziva privatne prakse, utvrđivanje slučajeva koji se ne smatraju reklamiranjem zdravstvenih usluga i sl. ${ }^{3}$

Strukovnim zakonima podrobno je definiran djelokrug Komora u sustavu zdravstva. U načelu je zakonskim odredbama utvrđeno da Komora zastupa i predstavlja interese pojedinih zdravstvenih radnika. Statutom Komora utvrđen je detaljnije djelokrug i opis poslova Komora. Poslove Komora shodno tome možemo podijeliti u dvije grupe: a/ Stručni poslovi Komore te b/ Poslovi javnih ovlasti Komore.

a/ Temeljni poslovi Komore u stručnom smislu jesu: sustavno očuvanje i unapređenje društvenog položaja i ugleda profesija u svakom obliku i sadržaju; predlaganje i utvrđivanje standarda i normativa obavljanja profesije; utvrđivanja Kodeksa etike i deontologije u obavljanju profesije te kontinuirano praćenje i nadziranje njegovog provođenja te sankcioniranje kršenja predmetnih načela; aktivna suradnja s fakultetima te stručnim zdravstvenim društvima s ciljem definiranja i unaprjeđenja standarda profesija; organiziranje, nadziranje trajnog stručnog usavršavanja zdravstvenih radnika; davanje mišljenja $u$ postupku osnivanja, preseljenja i prestanka rada privatnih zdravstvenih ustanova i privatnih praksi; zastupanje zdravstvenih radnika kod sklapanja ugovora s Hrvatskim zavodom za zdravstveno osiguranje te društvima za osiguranje u cilju vrednovanja rada u postupku formiranja cijena zdravstvenih usluga; predlaganje osnovne mreže zdravstvene djelatnosti; davanje prijedloga i stručnih mišljenja kod 
pripreme propisa koji imaju utjecaj na razvoj medicinske zdravstvene struke, zdravstvene zaštite i profesije.

b/ Poseban značaj čine poslovi javnih ovlasti. Javne ovlasti znače poseban oblik javne vlasti koje država može povjeriti odnosno podijeliti nedržavnim subjektima, dakle i pravnim osobama, da postupaju u ime države, a to su javne ustanove, agencije, društva i druge pravne osobe u djelatnostima koje čine sustav javnih službi. To pravo javnih ovlasti tim subjektima povjerava odnosno dodjeljuje država, a sastoji se u autoritativnom obavljanju određenih poslova od javnog interesa. Zakonom o sustavu državne uprave ((,Narodne novine“ br. 150/11, 12/13) dana je mogućnost pravnim osobama koje sukladno posebnim propisima imaju javne ovlasti, u povjerenim im poslovima državne uprave: 1. rješavati u upravnim stvarima u prvom i drugom stupnju kad su im ti poslovi zakonom izrijekom stavljeni u nadležnost; 2 . voditi očevidnike određene zakonom i drugim propisima i izdavanje propisanih uvjerenja i drugih potvrda; 3 . obavljati i druge poslove državne uprave koji su im zakonom izrijekom stavljeni u nadležnost. Kao što vidimo povjeravanje javnih ovlasti može se odnositi na različite poslove od javnog interesa, ali se uglavnom svodi na tri vrste pravnih poslova: normiranje određenih društvenih odnosa; rješavanje u pojedinačnim upravnim predmetima; obavljanje upravnih radnji. Subjekti kojima je država povjerila obavljanje javnih ovlasti uvijek djeluju autoritativno u odnosu na druge subjekte, a što je nužno da bi doneseni akti i poduzete radnje imale snagu pravnih učinaka. Ne postoji razlika u pravnoj prirodi upravnog akta kojeg donosi tijelo državne uprave, kao državni subjekt, i upravnog akta kojeg donosi drugi subjekt na temelju javnih ovlasti. Poslovi od javnog interesa su pod posebnim patronatom države pa se njihov rad kontinuirano nadzire.

Država je, dakle, odlučila delegirati javne ovlasti i u sustavu zdravstva kao posljedicu shvaćanja kako je svrsishodnije da određene poslove države obavljaju nedržavni subjekti na autoritativan način i u ime javne vlasti. Komore za obavljanje predmetnih poslova imaju formalno ovlaštenje tj. normu zakonodavca kojim je izražena volja države da podjeli obavljanje javnih ovlasti zastupnicima pojedine profesije smatrajući da isti mogu najbolje provoditi premetne poslove kao i da se svi poslovi vezani za određenu profesiju obavljaju na jednom nadležnom mjestu. Delegirane javne ovlasti odnose se na: 1. vođenje javnih registara; 2. izdavanje, obnavljanje i oduzimanje odobrenja za samostalan rad; 3. obavljanje stručnog nadzor nad radom zdravstvenih radnika; 4 . određivanje najniže cijene rada privatnih zdravstvenih radnika; 5. odobravanje pojedinačne cijene usluga privatnih zdravstvenih radnika; 6 . priznavanje inozemnih stručnih kvalifikacija. Osnova poslovanja Komore čine javne ovlasti. Javne ovlasti obavljaju se i provode u pravilu po načelima upravnog postupka.

Vođenje registra podrazumijeva ovlast $\mathrm{i}$ odobrenje registriranja svih članova, zdravstvenih radnika određene profesije sa svim relevantnim osobnim podacima koji uključuju podatke o stupnju i vrsti obrazovanja i poslova koje je zdravstveni radnik ovlašten obavljati i koje obavlja. Izdavanje odobrenja za samostalan rad podrazumijeva ovlast Komori davati pisane potvrde o ovlaštenju pojedinom zdravstvenom radniku za obavljanje djelatnosti svoje profesije. Općim aktima Komora propisani su uvjeti kojima mora udovoljavati pojedini zdravstveni radnik da bi mogao obavljati samostalno poslove djelatnosti pojedine profesije, što znači da svaki zdravstveni radnik mora ispunjavati 
određene zakonom propisane opće i posebne specifične uvjete za obavljanjem predmetnih poslova. Opći uvjeti bili bi stoga državljanstvo, poslovna sposobnost, određena dob, dok je posebni uvjet formalna kvalifikacija, stručni ispit, specijalizacija, izjava o poštivanju etičkih i deontoloških načela, te pojedini posebni oblici i uvjeti utvrđeni posebnim općim komorskim aktima. Postupak izdavanja licenci i obnavljanja licenci strogo je i striktno propisani određenim procesnim pravilima, kao i posebnim dodatnim uvjetima kojima moraju udovoljiti članovi da bi mogli obnoviti svoju licencu nakon određenog vremena. Licenca ili odobrenja za samostalan rad nisu trajne kategorije već su propisani kriteriji udovoljavanja uvjetima da se ista obnove nakon propisanog razdoblja, u pravilu šestogodišnjeg. Svaki zdravstveni radnik mora kontinuirano obnavljati svoja znanja te se stalno educirati i trajno usavršavati. Komora je propisala uvjete i sadržaje i načine stručnih usavršavanja koja se provode sustavno i konstantno u različitim oblicima (kongresi, tečajevi, radionice $\mathrm{i}$ dr.) u organizaciji Komora ili stručnih društava, zdravstvenih ustanova ali sve pod komorskim nadzorom. Takve oblike stručnih usavršavanja komora vrednuje kao uvjet obnavljanja licenci tj. nastavka kontinuiteta osposobljenosti obavljanja određene profesije. Komora je svoje članova ograničila na postupanja sukladno postavljenim standardima struke, te poštivanju etičkih i deontoloških načela prilikom svakog rada odnosno obavljanja poslova u okviru djelatnosti profesije. Svaki otklon strogo se kažnjava, tj. procesuira se, tako da nikome nije dopušteno da djelatnost profesije obavlja na proizvoljan način van postavljenih i jasno definiranih okvira stručnosti i profesionalnosti.

Određivanje najniže cijene rada, kao i pojedinačnih cijena usluga kao iznimno bitna ovlast s pozicije da struka sama ima ovlast procijeniti koju cijenu rada zaslužuje pojedini zdravstveni radnik u sustavu zdravstva, kao i koliko se može i treba vrednovati usluga koju on pruža primateljima usluga, tj. pacijentima.

Stručni nadzori kvalitete i stručnosti obavljanja poslova pojedinih zdravstvenih radnika, kao i poštivanja etičkih načela postavljeni su kao posebno iznimno bitna javna ovlast Komorama. Sustav je dao ovlast zdravstvenim radnicima određene profesije da mogu samostalno obavljati poslove djelatnosti, čime ih je jasno pozicionirao u sustavu zdravstva kao nezaobilazan čimbenik u pružanju zdravstvene zaštite i zaštite zdravlja. Dajući im navedenu ovlast državni sustav je na poticaj strukovnih organizacija $s$ isključivim ciljem zaštite interesa profesije kao cjeline, utvrdio i kriterije obavljanja poslova djelatnosti, kao i nadzor nad obavljanjem istih poslova u skladu s utvrđenim i postavljenim normativima. Svaki otklon procesuira se iz razloga da profesije bude neokrnjene u obavljanju poslova njene djelatnosti. U okviru stručnih nadzora nadzire se i utvrđuju se uvjeti rada u kojim poslove djelatnosti profesije obavljaju zdravstveni radnici, želeći jasno definirati i kriterije u kojima se poslovi profesije jedino mogu adekvatno i stručno profesionalno obavljati. Zato stručni nadzor ima i šire okvire i posljedično utječe na šire aspekte i više čimbenika u sustavu zdravstva, ali uvijek s jednim istim ciljem pružanja najbolje moguće zaštite primateljima usluga, tj. pacijentima .

Zadnja definirana djelatnost u okviru javnih ovlasti je priznavanje inozemnih stručnih kvalifikacija kao poseban element utvrđivanja standarda i ujednačavanja kvalifikacija profesija. Zakonom o reguliranim profesijama i priznavanju inozemnih stručnih kvalifikacija (,Narodne novine“ br. 82/15.) utvrđene su profesije iz sustava zdravstva kao 
regulirane profesije, te su primjenom europskog zakonodavstva utvrđeni kriteriji automatskog priznavanja pojedinih profesija (doktori medicine, stomatologije, magistri farmacije, medicinske sestre, primalje) kao i provedbe općeg sustava priznavanja kod ostalih zdravstvenih profesija. Cilj je omogućavanja zdravstvenim radnicima pristupu tržištu rada na području Europske unije, kao i utvrđivanja shodno tome zajedničkih okvirnih kompetencija poglavito za struke i profesije iz sustava zdravstva. Komore u predmetnom pogledu kao osnovna regulatorna tijela imaju jasnu ulogu, i poziciju temeljnog čimbenika i moderatora navedenih aktivnosti s ciljem usklađivanja standarda profesija te samim tim i zanimanja.

Nadležna komora provodi provjeru stručnog znanja kandidata radi ocjene osposobljenosti kandidata za obavljanje regulirane profesije. Mjerila za priznavanje inozemnih stručnih kvalifikacija pravilnikom propisuje ministar uz mišljenje nadležnih komora (ZOZZ, čl. 138.a)._U cilju omogućavanja mobilnosti zdravstvenih radnika Komore su nadležne za izdavanje odgovarajućih potvrda kao što je EU potvrda za neometano pružanje usluga na unutarnjem tržištu Europske unije - potvrda koja se izdaje pravnim i fizičkim osobama u svrhu neometanog obavljanja profesija i pružanja usluga na području drugih država članica, zapošljavanjem i obavljanjem gospodarske djelatnosti, odnosno samozapošljavanjem, poslovnim nastanom, odnosno privremenim i povremenim pružanjem usluga, ili pak potvrda o trenutnom profesionalnom statusu kojima se dokazuje da se protiv članova zdravstvenih radnika ne vode disciplinskih postupci, ili pak potvrda o stupnju sukladnosti obrazovanja kojom se potvrđuje da je obrazovanje zdravstvenog radnika sukladno utvrđenim programima te odredbama direktive i europskih standarda. Prema odredbama ZOZZ-a, zdravstvenom radniku državljaninu Republike Hrvatske koji zakonito obavlja zdravstvenu djelatnost na teritoriju Republike Hrvatske, nadležna komora izdaje potvrdu o stvarnom i zakonitom obavljanju te djelatnosti neprekidno tri godine u posljednjih pet godina (ZOZZ, čl. 138.b st. 1.). Nadležne komore izdaju potvrde za državljane Republike Hrvatske čiji dokaz o formalnom obrazovanju za doktora medicine, medicinske sestre u djelatnosti opće njege, doktore dentalne medicine, magistre farmacije i primalje nije sukladan zvanju (tituli) upisanom za Republiku Hrvatsku sukladno Zakonu o reguliranim profesijama i priznavanju inozemnih stručnih kvalifikacija, a tom potvrdom se utvrđuje da je formalna kvalifikacija izdana na temelju uspješnog završetka obrazovanja sukladno Zakonu o reguliranim profesijama i priznavanju inozemnih stručnih kvalifikacija (ZOZZ, čl. 138.b st. 3.).

Iz svega je vidljivo da u ovako postavljenim odnosima gro djelatnosti Komore obavlja se u okviru javnih ovlasti ili s ciljem adekvatnog obavljanja odnosno omogućavanja provedbe javnih ovlasti. Zaista je teško u načelu striktno provedbeno odvojiti i selektirati poslove Komore na način kako je zakonodavac isto učinio zato što se velik dio poslova iako formalno nedefiniranih kao javne ovlast, provodi i poduzima u okviru javnih ovlasti ili omogućavanja provedbe tih javnih ovlasti. Dakle, svi poslovi Komore isprepleteni su kroz svoju formu i sadržaj te u svakodnevnom obavljanju poslova iste definitivno nije moguće selekcionirati ili razdvajati. Naime jasno je i nedvojbeno da za obnavljanje licence dužnost zdravstvenog radnika je stručno se osposobljavati tijekom licencnog razdoblja, kao što je kod reguliranja profesije i priznavanja stručnih kvalifikacija nužno surađivati s učilištima u okviru utvrđivanja jednakosti standarda profesija. Slijedom toga evidentna je prožetost i međuodnos svih komorskih poslova ma kako se oni ili kako ih 
vlast formalno deklarirala, a sve kako bi se predmetna profesija obavljala sukladno utvrđenim standardima i normativima. Iz predmetnog razloga evidentno je da bilo kakvo zadiranje institucija ili pokušaj redefiniranja komorskih ovlasti nije moguć a da se pritom na učini šteta po sustav održavanja pozicioniranih i definiranih kriterija profesija.

Ovakav sustav Komora dao je mogućnost Komorama da se statusno definiraju kao pravne osobe $\mathrm{s}$ jasno definiranim delegiranim javnim ovlastima. Shodno zakonskim propisima poglavito Zakona o ustanovama („Narodne novine“ br. 76/93, 29/97, 47/99, 35/08) Komore su statusno određene kao ustanove (HLK, Hrvatska komora dentalne medicine, Hrvatska ljekarnička komora, Hrvatska komora medicinskih biokemičara, Hrvatska komora medicinskih sestara, Hrvatska komora zdravstvenih radnika), ili pravne osobe po posebnom zakonu (Hrvatska komora primalja, Hrvatska komora fizioterapeuta). Ustanova kao statusni organizacijski oblik u kontekstu ovako postavljenih odredbi Zakona o ustanovama, nije prilagodljiv i zastario je da bi se posve na nesmetan način kontinuirano i sustavno obavljali svakodnevni neuniformirani komorski poslovi u cilju zaštite interesa profesija zdravstvenih radnika, štoviše kad je teško i dvojbeno definirati jesu li Komore privatne ustanove ili javne ustanove. Dapače, nedostatak predmetnog nije se riješio ni statusnim definiranjem Komora kao pravnih osoba po posebnom zakonu kad taj isti posebni zakon nije u svojim odredbama decidirano, precizno i detaljno razradio organizacijsku strukturu i način obavljanja poslova Komore.

Kao što je vidljivo Komoru kao instituciju nije moguće uokviriti u sustav pojedinih organizacijskih oblika koji sami po sebi nisu dostatni ni odgovarajući za obavljanje ovako postavljenih poslova, a kamoli svih različitih i raznovrsnih poslova zaštite interesa profesija. $^{4}$

\section{Primjedbe}

${ }^{1}$ Usp. BABIĆ, T. - ROKSANDIĆ, S., Osnove zdravstvenog prava, Zagreb, 2006., str. 292.

${ }^{2}$ Spomenuti poslovi komora odnosno provođenje javnih ovlasti očituje se najčešće u neposrednoj primjeni zakona i drugih propisa, rješavanju u upravnim stvarima, vođenju propisanih očevidnika, izdavanju uvjerenja i drugih potvrda te obavljanju i drugih upravnih i stručnih poslova. BABIĆ, T. - ROKSANDIĆ, S., Osnove zdravstvenog prava, Zagreb, 2006., str. 243.

3 Tako BODNARUK, S. - ČIZMIĆ, J. - HRABAČ, B. - HUSEINAGIĆ, S., Komentari zdravstvenih zakona, knjiga 1., Privredna štampa, Sarajevo, 2011., str. 283.

${ }^{4}$ Vidi KLARIĆ, A. - CVITKOVIĆ, M. - MATIJAŠČIĆ ŽUGAJ, P., Komore u zdravstvu, Zbornik „Aktualna problematika u zdravstvu“, Varaždin (2015), str. 162.-182. 


\section{6/ Komora kao jamac zaštite prava pacijenata}

U svojem djelokrugu poslovanja Komore predstavljaju institucionalno sredstvo zaštite prava pacijenta. Zaštita prava pacijenata prezentira se na različite načine kroz svakodnevni rad Komora i njenih službi. Pri tome izdvajamo i razlikujemo neposredni i posredni utjecaj na zaštitu prava pacijenata.

Neposredni utjecaj na zaštitu prava pacijenta svakako imaju komorski poslovi rješavanja različitih pritužbi pacijenata na obavljanje liječničke i drugih profesionalnih djelatnosti zdravstvenih radnika. Dakle svaki pacijent i/ili treća osoba (zainteresirana osoba) ima pravo i mogućnost podnijeti pritužbu na rad liječnika/zdravstvenog radnika nadležnoj Komori a koja pritužba se može odnositi na profesionalni stručni rad pojedinog zdravstvenog radnika, odnosno na postupanje suprotno utvrđenim etičkim i deontološkim načelima. Temeljem podnesene pritužbe ista se dostavlja nadležnom stručnom povjerenstvu Komore koje ima dužnost i obvezu odlučiti u ingerencijama svojih ovlasti je li pojedini zdravstveni radnik u obavljanju svoje profesionalne djelatnosti počinio stručni profesionalni propust odnosno je li prekršio koje od utvrđenih pravila etike i deontologije zdravstvene profesije. Razmatranjem pojedinog slučaja povjerenstvo Komore će donijeti meritornu odluku koja će ako se utvrdi pogreška stručnog postupanja i povreda etičkih pravila biti temelj provođenja disciplinskog postupka protiv zdravstvenog radnika, ili će biti temelj pokretanja kaznenog postupka ukoliko se radi o pogrešci koja je definirana kao kazneno djelo (npr. nesavjesnog liječenja), ili će biti temelj određenog odštetnog zahtjeva pacijenta. Osim samog pacijenta pritužbu na profesionalni rad zdravstvenog radnika može podnijeti i samo povjerenstvo ili drugo tijelo Komore, nadležno državno tijelo (ministarstvo, ustanove) ili represivne državne institucije (policija, državno odvjetništvo)

Daljnji segment neposredne zaštite prava pacijenata ostvaruje se putem ostvarivanja prava na pristup informacijama. Pacijenti i treće osobe mogu u svako vrijeme zahtijevati od Komore bilo koji podatak o kojem Komora vodi evidencije a koji se odnosi na člana/zdravstvenog radnika poštujući privatnost i dostojanstvo imenovanog. Podaci se mogu odnositi na brojna pitanja koja se odnose na potrebu zaštite prava pacijenta.

Neposredna zaštita prava pacijenata ostvaruje se također provedbom stručnog nadzora nad radom pojedinog zdravstvenog radnika i djelatnosti u ustanovama ili privatnim praksama. Komora kao tijelo javne vlasti ima ovlast i dužnost redovno provoditi stručni nadzor nad radom svojeg člana u određenim organizacijskim jedinicama. Obavljanjem istog te donošenjem stručnog mišljenja o istom koje sadrži preporuke, naloge i prijedloge upućene nadziranom zdravstvenom radniku i ustanovi u kojoj radi odnosno obavlja profesionalnu djelatnost, Komora neposredno utječe na pružanje zdravstvene zaštite i samim tim na zaštitu prava pacijenta.

Svi drugi segmenti poslovanja Komora utječu kao posredni čimbenik zaštite prava pacijenta. Komora je kao institucija osnovana zakonskom normom s ciljem isključive 
zaštite interesa zdravstvenih radnika i zdravstvenih profesija. Međutim kad se šire sagleda element zaštite interesa članova te svi aspekti poslovanja Komore onda je posve jasno da ono u krajnjem cilju ima pružiti zaštitu i skrb pacijenta te ostvarivanje i unaprjeđenje zdravstvene zaštite kao temeljne i zakonskim normama zagarantirane vrijednosti. Jasno je i posve nedvojbeno da poslovi licenciranja i utvrđivanja formalne osposobljenosti za samostalan rad je temeljni kontrolni element koji treba garantirati da zdravstvenu djelatnost i zdravstvenu zaštitu trebaju i ovlašteni su jedino obavljati zdravstveni radnici koji odobrenje za rad zahtijevaju i dobivaju od nadležne Komore. Nadalje poslovi utvrđivanja i predlaganja standarda i kriterija obavljanja djelatnosti također predstavljaju nedvojben temelj utvrđivanja načela u zaštiti pacijenta kao korisnika tako utvrđenih zakonitosti u pružanju zdravstvenih usluga odnosno djelatnosti.

Određivanja mogućnosti obavljanja privatne prakse i cijena rada je garant uvođenja reda i korektiv na tržištu zdravstvenih usluga, opetovano u cilju jasno postavljenih granica odgovornosti i ovlasti kod ostvarivanja zaštite prava pacijenata.

Zaključno se može kazati da su Komore u svojem poslovanju neodvojivo vezane za segment zaštite prava pacijenta, te da u načelu krajnji cilj i svrha postojanja Komora kao institucija jest zaštita zdravstvenog sustava i pružanje adekvatne i sveobuhvatne zdravstvene zaštite i skrbi pacijentu odnosno društvu.

Javne ovlasti Komore koje strogo kogentnom formalnom pravnom normom određuju zdravstvenog radnika i njegovu djelatnost kao profesiju nesumnjivo kao takve jesu utvrđene i propisane kako bi profesija u ostvarivanju predmetnih zakonitosti mogla pružiti neposrednu i neophodnu zdravstvenu zaštitu i pružiti skrb i zaštitu pacijentu.

Sve druge ovlasti Komore, koje je zakonodavac propisao i dao Komorama kao djelatnosti koje upotpunjuju rad Komore i njen utjecaj na sustav u cjelini na zdravstvenu politiku, na rad zdravstvenih ustanova, na rad pojedinih zdravstvenih radnika, omogućuju nadogradnju i unaprjeđenje sustava zaštite prava pacijenta i pružanja zdravstvene zaštite. Ukoliko Komore u sustavu zdravstva dobiju i pronađu svoje mjesto kao najrelevantnijeg čimbenika koji će moći donositi meritorne i odlučujuće odluke onda će i koncept zaštite prava pacijenata kroz sve gore spomenute elemente poslovanja Komore biti jasno preciziran, utvrđen i izpoštovan. Obzirom da Komoru čine praktički zdravstveni radnici, te da su isti i članovi Komore, a da oni neposredno i svakodnevno u svojim ustanovama ili privatnim ordinacijama pružaju zdravstvenu skrb nije nimalo sporno da će punu podršku zaštiti prava pacijenta dati i kroz tako definiran institucionalni strukovno organizacijski oblik. Komora iz svih tih razloga nije i ne može biti institucija koja će u pružanju zaštite interesa svojih članove zanemariti prava pacijenta, već štoviše jasno je da se kroz primjenu svih segmenata komorskog poslovanja u načelu ostvaruje zagarantirani stav i zakonom postavljen cilj zdravstvene zaštite i zaštite prava pacijenata u cjelini. ${ }^{1}$ 


\section{Primjedbe}

${ }^{1}$ Vidi KLARIĆ, A. - CVITKOVIĆ, M. - MATIJAŠČIĆ ŽUGAJ, P., Komore u zdravstvu, Zbornik „Aktualna problematika u zdravstvu“, Varaždin (2015), str. 162.-182. 
354 | ZDRAVSTVENO STRUKOVNO STALEŠKO PRAVO 


\section{7/ Komora u novim izazovima}

Komore se po svemu sudeći i gore iznesenim argumentima trebaju prilagoditi novim izazovima. Novi izazovi vidjeli smo kontinuirano i stalno dolaze s činjenicama unaprjeđivanja i progresa samog sustava zdravstvene zaštite generalno, novih sustava i standarda pružanja zdravstvene zaštite i neposrednih postupaka u pružanju zdravstvene zaštite. Osim toga oni dolaze sa porastom primatelja usluga i redefiniranjem pozicija zdravstvenih radnika, potrebom temeljitijeg i kompleksnijeg sustava obrazovanja i osposobljavanja zdravstvenih radnika, načelima usklađivanja standarda profesija i zanimanja na širem tržištu rada, jačeg i sustavnijeg nadzora obavljanja djelatnosti s ciljem zaštite pacijenta i lociranja granica dužnosti kao i jasnim definiranjem ovlasti i odgovornosti zdravstvenih radnika u procesu pružanja usluga. Komora u takvom sustavu treba imati jasnu poziciju koja joj je i načelno dana zakonskim propisima. Međutim ta načelna ovlast nikako ne može biti kriterij oko koje bi se izgrađivao sustav jasnih i nedvojbenih ovlasti Komore.

Postojećim strukovnim zakonima predmetan cilj nije moguće ostvariti, iz razloga što su isti i krnje i neprecizno postavljeni, ali ponajviše iz razloga što se u praksi i provedbi pojedinih poslova pokazalo da Komore zahtijevaju jasniju i određeniju formulaciju organizacijskih oblika i ovlaštenja te odgovornosti prilagođenu kontinuitetu razvoja i promjena odnosa u zdravstvu te pozicija zdravstvenih radnika. Prvo, sustav uokvirivanja i uskog definiranja javnih i nejavnih ovlasti nije moguć, pa stoga nije dobar i provediv. Dakle javna ovlast je prema zakonskim odredbama izdavanje i obnavljanje odobrenja za samostalan rad, dok sustav vrednovanja stručnih usavršavanja nije utvrđen kao javna ovlasti. U praksi obnoviti licencu nije moguće bez kontinuiteta provedbe stručnih usavršavanja svakog pojedinog zdravstvenog radnika. Znači stručno usavršavanja je neposredni uvjet mogućnosti obnavljanja licence. Postupak obnavljanja je javna ovlast koja se provodi sukladno načelima upravnog postupka, obzirom da se radi i odlučuje o upravnoj stvari, dakle odlučuje se o pravima i obvezama pojedinca u okviru upravne stvari. Sustav vrednovanja tj. bodovanja svakog pojedinog stručnog usavršavanja kao preduvjeta javne ovlasti obnavljanja odobrenja za samostalan rad trebao bi po svoj pravnoj logici biti neodvojivo vezan za postupak obnavljanja licence, pa bi i takvi postupci po zahtjevu trebali biti postupci javnih ovlasti vođeni u okviru upravnog postupanja. Ovaj primjer nam daje za pravo da zaista utvrdimo praktičnu i teorijsku nemogućnost postavljanja jasnih granica što bi sve predstavljalo javne ovlasti Komora, a što ne.

Jednako tako predmetno možda i ne bi predstavljalo problem ako bi svi predmetni poslovi nedvojbeno bili i ostali utvrđeni kao poslovi Komore. Problem može nastati kad bi se pojedini elementi ovlasti pokušali delegirati nekim drugim tijelima, kao što problem može predstavljati i što se pojedini poslovi vezani za interese članova i njihovih profesija u svom izvornom obliku još uvijek nalaze pod nadležnošću više različitih državnih i drugih tijela. Dakle tendencija izgrađenog komorskog sustava trebala bi biti usmjerena na objedinjavanjem svih poslova iz djelokruga zaštite interesa profesije i njenih članova 
na jednom mjestu kroz jednu nadležnu instituciju koje bi svoje poslovanje usklađivala kontinuirano i svakodnevno potrebama promjena i razvitka profesija. Komora bi trebala biti relevantan čimbenik, partner ostalim institucijama koje na neposredan ili posredan način utječu na definiranje profesija u sustavu zdravstva. Komore moraju pokazati inicijativu kao regulatorno tijelo u utvrđivanju standarda i kompetencija profesija, konkretnije surađivati s visokim učilištima u izradi i definiranju programa obrazovanja zdravstvenih radnika, kao i utjecati jasno na definiranje i utvrđivanja specijalističkog usavršavanja.

Komore osim svojih javnih ovlaštenja, te regulatornih ovlaštenja, trebaju biti jamac zaštite rada i interesa profesije i svakog pojedinog zdravstvenog radnika. Komore trebaju aktivno zastupati interese svojih članova prije svega u utvrđivanju djelokruga kompetencija, djelokruga rada, kao i djelokruga i granica odgovornosti i ovlasti pojedinog radnog mjesta. U okviru navedenog potrebno je jasno i sustavno ukazivati na određenost poslova svakog pojedinca, profesionalca u sustavu zdravstva, utjecati svakodnevno na rad svakog člana u okviru svojih profesija, pružati neposrednu zaštitu interesima zdravstvenih radnika, pružati i neposrednu zaštitu profesije od nesavjesnih članova, kao i svakodnevno neposrednim radom štititi pacijenta od svakog neprofesionalnog postupanja pojedinih zdravstvenih radnika, te procesuiranje navedenih.

U svemu navedenom potrebno je u teorijskom i praktičnom smislu utvrditi poveznicu koja će prije svega omogućiti lakše shvaćanje svakom pojedincu, profesionalcu i pacijentu kao i samom sustavu koje su mogućnosti, postupci, posljedice različitih situacija i odnosa proisteklih iz pružanja zdravstvene zaštite. Vakum nedefiniranih situacija kontinuirao i sustavno opterećuje i ugrožava sustav zdravstvene zaštite, poglavito ako su nosioci istih situacija pružatelji i primatelji usluga. Ključ raslojavanja takvih zamršenih i nedefiniranih situacija leži u povezivanju, različitih disciplina koje u praktičnom smislu treba provoditi Komora. Najbolji primjer je medicinsko pravo i načela medicinskog prava. Primjenom istih načela Komora može definirati standarde edukacije različitih čimbenika koji sudjeluju u procesima kreiranja teorijskih normativa važnim za djelovanje profesija ili u neposrednim procesima utvrđivanja razina, djelokruga, granica ovlasti ili odgovornosti zdravstvenih radnika. Tim pristupom Komora neposredno utječe na rad profesija i pojedinih zdravstvenih radnika u smislu očuvanja i zaštite interesa istih i zaštite prava pacijenata.

Komore u zdravstvu jesu nedvojbeno bitni čimbenici kreiranja zdravstvene politike $u$ širem smislu. Isto se dakle ogleda u njenom pozicioniranju u sustavu zdravstva kao zastupnika i zaštitnika interesa pojedinih zdravstvenih radnika, kao i u svakodnevnom provođenju delegiranih javnih ovlasti. Kapital delegiranih javnih ovlasti daje Komorama za pravo da meritorno odlučuju o svim bitnim pitanjima za interese zdravstvenih radnika, njenih članova, kao i odgovornostima istih. Kontinuirane promjene u odnosima u pružanju zdravstvene zaštite, omogućuje Komorama kao ovlaštenim stručnim strukovnim organizacijama da prilagođavaju sustav zdravstva novim vrijednosnim sustavima. Takve nove situacije pružit će zdravstvenim radnicima jasno mjesto u okviru vlastitih ovlasti i odgovornosti u obavljanju poslova djelatnosti profesija, te sukladno tim pružiti najveću moguću zaštitu pacijentima kao krajnjim korisnicima usluga zdravstvene zaštite. Utvrđivanje standarda profesije u teorijskom i normativa postupanja različitih subjekata 
u procesnom pogledu u postupcima pružanja zdravstvene zaštite osnova je djelokruga postupanja Komora kao novog pristupa u sagledavanju i utvrđivanju poslovanja Komora u zdravstvu.

Komore kao normirane institucije unutar sustava zdravstva trebaju težiti jasnim i nedvojbenim definiranjem svojih ovlasti i djelokruga poslovanja. Osim stručnih pitanja koja se odnose na zaštitu interesa zdravstvenih radnika njihovih članova u neposrednim konkretnim slučajevima i definiranja standarda profesija u okvirima djelatnosti koje obavljaju zdravstveni radnici njihovi članovi, Komora mora imati ulogu bitnog faktora u kreiranju zdravstvene politike u širem smislu riječi. Postavlja se pitanje kako će se sustav politike i usmjeravanja razvoja sustava zdravstvene zaštite definirati na dobrobit i zadovoljstvo cijelog društva ako direktnog utjecaja u predmetnom neće imati Komore. Komore kao neposredni zastupnici zdravstvenih radnika i njihovih profesija mogu iznimno doprinijeti izgradnji boljeg, učinkovitog sustava zdravstvene zaštite utemeljenog na dostupnosti zdravstvene skrbi svima potrebnima, ali i zaštiti dostojanstva svih zdravstvenih radnika i kriterija profesija te stručnog i profesionalnog obavljanja poslova iz svih segmenata djelatnosti zdravstvene zaštite. ${ }^{1}$

\section{Primjedbe}

${ }^{1}$ Vidi KLARIĆ, A. - CVITKOVIĆ, M. - MATIJAŠČIĆ ŽUGAJ, P., Komore u zdravstvu, Zbornik „Aktualna problematika u zdravstvu“, Varaždin (2015), str. 162.-182. 
358 | ZDRAVSTVENO STRUKOVNO STALEŠKO PRAVO 


\section{V/ UDRUGE ZDRAVSTVENIH RADNIKA}





\section{Svrha i načini udruživanja zdravstvenih radnika}

Osim strukovnih zakonom utvrđenih neovisnih organizacija (komora), u sustavu zdravstva postoje brojne stručne i profesionalne udruge. Udruga je svaki oblik slobodnog i dobrovoljnog udruživanja više fizičkih, odnosno pravnih osoba koje se, radi zaštite njihovih probitaka ili zauzimanja za zaštitu ljudskih prava i sloboda, zaštitu okoliša i prirode i održivi razvoj, te za humanitarna, socijalna, kulturna, odgojno-obrazovna, znanstvena, sportska, zdravstvena, tehnička, informacijska, strukovna ili druga uvjerenja i ciljeve koji nisu u suprotnosti s Ustavom RH i zakonom, a bez namjere stjecanja dobiti ili drugih gospodarski procjenjivih koristi, podvrgavaju pravilima koja uređuju ustroj i djelovanje toga oblika udruživanja (Zakon o udrugama, „Narodne novine“, broj 74/14, 70, 17, dalje - ZOU, čl. 4.). Udruga stječe pravnu osobnost danom upisa u Registar udruga Republike Hrvatske (ZOU, čl. 5.). Djelovanje udruge temelji se na načelu neovisnosti što znači da udruga samostalno utvrđuje svoje područje djelovanja, ciljeve i djelatnosti, svoj unutarnji ustroj i samostalno obavlja djelatnosti koje nisu u suprotnosti s Ustavom i zakonom (ZOU, čl. 6.).

U području zdravstva mogu se formirati i udruge zdravstvenih profesionalaca određenih profila ili specijalnosti, odnosno udruge kojima je cilj zadovoljenje najveće moguće razine zdravlja određene populacije stanovništva, i to na načelima dragovoljnosti, kako bi svojim dobrovoljnim radom unaprijedili područje za koje su osnovane, usuglašavali i ujednačavali stručne stavove u tim područjima, te surađivali s nadležnim ministarstvom. Udruge mogu ostvarivati potporu iz proračuna. Njihov rad u području zdravstva značajan je i za tijela vlasti, naročito s aspekta kreiranja politike i propisa iz ovog područja. Odgovorno profesionalno ponašanje individualnog liječnika te učinkovit i djelotvoran sustav samoregulacije od strane nacionalnih medicinskih udruga potrebni su građanstvu kao jamstvo da će, u slučaju da postanu pacijenti, primiti kvalitetnu medicinsku zaštitu od kompetentnih liječnika. ${ }^{1}$

Udruge u zdravstvu možemo podijeliti na: stručna društva, udruge pojedinih zdravstvenih profesija, kao i sindikalne asocijacije.

Stručna društva osnivaju se radi stručnog i znanstvenog rada na pojedinim područjima iz profesionalne djelatnosti a što uključuje; trajno stručno i znanstveno usavršavanje svojih članova organiziranjem stručnih i znanstvenih sastanaka, kongresa, seminara, predavanja i tečajeva, odnosno svih oblika trajnoga medicinskog usavršavanja, suradnja sa stručnim znanstvenim i nastavnim organizacijama, predstavljanje struke predlaganje mjera za unapređenje i poboljšanje organizacije rada u stručnoj i znanstvenoj djelatnosti na području svoje struke, suradnja sa srodnim stručnim i znanstvenim društvima drugih zemalja, predstavljanje nacionalnih interesa svoje struke u odgovarajućim međunarodnim društvima, unapređivanje zdravstvene kulture stanovništva, njegovanje i razvijanje načela povezanosti i medicinske etike među svojim članovima, praćenje i nadziranje provođenja mjera zdravstvene zaštite bolesnika, davanje stručnih mišljenja i ekspertiza, predlaganje znanstvenih projekata. ${ }^{2}$ 
Pojedina udruženja zdravstvenih radnika osnivaju se sa ciljem unapređenja, razvoja i poboljšanja profesionalnog i društvenog statusa pojedinih struke, stručnog usavršavanja članova, uvođenja visoke kvalitete stručnog rada na dobrobit bolesnika, unapređenje obrazovanja te aktivno sudjelovanje u strukovnim udruženjima. Svaka pojedina zdravstvene profesija ima najmanje jedno udruženje.

Udruge zdravstvenih radnika djeluju na načelu neobvezatnog dobrovoljnog članstva, što je temeljna razlika u odnosu na komore kao tijela javne vlasti. Međutim, mnoge od udruga zdravstvenih radnika jesu zajedno sa resornim Ministarstvom zdravstva osnivači Komora, te u tom dijelu imaju bitan položaj u sustavu zdravstva. ${ }^{3}$ Najbitniji segment njihova poslovanja čini organiziranje raznih skupova te sudjelovanje kroz međunarodna udruženja s ciljem unaprjeđenja standarda pojedine struke. Svojim aktivnostima nadopunjuju rad Komora i drugih nadležnih tijela.

Sindikalne asocijacije, $s$ treće strane, predstavljaju poseban oblik udruživanja zasnovan na zakonskim propisima o radu. Naime, sindikati se osnivaju s ciljam kolektivnog pregovaranja i poboljšanja radno-pravnih uvjeta i standarda zdravstvenih radnika $s$ obzirom na mjesto rada. Ciljevi sindikalnog djelovanja u pravilu jesu: zaštita društvenih, materijalnih, i socijalnih interesa a, poboljšanje općih uvjeta života i rada zdravstvenih radnika, zaštita njihovih prava iz radnog odnosa - plaća, socijalna i zdravstvena zaštita, zaštita na radu i druga prava, zastupanje interesa zdravstvenih radnika u radnim sporovima, zaštita profesionalnih prava i obveza u obavljanju posla, sklapanje i ostvarivanje kolektivnih ugovora. Zdravstveni radnici udruženi su kroz različite sindikate u sustavu zdravstva ${ }^{4}$ te ih je praktični nemoguće sve nabrojati obzirom na brojnu hrvatsku sindikalnu scenu. Svaki od njih zastupa parcijalne interese pojedinih svojih članova u kolektivnom pregovaraju $\mathrm{s}$ poslodavcem, u predmetnom slučaju nadležnim ministarstvom. Rezultat kolektivnog pregovaranja jesu kolektivni ugovori (Kolektivni ugovor za zdravstvo i socijalnu skrb) kojim se uređuju radno pravni uvjeti, prava i obveze zdravstvenih radnika kao zaposlenika u sustavu zdravstva. Zanimljivo je napomenuti da je Komore u nekim europskim državama institucije zadužene unaprijeđene i zaštitu interesa svojih članova vezano za radno pravne odnose i uvjete radnom mjesta, gdje praktično objedinjavaju apsolutno na taj način sve poslove koje se tiču zaštite interesa članova uopćeno. Zaključno, nedvojbeno je da su Komore temeljne institucije koje u formalno-pravnom zakonskom smislu te po stručnom profesionalnom i sustavnom pristupu svojim članovima i samoj profesiji jedine institucije kao mogu i trebaju skrbiti i unaprjeđivati standarde profesije $i$ štititi prava i položaj svojih članova u sustavu zdravstva.

\section{$2 \quad$ O pojedinim udrugama zdravstvenih radnika}

Spomenuli bismo, primjerice, samo neke od brojnih zdravstvenih udruga:

Hrvatski liječnički zbor (skraćeni naziv: HLZ) je javna udruga hrvatskih liječnika (doktora medicine i doktora stomatologije). Osnovana je 26. veljače 1874. radi unapređenja zaštite zdravlja naroda, stručnog i znanstvenog rada, njegovanja liječničke etike i zaštite staleških interesa. Hrvatski liječnički zbor osnovan je pod imenom Sabora liečnikâ kraljevina Hrvatske i Slavonije, a službeni glasnik Liečnički viestnik izašao je 
siječnja 1877. godine. Godine 1919. mijenja ime u Zbor liječnika Hrvatske, Slavonije $i$ Medjumurja. 1923. potegnulo se pitanje promjene imena u Hrvatsko liječničko društvo. 1939. godine promijenio je ime u Hrvatski liječnički zbor.1945. godine promijenio je ime u Zbor liječnika Hrvatske. 1971. osnovana je Akademija ZLH, te nagrade uz dodjelu diploma počasnim članovima, diplome i spomen plakete Ladislav Rakovac i Pavao Ćulumović za istaknuti zdravstveni rad. 26. veljače 1991. vraćen je naziv Hrvatski liječnički zbor i ponovo pokrenute Liječničke novine. Godine 1992. primljen je u članstvo Svjetskog liječničkog društva. Hrvatski liječnički zbor djeluje na području Republike Hrvatske. Članstvo HLZ-a čine liječnici koji žive i djeluju u zemlji i inozemstvu, ali i druge osobe visoke stručne spreme koje rade u zdravstvenim državnim, županijskim i privatnim ustanovama i surađuju u stručnim društvima i podružnicama. Članovi mogu biti redovni, pridruženi i začasni. Članstvo izvješćuje preko Liječničkih novina, Liječničkog vjesnika i Acta stomatologica croatica, putem telematičkih sustava i na druge načine, prema potrebi. Djelatnost Hrvatskog liječničkog zbora obuhvaća: 1. stručno i znanstveno usavršavanje, 2. unapređenje znanstveno istraživačkog rada, u čemu surađuje s Akademijom medicinskih znanosti Hrvatske i drugim znanstvenim institucijama i društvima, 3. unapređenje medicinske nastave suradnjom s medicinskim fakultetima i Stomatološkim fakultetom te organizacijama studenata medicine i stomatologije, 4. njegovanje medicinske etike, pridržavanje etičkog kodeksa i medicinske deontologije, razrada novih etičkih načela i poštivanje općih moralnih i humanih principa, 5. unapređenje zdravstvenoga stanja stanovništva i zaštita čovjekova okoliša, 6 . unapređenje zdravstvene kulture stanovništva predavanjima, organiziranjem dana i tjedana zdravlja, tiskanjem popularnih publikacija, obavještavanjem sredstvima javnog informiranja, 7 . sudjelovanje predstavnika Zbora u tijelima zdravstvene uprave i izvršne vlasti, 8. davanje mišljenja i ekspertiza pri donošenju zakona i odluka o organizaciji zdravstvene zaštite i zdravstvene službe te ostalim javno zdravstvenim problemima, 9. izdavanje časopisa: Liječnički vjesnik, Liječničke novine, Acta stomatologica croatica; objavljivanje stručnih i znanstvenih knjiga, edukativnih i popularnih publikacija, obrazaca i drugo, 10. njegovanje društvenog, kulturnog, glazbenog i športskog života svojih članova, 11. suradnja s drugim liječničkim te zdravstvenim i srodnim udrugama u zemlji i inozemstvu, 12. briga za unapređenje društvenog i ekonomskog položaja liječnika te zaštita članova HLZ-a u svim slučajevima nepravednog i nezakonskog postupka prema časti i materijalnim interesima člana, 13. HLZ može radi ostvarivanja svojih ciljeva i djelatnosti osnovati trgovačko društvo, sukladno Zakonu. ${ }^{5}$ 


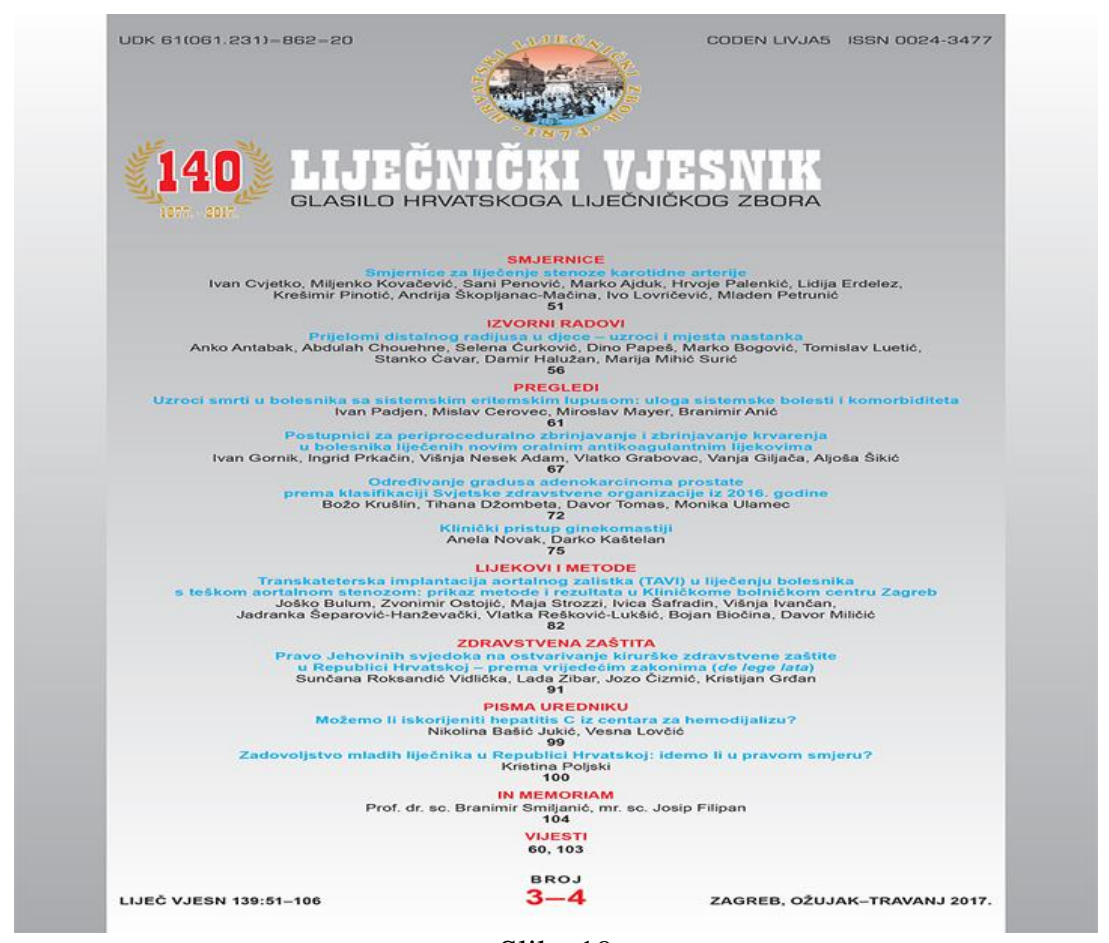

Slika 19

Hrvatska udruga bolničkih liječnika (HUBOL) osnovana je u Liječničkom domu u Zagrebu na Silvestrovo 2013. godine u vremenima velike zapostavljenosti liječničke struke i sustavnog zatiranja liječničkih prava i položaja. Udruga je bila reakcija na kompletno stanje u zdravstvenom sustavu i odraz volje velikog broja bolničkih liječnika, prvenstveno kao potreba za samoorganiziranjem i samozaštitom liječnika zaposlenih u državnom zdravstvenom sustavu. Otada smo prepoznatljiv sudionik svih javnih rasprava, aktivni zagovaratelji liječničkih prava, ali i prava pacijenata, gorljivi borci za pravdom u solidarnom javnom zdravstvenom sustavu, beskompromisni prema korupciji i nepotizmu, dosljedni u stavovima i uvijek na usluzi svekolikoj javnosti, a posebno našim članovima. HUBOL djeluje na nacionalnoj razini preko izvršnog tijela u kojemu su okupljeni liječnici iz svih regija i različitih specijalnosti. Veliko bogatstvo jesu naši bolnički koordinatori koji postoje gotovo u svim hrvatskim bolnicama i koji su zajedno s Izvršnim odborom konstantno na usluzi više od 2000 članova. Udruga je ustrojena kao strukovna članska organizacija. Redoviti član udruge može postati svaki poslovno sposoban doktor medicine s odobrenjem za samostalan rad u Republici Hrvatskoj, a podupirući član može postati svaka fizička i pravna osoba koja svojim radom, materijalno i/ili na drugi način pomaže u provođenju i djelatnosti i ostvarivanju ciljeva udruge. Krovno tijelo udruge je Skupština udruge koja bira izvršna i nadzorna tijela te časni sud udruge, a Izvršni odbor potvrđuje koordinatore po bolnicama. Rad članova je volonterski, a udruga zapošljava jednu administrativnu tajnicu. Namjeravamo i dalje poticati intelektualne kapacitete liječnika i maksimalno aktivirati članstvo kako bismo mu omogućili da jasno artikulira probleme koji ga opterećuju te da predlažu rješenja koja će unaprijediti zdravstveni 
sustav, ali i poboljšati statusni i materijalni položaj liječnika u društvu. HUBOL će i dalje vjerodostojno, časno i prepoznatljivo dosljedno zastupati interese liječnika u Republici Hrvatskoj, posebno zaposlenima u bolničkom sustavu. ${ }^{6}$
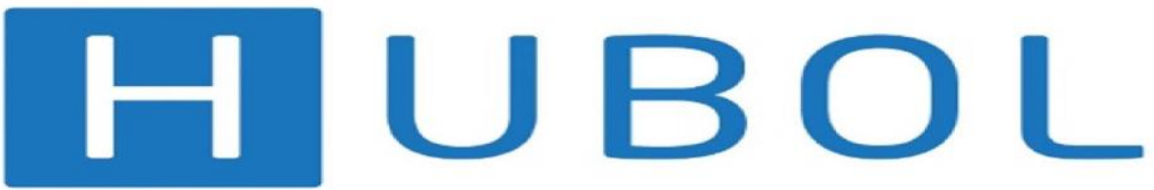

\section{Hrvatska udruga bolničkih liječnika}

\section{0 \\ hrabrih boraca za prava liječnika i održiv javni zdravstveni sustav}

\section{HALA VAM!}

Slika 20: Fotografija na stranici

:https://www.facebook.com/udruga.hubol/photos/a.1498040663744228.1073741828.14 98038167077811/1836441443237480/?type $=3 \&$ theater

Samostalni sindikat zdravstva i socijalne skrbi Hrvatske je sindikat djelatnosti organizira sve profile zaposlenika u zdravstvu i socijalnoj skrbi bez obzira na struku, kvalifikaciju ili stručnu spremu. Sindikat je osnovan 1991.godine. Unatoč organiziranju novih Sindikata u djelatnosti zdravstva (organizirano 18 sindikata na razini republike), ostao je i dalje najbrojniji i najveći sindikat sa oko 18000 plaćajući članova u 170 sindikalnih podružnica u cijeloj Republici Hrvatskoj. SSZSSH je stalni pregovarač za TKU i granske kolektivne ugovore za zdravstvo i socijalnu skrb, čime je preuzeo odgovornost za kolektivno pregovaranje. Sindikat članovima: Osigurava besplatnu pravnu pomoć i zastupanje u ostvarivanju prava iz rada i po osnovi rada - u najbližem središtu županije u kojoj član sindikata živi i radi. Osigurava povrat dijela troškova za nabavku naočala (200 kuna), i obavljanje skupe dijagnostičke preglede - CT, magnetska rezonanca (kod privatnika ako je zbog hitnosti bilo potrebno, do $500 \mathrm{kn}$ ). Daje pomoć obitelji u slučaju smrti člana sindikata (3 $000 \mathrm{kn}$ ), Organizira i financira sindikalno obrazovanje i osposobljavanje za sindikalne povjerenike i članove. Sufinancira učestvovanje u sportskim susretima zdravstva i socijalne skrbi. ${ }^{7}$

Promjenama u našem društvu početkom 90-tih godina javila se potreba da medicinske sestre organiziraju svoj strukovni sindikat. 11. svibnja 1991. godine u Zagrebu održana je Osnivačka skupština sindikata na kojoj je za prvu predsjednicu izabrana viša medicinska sestra Milena Delak. Donesen je Statut kojim je određen naziv Hrvatski strukovni sindikat medicinskih sestara - medicinskih tehničara. 1993. godine Sindikat je jedan od osnivača udruge više razine Matice hrvatskih sindikata javnih službi. 1995. godine uz sudjelovanje Sindikata donesen je prvi Zakon o radu, koji stupa na snagu 01. siječnja 1996. godine. 23. prosinca 1996. godine Sindikat uz ostale sindikate 
zdravstva potpisuje prvi Kolektivni ugovor za djelatnost zdravstva i zdravstvenog osiguranja 13. prosinca 2001. uz ostale pregovarače u javnim službama potpisnici smo Temeljnog kolektivnog ugovora za službenike i namještenike u javnim službama 2001. godine postajemo članica Public Services International - međunarodne udruge radnika javnih službi, kao i EPSU-a Osnovni ciljevi i zadaci Sindikata glede ostvarivanja interesa i djelovanja su: kolektivno pregovaranje i zaključivanje kolektivnih ugovora; iniciranje i sudjelovanje u donošenju procjena o realnoj cijeni rada; zaštita prava iz radnog odnosa; rad na poboljšavanju općih uvjeta rada i života medicinskih sestara i medicinskih tehničara; zaštita profesionalnih prava i obveze struke; rad na ostvarivanju prava na pogodnosti u svezi otežanih i po zdravlje štetnih uvjeta rada; zastupanje interesa zaposlenih medicinskih sestara i medicinskih tehničara; ostvarivanje međusobne solidarnosti; pružanje i druge pomoći u pitanju zaštite pojedinca, njegovih prava, imovine, života, te materijalne i socijalne sigurnosti medicinske sestre i medicinskog tehničara, kao i njegove obitelji; stalno i pravovremeno izvještavanje svojih članova o postignutim rezultatima rada Sindikata; zaštita svih sindikalnih i socijalnih prava. ${ }^{8}$

Hrvatska udruga medicinskih sestara - HUMS - djeluje na području zaštite zdravlja strukovne udruge u području zaštite zdravlja i prevencije bolesti. Ciljevi HUMS-a su: stručni i znanstveni rad medicinskih sestara, članova HUMS-a, zaštita interesa medicinskih sestara s ciljem unaprjeđenja zdravstvene zaštite; zastupanje stručnih interesa medicinskih sestara pred Vladom Republike Hrvatske; zastupanje stručnih interesa medicinskih sestara pred nadležnim ministarstvom i ostalim ministarstvima i vladinim uredima i agencijama od interesa za sestrinstvo, zastupanje stručnih interesa medicinskih sestara u sustavima u kojima medicinske sestre djeluju, suradnja s ministarstvima nadležnim za znanost i obrazovanje; izgradnja najboljeg mogućeg sustava zdravstvene skrbi u kome će medicinske sestre dati maksimalan doprinos; suradnja s institucijama u Republici Hrvatskoj u interesu struke; • suradnja sa Hrvatskom komorom medicinskih sestara; suradnja s udrugama koje okupljaju medicinske sestre u Republici Hrvatskoj; suradnja sa sindikalnim organizacijama koje zastupaju medicinske sestre. Djelatnosti HUMS-a su: stručno i znanstveno usavršavanje; unaprjeđenje znanstvenoistraživačkog rada; suradnja s obrazovnim ustanovama u Republici Hrvatskoj u interesu sestrinske profesije; suradnja s drugim sestrinskim te zdravstvenim i srodnim udrugama u zemlji i inozemstvu; sudjelovanje predstavnika HUMS-a u tijelima zdravstvene uprave i izvršne vlasti; davanje stručnog mišljenja promicanje provođenja zdravstvene njege po standardima prakse; unaprjeđenje zdravstvene kulture stanovništva organiziranjem predavanja, tribina, tiskanjem popularnih publikacija te drugim oblicima i sredstvima javnog informiranja u svim medijima; aktivno sudjelovanje na međunarodnim stručnim skupovima i kongresima; udruživanje u međunarodne asocijacije koje su od interesa hrvatskog sestrinstva; definiranje i promicanje Etičkog kodeksa HUMS-a; izdavanje službenog časopisa Sestrinski glasnik, znanstvenih časopisa, knjiga, priručnika i stručnih članaka u tiskanom i elektronskom obliku. ${ }^{9}$

Udruga ljekarnika dobrovoljna je i neovisna udruga poslodavaca koja štiti i promiče prava i interese svojih članova osobito u području uređivanja uvjeta poslovanja, odnosa s tijelima državne vlasti, sindikatima, radnog i socijalnog te gospodarskog zakonodavstva, kolektivnog pregovaranja i sklapanja kolektivnih ugovora, radnih sporova, te drugih pitanja važnih za gospodarski i socijalni položaj poslodavaca. Ustroj, djelovanje i Statut 
Udruge temelje se na načelima demokratskog zastupanja i demokratskog očitovanja volje poslodavaca - članova Udruge. U svojem djelovanju Udruga promiče ideje slobode poduzetništva i socijalne pravde. Udruga je nužni socijalni partner i protuteža udrugama radnika u sklopu slobodnog gospodarskog i demokratskog društvenog sustava. U odnosu sa sindikatima i drugim udrugama radnika, Udruga radi na ostvarenju trajnih i stabilnih dobrih odnosa, utemeljenih na uzajamnom uvažavanju interesa i poštivanju prava. Udruga radi na uspostavljanju i očuvanju socijalnog mira, kao trajne pretpostavke stabilnih uvjeta poslovanja, a u slučaju kolektivnih radnih sporova, napose štrajka i isključenja s rada, osigurava solidarnost i uzajamnu pomoć članovima Udruge. Udruga nastoji svojim aktivnostima djelovati na načelima slobodnog poduzetništva, a u interesu svih, ili većine članica. ${ }^{10}$

Hrvatsko farmaceutsko društvo je nacionalna, samostalna, dobrovoljna strukovna udruga koja okuplja farmaceute u Republici Hrvatskoj, u svrhu unaprjeđivanja stručnog i znanstvenog rada u području farmacije, na dobroto zdravlja cijele zajednice. Prva strukovna udruga osnovana je 1858. godine, a od 1946. godine djeluje pod imenom Hrvatsko farmaceutsko društvo. Glavni ciljevi HFD-a su razvoj farmaceutske struke, poticanjem stručnog i znanstvenog rada, održavanje tečajeva trajnog obrazovanja. organiziranje stručnih i znanstvenih skupova, izdavanje časopisa i knjiga, promicanje i unaprjeđivanje svih oblika farmaceutskog obrazovanja. Nadalje, HFD intenzivno i blisko surađuje s drugim institucijama, kao što su Hrvatska ljekarnička komora, liječnička strukovna i stručna udruženja, kao i udruženja ostalih zdravstvenih radnika. Veliki naglasak stavljamo na poštivanje etičkih / bioetičkih načela, te razvijanje svijesti o časti, dostojanstvu, ugledu i odgovornosti ljekarničkog poziva! Stručni i znanstveni rad odvija se kroz aktivnosti mnogih sekcija i udruženja farmaceuta iz različitih regija Hrvatske. U svom svakodnevnom radu, HFD se ističe i izvrsnom suradnjom na međunarodnoj razini. Hrvatsko farmaceutsko društvo je nacionalna, samostalna, dobrovoljna strukovna udruga koja okuplja farmaceute u Republici Hrvatskoj, u svrhu unaprjeđivanja stručnog i znanstvenog rada u području farmacije, na dobro zdravlja cijele zajednice. Prva strukovna udruga osnovana je 1858. godine, a od 1946. godine djeluje pod imenom Hrvatsko farmaceutsko društvo. Glavni ciljevi HFD-a su razvoj farmaceutske struke, poticanjem stručnog i znanstvenog rada, održavanje tečajeva trajnog obrazovanja. organiziranje stručnih i znanstvenih skupova, izdavanje časopisa i knjiga, promicanje i unaprjeđivanje svih oblika farmaceutskog obrazovanja. Nadalje, HFD intenzivno i blisko surađuje s drugim institucijama, kao što su Hrvatska ljekarnička komora, liječnička strukovna i stručna udruženja, kao i udruženja ostalih zdravstvenih radnika. Veliki naglasak stavljamo na poštivanje etičkih / bioetičkih načela, te razvijanje svijesti o časti, dostojanstvu, ugledu i odgovornosti ljekarničkog poziva. Stručni i znanstveni rad odvija se kroz aktivnosti mnogih sekcija i udruženja farmaceuta iz različitih regija Hrvatske. U svom svakodnevnom radu, HFD se ističe i izvrsnom suradnjom na međunarodnoj razini. Djelatnost HFD-a je: okupljanje pripadnika farmaceutske struke radi razvoja farmaceutske struke i njezinih etičkih načela; poticanje stručnog i znanstvenog rada na području farmacije; stručno i znanstveno usavršavanje magistara farmacije; organiziranje i održavanje stručnih i znanstvenih skupova i tečajeva trajne izobrazbe; provođenje javnozdravstvenih projekata; izdavanje znanstvenih i stručnih časopisa i knjiga; izdavanje propisanih knjiga i obrazaca potrebnih za vođenje evidencija u ljekarni; održavanje stručne biblioteke; razvijanje izdavačke djelatnosti na području farmacije; zastupanje 
članstva u pitanjima važnim za farmaceutsku struku; promicanje i poboljšanje svih oblika izobrazbe na području farmacije (poboljšanje programa farmaceutskog studija, specijalizacije i ostalih oblika usavršavanja, srednjeg obrazovanja farmaceutskog kadra); suradnja s Ministarstvom nadležnim za zdravlje, Ministarstvom nadležnim za znanost i obrazovanje, državnim Agencijama, zdravstvenim i znanstveno nastavnim ustanovama na teritoriju RH te zalaganje za provođenje i ostvarenje pozitivne zdravstvene politike; davanje mišljenja i ekspertiza pri donošenju zakona i odluka o organizaciji zdravstvene zaštite i zdravstvene službe te ostalim javnozdravstvenim problemima; razmjena iskustava i suradnja članova na društvenom, stručnom, znanstvenom i organizacijskom planu; pridržavanje načela i kodeksa farmaceutske etike, razvijanje osjećaja časti, dostojanstva i odgovornosti farmaceutskog poziva te poduzimanje odgovarajućih mjera u slučaju kršenja spomenutih načela; promicanje društvenog položaja magistara farmacije; informiranje javnosti o važnim zbivanjima u farmaceutskoj struci; ustroj i suradnja s Hrvatskom ljekarničkom komorom sukladno odredbama Zakona o zdravstvenoj zaštiti i Statuta HLJK; suradnja s drugim udrugama. ${ }^{11}$

Udruga poslodavaca u zdravstvu Hrvatske udruga je u djelatnosti zdravstva $s$ šezdesetogodišnjom tradicijom, te je nastavak povijesnog slijeda udruživanja subjekata u zdravstvenoj djelatnosti čiji počeci sežu od 1952. godine. U svojem članstvu okuplja pojedine zdravstvene ustanove. Članice ove Udruge, osim u tijelima Udruge (Skupština, Predsjedništvo, Nadzorni odbor) posebno djeluju unutar stručnih društava oblikovanih prema profilu zdravstvenih ustanova. To su Stručno društvo bolnica, Stručno društvo domova zdravlja, Stručno društvo zavoda za javno zdravstvo, Stručno društvo zavoda za hitnu medicinu, Stručno društvo ljekarni i Stručno društvo poliklinika. Stručna društva Udruge redovno održavaju sastanke na kojima se obrađuju aktualne teme iz domene poslovanja tih zdravstvenih ustanova, utjecaja pravno-regulatornog okvira na njih, te pitanja ugovornog odnosa s HZZO-om. Udruga svojim članicama pruža svakodnevnu pravnu i ekonomsku podršku, zastupanje ustanova kroz radna tijela u Ministarstvu zdravlja i HZZO-a, lobiranje prema zdravstvenoj administraciji, mogućnost izrade usporedne analize kretanja ključnih pokazatelja poslovanja (prihoda, rashoda, financijskog rezultata, obveza, potraživanja i dr.) zdravstvenih ustanova s prosjekom pokazatelja usporedivih ustanova grupacije (KAIP). Udruga obavještava svoje članice putem e-maila o svim aktivnostima tijela i uprave Udruge, izmjenama zakonske regulative, uvjetima financijskog poslovanja i drugim aktualnostima vezanim uz zdravstvo, te nudi mogućnost pregled tekućih objava u tisku vezanih uz zdravstvo putem mobilne aplikacije (Viber). Vodi i dnevno ažurira portal Udruge informacijama o aktivnostima Udruge i aktualnostima vezanim uz zdravstvo. Udruga posebnu pažnju posvećuje reviziji cijena zdravstvenih usluga (DTS i DTP). Udruga za svoje članice provodi edukaciju iz šifriranja i kodiranja DTS-a. U okviru svojih redovnih djelatnosti, pravna služba Udruge pruža usluge izrade ili korekcije pravnih akata zdravstvenih ustanova, pravnu asistenciju pri donošenju odluka upravnog vijeća, te interpretaciju izmjena pravnih propisa iz djelatnosti zdravstva i onih koji imaju utjecaj na uvjete poslovanja zdravstvenih ustanova. Udruga je član pregovaračkog odbora Vlade Republike Hrvatske u procesu kolektivnog pregovaranja u sustavu zdravstva i zdravstvenog osiguranja. Udruga već preko 40 godina održava savjetovanja i simpozije dva do tri puta godišnje koja okupljaju sudionike u sustavu zdravstva Hrvatske. ${ }^{12}$ 
Udruga pravnika u zdravstvu osnovana je 10. 11. 2006. godine s ciljem promicanja ugleda i unapređenja pravničke struke u zdravstvu u zemlji i inozemstvu, razvoja i napretka pravne struke u zdravstvenim ustanovama, stvaranja i njegovanja veza među diplomiranim pravnicima koji rade i djeluju u zdravstvenim ustanovama, njegovanja i razvitka ugleda i etike pravničkog poziva, raspravljanja znanstvenih i stručnih problema pravne struke i zauzimanja stanovišta o njima i poticanja i razvitka suradnje Udruge s drugim stručnim, obrazovnim, razvojnim i istraživačkim organizacijama, te suradnje sa sličnim Udrugama u zemlji i inozemstvu. ${ }^{13}$

\section{HRVATSKI SIMPOZIJ MEDICINSKOG PRAVA}

s medunarodnim sudjelovanjem

\section{Hotel Olympia / Vodice 11. - 13. 11. 2016.}
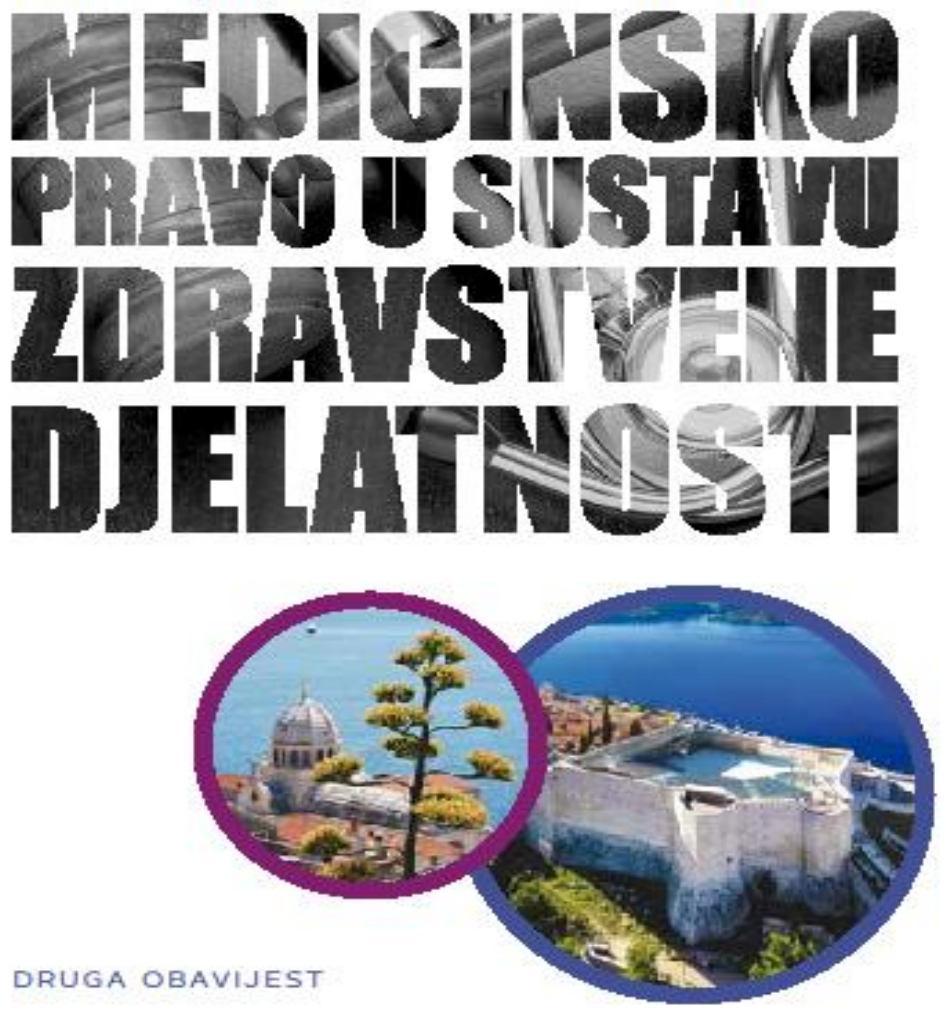

Slika 20 


\section{Primjedbe}

1 Tako HALlER, H., Medicinski pogled na liječničku odgovornost, rad u zborniku „Građanskopravna odgovornost u medicini““, HAZU, Zagreb, 2008., str. 20.

${ }^{2}$ Hrvatski liječnički zbor ima 138 različitih stručnih društava. HLZ je javna udruga hrvatskih liječnika (doktora medicine i doktora stomatologije). Osnovana je $\underline{26}$. veljače $\underline{1874}$. radi unaprjeđenja zaštite zdravlja naroda, stručnog i znanstvenog rada, njegovanja liječničke etike i zaštite staleških interesa.

${ }^{3}$ HLZ i Medicinski fakultet u Zagrebu jesu osnivači Hrvatske liječničke komore. Hrvatsku komoru zdravstvenih radnika osnovali su Ministarstvo zdravstva, Hrvatska udruga inženjera medicinske radiologije, Hrvatska udruga radnih terapeuta, Hrvatska sanitarna udruga Hrvatska udruga laboratorijeske medicine.

${ }^{4}$ Hrvatski liječnički sindikat kao stukovni sindikat liječnika, Samoslani sindikat zdravstva i socijalne skrbi koji zastupa radne interese nezdravstvenih radnika u sustavu zdravstva, Hrvatski strukovni sindikat medicinskih sestara i tehničara koji zastupa radne interese medicinskih sestara i dr.

${ }^{5}$ Podatak na stranici https://hr.wikipedia.org/wiki/Hrvatski_lije\%C4\%8Dni\%C4\%8Dki_zbor

${ }^{6}$ Vidi stranicu http://www.hubol.hr/o-hubol-u/\#

${ }^{7}$ Podatak na stranici http://www.sszssh.hr/o-sindikatu.

${ }^{8}$ Vidi stranicu http://www.hssms-mt.hr/naslovna/.

${ }^{9}$ Podatak na stranici http://hums.hr/word/o-nama/ciljevi-i-djelatnosti/.

${ }^{10}$ Vidi stranicu http://www.hup.hr/hup-udruga-ljekarnika.aspx.

${ }^{11}$ Podatak na stranici http://www.farmaceut.org/o-nama/djelatnost-hfd-a-ciljevi.

${ }_{12}$ Podatak na stranici http://upuz.hr/o-nama/o-nama.

${ }^{13}$ Vidi na stranici http://www.upzh.hr/index.php/o-nama. 

EGP - Europski gospodarski prostor

EKZLJP - Europska konvencija za zaštitu ljudskih prava

engl.-engleski

EU - Europska unija

franc.-francuski

grč.- grčki

HFD- Hrvatsko farmaceutsko društvo

HKDM- Hrvatska komora dentalne medicine

HKF- Hrvatska komora fizioterapeuta

HKMB- Hrvatska komora medicinskih biokemičara

HKMS- Hrvatska komora medicinskih sestara

HKP- Hrvatska komora primalja

HKZR- Hrvatska komora zdravstvenih radnika

HLK- Hrvatska liječnička komora

HLZ - Hrvatski liječnički zbor

HLJK - Hrvatska ljekarnička komora

HUBOL- Hrvatska udruga bolničkih liječnika

HUMS- Hrvatska udruga medicinskih sestara

HZZO - Hrvatski zavod za zdravstveno osiguranje

JANKOVIĆ - JANKOVIĆ, M. - KARAMARKOVIĆ, H. - JANKOVIĆ, Ž. PETROVIĆ, D., Komentar zakona o parničnom postupku, 3. izdanje, Beograd, 1990.

KMED - Kodeks medicinske etike i deontologije Hrvatske liječničke komore, „Narodne novine“, br. 55/08., 139/15., pročišćeni tekst od 15. siječnja 2016.

Kolektivni ugovor - Kolektivnog ugovora za djelatnost zdravstva i zdravstvenog osiguranja (Urednički pročišćeni tekst, „Narodne novine“, broj 143/13 i 96/15.)

KZ- Kazneni zakon („Narodne novine“, br. 125/11, 144/12, 56/15, 61/15)

lat.-latinski

MU-Međunarodni ugovori

NN- Narodne novine

njem.-njemački

POL - Pravilnik o odobrenju za samostalan rad (licenci) Hrvatske liječničke komore od 10. travnja 2017.

PPSDM - Pravilnik o pripravničkom stažu doktora medicine („Narodne novine“, broj 114/13.)

Pravilnik o radnom vremenu - Pravilniku o početku, završetku i rasporedu radnog vremena zdravstvenih ustanova i privatnih zdravstvenih radnika u mreži javne zdravstvene službe (,Narodne novine“", broj 4/14.)

PSSV - Pravilnik o stalnim sudskim vještacima („Narodne novine“, broj 38/14.)

PZPPG - Pravilnikom o znanstvenim i umjetničkim područjima, poljima i granama (,Narodne novine“" broj 118/09, 82/12, 32/13)

RH - Republika Hrvatska

RISTIĆ - RISTIĆ, V. - RISTIĆ, M., Praktikum za parnicu, Beograd, 1989.

SLU- Svjetsko liječničko udruženje

SP - Sudski poslovnik („Narodne novine“, broj 37/2014.) 
SSZSSH -Samostalni sindikat zdravstva i socijalne skrbi Hrvatske

SZO- Svjetska zdravstvena organizacija

talij.-talijanski

TKU- Temeljni kolektivni ugovor

TRIVA- TRIVA, S. - BELAJEC, V. - DIKA, M., Građansko parnično procesno pravo, Zagreb, 1986.

UNESCO- United Nations Educational, Scientific and Cultural Organisation

UOMV - Uredba o medicinskom vještačenju u mirovinskom osiguranju (,Narodne novine" br. 12/13)

Ustav RH - Ustav Republike Hrvatske („Narodne novine“, pročišćeni tekst, beoj 56/90, 135/97, 8/98, 113/00, 124/00, 28/01, 41/01, 55/01, 76/10, 85/10, 05/14)

VSFBiH - Vrhovni sud Federacije Bosne i Hercegovine

VSH - Vrhovni sud Republike Hrvatske

VTSH- Visoki trgovači sud Hrvatske

ZAGA -Zakon o arhivskom gradivu i arhivima, ( »Narodne novine«, br. 105/97)

ZEOZ - Zakon o evidencijama u oblasti zdravstva (,"Službeni list SFRJ“, broj 22/78., 18/88.)

ZRPPISK- Zakon o reguliranim profesijama i priznavanju inozemnih stručnih kvalifikacija (,Narodne novine“, br. 82/15)

ZKP- Zakon o kaznenom postupku (,Narodne novine“, br. 152/08, 76/09, 80/11, 121/11, 91/12, 143/12, 56/13, 145/13, 152/14, 70/17)

ZM - Zakon o medijima (NN 163/2003., NN 59/2004.)

ZZODS- Zakon o zaštiti osoba s duševnim smetnjama („Narodne novine“, br. 76/14)

ZODM - Zakon o dentalnoj medicini („Narodne novine“, broj 121/03, 117/08, 120/09)

ZODUZ - Zakonom o djelatnostima u zdravstvu (,Narodne novine“, broj 87/09)

ZOK- Zakon o krvi i krvnim sastojcima (,Narodne novine“" br. 76/06, 124/11)

ZOL - Zakon o liječništvu („Narodne novine“, br. 121/03, 117/08)

ZOLJK - Zakon o ljekarništvu („Narodne novine“", broj 121/03, 142/06, 35/08, 117/08)

ZOMBD - Zakon o medicinsko-biokemijskoj djelatnosti (,Narodne novine“, broj 121/03, 117/08),

ZOO- Zakon o obveznim odnosima („Narodne novine“, br. 35/05., 41/08, 125/11, 78/15)

ZOP - Zakon o primaljstvu (,Narodne novine“, br. 120/08, 145/10)

ZOS - Zakon o sestrinstvu („Narodne novine“, br. 121/03, 117/08, 57/11)

ZOSD- Zakon o stomatološkoj djelatnosti ( „Narodne novine“, broj 121/03)

ZOU - Zakon o udrugama („Narodne novine“, broj 74/14, 70, 17.)

ZOZPP - Zakon o zaštiti prava pacijenata («Narodne novine», broj 169/04., 37/08.)

ZOZZ - Zakon o zdravstvenoj zaštiti („Narodne novine“, br. $\underline{150 / 08}, \underline{71 / 10}, \underline{139 / 10}, \underline{22 / 11}, \underline{84 / 11}, \underline{154 / 11}, \underline{12 / 12}, \underline{35 / 12}, \underline{70 / 12}, \underline{144 / 12}, \underline{82 / 13}$, $\underline{159 / 3}, \underline{22 / 14}, \underline{154 / 14})$

ZPP - Zakon o parničnom postupku („Narodne novine“, broj 53/91, 91/92, 112/99, 88/01, 117/03, 88/05, 2/07, 84/08, 96/08, 123/08, 57/11, 148/11, 25/13, 89/14)

ZR - Zakon o radu („Narodne novine“, broj 93/14)

ZS - Zakona o sudovima („Narodne novine“", broj 28/13, 33/15, 82/15, 82/16)

ZTP - Zakon o tajnosti podataka („Narodne novine“, broj 79/07., 86/12.)

ZUGLIA-TRIVA - ZUGLIA, S. - TRIVA, S., Komentar zakona o parničnom postupku, Zagreb, 1957.

ZZOP - Zakon o zaštiti osobnih podataka ("Narodne novine”, br. 103/03.) 
ZZPZB- Zakon o zaštiti pučanstva od zaraznih bolesti („Narodne novine“ br. 79/07, 113/08, 43/09)

ZZTP - Zakonom o zaštiti tajnosti podataka („Narodne novine“, broj 108/96.)

ŽS- Županijski sud 
376 | ZDRAVSTVENO STRUKOVNO STALEŠKO PRAVO 
ZDRAVSTVENO STRUKOVNO STALEŠKO PRAVO

J. Čizmić, M. Cvitković \& A. Klarić

\section{LITERATURA}



ANĐELINOVIĆ, Š., Sudsko-medicinski aspekti odgovornosti liječnika, u Zborniku radova skupine autora, Liječnička pogreška - medicinski i pravni aspekti, Medicinski i Pravni fakultet Split, Split, 2007.

Arbitraža, SIS-HGK, Zagreb, 1995.

Arbitraža i alternativno rješavanje sporova - kako rješavati međunarodne poslovne sporove, Hrvatska gospodarska komora, Zagreb, 2003.

AVIANI, D., Prekršajno pravo, Split, 203.

AZDEJKOVIĆ, P. M., Borba: Prigovor savesti - Muški spas od vojske, http://azdejkovic.com/borba-prigovor-savesti-muski-spas-od-vojske/.

\section{B/}

BABIĆ-BOSANAC, S. - BOROVEČKI, A., Medicinske pogreške u Hrvatskoj, rad u zborniku radova „hrestomatija hrvatskoga medicinskog prava“, Pravni fakultet Sveučilišta u Zagrebu, Zagreb, 2016.

BABIĆ, I., Rad u dežurstvu, rad u pripravnosti i rad po pozivu kod zdravstvenih radnika rad po pozivu kod zdravstvenih radnik, PRILOG ČASOPISU RAČUNOVODSTVO, REVIZIJA I FINANCIJE, br. 4/2012., str. 40.-44.

BABIĆ, T., Nadzor nad radom liječnika, Zbornik radova sa simpozija „Liječnička pogreška medicinski i pravni aspekti“", Poslijediplomski tečaj stalnog medicinskog usavršavanja I. kategorije, Medicinski i Pravni fakultet Sveučilišta u Splitu, Split, 2007.

BABIĆ, T. - ROKSANDIĆ, S., Osnove zdravstvenog prava, Zagreb, 2006.

BABIĆ, T., Stegovni (disciplinski) postupak pred tijelima Hrvatske liječničke komore, Hrvatski ljetopis za kazneno pravo i praksu, vol. 15, broj 1/2008, Zagreb, 2008.

BAČIĆ, A., Komentar Ustava Republike Hrvatske, Pravni fakultet Sveučilišta u Splitu, Split, 2004.

BAČIĆ, A., Leksikon Ustava Republike Hrvatske, Pravni fakultet Sveučilišta u Splitu, Split, 2000.

BAČIĆ, F. - PAVLOVIĆ, Š., Kazneno pravo - posebni dio, Zagreb, 2001.

BAČIĆ, F. - PAVLOVIĆ, Š., Komentar kaznenog zakona, Zagreb, 2004.

BAČIĆ, F. - ŠEPAROVIĆ, Z., Krivično pravo - posebni dio, Zagreb, 1997.

BANKOLE, A. - SINGH, S. - HAAS, T., Reasons Why Women Have Induced Abortions: Evidence from 27 Countries, „International Family Planning Perspectives“, (1998), 24 (3), str. 117127.

BENAČIĆ, A., PRIZIV SAVJESTI ILI OPORTUNIZAM: Prije 20-30 godina najnormalnije su radili abortuse, a sad..., http://lupiga.com/vijesti/priziv-savjesti-ili-oportunizam-prije-2030-godina-najnormalnije-su-radili-abortuse-a-sad.

BEVANDA, M. - ČOLAKOVIĆ, M., Pravo pacijenta na obaviještenost i pristanak $i$ pravne posljedice liječenja bez pristanka pacijenta, zbornik radova sa 7. međunarodnog savjetovanja „Aktualnosti građanskog i trgovačkog zakonodavstva i pravne prakse“, Neum, 12.-14. lipnja 2009.

BIKIĆ, A., Obligaciono pravo, Opći dio, Drugo izdanje, Pravni fakultet univerziteta u Sarajevu, Sarajevo, 2007.

BLAŽEVIĆ, D. - CIVIDINI STRANIĆ, E. - BECK DVORŽAK, M., Medicinska psihologija, Zagreb, 1979.

BOCKELMANN, P., Die Dokumentationspflicht des Arztes und ihre Konsequenzen, Berlin, 1985.

BODIROGA, N. - DULČIĆ, K., Zaštita osobnih podataka u europskome i hrvatskome pravu, «Zbornik radova Pravnog fakulteta u Splitu», god. 42, 2005., str. 327.-356. 
BODNARUK, S. - ČIZMIĆ, J. - HRABAČ, B. - HUSEINAGIĆ, S., Komentari zdravstvenih zakona, knjiga 1., Privredna štampa, Sarajevo, 2011.

BOGDANIĆ, M., Odnos moralnog i legalnog u medicinskoj etici-američko iskustvo 40 godina povezanosti bioetike i pravnog sustava, referat na 9. bioetičkom okruglom stolu «Bioetika i medicinsko pravo», održanom u Rijeci, 15. i 16. svibnja 2008.

BOIĆ, V. i dr., Naknada neimovinske štete, Pravno-medicinski okvir, Inženjerski biro, Zagreb, 2009.

BOŠKOVIĆ, Z., Kodeks medicinske etike i deontologije - etika profesije liječnik, „Informator“, broj 5046-5047. od 17. i 20. srpnja 2002.

BOŠKOVIĆ, Z., Medicina i pravo, Zagreb, 2007.

BOŠKOVIĆ, Z., Odbijanje transfuzije krvi zbog vjerskog uvjerenja-pravni aspekti, „Informator“, broj 4867. od 28. 10. 2000.

BOŠKOVIĆ, Z., Osnivanje i organiziranje ljekarničke djelatnosti - pravni aspekti, „Hrvatska pravna revija“, godina IX., 2009., broj 7-8,

BOŠKOVIĆ, Z., Prava pacijenata na primjerenu obaviještenost $i$ odlučivanje, „Informator“, br. 5343. od 21. svibnja 2005.

BOŠKOVIĆ, Z., Pravni nadzor u području farmacije, JAHR, vol. 3, 2012., br. 6.

BOŠKOVIĆ, Z., Priziv savjesti u medicini, „Hrvatska pravna revija”, broj 4/2005.

BOŠKOVIĆ, Z., Profesionalna liječnička tajna, „Informator“, broj 5329. od 2. travnja 2005.

BOŠKOVIĆ, Z., Profesionalno obrazovanje zdravstvenih djelatnika, „Informator“, broj 4987 4990. od 22.,26. i 29. prosinca. 2001. i 2.siječnja. 2002.

BOŠKOVIĆ, Z., Specijalizacija zdravstvenih djelatnika, „Informator“, broj 4660-4661. od 4. i 7. studenoga 1998.

BOŠKOVIĆ, Z., Sustav zdravstvene zaštite te prava i dužnosti građana u ostvarivanju zdravstvene zaštite, «Informator», broj 4838-4839., od 19. i 22. srpnja 2000.

BOŠKOVIĆ, Z., Zakon o izmjenama i dopunama Zakona o zdravstvenoj zaštiti, «Informator», br. 5475-5476. od 26. i 30. kolovoza 2006.

BOŠKOVIĆ, Z., Zakon o liječništvu - Reforma zdravstvenog zakonodavstva Republike Hrvatske, «Hrvatska pravna revija», god. III, 2003., br. 9.

BOŠKOVIĆ, Z., Zakon o zaštiti prava pacijenata - reforma zdravstvenog zakonodavstva Republike Hrvatske, „Hrvatska pravna revija“, god. V., 2005., br. 1

BUKOVČAN, T., Želim odabrati koga ću voljeti i kamo ići na liječenje, aktivizam u istraživanju komplementarne i alternativne medicine u Hrvatskoj, Etnološka istraživanja/Ethnological Researches, FF Zagreb, Zagreb. 2008., 12/13, str. 63-76.

\section{C/}

CALLAHAN, D., Bioethics, In: Reich WT, editor. Encyclopedia of Bioethics. 2nd ed., New York, 1995., str. 1624., podatak kod SORTA-BILAJAC, I., Od eutanazije do distanazije, Rijeka, 2005.

CAPRON, A. M., Law and Bioethics, Encyclopedia of Bioethics, vol. 3., str. 1329.-1335.

CEKOVIĆ-VULETIĆ, S. et al., Medicinsko pravo, Institut društvenih nauka, Centar za pravna istraživanja, Beograd 1998.

CERAR, M., Nekateri pravni in moralni vidiki ugovora vesti, „Zbornik znanstvenih rasprav“, Ljubljana, 1993., br. LIII.

CERJAN, S., Zakon o zdravstvenoj zaštiti, „Informator“, broj 5176. od 15. listopada 2003.

CLERK \& LINDSELL, On Torts, Eighteen edition, General Editior: Anthony M. Dugdale; Sweet \& Maxwell, London, 2000.

CRNIĆ, I., Odgovornost liječnika za štetu, Organizator, Zagreb, 2009.

CRNIĆ, I., Odštetna odgovornost liječnika i zdravstvenih ustanova, zbornik radova sa savjetovanja „Aktualnosti hrvatskog zakonodavstva i pravne prakse“, Godišnjak 15, Organizator, Zagreb, 2008. 
CRNIĆ, I., Zadaće medicinskog vještaka u parničnom postupku za naknadu neimovinske štete, „Odvjetnik“, 2008., broj 5-6.

CRUZ, P., Medical Law, London, 2002.

CVRCIĆ, R., Poslovna, profesionalna i službena tajna, Pravo i porezi, god. XV, 2006.

$$
\text { Ć, } \check{\mathbf{C}} /
$$

ČEBULJ, J., Načela varstva osebnih podatkov na području medicine, zbornik «Medicina in pravo», god. 1996.-1998., Maribor, 1998., str. 212.-215.

ČEHIĆ, D., Ljudima koji ne haju za savjest sloboda savjesti ne znači baš ništa , http://zdravstveniodgoj.com/news/-ljudima-koji-ne-haju-za-savjest-sloboda-savjesti-neznaci-bas-nista.

ĆEPULIĆ, E., Profesionalna odgovornost liječnika i skandinavski model osiguranja liječnika, u: Profesionalna odgovornost liječnika, Zagreb, Narodne novine, 2007.

ĆESIĆ, Z. - GORENC, V. - KAČER, H. - MOMČINOVIĆ, H. - PAVIĆ, D. - PERKUŠIĆ, A. PEŠUTIĆ, A. - SLAKOPER, Z. - VIDOVIĆ, A. - VUKMIR, B., Komentar Zakona o obveznim odnosima, RRIF, Zagreb, 2005.

ČIRIĆ, A., Crkva protiv abortusa, „Vreme“, br. 481, 2000., podatak kod JOVANOVIĆ, S. SIMEUNOVIĆ PATIĆ, B., (Ne)dozvoljeni prekid trudnoće, „Pravni život“, 2007., broj 9.

ČIZMIĆ, J., Bioetika i medicinsko pravo, „Medicina Fluminensis“, vol. 44, No 2, 2008., str. 171.-185.

ČIZMIĆ, J. - BOBAN, M., Elektronički dokazi u sudskom postupku i računalna forenzička analiza, Zbornik Pravnog fakulteta Sveučilišta u Rijeci, (1991), v. 38, br. 1, 2017., str. 23.-50.

ČIZMIĆ, J., Intelektualno vlasništvo, Slobodno poduzetništvo, god. VIII., 2001., br. 6, str. 73.-87.

ČIZMIĆ, J., Intelektualno i industrijsko vlasništvo, Pravo i porezi, godina XI., 2002., br. 8, str. 26.-30.

ČIZMIĆ, J., Komentar Zakona o parničnom postupku, drugo izmijenjeno i dopunjeno izdanje, "Privredna štampa", Sarajevo, 2016., str. 383.-475.

ČIZMIĆ, J. - BABIĆ, T. - ROKSANDIĆ VIDLIČKA, S, Liječničko pravo, Split, 2009., neobjavljeno,

ČIZMIĆ, J., Medicinskopravna dokumentacija, zbornik radova „Aktualnosti zdravstvenog zakonodavstva i pravne prakse“, Novalja-Split, 2011., str. 65.-97.

ČIZMIĆ, J., Medicinsko pravo - pojam izvori i značaj, Zbornik radova s međunarodnog simpozija "Medicinsko pravo u sustavu zdravstvene djelatnosti", Plitvice, 13. i 14. studenoga 2015., str. 1.-34.

ČIZMIĆ, J., PERDIĆ, A., Neka zapažanja o profesionanoj tajni, Zbornik radova Pravo na tajnost podataka, Znanstveni skup, Novalja - Split, 2008.

ČIZMIĆ, J. - BOBAN, M. - ZLATOVIĆ, D., Nove tehnologije, intelektualno vlasništvo $i$ informacijska sigurnost, Pravni fakultet Sveučilišta u Splitu, Split, 2016.

ČIZMIĆ, J. - KAČER IVANČIĆ, B., Odgovornost za greške doktora medicine - specijalizanta, zbornik radova sa II. simpozija s međunarodnim sudjelovanjem „PRAVNI, ETIČKI I MEDICINSKI ASPEKTI SUVREMENOG VOĐENJA PORODA“, Šibenik, 11. i 13. svibnja 2017. Godine, str. 51.-67.

ČIZMIĆ, J., O vještačenju u parničnom postupku s posebnim osvrtom na vještačenje u području medicine, „Zbornik Pravnog fakulteta Sveučilišta u Rijeci“, (1991) v. 32, 2011., broj 1, str. 473.-510.

ČIZMIĆ, J., Pravo zdravstvenih radnika na „priziv savjesti“, Zbornik Pravnog fakulteta Sveučilišta u Rijeci, (1991), v. 37, br. 1, 2016., str. 753.-786.

ČIZMIĆ, J., Pravno uređenje instituta liječničke tajne u hrvatskom pravu, «Pravo i porezi», god. XVI., 2007., br. 2., str. 12-25.

ČIZMIĆ, J., Specijalisti medicinskog prava, referat na 19. posvetovanju „Medicina in pravo“, na temo Odgovornost v zdravstvu, Maribor, 26. i 27. marec 2010., Zbornik izvlečkov, str. 80.99. 
ČIZMIĆ, J., Zaštita prava iz područja industrijskoga vlasništva poslovnom tajnom, „Pravo u gospodarstvu“, god. 38, 1999., br. 2, str. 236.-237.

ČIZMIĆ, J., Značaj medicinskog prava za uređenje odnosa u području zdravstva, rad u zborniku radova sa savjetovanja «Aktualna pravna problematika u zdravstvu», 1. kongres pravnika u zdravstvu, Topusko 9. i 10. listopada 2008., str. 13.-54.

ČOLOVIĆ, V. - PETROVIĆ, Z. - TEŠIĆ, A., Osiguranje profesionalne odgovornosti lekara $i$ ostalih zdravstvenih radnika; Institut za uporedno pravo, Beograd, Srbija; Univerzitet „Sigmund Freud“, Beč ,Austrija; Univerzitet „Privredna akademija“ Novi Sad, Srbija, 2015.

ČOLOVIĆ V., Obavezno osiguranje od odgovornosti stečajnog upravnika, Tradicionalno IV savetovanje pravosuđa „Stečaj i privatizacija“, Vršac, 2007., Zbornik radova

ČOLOVIĆ, V., Osiguranje od lekarske odgovornosti, „Strani pravni život“, Institut za uporedno pravo, Beograd, 3/2010.

ČOVIĆ, A., Integrativna bioetika $i$ problem istine, $\operatorname{rad}$ objavljen na stranici http://epub.ff.uns.ac.rs/index.php/arhe/article/viewFile/1219/1238

ČOVIĆ, A., Pojmovna razgraničenja: moral, etika, medicinska etika, bioetika, integrativna bioetika, rad objavljen na starnici http://www.ffzg.unizg.hr/filoz/wpcontent/uploads/2011/11/Clanak-COVIC-Bioetika-i-dijete.pdf.

ČUKIĆ, D., Pravo na medicinsku istinu preko medicinske dokumentacije - teškoće, greške, predlog mjera za njihovo otklanjanje, «Pravni život», vol. LI, 2002., br. 9.

ĆURKOVIĆ, M., Osiguranje od odgovornosti liječnika, rad u zborniku „Građanskopravna odgovornost u medicini“", HAZU, Zagreb, 2008.

ĆURKOVIĆ, M., Osiguranje od odgovornosti liječnika, zbornik radova „Aktualnosti građanskog i trgovačkog zakonodavstva i pravne prakse“, Mostar, 2008.

\section{D/}

DAVID Udruga građana za zaštitu ljudskih prava, Prijedlozi za cjelovito reguliranje prava na priziv savjesti u medicini/ zdravstvenoj djelatnosti, Inicijativa liječnika/-ca za reguliranje priziva savjesti u medicini i CESI- Centar za edukaciju, savjetovanje i istraživanje, Poruke Okruglog stola „Priziv savjesti u medicini“, Zagreb, Novinarski dom, 21. 01. 2015., http://david-udruga.hr/novosti/2015/02/11/prijedlozi-za-cjelovito-reguliranje-prava-napriziv-savjesti-u-medicini-zdravstvenoj-djelatnosti/.

DEUTSCH, E., Arztrecht und Arzneimittlerecht, 2. Auflage, Berlin - New York, 1991.

DEUTSCH, E., Die Anfangeroperation: Autklarung, Organisation, Haftung und Beweislastumkehr, „Neue Juristiche Wochenschrift, 1984., broj 12,

DEUTSCH, E., Medizinische Fahrlässigkeiten, Neue Juristische Wochenschrift, br. 39/1976.,DEUTSC, E., Unerlaubte Handlungen und Schadensersatz, Ein Grundriss, Köln, 1987.

DEUTSCH, E., Medizin und Forschung vor Gericht, Heidelberg - Karlsruhe, 1978.

DEUTSCH, E. - SPICKHOFF, A., Medizinrecht, Berlin, 2003.

DEUTSCH, E. - SPICKHOFF, A., Medizinrecht, Springer, Berlin, 2008.

Dežurstvo, pripravnost i rad po pozivu, podatak na stranici http://upuz.hr/aktualnosti/dezurstvopripravnost-i-rad-po-pozivu.

DIKA, M-ČIZMIĆ, J., Komentar Zakona o parničnom postupku Federacije Bosne i Hercegovine, Sarajevo, 2000.

DIKA, M., Rješavanje sporova za naknadu štete zbog liječničke greške, referat na savjetovanju“"Medicinski, pravni i ekonomski pogledi na profesionalnu odgovornost u zdravstvu i osiguranje od odgovornosti“", Šibenik, listopad 2007.

DIKA, M., Zakon o izmjenama i dopunama Zakona o parničnom postupku od 2. srpnja 2008. Opći pregled, rad u zborniku DIKA, M. i drugi, Novela Zakona o parničnom postupku iz 2008., Zagreb, 2008. 
Donald's Medical Dictionary, 28. ed., 1994.

DOURAKI, T., Ethical and Legal Dimensions of Medical Confidentiality in European Law of Human Rights, «Pravni život», god. LI, 2002., br. 9,

DRAKULIĆ, V. i dr., Zdravstvena djelatnost i priprema sustava zdravstvene zaštite za pristupanje Hrvatske Europskoj uniji, TEB poslovno savjetovanje, Zagreb, 2012

DRAŠKIĆ, M., Prava pacijenata - kraj paternalističkog koncepta medicine, „Pravni život“, 1998., br. 9.

DROPULIĆ, J., Pravo na privatni život i duševni integritet, Zagreb, 2002.

DUKIĆ-MIJATOVIĆ, M., Položaj arbitra u arbitražnom postupku, „Strani pravni život“, 2011., broj 1 .

\section{Đ/}

ĐURĐEVIĆ, N., Pristanak pacijenta na lečenje, Pravni fakultet, Institut za pravne i društvene nauke, Kragujevac, 1997., str. 86. - 90.

\section{E/}

Enciklopedijski članak: zdravstvena zaštita, on-line izdanje Hrvatske enciklopedije Leksikografskog zavoda Miroslav Krleža, http://www.enciklopedija.hr/natuknica.aspx?ID=67020.

ERTEL, W. A., Grundfragen des deutschen und italienischen Arzthaftungsprozess im Vergleich, Konstanz, 1989.

\section{F/}

FLETCHER, J. C. - BRODY, H., Clinical Ethics, In: Reich WT, editor. Encyclopedia of Bioethics. 2nd ed., New York, 1995.

FLIS, V., Medicinska dokumentacija in pravice bolnikov, zbornik „Medicina in pravo“, god. 1996.1998., Maribor, 1998.

FRANZKI, HARALD i DIETMAR Waffengleicheit im Arzthaftungsprozess, Neue Juristische Wochenschrifft, br. 49/1975.GAVELLA, N., Osobna prava - I. dio, Zagreb, 2000.

\section{G/}

GAVELLA, N., Osobna prava - I. dio, Zagreb, 2000.

GIESEN, D., Arzthaftungsrecht, Tübingen, 1990.

GIUNIO, M., Novine u hrvatskom arbitražnom pravu s posebnim osvrtom na ad hoc arbitražu $i$ ulogu državnog suda, referat objavljen u zborniku sa 40. susreta pravnika u Opatiji 2002.

GJURAŠIN, M. - HALLER, H. - RUMEK ČRNE, R., Zaštita interesa liječnika i bolesnika u Hrvatskoj liječničkoj komori - O radu Povjerenstva za stručna pitanja i stručni nadzor, „Liječničke novine“, godina IX, 2009., broj 77.

GJURIĆ, G., Prigovor savjesti i nagovor savjesti u ratu oko pobačaja, http://www.libela.org/sastavom/5621-prigovor-savjesti-i-nagovor-savjesti-u-ratu-oko-pobacaja/.

GNJIDIĆ, Ž. - BILIĆ, R. i dr., Uvod u medicinsko vještačenje u građanskim parnicama, Zagreb, 2008.

GOLDŠTAJN, A. - TRIVA, S., Međunarodna trgovačka arbitraža, Zagreb,1987.

GORETA, M., O odgovornosti psihoterapeuta, rad izložen na V. kongresu psihoterapeuta Jugoslavije u Sarajevu, 25-29.X 1987.

GORETA, M., Psihijatrijska vještačenja povrede duševnog integriteta kao oblika neimovinske štete, „Narodne novine“, Zagreb, 2008. 
GOSIĆ, N., Pravna perspektiva u bioetičkoj edukaciji u Hrvatskoj, referat održan na 9. bioetičkom okruglom stolu «Bioetika i medicinsko pravo», održanom u Rijeci, 15. i 16. svibnja 2008.

GOSIĆ, N., Privatnost i povjerenje u medicinskoj etici i bioetici, «Sestrinski edukacijski magazin», god. II, 2005., broj 2.

GRBČIĆ, Ž., Kakva prava pruža Zakon o zaštiti pacijenata, «Informator», god. LII, 2005., br. 5145.

H/

HALLER, H., Medicinski pogled na liječničku odgovornost, rad u zborniku „Građanskopravna odgovornost u medicini“", HAZU, Zagreb, 2008.

HARLAND, C. - ROCHE, R. - STRAUSS, E., Komentar Evropske konvencije o ljudskim pravima prema praksi u Bosni i Hercegovini i Strasbourgu, Sarajevo, 2003.

HERVEY, T. - McHALE, J. V., Health Law and the European Union, Cambridge, 2004., str. 169.172.

HLAĆA, N., O bioetici u povodu potpisa u Vijeću Europe dvaju međunarodnih dokumenata s bioetičkim sadržajima, «Vladavina prava», god. II., 1998., br. 3-4, str. 45.-52.

HONSELL, H., Die zivilrechtliche Haftung des Arztes, Zeitschrift für Schweizerisches Recht, 1990.

HOROVIĆ, S. - RADANOVIĆ MIŠIĆ, N., Kaznenopravna i građanskopravna odgovornost liječnika, Zbornik radova s petnaestog međunarodnog savjetovanja „Aktualnosti građanskog i trgovačkog zakonodavstva i pravne prakse“, održanog u Neumu 16-18. lipnja 2017., Mostar, 2017.

HRANILOVIĆ, A. - ROVIS, D., Pogledi osiguratelja na profesionalnu odgovornost: Što su nam zakoni i praksa donijeli u Hrvatskoj po pitanju profesionalne odgovornosti?; Pravna zaštita liječnika u obavljanju liječničke djelatnosti, Simpozij HLK, Opatija, 2012.

Hrvatska enciklopedija, na stranici http://www.enciklopedija.hr/natuknica.aspx?id=14605.

Hrvatski leksikon, na stranici http://www.hrleksikon.info/definicija/deontologija.html.

\section{I/}

IVANČEVIĆ, N., Zakon o liječništvu, rad u zborniku «Zbirka zdravstvenih zakona s obrazložnjem, Zagreb, 2003.

IVANJKO, Š., Medicinska dokumentacija pri opravljanju zavarovalne djelatnosti, zbornik „Medicina in pravo“, god. 1996.-1998., Maribor, 1998.

IVEKOVIĆ, R., Izrada medicinskog vještačenja, rad u materijalu „Tečaj izobrazbe kandidata za stalne sudske vještake, Zagreb, 2010.

\section{J/}

JADRO, D. - HRABRIĆ, M. - KRAMARIĆ, D., Zakon o zdravstvenoj zaštiti, rad u knjizi Zbirka zdravstvenih zakona s obrazloženjem, Zagreb, 2003.

JAGIĆ, Z., Prekršajna odgovornost članova komora u zdravstvu, Zbornik radova s međunarodnog simpozija "Medicinsko pravo u sustavu zdravstvene djelatnosti", 2015.

JAHNKE, Leipziger Kommentar zum Strafgesetzbuch, 10. Auflage, 5. Band, Leipzig, 1988.

JAKŠIĆ, Ž. Medicinska dokumentacija. U: Jakšić, Ž. i sur., Socijalna medicina. Praktikum II. 5. izd., Zagreb, Medicinski fakultet Sveučilišta u Zagrebu, 1989., str. 355.-372.

JANKOVIĆ, M. - KARAMARKOVIĆ, H. - JANKOVIĆ, Ž. - PETROVIĆ, D., Komentar zakona o parničnom postupku, 3. izdanje, Beograd, 1990.

JAŠARSPAHIĆ, Š., Nematerijalna šteta, Zbornik radova Jahorina, 20 -22 Oktobar 2011.

JELAČIĆ, O., „Liječnička tajna u našem zakonodavstvu“, Zbornik radova Pravnoga fakulteta u Splitu, god X, 1973. 
JELAČIĆ, O., O nastavi iz sudske medicine na pravnim fakultetima, Zbornik radova Pravnog fakulteta u Splitu, 1977., XIV.

JELAČIĆ, O., Osnove sudske medicine za studente prava, Split, 1981.

JELAČIĆ, O., Pravni $i$ deontološki aspekt lekarske delatnosti, «Jugoslavenska revija za kriminologiju i krivično pravo», god. IX, 1971., br. 3.

JELAČIĆ, O., Sudsko-medicinski aspekt kvalifikacije tjelesnih povreda, «Zbornik Pravnog fakulteta u Splitu», god. XVII, 1980.

JELENC PUKLAVEC, A., Zdravstvena dokumentacija, zasebnost in kazenski postopek, zbornik «Medicina in pravo», god. 1996.-1998., Maribor, 1998.

JONSEN A. R. - JAMETON A., Medical Ethics, In: Reich WT, editor. Encyclopedia of Bioethics. 2nd ed., New York, 1995., str. 1624., podatak kod SORTA-BILAJAC, I., Od eutanazije do distanazije, Rijeka, 2005.

Još su žive žene koje su same napravile pobačaj vješalicama, ne želimo da se to ikad ponovi, http://www.vecernji.hr/hrvatska/jos-su-zive-zene-koje-su-same-napravile-pobacajvjesalicama-ne-zelimo-da-se-to-ikad-ponovi-976203.

JOVANOVIĆ, LJ., Lekarska tajna - krivičnopravna razmatranja, Beograd, 1959.

JOVANOVIĆ, S., Osiguranje od odgovornosti-ugovorno pokriće po sistemu nastanka osiguranog uzroka ili datuma postvljanja odštetnog zahtjeva, Revija za prvo osiguranja, broj 1/2010.

JOVANOVIĆ, S. - SIMEUNOVIĆ PATIĆ, B., (Ne)dozvoljeni prekid trudnoće, „Pravni život“, 2007., broj 9.

JUKIĆ, M., Liječničke pogreške - osnovana sumnja, Sudsko-medicinski slučaj, „Medicinska naklada“, Zagreb, 2014.

JURAS, D., Disciplinska odgovornost liječnika, ,Zbornik radova Pravnog fakulteta u Splitu“, god. 51., 2014., broj 3

JURASIĆ, M., SDP-ovski priziv savjesti Peđe Grbina, „Večernji list“ od 8. srpnja 2014., na stranici http://www.vecernji.hr/hrvatska/sdp-ovski-priziv-savjesti-pede-grbina-949048.

JURČEV SAVIČEVIĆ, A., Zdravlje, rad u knjizi PUNTARIĆ, D. i dr., Javno zdravstvo“, Medicinska naklada, Zagreb, 2015., str. 24.-26.

JURIĆ, H., Hrvatska uporišta za integrativnu bioetiku u djelu Van Rensselaera Pottera, rad na stranici http://www.ffzg.unizg.hr/filoz/wp-content/uploads/2011/09/45_dok.doc_.pdf.

\section{K/}

KAČER, H., Naknada štete zbog liječničke griješke, u: LIJEČNIČKA POGREŠKA MEDICINSKI I PRAVNI ASPEKTI, Sveučilište u Splitu - Medicinski i Pravni fakultet, ožujak 2007., str. 149.-190.;

KAČER, H., Jedna novija odluka Ustavnog suda Republike Hrvatske o objektivnoj odgovornosti u medicini, „Hrvatska pravna revija“, broj 4 / 2008., str. 35.-40.;

KAČER, H. - IVANČIĆ KAČER, B., Građanskopravna odgovornost za štete nastale zbog liječničke greške - I dio, ,Pravo i porezi““ broj 7/2007., str. 12.-18.;

KAČER, H. - IVANČIĆ KAČER, B., Građanskopravna odgovornost za štete nastale zbog liječničke greške - II dio, „Pravo i porezi“, broj 8/2007., str. 14.-24.

KALADIĆ, I., Nelagodnosti tijekom liječenja i novčana naknada za fizičke boli, „Hrvatska pravna revija“, god. III., 2003., broj 4.

KAUZLARIĆ, Ž., Stalni sudski vještaci (2. dio), „Informator“, broj 5541. od 14. travnja 2007.

KAUZLARIĆ, Ž., Sudski vještaci i njihova uloga u parničnom postupku - s osvrtom na posebnosti u postupku osporavanja očinstva i vještačenja mobinga, „Hrvatska pravna revija“, broj, 6/07, str. 91.-100.

KERETA J., Osiguranje od profesionalne odgovornosti, časopis Sigurnost, vol. 48, br. 3, od 01. 10. 2006. 
KLARIĆ, P., Građanskopravna odgovornost za liječničku grešku, rad u zborniku radova „Hrestomatija hrvatskoga medicinskog prava“, Pravni fakultet Sveučilišta u Zagrebu, Zagreb, 2016.

KLARIĆ, A. - CVITKOVIĆ, M. - MATIJAŠČIĆ ŽUGAJ, P., Komore u zdravstvu, Zbornik Aktualna problematika u zdravstvu, Varaždin (2015), str. 162.-182.

KLARIĆ, A., Medicinsko pravo - osnov definiranja komorskih prava, Zbornik radova s međunarodnog simpozija „Medicinsko pravo u sustavu zdravstvene djelatnosti“, Split, Sveučilište u Splitu - Pravni fakultet, 2015., str. 65-82.

KLARIĆ, A. - CVITKOVIĆ, M., Vrste i načini odgovornosti unutar tima, Zbornik radova „2. Hrvatski simpozij medicinskog prava“, Vodice, 2016.

KLARIĆ, P., Odgovornost za štete u medicini, «Informator», br. 5016-5017. od 3. i 6. travnja 2002., male stranice,

KLARIĆ, P., Odgovornost za štetu zbog grešaka u medicini, Klub pravnika, Tribina od 19. 12. 2001., na ntranici: www.pravnadatoteka.hr/pdf/aktualno/hrv/20030211/Odgovornost_za_stetu_zbog_gresaka u_medicini.doc.

KLARIĆ, P., Odgovornost zdravstvene ustanove i zdravstvenih djelatnika za štetu ( Prvi dio), Hrvatska pravna revija, 2008., br. 8 .

KLARIĆ, P., Odštetno pravo, Zagreb, 2003.

KLARIĆ, P., Uzročna veza kod odgovornosti za štete u medicini, Zbornik radova II. Znanstvenog skupa „Aktualnosti zdravstvenog zakonodavstva i pravne prakse“, Novalja-Split, 2011.

KLARIĆ, P. - VEDRIŠ, M., Građansko pravo, Narodne novine, Zagreb, 2008.

KNESTOUT, B. P., An Essential Prescription: Why Pharmacist - Inclusive Conscience Clauses Are Necessary, „Journal of Contemporary Health Law \& Policy“, 2006., broj 2

KNEŽEVIĆ, G., Međunarodna trgovačka arbitraža, Beograd, 1999.

KNEŽIĆ-POPOVIĆ, D., Istorija slobodnih profesija od Artes Liberales do savremenog doba, Strani pravni život 2/2008, Beograd, str. 7-28.

KNOL RADOJA, K., Alternativno rješavanje medicinskih sporova, Zbornik radova „Usluge i zaštita korisnika“, Kragujevac, 2016., str. 589.-607.

KOROŠEC, D., Medicinsko kaznensko pravo, Ljubljana, 2004.

KREHO, S., Zbirka sudskih odluka iz oblasti Zakona o krivičnom postupku, Sarajevo, 1996.

KUKOLJAC, M., Parnični postupak, Beograd, 1970.

KULENOVIĆ, Z. i drugi, Komentari Zakona o parničnom postupku u Federaciji Bosne $i$ Hercegovine i Republici Srpskoj, Sarajevo, 2005.

KULIĆ, R., Upis i status vještaka u sudskom postupku, „Pravni život“, broj 12/1998.

\section{L/}

LAUDE, A., Pharmacie - Actualite juridique, „Revue de droit sanitaire et social“, 1999., broj 1.

LAUFS, A. - UHLENBRUCK, Handbuch des Arztrecht, Munchen, 2002.

LEHTONEN, L., Protection of patient data and right to privacy in Finland-recent implementation of the Directive on the protection of personal data and centralized registries containing sensitive health data, referat u zborniku 13th World Congress on Medical Law, 6-10 August 2000, Helsinki

LINIĆ, Z., Ispovijed grijeha pred svećenikom, Glas Koncila, 12 (1709), 21. 3. 2007.

LOVIĆ, S., Prisilne arbitraže, „Pravo u gospodarstvu“, dod. 55, 2016., broj 4.

\section{M/}

MAHMUTEFENDIĆ, I., Načelo suradnje $i$ dobrih odnosa među zdravstvenim radnicima u svrsi dobrobiti bolesnika, rad u knjizi „Odnosi među liječnicima u Hrvatskoj“, Knjiga izlaganja 
na XIV. proljetnom simpoziju medicinske etike Hrvatskoga liječničkog zbora, Zagreb, 10. lipnja 2014., urednik Goran Ivanišević, Hrvatski liječnički zbor, Zagreb, 2014.

MALLACH, H. J. - SCHLENKER, G. - WEISER, A., Ärztliche Kunstfehler, Stuttgart - New York, 1993.

MALETIĆ, D., Profesionalna sloboda lekara, „Pravni život“, 2011., broj 9.

MARIĆ, J. - LUKIĆ, M., Pravna medicina, Beograd, 1998.

MATIJEVIĆ, B., Osiguranje od profesionalne odgovornosti u djelatnosti zdravstva, „Hrvatska pravna revija“", 2008., broj 6.

MATIJEVIĆ, B., Prava osobnosti: pravo na privatnost osobnoga i obiteljskoga života, Hrvatska pravna revija, god. VI., br. 5, svibanj 2006.

MARIĆ, J. - LUKIĆ, M., Pravna medicina, Beograd, 1998.

MARKELJEVIĆ, J., Savjest i priziv savjesti, predavanje održano 21. siječnja 2015. godine u Domu HKLD-a u Zagrebu.

MAROVIĆ, A. - MEDVIDOVIĆ, L. - ŠTIMAC, S., Zaštita prava osobnosti, Split, 2006.

MATULIĆ, T., Bioetika, Zagreb, 2001.

MATULIĆ, T., Identitet, profesija i etika sestrinstva, BS 77 (2007.), br. 3, str. 727-744.

Medicinska enciklopedija, knjiga 4., Zagreb, MCMLXIX.

Medicinski leksikon, Zagreb, 1990.

MEDIĆ, D., Značaj vještačenja u parnicama za naknadu nematerijalne štete, „Pravni savjetnik“, god. I, 2001., broj 9.

MEMETEAU, G., Droit medical, Paris, 1986.

MIHALIĆ, A., Osiguranje od odgovornosti liječnika pri obavljanju djelatnosti, „Osiguranje“, godina XXXXVII, 2006., broj 7-8.

MILADIN, P., „Odnos između privatnopravnog $i$ kazneno pravnog uređenja poslovne $i$ profesionalne tajne ", Pravo u gospodarstvu, br. 4, 2000.

MILADIN, P., Poslovna i profesionalna tajna kao prava osobnosti, Zbornik radova znanstvenoga skupa Pravo na tajnost podataka, Novalja - Split, 30. i 31. svibnja, 2008. godine, str.107.124.

MILADIN, P., Temeljni pravni i ekonomski okvir privatnoga upravljanja imovinom, Zbornik radova / Drugi skopsko-zagrebački pravni kolokvij, Skopje, 2009.; str. 121.-142.

MILAKOVIĆ, G., Ugovor o specijalističkom usavršavanju doktora medicine $i$ posljedice nepridržavanja ugovornih odredaba, „Informator“, broj 6423. od 20. lipnja 2016., str 15.17.

MILETIĆ MEDVED, M., Načela na kojima se temelji medicinska etika, rad u knjizi PUNTARIĆ, D. i dr., Javno zdravstvo“, Medicinska naklada, Zagreb, 2015.

MILIČIĆ, V., Deontologija profesije liječnik, život čovjeka i integritet liječnika - ćudoredna raskrižja bioetike, Zagreb, 1996., Prilog B.

MUJOVIĆ ZORNIĆ, H. - SJENČIĆ, M., Kodeks lekarske etike kao izraz staleške samoregulative u medicini, «Pravni informator», 2003.

MUJOVIĆ-ZORNIĆ, H., Medicinsko pravo - Interdisciplinarnost i suradnja, Beograd, 2013., podatak na stranici www.ius.bg.ac.rs/pro/Mateirjali/dramar/h.mujovic.medicinsko\%20pravo.pdf.

MUJOVIĆ ZORNIĆ, H., Perspektive medicinskog prava u svjetlosti Evropske konvencije o ljudskim pravima $i$ biomedicini, zbornik radova „Aktualnosti građanskog i trgovačkog zakonodavstva i pravne prakse“, Neum - Mostar, 2004., str. 137.-145.

MUJOVIC-ZORNIC, M. H., Physician's error: medical or legal concept? Med Law (2010) 29.

MUJOVIĆ-ZORNIĆ, H., Pravni aspekti etičkih komiteta u medicini, „Pravni život“, broj 9/2007.

MUJOVIĆ-ZORNIĆ, H., Pravo kao garant vršenja medicine, «Bilten Jugoslovenskog udruženja za medicinsko pravo», septembar/decembar 2001.

MUJOVIĆ-ZORNIĆ, H., Promene u shvatanju klauzule savesti kod pružanja zdravstvenih usluga, „Pravni život", tematski broj „Pravo i načelo savesnosti i poštenja“, 2014., broj 9, TOM I 
MUJOVIĆ ZORNIĆ, H., Značaj veštačenja lekarske greške u građanskom postupku, zbornik radova "Aktualnosti građanskog i trgovačkog zakonodavstva i pravne prakse", br. 6, Mostar 2008.

MUSA, K., Arbitraža u organizaciji udruženog rada - samoupravni sud, Zagreb, 1982.

MUSTAJBEGOVIĆ, J., Liječnici i njihove kolege u svjetlu svjetskog liječničkog udruženja, rad u knjizi „Odnosi među liječnicima u Hrvatskoj“, Knjiga izlaganja na XIV. proljetnom simpoziju medicinske etike Hrvatskoga liječničkog zbora, Zagreb, 10. lipnja 2014.

MUZUR, A. - RINČIĆ LERGA, I., Etika i bioetika: sličnosti i razlike u odnosu prema pravu, referat održan na 9. bioetičkom okruglom stolu «Bioetika i medicinsko pravo», održanog u Rijeci, 15. i 16. svibnja 2008., Program i sažeci.

\section{N/}

NIKOLIĆ, K., Krivično-pravna odgovornost ljekara zbog neurednog vođenja medicinske dokumentacije, «Pravni život», 1998., br. 9.

NIKOLIĆ, S., Etika zdravstvenih radnika danas, «Timočki medicinski glasnik», vol. 28., 2003., broj 3-4, str. 87.-90.

NIKŠIĆ, S., Aktualnosti na području odgovornosti za štete u medicini, rad u knjizi DRAKULIĆ, V. i dr., Zdravstvena djelatnost $i$ priprema sustava zdravstvene zaštite za pristupanje Hrvatske Europskoj uniji, TEB poslovno savjetovanje, Zagreb, 2012.

NOVOSELEC, P., Posebni dio kaznenog prava, Prvo izdanje, Zagreb, 2007.

\section{O/}

ODAK, V., Obvezna osiguranja, Dani hrvatskog osiguranja, Opatija 15. - 16. 11. 2004.

OMEJEC, J., Konvencija za zaštitu ljudskih prava i temeljnih sloboda u praksi Europskog suda za ljudska prava - Strasbourški aquis, ,Informator“, Zagreb, 2013.

OPDERBECKE, H. W. - WEISSAUER, W., Aerztliche Dokumentation und Pflege dokumentation, «Medizinrecht», 1984., br. 6.

\section{P/}

Papa Franjo: Prigovor savjesti - liječnici, Prigodom 70 godišnjice uspostave Udruge Talijanskog katoličkog liječničkog društva http://www.ika.hr/index.php?prikaz=vijest\&ID=164838.

PAVIČIĆ, D., Pozaić o Holy: navodna stranka ekologije propagira kulturu smrti, „Večernji list“ od 27. studenoga 2014., http://www.vecernji.hr/hrvatska/biskup-pozaic-ginekologe-kojine-zele-pobacaje-pretvorili-su-u-udbase-976025.

PEROVIĆ, J. S., Ugovor o međunarodnoj trgovinskoj arbitraži, Javno preduzeće Službeni list SRJ, Beograd, 2002.

PETRIĆ, S., Pretpostavke odštetne odgovornosti davatelja zdravstvenih usluga u pravu BiH, zbornik radova „Aktualnosti građanskog i trgovačkog zakonodavstva i pravne prakse“, Mostar, 2005., broj 3.

PETROVIĆ, F. - STANOJEVIĆ, S. - MARČETIĆ, LJ., Zaštita i valorizacija medicinske dokumentacije, Beograd, 1995.

PETROVIĆ-ŠKERO, V., Lekarska tajna i veštačenje, «Svet rada», vol. 1, 2004., br. 4

Pitanja $i$ odgovori: Pripravnost $i$ prava radnika $i z$ rada, podatak na stranici http://www.poslovni.hr/tips-and-tricks/pitanja-i-odgovori-pripravnost-i-prava-radnika-izrada-245330.

PLAVŠIĆ-NEŠIĆ, A., Komore zdravstvenih radnika Srbije, „Pravni život“, 2009., broj 9, TOM I, 
PLOEM, C., Medical confidentiality after patient's death, „Medicine and Law“, vol. 20, 2001., br. 2

POČUČA, M. - ŠARKIĆ, N. - MRVIĆ PETROVIĆ, N., Lekarska greška kao razlog pravne odgovornosti lekara $i$ zdravstvenih ustanova, Pravni fakultet za privredu i pravosuđe univerziteta Privredna akademija Novi sad, Pravni fakultet univerziteta Union Beograd, Beograd, 2013.

POGARČIĆ, Z., Dokazi i izvođenje dokaza u parničnom postupku, "Slobodno poduzetništvo", 1999., br. 20.

POLIĆ, J., Zakon o stomatološkoj djelatnosti, rad u zborniku «Zbirka zdravstvenih zakona s obrazložnjem», Zagreb, 2003.

POROBIĆ, M. - POROBIĆ, V. - POROBIĆ, J., Zakoni o parničnom postupku (Federacija BiH, Republika Srpska, Brčko Distrikt BiH) sa komentarom i sudskom praksom, Sarajevo, 2004.

POZAIĆ, V., „Teološki vidici liječničke tajne“, Zbornik radova Medicinska etika 1, Znidarčić, Ž., (ur.), Centar za bioetiku, Zagreb, 2004.POZNIĆ, B. -VRŽALIĆ, M. -BAČIĆ, F., Zakon o parničnom postupku sa komentarom, Beograd, 1957.

POZNIĆ, B. -VRŽALIĆ, M. -BAČIĆ, F., Zakon o parničnom postupku sa komentarom, Beograd, 1957.

Pravobraniteljica: Pravo na pobočaj je utemeljeno na nadnacionalnim zakonima EU, „Indeks“ od 4. studenoga 2014., http://www.index.hr/vijesti/clanak/pravobraniteljica-pravo-napobacaj-je-utemeljeno-na-nadnacionalnim-zakonima-eu/781753.aspx.

Pravo na priziv savjesti, Priopćenje Pučkog pravobranitelja RH od 22. kolovoza 2013., na stranici http://www.ombudsman.hr/index.php/hr/za-javnost/priopcenja/182-pravo-na-priziv$\underline{\text { savjesti. }}$

PROSKE, M., Aerztliche Aufklarungspflicht und Einwilligung des Patienten aus strafrechtlicher Sicht, u: Haftung des Arztes in zivil - und strafrechtlicher Sicht unter Einschluss des Arzneimittelrechts, Graz, 1983.

PROSO, M., Sustavi osiguranja od odštetne odgovornosti u zdravstvenoj djelatnosti, Zbornik radova Pravnog fakulteta u Splitu, god. 46, 2/2009., str. 359.-372.

Protiv priziva savjesti i Ustava: 'Liječnike koji odbijaju pobačaj izbaciti iz javnog zdravstva', „Dnevno.hr“ od 28. siječnja 2015., http://www.dnevno.hr/vijesti/hrvatska/protiv-prizivasavjesti-i-ustava-lijecnike-koji-odbijaju-pobacaj-izbaciti-iz-javnog-zdravstva-143361\#.

PULANIĆ, R., Algoritmi u gastrointestinalnoj endoksopiji i endoskopskom ultrazvuku, podatak na stranici http://www.medicinskanaklada.hr/product.aspx?p=4177.

PULJKO, V., Arbitražno rješavanje sporova u nogometu, "Pravni vjesnik", broj 10/2.

\section{$\mathbf{R} /$}

RADANOVIĆ MIŠIĆ, N., Liječnik kao subjekt deliktne odgovornosti, doktorska disertacija, Mostar, 2017.

RADIĆ, M., Zakon o ljekarništvu, u knjizi Zbirka zdravstvenih zakona s obrazloženjem, Zagreb, 2003.

RADIĆ, M., Zakon o medicinsko-biokemijskoj djelatnosti, u knjizi Zbirka zdravstvenih zakona s obrazloženjem, Zagreb, 2003.

RADIŠIĆ, J., Dužnost čuvanja medicinske tajne, „Anali Pravnog fakulteta u Beogradu“, god. L., 2002.

RADIŠIĆ, J., Građanska odgovornost lekara koja proističe iz njihovog zanimanja, Revija za pravo osiguranja, broj 1/2009.

RADIŠIĆ, J., Ko je odgovoran zbog greške lekara na specijalizaciji, „Pravni život“, 2009., TOM I, broj 9 .

RADIŠIĆ, J., Medicinsko pravo, „Nomos“, Beograd, 2004.

RADIŠIĆ, J., Medicinsko pravo, Beograd, 2008.

RADIŠIĆ, J., Medicinsko pravo u svetu i kod nas, „Pravni informator“, 2002., br. 9. 
RADIŠIĆ J., Odgovornost lekara i medicinskih ustanova zbog sekundarnih šteta, u CEKOVIĆVULETIĆ, S. et al., Medicinsko pravo, Institut društvenih nauka, Centar za pravna istraživanja, Beograd 1998.

RADIŠIĆ, J., Odgovornost lekara u slučaju kad nije dovoljno sigurno da je njegova greška nanela štetu pacijentovom zdravlju, Revija za pravo osiguranja, broj 3/2010.

RADIŠIĆ, J., Odgovornost za štetu uzrokovanu operacijom koju je obavio liječnik na specijalizaciji, u zborniku radova skupine autora: Medicinsko pravo i medicinska etika, Univerzizet u Beogradu, Beograd, 1994.

RADIŠIĆ, J., Profesionalna odgovornost medicinskih poslenika, Beograd, Institut društvenih nauka u Beogradu, 1986.

RADIŠIĆ, J., Uzročna veza kao osnov i kao mera odgovornosti zbog lekarske stručne greške, Pravni život, 9/1998.

RADOLOVIĆ, A., Pravo osobnosti u novom Zakonu o obveznim odnosima, «Zbornik Pravnog fakulteta Sveučilišta u Rijeci», vol. 27., 2006., br. 1

RADOVANČEVIĆ, LJ., (Ko)relacije bioetike $i$ zdravstvenog prava, referat održan na 9. bioetičkom okruglom stolu «Bioetika i medicinsko pravo», održanog u Rijeci, 15. i 16. svibnja 2008., Program i sažeci

RADOVANČEVIĆ, LJ. - RUŠINOVIĆ SUNARA, Đ., Sadržaj i kontekst zdravstvenog prava $i$ bioetike, referat na skupu Lošinjski dani bioetike, Mali Lošinj, Hrvatska, 13.-15. lipnja 2005.

RAJIĆ, Z. - TOMIĆ, M. - MILJKO, Z., Komentar Kaznenog zakona, Mostar, 2000.

RAMLJAK, A. - VESEL, J., - Pravna medicina, Banja Luka, 1986.

RAŠEVIĆ. M., Bela kuga i abortus, rad u knjizi „Pomeramo granice“, Institut društvenih nauka, Beograd, 2007.

REHBERG, J., Handbuch des Arztrechts, Zurich, 1994.

Report on Medical Liability in Council of Europe Member States - A Comparative study and Recommendations, European Committee on Legal Co-operation, CDCJ (2005) 3, Strasbourg, 21. ožujka 2005.

RIMAC-LESIČKI, I., Kod prodaje tablete za „,dan poslije“ moguć je - priziv savjesti, „Večernji list“" od 25. travnja 2015., http://www.vecernji.hr/hrvatska/kod-prodaje-tablete-za-danposlije-moguc-je-priziv-savjesti-1002181.

RISTIĆ, J., Medicina i društvo, Beograd, 1975.

RISTIĆ, V. - RISTIĆ, M., Praktikum za parnicu, Beograd, 1989.

RITTOSSA, D., Prijepori o pravu na pobačaj u Republici Hrvatskoj, „Zbornik Pravnog fakulteta Sveučilišta u Rijeci“, v. 26, 2005., broj 2 (1991).

RODRÍGUEZ-VÁZQUEZ, V., Doctors in Spanish Criminal Law: medical criminal responsibility for deaths and injuries caused by negligence in present-day Spain, 25 Med. \& L., 2006. Dostupno na: http://heinonline.org.

ROKSANDIĆ-VIDLIČKA, S., Aktualna pitanja pojedinih kaznenih djela protiv zdravlja ljudi u svijetlu donošenja Nacrta izmjena hrvatskog kaznenog zakona, Godišnjak akademije pravnih znanosti Hrvatske, Vol.1. No 1, prosinac 2010.

ROKSANDIĆ, S. - BABIĆ, T. -BUDIĆ, N., Legal Classification of Relations btw Doctors and Patients in Republic of Croatia, 2005, International Congress on Medical law, Seoul, Južna Koreja, kolovoz 2005.

ROKSANDIĆ VIDLIČKA, S. - ZIBAR, L. - ČIZMIĆ, J. - GRĐAN, K., Pravo Jehovinih svjedoka na ostvarivanje kirurške zdravstvene zaštite u Republici Hrvatskoj - prema vrijedećim zakonima (de lege lata), "Liječnički Vjesnik - Glasilo Hrvatskog liječničkog zbora", god. 139, 2017., broj 3-4, str. 91.-98.ROŽMAN, K., O prizivu savjesti, „Primaljski Vjesnik“, 2013., broj 15, str. 19.-21.

RUMEK ČRNE, R. - ROKSANDIĆ, S., Sud Hrvatske liječničke komore - pravni aspekti, objavljen u Hrvatska liječnička komora 193-1995-2005., Zagreb, 2005., str. 237.-244. 
SAJKO, K. - DIKA, M., Arbitražno rješavanje međunarodnih trgovačkih sporova, Ljubljana, 1989.

SALAJ, Š., Uloga vještaka u parničnom postupku, "Pravo i porezi”, XLIX, 2000., br. 10.

SANDOR, J., Data Protection in Health Care, Beyond Biomedical Use, „Frontiers of European Health Law", Yearbook 2002.

SAVULESCU, J., Prigovor savjesti u medicini, Cijepljenje.info, http://www.cijepljenje.info/juliansavulescu-prigovor-savjesti-u-medicini/.

SCALISI., A., Il valore della persona nel sistema e nei nuovi diritti della personalita, Giuggre Ed., 1990.

SCHMID, H., Ueber den notwendigen Inhalt arztlichen Dokumentation, «Neue Juristische Wochenschrift», 1987., br. 12

SCHULTZE-ZEU, R., Das Vorliegen eines einfachen Befunderhebungsfehlers und die Bevveislastumkehr hinsichtlich der Kausalitat, Versicherungsrecht, br.19/2008.

SIJERČIĆ-ČOLIĆ, H. - VULETA, D. - HADŽIOMERAGIĆ, M., Komentar Zakona o krivičnom postupku, Sarajevo, 1999.

Skupina eksperata, Naziv stručnih smjernica, podatak na stranici http://www.hdgo.hr/userFiles/upload/documents/HDGO\%20smjernice/OPCE/ObrazacStrucne-Smjernice.pdf.

SLAVNIĆ, J., Osiguranje od profesionalne odgovornosti danas, Revija za pravo osiguranja, broj 3/2006.

SMERDEL, B., Temeljne značajke ustavnoga poretka Republike Hrvatske na dvadesetu obljetnicu Božićnoga Ustava, Novi informator, 16. izmijenjeno i dopunjeno izdanje, Zagreb, 2010.

SMERDEL, B., Ustavna osnova prava javnosti na informaciju, Informator, br. 5527, 2007. str. 1.2.

SORTA-BILAJAC, I., Od eutanazije do distanazije, Rijeka, 2005., str. 15.-28.

SREMAC, Đ. - ŽUŽA, B., Hrvatsko zdravstveno zakonodavstvo 1830.-1941., Školska Knjiga, Zagreb, 2002.

STAUCH, M. - WHEAT, K., Sourcebook on Medical Law, London-Sydney, 1999.

STOJANOVIĆ, I., Međusobni odnosi lekara, „Pravni život“, 2013., broj 9, TOM I .

STOJANOVIĆ, I., Pretpostavljena odgovornost lekara i tzv. defanzivna medicina, „Pravni život“, knjiga 583, 2016., broj 9.

STRINOVIĆ, D. - ZEČEVIĆ, D., Komplikacija i greška - sudskomedicinski pristup, rad u knjizi: BOIĆ, V. i dr., Naknada neimovinske štete, Pravno-medicinski okvir, Inženjerski biro, Zagreb, 2009.

STUŽIĆ, V., Sestrinska dokumentacija, «Sestrinski list KB Merkur», 2006., br. 4

SUDŽUM R., Pravo na zdravstvenu zaštitu i participacija, Pravna praksa, br. 7-8/2007, Liber, Beograd 2007.

SVIRČIĆ, J. - GRUJIĆ, J., Redukcijom prava na pobačaj najviše će biti pogođene mlade $i$ širomašne žene, „Lupiga.com“, od 22. prosinca 2015., podatak na stranici http://lupiga.com/intervjui/intervju-pravo-na-pobacaj.

Svjetsko liječničko udruženje - Priručnik medicinske etike, Medicinska naklada, Zagreb, 2010.

\section{$\check{\mathbf{S}} /$}

ŠABIĆ, S., Osiguranje od odgovornosti za štetu pričinjenu medicinskom greškom kao način pravne zaštite u postupku liječenja, „Anali Pravnog fakulteta Univerziteta u Zenici, god. 9, 2016., broj. 17, str. 335.-356.

ŠARIĆ, D., Liječnička pogreška - pravni i medicinski aspekti, završni rad na poslijediplomskom specijalističkom studiju „Medicinsko pravo“ na Pravnom fakultetu Sveučilišta u Splitu, Split, 2015. 
ŠAULA, V., Osnovi međunarodnog građanskog procesnog prava Republike Srpske, Banja Luka, 2008.

ŠEGOTA, I., Nova medicinska etika (bioetika), Rijeka, 2000.

ŠEGOTA, I., Van Rensselaer Potter II - «otac» bioetike, Bioetički svesci 1999., 6, str. 14.-21.

ŠEGVIĆ, S., Legitimnost građanskog otpora - neki teorijski aspekti, „Zbornik radova Pravnog fakulteta u Splitu“, god. 44, 2/2007.

ŠEPAROVIĆ, Z., Granice rizika - Etičkopravni pristupi medicini, Zagreb, 1998.

ŠKAVIĆ, J. - ZEČEVIĆ, D., Komplikacija i greška - sudskomedicinski pristup, u Zborniku radova skupine autora: Građanskopravna odgovornost u medicini, Hrvatska akademija znanosti i umjetnosti, Zagreb, 2008.

ŠKAVIĆ, J. - ZEČEVIĆ, D., Načela sudskomedicinskih vještačenja, Zagreb, 2010.

ŠMALCELJ, R., Rad u bolnici, poglavlje u knjizi „Medicinska etika 1, urednica ZNIDARČIĆ, Ž., Centar za bioetiku, Zagreb, 2004.

Šta je zapravo - prigovor savesti? http://www.respecta.co.rs/2011/09/29/sta-je-zapravo-prigovorsavesti/.

S̆TIMAC, S. - MAROVIĆ, A. - ড̌ARIĆ, J., Medicinski i pravni kriteriji u postupcima naknade nematerijalne (neimovinske) štete, „Osiguranje“, 2010., broj 10.

ŠTIMAC, S., Pravni aspekt medicinskog vještačenja nematerijalne/neimovinske štete, „Vještak”, god. XXVIII, 2008., broj 1, str. 181.-192.

Šta je zapravo - prigovor savesti? http://www.respecta.co.rs/2011/09/29/sta-je-zapravo-prigovorsavesti/.

Što je zdravlje? https://uppt.hr/savjeti-mainmenu-44/zdravlje-mainmenu-62/353-to-je-zdravlje.

Što je zdravlje i kako biti zdrav?, http://savjetovaliste.tvz.hr/briga-o-zdravlju/sto-je-zdravlje-ikako-biti-zdrav/.

TIMOTIĆ, B. - ANĐELSKI, H., Zdravstveno zakonodavstvo, Elita - Medica, Beograd, 2004.

TRAJKOVIĆ, M., Međunarodno arbitražno pravo, Beograd, 2000.

TRIFKOVIĆ, M. - OMANOVIĆ, S., Međunarodno poslovno pravo i arbitraže, Sarajevo 2001.

TRIVA, S., Arbitražno ili državno sudovanje, «Pravo u gospodarstvu», god. 43., 2004., br. 2

TRIVA, S. - BELAJEC, V. - DIKA, M., Građansko parnično procesno pravo, Zagreb, 1986.

TRIVA, S. - DIKA, M., Građansko parnično procesno pravo, Zagreb, 2004.

TUCAK, A. - FATOVIĆ FERENČIĆ, S, Povijesni razvoj Medicinskog fakulteta Osijek, Osijek 2010.

TURKOVIĆ, K., Kaznena djela protiv zdravlja ljudi, u: Novoselec, P., Posebni dio kaznenog prava, Prvo izdanje, Zagreb, 2007.

TURKOVIĆ, K. i dr., Komentar Kaznenog zakona i drugi izvori novoga hrvatskog kaznenog zakonodavstva, „Narodne novine“, Zagreb, 2013.

TURKOVIĆ, K., Novi pogledi u svijetu na odgovornost liječnika za liječničku grešku, na stranici: sretnaobitelj.odlican.net/index.php?

TURKOVIĆ, K., Novi pogledi u svijetu na odgovornost liječnika za liječničku pogrešku, www.pravo.hr/download/repository/Turkovic-lijecnicka_greska.doc, 27. 7. 2009.

TURKOVIĆ, K., Prava pacijenta na suodlučivanje prema Zakonu o zaštiti prava pacijenata, Zbornik "Medicina i pravo - sodobne dileme", Maribor, 2006.

TURKOVIĆ, K. - ROKSANDIĆ VIDLIČKA, S., Reforma kaznenog zakonodavstva u području zdravstva, Zbornik radova Aktualnosti zdravstvenog zakonodavstva i pravne prakse, II. znanstveni skup, Novalja, 2011., str. 111-136.

TURKOVIĆ, K. - DIKA, M. - GORETA, M. - ĐURĐEVIĆ, Z., Zakon o zaštiti osoba s duševnim smetnjama - s komentarom i prilozima, Zagreb, 2001. 
UČUR, Đ. M., Radno vrijeme u đežurstvu, podatak na stranici https://burza.com.hr/portal/radnovrijeme-u-dezurstvu/9261.

UHLIR, Ž., Promišljanje o dilemi - komora vs udruga vještaka, poglavlje magistarskog rada na Ekonomskom fakultetu u Zagrebu, 2011., podatak na stranici: http://www.sudskivjestaci.hr/fdsak3jnFsk1Kfa/inicijative/Promisljanje_o_dilemikomora_vs_udruga_vjestaka.pdf.

ULSENHEIMER, K., Die arztliche Schweigpflicht, objavljen u LAUFS-UHLENBRUCK, Handbuch des Arztrechts, Munchen, 2002.

URDAREVIĆ, B., Zdravstveni radnici kao pružaoci zdravstvenih usluga i stručna greška lekara, rad u Zborniku radova „Usluge i zaštita korisnika“, Kragujevac, 2016.

URLEP, F., Pojasnilna dolžnost v splošni medicini, rad u zborniku «Medicina in pravo - pojasnilna dolžnost», Maribor, 1995.

\section{V/}

Van DIJK, P. - Van HOOF, G. J. H., Teorija i praksa Evropske konvencije o ljudskim pravima, Sarajevo, 2001., str. 459.-508.

VASILIĆ J., Osiguranje stečajnog upravnika od građanske odgovornosti za štete učesnicima u stečajnom postupku, Revija za pravo osiguranja, br. 2/2002, Beograd 2002.

VEDRIŠ, M. - KLARIĆ, P., Građansko pravo, Zagreb, 1998.

VELČIĆ, B., Nerođeno dijete ima pravo na nasljeđivanje imovine, ali pravo na život - ne!, podatak na stranici http://spiritus-movens.me/zivot/06/13/nerodeno-dijete-ima-pravo-nanasljedivanje-imovine-ali-pravo-na-zivot-ne/.

VISKOVIĆ, N., Država i pravo, Zagreb: Birotehnika., 1995.

VISKOVIĆ, N. (1995). Bioetika i biomedicinsko pravo, Zbornik radova Pravnog fakulteta u Splitu, god. 32, 1995., (1-2), str. 78.-82.

VISKOVIĆ, N., Kakva bioetika?, poglavlje u knjizi Nikola Visković «Sumorne godine nacionalizam, bioetika, globalizacija», Split, 2003.

VRHOVAC, B., Liječnička tajna, «Liječničke novine», 2001., broj 5.

VUKADIN, D., Pravo prigovora savjesti, „Filozofska istraživanja“, god. 23., 2003., sv. 2.

W/

WILLIAMS, P.L., How to keep trade secrets, Seattle/Washington, 1993.

\section{$\mathbf{Z}$}

ZABEL, B. Poslovna tajna, Beograd, 1970.

ZATTI, P., Bioetica e diritto, «Rivista italiana di medicina legale, 1995., br. 17

Zdravlje $i$ faktori koji na njega utječu, podatak na web stranici http://www.izjzv.org.rs/app/soc.katedra/Zdravljeifakorikojinanjegauticu.pdf.

ZEČEVIĆ, D. i dr., Sudska medicina i deontologija, Zagreb, 2004.

ZEČEVIĆ, D. - ŠKAVIĆ, J., Kaznenopravna i građanskopravna odgovornost liječnika - Teorija i praksa, „Medicinska naklada“, Zagreb 2012.

ZLATOVIĆ, D., Zaštita i čuvanje poslovne tajne, „Slobodno poduzetništvo“, god IV, 1997., br. 8.

Znanstveni program Znanstvenog centra izvrsnosti za integrativnu bioetiku, rad na stranici http://www.bioetika.hr/wp-content/uploads/2016/04/ZCI-IB-znanstveni-program.pdf

ZNIDARČIĆ, Z., Medicinska etika 1 - Uvod, Svrha raspravljanja o medicinskoj etici, Zagreb, 2004.

ZNIDARČIĆ, Ž, Pogreške i propusti liječnika i mogućnosti njihova ispravljanja, rad u knjizi Medicinska etika 2, Centar za bioetiku Zagreb, 2006. 
ZORNIĆ-MUJOVIĆ., H., Prekid trudnoće - abortus, INSTITUT DRUŠTVENIH NAUKA, Centar za pravna istraživanja, Beograd, 2013., www.ius.bg.ac.rs/.../h.mujovic.prekid\%20trudnoce.

ZUGLIA, S. - TRIVA, S., Komentar zakona o parničnom postupku, Zagreb, 1957.

\section{$\check{\mathbf{Z}} /$}

ŽOKALJ, I. - SABLJAR MATOVINOVIĆ, M., Odnosi među liječnicima u radu Povjerenstva za medicinsku etiku i deontologiju Hrvatske liječničke komore, rad u knjizi „Odnosi među liječnicima u Hrvatskoj“, Knjiga izlaganja na XIV. proljetnom simpoziju medicinske etike Hrvatskoga liječničkog zbora, Zagreb, 10. lipnja 2014., urednik Goran Ivanišević, Hrvatski liječnički zbor, Zagreb, 2014.

ŽOKALJ, I. - SABLJAR - MATOVINOVIĆ, M., Dealing with interpersonal miscommunication problems as presented to the Commission for Medical Ethics and Deontology of Croatian Medical Chamber, Odnosi među liječnicima u Hrvatskoj, Knjiga izlaganja na XIV. proljetnom simpoziju medicinske etike Hrvatskoga liječničkog zbora, Zagreb, 2014.

ŽUNIĆ, LJ., Značaj poznavanja medicinskog prava za zdravstvene radnike, seminarski rad neobjavljeno, Split, 2009.

ŽUŽA, Ž., Disciplinska odgovornost liječnika, „Informator“, broj 5863. od 15. svibnja 2010.

\section{Propisi}

Ustav Republike Hrvatske („Narodne novine“, br. 41/01 - pročišćeni tekst, 55/01., 76/10, $85 / 10,05 / 14)$,

Zakon o zdravstvenoj zaštiti (,Narodne novine“", br.

$\underline{150 / 08}, \underline{71 / 10}, \underline{139 / 10}, \underline{22 / 11}, \underline{84 / 11}$,

$\underline{154 / 11}, \underline{12 / 12}, \underline{35 / 12}, \underline{70 / 12}, \underline{144 / 12}, \underline{82 / 13}, \underline{159 / 3}, \underline{22 / 14}, \underline{154 / 14})$

Zakon o zaštiti prava pacijenata („Narodne novine“, br. 169/04., 37/08)

Zakon o obveznom zdravstvenom osiguranju (,Narodne novine“, br. 80/13, 137/13)

Zakon o obveznim odnosima („Narodne novine“, br. 35/05., 41/08, 125/11, 78/15)

Kazneni zakon („Narodne novine“, br. 125/11, 144/12, 56/15, 61/15)

Zakon o zaštiti tajnosti podataka (,Narodne novine“, br. 108/96)

Zakon o tajnosti podataka („Narodne novine“, br. 79/07, 86/12)

Zakon o zdravstvenoj zaštiti stranaca, („Narodne novine“, br. 114/97)

Zakon o zaštiti osobnih podataka ("Narodne novine", br. 103/03, 118/06, 41/08, 130/11, $106 / 12)$

Zakon o pravu na pristup informacijama ("Narodne novine”, br. 25/13, 85/15)

Zakon o kaznenom postupku („Narodne novine“, br. 152/08, 76/09, 80/11, 121/11, 91/12, 143/12, 56/13, 145/13, 152/14, 70/17)

Zakon o parničnom postupku („Narodne novine“", br. 53/91, 91/92, 58/93, 112/99, 88/01, 117/03, 88/05, 02/07, 84/08, 123/08, 57/11, 148/11, 25/13, 89/14)

Zakon o arbitraži (,Narodne novine“, br 88/01)

Zakon o mirenju (,Narodne novine“, br 18/11)

Zakon o općem upravnom postupku (,Narodne novine“, br. 47/09)

Zakon o zaštiti od ionizirajućih zračenja („Narodne novine“, br 91/10)

Zakon o sanitarnoj inspekciji (,Narodne novine“, br 113/08, 88/10)

Zakon o otrovima („Narodne novine“, br. 27/99)

Zakon o obrtu (,Narodne novine“, br. 143/13)

Zakon o trgovačkim društvima („Narodne novine“, br 111/93, 34/99, 121/99, 52/00, $118 / 03,107 / 07,146 / 08,137 / 09,125 / 11,152 / 11,111 / 12,68 / 13,110 / 15$ ) 
Zakon o lijekovima („Narodne novine“, br 76/13, 90/14)

Zakon o medicinskim proizvodima(,Narodne novine“", br. 76/13)

Zakon o zaštiti osoba s duševnim smetnjama („Narodne novine“, br. 76/14)

Zakon o sustavu državne uprave („Narodne novine“", br. 150/11, 12/13)

Zakon o liječništvu („Narodne novine“, br. 121/03, 117/08)

Zakon o ljekarništvu („Narodne novine“, br. 121/03, 142/06, 35/08, 117/08)

Zakon o medicinsko-biokemijskoj djelatnosti („Narodne novine“, br. 121/03, 117/08)

Zakon o dentalnoj medicini („Narodne novine“", broj 121/03, 117/08, 120/09)

Zakon o sestrinstvu (,Narodne novine“, br. 121/03, 117/08, 57/11)

Zakon o primaljstvu (,Narodne novine“", br. 120/08, 145/10)

Zakon o fizioterapeutskoj djelatnosti (,Narodne novine“,br. 120/08)

Zakon o djelatnostima u zdravstvu (,Narodne novine“, br. 87/09)

Zakona o stomatološkoj djelatnosti (,Narodne novine“", br. 12/03)

Zakona o zaštiti osoba s duševnim smetnjama („Narodne novine“", br. 111/97, 27/98, 128/99, 79/02)

Zakon o arhivskom gradivu i arhivima, (»Narodne novine«, br. 105/97)

Zakon o ustanovama („Narodne novine“, br. 76/93, 29/97, 47/99, 35/08)

Zakon o sudovima („Narodne novine“, br. 28/13, 33/15, 82/15, 82/16)

Sudski poslovnik („Narodne novine“, br. 37/2014

Zakon o reguliranim profesijama i priznavanju inozemnih stručnih kvalifikacija

(,Narodne novine“, br. 82/15)

Zakon o evidencijama u oblasti zdravstva (,"Službeni list SFRJ“, broj 22/78, 18/88)

Zakon o medijima („Narodne novine“ br. 59/04, 84/11,81/13)

Zakon o zaštiti osobnih podataka („Narodne novine“ br. 103/03)

Zakon o pravu na pristup informacijama („Narodne novine“ br 25/13, 85/15)

Zakon o radu („Narodne novine“, br. 93/14)

Kolektivni ugovor za djelatnost zdravstva i zdravstvenog osiguranja (Urednički pročišćeni tekst, „Narodne novine“, br. 143/13 i 96/15)

Kodeks medicinske etike i deontologije („Narodne novine“, br. 55/08,139/15)

Kodeks stomatološke etike i deontologije, od 7. lipnja 1996. godine

Kodeks ljekarničke etike i deontologije, od 18. travnja 1996. godine

Etički kodeks medicinskih sestara, od 22. prosinca 2005. godine

Kodeks etike i deontologije djelatnosti sanitarnih inženjera, zdravstvene radiološkotehnološke djelatnosti, djelatnosti radne terapije i medicinsko laboratorijske djelatnosti, od 5.12.2012. godine

Kodeks etike i deontologije medicinskih biokemičara, od 8. svibnja 1996. godine

Etički kodeks primalja od 27. siječnja 2010 godine

Etički kodeks fizioterpeeuta od 21. veljače 2011. godine

Statut Hrvatske liječničke komore

Statut Hrvatske stomatološke komore

Statut Hrvatske ljekarničke komore

Statut Hrvatske komore medicinskih sestara,

Statut Hrvatske komore medicinskih biokemičara

Međunarodni kodeks medicinske etike

Načela etike za europske liječnike, Međunarodne konferencije predstavnika liječničkih komora

Konvencija o zaštiti ljudskih prava i temeljnih sloboda 
Konvencija Vijeća Europe o zaštiti ljudskih prava i dostojanstva ljudskog bića u pogledu primjene biologije i medicine;

Konvencija o ljudskim pravima i biomedicini

Dodatni protokol uz Konvenciju o zaštiti ljudskih prava i dostojanstva ljudskog bića u pogledu primjene biologije i medicine o zabrani kloniranja ljudskih bića

Dodatni protokol uz Konvenciju o zaštiti ljudskih prava i dostojanstva ljudskog bića u pogledu primjene biologije i medicine u svezi presađivanja organa i tkiva ljudskog porijekla,

Deklaracija Svjetske zdravstvene organizacije o promicanju prava pacijenata u Europi Deklaracija ujedinjenih naroda o borbi protiv HIV/AIDS-a

Helsinška Deklaracija o etičkim načelima biomedicinskih istraživanja na ljudskim subjektima

Madridska deklaracija o etičkim standardima za psihijatrijsku djelatnost

Lisabonska deklaracija o pravima pacijenata

Deklaracija Svjetskog medicinskog udruženja o nezavisnosti i profesionalnoj slobodi liječnika

Deklaracija Svjetskog medicinskog udruženja o ljudskim pravima i osobnoj slobodi medicinskih radnika

Deklaracija Svjetskog medicinskog udruženja o medicinskoj edukaciji

Madridska deklaracija Svjetskog medicinskog udruženja o profesionalnoj autonomiji i samoregulaciji

Malteška deklaracija Svjetskog medicinskog udruženja o štrajku glađu

Temeljni sporazum između Vlade Republike Hrvatske i Svjetske zdravstvene organizacije o uspostavi tehničko-savjetodavne suradnje («Narodne novine Međunarodni ugovori», broj 5/06.)

Sporazum o suradnji u oblasti zdravstvene zaštite SFRJ i ČSSR («Službeni list Međunarodni ugovori i drugi sporazumi», br. 6/64.) (sukcesija);

Konvencija između Vlade FNRJ i Vlade NR Mađarske o sprječavanju i suzbijanju zaraznih bolesti («Službeni list - Međunarodni ugovori i drugi sporazumi», br. 9/58)

Pravilniku o početku, završetku i rasporedu radnog vremena zdravstvenih ustanova i privatnih zdravstvenih radnika u mreži javne zdravstvene službe (,Narodne novine“, br. 4/14)

Pravilnik o pripravničkom stažu doktora medicine („Narodne novine“", br. 114/13)

Pravilnik o znanstvenim i umjetničkim područjima, poljima i granama (,Narodne novine“", broj 118/09, 82/12, 32/13)

Pravilnik o mjerilima za davanje odobrenja zdravstvenom radniku za sklapanje poslova iz djelatnosti poslodavca („Narodne novine“ br. 113/15)

Pravilnik o načinu vođenja, čuvanja prikupljanja i raspolaganja medicinskom dokumentacijom pacijenata u centralnom informacijskom sustavu zdravstva RH (,Narodne novine“ br. 82/10)

Pravilnik o načinu vođenja osobnog zdravstvenog kartona u elektoničkom obliku (,Narodne novine“ br. 82/10)

Pravilnik o provedbi zakona o evidencijama u oblasti zdravstva za primarnu i specijalističko-konzilijarnu zdravstvenu zaštitu (,Narodne novine“ br. 4/95)

Pravilnik o provedbi zakona o evidencijama u oblasti zdravstva na području zdravstvene zaštite gerijatrijskih bolesnika (,Narodne novine“ br. 82/02) 
Uredba o medicinskom vještačenju u mirovinskom osiguranju (,Narodne novine“ br. 12/13)

Pravilnik o provedbi zakona o evidencijama u oblasti zdravstva za primarnu i specijalističko-konzilijarnu zdravstvenu zaštitu (,Narodne novine“ br . 4/95)

Pravilnik o uvjetima i postupku ostvarivanja prava iz obveznog zdravstvenog osiguranja s osnove ozljede na radu i profesionalne bolesti („Narodne novine“ br. 75/14, 154/14, 79/13, 139/15, 105/15, 40/17 66/17)

Pravilnik o načinu vođenja, čuvanja, prikupljanja i raspolaganja medicinskom dokumentacijiom pacijenata u centralnom informacijskom sustavu zdravstva Republike Hrvatske („Narodne novine“ br. 82/10)

Pravilnik o pravima, uvjetima i načinu ostvarivanja prava iz obveznog zdravstvenog osiguranja (,Narodne novine“" br . 49/14, 51/14, 11/15, 17/15, 123/16)

Pravilnik o ortopedskim i drugim pomagalima (,Narodne novine“ br. 7/12, 14/12, 23/12, 25/12, 45/12, 69/12, 85/12, 92/12, 119/12, 147/12, 21/13, 38/ $13,93 / 13,119 / 13,125 / 13,129 / 13,136 / 13,141 / 13,154 / 13,11 / 14,12 / 14,22 / 14$, 34/14, 45/14, 54/14, 59/14, 86/14, 92/14, 119/14, 129/14, 149/14, 17/15, 29/15, 7 $7 / 15,86 / 15,124 / 15,129 / 15,132 / 15,139 / 15,25 / 16,30 / 16,106 / 16,108 / 16)$,

Pravilnik o uvjetima, organizaciji i načinu obavljanja hitne medicine (,Narodne novine" br. 71/16),

Pravilnik o načinu pregleda umrlih te o utvrđivanju vremena i uzroka smrti (,Narodne novine“ br . 46/11., 6/13, 63/14)

Pravilnik o utvrđivanju uvjeta zdravstvene sposobnosti članova posade pomorskih brodova i brodica i jahti („Narodne novine“ br . 93/07,107/14)

Pravilnik o poslovima na kojima radnik može raditi samo nakon prethodnog utvrđivanja zdravstvene sposobnosti („Narodne novine“ br . 70/10)

Pravilnik o načinu vođenja evidencije o izvršenim laboratorijskim ispitivanjima (,Narodne novine“ br . 23/94)

Pravilnik o načinu i rokovima provedbe neposrednog nadzora nad izvorima ionizirajućih zračenja, načinu mjerenja ozračenja djelatnika i bolesnika koji su izloženi ionizirajućim zračenjima, vođenju i sadržaju evidencija i registara te načinu izvješćivanja u vezi s tim zračenjima („Narodne novine“ br 63/00)

Pravilnik o specijalističkom usavršavanju doktora stomatologije (,Narodne novine“ br. 115/07).

Pravilnik o specijalističkom usavršavanju medicinskih sestara-medicinskih tehničara (,Narodne novine“ br.139/09)

Pravilnik o specijalističkom usavršavanju medicinskih sestara - medicinskih tehničara u djelatnosti hitne medicinske pomoći ((„Narodne novine“ br. 28/11)

Pravilnik o specijalističkom usavršavanju magistara medicinske biokemije (,Narodne novine" br.78/03).

Pravilnik o specijalističkom usavršavanju doktora medicine (,Narodne novine“ br. 100/11, 133/11, 54/12, 49/13, 139/14, 116/15, 62/16, 69/16 - Ispravak i 6/17).

Pravilnik o specijalističkom usavršavanju doktora medicine iz obiteljske medicine (,Narodne novine“ br. 129/11, 129/12, 120/13 i 31/17)

Pravilnik o stalnim sudskim vještacima, („Narodne novine“ br. 38/14, 123/15, 29/16)

Pravilnik o mjerilima za priznavanje naziva primarijus (,Narodne novine“, broj 28/12)

Pravilnik o mjerilima za priznavanje inozemnih stručnih kvalifikacija („Narodne novine“" br 89/13) 
Pravilnik o stručnom nadzoru Hrvatske liječničke komore

Pravilnik o provođenju izobrazbe kandidata za stalne sudske vještake Hrvatske liječničke komore

Pravilnika o trajnoj medicinskoj izobrazbi Hrvatske liječničke komore

Pravilnik o trajnom usavršavanju magistara medicinske biokemije

Pravilnik o sadržajima, rokovima i postupku stručnog usavršavanja magistara

\section{farmacije}

Pravilnik o stručnom usavršavanju člana Komore

Pravilnik o trajnom usavršavanju magistara medicinske biokemije

Pravilnik o sadržaju, rokovima i postupku trajnog stručnog usavršavanja primalja, primalja asistentica, primaljskih asistenata, prvostupnika/ca primaljstva $\mathrm{i}$ magistara primaljstva

Pravilnik o sadržaju, rokovima i postupku provjere stručnosti fizioterapeuta, fizioterapeutskih tehničara, radnih terapeuta i masera-kupeljara

Pravilnik o sadržaju, rokovima i postupku provjere stručnosti zdravstvenih radnika iz djelatnosti sanitarnog inženjerstva, zdravstvene radiološko-tehnološke djelatnosti, djelatnosti radne terapije i medicinsko-laboratorijske djelatnosti

Pravilnik o sadržaju, rokovima i postupku trajnog/stručnog usavršavanja i provjere stručnosti medicinskih sestara

Pravilnik o odobrenju za samostalan rad (licenci) Hrvatske liječničke komore

Pravilnik o registru članova HKZR,

Pravilnik o registrima HKF

Pravilnik o vođenju registra HKMS

Pravilnik o vođenju registra članova HKMB

Pravilnik o registrima HKDM

Pravilnik o postupku upisa u registre HKP

Pravilnik o javnim knjigama Hrvatske liječničke komore

Pravilnik o dužnosti čuvanja poslovne i profesionalne tajne te postupanja s klasificiranom dokumentacijom HLK

Pravilnik o nadležnosti, ustrojstvu i načinu djelovanja Časnog suda pri HKDM

Pravilnik o ponašanju i odgovornosti u struci članova Hrvatske komore medicinskih biokemičara

Pravilnik o radu i kaznenim mjerama Stegovnog suda Hrvatske ljekarničke komore

Pravilnik o pravima i odgovornostima medicinskih sestara Hrvatske komore medicinskih sestara

Pravilnik o disciplinskom postupku Hrvatske komore primalja

Pravilnik o pravima i odgovornostima fizioterapeuta

Pravilnik o pravima i odgovornostima članova Hrvatske komore zdravstvenih radnika

Pravilnik o disciplinskom postupku Hrvatske liječničke komore

Pravilnikom o arbitraži HLK

Pravilnik o mirenju HKDM

Pravilnik o arbitraži HLJK

Prijedlog Strateškog plana razvoja zdravstva u Federaciji Bosne i Hercegovine u periodu od 2008. do 2018. godine, Sarajevo

Odluka Ustavnog suda U-II-187/2015 i dr.

Odluka Ustavnog suda U-II-13/2016

Odluka Ustavnog suda U-II-249/2016 
www.hlk.hr/

http://www.iusinfo.hr/

http://www.sudski-vjestaci.hr/

http://www.izjzv.org.rs

http://www.enciklopedija.hr

https://hr.wikipedia.org 

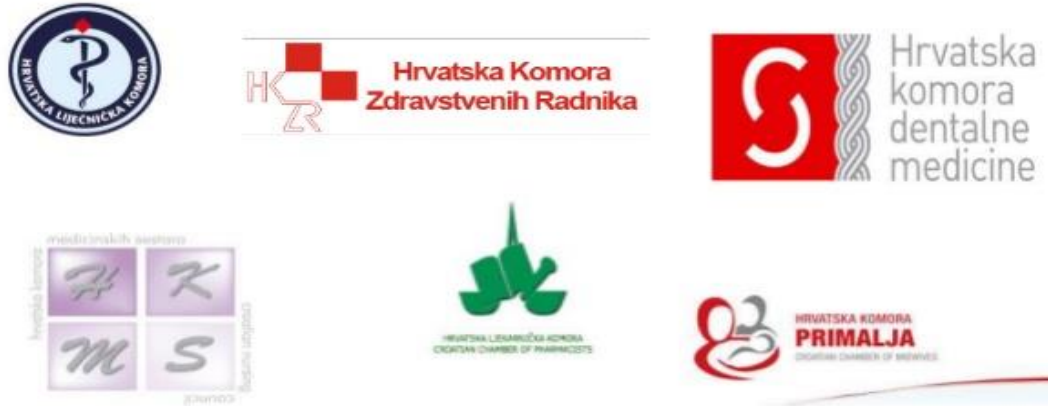

PRIMA

HRVATSKA KOMORA

MEDICINSKIH BIOKEMIČARA

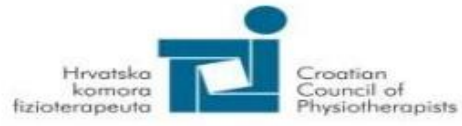



Knjiga koja je pred nama po svojemu je karakteru i namjeni (sveučilišni) udžbenik, obzirom kako je, između ostalog, osnovna nastavna literatura za predmet „Zdravstveno strukovno staleško pravo”, na Poslijediplomskom specijalističkom studiju „Medicinsko pravo, ' Pravnoga fakulteta Sveučilišta u Splitu. Udžbenik je po svom sadržaju, opsegu i razradi pojedinih instituta prilagođen tomu biti nastavni materijal za praćenje nastave i pripremanje ispita. Udžbenik je i pomoćna literatura pri izradi seminarskih i završnih radova i to ne samo na navedenom studiju, već i na drugim studijskim programima na kojima se izvodi predmet „Zdravstveno/Medicinsko pravo', na bilo kojoj razini sa istim ili sličnim sadržajem i opsegom programa predmeta.

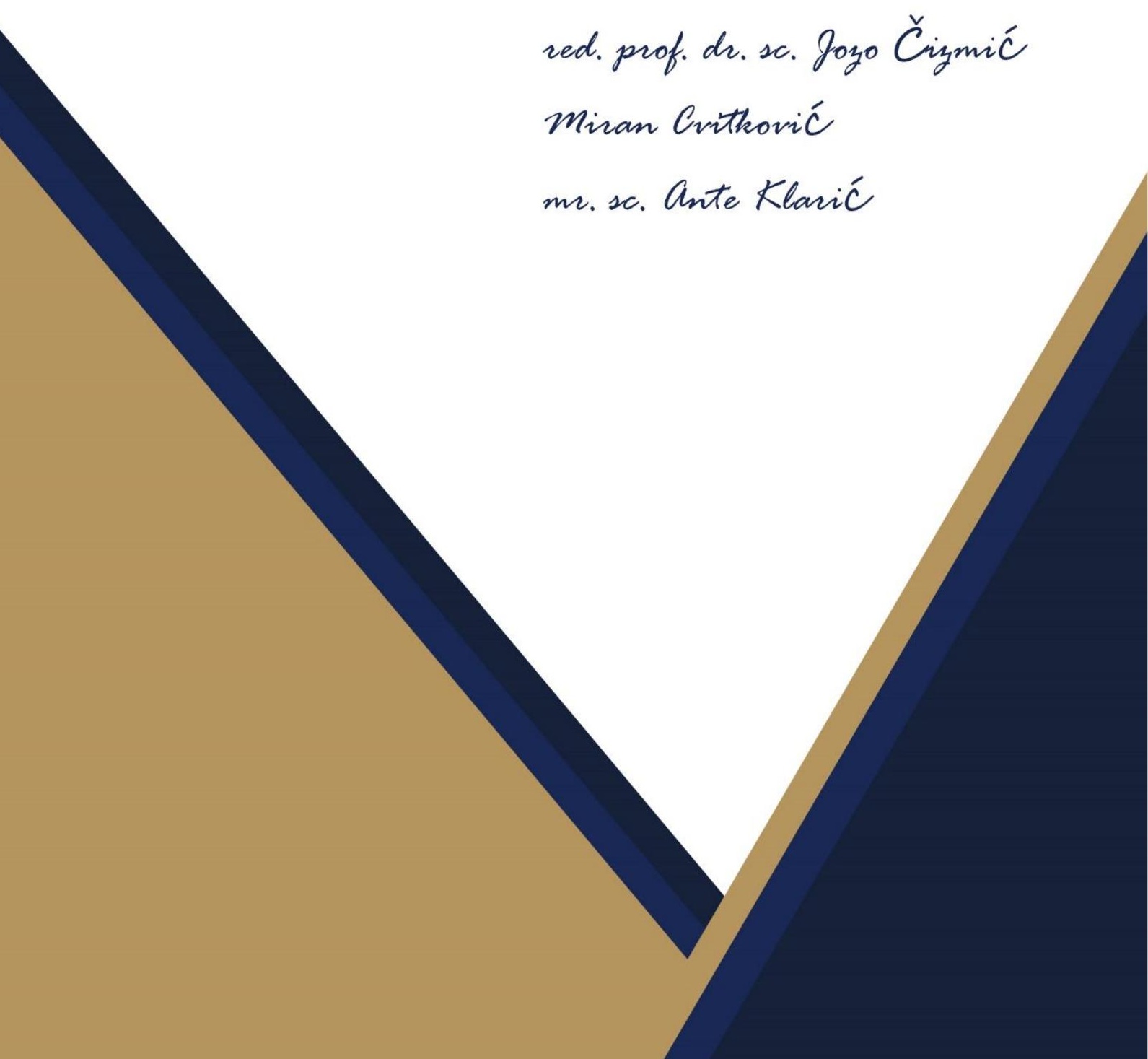

